Universidad de Lima

Facultad de Ingeniería y Arquitectura

Carrera de Arquitectura

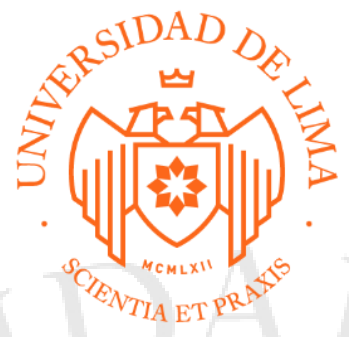

\title{
UNA PROPUESTA DE ESPACIO CÍVICO EN EL ACANTILADO DE SAN ISIDRO: NUEVO MERCADO DE PRODUCTORES
}

Trabajo de suficiencia profesional para optar el Título Profesional de Arquitecto

Proyecto de Fin de Carrera

María José Barbosa Alvistur

Código 20110115

Gabriela del Pilar Guevara Mercado

Código 20111443

Asesor

Pablo Inty Díaz Mora

Lima - Perú

Julio de 2019 


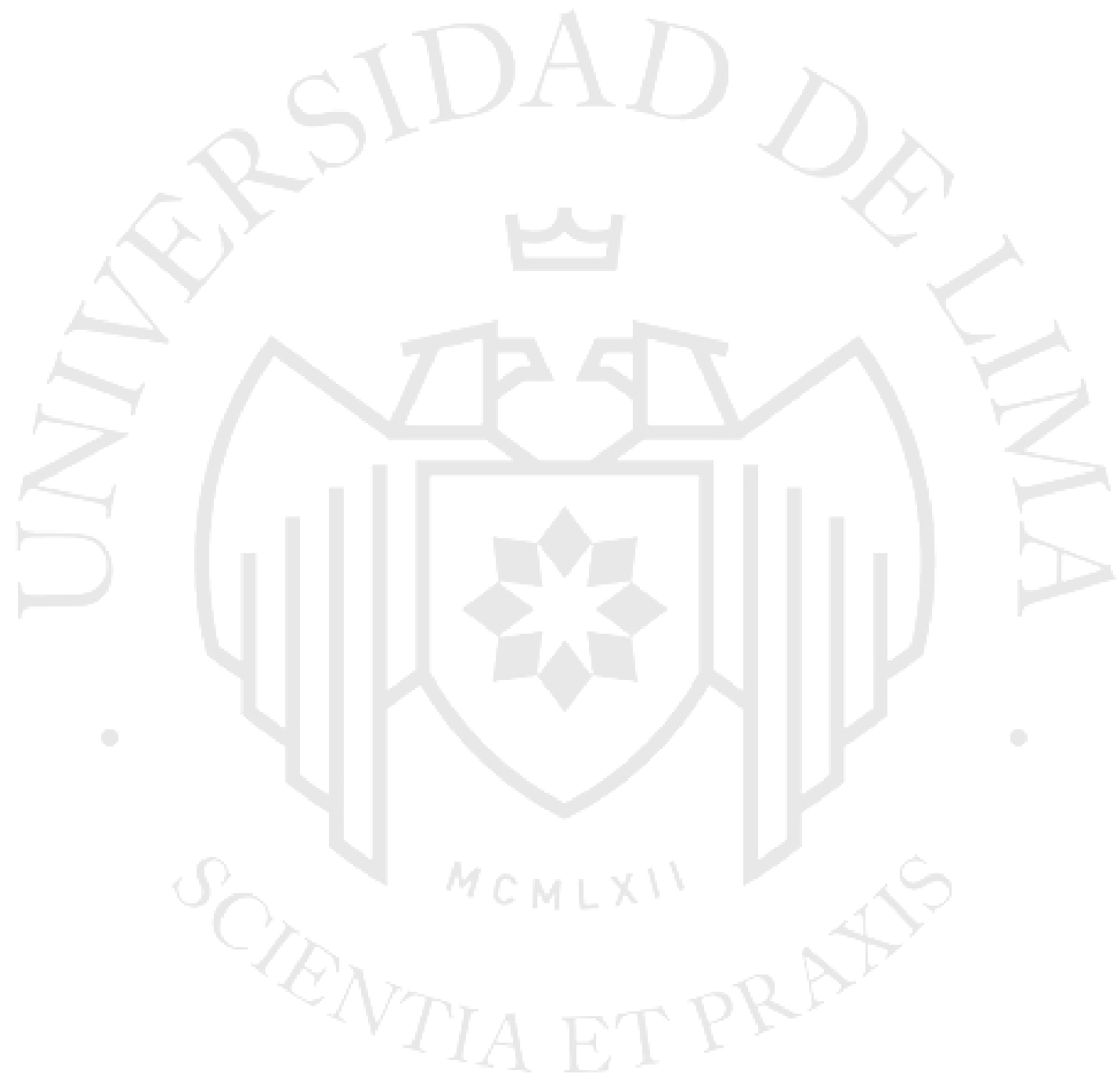




\section{UNA PROPUESTA DE ESPACIO CÍVICO EN EL ACANTILADO DE SAN ISIDRO: NUEVO MERCADO DE PRODUCTORES}




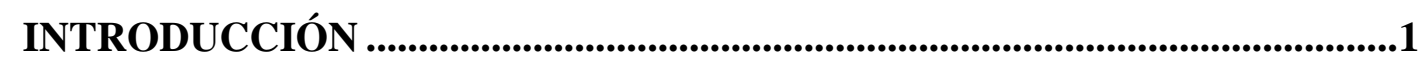

1 CAPÍTULO I: GENERALIDADES..........................................................

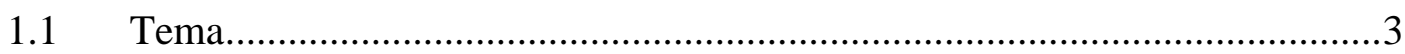

$1.2 \quad$ Justificación del tema.............................................................................

$1.3 \quad$ Planteamiento del problema...................................................................

1.3.1 Problemas principales ...........................................................................

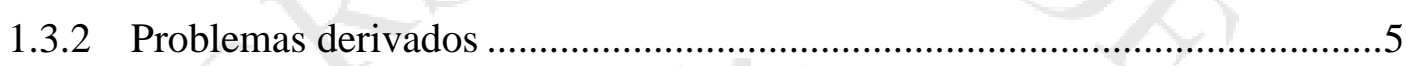

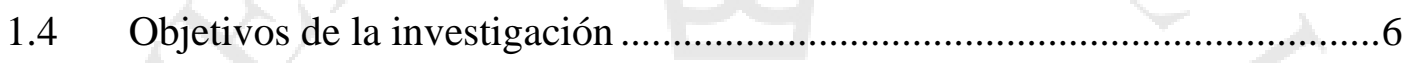

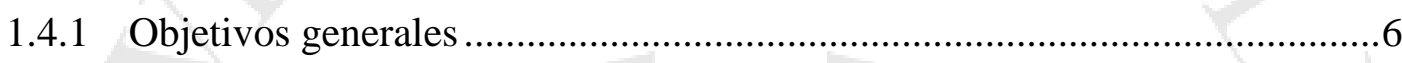

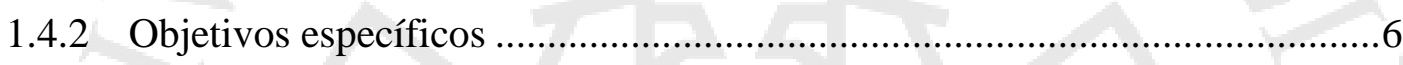

1.5 Supuesto básico de la investigación .............................................................

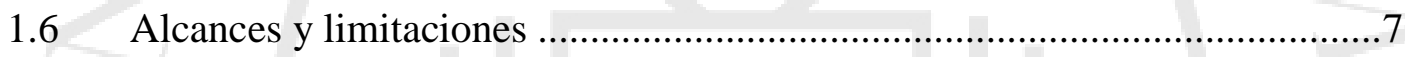

1.6.1 De la investigación...............................................................................

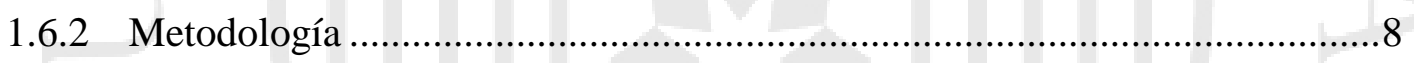

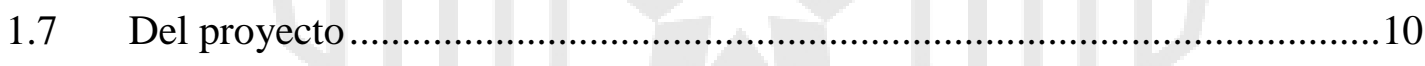

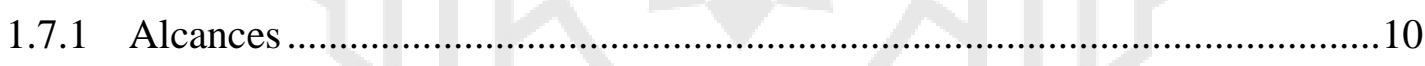

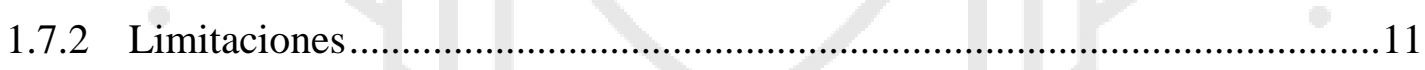

2 CAPÍTULO II: MARCO REFERENCIAL ...................................................12

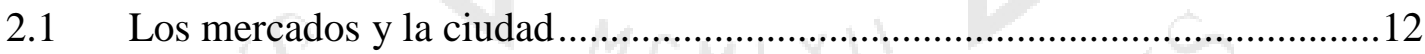

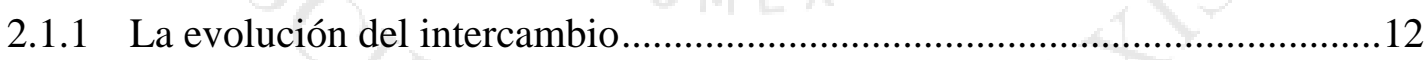

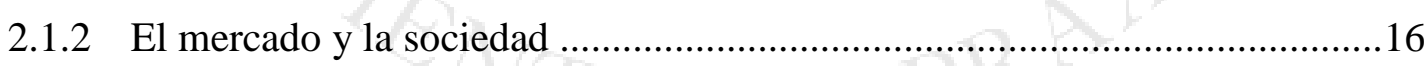

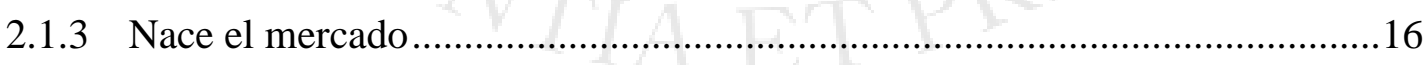

2.1.4 Casos (Born, Les Halles) ...............................................................................

2.1.5 La función del mercado en la ciudad ...........................................................20

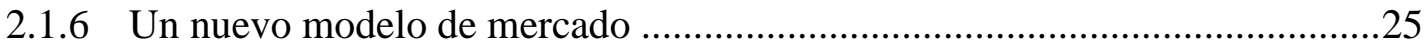

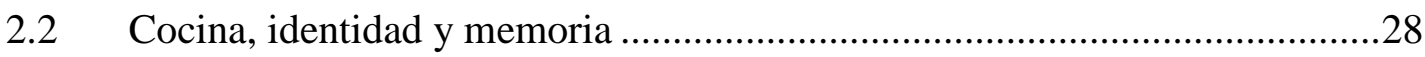

2.2.1 Antecedentes de la gastronomía peruana …………………...........................28

2.2.2 El "Boom" y el crecimiento gastronómico en el Perú .....................................30

2.2.3 Lima como capital gastronómica .................................................................... 31 


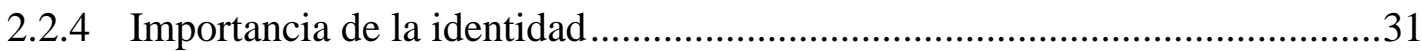

2.3 Situación actual de los mercados de Lima Metropolitana .............................33

2.3.1 Los mercados en la ciudad de Lima ..............................................................33

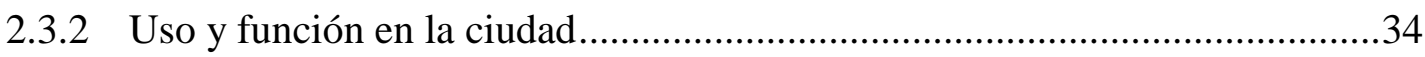

2.3.3 El Mercado de Productores de San Isidro ........................................................34

2.3.4 Línea de tiempo: a nivel nacional e internacional.......................................35

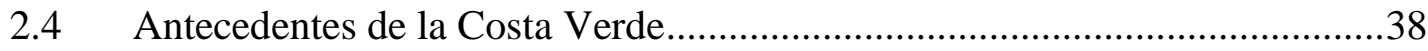

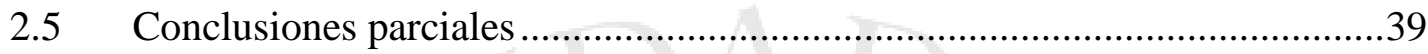

3 CAPÍTULO III: MARCO TEÓRICO ...........................................................44

3.1 En relación a la ciudad, el espacio público y el espacio cívico .....................44

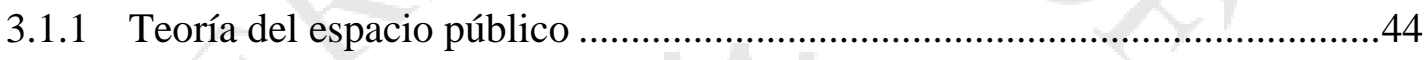

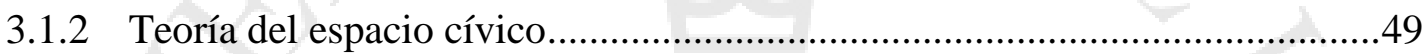

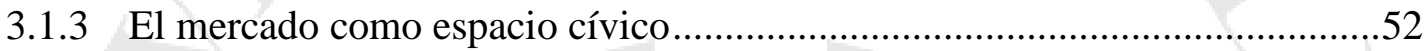

3.1.4 El espacio público relacionado a la arquitectura.......................................54

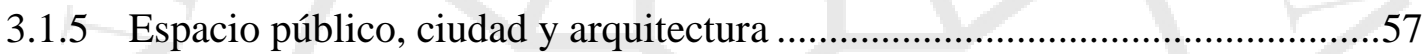

3.2 En relación a la identidad del lugar...........................................................66

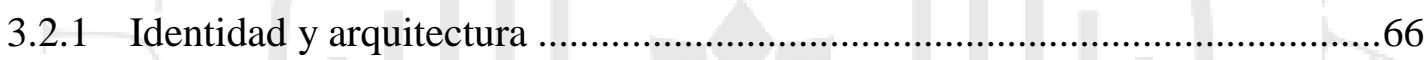

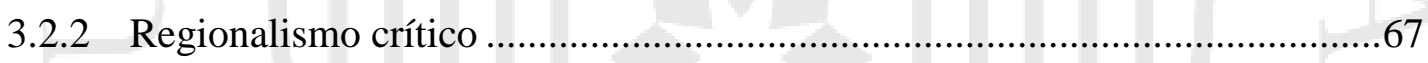

3.2.3 Identidad en América Latina .......................................................................68

3.3 En relación a la memoria y el paisaje ......................................................69

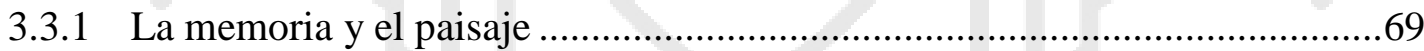

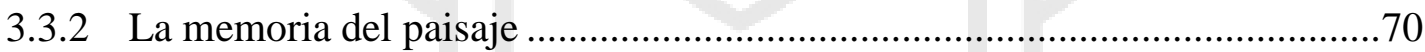

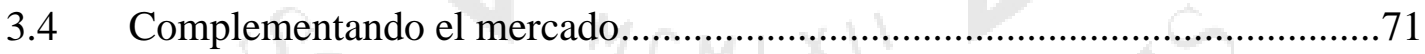

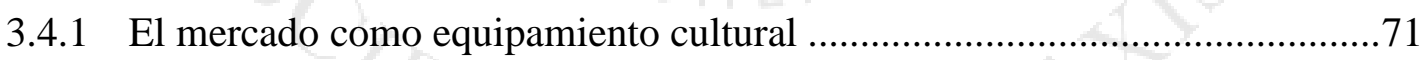

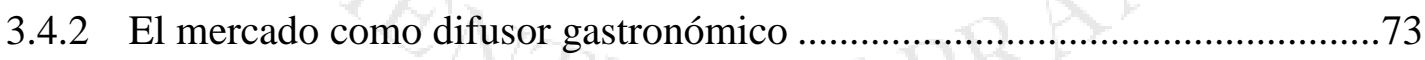

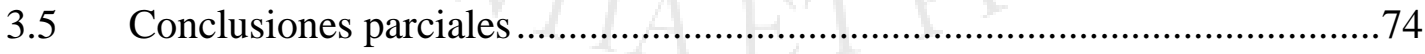

4 CAPÍTULO IV: MARCO NORMATIVO...........................................................81

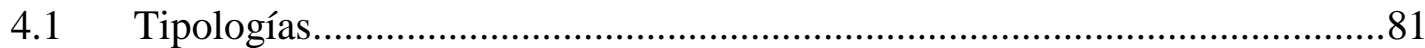

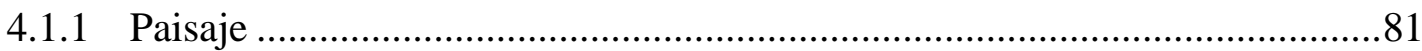

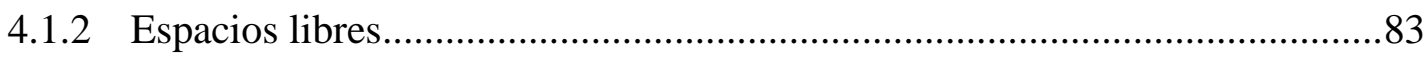

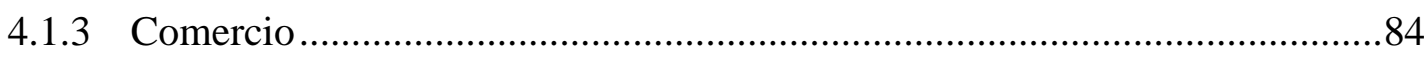

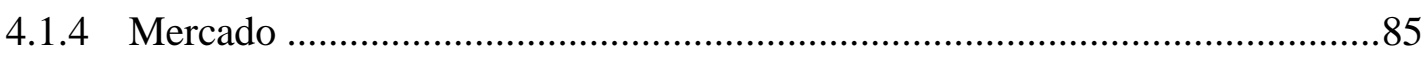

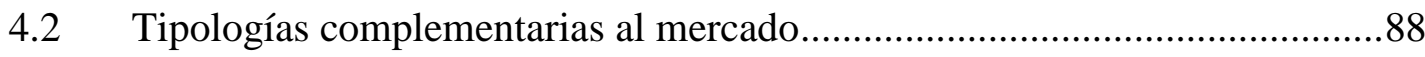




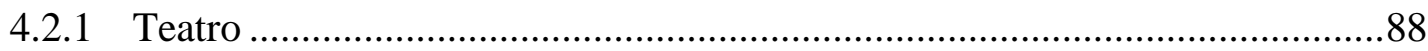

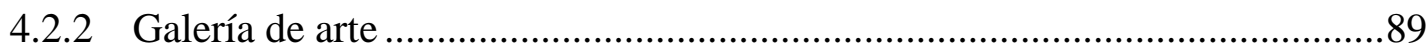

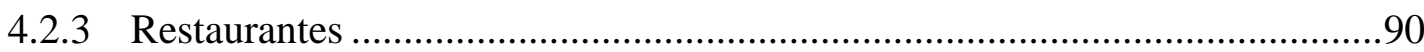

4.3 Concepto y categorización del mercado ...................................................91

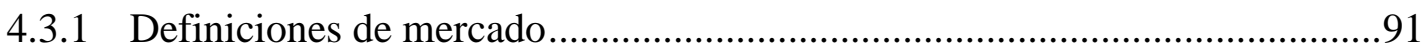

4.3.2 Categorización y tipologías avaladas a nivel nacional................................92

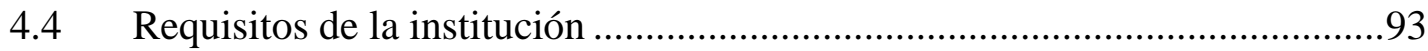

4.4.1 El mercado como institución: caso Madrid, España ....................................93

4.4.2 El mercado como institución: Lima, Perú ..................................................97

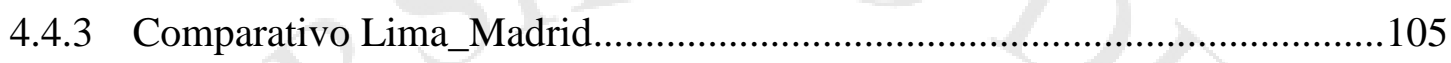

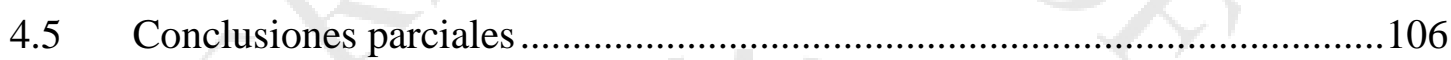

5 CAPÍTULO V: MARCO OPERATIVO......................................................108

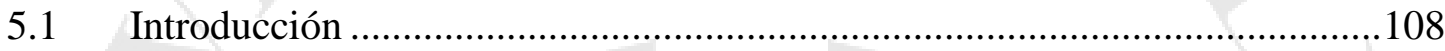

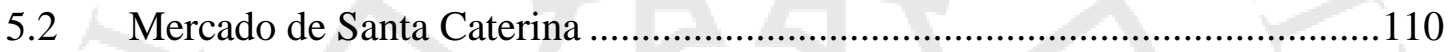

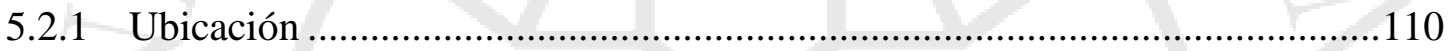

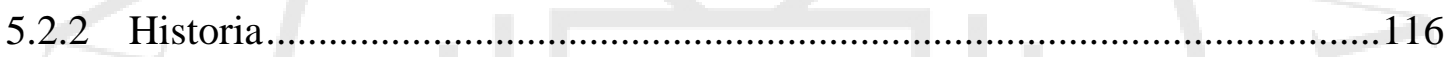

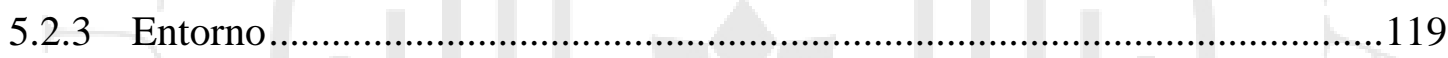

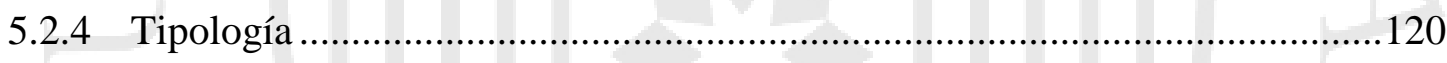

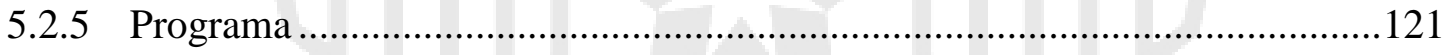

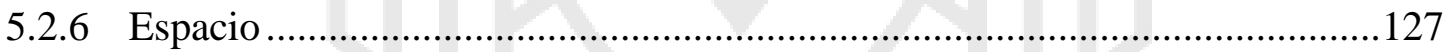

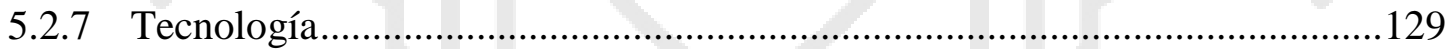

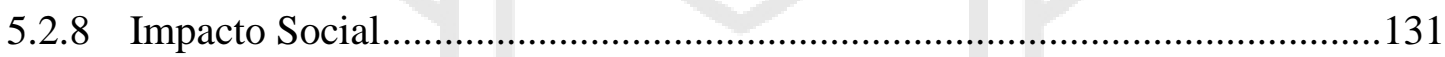

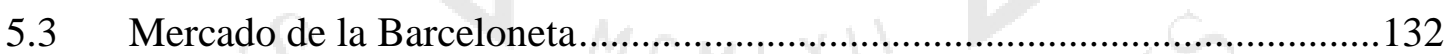

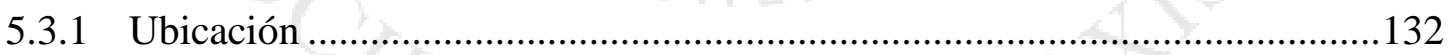

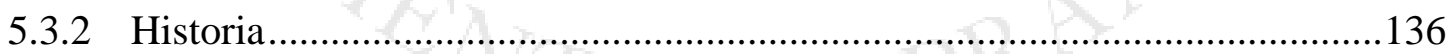

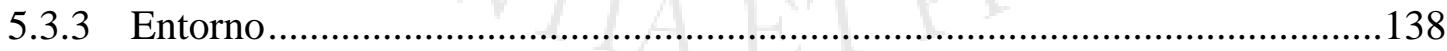

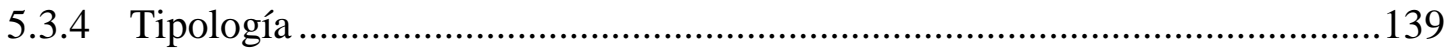

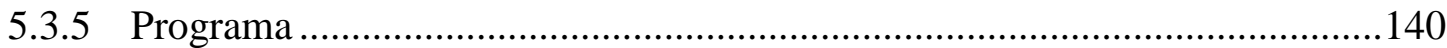

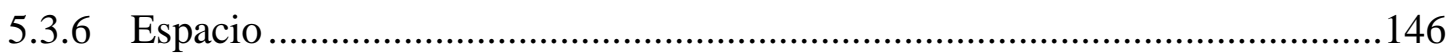

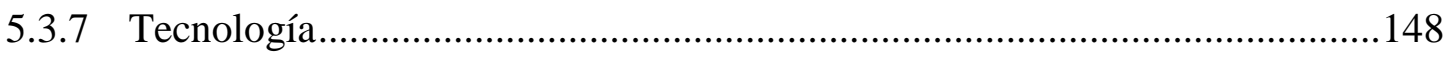

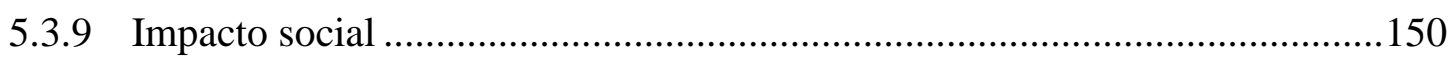

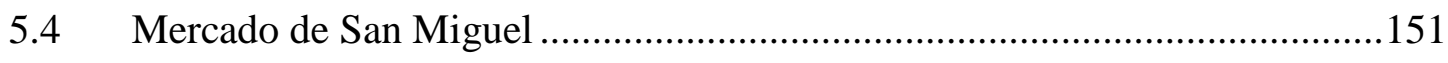

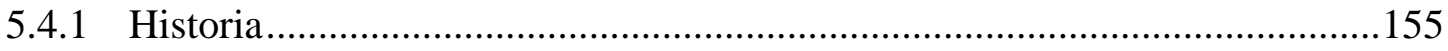




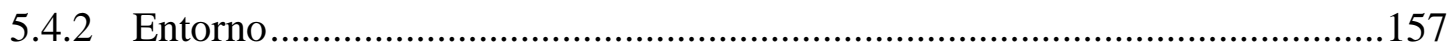

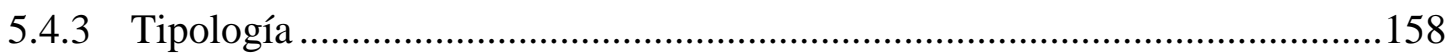

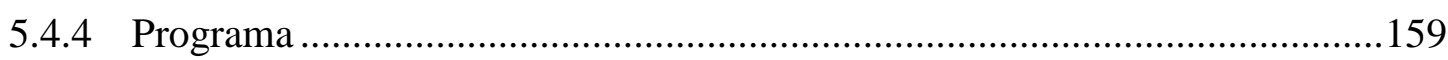

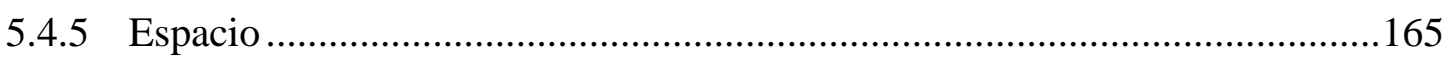

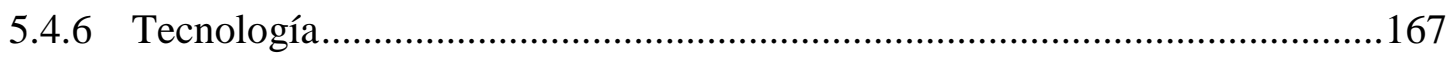

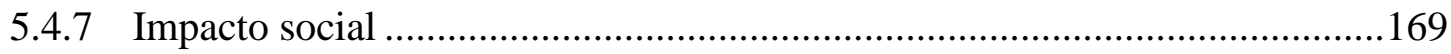

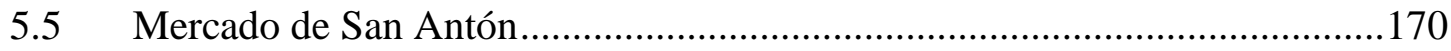

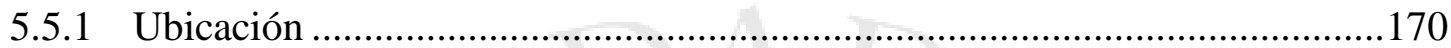

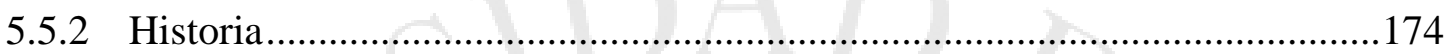

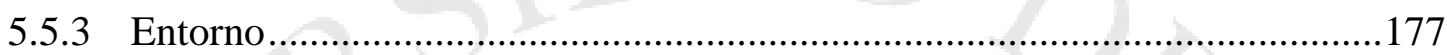

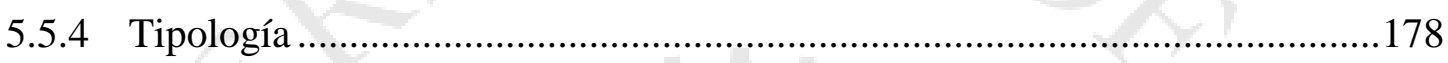

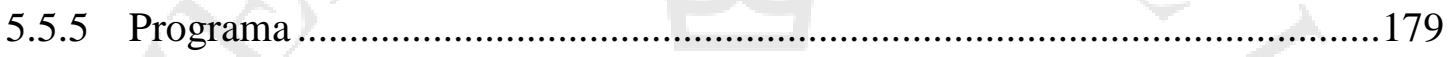

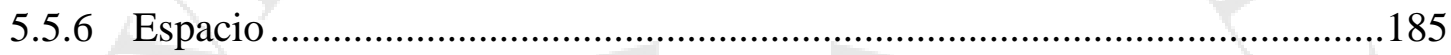

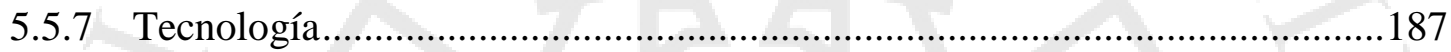

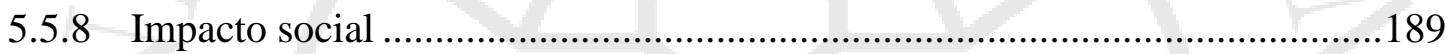

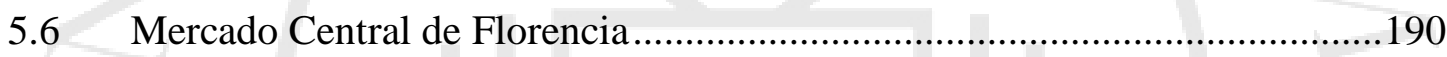

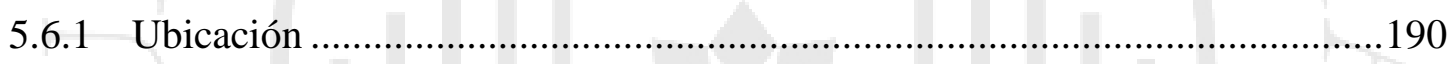

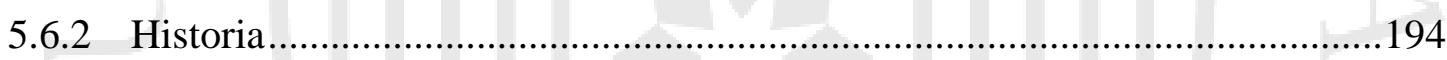

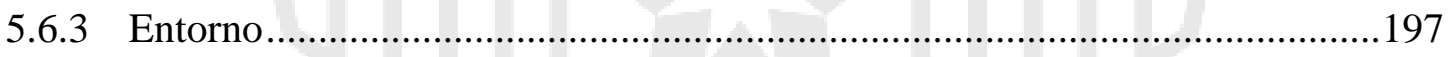

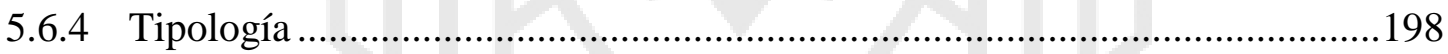

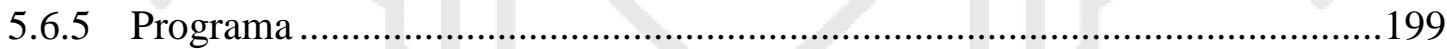

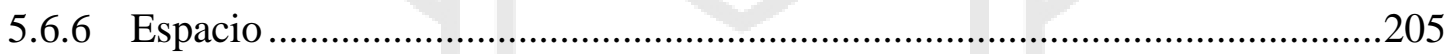

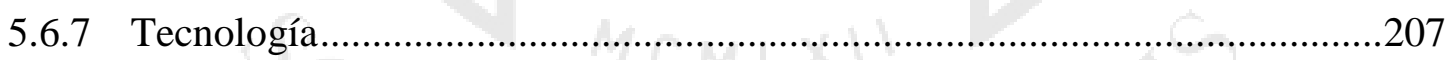

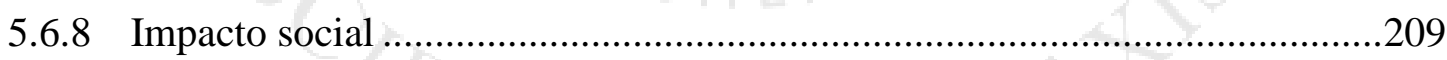

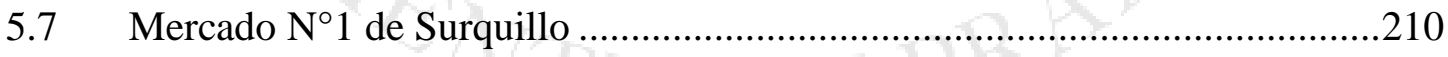

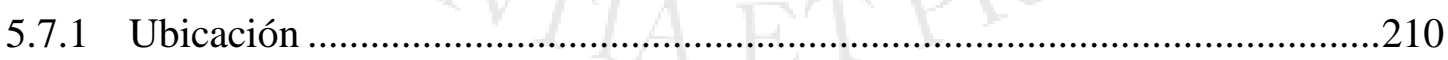

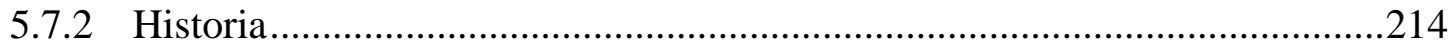

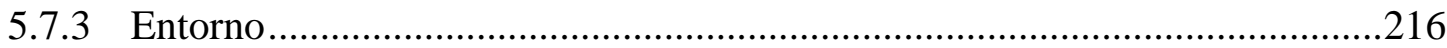

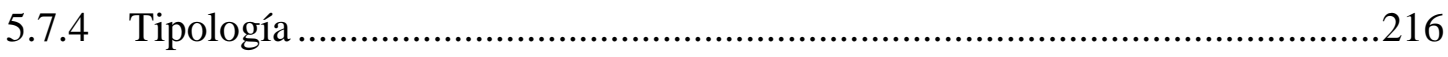

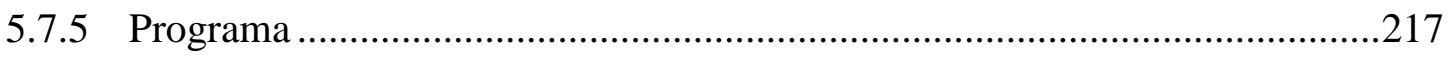

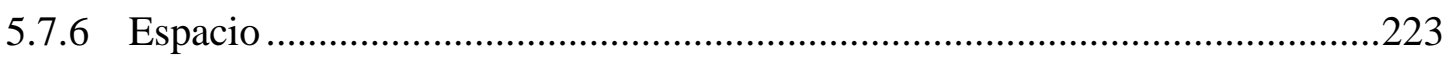

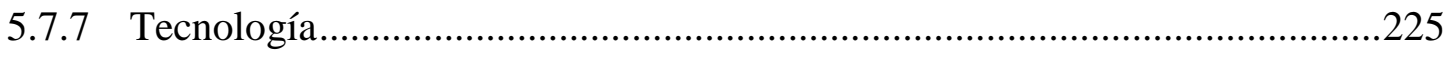

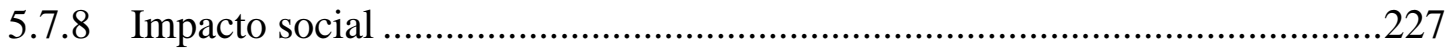




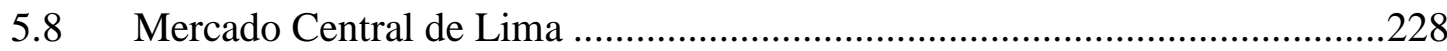

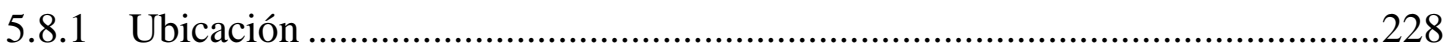

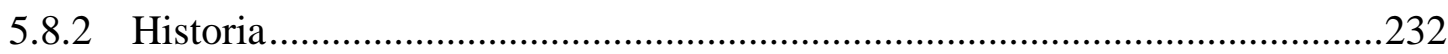

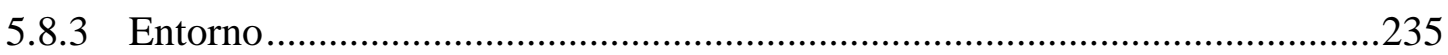

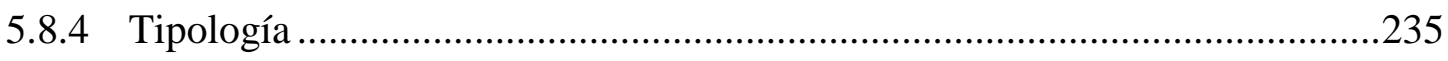

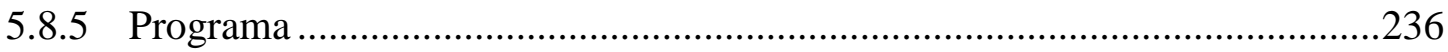

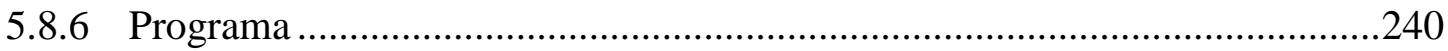

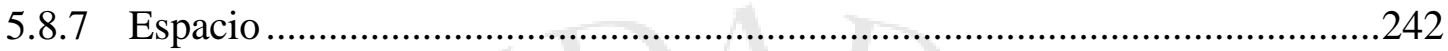

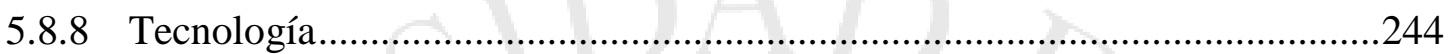

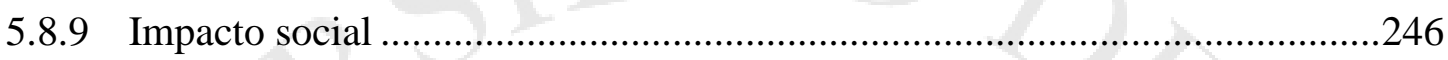

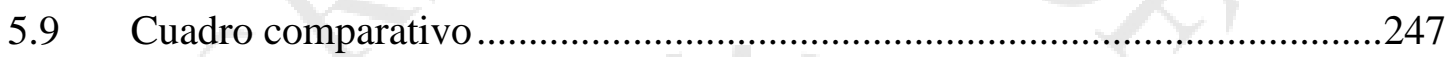

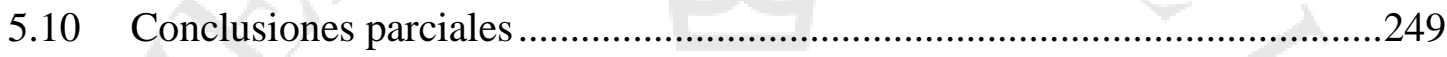

6 CAPÍTULO VI: MARCO CONTEXTUAL ..................................................252

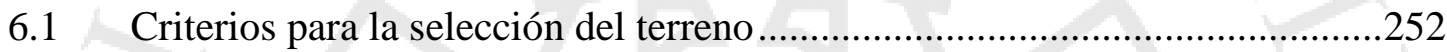

6.1.1 Motivos de selección de la Costa Verde ...................................................253

6.1.2 Motivos de la selección del distrito de San Isidro .......................................254

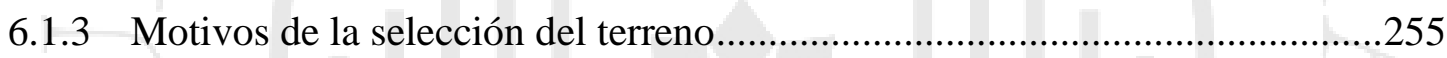

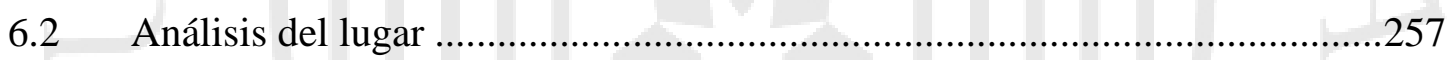

7 CAPÍTULO VII: CONCLUSIONES ..........................................................275

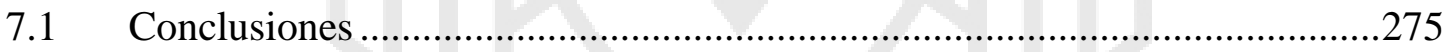

8 CAPÍTULO VIII: PROYECTO .....................................................................2278

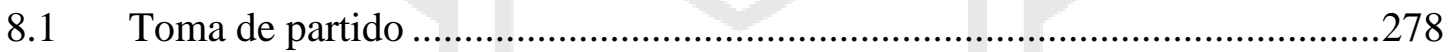

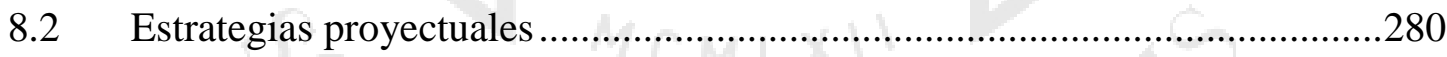

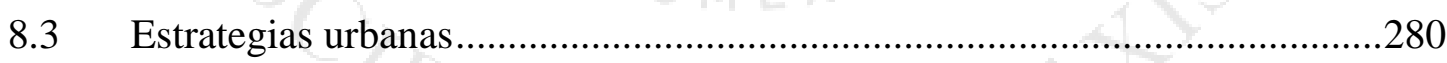

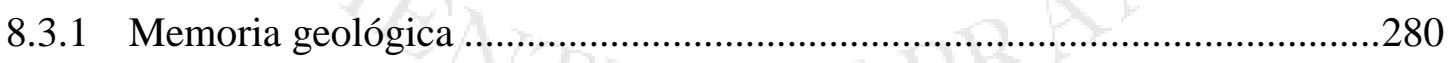

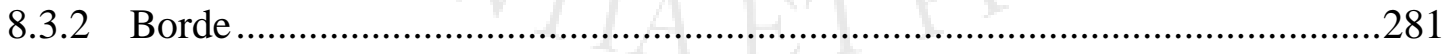

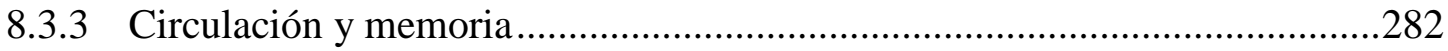

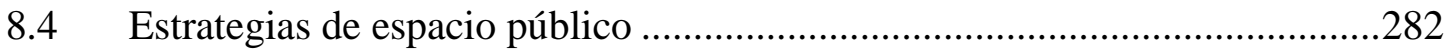

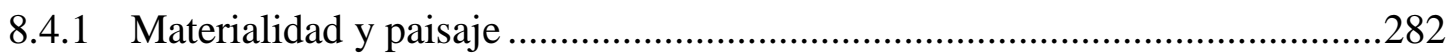

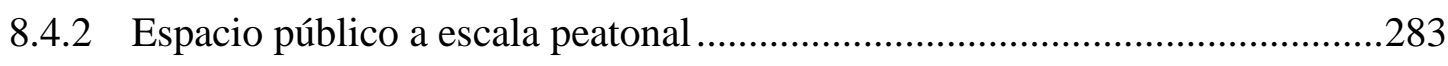

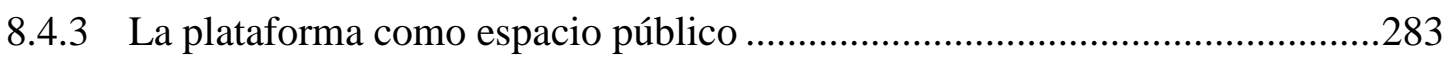

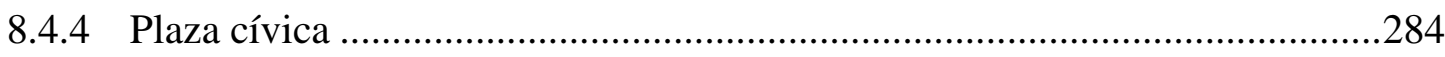

8.4.5 Intensidades / velocidades de recorrido ...................................................28 
8.4.6 Tratamiento topográfico en espacios públicos ............................................285

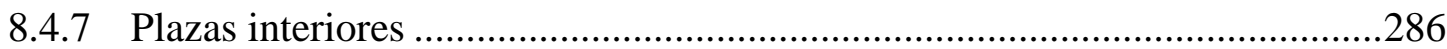

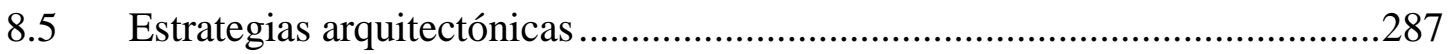

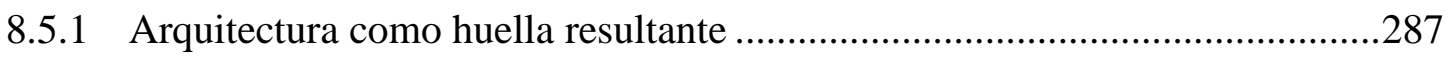

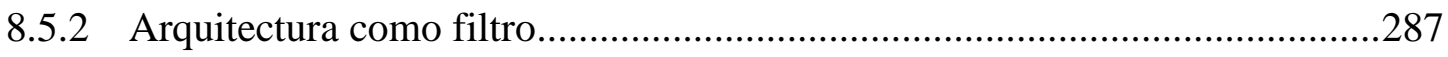

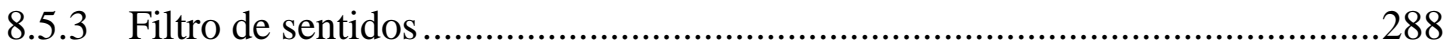

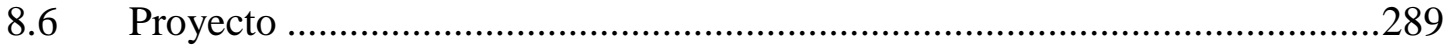

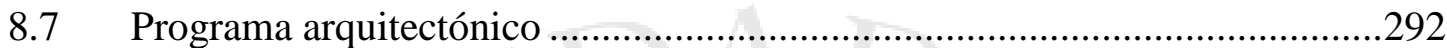

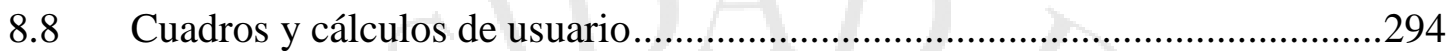

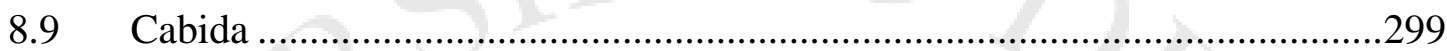

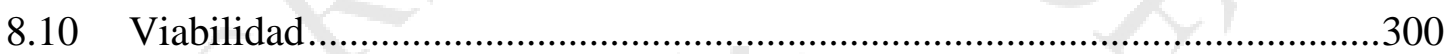

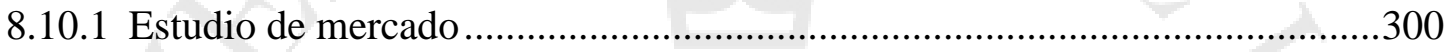

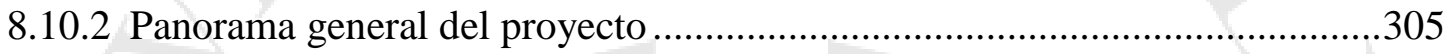

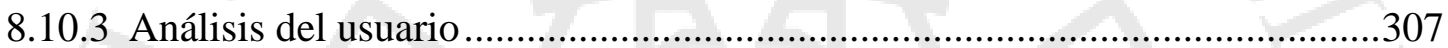

8.10.4 Oferta y demanda de estacionamiento y almacenes.....................................310

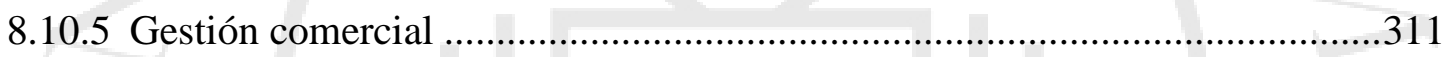

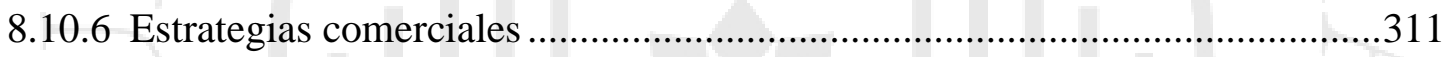

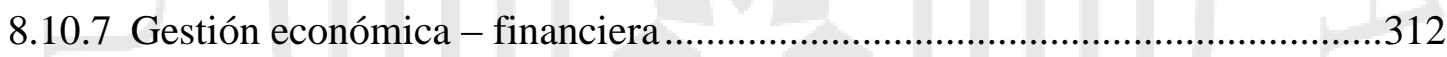

9 REFERENCIAS ........................................................................................................320

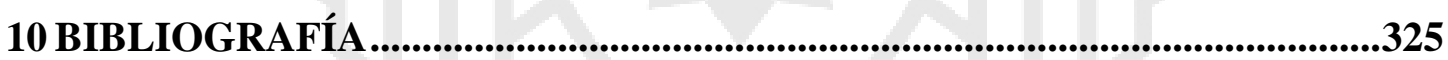




\section{ÍNDICE DE TABLAS}

Tabla 4.1 Comparación de los reglamentos de las distintas organizaciones reguladoras

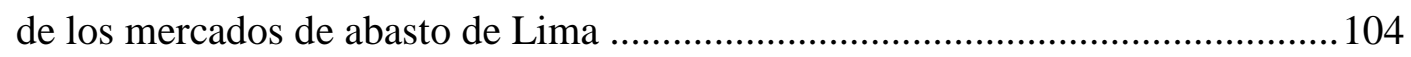

Tabla 4.2 Comparación del sistema de administración de Madrid y Lima ................... 106

Tabla 5.1 Cuadro de áreas del Mercado de Santa Caterina ........................................ 121

Tabla 5.2 Cuadro de áreas del Mercado de Barceloneta............................................ 140

Tabla 5.3 Cuadro de áreas del Mercado de San Miguel ............................................ 159

Tabla 5.4 Cuadro de áreas del Mercado de San Antón.............................................. 179

Tabla 5.5 Cuadro de áreas del Mercado Central de Florencia .....................................199

Tabla 5.6 Cuadro de áreas del Mercado $\mathrm{N}^{\circ} 1$ de Surquillo .........................................217

Tabla 5.7 Cuadro de áreas del Mercado Central de Lima ..........................................236

Tabla 8.1 Resumen de áreas del programa arquitectónico ........................................293

Tabla 8.2 Análisis y cálculo de usuario del proyecto ...............................................224

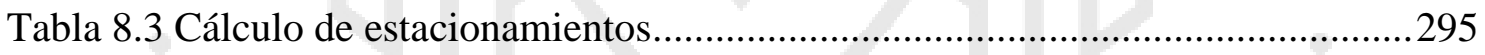

Tabla 8.4 Cálculo de dotación de servicios planta N01 y N02 …................................297

Tabla 8.5 Cálculo de dotación de servicios planta N03 y N04 …...............................298

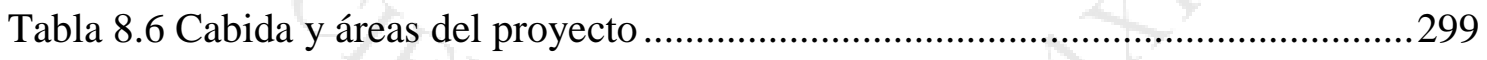

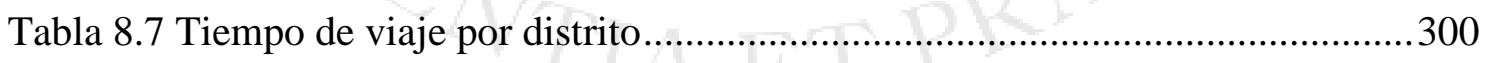

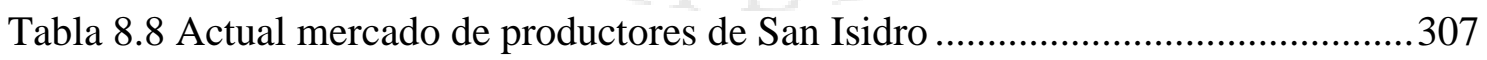

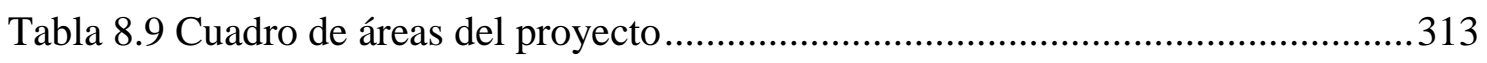

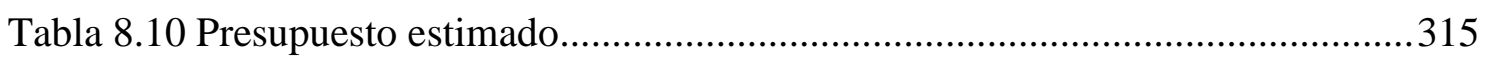

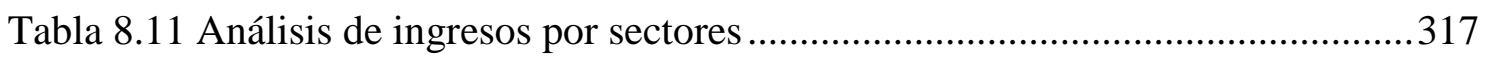

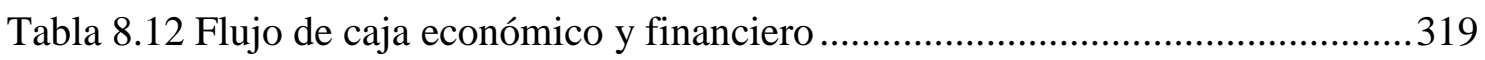




\section{ÍNDICE DE FIGURAS}

Figura 2.1 Mercado en plazoleta de San Blas, antiguamente en el mercado se realizaban

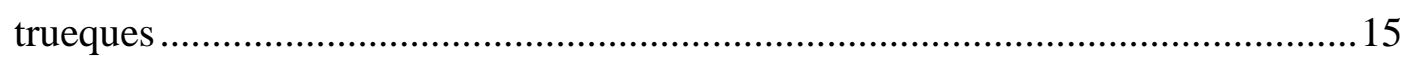

Figura 2.2 Mercado El Born, Barcelona. Actualmente centro cultural ........................ 18

Figura 2.3 Mercado El Born, Barcelona ................................................................. 19

Figura 2.4 Fachada principal del Mercado de San Antón, Madrid................................24

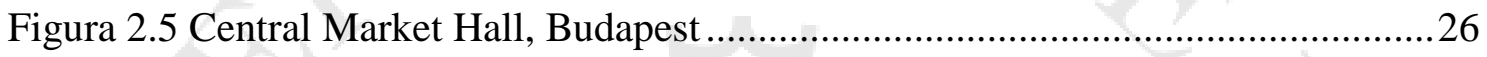

Figura 2.6 Aerofoto de la costa verde 1944, Lima .................................................. 38

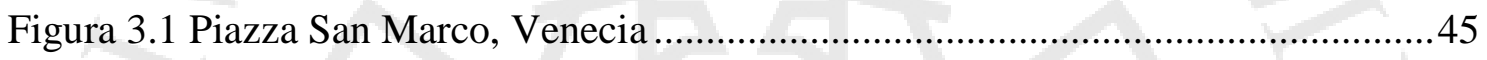

Figura 3.2 Cloud Gate de Sir Anish Kapoor en AT\&T Plaza, Chicago .........................46

Figura 3.3 Plaza Gran Mercado, Brujas. Espacio cívico .............................................51

Figura 3.4 Mercado en Piazza dei Signori, Verona .....................................................53

Figura 3.5 Espacio público, ciudad y arquitectura en Musee du Louvre, Paris..............55

Figura 3.6 Ciudad como lugar de encuentro. Grande Arche de la Defense, Paris .........57

Figura 3.7 Los sentidos y la escala en Chicago. Tratamiento de espacio público en

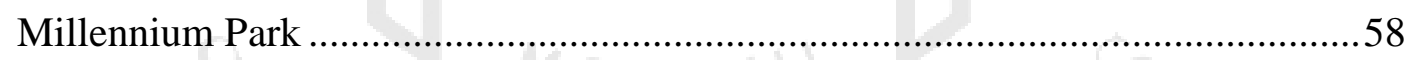

Figura 3.8 Dimensión humana en Venecia. Fondamenta Arsenale ...............................59

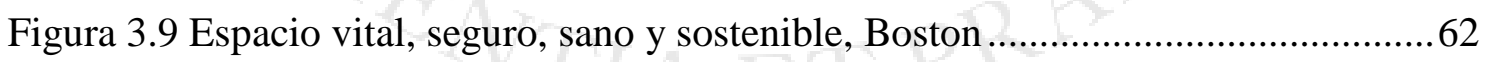

Figura 3.10 La ciudad a la altura de los ojos Marché de Noël des Champs-Elysées, Paris

Figura 3.11 La Rambla, Barcelona. Conectividad en los espacios públicos ..................66

Figura 3.12 Mercado como difusor gastronómico. TimeOut Market, Lisboa ................. 74

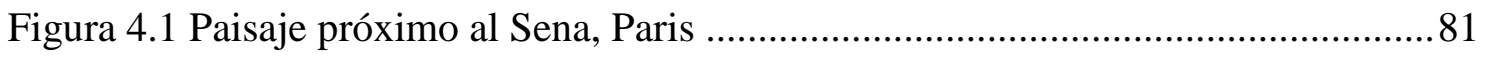

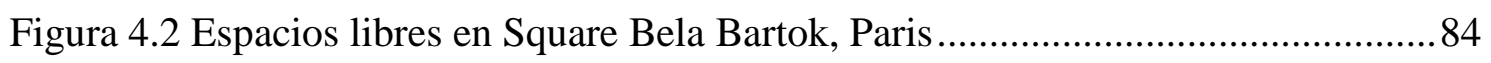


Figura 4.3 Mercado en Vía Cammeo Carlo Salomone, Pisa .85

Figura 4.4 Mercado La Boquería, Barcelona. .86

Figura 4.5 Scuola di Cucina Lorenzo de' Medici en el Mercado Central de Florencia, Florencia .88

Figura 4.6 Anfiteatro en graderías de Piazza di Michelangelo, Florencia..... .89

Figura 4.7 Restaurantes dentro del Mercado de San Antón, Madrid .90

Figura 4.8 Diagrama de la estructura administrativa de los mercados municipales de Madrid .94

Figura 4.9 Diagrama de la estructura administrativa del Mercado Municipal de San Isidro .98

Figura 5.1 Collage aérea del Mercado de Santa Caterina 111

Figura 5.2 Vista superior del Mercado de Santa Caterina 112

Figura 5.3 Foto composición de las excavaciones del Mercado de Santa Caterina ......116

Figura 5.4 Uso del espacio público del Mercado de Santa Caterina

Figura 5.5 Esquema de tipología según distribución de puestos 120

Figura 5.6 Flujos de los visitantes al interior del Mercado Santa Caterina 127

Figura 5.7 Fotocomposición de la maqueta del sistema constructivo de la cobertura.. 129

Figura 5.8 Actividades en la plaza del Mercado Santa Caterina 131

Figura 5.9 Ingreso al Mercado de la Barceloneta 132

Figura 5.10 Plaza y Mercado de la Barceloneta 136

Figura 5.11 Vista peatonal del Mercado de la Barceloneta 138

Figura 5.12 Esquema de tipología según distribución de puestos 139

Figura 5.13 Flujos de los visitantes al interior del Mercado de la Barceloneta 146

Figura 5.14 Momento de la instalación de la cobertura metálica del Mercado de la Barceloneta 148

Figura 5.15 Relación entre el mercado y la plaza 150 
Figura 5.16 Ingreso principal del Mercado de San Miguel

Figura 5.17 Relación del mercado con el entorno próximo.

Figura 5.18 Esquema de tipología según distribución de puestos 158

Figura 5.19 Interior del Mercado de San Miguel 165

Figura 5.20 Techo del Mercado de San Miguel. 167

Figura 5.21 Vista interior del Mercado de San Miguel 169

Figura 5.22 Interior del Mercado de San Antón 170

Figura 5.23 Mercado de San Antón relación con el exterior. 172

Figura 5.24 El Mercado de San Antón en el Barrio de Chueca 1945. 174

Figura 5.25 Terraza del Mercado de San Antón 175

Figura 5.26 Fachada principal del Mercado de San Antón. 177

Figura 5.27 Esquema de tipología según distribución de puestos 178

Figura 5.28 Interior del Mercado de San Antón 185

Figura 5.29 Claraboya de vidrio con paneles solares 187

Figura 5.30 Movimiento del Mercado de San Antón 189

Figura 5.31 Mercado Central de Florencia 190

Figura 5.32 Mercado Central de Florencia 194

Figura 5.33 Ingresos al Mercado Central de Florencia 197

Figura 5.34 Esquema de tipología según distribución de puestos 198

Figura 5.35 Interior del Mercado Central de Florencia 203

Figura 5.36 Interior del Mercado Central de Florencia 207

Figura 5.37 Espacio público del Mercado Central de Florencia. 209

Figura 5.38 Mercado $\mathrm{N}^{\circ} 1$ de Surquillo 210

Figura 5.39 Contexto del Mercado $N^{\circ} 1$ de Surquillo 212

Figura 5.40 Mercado $\mathrm{N}^{\circ} 1$ Surquillo durante su construcción 214 
Figura 5.41 Esquema de tipología según distribución de puestos .216

Figura 5.42 Interior del Mercado $\mathrm{N}^{\mathrm{o}} 1$ de Surquillo .221

Figura 5.43 Circulación vertical del Mercado $\mathrm{N}^{\circ} 1$ de Surquillo .223

Figura 5.44 Construcción de la estructura de la cúpula del Mercado $\mathrm{N}^{\circ} 1$ de Surquillo

Figura 5.45 Andrew Zimmern y Gastón Acurio filmando en el Mercado $\mathrm{N}^{\mathrm{o}} 1$ de Surquillo.

Figura 5.46 Vista aérea del Mercado Central de Lima .228

Figura 5.47 Exterior del Mercado Central de Lima... .230

Figura 5.48 Mercado Central de Lima 232

Figura 5.49 Esquema de tipología según distribución de puestos 235

Figura 5.50 Interior del Mercado Central de Lima.... 244

Figura 5.51 Apunte del Mercado Central de Lima 246

Figura 6.1 Conjunto de aerofotografías de Lima, hecho para el Ministerio de Agricultura, 1975 252

Figura 6.2 Aerofotografía de la Costa Verde. Vista San Isidro y Miraflores, Lima 1964 .254

Figura 6.3 Aerofotografía de San Isidro, Lima 1964 .255

Figura 6.4 Aerofotografía del terreno a intervenir, Lima 1956 .256

Figura 8.1 Esquema de toma de partido 279

Figura 8.2 Estrategia - Memoria del paisaje 280

Figura 8.3 Estrategia - Tratamientos de borde 281

Figura 8.4 Estrategia - Recorrido histórico .282

Figura 8.5 Estrategia - Materialidad y paisaje .282

Figura 8.6 Estrategia - Escala en plazas 283

Figura 8.7 Estrategia - Espacio público como plataforma 283 


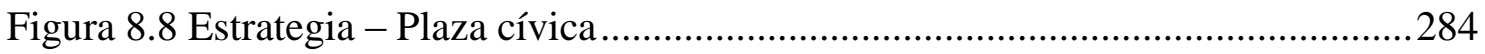

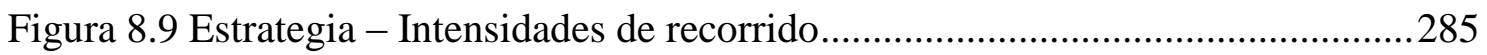

Figura 8.10 Estrategia - Intensidades de recorrido...................................................2. 285

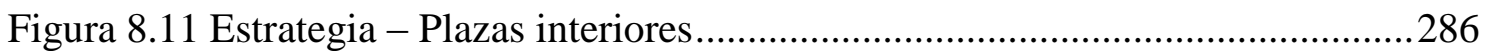

Figura 8.12 Estrategia - Arquitectura como huella resultante...................................287

Figura 8.13 Estrategia - Arquitectura como filtro ................................................28

Figura 8.14 Estrategia - Arquitectura como filtro ...............................................28

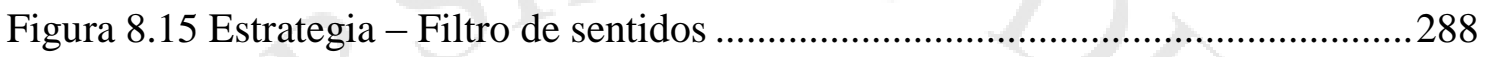

Figura 8.16 Zona de influencia cercana al Mercado de Productores de San Isidro, Lima .304

Figura 8.17 Zona de influencia lejana al Mercado de Productores de San Isidro, Lima 


\section{INTRODUCCIÓN}

"Public markets can become the heart and soul of a community, its common ground, a place where people easily interact, alive with social and economic activity."1

Project for Public Spaces

Desde inicios de la historia y junto con el proceso de civilización se ha ido desarrollando la idea del mercado, la cual ha tenido un periodo largo de evolución. Su origen se remite a un espacio de carácter efímero y de procedencia espontánea, pasando de ser la plaza pública, determinante para la configuración de ciudades, hasta consolidarse como equipamiento y convertirse en lo que hoy en día conocemos como mercado de abasto.

Si bien en países desarrollados el mercado tiene una tendencia de declive progresivo, en nuestro contexto el vínculo entre la sociedad y el mercado aún se mantiene en pie. Esto pone en manifiesto, que el mercado en una sociedad como la que habitamos resulta una oportunidad de valor para rescatar su relevancia social y cultural que ha trascendido en el tiempo.

El mercado se concibe durante años, como espacio de intercambio, que da pie a las relaciones sociales y es capaz de mostrar las riquezas de un territorio determinado. Es evidente la ausencia de un referente de modelo sostenible, que dote de reconocimiento y connotación positiva a los mercados del Perú, al igual que potencie la conexión entre el productor y el consumidor final, pudiendo ser este último local o turista. Un modelo de mercado que acorte brechas sociales; que funcione cual plaza cívica, permitiendo la congregación de la ciudadanía; que nos ate a nuestras raíces y al mismo tiempo nos permita conectarnos con el mundo.

\footnotetext{
${ }^{1}$ (Project for Public Spaces, s.f.)
} 
La biodiversidad de productos, el valor gastronómico y el interés de promoción turística que el país viene desarrollando es un indicador que, en parte, no va acorde con la inexistencia de un mercado símbolo, capaz de fusionar y dar a conocer, en distintos niveles, la memoria, la identidad, la calidad y la pluriculturalidad que se ha venido conservando a lo largo de nuestra historia.

Por ende, la siguiente investigación trata de entender el comportamiento y repercusión de los mercados en las diferentes ciudades, y como la intervención en el Mercado de Productores de San Isidro, podría contribuir en la renovación del entorno próximo mediante su tratamiento como espacio cívico. 


\section{CAPÍTULO I: GENERALIDADES}

\subsection{Tema}

La siguiente investigación tiene como tema de estudio el mercado de abasto como herramienta de desarrollo comercial, cultural y urbano. En otros términos, se busca darle un valor agregado al mercado, como reactivador y difusor de cultura, arte y gastronomía, así como espacio cívico que potencie la interacción social. De esta manera se propone un espacio que involucre al productor con el turista, donde intervengan actores locales e internacionales, y que la cultura, la gastronomía y la memoria del lugar, complementen la función básica de abastecimiento que cumplen los mercados hoy en día.

Asimismo, se plantea que el mercado integre en varias escalas aspectos socioculturales de nuestro contexto. Desde permitir la interacción de los vecinos en un espacio de encuentro, hasta impulsar el vínculo entre los peruanos y su diversidad cultural. Por ende, se propone incluir establecimientos gourmet propios de la gastronomía peruana, espacios para la difusión de la cultura, y lugares de encuentro que involucren áreas verdes, espacios públicos y de ocio; todos estos debidamente conectados a su entorno.

Con respecto al lugar, el mercado se ubica en un punto céntrico y estratégico de la ciudad de Lima, particularmente en el actual Mercado Municipal de San Isidro (Ex Productores).

Actualmente, dicho mercado es resultante de un pasado muy ligado a la venta de productos de calidad, que hasta el día de hoy sirven de ejemplo y abastecimiento a los vecinos de San Isidro. Sin embargo, este espacio que desde un principio involucró a la gente y a la comida en un contexto con una identidad determinada, está perdiendo protagonismo en el tejido urbano de la ciudad, en lugar de tratarse de un espacio donde las personas se encuentren y vivan una experiencia diferente vinculada a su propia memoria colectiva. 


\subsection{Justificación del tema}

Si nos remitimos al origen de las ciudades, la verdadera esencia y su razón de ser se deriva de la comida. Alrededor del año 8,000 A.C. el sedentarismo se convierte en el primer paso del origen de las ciudades. Es decir, el hombre originalmente dependiente de la caza, recolección y búsqueda de refugio, al cultivar su propio alimento, logra permanecer en un lugar y con ello empiezan a aparecer los primeros asentamientos.

Esta realidad nos lleva a decir que, a lo largo de la historia, la urbe se ha visto vinculada con la comida, ya sea porque nos remite a su origen o porque debido al excedente generado de la agricultura, nace uno de sus aspectos más importantes: el intercambio.

Este trueque iniciado en un espacio espontáneo permitió una interrelación entre personas, afianzando las relaciones sociales y dando pie a la difusión de productos y conocimientos. Por consiguiente, el comercio dio paso al establecimiento de un lugar propio, donde el encuentro, la relación y la difusión se desarrollaron: la plaza, el mercado.

A pesar de que esta tipología perdura en la actualidad, en algunos casos, ha perdido su valor original como articulador social, difusor de conocimientos, espacio cívico, entre otros; y en otras oportunidades se ha visto reemplazado por otros formatos comerciales. No obstante, en Lima el valor cultural y gastronómico de los mercados, permite estrechar el vínculo de estos con la sociedad.

Si bien el mercado es el punto de encuentro de las primeras grandes ciudades, y el que ha cumplido un papel determinante para el desarrollo de la actividad social y comercial ¿Por qué no involucrar su valor esencial de espacio de encuentro e intercambio, con el valor gastronómico y cultural de las ciudades actuales?

A lo largo del tiempo, el Perú ha conservado una cultura gastronómica que deriva de la historia de nuestros antepasados y de la gran diversidad de productos que se cultivan en nuestro territorio.

En los últimos años, nuestra gastronomía ha ganado elevada importancia y reconocimiento a nivel nacional e internacional. Este legado, no tendría que quedar reflejado solo en el ámbito culinario, sino que además se debería desarrollar en lugares 
que concentren y reflejen nuestra identidad cultural y gastronómica, permitiendo involucrar la comida con aquellos actores que le dieron origen: la gente.

Sin embargo, existe una problemática evidente, y es que hay gran cantidad de mercados de abastos, locales, municipales, regionales en el Perú y no se puede percibir un patrón de calidad en ellos. Esto resulta uno de los grandes problemas que aborda el tema: la higiene y, la condición de la infraestructura.

Es lamentable que, en nuestro contexto, el término mercado, no está asociado a la higiene, a lo saludable, a la calidad, sino por el contrario tiene una connotación más vinculada a la suciedad, al desorden, a la inseguridad y a la informalidad. Por lo tanto, su función como articulador de la identidad del lugar y su gente; su carácter sociocultural; y su relevancia demostrada desde el origen de las ciudades, se ve opacada por la propia imagen que hoy transmiten los mercados de nuestra ciudad y no tomando provecho de la conexión que aún existe con este equipamiento.

\subsection{Planteamiento del problema}

\subsubsection{Problemas principales}

- ¿Qué modelo de mercado sería vigente para la sociedad actual, caracterizada por el consumismo y la globalización?

- ¿Qué enfoque hace falta en los mercados, para potenciar su uso como espacio de intercambio?

\subsubsection{Problemas derivados}

- ¿Cuál es el vínculo entre el espacio cívico y el mercado/plaza de abasto?

- ¿ ¿Hasta qué punto los mercados pueden cumplir el rol de integrador social y difusor de nuestra cultura?

- ¿Cuál es la importancia de la memoria colectiva y el lugar en los mercados? 
- ¿Qué nuevos conceptos de mercados existen, que involucren aspectos complementarios como el turismo, la gastronomía, la ecología, la educación, la cultura y la memoria?

\subsection{Objetivos de la investigación}

\subsubsection{Objetivos generales}

- La siguiente investigación tiene como finalidad mostrar y describir el valor agregado que han proporcionado los mercados a las ciudades, en diversos periodos de la historia; tomando en cuenta la importancia para los seres humanos, la vida en comunidad, la sociedad, la economía, la educación, el desarrollo y el futuro sostenible.

- Asimismo, pretende investigar la situación actual de mercados de Lima y el mundo, con el fin de evaluar su papel en casos de estudio. Así, en base a referentes identificar criterios, para que estos puedan ser aplicados en un proyecto dentro de nuestro contexto.

- Por otro lado, reconocer el vínculo entre el lugar y su identidad y como esta forma parte de la memoria colectiva.

- Por último, justificar el nuevo papel que el mercado contemporáneo debe cumplir en la ciudad, que va más allá de la función de abastecimiento.

\subsubsection{Objetivos específicos}

- Investigar los antecedentes de los mercados, específicamente el origen del mismo y su papel en las ciudades, de la misma manera evaluar el desarrollo de los mercados en nuestro contexto. Dar a conocer el valor gastronómico peruano y su repercusión en la ciudad. Además de entender los nuevos modelos de mercado para definir la propuesta.

- Ver la relación entre el mercado y el espacio público y entender las dimensiones que este presenta. De la misma manera conocer la importancia de la identidad en la arquitectura, así como también la 
memoria del paisaje y el lugar. Por otro lado, relacionar el espacio público con equipamientos culturales que le doten de valor agregado.

- Buscar y catalogar los tipos de mercados existentes, según los distintos organismos públicos y privados encargados de estas infraestructuras. Por otro lado, evaluar los requisitos de la institución, tomando como ejemplo el caso de Madrid y analizar el mismo aspecto en el Perú, así identificar una posible problemática derivada del mismo.

- Analizar y evaluar casos análogos, en base a una comparación de aspectos formales, funcionales y sustanciales. Involucrando variables ligadas al ámbito arquitectónico, urbano, sociocultural, gastronómico e histórico.

- Definir la importancia de los mercados como herramienta para la configuración urbana, analizar e identificar la relevancia del lugar a intervenir, y así poder evaluar e involucrar su identidad, a favor de la memoria colectiva.

\subsection{Supuesto básico de la investigación}

$\mathrm{Si}$ se involucraran más actividades complementarias de tipo cultural, social y gastronómico derivadas de la identidad del lugar, entonces los mercados contemporáneos podrían complementar su actual valor social y cultural trascendente en el tiempo.

\subsection{Alcances y limitaciones}

\subsubsection{De la investigación}

\section{- Tipología}

La presente investigación será planteada de tipo descriptivo e histórico. Iniciará con una mirada retrospectiva del origen del mercado de abasto y su relevancia para el desarrollo de las ciudades. Del mismo modo, se explicarán las fases de evolución, tanto en el aspecto de la función que desempeñan los mercados, como su incidencia en la sociedad. 
Los hechos expuestos serán interpretados para extraer ideas en relación a la esencia de los mercados y cómo estas pueden repotenciar un nuevo modelo que se diferencie de otros locales de abastecimiento.

En cuanto al punto de vista descriptivo, la investigación busca vincular y describir la relación del mercado con el espacio cívico, el valor de la identidad y la memoria del lugar; sus principales problemáticas en el ámbito internacional y su situación actual en el Perú, además se tomará en cuenta el aspecto normativo al momento de analizar su respectiva administración y regulación. Por último, mediante el análisis de casos análogos, mercados contemporáneos que involucren aspectos complementarios, se buscará determinar la influencia en las ciudades donde se desarrollaron.

\subsubsection{Metodología}

\section{- Forma de recopilación de la información}

Para la investigación, se tomarán referentes de fuentes tanto primarias como secundarias.

Respecto a fuentes de primera mano, estas serán utilizadas durante el tiempo de estudio tomando como base testimonios, entrevistas y fotografías de los autores, así como reportajes, crónicas y experiencias de terceros.

Por otro lado, en cuanto a fuentes secundarias, se tomarán datos de artículos científicos (papers), revistas indexadas y de divulgación, libros, tesis, conferencias y documentales.

\section{- Forma de análisis de la información}

La investigación desarrollará el tema desde cuatro enfoques: el Marco Referencial, el Marco Teórico, el Marco Operativo y el Marco Contextual.

Se iniciará desarrollando el Marco Referencial, explicando el origen de las ciudades y cómo el mercado corresponde desde su inicio, un elemento esencial en ellas con el fin de comprender su repercusión en el ámbito sociocultural, gastronómico, comercial y urbano, en distintos periodos de la historia. Del mismo modo, se verá la 
importancia de la comida en el ámbito gastronómico del Perú, explicando su origen y la oportunidad actual que significa el desarrollo de este campo. Además, se incluirá un análisis de la situación actual de determinados mercados representativos de la ciudad de Lima.

En cuanto al desarrollo del Marco Teórico, se iniciará con la relación del entre la ciudad, el espacio y el espacio cívico y como este está presente en el mercado. Por otro lado, se hablará de la relación entre la identidad del lugar, la memoria del paisaje y el espacio arquitectónico.

En el marco normativo se hará hincapié en la definición del concepto de mercado y se identificará las diferentes categorías en las que se pueden clasificar los mercados del Perú, en base a los organismos encargados de su regulación y administración. Asimismo, se aclarará el papel que estos deben desempeñar, los requisitos necesarios de cada institución, para finalmente determinar el tipo de mercado a desarrollar, los alcances del mismo y el público objetivo. Por otro lado, se identificará y analizará la problemática actual de los mercados, en base a los requisitos de la institución, principalmente en la ciudad de Lima.

En lo que respecta al Marco Operativo, se identificarán casos análogos para un mejor entendimiento del funcionamiento y repercusión de los mercados. Con tal objetivo, se hará un análisis en base a referentes extranjeros como el Mercado de Santa Caterina, el Mercado de la Barceloneta, el Mercado de San Miguel, el Mercado de San Antón y el Mercado Central de Florencia, así como también, se analizarán dos mercados de modelo tradicional, que significan un ejemplo importante en nuestro contexto, debido a su diseño y relevancia histórica en la ciudad: el Mercado $\mathrm{N}^{\mathrm{o}} 1$ de Surquillo y el Mercado Central de Lima. Será conveniente evaluarlos en relación a la importancia y repercusión en distintos ámbitos a tratar: sociocultural, gastronómico, comercial y urbano. Asimismo, se analizarán los programas, su relación con el entorno y aporte arquitectónico al contexto en que se encuentran.

Por último, en el Marco Contextual se evaluará la capacidad y relevancia del terreno, realizando un análisis urbano. Asimismo, se verá el valor de la memoria colectiva respecto a este lugar y el vínculo que esta genera en sus habitantes. Estas ideas se contextualizarán mediante un análisis del lugar y de las proximidades del Mercado de San Isidro. En este estudio, se incluirán fuentes de primera mano las cuales serán 
obtenidas mediante la recopilación de datos de entrevistas y experiencias de los vecinos de la zona.

\section{- Forma de presentación}

La estructura de la investigación cuenta con una introducción, ocho capítulos que comprenden: Generalidades, Marco Referencial, Marco Teórico, Marco Normativo, Marco Operativo, Marco Contextual, Conclusiones y finalmente, el Capítulo del Proyecto con el desarrollo de la propuesta arquitectónica y su viabilidad.

Además de incluir índices, referencias y anexos, se incluirán imágenes, tablas y textos que acompañen a la investigación. Asimismo, se desarrollarán esquemas y diagramas de síntesis que ayuden a la compresión de los análisis a realizar. En cuanto a la referencias, serán presentadas en formato APA.

\subsection{Del proyecto}

\subsubsection{Alcances}

- El proyecto se desarrolla en el distrito de San Isidro, específicamente en el actual Mercado Municipal de San Isidro (Ex Productores).

- Se realizará un análisis urbano del lugar a intervenir, para entender la configuración del contexto inmediato.

- Se recopilará la historia del Mercado Municipal de San Isidro mediante fuentes escritas, experiencias y entrevistas, con la finalidad de analizar y repotenciar parte de la memoria colectiva del lugar.

- La propuesta incluirá el terreno contiguo, perteneciente a la Municipalidad de San isidro, abarcará la vía peatonal que une el malecón e integrará el espacio público colindante. Es relevante hacer mención, ya que se incluirán en la propuesta pese a no formar parte del terreno.

- Si bien la propuesta considera la conexión a nivel urbano hacia el malecón de Miraflores, el de San Isidro y la conexión vertical de la Costa Verde, se debe hacer mención que el desarrollo a nivel proyecto arquitectónico será trabajado solo en los volúmenes y plazas indicadas a continuación. 
- Si bien el proyecto contempla 5 bloques y un tratamiento de espacio público que se integra al paisaje, se desarrollar a nivel proyecto en los tres bloques centrales de la propuesta y sus respectivas plazas anexas.

- La propuesta se desarrollará a nivel de proyecto, debidamente trabajado con reglamentos y parámetros vigentes de la Municipalidad de San Isidro y entidades pertinentes a la Costa Verde.

\subsubsection{Limitaciones}

- Las cifras que se utilicen como apoyo, serán en base a referencias ya existentes.

- Debido a limitaciones como la lejanía y la cantidad de recursos, el análisis y estudio de algunos mercados nacionales e internacionales, serán en base a fuentes e investigaciones ya realizadas.

- El proyecto no contemplará unos estudios de suelos ni de impacto ambiental y vial. 


\section{CAPÍTULO II: MARCO REFERENCIAL}

\subsection{Los mercados y la ciudad}

\subsubsection{La evolución del intercambio}

- Origen y definición del intercambio

El origen de las ciudades radica a una serie de procesos que involucra al hombre con su entorno, tanto natural como social. El autor Gordon Childe, sostiene que el suceso previo a la configuración de ciudades fue la agricultura. Ya que, debido a esta actividad, el hombre nómada, hace alrededor 10,000 años, fue convirtiéndose a sedentario, dando paso a la creación de los primeros asentamientos. (Childe, 1992)

La agricultura en su etapa inicial tuvo como objetivo la subsistencia de la población, pero a medida que se fueron desarrollando nuevas técnicas, herramientas y tecnología, se obtuvo el excedente que dio paso a la división del trabajo. Es decir, la población empieza a especializarse en otras actividades, una de las cuales sería el intercambio. Esta actividad que dio pie a la organización económica y de recursos va a permitir que la ciudad reparta el trabajo y se abastezca de los recursos de la comunidad.

El intercambio como actividad va a tomar un papel esencial en la ciudad, capaz de desarrollar económicamente y tener un vínculo de dependencia hacia los núcleos urbanos.

\section{- Función y valor del intercambio}

El intercambio en un inicio, de manera primitiva, tuvo como objetivo el abastecimiento de productos para la subsistencia. Este canje, también conocida como trueque, tiene como "definición tradicional como "una transacción en la cual los objetos se intercambian directamente uno contra otro, sin uso del dinero"." (Ferraro, 2002) 
Esta operación comercial radica su importancia en que guarda una relación social más allá de la económica. Ya que más allá de existir un intercambio comercial, económico, genera el intercambio entre personas, comunidades y hasta culturas distintas, dando origen a una cohesión entre grupos sociales. En otras palabras, el intercambio guarda como origen y esencia, no solo el canje o truque entre productos permitiendo un abastecimiento a la ciudad, sino que su valor social se rescata en la difusión e intercambio social y cultural.

"La ciudad vive cada día del intercambio, es la plaza, es el mercado. Intercambio de bienes y de informaciones. El intercambio supone paz y reglas, convivencia y pautas informales que regulen la vida colectiva. La ciudad es comercio y cultura, comercio de ideas y cultura de la producción de servicios para los otros. Comercio y ciudad son tan indisolubles como campo y naturaleza. La ciudad existe como encuentro de flujos." (Borja, 2003, pp. 27-28)

\section{- El tianguis prehispánico}

Cuando hablamos del origen del mercado como espacio físico debemos remitir a los orígenes de los mercados o plataformas de intercambio en ámbitos próximos a nuestro contexto. Uno de los caso cercanos dentro de la cultura hispanoamericana es el tianguis o mercado en el México prehispánico, que "era el centro irradiador de comunicación y trueque...aquella plaza dedicaba a los intercambios....“(Villegas, 2010, p. 93)

Como se definió anteriormente el intercambio fue de carácter social, político y comercial y en el contexto mesoamericano no fue la excepción, ya que el tianguis (espacio físico de intercambio) se vio definido por el encuentro. En este lugar, la plaza, se desarrollaron actividades y encuentros sociales, comerciales políticos y religiosos. Lo que permitió adquirir un valor sagrado para sus pobladores, ya que era el único lugar concordado para el trueque, por lo que se convirtió en un espacio de gran repercusión para la ciudad. "Al momento de la Conquista y durante todo el primer siglo de la Colonia los testimonios españoles fluyen e inmortalizan la grandeza, la muchedumbre, los productos y la importancia que tenía el tianguis para los indígenas.“ (Villegas, 2010, p. 93) 
Ante la percepción que tuvieron los españoles respecto a este espacio "sagrado" con gran valor social y urbano tomaron medidas adaptadas a este centro de importancia en la ciudad, que en parte involucró no solo al poder político sino también religioso. "La iglesia, por su parte, no pasó por alto la ventaja de tener reunidas a tantas personas; de modo que plantó y estableció la catedral junto al mercado (como en Europa) y reemplazó las reliquias prehispánicas erguidas en el momoxtli del tianguis por un predicador.“ (Villegas, 2010, p. 93) Este hecho refleja la importancia que tuvo el tianguis en la ciudad como espacio de uso primario en la cultura mesoamericana, donde el encuentro, la interrelación y el intercambio rigen el modo de vida de los pobladores.

Al igual que sucedió en otras culturas, el tianguis se convirtió en el centro de cohesión social, económica, religiosa. Es por ello que fue considerado punto estratégico en la conquista española al tener como certeza que cuando se controle el mercado "era toda la ciudad tomada y su fuerza y esperanza de los indios tenían allí" (Cortés, 1770, p. 240). Su influencia como espacio de identidad e intercambio en una población permitió desarrollar en la Colonia una ciudad a partir de este punto y aunque se intentó implantar un nuevo sistema, su importancia se mantuvo como "centro de donde irradie la comunicación, estableciendo a la vez relaciones públicas, económicas, políticas y religiosas.“(Villegas, 2010, p. 100)

\section{- Reciprocidad e intercambio}

Al igual que en el ámbito mesoamericano, en nuestro contexto, el intercambio está presente en la cultura andina desde la conexión que tiene esta, con la naturaleza y los principios fundamentales entre las comunidades. En este ámbito no solo se emplea el término intercambio, sino que se involucra la reciprocidad o truki, que se relaciona con la producción comunitaria, donde la redistribución y el intercambio intervienen, para el manejo del excedente. Es decir "Si hay un excedente en la producción, éste es redistribuido en el contexto de las necesidades materiales, los festivales y los rituales. Compartir los productos da prestigio y, por lo tanto, es una forma de redistribución (ampliada) de los productos fuera del ciclo económico, generado por las relaciones de reciprocidad y parentesco y retroalimentado por la vida espiritual.” (Delgado, San Martín, \& Torrico, n.d.) 
El intercambio y la reciprocidad se convierten, en el ámbito andino, no sólo en principios fundamentales en la organización económica, sino que fortalece los vínculos sociales entre la comunidad y hacia otros grupos sociales. Este principio y permitió relacionar social y culturalmente grupos sociales mediante el canje de productos, conocimientos, herramientas, textiles, etc.

En el ámbito andino el intercambio se concibe en otra dimensión, ya que esta cumple un principio fundamental dentro de la cosmovisión andina y por ende representa un valor infaltable dentro de la comunidad. Su visión respecto al intercambio de información y conocimientos va más allá de la interrelación social que existe, ya que asimismo encuentran ese valor en la naturaleza, en los productos y en la biodiversidad. "sino todo lo que en la naturaleza coexiste con ellos: los ríos, los cerros, las piedras, las estrellas, las plantas, los animales, etc. Bajo esta concepción todos los integrantes del Ayllu, animados o inanimados, son equivalentes, iguales y equitativos, se interrelacionan entre sí y se transmiten sus saberes." (De la Torre \& Sandoval Peralta, 2004, p. 22)

Al igual que en el ámbito mesoamericano, la cultura andina desarrollo la actividad del intercambio en espacios, plazas, donde ocurría este intercambio. Ferias temporales y festividades importantes, acompañaban esta actividad donde las distintas clases sociales se involucraban y relacionaban, para el intercambio de productos, objetos y textiles, pero en mayor importancia, cultura, información y técnicas.

Figura 2.1

Mercado en plazoleta de San Blas, antiguamente en el mercado se realizaban trueques

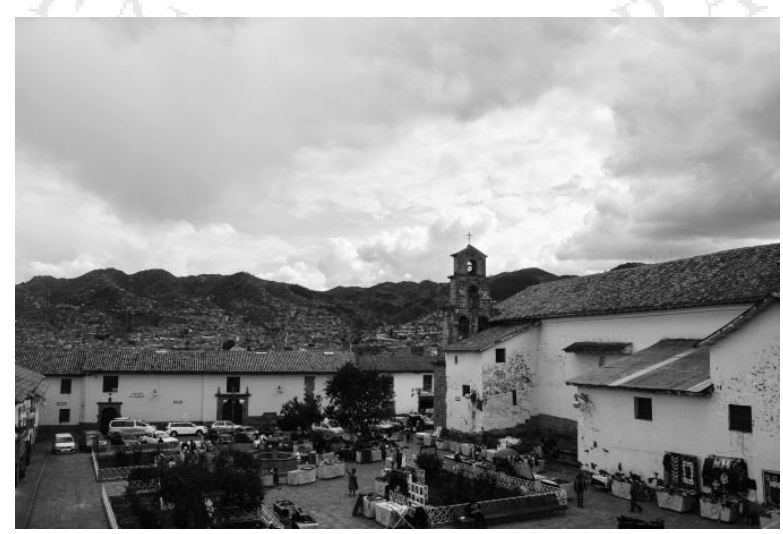

Fuente: fotografía propia 


\subsubsection{El mercado y la sociedad}

Existen diversas fuentes que reiteran la importancia y la fuerza modeladora que los mercados significaron para las ciudades y para las personas desde tiempos muy lejanos.

Desde los inicios de la humanidad el hombre se ha visto obligado a subsistir, en un comienzo de manera autosuficiente, para luego pasar a la negociación o comercialización bajo diversas técnicas y modalidades. Por ellos, con la creatividad que lo caracteriza, el hombre, pone en marcha estrategias para conseguir sus objetivos. Parte de sus necesidades se han visto abastecidas por medios de intercambio social, es así como el mercado resulta ser una de estas estrategias para el desarrollo de la sociedad.

"Lo que le da al mercado un lugar permanente en la ciudad es la existencia de una población bastante grande que ofrezca una vida satisfactoria a mercaderes con relaciones distantes y costosos artículos de consumo, y con una productividad local suficiente que permita que el excedente de productos urbanos sea ofrecido en venta al público en general.” (Murford, 2014, p. 54)

Vemos entonces como los mercados fueron naciendo por necesidades de abastecer a los pueblos y ciudades de productos agrícolas necesarios para el consumo y supervivencia de los seres humanos.

"El mercado fue el centro de la vida social y económica en la antigüedad" (Hirth, s.f.) Similares a los bazares de oriente, los zocos musulmanes o las ferias medievales, empezaron su movimiento al aire libre, para centralizarse luego en edificios municipales al aumentar la economía y al hacerse imprescindibles ciertas pautas de higiene y calidad de productos y servicios.

\subsubsection{Nace el mercado}

En la edad antigua nace la civilización y con la aparición de algunas nuevas ciudades como Mesopotamia, Egipto, Grecia, Roma: el mercado. El Ágora en Grecia y el Foro en Roma, por ejemplo, siempre fueron espacios destinados al comercio por excelencia y estos a su vez determinaban la configuración urbana. Eran lugares entendidos como sitios de intercambio que en su momento fueron puntos clave en la ciudad, para el 
abastecimiento de productos agrícolas, el encuentro de los ciudadanos y su interacción cultural.

Así vemos como poco a poco se establecen las plazas como lugares destinados al mercado, al comercio, al intercambio de bienes, que siempre fue el núcleo y organizador de la ciudad.

"El mercado fue el elemento que generó y cimentó la ciudad europea de la baja edad media como realidad social, económica y física." (Tangires, 2008). De esta manera, se ve una intención de ordenamiento, de definir la plaza de mercado en determinados días de la semana, abierta de toda la población. Es en este momento que el mercado se consolida como tal. Queda claro que el impulso precedió del campo, del acceso de los campesinos al comercio y su incorporación al mundo del intercambio. (Tangires, 2008)

Los mercados en la edad moderna crecen, porque crece la población y por ende los centros de producción en distintos puntos de esta. Es en este contexto que en 1790 se establece el mercado como equipamiento formal.

Se buscaba imponer espacios públicos a los mercados y viceversa pues ellos daban ese poder de contribuir positivamente a la imagen de la ciudad y lograban reintegrarlo con sus orígenes de espacio espontáneo al aire libre.

\subsubsection{Casos (Born, Les Halles)}

Después de la revolución industrial 1760-1840 y con la aparición de los nuevos materiales, nuevas tecnologías, nuevos medios de comunicación, se dio origen a la construcción de una nueva tipología de mercados: los mercados metálicos. Pero fue específicamente en París donde se estableció un modelo influyente para la época.

"El éxito convirtió Les Halles en modelo de los más de veinte mercados de barrio construidos en Paris..." (Guardia, 2006, p. 54); sin embargo, años más tarde este mercado, que en algún momento fue un icono importante en el mundo, lamentablemente fue demolido.

"La demolición final de les Halles, en 1971 fue el momento más dramático y más visible de este proceso de destrucciones; el episodio que tuvo 
mayor repercusión internacional y despertó la conciencia sobre la necesidad de conservar estas estructuras del siglo XIX." (Tangires, 2005)

El caso del Born fue uno de los varios modelos de mercado inspirados en el modelo parisino. Fue proyectado por el maestro de obras Josep Fontsere i Mestre y el ingeniero Josep Maria Cornet i Mas. También es considerado uno de los ejemplos más importantes e innovadores de la incorporación del hierro en la arquitectura.

"El Born nace como un enorme paraguas de unos $8000 \mathrm{~m}^{2}$ de superficie, envuelto por un cerramiento vertical permeable a la luz y al aire. Esto permitía a coger la actividad comercial para mantener en buen estado los productos almacenados y mejorar la comodidad de la gente que trabajaba ahí o accedía a él." (Institut de Cultura de Barcelona. Consell d'Administració, 2013, p. 60)

Figura 2.2

Mercado El Born, Barcelona. Actualmente centro cultural

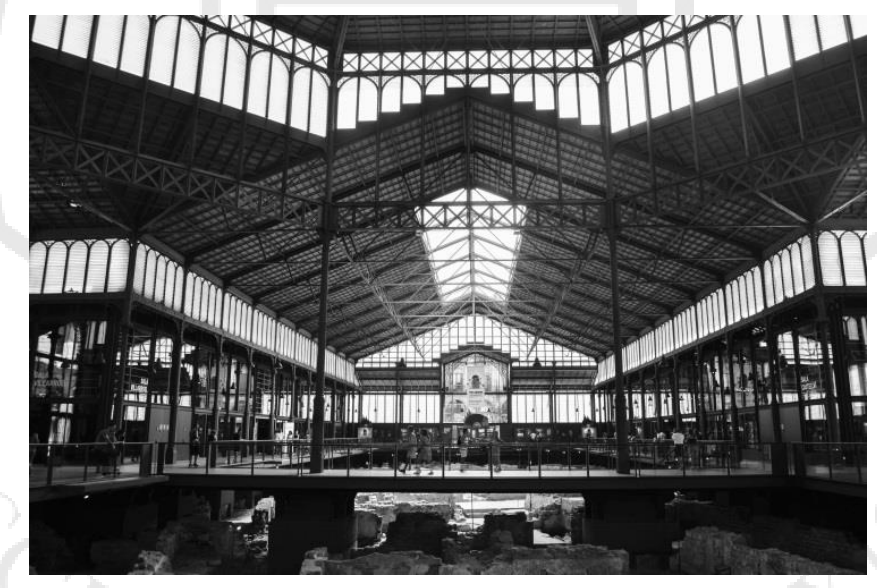

Fuente: Fotografía propia

Con los mercados metálicos se impuso una nueva urbanidad en los espacios comerciales que seguir a criterio de respetabilidad burguesa. Los mercados de barrio eran los espacios públicos de la ciudad donde las mujeres tenían más visibilidad, como compradoras y como vendedores. Durante los años en que se establecen los mercados minoristas la mayoría de los permisos establecidos para vender se lo consiguen se les concedieron a las mujeres quienes trabajaban sobre todo en puesto de frutas y verduras. (Institut de Cultura de Barcelona. Consell d'Administració, 2013) 
Es en este momento de la historia, que los mercados se comienzan a ver perturbados por supermercados y autoservicios, debido a los nuevos modos de comercialización. Lo cual ha generado que su función como centro de intercambio y entretenimiento social se pierda casi del todo, gracias a la introducción, por parte de Estados Unidos a mediados del siglo XX, del automatismo y sistemas rápidos de transacciones comerciales.

A medida que la producción aumenta, las comunicaciones y las nuevas tecnologías empiezan a desempeñar papeles más importantes, no solo en los mercados, sino en la arquitectura y en la vida en general.

Hoy en día existe una fuerte tendencia a la compra virtual, lo cual puede ser considerado un atentado a los mercados y su posible declive. "Se considera que las nuevas formas de comercio on-line, que pueden garantizar mejores precios, provocarán una caída del comercio tradicional y la concentración de la distribución en unos pocos gigantes". (Tangires, 2005)

No obstante, a pesar de esta problemática intensificada por la globalización, en la que los mercados han perdido parte de su valor original de relevancia en la ciudad, vemos hoy en día que existen otros mercados que suponen un motivo para fomentar la cultura y el turismo, pues a la actividad de compra, venta e intercambio de bienes, se suman actividades socioculturales, de ocio y gastronomía.

Figura 2.3

Mercado El Born, Barcelona

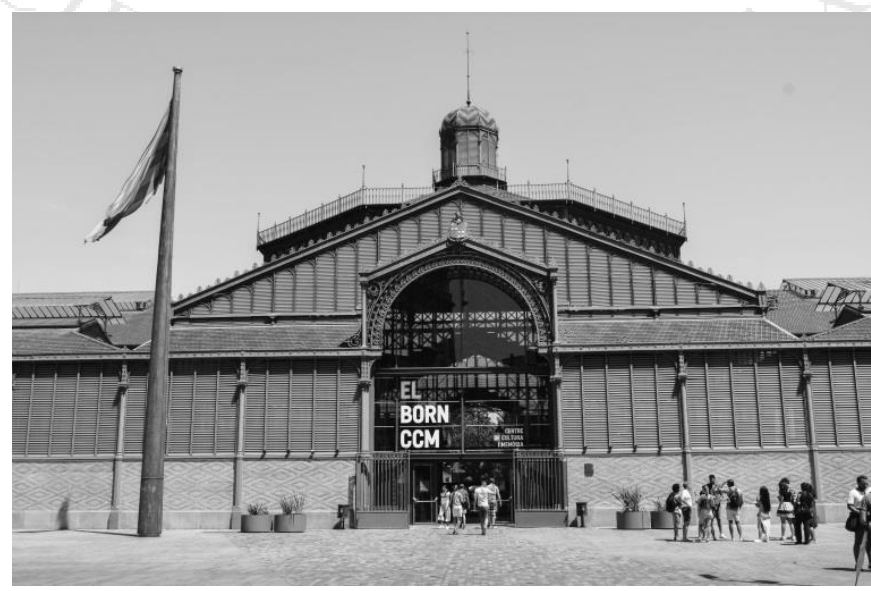

Fuente: fotografía propia 


\subsubsection{La función del mercado en la ciudad}

- El mercado y la urbe

Como se mencionó anteriormente el intercambio se dio desde la aparición de agricultura que permitió el excedente agrícola. Sin embargo, el mercado como espacio concertado y consolidado, como actualmente lo conocemos, aparece en la antigüedad. A continuación, se explicará la función del mercado en las diferentes culturas y ciudades a nivel global.

En occidente, los fenicios y griegos "fueron capaces de articular una densa red comercial basada en el comercio a larga distancia entre uno y otro extremo del Mediterráneo." (Soler, 2004a) Ya que, debido a la falta de producción, el abastecimiento y el comercio fueron vital para el desarrollo socioeconómico de ambas culturas. Es en este momento que el ágora toma un papel fundamental en la configuración de la ciudad, al corresponder en el espacio donde estas transacciones tomaban lugar. Esta además del aspecto comercial, tenía distintas funciones que le permitió convertirse en un espacio cívico en la ciudad. Tenía finalidad política, social, espiritual y comercial.

"El ágora es el principal espacio público urbano en estas ciudades, el espacio abierto - la plaza - que posibilita el encuentro cívico de la comunidad.“ (Pérgolis, 2002, p. 17)

Durante el imperio romano, "El espacio económico por excelencia de estas últimas era el foro. Situado en el centro de su trama urbana, en el punto de intersección de las dos calles principales que articulaban la ciudad" (Soler, 2004a) En este espacio se desarrollaba una de las actividades que generaba una de las principales fuentes de ingreso, el comercio. Y la necesidad de control por parte de la administración hizo que las funciones del foro o plaza cívica vayan más allá de lo económico.

El foro constituyo un espacio de importancia urbana, configuraba y articulaba la ciudad; social y económica, punto de encuentro de la actividad del intercambio; y reguladora y administrativa, por ser un medio de control de la ciudad.

En el contexto al-Andalus, como en el islámico medieval, donde su economía se basaba fundamentalmente en el comercio, manufactura o administración y no la 
producción agrícola se crearon dos tipos de mercados con funciones distintas, el mercado extramuros y los suq intramuros.

El mercado extramuros fomentaba la afluencia de los campesinos del hinterland hacia la ciudad. Mientras que el suq intramuros se ubicaba en uno de los espacios más importantes de la ciudad, junto a una mezquita. Como resultado, en los mercados extramuros, el comercio funcionó como activador social y dinamizador urbano, para atraer productores a zonas no consolidadas en la ciudad. Y en el caso del suq intramuros servía como espacio de encuentro y complemento del lugar espiritual, al ubicarse en espacio de recibo de las mezquitas donde se encontraban todos los estratos sociales de la ciudad.

"La progresiva conquista del territorio andalusí por parte de los reinos cristianos ... determinó la expansión y posterior consolidación de un nuevo modelo económico y social: el feudalismo" (Soler, 2004b). Este modelo se basó en la comercialización del excedente agrario, el mercado fue la principal estrategia de dinamización económica entre grupos feudales. Funcionando como base económica y de abastecimiento entre jurisdicciones feudales. El mercado tomó un papel importante para el crecimiento económico.

Durante la Edad Media se desarrollan tres tipos de mercados: el mercado diario, local ubicado en la plaza de la iglesia; el mercado semanal, de carácter comarcal ubicada en villas; y las ferias regionales, desarrolladas una o dos veces al año. Cada tipo de mercado tenía usuarios y jerarquías distintas. Mientras que en el mercado local donde distintos estratos de la población de un núcleo urbano se encuentran; en el mercado semanal, intervienen distintos agentes, donde los campesinos y los pobladores ya sean del núcleo o de villas de cierta prestancia económica se relacionan. En las ferias existe un intercambio que no solo trasciende grupos sociales, sino que además intervienen usuarios y mercaderes de otras localidades lejanas. (Soler, 2004b)

En la edad media el mercado sirve como espacio de encuentro entre grupos sociales y según su jerarquía tiene un espacio y tiempo concertado por las autoridades. El mercado en este ámbito permitió el intercambio económico, social y cultural entre núcleos urbanos, comarcas y comunidades, mediante la participación de campesinos, artesanos, pobladores y mercaderes. 
Posterior a la crisis del feudalismo y con el proceso de industrialización, el mercado como se conocía tiene un cambio orientado al consumo. Sin embargo, en la edad moderna aún se mantiene la importancia de las ferias y mercados.

Es a partir del Siglo XVIII, con los cambios sociales a raíz de la industrialización y la concentración de la población en las ciudades, que el mercado semanal pierde vigencia y aparece el formato de intercambio: tienda. "Esta última, especializada en la venta de un producto alimenticio concreto - carne, pescado, fruta -, y no regentada por productores directos sino por intermediarios..." (Soler, 2004b), es en este momento que el mercado debe cambiar su formato, orientado al esquema de la tienda con venta diaria y teniendo como distribuidor a los centros de abastecimiento a gran escala como el mercado central.

La aparición del supermercado tuvo éxito ya que este se basaba en responder a las nuevas necesidades de una sociedad globalizada, con una rutina diaria orientada a cubrir las necesidades básicas de forma rápida y eficiente. (Soler, 2004b)

A pesar de este éxito del supermercado en una sociedad globalizada del siglo XXI, el mercado en la actualidad tiene una repercusión en la zona urbana y barrio donde se sitúa. Un ejemplo es la transformación que sufrió el barrio de Sant Pere, Santa Caterina i la Ribera, donde actualmente se encuentra el renovado mercado de Santa Caterina.

“Tras ser cerrado y trasladado temporalmente el mercado para acometer su remodelación, el barrio asistió a una rápida degradación de su tejido social y comercial. El pequeño comercio de barrio, activo y numeroso en el pasado, decayó en picado; un número importante de tiendas cerraron y la afluencia de visitantes al barrio se redujo considerablemente, degradándose además el paisaje urbano que rodeaba aquella área comercial y provocando durante largo tiempo las protestas continuadas de las asociaciones locales de vecinos y de comerciantes.” (Medina Luque, 2014, pp. 185-186)

Luego de su reinauguración del Mercado de Santa Caterina el barrio y alrededores donde se sitúa el mercado, se han reactivado con nuevas inversiones públicas y privadas, que han logrado recuperar el tejido comercial y la afluencia de visitantes. (Medina Luque, 2014) Este ejemplo hace notar que actualmente el mercado 
puede permitir activar zonas comerciales o barriales. Asimismo, que tiene un radio de influencia en los comercios e inversiones próximas al mercado, complementando la actividad en la zona.

\section{- $\quad$ Formatos comerciales}

\section{- Caso España}

Como se vio anteriormente el mercado y los formatos comerciales han evolucionado según las condiciones económicas de las distintas épocas y los requerimientos y rutinas de la sociedad. El supermercado en países del primer mundo como es el caso de España ha significado una repercusión en la popularidad del mercado tradicional.

Este formato comercial, los supermercados, se implanta en España 1957. Pero no es hasta los años setenta que guardan una repercusión en el funcionamiento y acogida del mercado tradicional, ya sea por el distinto modo de vida de las personas o por tratarse de estructuras económicas más competitivas. Asimismo, otro factor que determinó la decadencia de los mercados madrileños fue por la poca intervención de las administraciones. (Medina \& Álvarez, n.d., p. 191)

En los años noventa en Madrid se extiende la ciudad hacia la periferia donde los "grandes suburbios de viviendas sin verdaderos espacios públicos y comercio minoristas...son totalmente dependientes de un gran centro comercial y anexo hipermercado." (García Perez, Rodríguez, \& Maiello, 2016, p. 44)

Esta idea de extender la ciudad y restarle importancia al comercio tradicional, ha logrado la dejadez y decadencia de algunos mercados madrileños, que deben lidiar directamente con un formato competitivo y al alcance de la sociedad, llegando a tener una cuota en volumen de compra por encima de 50\%. (García Perez et al., 2016) Esta situación dejo en evidencia la necesidad de incorporar un cambio en el formato tradicional del mercado.

Ante este panorama el Ayuntamiento de Madrid y asociaciones privadas deciden recuperar mercados de abastos con un fin turístico y dado la necesidad de convivir con los nuevos formatos comerciales que tenían mayor presencia y cercanía al público general, algunos de estos mercados renovados incorporan en su interior un 
supermercado. Vemos el caso del Mercado San Antón o Santa María de la Cabeza en Madrid.

Figura 2.4

Fachada principal del Mercado de San Antón, Madrid

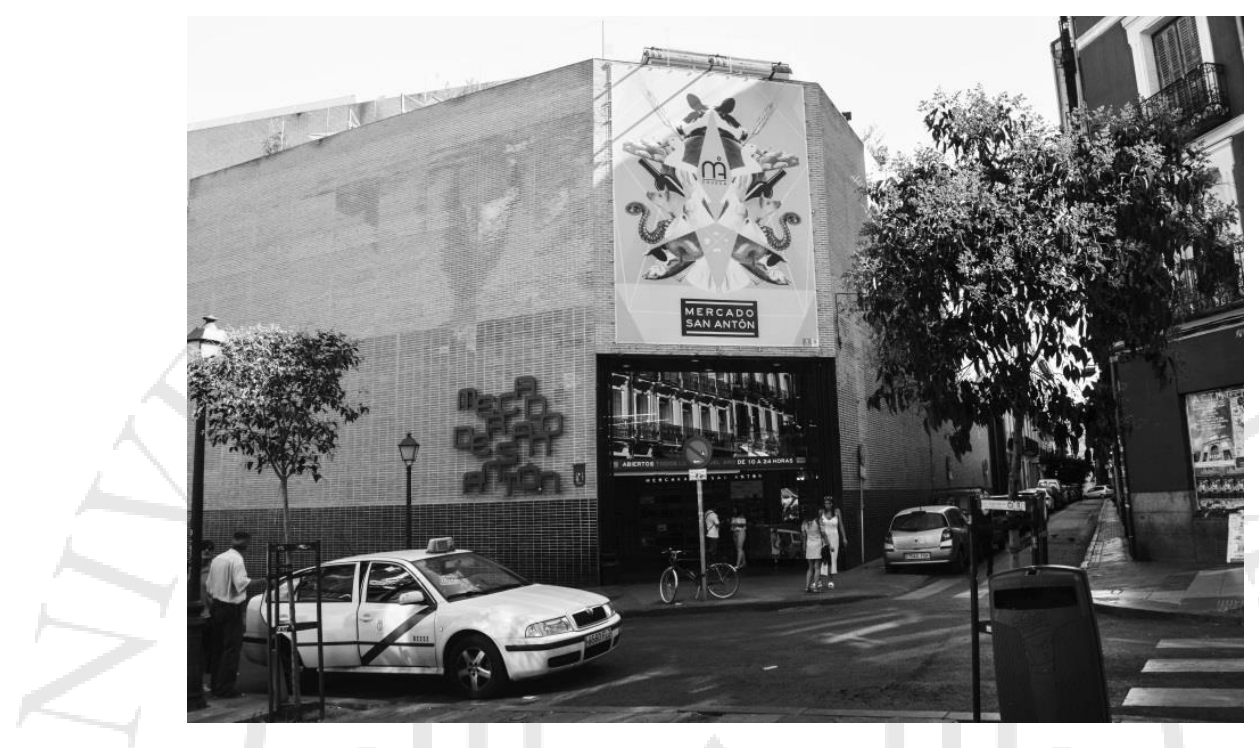

Fuente: fotografía propia

De este modo, ambas estructuras refuerzan su poder de atracción uniendo sus fuerzas, aunque cada una salvando sus sectores principales de actuación. El supermercado se aprovecha de la importante atracción que el mercado ejerce sobre un público amplio; al mismo tiempo, el mercado se asegura de que en los alrededores inmediatos de ese supermercado no se instalará demasiada competencia. (Medina Luque, 2014) Asimismo permite que los gastos en la recuperación del mercado en parte sean sufragados por la entidad comercial privada.

\section{- El papel del mercado tradicional en Lima}

En este capítulo hemos podido rescatar la importancia del mercado, el intercambio y su valor esencial en las distintas culturas. Sin embargo, hemos visto a lo largo de la historia que los cambios sociales y las nuevas demandas urbanas de las diferentes localidades han motivado la creación de formatos comerciales como los supermercados. Estos en ciudades como Madrid han afectado la acogida de los mercados tradicionales. 
Por otro lado, en nuestro contexto, Lima, como resultante de un valor sostenido del mercado para la ciudad, a pesar de la introducción de los supermercados en la década de los sesenta, actualmente el mercado tradicional y formatos como las paraditas y ferias, representa el $70 \%$ del abastecimiento de los hogares. El mercado tradicional en la capital, incluido el Callao, bordean los 1,300, mientras que los supermercados cuentan con 72 locales, con una penetración del 30\%. (García Calderón, n.d.)

Esta situación distinta a la de Madrid, revelan que una de las fortalezas de los formatos comerciales tradicionales se encuentra en la relación social y directa que se genera entre el consumidor y el vendedor. A diferencia de la experiencia del supermercado caracterizado por la velocidad e inmediatez. Asimismo, es en los mercados donde encontramos parte de la tradición popular gastronómica y donde lo cotidiano se vuelve una experiencia distinta.

A pesar del gran número de mercados existentes en Lima Metropolitana y su relevante penetración en la sociedad, el distrito de San Isidro solo cuenta con 1 mercado tradicional, convirtiéndose en el distrito con menos mercados de Lima Central Sur. (Instituto Nacional de Estadistica e Informatica, 2017)

\subsubsection{Un nuevo modelo de mercado}

Es evidente que hoy en día los mercados de abasto tradicionales ya no cumplen la misma función que antes. Muchos mercados han evolucionado, han sido modificados, trabajados, regenerados, restaurados para lograr un grado de turistificación importante, siempre atravesando por un proceso de evolución de ser equipamientos y servicios públicos a ser equipamientos propiamente de comercio y consumo, generando grandes cambios en la sociedad. 
Figura 2.5

Central Market Hall, Budapest

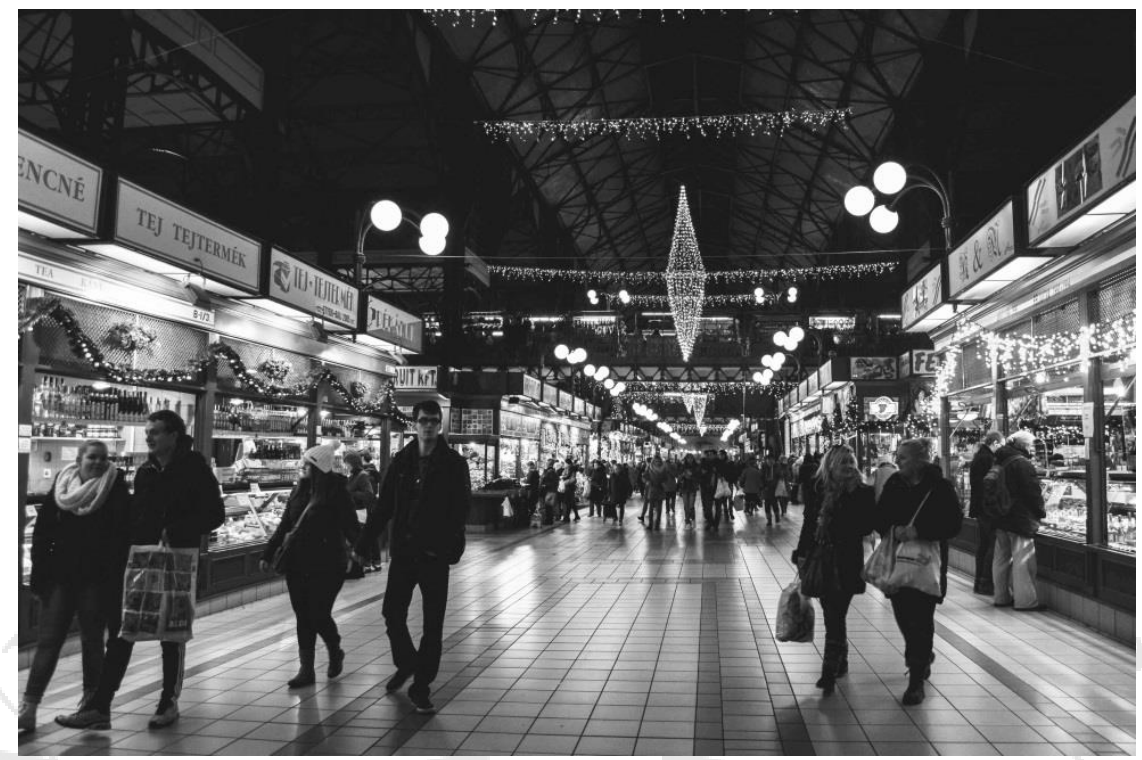

Fuente: fotografía propia

"El crecimiento de los supermercados, el escaso movimiento económico para con ellos, hace notar que la única receta que pareciera garantizar el éxitos es la transformación total de los mercados, sea convertirlos en gourmets o turísticos" (Crespi Vallbona \& Domínguez Perez, 2016)

Como el claro ejemplo del Mercado de San Miguel de Madrid, el cual ha sacrificado puestos de venta para ampliar espacios de uso común, bares, puestos de degustación, mesas para los clientes o incluso espacio para el desarrollo de acontecimientos culturales.

"Entonces es evidente este reciente cambio de los mercados de abastos que comienzan a convertirse en modernos centros de atracción turística. Mercados que funcionan como atractivos turísticos. Estos mercados se han convertido en exponentes turísticos e identitarios de las ciudades, que proyectan su imagen atractiva hacia el visitante, el extranjero." (Crespi Vallbona \& Domínguez Perez, 2016) 


\section{- Los mercados turísticos a nivel internacional}

Se sabe que hoy en día existe un tipo de turista muy diferente al turista de años atrás. El de ahora, "turista de ultima o tercera generación "es un turista amante de nuevas experiencias. Buscan monumentos, museos, idiosincrasias de la gente, mercados de abastos, experiencias auténticas, enriquecedoras y únicas, y una mayor profundización cultural. Busca sentirse parte de la vida cotidiana de la ciudad que visita, de las costumbres y la cultura del lugar, a través del contacto con la gente local.

"Para estos nuevos turistas las vacaciones ya no son un motivo de descanso, sino un espacio para el aprendizaje y el desarrollo social, en donde los mercados juegan un papel súper importante. Buscan un turismo experimental donde tienen tiene su relevancia los mercados de abastos."(Crespi Vallbona \& Domínguez Perez, 2016)

En ese sentido los mercados son uno de los recursos que usan los países para promocionarse pues es la manera de llevar lo local y lo turístico de la mano. En estos espacios es posible encontrar lo auténtico y lo local, la idiosincrasia de los ciudadanos se ve claramente su forma de expresarse, su forma de vender, de comprar, de regatear, se aprende sobre sus hábitos alimenticios, entre otros.

"Los mercados ofrecen esta particularidad: poder deambular como un local, comer como uno más y formar parte de la esencia de aquel territorio social.” BESSIERE 1998 URRY 1990.(Crespi Vallbona \& Domínguez Perez, 2016)

Así los mercados ya no están solo al servicio de las familias y vecinos de una población o barrios, sino además funcionan como atractivos turísticos, lo cual permite incrementar ingresos y mejorar la imagen de estos.

"Todo esto gracias a que la gastronomía es una industria cultural que está muy ligada al turismo. Pues la gastronomía en general tiene una dimensión que puede ser evaluada y cuantificada en términos económicos. Por ellos algunas ciudades se ven interesadas en repotenciar sus mercados de abastos pues ven un crecimiento cuantitativo del turismo.’(Crespi Vallbona \& Domínguez Perez, 2016) 
El artículo de la Revista de Turismo y Patrimonio Cultural, PASOS, establece 3 tipologías de las cuales rescatamos dos: el primero ya mencionado que se refiere a todos aquellos mercados que han recibido una remodelación o reestructuración con el fin de satisfacer las demandas turísticas más puras. Como el de Mercado de San Miguel o el de San Antón. La otra tipología es la de mercados sostenibles, aquellos que atraen tanto al público tradicional como a los turistas. Por ejemplo, los mercados La Boquería, Santa Caterina y la Barceloneta. Son casos en los que convive lo tradicional con lo más moderno en una tensión particular. Son atractivos, sostenibles y tienen horarios más amplios de atención.

Puede sonar bastante positivo la idea de convertir los mercados en mercados únicamente turísticos con el fin de promover su existencia, y aumentar los ingresos. Sin embargo, estos mercados niegan el origen del mismo, reformando al $100 \%$ de la demanda ya que no consideran los puestos tradicionales del mismo. A diferencia de los mercados sostenibles que buscan mantener un punto de equilibrio entre lo tradicional y lo turístico.

\subsection{Cocina, identidad y memoria}

\subsubsection{Antecedentes de la gastronomía peruana}

Desde el inicio de las primeras civilizaciones peruanas, existen dos factores que han determinado el reconocido valor que posee actualmente la gastronomía peruana: la biodiversidad de productos en nuestro territorio y la capacidad creativa de los actores en cuestión. Entendido, tanto en el manejo de la tecnología y el territorio, como en la adaptación de insumos para la creación y reinvención de comidas.

La compleja geografía de nuestro territorio significó un desafío que pudo ser aprovechado por los primeros habitantes para el cultivo de distintas especies.

"En un territorio accidentado como el andino, las tierras tienen fuertes pendientes y eso supone una extrema variabilidad en las condiciones de exposición a la luz solar, temperatura, lluvia, humedad y viento...por lo tanto los agricultores debían manejar varias parcelas dispersas situadas en diversos 
pisos ecológicos, en lugar de concentrar su propiedad en una sola extensión continua.” (Cánepa Koch, Hernández Macedo, Biffi Isla, \& Zuleta García, 2011, p. 35)

De esta manera, se puede entender que las distintas condiciones geográficas en las que fueron cultivados los productos y el manejo ambiental eficiente fueron aspectos indispensables para justificar la actual biodiversidad que contiene el Perú.

El empleo de tecnologías y el adecuado manejo del entorno natural, principalmente durante el incanato, permitieron el desarrollo e incremento de diversos productos. Es en este periodo, que la agricultura, además de ser una fuente esencial de recursos para los poblados, involucró labores como la producción, la administración, la repartición y el almacenamiento.

La actividad agrícola desarrollada durante el periodo inca fue enriquecida por un medio de difusión que poco a poco fue tomando un perfil más comercial: el intercambio. Se puede decir que, en esencia, el intercambio no comprendió únicamente su labor comercial de productos y riquezas, sino que permitió la difusión y expansión de saberes, conocimientos y cultura.

Por otro lado, en la época de la conquista, debido a la introducción de nuevos insumos traídos de Europa por los conquistadores, inició el periodo denominado por autores como Carlos Degregori, "adaptación en resistencia".

“(...)la comida ha servido como bastión de resistencia pero también como medio de adaptación a una nueva realidad social, gracias a lo cual se ha contribuido a mantener y desarrollar, no sin dificultades y contradicciones, los principios de gestión y valoración de la diversidad...” (Cánepa Koch, 2011, p. 47)

Este proceso trajo incertidumbre a los pobladores indígenas que, entre el sentimiento de rechazo y resignación, tuvieron que adaptar insumos y costumbres foráneas, por ejemplo, reflejadas en platos típicos y maneras de comer.

Poco a poco, las estrategias implantadas por los españoles para la obligación al uso de insumos ajenos a la cultura andina, logró una mayor dimensión con la imposición del sistema de la encomienda, que ordenaba el pago de tributos con productos foráneos. Sin embargo, debido a la falta de algunos de estos, los españoles 
debieron adaptar en su dieta ciertos productos de origen nativo. Este intercambio cultural trascendió las brechas sociales debido a la comida, que de manera gradual se incorporó y dio paso a variedad de recetas mestizas.

Sin embargo, un acontecimiento importante para determinar la identidad de la comida que hoy día conocemos ocurre con la independencia del Perú. Con este acontecimiento, nace una necesidad de poseer una identidad nacional. La búsqueda de la diferenciación, la apropiación e incorporación de nuevos estilos, son factores importantes para la creación de recetas que hoy en día le dan renombre a nuestra gastronomía. Ya que en aquella época se buscaba reinventar recetas tradicionales con insumos y estilos nuevos, ajenos su origen nativo.

Lo mismo sucedió con la inmigración china, japonesa e italiana; que, debido a su representativa población en el Perú, se inicia un proceso de intercambio cultural. La comida fue un aspecto que hasta la fecha da testimonio de ello, que, debido la reinvención de nuevas recetas, la introducción de insumos y la adaptación de muchos ámbitos de su cultura, terminaron por crear parte de la nuestra.

\subsubsection{El "Boom" y el crecimiento gastronómico en el Perú}

A la fecha, nuestra gastronomía viene siendo galardonada y reconocida no solo en el ámbito local, sino que a nivel internacional. El turismo corresponde un ámbito crucial para la difusión de nuestra cultura y la gastronomía representa un aspecto influyente en la satisfacción de los extranjeros. Según datos obtenidos de turistas, PromPerú asegura que uno de los aspectos que influyó en la elección del Perú como destino turístico, fue debido a su gastronomía. Y más del $95 \%$ se encontró satisfecho con la calidad de la comida. (APEGA Sociedad Peruana de Gastronomía, 2012, p. 22)

El valor gastronómico ha podido trascender fronteras, tanto por el hecho de que existen cada vez más restaurantes peruanos en otros países, como por el interés de los extranjeros en ferias gastronómicas de gran envergadura como lo es Mistura. Por ejemplo, al año 2012, el Perú contaba con más de 1,000 restaurantes, en alrededor de 5 países extranjeros (Estados Unidos, Argentina, Chile, Colombia y Japón). Por otro lado, se estima que en la sétima edición de Mistura (2014), la feria recibió a un total de 
30,000 turistas extranjeros. ("Mistura 2014 recibió a 420,000 visitantes peruanos y extranjeros," 2014)

\subsubsection{Lima como capital gastronómica}

Lima, en el ámbito gastronómico, refleja los distintos acontecimientos históricos que llevaron al desarrollo de una diversidad cultural, a lo que hoy en día comprende su propia identidad. Su importancia, como centro administrativo del virreinato $\mathrm{y}$ posteriormente como capital de la República del Perú, dio paso a la recepción de una serie de inmigraciones internacionales y del interior del país, que dieron como resultado la incorporación de distintos estilos e insumos para la creación de una nueva fusión.

Además de guardar una tradición de antaño, teniendo vigentes platos representativos según fechas especiales, la ciudad de Lima está permitiendo poco a poco la difusión del valor gastronómico de nuestro país, ya sea mediante eventos y ferias que promueven nuestra cultura, como albergando cerca del $50 \%$ de los restaurantes a nivel nacional. (APEGA Sociedad Peruana de Gastronomía, 2012, p. 47)

"Un primer objetivo a contemplar es el de consolidar a Lima como Capital Gastronómica de América Latina. Lima es única pues representa un crisol de las cocinas, enriquecida con el flujo de migrantes de las regiones y del extranjero (europeos, africanos, chinos, japoneses) a la capital. Ofrece, además, una oferta variada de productos que incluye la alta cocina, huariques y potajes populares (...)” (APEGA Sociedad Peruana de Gastronomía, 2012, p. 22)

\subsubsection{Importancia de la identidad}

La identidad puede expresarse como parte de tres factores en relación al sujeto y su contexto. Estos factores son la identidad personal, la identidad social y la identidad colectiva.

Según la autora Molano la identidad se puede entender como "el sentido de pertenencia a una colectividad, a un sector social, a un grupo específico de referencia“" (Molano, 2007, p. 73). Para este caso de estudio se va a ver relevante estudiar la importancia de la identidad colectiva, que según el autor Giménez, se construye por 
analogías con las identidades individuales (la cultura como identidad). La identidad colectica permite dar un sentido de pertenencia a un grupo social, diferenciarse del resto y crear vínculos estrechos entre ellos mismos. Así, un grupo puede sentirse propio a un colectivo con particularidades de distinta índole, como a su origen o procedencia, tanto dentro como fuera de su contexto.

\section{- La cocina como identidad}

A lo largo de la historia del Perú, nuestra gastronomía ha significado una síntesis de nuestra historia y cultura, desde la gran biodiversidad manejada y controlada prodigiosamente por los incas; la introducción de insumos con la conquista española, hasta la reinvención de recetas en su búsqueda de una identidad nacional tras la independencia.

Si bien en un momento, la comida sirvió para distinguir la diferencia social en el virreinato, atribuida tanto a la comida nativa con la foránea; desde poco antes de la república, esto se disipa debido a la conquista de los paladares de las elites por medio de la comida popular llevada a otras expresiones culinarias. (Luciano, 1993).

Por ello, se puede decir, que la comida ha permitido acortar la brecha social presente en varios periodos de la historia. Dicho de otro modo, su capacidad de oscilar entre distintos estratos sociales, sin importar su origen, permitió que el vínculo se acrescente y hasta el día de hoy corresponda a un punto en común que fusiona una sociedad tan plural.

Y es el tema de la comida, como símbolo de unión, que se visualiza en distintas escalas, es decir involucra, repercute y conecta a los actores presentes en las cadenas gastronómicas, por ejemplo, de manera directa a la industria con los distribuidores; a los distribuidores con los mercados y a los mercados con el consumidor local. Por otra parte, de manera indirecta a los productores con el consumidor local. (APEGA Sociedad Peruana de Gastronomía, 2012, p. 8)

Según Apega, el " $70 \%$ de los alimentos que consumimos, provienen de la pequeña producción agraria.” (APEGA Sociedad Peruana de Gastronomía, 2013, p. 32). $\mathrm{Y}$ es esta la que muchas veces guarda el deseo de mantener la calidad, diversidad y 
valor agregado de sus productos, y que ha llegado mantener en alto el nivel de la gastronomía peruana.

"En tal sentido, es evidente que ya es tiempo de llevar los beneficios del auge gastronómico a sus raíces. Es decir, a quienes cultivan y pescan esos insumos únicos que hacen posible la propuesta culinaria peruana". (Ginocchio Balcázar, 2012, p. 10)

\section{- El lugar como la identidad}

Cada lugar guarda un carácter propio, determinado no solo determinado por el usuario o habitante sino por sus propias características contextuales. Para el presente trabajo de estudio cuando hablemos de identidad del lugar, más allá de la identidad que una persona puede vincular con el lugar que se encuentra, se va a profundizar la idea la identidad característica propia del contexto. Y esta identidad contextual es la que va a afectar el modo que un lugar es entendido y percibido por el usuario.

\subsection{Situación actual de los mercados de Lima Metropolitana}

\subsubsection{Los mercados en la ciudad de Lima}

El origen del mercado en Lima se remonta a la llegada de los españoles, cuando en la plaza central se establece el mercado más importante de la ciudad.

Los mercados en Lima han representado durante muchos años el principal centro y forma de abastecimiento de alimentos para la población. Esta condición permanece hasta la actualidad, pese al rápido crecimiento de los supermercados y centros comerciales; al evidente abandono de los mercados públicos por parte de las instituciones públicas, para la creación y mejora de los supermercados y centros comerciales; y a la escasez de intervención por parte de empresas privadas para su potenciación

Hoy en día, en Lima Metropolitana, encontramos un total de 1,206 mercados, que comprenden la siguiente clasificación: mercados mayoristas, mercados municipales y mercados locales. 


\subsubsection{Uso y función en la ciudad}

Así como Lima, cada provincia, pueblo o distrito, tiene su propio mercado -a veces más de uno-, los cuales se puede frecuentar, no solo para comprar, sino también para vender, para conocer, aprender, intercambiar conocimientos, entre otros.

Pese a la poca calidad sanitaria, arquitectónica y pese a los defectos con los que un mercado pueda contar, en nuestro país, muchos de ellos siguen concentrando interés masivo, representando en su totalidad alrededor de 1,200 mercados a nivel de Lima Metropolitana y Callao, como lo menciona el PLAM 2035. (PLAM Lima y Callao 2035: plan metropolitano de desarrollo urbano, 2035)

Por ello, el Perú está en una constante búsqueda de mejora arquitectónica, sanitaria, de productos de calidad, así como también la calidad, como dice Manuel de Rivero en el artículo del comercio, “... de ese infaltable vínculo social que genera la plaza. Un lugar democrático donde los precios los deciden la oferta y la demanda popular, donde el sonido de las monedas aleja el dinero plástico y atrae el ingenio del cálculo mental. Y donde regatear es costumbre, y la yapa, un derecho para todos." (“Mercados de Lima: una mirada a su pasado y presente," 2015)

\subsubsection{El Mercado de Productores de San Isidro}

El mercado de San Isidro es uno de los mercados más cuidados y limpios que tiene la capital, además es seguro y de fácil acceso, cuenta con una plataforma con vista al océano pacifico bastante agradable la cual casi siempre es fotografiada por quienes la frecuentan. Cualquier visitante podría tener una experiencia grata obteniendo productos de buena calidad. Hoy en día, el mercado de San Isidro en muy conocido por la personalidad de sus comerciantes, quienes se toman el trabajo de ayudar a los visitantes a encontrar los productos adecuados, explicarles sobre sus orígenes o las formas más típicas o interesante de prepararlos.

Modernizar los mercados de abasto de Lima Perú y darles un valor agregado que pueda no tener un supermercado o un centro comercial es clave para el funcionamiento adecuado de los nuevos mercados limeños. 
2.3.4 Línea de tiempo: a nivel nacional e internacional
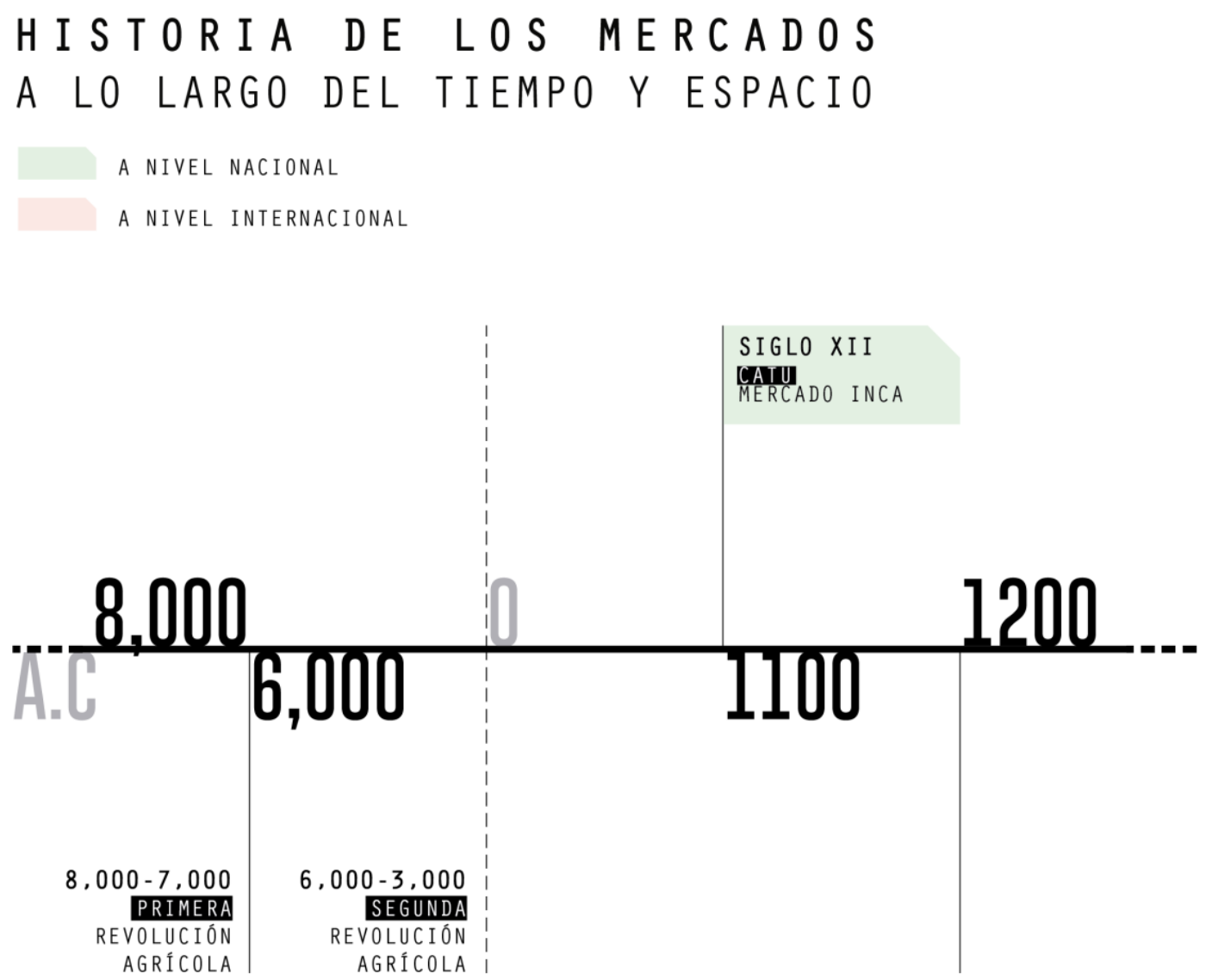


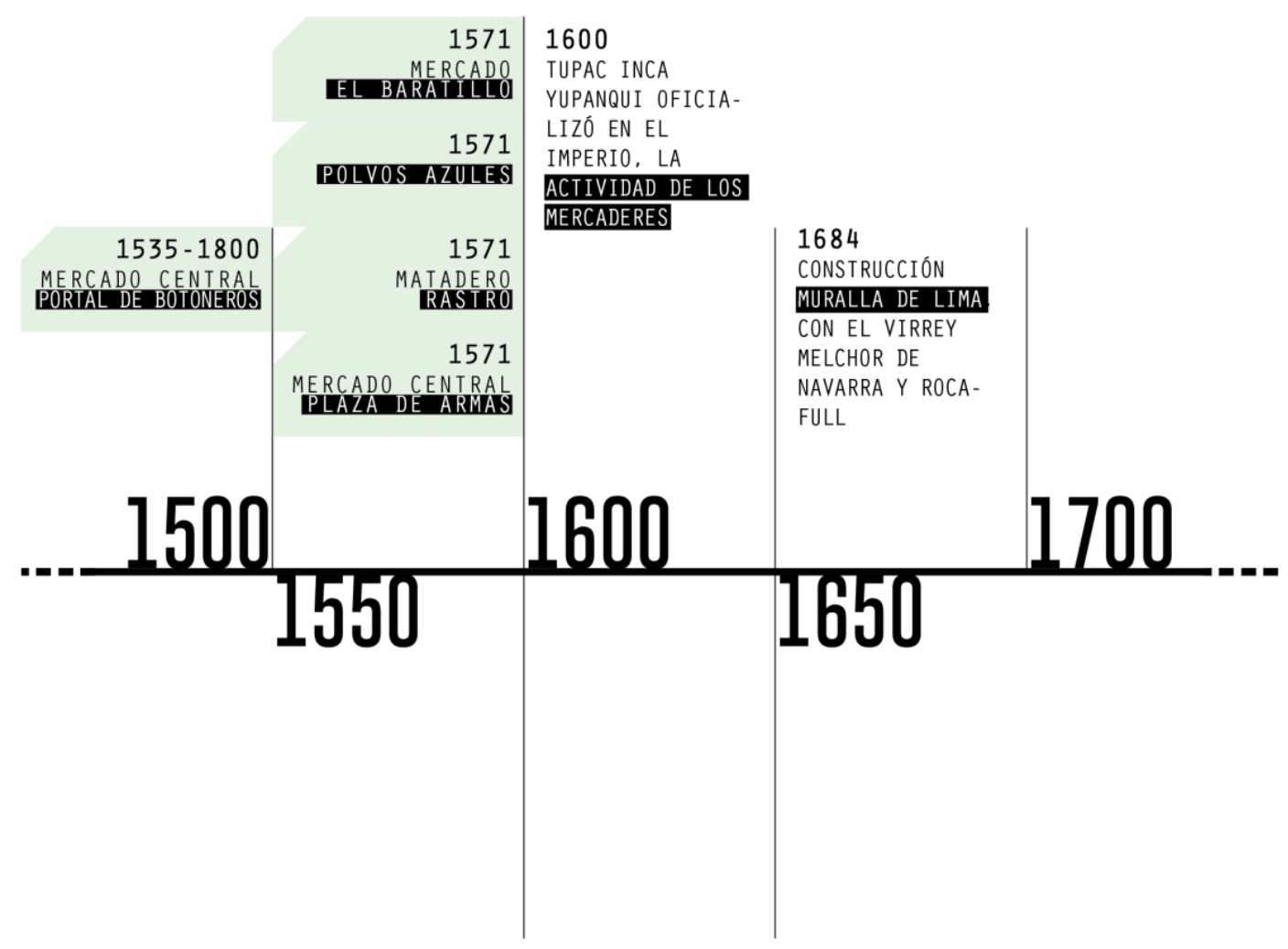




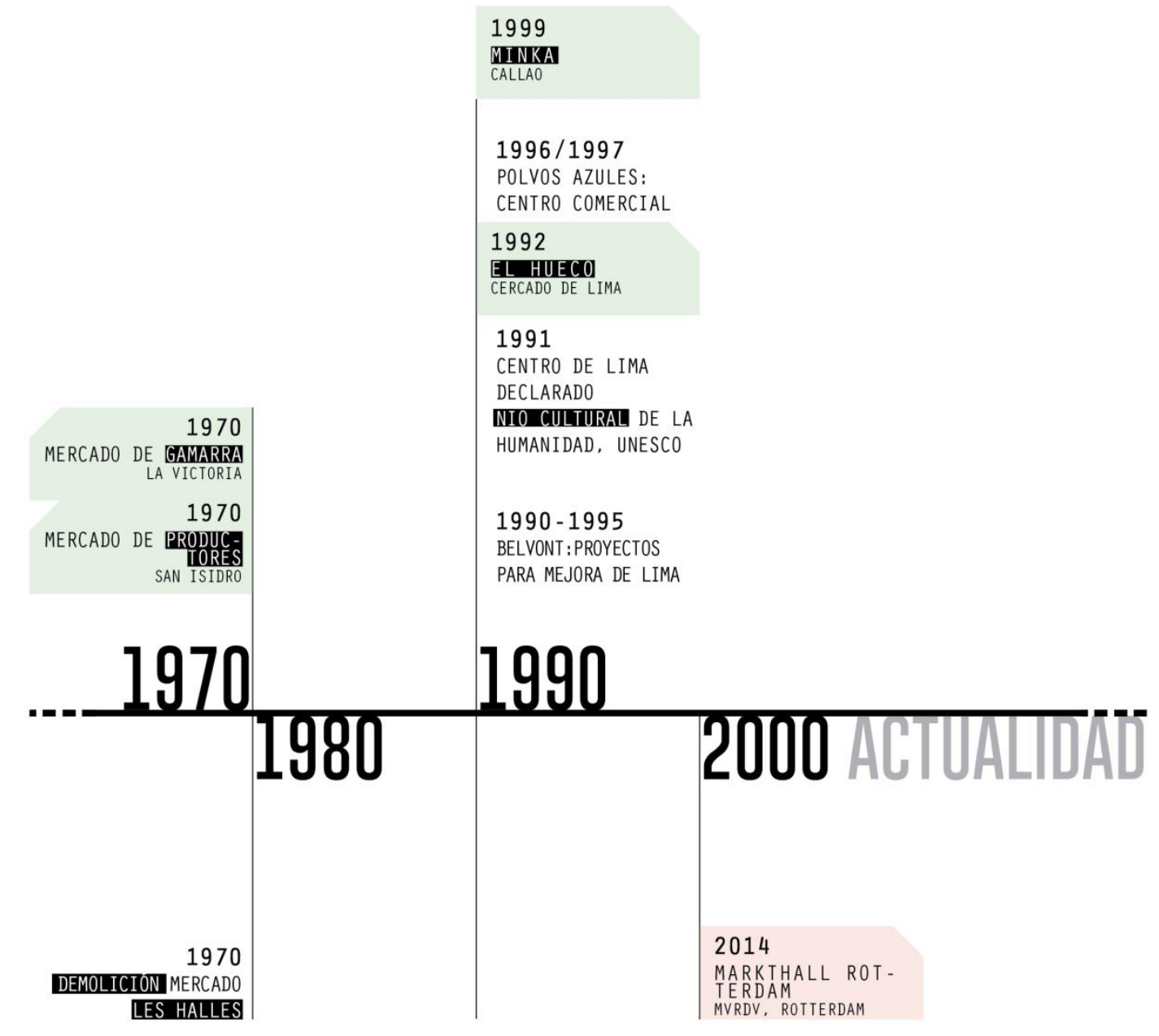




\section{MINKA}

MERCADO DE UNIDAD VECINAL NO3

MATADERO SAN LAZARO

COLEGIO DOMINICO SANTO TOMÁS EL BARATILLO

PLAZA DE ARMAS PLAZA SAN FRANCISCO

MERCADO DE LA AURORA PLAZA DE LA INQUISICIÓN

Mercado unidad Vecinal mirones Mercado Central

CLL HUECO

MERCADO CENTRAL DEL CALLAO

MERCADO MODELO NNo4 (28 DE JULIO)

MERCADO MODELO (MERCADO BOLÍVAR)

MERCADO SAN FELIPE
POLVOS AZULES GAMARA PARADA
GA Para

MERcado unidad Vecinal matute

MERCADO COPERATIVO BALCONCILLO

MERCADO MODELO LINCE (MERCADO LOBATÓN)

\section{RED DE MERCADOS LIMA METROPOLITANA}

\section{MERCADO SANTA CRUZ}

\author{
$1535-180-$ MERCAD CENTRL: EL
POTHAL DE-BOTONEROS (PLALA DE
ARMAS) \\ 1571_MATADERO - RASTRO \\ 1571_POLVOS AZULES: Ambulantes \\ 1571_EL BARATILLO \\ $1800-1820$ MERCADO CENTRAL
PLAZA DE SAN FRANCISCO \\ 1820-1840 MERCADO CENTRAL:
PLAZA DE LA INQUISICION \\ 1840 MERCADO CENTRAL: COLEGIO
DOMITICO SANTO TOMAS: \\ 184991851 MERCADO CENTRAL: JR.
HUALLGAJTR. AYACUCHO \\ 1872MERRADO CEETRAL: MERCADO \\ 1892_mercado Central del callao \\ 1924 MEECAAD MODELO, BARRANCO
(ACTUA METRO) \\ 1927 MERCADO MODELO N N 4 (28 DE
JULTO). CERCADD DEE LIMA \\ 1933 MERCADO MODELO (MERCADO
LOBATONC), LINCE
}

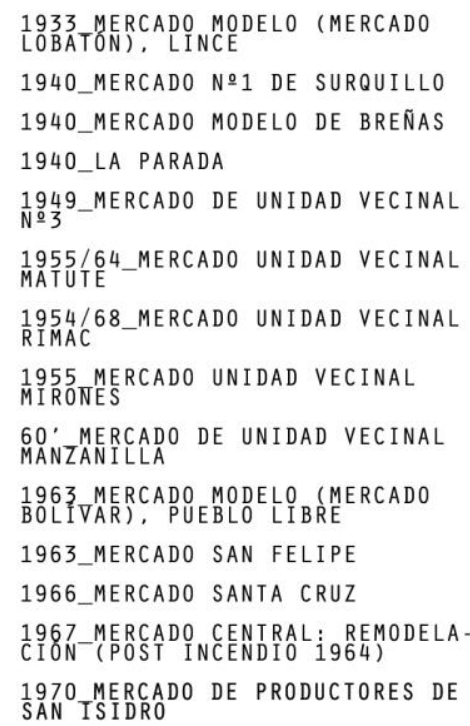

1933 MERCADO MODELO (MERCADO
LOBATON). LINCE 1940_MERCADO №1 DE SURQUILLO 1940_MERCADO MODELO DE BREÑAS

DE UNIDAD VECINAL MA55 /64_MERCADD UNIDAD VECINAL 1954/68_MERCADO UNIDAD VECINAL 1955 MERCADD UNIDAD VECINAL G0' MERECADO DE UNIDAD VECINAL 1963 MERCADO MODELO (MERCADO
BOLIVAR), PUEBLOLIBRE 1963_MERCADO SAN FELIPE
1966_MERCADO SANTA CRUZ

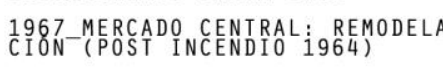
1970 MERCADO DE PRODUCTORES DE
SAN ISIDRO

MERCADO NNo1 DE SURQUILLO

$$
\begin{aligned}
& \text { 1992_EL HUECO } \\
& \text { 1996/1997_POLVOS AZULES: CENTRO } \\
& \text { 1999_MinKa, CALLAO } \\
& \text { 1999_MINKA, CALLAO } \\
& \begin{array}{l}
\text { MERCADO COPERAIVO BALCONCI- } \\
\text { LLO. LA VICTORIA }
\end{array} \\
& \text { ELL. LA VICTORIA } \\
& \text { _MERCADO No2 ANEXO SURCO } \\
& \text { IERRCADO MODELO LA VICTORI } \\
& \text { - MERCADO DE BARRIO RIMAC } \\
& \text { MERCADO DE BarRIO LA VICTORIA } \\
& \text { S.XIX MERCADO DE LA AURORA } \\
& \text { MERCADO DE PRODUCTORES DE LIMA } \\
& \text { MERCADO ARQ. LLONA (32333) } \\
& \begin{array}{l}
\text {-MERCADO DE PUNO } \\
\text { MECADO DE CHICLAYO }
\end{array} \\
& \begin{array}{l}
\text { MERCADD DE SAN ISIDRO-GASTELU- } \\
\text { MENDII, LAOS } 2212151921 \text {. }
\end{array}
\end{aligned}
$$




\subsection{Antecedentes de la Costa Verde}

La costa verde es la franja costera que hoy en día sabemos va desde el distrito de San Miguel hasta el de Chorrillos, pasando por Barranco, Miraflores, San Isidro y Magdalena del Mar. comprende las playas y terrenos existentes, desde la línea de más alta marea, hasta el borde superior de los acantilados. Es de acceso vehicular inmediato por varias bajadas vehiculares y unas cuantas peatonales.

Figura 2.6

Aerofoto de la costa verde 1944, Lima

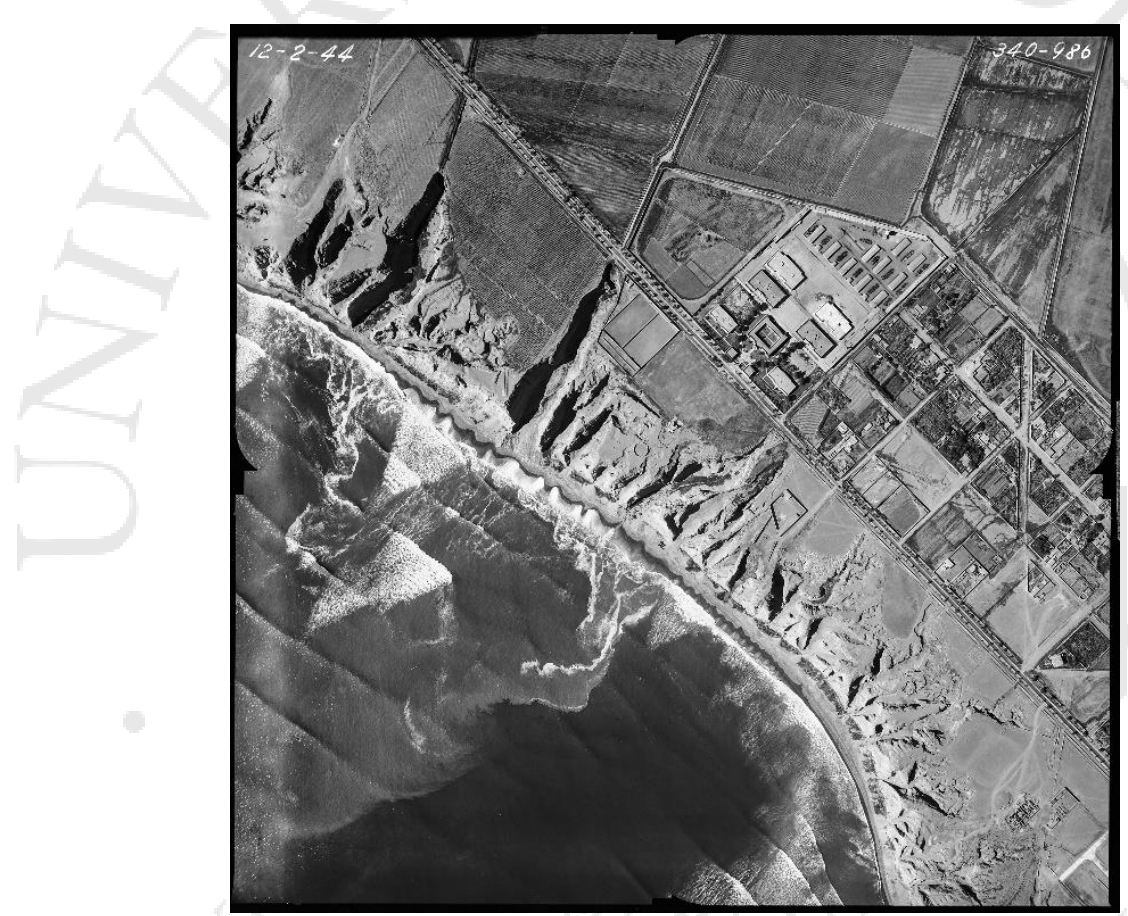

Fuente: Departamento de Aerofotografía de la Fuerza Aérea del Perú

El proyecto para con la Costa Verde por parte del arquitecto Aramburú ex alcalde de Miraflores pretendía regenerar el litoral costero y darle esa fachada que tanto le hacía falta a Lima. El motivo del proyecto del arquitecto Aramburú era el siguiente:

"Lima ha vivido desde su fundación dándole la espalda del mar. Por este inexplicable rechazo, el sector litoral comprendido entre la punta y chorrillos, fue en casi toda su extensión, un sector de total abandono... desde luego el proyecto implica una transformación de la pauta tradicional urbana y la 
ejecución de obras de gran inversión para atraer la naturaleza y hacerla favorable a los deseos del hombre"(Instituto Metropolitano de Planificación, 1995)

Así es como poco a poco la costa verde ha logrado adquirir áreas para realizar actividades deportivas, recreativas y ganar mirada al pacifico.

Eduardo Orrego Villacorta califico la costa verde como "la zona de recreación más importante de nuestra capital, tanto por su extensión, inversiones que ha demandado ponerla operativo en un tramo de varios kilómetros, como por el gran número de visitantes que recibe diariamente." (Instituto Metropolitano de Planificación, 1995)

Hoy en día la costa verde dispone de una hermosa vista a un horizonte infinito que ofrece algunas áreas rescatadas sobre y al lado del mar, paradero obligado de peruanos y turistas, cuenta con algunos parques y zonas verdes de espacio público para uso libre de los ciudadanos. Tanto en verano, como en invierno, en días de sol y aún nublados y fríos con mucha neblina se encuentra habitantes de la ciudad que acuden a la playa, a realizar deporte, gimnasia, pesca o simplemente a visualizar el horizonte infinito. Sin embargo, la zona del acantilado de San Isidro está abandonada casi en su totalidad. Es trabajo de todos proteger la belleza natural de los farallones, proponer conexiones verticales y horizontales respetando el acantilado y aprovechando los dotes del mismo.

\subsection{Conclusiones parciales}

A lo largo de la historia y desde su origen, el intercambio ha tenido repercusiones vinculadas al desarrollo cultural y económico de la sociedad. Como se ha visto en este capítulo, en esencia el intercambio deriva de la producción agrícola, ambas prácticas contenidas en lo que ahora conocemos como mercado. La importancia de analizar la historia, origen y las distintas dimensiones de valores (sociales, culturales) nos da a entender la importancia que hasta la actualidad guarda el intercambio y su relación con la sociedad. Es decir, que esta actividad presente desde inicio de ciudades permitió no solo permitió el comercio, sino que además integro en un lugar concertado distintas clases sociales; permitió la difusión cultural entre comunidades mediante el canje de utensilios y técnicas; favoreció el encuentro y la interacción entre las personas. 
Al inicio se entiende por intercambio el acto y la actividad comercial para la subsistencia de las personas, sin embargo, con el paso del tiempo este toma una posición determinante en la ciudad como se ha podido ver en el tianguis prehispánico. Este espacio tuvo una relevancia única en la cultura mesoamericana, al punto de ser considerada el centro social con mayor influencia, ya que como explica el cronista Cortés si uno controlaba la plaza de mercado tenía el control de la ciudad.

En el ámbito andino el intercambio toma una dimensión distinta a la acción comercial, ya que la reciprocidad está dentro del modo de vida y cosmovisión de la cultura andina. Dentro de sus conductas cotidianas se encuentra el sentido de reciprocidad que permite mantener un vínculo y relación social entre comunidades, grupos y productores. Es valorable el sentido que en nuestro contexto desde

Para definir la importancia del intercambio, esencia y naturaleza de lo que hoy conocemos como el mercado tradicional, explicamos su valor en la cohesión social entre comunidades para el truque de productos, objetos o técnicas que les permitió el desarrollo cultural y económico de las comunidades. Esta interacción además del fin económico y de abastecimiento, permitió la interrelación entre distintas clases sociales vinculando productores, campesinos y pobladores de todos los niveles socioeconómicos. Es decir, tuvo un interés por parte muchos sectores de la población y por ende repercutía en un ámbito común de la ciudad. El mercado tiene como fin el intercambio y abastecimiento de productos y a pesar de que su visión ha evolucionado en el tiempo, aún se mantiene como plataforma para el encuentro y la relación entre los que habitamos en la ciudad.

Los mercados han ido, siempre, de la mano del crecimiento del ser humano y la civilización; es decir, la evolución de este ha sido crucial para lograr finalmente su instauración como institución de uso público para el abastecimiento de la ciudad.

Hoy en día se ve que se está perdiendo la tradición de ir a comprar al mercado, a la plaza. Los mercados tradicionales están en vías de extinción debido a la reciente y constante instauración de supermercados, hipermercados, mercados on-line, que se están tomando como alternativas para la reducción de costos, para facilitar las transacciones, reducir precios y ahorro de tiempo. Todos estos aspectos, eliminan el contacto directo; vemos como con el pasar del tiempo se ha perdido la relación entre en 
productor y el cliente, se ha perdido la costumbre de ir a la plaza a hacer el mercado y de paso reunirse con la gente.

El mercado desde su aparición ha ido cambiando de funciones y usos en la ciudad. Según contexto, actividad económica, ubicación y cultura en las ciudades, el espacio del mercado ha cumplido y compartido roles distintos no solo en el ámbito económico. La función del mercado ha ido cambiando en el tiempo como espacio de importancia cívica, reuniendo en el centro las funciones más relevantes para la ciudad: comercial, religiosa, administrativa y social; activador y reanimador urbano de zonas no consolidadas con la actividad comercial y económica; espacio de encuentro social de distintos sectores socioeconómicos, complemento del lugar espiritual situado anexo al mercado; base económica y de abastecimiento entre grupos y comunidades.

Según acontecimientos de históricos ha ido evolucionado y enfocándose en ámbitos según la sociedad lo necesitaba. Unos de los cambios con más repercusiones en la actualidad respecto a los mercados tradicionales fueron las nuevas necesidades de la sociedad que llevaron a la creación de nuevos formatos comerciales y en ciertas ciudades la decadencia de los mercados. Estos formatos se caracterizan y se diferencian de los mercados tradicionales en la rapidez de las transacciones y su fin económico únicamente ligado al abastecimiento, excluyendo el vínculo social entre vendedorcliente y su función como espacio de encuentro y activador del barrio.

Como es evidente, el turismo está abriendo puertas para la evolución de los centros urbanos y concretamente para los mercados de abastos. Por ellos en estos tiempos la instauración de un nuevo modelo de mercado está invadiendo las ciudades. Gran cantidad de mercados de abastos están demostrando una necesidad de convertirse en mercados turísticos tanto para su propia sobrevivencia como para aportar al desarrollo y crecimiento económico y cultural de las ciudades que los contienen. Este nuevo modelo de mercado turístico si bien es considerado como un aspecto positivo para la reactivación de las zonas, de los mercados, se debe tener cuidado pues concentrar los mercados únicamente para satisfacer las demandas turísticas puede resultar perjudicial.

Así como los mercados turísticos, hemos visto que también existen los mercados sostenibles, los cuales resultan una mejor opción en vista que están enfocados no solo en abastecer al ciudadano local sino también al turista visitante. 
La gastronomía, corresponde a un aspecto importante para nuestra cultura, ya sea por la inmensa biodiversidad que hizo posible la creación y reinvención de recetas, así como por significar y poner en manifiesto el proceso de búsqueda de una identidad nacional, influenciada por acontecimientos de distinta índole.

La comida peruana, corresponde a un resumen de todas las fases que se han podido vivir en su historia, desde el aprovechamiento de su condición geográfica y fértil en la época prehispánica; hasta la reinterpretación e integración de características de culturas foráneas encontradas en la república; que a la fecha dan como resultado la propia identidad gastronómica peruana.

En la actualidad, este aspecto se viene desarrollando en el ámbito culinario con la instauración de cada vez más restaurantes y ferias. Sin embargo, aún es indispensable trabajar este potencial de lo que significa la comida peruana, que como hemos visto involucra de manera directa e indirecta otros ámbitos de nuestra sociedad.

Como pudimos ver el mercado y su papel actual en países primermundistas están viéndose afectados por la competencia directa que les representa los centros comerciales, por lo cual una de las medidas que se tomaron fue la revaloración de los mercados municipales convirtiéndolos en mercados turísticos para cubrir otra demanda y otro público objetivo.

Sin embargo, si nos situamos en nuestro contexto, hemos podido ver que la introducción de nuevos formatos comerciales no ha podido desligar la relación del mercado como espacio de intercambio social en la sociedad, reflejado en su posicionamiento en el abastecimiento de los hogares. Esta diferencia entre casos hace entender que un factor decisivo en la acogida del mercado tradicional es que sirve como plataforma de relación social, el cual le otorga un valor distinto a lo experimentado en otros formatos comerciales.

En relación a lo descrito sobre la costa verde podemos decir que si bien hay un interés por recuperar el litoral de la costa limeña, hay un interés por recuperar la vista al mar, no hay muchas obras que muestren resultados de los hechos, es necesario intervenir en la costa verde de manera adecuada con el fin de proporcionar a los ciudadanos espacios óptimos, al aire libre, con vista al horizonte infinito, con buenos espacios públicos recuperados con vista al mar, destinado al uso y disfrute de los 
vecinos y visitantes del distrito, que permitirá el desarrollo de diversas actividades de recreación, lúdicas, culturales y educativas.

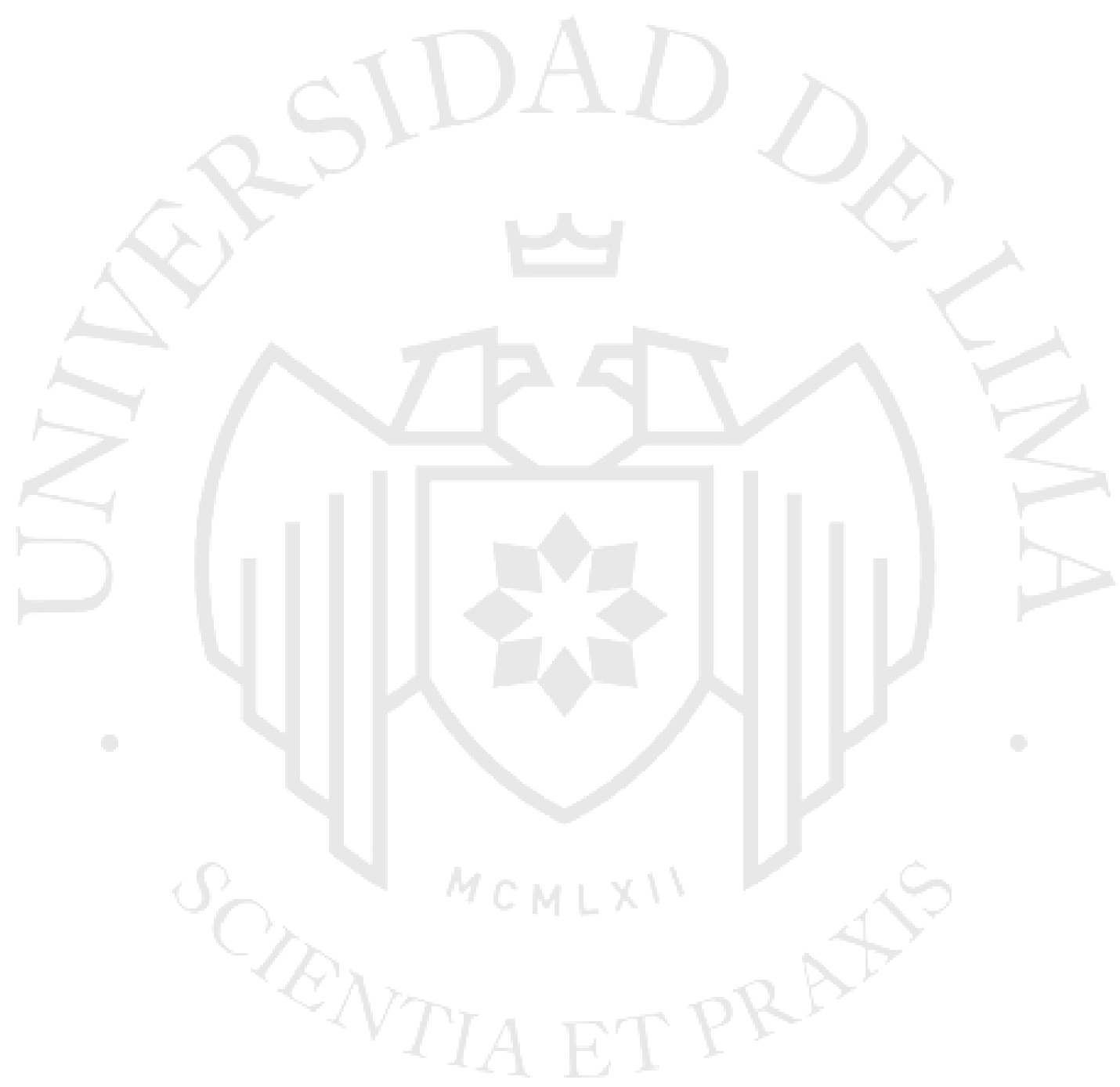




\section{CAPÍTULO III: MARCO TEÓRICO}

\subsection{En relación a la ciudad, el espacio público y el espacio cívico}

En los siguientes subcapítulos se abordarán temas relacionados al espacio público vinculado a la ciudad y a los ciudadanos, al espacio cívico como dimensión del espacio público, se tocará también la importancia del mercado como espacio cívico y finalmente se hablará del papel fundamental que cumple la arquitectura en todos estos espacios públicos, cívicos y en la ciudad en general.

\subsubsection{Teoría del espacio público}

Existen muchas definiciones de espacios públicos, las que hacen referencia al espacio público como lugar de encuentro e interacción en la ciudad, las que hacen referencia a un lugar construido delimitado dentro de un público, comunidad barrio o vecindario, otras que describen el espacio público como espacio verde, con vegetación, al aire libre, con juegos y mobiliario de descanso u ocio, otras definiciones que guardan vínculo con la identidad ciudadana, la historia del lugar y el valor de la memoria. A continuación, detallaremos algunas de ellas, que algunos arquitectos, urbanistas, historiadores, hacen mención y mediante las cuales podremos finalmente definir espacio público para la propuesta de mercado.

Jordi Borja nos hace un acercamiento bastante general y abarca varios conceptos de nuestro interés, cuando en diversos momentos de su Libro La Ciudad Conquistada, menciona al espacio público. En primer lugar, hacer referencia a este como espacio para la comunidad, destinado a equipamientos o infraestructuras de uso colectivo.

Sin embargo, no deja de lado, la idea de espacio público como vinculador social y cultural. Según Borja, el espacio público se puede valorar por la intensidad y la calidad de las relaciones sociales que facilita, por su capacidad de mezclar grupos y comportamientos, de estimular la identificación simbólica, la expresión y la integración cultural. Es decir, el espacio público está reservado al ejercicio de la ciudadanía y de expresión de los derechos civiles. 
Si bien para la mayoría de las personas, espacio público son los parques, plazas, áreas verdes más singulares de la ciudad, Doménico di Siena especifica el espacio público como:

“...todos los lugares de encuentro, en los que se establece una forma de relación ciudadana y en los que se va configurando la cultura propia de esa comunidad. Por ello, también son espacio público las plazas y parques de los barrios, los mercados, los mercadillos, los locales de ocio y deportivos, los teatros y cines, las calles...y los que se configuran continuamente en la red. El espacio público crea ciudad, la cohesiona y, a la vez, redefine continuamente la esencia de la misma.'(Di Siena, 2009, p. 23)

Figura 3.1

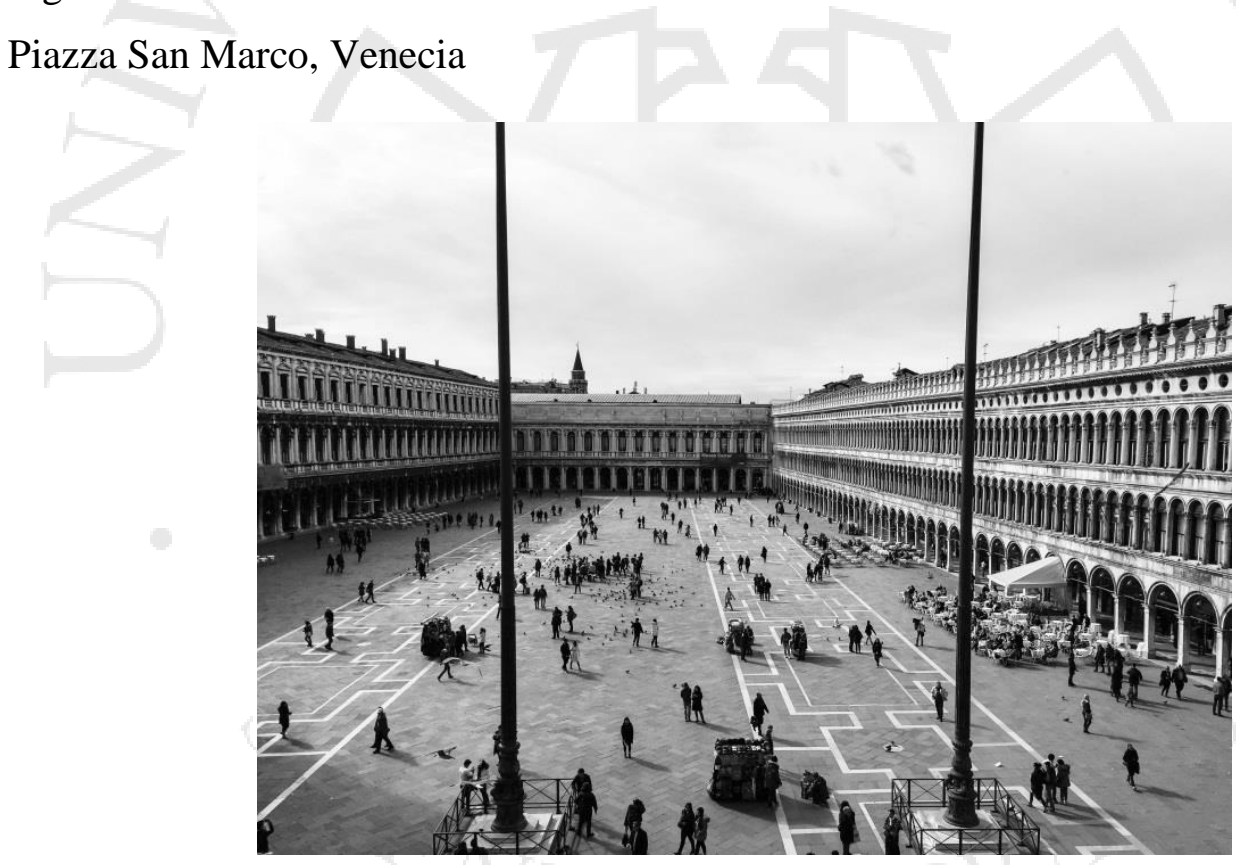

Fuente: fotografía propia

Los especialistas contantemente abordan el espacio público como lugar de encuentro en la ciudad, de libre acceso, en donde la población de expresa, es un “...lugar de representación y de expresión colectiva de la sociedad...” (Borja, 2003, p. 21), donde la identidad colectiva, la identidad cultural, lugar donde diversas infraestructuras y equipamientos converger para uso de la sociedad. Tal como lo dice Borja: 
“el espacio público supone pues dominio público, uso social colectivo y multifuncionalidad. Se caracteriza físicamente por su accesibilidad, por que lo convierte en un factor de centralidad. La calidad de espacio público se podrá evaluar sobre todo por la intensidad y la calidad de las relaciones sociales que facilita, por su capacidad para generar mixturas de grupos y comportamientos, por su cualidad de estimular la identificación simbólica, la expresión y la integración cultural. Por ellos, es necesario que el espacio público se piense como obra de cualificación del entorno y de calidad intrínseca, como son la continuidad en el espacio urbano y su facultad ordenadora, la generosidad de sus formas, de su diseño y de sus materiales y la adaptabilidad a usos diversos a través del tiempo.”(Borja, 2003, p. 124)

Lo mismo pasa con Doménico di Siena que establece tres consideraciones para con el espacio público. El primero tiene que ver con el espacio público como ciudad, pues es este el que se convierte en elemento ordenador, la ciudad, dice el autor, empieza y se desarrolla a través del espacio público. El segundo tiene que ver con los valores que el espacio público tiene: funcional (racional), cultural (simbólico) y cívico-político (representación y expresión de la colectividad). Finalmente, el tercero tiene que ver con la capacidad que tiene los espacios públicos para transformar el entorno (tanto el físico como el social). (Di Siena, 2009, pp. 21-22)

Figura 3.2

Cloud Gate de Sir Anish Kapoor en AT\&T Plaza, Chicago

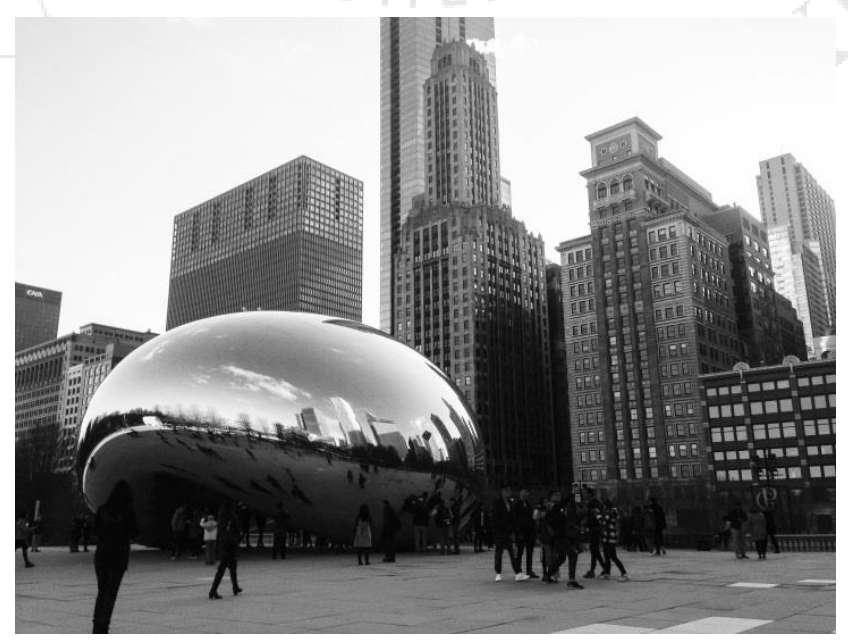

Fuente: fotografía propia 
Borja al definir espacio público, lo liga constantemente a la palabra "ciudad", indica que no los puede separar uno de otro pues considera que el espacio público hace ciudad y la ciudad, espacio público. Por ello define la ciudad como un escenario abierto a todos, que expresa democratización y política social, como “... Un lugar con mucha gente que interactúa cara a cara, un espacio público, abierto y protegido. Un lugar como hecho material y social, productor de sentido. Una concentración de puntos de encuentros. ..." (Borja, 2003, p. 135)

Por otro lado, Allan Jacobs, en su libro Great Streets, menciona la estrecha relación entre el espacio público y la ciudad, hace hincapié en que "el espacio público define la calidad de la ciudad, porque indica la calidad de vida de la gente y la calidad de la ciudadanía de sus habitantes" Allan Jacobs en libro Great Streets (Borja, 2003, p. 135)

Percival Goodman (1947), también menciona que la ciudad “... está constituida por la reunión social de personas para el trabajo, el placer y la ceremonia. ..." Entonces, afirma que la condición de ciudadanía es inherente a la calle, es un lugar para estar, un lugar para pasear, a un espacio público. (Hernández Aja, 1997, p. 19)

Entonces la ciudad debería funcionar como espacio público, y viceversa, como diría Borja, en un sentido físico por las centralidades, la movilidad y la accesibilidad socializadas, a las zonas sociales y diversificadas, lugares con atributos o significantes) y en un sentido político y cultural por la expresión y representación colectivas, por la identidad, por la cohesión social y la integración ciudadana.

Así ambos, ciudad y espacio público funcionarían como lugar para la representación y expresión de la sociedad. Por ello, el hecho de que el espacio público sea el elemento determinante de la forma de la ciudad ya es razón suficiente para atribuirle el rol ordenador del urbanismo, de trama urbana.

"Es la ciudad en su conjunto la que merece la consideración de espacio público. La responsabilidad principal del urbanismo es producir espacio público, espacio funcional polivalente que relacione todo con todo, que ordene las relaciones entre los elementos construidos y las múltiples formas de movilidad y de permanencia de las personas. Espacio público cualificado culturalmente para proporcionar continuidades y referencias, hitos urbanos y entornos protectores, 
cuya fuerza significante trascienda sus funciones aparentes. El espacio público concebido también como instrumento de redistribución social, de cohesión comunitaria, de autoestima colectiva. Y asumir también que el espacio público es espacio político, de formación y expresión de voluntades colectivas, espacio de la representación, pero también del conflicto. Mientras haya espacio público, hay esperanza de revolución, o de progreso." (Borja, 2003, p. 29)

Con lo mencionado anteriormente vale la pena recalcar otro punto que Jordi Borja también menciona, y es que "la ciudad vive cada día del intercambio, es la plaza, es el mercado... El intercambio supone paz y reglas, convivencia y pautas informales que regulen la vida colectiva. La ciudad es comercio y cultura, comercio de las ideas y cultura de la producción de servicios para otros. Comercio y ciudad son la indisolubles como campo y naturaleza..." (Borja, 2003, pp. 27-28) Y al funcionar como intercambio hace falta el usuario, quien llevara a cabo las transacciones, quien establece esas reglas, quien llega a los acuerdos mediante las pautas determinadas y establecidas. Por eso, así como la ciudad y el comercio son indisolubles, el comercio y el comerciante también lo son, porque no existe uno sin el otro, son los usuarios lo que llevaran a cabo esta actividad en esta ciudad.

Entonces vemos como todos estos conceptos y características también está estrechamente vinculados a la palabra ciudadanía, en vista que esta está constantemente interactuando en estos espacios. La permanencia de los espacios públicos urbanos frecuentados exige niveles mínimos de integración y cohesión social. Por ello, “desde una dimensión sociocultural, el espacio público es un lugar de relación y de identificación, de contacto entre las personas, de animación urbana y a veces de expresión comunitaria...” (Borja, 2003, p. 122)

En esa dimensión socio-cultual, el espacio público, se caracteriza por ser un lugar de relación y de identificación, de contacto entre las personas, de animación urbana y de expresión comunitaria. La dinámica propia de la ciudad y los comportamientos de sus gentes pueden crear espacios públicos que jurídicamente no lo son, o que no estaban previstos como tales, abiertos o cerrados, de paso o a los que hay que ir, pero que sin embargo gracias a estos usuarios se convierte en tales." (Di Siena, 2009, p. 31) 
Finamente Alfonso Vergara y Juan Luis de las Rivas también se refieren a los espacios públicos del futuro como territorios en los que se trabaja para lograr la cohesión y el equilibrio social, es decir la "inclusión" de todos los ciudadanos. Dedican esfuerzos importantes a la renovación urbana, a la mejora de la calidad ambiental y a la imagen urbana ya que estos aspectos repercuten en todas las clases sociales y grupos de la ciudad. Son además territorios que propician el sentimiento de pertenencia y fortalecen la identidad." Fundación metrópolis, Madrid, 2004. Vergara, a. \& de las Rivas, j.1. (2004): territorios inteligentes. Nuevos horizontes del urbanismo.

\subsubsection{Teoría del espacio cívico}

Como hemos visto anteriormente, el concepto de espacio público puede definirse según distintos ámbitos. El autor Di Siena analiza la aparición de la noción de espacio público en distintas disciplinas científicas y técnicas, que dan lugar a varios significados y perspectivas respecto al espacio público. Es decir, que el concepto puede estar definido en varias dimensiones según el ámbito de estudio y su valoración respecto al uso, función, significado y valor otorgado por el usuario fundamental: el ciudadano.

Históricamente el término ciudad deriva de los términos urbs (urbe, espacio construido de la ciudad), civitas (ciudadanía), y polis (ciudad). Entendiéndose que el término necesariamente corresponde a un entorno físico construido y los individuos que habitan en el entorno urbano.

"CIVITAS o la ciudad como lugar productor de ciudadanía y ámbito de ejercicio de esta. Entendemos por ciudadanía un status que reconoce los mismos derechos y deberes para todos los que viven - y conviven - en un mismo territorio caracterizado por una fuerte continuidad física y relacional y con una gran diversidad de actividades y funciones.“ (Borja, 2000, p. 64) La ciudad se puede ver como el territorio físico productor de ciudadanía, es decir en ella deberían espacios idóneos a favor del ciudadano.

Cuando uno quiere entender las funciones del espacio otorgado a la ciudad, al ciudadano, recurre a analizar el espacio público. El autor Jordi Borja entiende el espacio público no solo por el espacio jurídico otorgado para el libre tránsito, sino como aquel 
espacio que "contribuirá más a la ciudadanía cuanto más polivalente sea funcionalmente y más se favorezca el intercambio.“ (Borja, 2000, p. 69)

En la publicación "El espacio público, ciudad y ciudadanía” el espacio público toma distintas dimensiones según su escala, uso, concepción y función que cumple en la ciudad. Este, según Borja, se entiende por un espacio multifuncional que refleja la identidad de una sociedad. En este sentido, queremos diferenciar una de las dimensiones del espacio público que está ligado al ciudadano y su relación social, cultural y cívica con la ciudad, dándole énfasis como tema de estudio al espacio cívico.

"Las relaciones entre los habitantes y entre el poder y la ciudadanía se materializan, se expresan en la conformación de las calles, las plazas, los parques, los lugares de encuentro ciudadano..., áreas comerciales, equipamientos culturales es decir espacios de uso colectivos debido a la apropiación progresiva de la gente - que permiten el paseo y el encuentro, que ordenan cada zona de la ciudad y le dan sentido, que son el ámbito físico de la expresión colectiva y de la diversidad social y cultural. Es decir que el espacio público es a un tiempo el espacio principal del urbanismo, de la cultura urbana y de la ciudadanía. Es un espacio físico, simbólico y político.“(Borja, 2000, p. 8)

Es en este punto que se encuentra la relación del espacio público con el espacio cívico. El espacio cívico puede entenderse como el espacio de expresión sociocultural otorgado para el encuentro de los ciudadanos. Un espacio de carácter público complementado por equipamientos para el servicio de la ciudad. A pesar de que cumple otra función social de integración y servicio al ciudadano podría considerarse dentro de la polivalencia que el espacio público significa, ya que propicia el encuentro y la apropiación colectiva.

Dentro de este entendimiento no se debería desvincular el espacio público del término espacio cívico, ya que ambos coinciden en el mismo territorio dentro de la ciudad. Espacio donde no solo se involucra espacio físico donde los ciudadanos interactúan, sino también la cultura, la identidad y la memoria. 
Figura 3.3

Plaza Gran Mercado, Brujas. Espacio cívico

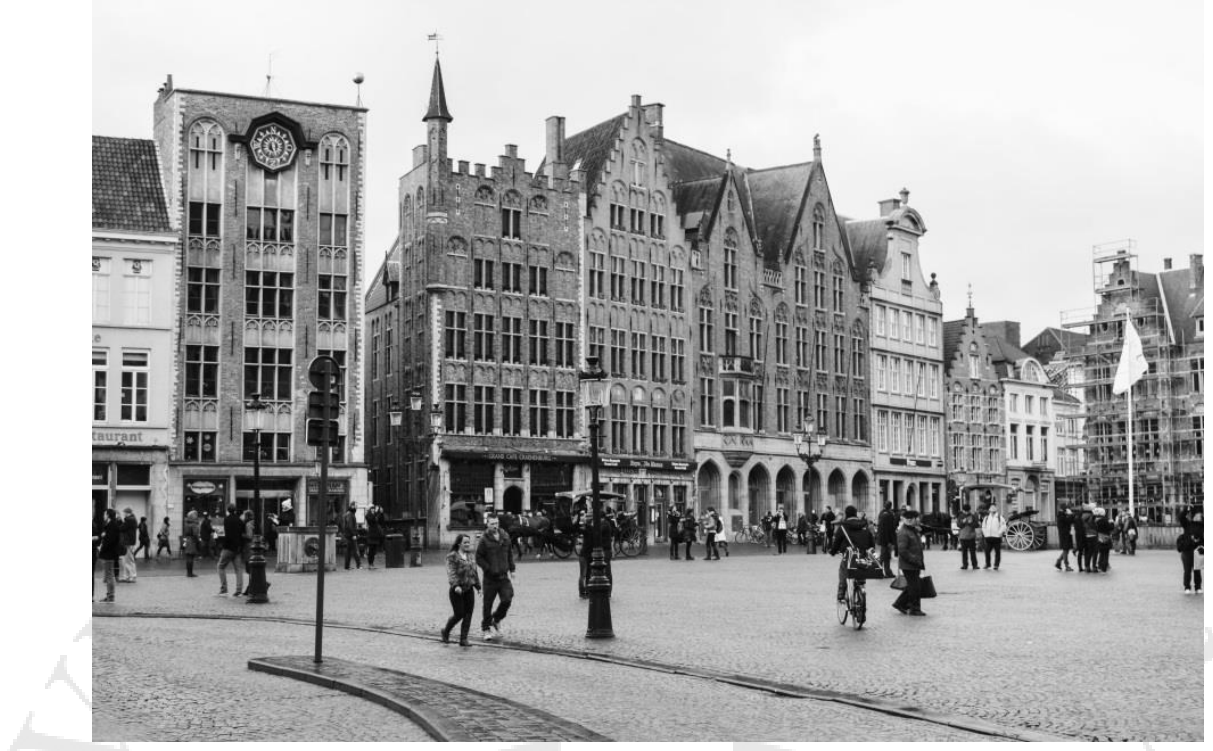

Fuente: fotografía propia

El autor Jordi Borja en su publicación "La Ciudad Conquistada", menciona la existencia de los espacios públicos ciudadanos, que por su definición se entienden como espacios cívicos. Estos pudiendo ser desde un espacio abierto hasta un equipamiento cultural. Borja describe una serie de elementos comunes, que, según el análisis de experiencias exitosas, aparecen en este tipo de espacios:

Localización. Según su análisis el entorno inmediato a la ubicación de este tipo es espacios "no representa en ningún caso un obstáculo insuperable...cuanto más pobre o deteriorado sea el entorno, más fuerte y de mejor calidad tiene que ser la arquitectura como factor de atracción, de identidad y de prestigio". (Borja, 2003, p. 142)

Multifuncionalidad. En este elemento se entiende que la oferta debe ser diversa, que el espacio proyectado debe contener oferta cultural, espacios interactivos, creativos, centros de formación, talleres y comercio. Asimismo, pueden involucran usos de carácter social, administrativo y/o equipamientos que complementen la oferta turística como hoteles, restaurantes. Por último, la existencia de espacio de transición abierto al entorno.

Públicos objetivos. Otro elemento es el público o usuario que intervienen en el espacio. Este puede ser procedente del entorno inmediato; de la ciudad o región; 
determinado por la oferta principal; o el turístico. El impacto sobre el entorno se verá determinado por el tipo de público, pero el espacio será un factor de actividad urbana.

Gestión. La gestión y financiamiento de los espacios públicos ciudadanos en su mayoría de sus casos son públicos o mixtos. "El sector público (local o estatal) desempeña casi siempre un rol motos indispensable. Pero también son cada vez más frecuentes las fórmulas de partenariado”. (Borja, 2003, p. 144)

Impacto sobre el entorno. Los elementos característicos del espacio debería impactar de manera positiva a la imagen de la zona, "de rehabilitación urbana, de mejora de los servicios públicos y de la seguridad, de aparición o modernización de actividades económicas (comerciales especialmente), de sensibilización de una parte de la población residente a la oferta cultural, de autoestima...” (Borja, 2003, p. 144)

Seguridad ciudadana. La actividad planteada en la zona con una propuesta participativa y abierta crea una mayor seguridad no solo en el interior del completo sino a sus entornos inmediatos. "en la medida en que vigoriza el uso de los espacios públicos, estimula actividades comerciales y facilita una mayor relación de los habitantes de la zona con el equipamiento. (Borja, 2003, p. 144)

Imagen de la zona y de la ciudad. Este elemento propone que además de los equipamientos públicos que generen actividad en la zona, estos estén acompañados de espacios de encuentro público de calidad y con un impacto hacia sus entornos inmediatos. "Los elementos impactantes, sin raíces ni relación con el entorno, no podrán perdurar más allá de los que dure la novedad.” (Borja, 2003, p. 145)

\subsubsection{El mercado como espacio cívico}

Como hemos podido ver en el capítulo anterior, el mercado a lo largo de su existencia en la ciudad ha cumplido un rol de espacio de intercambio. Esta función de intercambio no solo con un fin comercial, de compra y venta de productos, sino de espacio de encuentro de los ciudadanos que posibilita el intercambio social y cultural. La plaza de mercado, espacio multifuncional que significó el centro de las ciudades a lo largo de la historia, ha tenido diversas funciones otorgándole polivalencia al espacio donde se desarrolló. 
El mercado como parte de su definición, puede ser espacio público para un barrio, distrito, ciudad. Sin embargo, luego de haber analizado sus funciones en el tiempo, y visto las dimensiones que el espacio público puede tener, correspondería a formar parte de los espacios cívicos de la ciudad.

Figura 3.4

Mercado en Piazza dei Signori, Verona

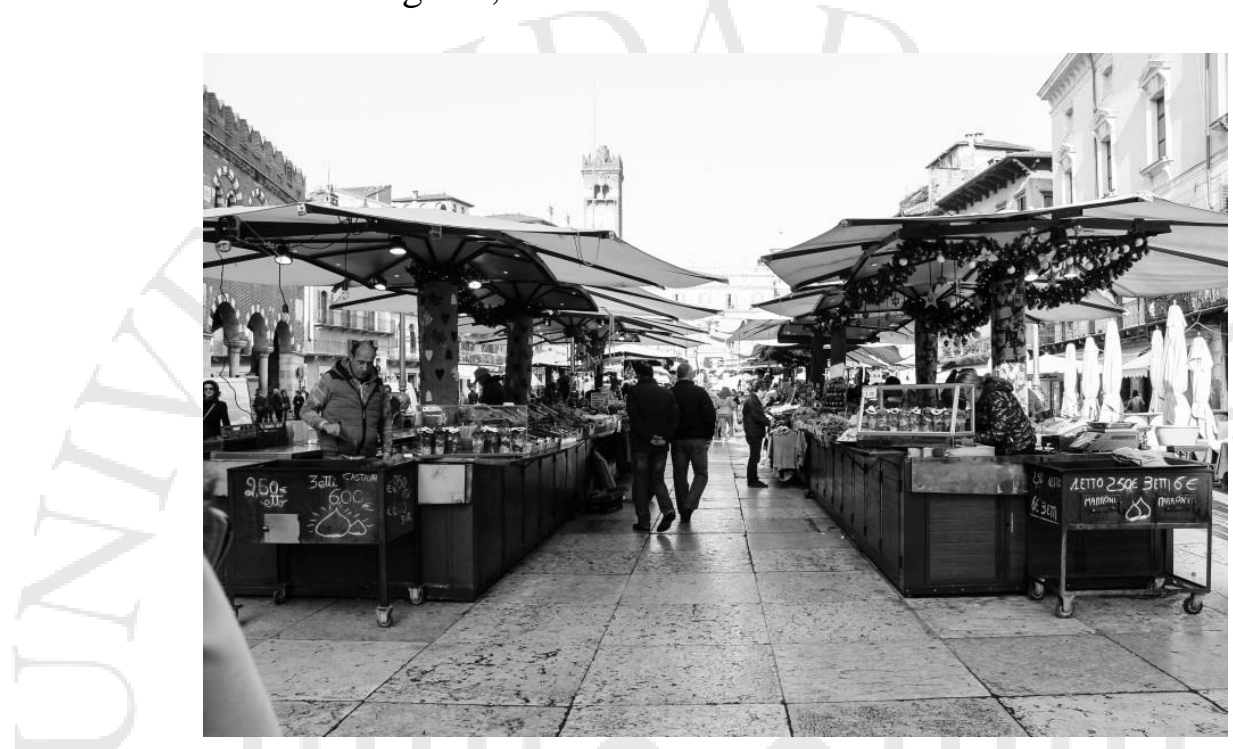

Fuente: fotografía propia

"La función concreta que le dio razón de ser a la plaza fue, sin duda, la reunión pública para el intercambio de bienes y servicios, es decir, el mercadeo. A través del tiempo se fueron adicionando actividades furtivas, sociales, o de concentraciones políticas.“ (Plazola Cisneros, Plazola Anguiano, \& Plazola Anguiano, 1999, p. 64) El autor Plazola cuando define la función de la plaza no deja de mencionar la importancia que significó el mercado para la ciudad, siendo el espacio físico multifuncional donde se desarrollaban las actividades políticas, sociales y religiosas. Esta estrecha relación entre la plaza y el mercado, que viene desde una perspectiva histórica ha permitido poder catalogar al mercado como un espacio cívico en su conjunto, ya que en muchas ocasiones parte de o corresponde una plaza. Por ende, el tratamiento respecto a la traza urbana, ubicación e identidad de lugar, debería ir acorde al uso como espacio cívico de la ciudad. 
Plazola clasifica la plaza según su uso y función a la ciudad siendo la plaza cívica y la plaza recreativa y comercial dos tipos de espacios urbanos en los cuales el mercado pasaría a identificarse o complementar. Las plazas, al ser espacios públicos, donde el usuario es el que le da la dimensión según su uso, cambian en el tiempo. "En la actualidad, algunas plazas cívicas han cambiado de uso por los habitantes de una zona. Estas plazas se han utilizado como lugares de intercambio cultural, comercial y social. Son lugares de reunión...un espacio al aire libre con el fin de reunirse para conversar, aprender o comprar“" (Plazola Cisneros et al., 1999, p. 65). A pesar de que se plantean estos dos tipos de plaza con usos distintos no tendría porque no haber una relación entre las mismas, ya que los espacios cívicos, comerciales y de intercambio social, en el tiempo se han complementado en el mismo espacio. El mercado viene de ser una plaza y por ende su identificación, valor y función para con la ciudad hoy en día permanecen arraigadas a este territorio.

\subsubsection{El espacio público relacionado a la arquitectura}

Según la RAE (Real Academia Española) Equipamiento vendría a ser el conjunto de todos los servicios necesarios en industrias, urbanizaciones, ejércitos, etc. Es decir, aquellas dotaciones que la comunidad estima imprescindibles para el funcionamiento de su estructura social y que requieren de un carácter público.

Los equipamientos colectivos forman, dentro del ámbito económico y social en el que nos encontramos, el sistema básico de cohesión social en un doble sentido. En primer lugar, como instrumento para paliar las desigualdades de la economía de mercado, mediante la distribución generalizada de los servicios básicos del estado del bienestar, como la salud y la enseñanza, y en un segundo lugar como espacio colectivo donde los ciudadanos desarrollan una serie de actividades sociales, culturales y lúdicas, fundamentales para componer una sociedad articulada. (Hernández Aja, 1997, p. 5)

Los equipamientos deben ser, como plantea Hannerz (1986), «instituciones nodales en los que muchos mundos urbanos se encuentran». Se trataría de la creación de espacios «convivenciales», espacios de consumo colectivo diversificado con carácter poroso, en contraposición con la impermeabilidad de los funcionamientos en los equipamientos tradicionales, que sólo sirven para un uso y sólo admiten un modelo de 
gestión que es ajeno al usuario... la existencia de nuevas situaciones en la sociedad demanda nuevos espacios y servicios para la misma. (Hernández Aja, 1997, p. 46)

Figura 3.5

Espacio público, ciudad y arquitectura en Musee du Louvre, Paris

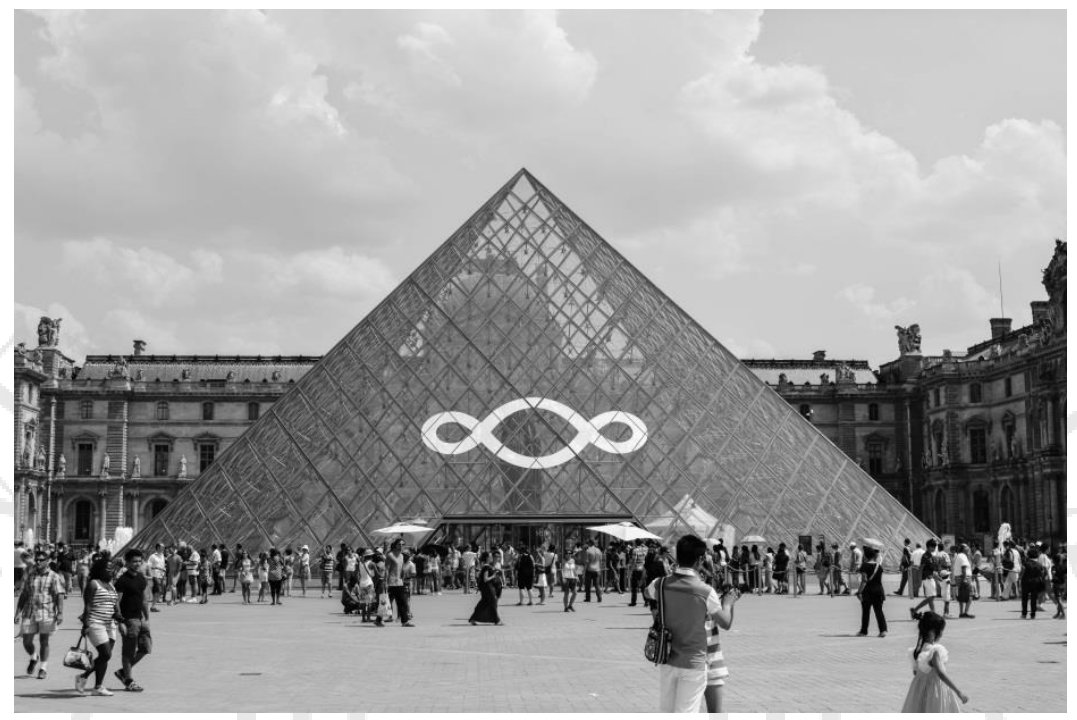

Fuente: fotografía propia

El espacio público y los equipamientos colectivos en conjunto, como se ha mencionado, permiten el encuentro del uno con el otro y además de cumplir su rol funcional en la ciudad, también cumplen el trabajo de nodos en procuran la articulación de tejidos urbanos en varias escalas. Por poner algunos ejemplos, se encuentra el Parque Kennedy de Miraflores con sus restaurantes y tiendas para un distrito, Champs Elysées la avenida más importante de París con sus tiendas para un barrio o el Central Park de New York y sus edificios multifuncionales para la ciudad.

Entonces nos queda claro que los equipamientos juegan un papel sumamente importante para determinar el sentido y naturaleza de los espacios en las ciudades. “... Se trata de entender los equipamientos como eje para recomponer o recrear una sociedad articulada que sea germen y sostén de una cultura propia, de un proyecto de vida urbana compartido por la mayoría de los habitantes de estos lugares." (Hernández Aja, 1997, p. 45) 
Agustín Hernández en el libro La Ciudad de los Ciudadanos habla acerca de una estructura urbana que deba cumplir con 3 conceptos fundamentales. Debe ser útil en primer lugar para sus habitantes, ofrecerle las estructuras correspondientes a la sociedad “...útil para la sociedad, no destruyendo espacios y sociedades sino partiendo de ellos. Útil de forma que su mantenimiento y utilización no sean gravosos para sus ciudadanos, de forma que sus viviendas y espacios sean adecuados a las necesidades normales de cada individuo, cumplimentando adecuadamente los espacios públicos necesarios para la satisfacción de las necesidades de sus ciudadanos, mediante la existencia de un espacio público y unas dotaciones de servicio universal y accesible..." En segundo lugar, debe ser firme en cuanto a su estabilidad estructural y funcional, pero sobre todo “...en cuanto a su relación con el medio ambiente, adecuándose a las condiciones ambientales, reduciendo el consumo de energía y la producción de residuos..." Página 13 (la ciudad de los ciudadanos). Y finalmente menciona que debe ser bella, tanto estéticamente como de acuerdo a su correcto emplazamiento en donde se localiza. Acota “...Belleza que no está sólo relacionada con el sólido edificado, sino con las condiciones y cualidades del espacio urbano en el que se localiza, realizando adecuadamente la articulación de los usos y dotaciones necesarias en cada espacio urbano.” (Hernández Aja, 1997, p. 13)

Para cerrar vale recordar lo que el libro la ciudad de los ciudadanos nos menciona “... tanto equipamientos como servicios forman parte del sistema dotacional integrado por todos aquellos elementos que representan el espacio común donde la comunidad se reconoce a sí misma, formando una red de lugares sobre los que se desarrollan las actividades simbólicas y lúdicas de la colectividad. El conjunto de estos espacios, libres o construidos, constituye el soporte físico destinado a proveer a los ciudadanos prestaciones sociales o servicios colectivos y definen el sistema de la calidad urbana, integrado por el sistema de espacios de usos y dominio público, el sistema de equipamiento y el sistema de dotaciones al servicio de la ciudad." (Hernández Aja, 1997, p. 127)

En conclusión, los equipamientos son elementos fundamentales en la estructuración urbana, permiten al ciudadano identificarse con el lugar y su gente y además son creadores o calificadores del espacio público al que pueden añadir pluses diversos. Ese resultado se consigue cuando un lugar además de ser colectivo es propio, 
sus puertas se abren a toda la población generando confianza en el movimiento de las personas. La clave, nos recalca Hernández, está en encontrarle ese doble papel que debe cumplir la arquitectura de la ciudad, debe ser eficaz funcionalmente y multidireccional con sus usuarios y los espacios públicos. (Hernández Aja, 1997, p. 46)

Figura 3.6

Ciudad como lugar de encuentro. Grande Arche de la Defense, Paris

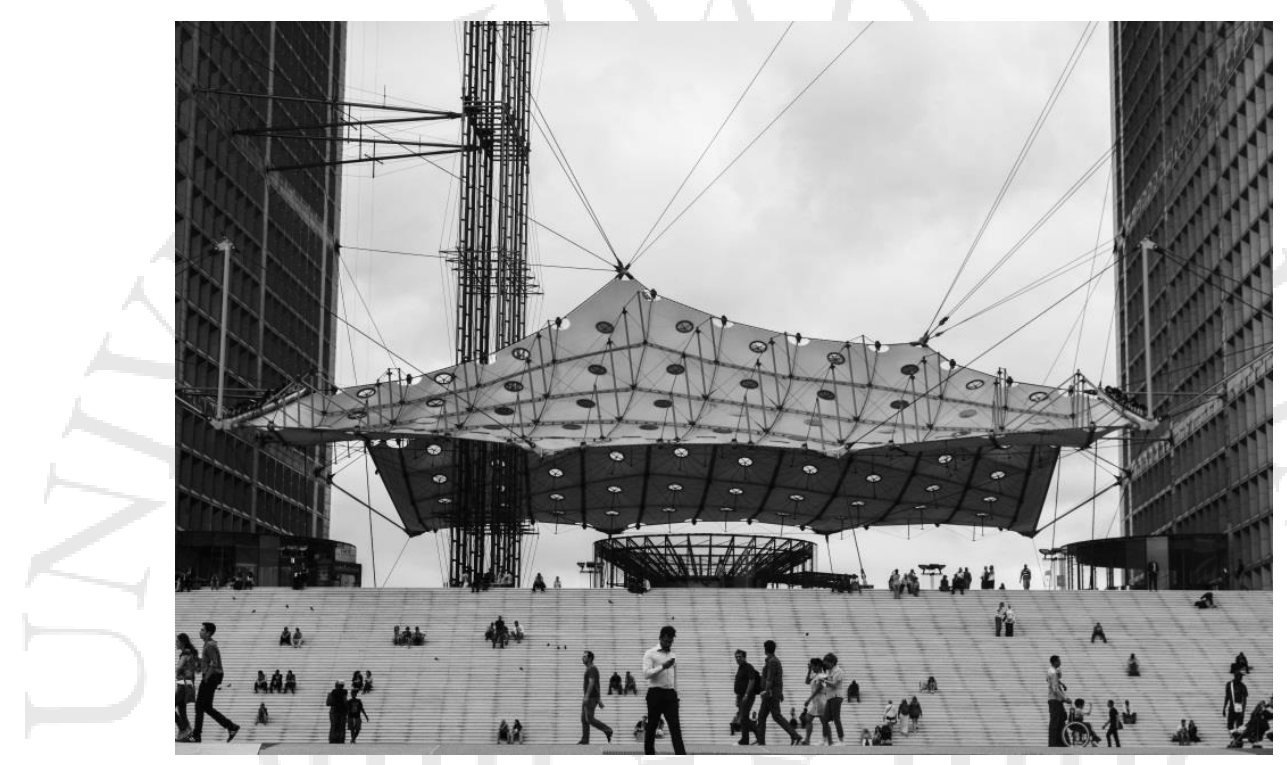

Fuente: fotografía propia

\subsubsection{Espacio público, ciudad y arquitectura}

"Las calles le brindan a la ciudad un canal estructurador en el que confluyen el significado social, la movilidad personal y comercial, el compromiso cívico, la salud humana y la integridad ambiental.” Prólogo por Joan Clos en el libro Streets as Public Spaces and Drivers of Urban Prosperity (HABITAT, 2013, p. III)

Jan Gehl, arquitecto danés referente a nivel mundial de diseño urbano y espacios públicos, deja algunas lecciones urbanas, sociales, medio ambientales y arquitectónicas relacionadas al espacio vinculado a la sociedad. 
Cada vez que pones un ladrillo en cualquier parte, manipulas la calidad de vida de las personas. (...) Si sólo haces forma, es escultura. Pero se convierte en arquitectura si la interacción entre la forma y la vida es exitosa. - Jan Gehl. (Gaete, 2016)

Su principal idea de diseño arquitectónico urbanístico gira en torno a retomar a la persona como unidad de medida y aboga por el diseño urbano teniendo siempre en mente y como prioridad la escala humana, los sentidos, la calidad de vida de las personas, entre otros.

Figura 3.7

Los sentidos y la escala en Chicago. Tratamiento de espacio público en Millennium Park

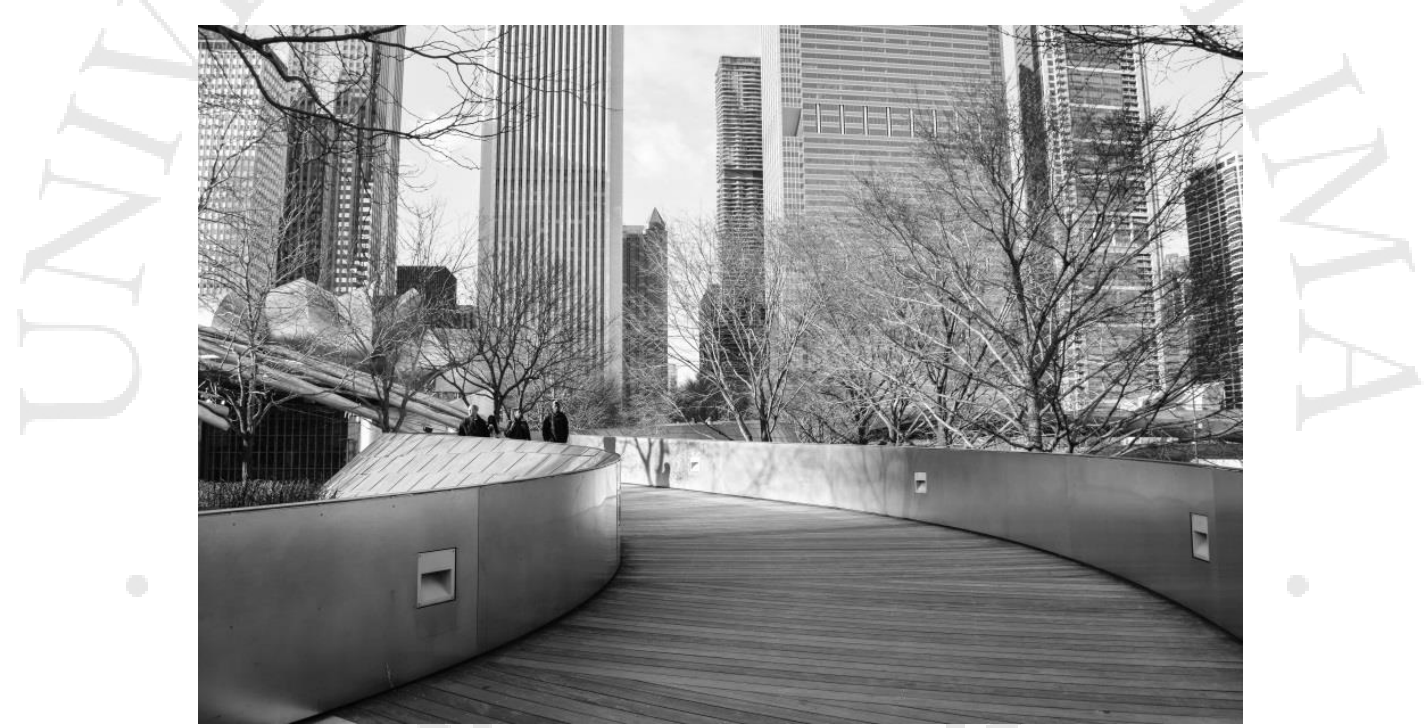

Fuente: fotografía propia

Gehl asegura que hay muchos edificios, barrios y espacios que son sugerentes y de una arquitectura llamativa y atractiva si los aislamos unos de otros o los observamos a vista aérea, pero en general tienden a formar espacios urbanos inhabitables, lo cual se evidencia cuando se desciende a la escala del peatón.

"Un buen patrón de calles contribuye al desarrollo de la infraestructura, mejora la sostenibilidad ambiental, permite una mayor productividad, enriquece la calidad de vida, promueve la equidad y la inclusión social.” (Gehl, 2014) 
En referencia al párrafo previamente citado a continuación, se mencionan algunas de las posturas urbanas del arquitecto danés, las cuales mencionan en su libro Ciudades para la Gente y que merecen la pena plasmar en la presente investigación:

\section{La dimensión humana}

Gehl propone constantemente diseñar espacios pensando siempre desde el punto de vista humano, propone centrarse en las personas, “... que no es una tarea fácil, centrarse en las personas puede ser difícil de lograr en la planificación, el diseño, y en la fabricación real de la ciudad, construir ciudades es verdaderamente un arte de muchos" (Classic: Ciudades para la gente, por Jan Gehl, 2015)

Por ejemplo, el autor menciona que la ciudad de Venecia es una ciudad hecha para las personas únicamente, consta de calles estrechas, sus calles miden 3 metros en promedio. Es una ciudad para caminar, pasear, conocer, hacer compras a pie, ir a trabajar a pie, tiene espacio públicos y plazas en cada esquina. Por eso esta ciudad Gehl la considera diseñada de acuerdo a la dimensión humana, pequeña, personal, intima, "mientras que lugares como Dubái es para dinosaurios, no seres humanos." (Alonso, 2017)

Figura 3.8

Dimensión humana en Venecia. Fondamenta Arsenale

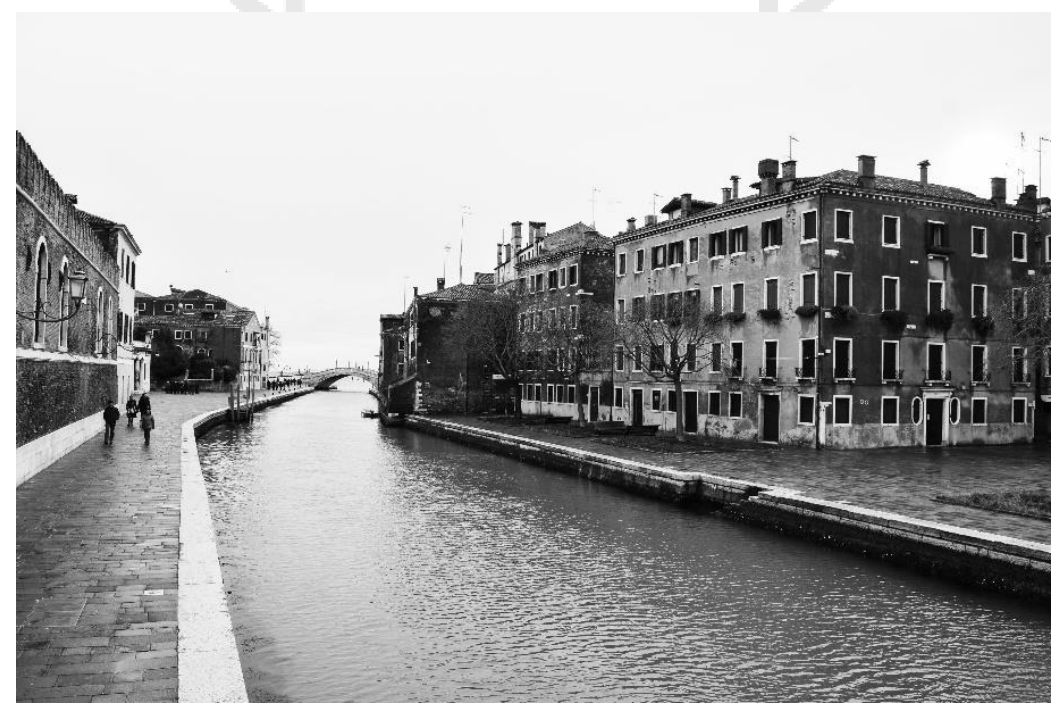

Fuente: fotografía propia 


\section{Primero moldeamos a las ciudades y luego ellas nos moldean a nosotros}

El arquitecto danés nos recuerda que lo que diseñamos y después es habitado tiene una gran influencia en el comportamiento; en el estilo de vida de las personas; y esto puede llegar a significar mucho en la forma de ser de una persona. Es muy diferente si vive en un suburbio o si este vive en el centro de una ciudad, en las urbes se camina más, mientras que en los suburbios sucede lo contrario, se utiliza con mayor frecuencia el auto y se camina mucho menos. Si no nos movemos lo suficiente, la salud no es tan buena y la expectativa de vida es más corta. Esto es sólo una muestra de cómo las metrópolis influyen en las personas y su estilo de vida. Hay una enorme repercusión del ambiente físico en nuestra manera de vivir, así que cada vez que construimos manipulamos la vida de las personas, pero lo interesante es que no sabemos mucho sobre cómo lo hacemos y cuáles son las consecuencias, pero estamos conscientes de que hay una gran influencia del ambiente físico en el estilo de vida del ser humano.

Al estudiar las ciudades a lo largo de la historia, claramente se puede ver como las estructuras y planteamientos urbanos han influido sobre el comportamiento humano. El modo como las ciudades funcionan, como se diseñan, la distancia física de los espacios influye sobre el comportamiento de las personas y repercute en el contacto social. (Gehl, 2014, p. 9)

“A mejores condiciones para la vida urbana - más vida urbana." (Gehl, 2014, p. 12)

\section{La ciudad como lugar de encuentro}

La mayor atracción de una ciudad es la gente, los espacios públicos urbanos proveen mayores posibilidades que los centros privados y comerciales para que los miembros de una sociedad se expresen, además permiten que se desarrolle una serie de actividades que no encuentra cabida en otro lado.

"La seguridad, la confianza, el fortalecimiento de los lazos sociales, la democracia y la libre expresión son conceptos clave a la hora de tratar de describir qué tipo de ideales están atados a esta idea de la ciudad como lugar de encuentro." (Gehl, 2014, p. 29) 
El concepto de vida entre la arquitectura incluye una gran cantidad de actividades que la gente realiza cuando usa el espacio público: caminatas de un lugar a otro, paseos al aire libre, paradas cortas, traslados, conversaciones y encuentros, ejercicios, bailes, actividades recreativas, intercambio, comercio, espectáculos callejeros, entre otros.

Entonces caminar es el punto de partida de todo, es mucho más que solo circular y Gehl lo tiene muy claro, el hombre fue creado para caminar y todos los sucesos de la vida le ocurren mientras circulamos entre nuestros semejantes. La vida, en toda su diversidad y esplendor, se muestra ante nosotros cuando estamos a pie. Hay contacto entre las personas y la comunidad, se disfruta del aire fresco, de la permanencia en el exterior, de los placeres gratuitos de la vida y de las diversas experiencias sensoriales. Caminar otorga vida urbana multifacética. (Gehl, 2014, p. 19)

\section{Los sentidos y la escala}

Al momento de diseñar, Gehl toma en cuenta los sentidos y actividades humanas, solo y únicamente para que el ser humano se sienta cómodo. Porque se diseña para el ser humano.

\section{La ciudad vital, segura, sana y sostenible}

"Los gobiernos deben urgir a sus arquitectos y urbanistas para que incorporen la caminata en sus propuestas y así convertirlo en una política pública, capaz de contribuir en el desarrollo de ciudades vitales, sostenibles, sanas y seguras. También es necesario reforzar la función social del espacio público como un lugar de encuentro, una herramienta vital en pos de lograr una sociedad sostenible y una comunidad abierta y democrática. (...) Lograr un proyecto que contemple desarrollar una ciudad vital, sostenible, sana y segura se ha convertido en un deseo urgente y casi unánime. En este sentido, incrementar el bienestar de los peatones y de los ciclistas es un paso fundamental para lograr estos cuatro objetivos principales: vitalidad, seguridad, sostenibilidad y salubridad.” (Gehl, 2014, p. 6) 
El arquitecto danés explica algunos de las pautas a tomar en cuenta para lograr ciudades habitables, saludables, seguras y sostenibles.

Un lugar donde numerosos grupos de personas puedan usarlo, frecuentarlo, cruzarse entre sí, lo convierte un espacio en vital.

La presencia de otras personas en las calles, los parques, los espacios públicos es una señal de que un lugar vale la pena ir y es seguro, esto puede lograrse con la inclusión de mobiliario urbanos para estar, con ambientes de recreación entre calles.

A fin de contar con políticas sostenibles en la ciudad, es importante darle prioridad a la circulación peatonal, al ciclismo. Además, la sostenibilidad urbana propone contar con ciudades que cuenta con las mismas oportunidades para acceder al espacio público y desplazarse a través de él, de esa igualdad habla Gehl, de esa igualdad de oportunidades que se ve reforzada cuando las personas además de usar el transporte público pueden circular caminando de arriba abajo a pie o con bicicleta.

Figura 3.9

Espacio vital, seguro, sano y sostenible, Boston

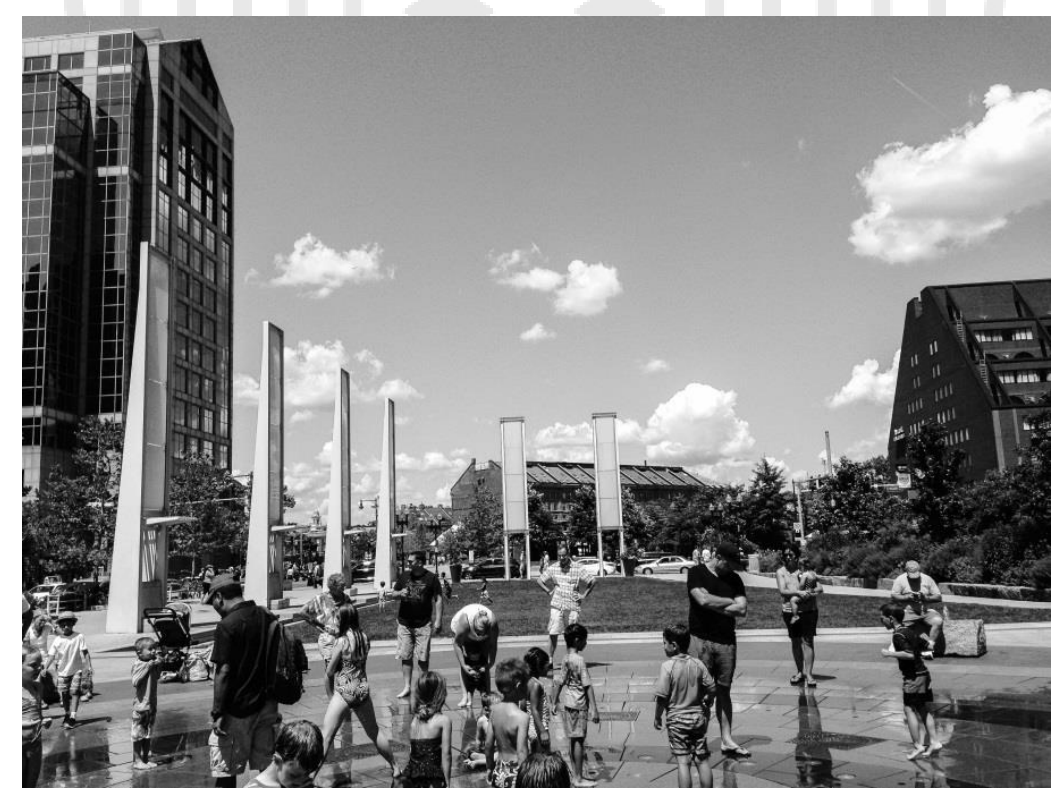

Fuente: fotografía propia

El planteamiento urbano toma un papel importante si de salud se habla. Hoy en día existen muchos problemas de salud en las personas, varios de ellos a nivel 
nerviosos, circulatorios, de obesidad y parte de ello es debido a la inmovilidad humana. El costo de dejar de hacer ejercicios, dejar de movilizarse es alto: deteriora la calidad de vida, acorta de tiempo de vida, entre otros. Frente a esto, urge implementar en las ciudades salud pública al alcance de todos, es decir considerar propuestas con niveles óptimos de infraestructura planificada: rutas peatonales atractivas, ciclo vías, veredas anchas, mejores tramas peatonales, calidad en la materialidad de pavimento, árboles para otorgar sombra, remover obstáculos innecesarios, entre otros. De esta manera se adoptan políticas que aliente a la gente a caminar, a circular también en bicicleta.

De esta manera Gehl nos deja bien claro los enormes beneficios que puede significar considerar estas pautas a la hora de planificar y proponer espacios públicos para la gente.

\section{La ciudad a la altura de los ojos}

“... lograr calidad espacial urbana en la pequeña escala — a la altura de los ojos- es crucial.” (Gehl, 2014, p. 115)

Las ciudades deben proveer buenas condiciones para que la gente camine, se pare, se siente, observe, hable y escuche. Jan Ghel explica que hoy en día vivimos en ciudades diseñadas para una arquitectura de $60 \mathrm{Km} / \mathrm{h}$, y que debemos comenzar a considerar que si vamos a diseñar para la gente -para el ser humano- debemos diseñar para una arquitectura de $5 \mathrm{~km} / \mathrm{h}$, porque es el humano quien se va a desplazar, es el ser humano quien va a hacer uso de ella; no es el carro, no es el bus, no los aviones. Una arquitectura de $60 \mathrm{Km} / \mathrm{h}$ implica calles anchas, edificios enormes, anuncios que invaden, mientras que una arquitectura de $5 \mathrm{Km} / \mathrm{h}$ implica diseño y diferenciación en los pisos, implica lugares cálidos de acogida al ser humano, tratamiento de áreas verdes de acuerdo a cada uso, de acuerdo al clima. Gehl no descarta que para algunas actividades necesitemos tener cosas a escala de $60 \mathrm{Km} / \mathrm{h}$ a o a escala automóvil, pero cuando las personas viven, trabajan, van de compras, se visitan y se trasladan como peatones, podríamos fácilmente hablar de cosas más cómodas, de una arquitectura de 5 $\mathrm{Km} / \mathrm{h}$. 
Figura 3.10

La ciudad a la altura de los ojos Marché de Noël des Champs-Elysées, Paris

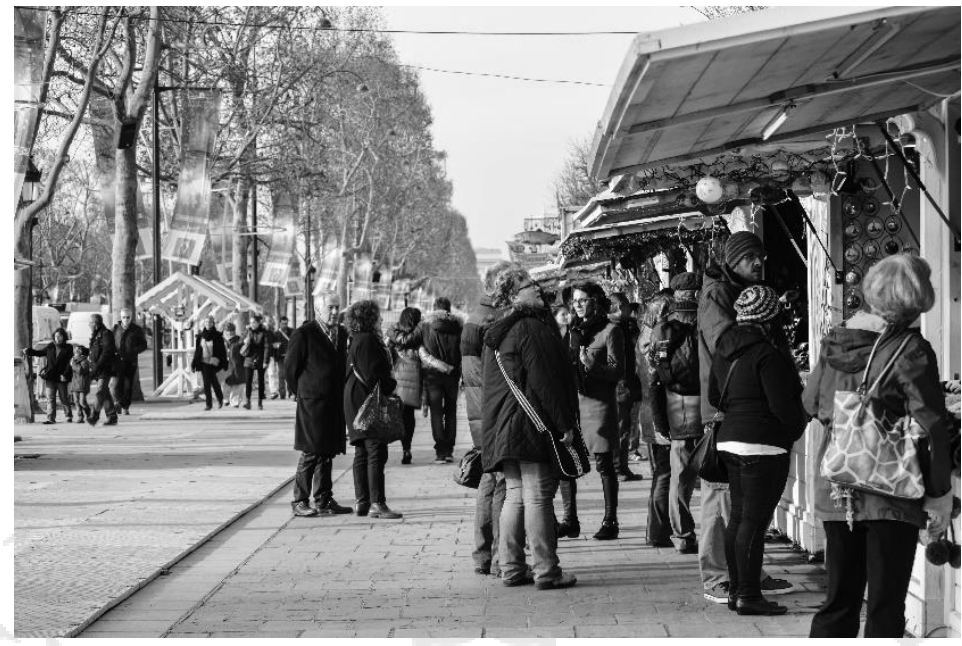

Fuente: fotografía propia

"Cuando hablo de este concepto tomo como punto de partida los sentidos humanos y cómo nosotros, las personas, nos movemos. El hombre, por supuesto, es un ente andante y nuestros sentidos, y todo, está organizado muy bien para una gente que camina hasta cinco kilómetros por hora.

Las ciudades antiguas fueron hechas para que este homo sapiens se sintiera cómodo. Los espacios no eran demasiado amplios ni grandes, por eso el hombre siempre estuvo muy cómodo.

En las antiguas metrópolis todo estaba hecho de acuerdo y a la medida de él, pero después de la introducción del modernismo y del automóvil cada escala fue derrumbada; pasamos de tener una arquitectura de cinco kilómetros por hora a ciudades enteras de 60 kilómetros por hora; esto implica calles anchas, anuncios grandes, edificios altos, donde no se puede ver nada a detalle si te mueves rápido.

Entonces, el modernismo y el "motorismo" han confundido mucho a los arquitectos y a los planificadores con respecto a lo que sería una escala cómoda para los seres humanos. He estudiado este tema durante mucho tiempo porque en verdad creo que en los últimos 50 años los planificadores y los arquitectos 
han olvidado lo que es una buena escala para el ser humano. En la antigüedad, las personas sabían muy bien qué hacer.” (Alonso, 2017)

“... por favor que ocurran cosas interesantes a la altura de los ojos (...) por favor, que las unidades sean estrechas con numerosos detalles y con un ritmo de fachada vertical (...) que no haya ni escalones ni escaleras (...) las escaleras <son> como una barrera física y psicológica." (Gehl, 2014, p. 129)

"De modo resumido, se puede afirmar que los requerimientos generales que hacen a la calidad de un buen sitio para sentarse son: un microclima agradable, una correcta ubicación, preferentemente cerca de un borde, con la espalda contra la pared, vistas interesantes, un bajo nivel de ruido que permita la conversación y la ausencia de polución. Las vistas son muy importantes. Si hay atracciones especiales, como ser espejos de agua, árboles, plantas, espacios que no se extienden al infinito, buena arquitectura y obras de arte, el individuo querrá. verlas. Al mismo tiempo, pretenderá observar la gente y las interacciones que se dan en el espacio que lo rodea." (Gehl, 2014, p. 140)

\section{La vida, el espacio y los edificios - en ese orden}

Para trabajar con la dimensión humana requiere que, al momento de la planificación y como punto de partida, la vida y el espacio urbano sean tomados como las cuestiones primordiales antes que los edificios. Entonces si se va a hablar de un orden, la prioridad radica en la imagen que se presenta a la altura de los ojos del peatón y finaliza con lo que se observa en vita aérea.

"Así como los desarrollos de nuevos emprendimientos refuerzan la importancia que tiene priorizar primero la vida, luego el espacio y por último los edificios, las experiencias recogidas tras trabajar en ciudades existentes y áreas urbanas indican que la vida urbana debe ser visibilizada y priorizada dentro del proceso planificador. (Gehl, 2014, p. 211)

Entonces a manera de cierre podemos decir que un espacio público de "calidad" provee conectividad y acceso físico, protección del crimen, cobijo del clima, aislamiento del tránsito, oportunidades para descansar y trabajar, como así también chances de congregarse. Los espacios vivibles y calles vibrantes deben ser abordados 
como áreas multifuncionales que sirvan para la interacción social, el intercambio económico y la expresión cultural para una amplia variedad de participantes.

"Los espacios públicos y las calles son, y deben ser vistos como tales, áreas multifuncionales en las que se produce la interacción social, el intercambio económico y la manifestación cultural para una gran diversidad de actores. La planificación urbana tiene la tarea de organizar estos espacios, y el diseño tiene la responsabilidad de alentar su uso, logrando que transmitan una sensación de identidad y de pertenencia." (Gehl, 2014, p. XIV)

Figura 3.11

La Rambla, Barcelona. Conectividad en los espacios públicos

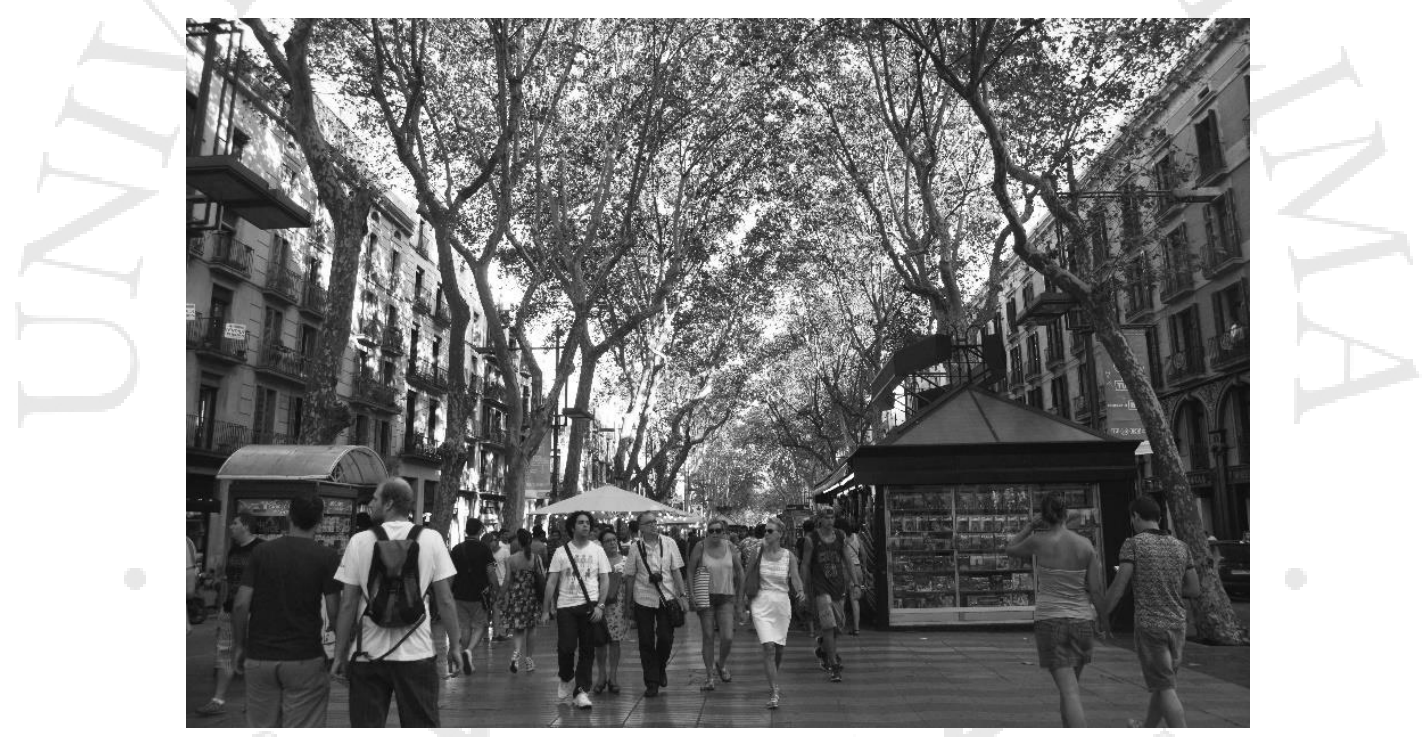

Fuente: fotografía propia

\subsection{En relación a la identidad del lugar}

\subsubsection{Identidad $y$ arquitectura}

El vínculo entre ciudad e identidad radica en el carácter de sus edificios, equipamientos, pero en mayor intensidad es sus espacios públicos. Ya que son estos lo que terminan por ser dotados de la actividad de una ciudad con características propias y locales. Pero 
más allá de la identidad que le dote o se vincule con el usuario, la arquitectura como elemento generado por el hombre podría estar dotado de identidad.

Existen teorías de arquitectura que vinculan la identidad y la arquitectura mediante el contexto, el entorno donde se ubica. Estas teorías rescatan la importancia de una arquitectura que va de la mano con su medio y lugar.

\subsubsection{Regionalismo crítico}

Uno de los críticos de la arquitectura que empleo término de identidad y el locus en los proyectos arquitectónicos, fue el arquitecto Kenneth Frampton. Quien sostiene que existe una tendencia progresiva que separa la arquitectura con la identidad contextual y cultural de su entorno. Afirma que en parte la arquitectura tiende a solo enfocarse en el desarrollo tecnológico que vivimos.

Asimismo, define la arquitectura como un fenómeno propio de un lugar que lo identifica y lo define, ya que toma en cuenta todos los factores presentes en el entorno y los aplica de manera que se logra crear un vínculo directo entre el locus y el proyecto. En este sentido relaciona la arquitectura con el locus y como esta debería tener una identidad contextual definida de manera propia.

La teoría llamada "Regionalismo Crítico" se centra en la importancia de en los proyectos arquitectónicos se integren elementos del carácter del lugar. Estas características determinadas por el entorno son el clima, la luz, la topografía, los sentidos y las condiciones externas. Asimismo, incorporar aspectos, rasgos socioculturales dentro del diseño que muestren la idiosincrasia del lugar. Por último, los autores rechazan la tendencia hacia una cultura global, rescatando que cada lugar es único con rasgos culturales y contextuales que deben ser evidenciados en la arquitectura.

El regionalismo crítico integra una serie de elementos en el proyecto arquitectónico, de tal manera que esta debería verse vinculada con la identidad contextual y cultural en la que se desarrolló.

Kenneth Frampton expone una serie de puntos para una arquitectura de resistencia. Esta estrategia plantea a través de pares de oposiciones la necesidad de un 
sentido de lugar; revela la relación de la tipología con la historia del medio y la topografía con la configuración de un lugar específico; ve la importancia de la interacción del medio (clima y tiempo) con la arquitectura y como existe una tendencia a suprimir procesos constructivos creando imágenes escenográficas; señala la relación directa de esta disciplina con la naturaleza y el deber de la arquitectura por responder a la misma; y como esta posee "una capacidad única para ser percibida por todos los sentidos." (Frampton, 1990)

Esta última revela lo sensible que es la arquitectura ante percepciones complementarias tales como los niveles de iluminación, sensaciones térmicas y movimientos del aire, aromas y sonidos diferentes producidos por materiales, acabados del pavimento, que generan en el usuario involuntarios cambios de postura, ritmo del paso, etc. (Dobles Alvarado, n.d.)

\subsubsection{Identidad en América Latina}

Las teorías en relación al regionalismo crítico y la identidad en la arquitectura, cuando llegaron al contexto latinoamericano, empezaron a generar una crítica con respecto a utilizar teorías generadas por las vanguardias centrales y no propias del contexto. Ya que en la producción debía ser juzgada según criterios del lugar y no de autores ajenos al contexto.

Es por ello por lo que autores como Marina Waisman y Cristian Fernández Cox se avocaron y pronunciaron opiniones con el fin de difundir el planteamiento de la identidad arquitectónica latinoamericana.

"Si bien Waisman comparte el reconocimiento que hace Frampton al valor e identidad que ha tenido la producción arquitectónica regional, en este caso la de América Latina, difiere con el sobre que este valor de deba a una resistencia o competencia con la arquitectura europea y norteamericana. Más bien reconoce y plantea al mismo tiempo que para que la arquitectura en el continente pueda ser realmente regional debe realizarse de manera divergente a la producida en el resto del mundo, desarrollando su propio lenguaje tanto de concepción, producción y divulgación.” (Aceves Alvarez, 2013) 
Además, difundir este planteamiento de la identidad y la arquitectura, el arquitecto chileno Cristian Fernández Cox "no solo se avocó a difundir el planteamiento de la identidad arquitectónica latinoamericana, sino se preocupó por conceptualizar el planteamiento." Con su búsqueda de una "modernidad apropiada" el autor propone que la producción arquitectónica debe plantearse en base a las condiciones y problemas del contexto donde se encuentra y que esta podría o no tener una imagen similar a las formas tradicionales.

"Podemos hablar entonces de una arquitectura apropiada, nos encontramos con la feliz coincidencia lingüística del triple significado del término: apropiada en cuanto "adecuada" (...), apropiada en cuanto "hecha propia” (...) apropiada en cuanto “propia” (...).” (Aceves Alvarez, 2013)

Según el autor, aplicar el concepto de Modernidad Apropiada en el diseño de una edificación consistía en que esta fuera adecuada al tiempo (moderna) y al lugar (apropiada).

\subsection{En relación a la memoria y el paisaje}

\subsubsection{La memoria y el paisaje}

Bajo una perspectiva sociológica, la memoria puede ser entendida como un "proceso social en el que se condensa historicidad, tiempo, espacio, relaciones sociales, poder, subjetividad, prácticas sociales, conflicto $\mathrm{y}$, por supuesto, transformación $\mathrm{y}$ permanencia.“ (Kuri Pineda, 2017, p. 11) Es decir, la memoria es erigida por la vida social, el espacio y el tiempo donde esta se desarrolla. El sociólogo Maurice Halbwachs considera al mismo tiempo la memoria como un producto del mundo social como el productor de esta. Es por ello que cuando uno habla de la memoria es consiente que esta sirve para tanto rememorar el pasado al igual que para constituir el presente pensamiento social.

Como se ve en la memoria de una sociedad, la memoria colectiva según Halbwachs está compuesta por marcos sociales que permiten la rememoración. (Kuri Pineda, 2017, p. 11) Es decir elementos como el tiempo, el lenguaje y el espacio, son 
para la memoria variables determinantes en el recuerdo y construcción de la misma. El espacio, al igual que las demás variables o marcos de la memoria, tiene un valor que constituye en la construcción de la misma.

El lugar donde se desarrollan los grupos sociales guarda una imagen específica, que es parte importante en la memoria colectiva. "El espacio es una realidad perdurable: dado que nuestras impresiones vuelan una detrás de la otra y no dejan nada en la mente, solo podemos entender como recapturamos el pasado si entendemos como, de hecho, este es conservado por nuestro medio ambiente físico.” (Halbwachs, 1990)

Es el espacio el reflejo del desarrollo de un grupo social, "donde se imbrican y cristalizan la historicidad, el poder, la cultura, la dominación y la resistencia, la identidad, la subjetividad y la memoria; en síntesis, la experiencia humana que, como se puede inferir, es una experiencia especializada.” (Halbwachs, 1990, p. 16)

Estas huellas que corresponden a la memoria del espacio son el resultante de la construcción social y tienen una dimensión material y una simbólica.

La dimensión sensorial del espacio permite generar un vínculo entre la memoria y el espacio ya que a través de la interpretación de estímulos mediante los sentidos (vista, olfato, tacto y oído) puede provocar en la persona la rememoración de contextos o situaciones determinadas. Por otro lado, en relación a la dimensión sensorial de los espacios, esto se relaciona a los "espacios de memoria, es decir, en lugares memorables que están revestidos simbólicamente y en muchas ocasiones cargados también de afectividad." (Kuri Pineda, 2017, p. 20)

\subsubsection{La memoria del paisaje}

El paisaje corresponde a una parte del territorio en el cual involucran factores humanos y naturales para la definición de su carácter. (Pérez Morales, 2008, p. 90) Es decir que es el espacio en el que vivimos e interactuamos con el medio, con el crecimiento de la ciudad, los elementos naturales, los pueblos, etc.

Debido a la interrelación entre el paisaje y la vida urbana, este territorio se convierte en la herencia histórica formando parte de nuestra memoria. Es por ello que "La historia se convierte en una vía fundamental indagación paisajística, y al mismo 
tiempo, como ha señalado Daniel Marcucci, en un objetivo explícito de prospectiva, de planificación, por cuanto en la intensidad paisajística el territorio debería enraizarse los proyectos territoriales y arquitectónicos.” (Pérez Morales, 2008, p. 48)

Para intervenir en el paisaje es necesario usar una metodología de análisis que involucre 3 escalas de evaluación. La escala municipal, o nivel territorial; a escala urbana, considerando los núcleos cercanos; y a escala arquitectónica, "estudiando con detenimiento los elementos relevantes presentes en cada uno de ellos, así como la relación existente entre los mismos." (Maderuelo, 2010, p. 12)

"Todo ello nos transporta a no olvidar que el paisaje es dinámico y cambiante y que es preciso constantemente intervenir en los paisajes, pero debe ser siempre con equilibrio, tratando de conseguir que las innovaciones que exige nuestro tiempo se estudien con el máximo rigor al aplicar a un espacio o paisaje catalogado. Es preciso, pues, retornar al concepto de compatibilidad entre los rasgos y caracteres auténticos el objeto y su actuación a los nuevos usos o tiempos.” (Maderuelo, 2010, p. 27)

\subsection{Complementando el mercado}

\subsubsection{El mercado como equipamiento cultural}

Los espacios públicos se pueden entender como lugar del acontecimiento cultural comunicacional, es decir de actividades de comunicación para el consumo. Según Carlos Guzmán Cárdenas, esto implica admitir que en el consumo de la ciudad se construye parte de la racionalidad comunicativa e integrativa de una sociedad. Se suele imaginar el consumo como un lugar de lo suntuario y lo superfluo. Sin embargo, al consumir la "ciudad cultural" también se piensa, se elige y reelabora el sentido social de lo público; como afirman Mary Douglas y Baron Isherwood (1990), el consumo "sirve para pensar”. Pero, además sirve para ordenar políticamente cada sociedad ya que es un proceso en el cual los deseos se convierten en demandas del "nosotros" y en actos socialmente regulados (García Canclini, Néstor. 1995) a través de diversos ritos e instituciones sociales. 
Jordi Borja nuevamente interviene sobre lo que los equipamientos culturales significan para los espacios públicos:

“el espacio público ciudadano no es un espacio residual entre calles y edificios. Tampoco es un espacio vacío considerado público simplemente por razones jurídicas. Ni es un espacio especializado, al que se ha de ir, como quien va a un museo o a un espectáculo. Aun así, los equipamientos culturales tiene la capacidad de potenciar los espacios público, capacidad que dependerá de la relación que establezcan con el tejido urbano, de su apertura y de la creación de espacios de transición para que sean espacios públicos ciudadanos."(Borja, 2003, p. 142)

Entonces queda claro que la relación que establecen los equipamientos culturales urbanos con sus entornos próximos, tanto físicos como sociales es una oportunidad para mejorar la ciudad. En este sentido los equipamientos culturales deben ser multifuncionales, deben cumplir su tarea específica de culturizar, pero además deben potenciar su uso y el uso del área urbana circundante como espacio público.

"la oferta cultural convencional (museo, exposiciones, espectáculos, etc.) casi siempre va unida a espacios interactivos y de creatividad, a centros de formación, a talleres y comercios, etc. En algunos casos se integran servicios de carácter social o administrativo. En otros se realizan operaciones paralelas de oficinas y viviendas. $\mathrm{O}$ de servicios de comunicación y transportes. $\mathrm{O}$ equipamientos turísticos, hoteles, restaurantes, etc. Es importante la existencia de espacios de transición, abiertos al entorno (es decir, sin controles de acceso ni elementos formales divisorios) pero articulados (contigüidad, mantenimiento) con el equipamiento cultural.” (Borja, 2003, pp. 142-143)

Finalmente, como menciona Borja y algunos otros autores, el impacto que generan los equipamientos culturales sobre los espacios públicos es muy diferente y particular en casa caso, sin embargo, es evidente que la mayoría de los casos arroja un impacto positivo en la zona intervenida. Proporciona seguridad, moderniza y activa las actividades económicas, comerciales, sensibiliza y culturiza a la población residente. 


\subsubsection{El mercado como difusor gastronómico}

Recientemente la UNESCO ha definido la gastronomía como parte integrante del patrimonio cultural inmaterial de un país, en vista a que se está incorporando cada vez más activamente en las políticas culturales y de promoción del turismo.

A menudo la comercialización de los productos gastronómicos locales se concentra únicamente a lógica económica, dejando de lado el interés cultural de mantener y difundir la herencia gastronómica. Pese a ello, en el Perú se ha avanzado mucho en el reconocimiento del patrimonio gastronómico local, y existen iniciativas institucionales o privadas que trabajan para promocionar productos alimentarios y platos tradicionales como vía para dar a conocer también la cultura de un país o una región.

"El aporte de la gastronomía peruana trasciende el aspecto económico e incide de manera gravitante en la revalorización de nuestra cultura. La cocina se ha convertido en un factor de reafirmación de nuestra identidad, de revaloración de comidas regionales $\mathrm{y}$, sobre todo, de nuestros productos agropecuarios e hidrobiológicos. ... entre los peruanos crece el orgullo por la comida peruana. ... la gastronomía es hoy una de las pocas expresiones nacionales que no genera discusión ni antagonismos. Se puede decir que es un mecanismo de afirmación de la peruanidad en medio del proceso de internacionalización que vive el país. Se trata de un proceso de reinvención con orgullo patrio de reconocimiento de la gastronomía peruana como patrimonio cultural inmaterial de la humanidad, tal como lo han conseguido recientemente México, Francia..." (APEGA Sociedad Peruana de Gastronomía, 2012, p. 9)

Hoy un reciente proyecto por parte de Apega para potenciar la gastronomía peruana: Apega ha planteado estratégicamente convertir a mistura en la feria gastronómica líder en el mundo hacia el 2021. Se trata de una experiencia piloto que podría ser continuada en las mismas regiones y extendida a otras. (APEGA Sociedad Peruana de Gastronomía, 2012, pp. 24-23)

"Se plantea se propone complementar los atractivos arqueológicos monumentales, y otros recursos como cultura viva, naturaleza y deportes con la gastronomía.” (APEGA Sociedad Peruana de Gastronomía, 2012, p. 24) 
Figura 3.12

Mercado como difusor gastronómico. TimeOut Market, Lisboa

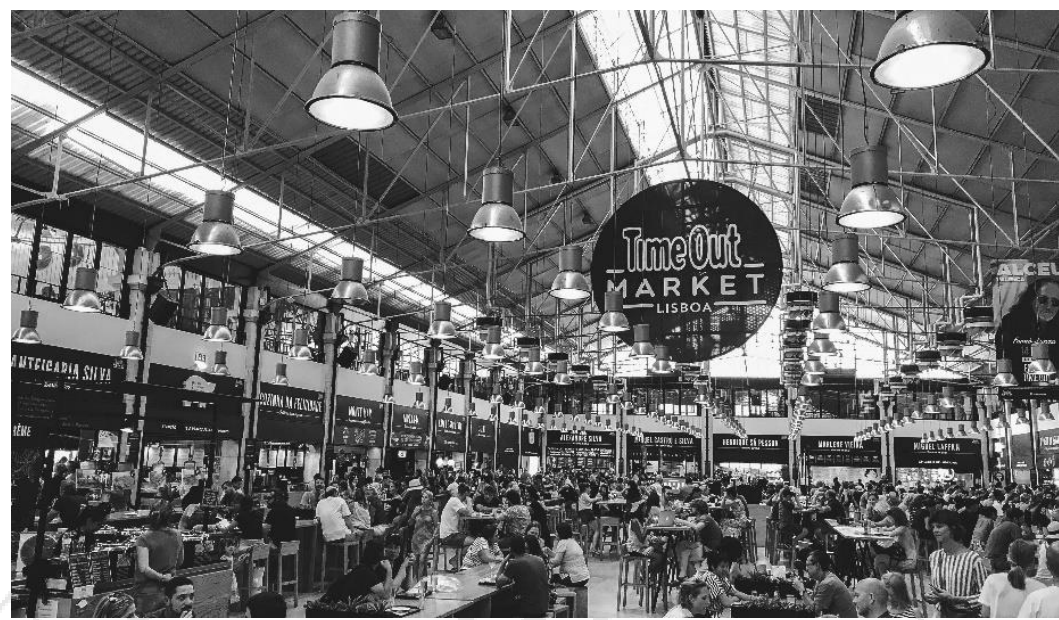

Fuente: fotografía propia

En el Perú, al igual que en otros países del mundo, los mercados no solo han sido centros vitales de abastos, sino también lugares donde la gente se reunía a departir y comer. Hoy en día se convierten en el mundo en puntos obligados de atracción turística. No por el interés infraestructural sino porque el Perú cuenta con una gran variedad de productos oriundos, frutas, verduras, carnes que deleitan a cocineros y amas de casa y asombran a cualquier turista internacional.

\subsection{Conclusiones parciales}

Entendidas las diferentes definiciones especificadas en el marco teórico, para nuestro caso de estudio, más allá de encontrar la definición más precisa, es entender que este espacio es la plataforma de encuentros, pudiendo ser una plaza, un parque, un equipamiento, de libre acceso en donde ocurre el encuentro de la ciudadanía y en el que se establezcan relaciones e intercambios. Asimismo, el espacio público se establece como tal cuando las diferentes personas que lo frecuentan se identifican y se apropian de él forjando la identidad colectiva.

El espacio público se caracteriza por ser un lugar de libre acceso, frecuentado y con carácter de centralidad; por la calidad espacial, que facilita las relaciones sociales; por estimular el sentimiento de identidad del lugar y de las personas; por servir de 
plataforma de expresión sociocultural; así como también por ser transformador de su entorno tanto físico como social. Con esto se comprueba la estrecha relación que tiene la ciudad con el espacio público y viceversa, como lo menciona Jordi Borja. Espacio público no debe verse desligado de la ciudad ni del ciudadano, ya que es el medio donde estos se encuentran. Así, un espacio público corresponde en primer plano el espacio donde los encuentros ocurren, sin importar su condición de apertura a la ciudad, pudiendo ser plazas, calles o equipamientos públicos. De esta manera el espacio público continúa siendo el elemento que define la forma de la ciudad, y le atribuye ese rol ordenador en la trama urbana.

El espacio público tiene un valor funcional, cultural y cívico político ya que cumple una finalidad de uso determinado por sus usuarios; representa un valor simbólico de una sociedad; y se presta para ser un espacio de representación y expresión de la colectividad y ciudadanía. Por ello, para proyectar espacio público se requiere conocer la naturaleza y comportamiento del usuario, porque es él quien va a hacer uso y apropiación de este y quien le dará la polivalencia tan característica que tiene.

La ciudad o el espacio conformado por los comportamientos referidos a la ciudadanía y la vida pública, se puede traducir como el lugar de los ciudadanos, donde lo referido a los mismos toma un espacio en concreto. El ciudadano, pasa ser quien da sentido a su espacio de expresión y según su uso, apropiación e identificación le otorgará valor a un determinado lugar. Para comprender la necesidad de tener espacios con valor para la ciudad, donde el intercambio social y cultural defina el espacio público como tal, vimos esencial definir el espacio cívico y ver su relación con el espacio público.

El espacio público, como se ha analizado anteriormente corresponde al lugar donde el ciudadano tiene el derecho a permanecer, circular y estar, sin importar su condición de espacios abiertos (calles, plazas) o cerrados (equipamientos públicos, culturales). Cuando uno analiza esta definición, el espacio público podría significar espacios sumamente variados y con funciones y usos distintos. En algunos casos tan solo con la definición de público, otorgada jurídicamente, lo podría definir como este tipo de espacio. Es por ello que vimos preciso definir, según las dimensiones del espacio público, un espacio acorde al tema de estudio con condiciones relacionadas al 
valor cultural, social y cívico, donde la participación e identidad de la ciudad le otorguen ese carácter de espacio público que según Jordi Borja contribuirá a la ciudadanía. Esta dimensión del espacio público vendría ser específicamente lo que entendemos como espacio cívico.

El espacio cívico, como su nombre mismo lo señala, es un espacio otorgado al ciudadano que contribuya a su encuentro y expresión social y cultural. Tiene como características ser de carácter público, a favor de la colectividad; estar complementado por equipamientos de diversas índoles como cultural, social e institucional; significar un espacio que contribuya a la integración, intercambio y al servicio ciudadano; así como también, permitir la existencia de la cultura, la identidad, la memoria y la expresión social.

Vista esta importancia de los espacios cívicos en la configuración de la ciudad, relacionamos el concepto de espacio cívico con el mercado. Es precisamente por los distintos roles que históricamente ha cumplido en la ciudad que entraría dentro de los espacios donde la identidad, la cultura y la expresión de la ciudadanía se ve reflejada. Asimismo, el hecho de saber que el mercado es entendido como espacio público, y que el espacio cívico es una dimensión del mismo, sirve para identificar al mercado como espacio cívico.

Existe una estrecha relación entre el mercado y la plaza, ya que desde su origen esta última tuvo como parte de sus actividades el comercio, que según Plazola fue aquella actividad la que le dio razón de ser a este espacio público. Por otro lado, clasifica dos tipos de plazas, la cívica y la comercial, que algún momento fue el mercado quien cumplía estas funciones. Es por ello que hoy en día el mercado, puede tomar distintos valores en la ciudad y ser considerada como plaza para el tratamiento espacial, favoreciendo el encuentro e identidad del ciudadano.

Como bien hemos entendido, los equipamientos urbanos, ubicados a lo largo de la ciudad, distritos, barrios, tienen un valor fundamental, tanto para equilibrar el dinamismo de la ciudad, dotándola de servicios ideales en puntos estratégicos, así como también para funcionar como espacio colectivo, donde los ciudadanos realizan sus actividades, sociales, culturales, de ocio y de tal manera componer la ciudad armónicamente entre el espacio público, sus ciudadanos y la arquitectura, a manera de equipamientos urbanos. 
Entonces se llega a la conclusión que tanto los espacios públicos que fomentan el encuentro entre los ciudadanos, como los equipamientos colectivos en los cuales se desarrollan actividades humanas y se satisfacen sus necesidades, son elementos clave que al funcionar conjuntamente articulan los tejidos urbanos en distintas escalas en la ciudad.

Así la arquitectura de la ciudad se torna: útil al dotar a la sociedad de servicios complementarios y accesibles; beneficiosa en relación al medio ambiente y entorno que la rodea y apropiada en relación a las condiciones y cualidades del espacio urbano en el que se localiza.

La identidad es una circunstancia formada por un persona o colectivo para distinguirse en el medio. El individuo, que vive en constante relación con el espacio que le rodea, puede mantener un dialogo con el mismo mediante la vinculación o identificación de su "yo" interno con en el espacio físico. La arquitectura, como contenedor del espacio colectivo y de la vida de las personas, debería guardar una relación con la identidad del que lo apropia o del medio que la contiene, para así guardar un carácter que no sea ajeno al lugar donde se encuentra.

En base a esto, existen teorías que sustentan la importancia de identidad en la arquitectura y su relación con el medio donde se encuentran. El regionalismo crítico, es un concepto desarrollado por teóricos como Kenneth Frampton, que se centra en ideas que relacionan la arquitectura con su contexto evaluando la topografía, el clima, la luz, el sentido del tacto, entre otros. Asimismo, afirma la importancia de la cultura e identidad para el desarrollo, en contra posición con el fenómeno de la universalización, que mediante una "cultural elemental" existe una amenaza con descartar el pasado cultural de las naciones.

Si bien la idea del regionalismo parte del valor e identidad de la arquitectura regional, para el discurso y producción latinoamericano, que tuvo un desarrollo moderno como consecuencia del primer mundo significó la necesidad de formular discursos en base a una arquitectura con vinculo en sus raíces y que responda a un medio determinado. La arquitecta Marina Waisman fue una crítica que a pesar de reconocer el valor de la identidad planteado por Kenneth Frampton, sostiene que para que exista una producción verdaderamente regional en el continente latinoamericano, la arquitectura debe ser planteada de manera divergente con respecto al resto, otorgándole 
una concepción, elaboración y lenguaje propio. Por otro lado, el arquitecto Cristian Fernández Cox vincula el valor de relacionar la arquitectura en su contexto con una arquitectura apropiada, que lo sustenta como una actitud que responde según su adecuación al tiempo y lugar.

Las teorías relacionadas con la identidad y la importancia de proyectar la arquitectura en un contexto con factores climáticos, topográficos, temporales, ambientales e históricos, permitió retomar el estudio por el lugar donde el objeto arquitectónico interactúa, otorgándole una imagen e identidad que responda propiamente al medio donde se encuentra. El regionalismo crítico, la arquitectura divergente o la arquitectura apropiada, más allá si corresponde a contextos diferenciados, donde la modernidad pudo significar un proceso histórico o una consecuencia de la producción del primer mundo, señalan una serie de términos que amarran la arquitectura con su medio. Estos determinarán y permitirán dar una propuesta arquitectónica que más allá del estilo responderá o potencializará circunstancias propias del lugar arraigadas a factores ambientales, sociales, topográficos y culturales.

Como se definió anteriormente la memoria colectiva hace referencia a los recuerdos, las imágenes y las características particulares que una sociedad guarda o demuestra en su conjunto. Desde la perspectiva sociológica el espacio y la memoria colectiva se anexan gracias a que esta última significa una construcción social definida por el espacio y el tiempo.

La memoria colectiva permite mantener la identidad de un grupo determinado, sin embargo, como la misma definición de memoria lo indica, estás quedan retenidas como imágenes mentales por un lapso de tiempo. En cambio, el espacio es una realidad física perdurable que permite remitir imágenes al grupo que interviene y puede reflejar sus etapas, actividades y evolución en términos espaciales. Por ende, el espacio funciona como huella de la memoria de un lugar, y que al igual que esta cambia en el transcurso del tiempo.

El espacio está compuesto por marcas sociales que revelan la cultura, la historia y el poder. Este término en relación a la memoria se erige de una dimensión material y una dimensión simbólica/sensorial que permitirán rememorar los distintos acontecimientos o imágenes de una sociedad. La dimensión material manifiesta 
físicamente la memoria de un lugar, mientras que la dimensión simbólica es percibida mediante la apropiación social en los espacios habitados y la percepción a través de los sentidos. Si bien en términos de rememoración, el espacio no habla por sí solo, este complementa la identificación de los individuos que interactúan en el lugar y se carga de símbolos, percepciones y sentidos dotados por la misma sociedad.

Memoria del lugar: conclusión al lugar: que componente físico y que componente simbólico.

Entendemos por paisaje, al territorio en el que factores naturales y/o humanos definen el carácter y se relacionan entre sí. El paisaje corresponde al lugar físico heredado de nuestro pasado que, al igual que el espacio construido, participa en la construcción de la memoria colectiva. Al referirnos a la memoria de un lugar, la configuración del paisaje pasa a corresponder la marca de la sociedad sobre el medio natural y por ende sobre paisajes anteriores. Esta huella junto con el tiempo histórico construye el carácter a cada territorio.

Para la comprensión del paisaje, es necesario recurrir a la historia y analizar el mismo en distintas escalas de vinculación con el territorio. Este análisis permitirá comprender la memoria del lugar y su relación con los distintos actores del territorio para lograr una intervención compatible con la identidad del lugar. El paisaje, como cualquier elemento material en el tiempo, inevitablemente evoluciona y cambia, por ende, su intervención y trayectoria debería tener una tendencia hacia el equilibrio para una compatibilidad armoniosa en el entorno.

Los equipamientos culturales tienen la capacidad de potenciar los espacios públicos, en mayor o menor grado dependiendo de la relación que establezcan con el tejido urbano, su apertura a la ciudad, los espacios de transición que ofrezcan, entre otros. Este potencial que la cultura ofrece al espacio público se puede ver reflejado ya sea en un equipamiento cultural o en un espacio dotado del mismo, ya que en la ciudad y más aún en espacios públicos, confluyen muchas artes, que resultan una gran concentración de cultura, lo que genera una sensibilidad en la población. Estos espacios públicos donde la expresión prima, permiten una fuerte circulación de nuevas ideas, logrando continuar con la producción y difusión de la cultura. Por ende, si concebimos el mercado como espacio público, como manifiesto de la ciudad y la ciudadanía, este 
podría verse complementado con equipamientos o espacios difusores de arte y cultura, para retomar la dimensión cultural de espacio público que lo caracteriza.

Por otro lado, el valor de la nueva cultura urbana si bien no se ve reflejada en objetos, ni en imágenes, se desenvuelve en manifestaciones, comportamientos y patrones sensitivos, los cuales son percibidos en espacios cívicos.

Estas dos circunstancias que relacionan la cultura con el espacio de la ciudadanía nos dan a entender que el espacio público y la arquitectura vinculada a este, sirven como plataforma para la expresión urbana, permitiendo al ciudadano plasmar sus ideas, apropiarse indirectamente y dotar a este espacio de una dimensión cultural, ligada a espacios interactivos y de creatividad. 


\section{CAPÍTULO IV: MARCO NORMATIVO}

\subsection{Tipologías}

Las siguientes definiciones y explicaciones de las diferentes tipologías de edificaciones están explicadas en base diferentes libros, diccionarios y publicaciones, especificada en base a la enciclopedia de Arquitectura Plazola, la cual además de explicar el origen, las características y funcionamiento de las edificaciones, pone en manifiesto algunos ejemplos que apoyan la teoría para un mejor entendimiento.

\subsubsection{Paisaje}

Es la configuración del terreno, determinada por factores fisiobiológicos y humanos. Plazola también define una arquitectura del paisaje como la disciplina que conforma tres elementos: la arquitectura, la ciudad y el medio ambiente. Trata el diseño del espacio abierto mediante un proceso lógico para solucionar los problemas fisicoambientales, históricos, sociales y estéticos de un sitio determinado

Figura 4.1

Paisaje próximo al Sena, Paris

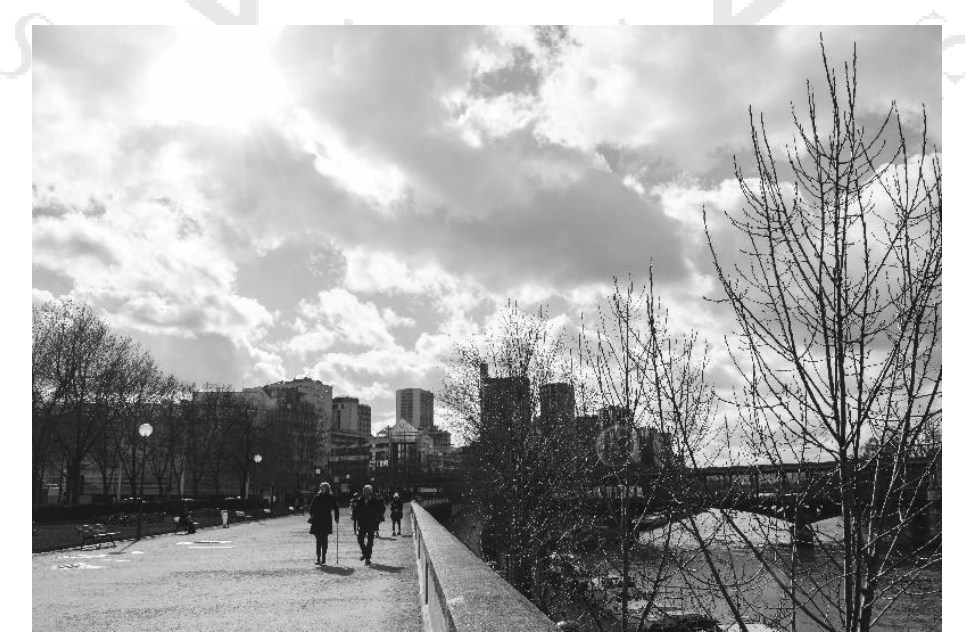

Fuente: fotografía propia 
Respecto a los elementos arquitectónicos que se puedan encontrar en un paisaje, en un tratamiento de espacio público, Plazola menciona una serie dentro de los cuales, para el caso de estudio, se rescatan los siguientes:

\section{Escaleras}

Muros

Terrazas y miradores

Bancas

Caminos

Bordes

Brandas

Iluminación

Canales y caídas de agua

Zona de juegos

Plazas

Parques

La plaza, la define como un lugar grande, espacioso, amplio de un poblado, donde se celebran ferias, mercados y fiestas públicas. La plaza es el lugar de estar y recreación de la gente, sirve como paisaje de la ciudad y además tiene un entorno urbano que la delimita. Por lo general es un espacio abierto, público y de convivencia a la que accede la población, la cual permite que esta esté relacionada a la ciudad, sus espacios abiertos públicos y edificios importantes. En las plazas se observa la vida cotidiana de la ciudad y sus diferentes actividades comerciales y recreativas, ya que a su alrededor cuenta con restaurantes, oficinas públicas, iglesias y teatros, entre otros.

Las plazas casi siempre son hitos, puntos de referencia, son articuladoras del sistema urbano, se prestan para realizar actividades al aire libre, ceremonias, publicas, desfiles, fiestas, manifestaciones, comercios, actividades recreativas, culturales y artísticas. Tipos de plazas: plazoleta, plaza cívica, plazas recreativas y comerciales. 
Los parques, como dice la enciclopedia, son aquellos espacios abiertos en donde predominan los elementos naturales, como árboles, arbustos, piedras, flores, etc. Sobre lo construido. Funciona principalmente como lugar de reunión donde se propicia el esparcimiento, la recreación y el descanso. Las funciones más relevantes que desempeña un parque son las de adornar, agrupar, comerciar, deambular, delimitar, estar, exhibir, intercambiar, jugar, platicar, proteger, situar, vestibular. Los parques están destinados especialmente a los usuarios que lo transitarán.

Estos componentes urbanos guardan relación con el tratamiento paisajístico que debe tomarse en cuenta en zonas donde predominan los elementos naturales.

El diseño de los parques debe satisfacer los requerimientos de la población, la arquitectura, materiales y vegetación. Además, su imagen debe reflejar la vida cotidiana y el pasado histórico del lugar considerando: la circulación, enlace visual, modelado de suelo, delimitaciones, mobiliario.

\subsubsection{Espacios libres}

El sistema de espacios libres se define como la sucesión de lugares abiertos y de uso público. Estos se reconocen por su carácter público y por la realización de actividades relacionadas con la estancia, comunicación, ocio, práctica de deportes y fomento de los aspectos naturales tendentes a garantizar la salubridad, reposo y esparcimiento, acentuar la variedad urbana, reducir la densidad y optimizar las condiciones ambientales y estéticas de la ciudad. (Hernández Aja, 1997, p. 137)

Espacio común: el concepto de espacio común hace referencia a la idea de espacios que no están sujetos a ningún orden preestablecido, son espacios que se crean por necesidad o acción en un momento en el que actúan dos o más personas. Como nos recuerda Eduardo Serrano, estos espacios se crean casi siempre en las fronteras, en ese espacio donde dos mundos se encuentran, se tocan o colisionan. La necesidad o la simple creatividad de sus "usuarios" es el elemento portante y estructural de estos espacios. ...el espacio público puede desempeñar una importante función dentro del sistema económico y social contemporáneo al caracterizarse como espacio de desarrollo y de acceso universal al procomún... (Di Siena, 2009, p. 7) 
El espacio público puede definirse como la esfera de lo social, el lugar en la que todo puede ser visto y entendido por todos, en donde las personas pueden disfrutar de la mayor publicidad posible. (Di Siena, 2009, p. 20)

Figura 4.2

Espacios libres en Square Bela Bartok, Paris

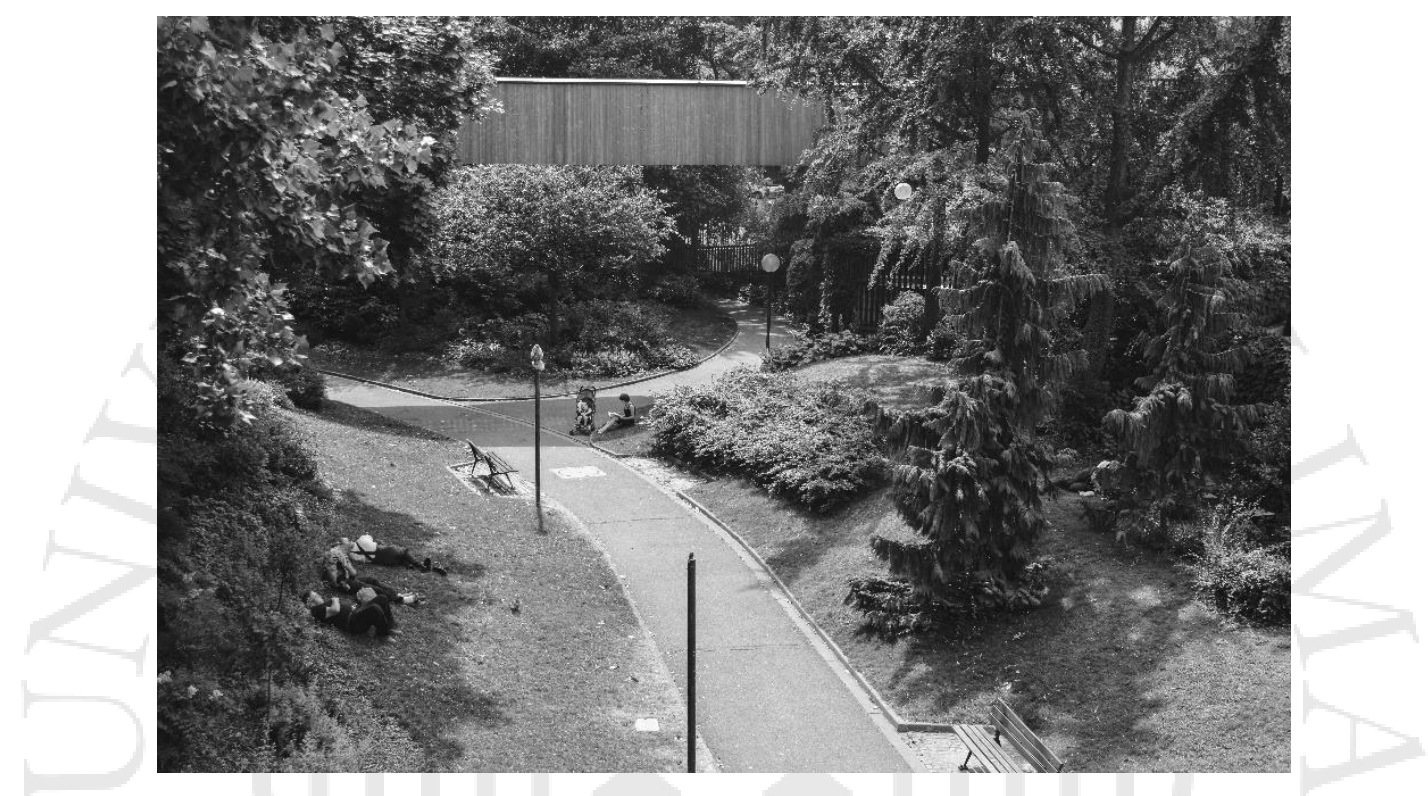

Fuente: fotografía propia

\subsubsection{Comercio}

Abastecimiento alimentario y de consumo: agrupa todas las instalaciones públicas dedicadas al comercio e incluye desde pequeñas dotaciones como los centros comerciales de barrio, los mercados municipales o los pequeños locales para información y defensa del consumidor hasta implantaciones de grandes dimensiones como los mataderos o los mercados centrales, mercados de distrito, mataderos, desde los que se garantiza el abastecimiento alimentario de la población. (Hernández Aja, 1997, p. 134)

Comercio: se define como el servicio destinado al ejercicio de actividades relacionadas con el suministro de mercancías al público o a servicios a particulares. Los índices de dotación comercial utilizados hacen referencia al comercio al por menor. Se divide en: 
Pequeño comercio: cuando la actividad tiene lugar en establecimientos independientes, de dimensión no superior a $120 \mathrm{~m} 2$ de superficie de venta en comercio alimentario y $500 \mathrm{~m} 2$ en los no alimentarios.

Figura 4.3

Mercado en Vía Cammeo Carlo Salomone, Pisa

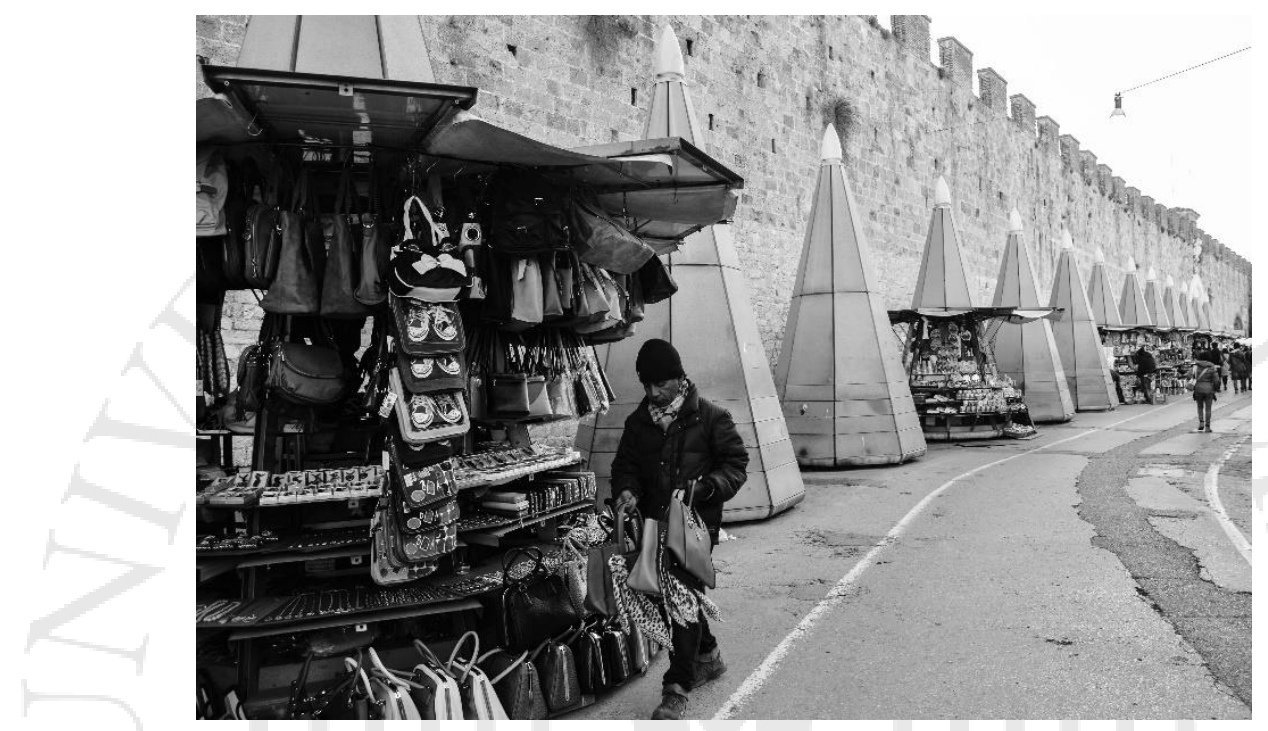

Fuente: fotografía propia

Local comercial: cuando la actividad comercial tiene lugar en establecimientos independientes de superficie de venta comprendida entre 120-750 m2 en comercio alimentario, entre 500-2.500 $\mathrm{m} 2$ en comercio no alimentario y agrupado de superficie menor a la establecida para grandes superficies comerciales.

Grandes superficies comerciales: fundamentalmente son los mercados, que se incluyen en el apartado de sistema de servicios básicos por ser, en la mayoría de los casos, de propiedad pública. (Hernández Aja, 1997, p. 135)

\subsubsection{Mercado}

El mercado etimológicamente deriva del latín mercatus. Sitio destinado en ciertas poblaciones a la venta y compra de mercancías. Siendo un poco redundante, Plazola también lo define como lugar público donde concurren comerciantes y compradores 
que van a realizar alguna transacción comercial. Y finalmente para darle carácter de presencia específica, un mercado es una contratación pública de mercancías en un sitio determinado para tal efecto y en días determinados. El mercado es un lugar público sumamente importante para cualquier estado y su economía. El mercado es "un conjunto de establecimientos que forman parte del comercio organizado, por disponer de una estructura fija. Su construcción se basa en las necesidades de la población a la que dará servicio" y como bien ya se ha mencionado su función principal es la transacción comercial y en esta intervienen compradores y vendedores, se lleva a cabo la oferta y la demanda.

Plazola especifica que un mercado debe ser diseñado con el fin de que estas actividades se desarrollen en un espacio cómodo, funcional y estético, cuya construcción se pueda llevar a cabo utilizando técnicas contemporáneas adaptadas a los sistemas constructivos locales.

Figura 4.4

Mercado La Boquería, Barcelona

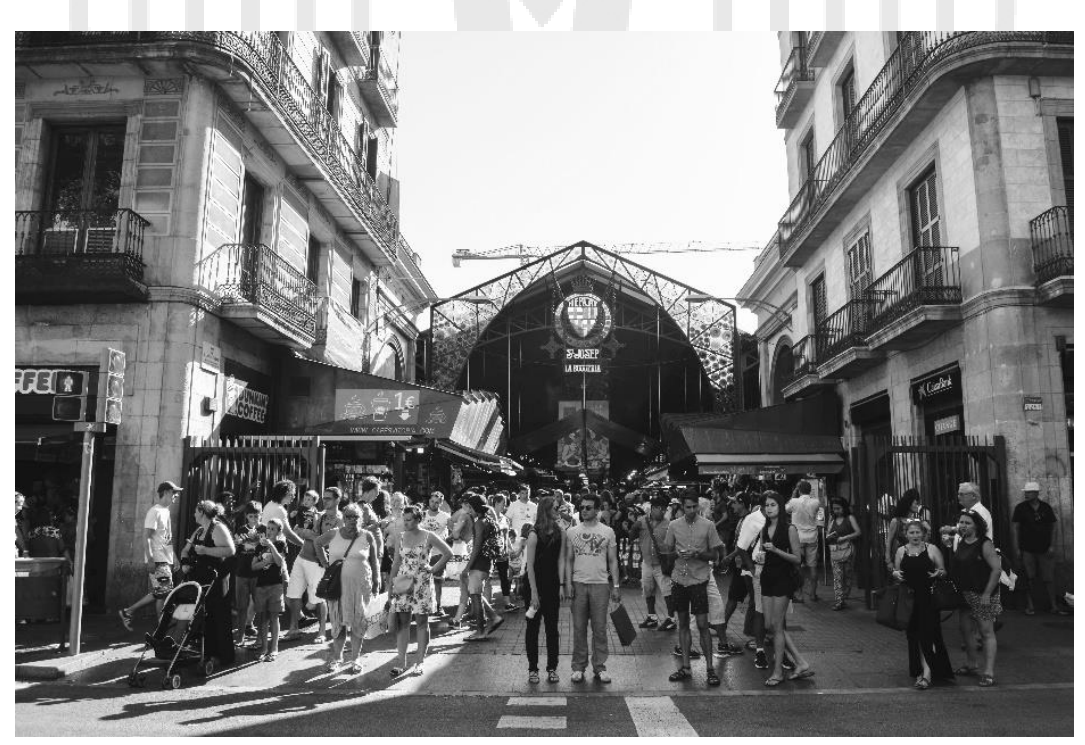

Fuente: fotografía propia

La ubicación de los mercados debe ser estratégica, como bien se ha visto durante toda la historia de la civilización, en todas las culturas: "la elección del sitio está determinada por dos factores: demanda de productos básicos de la población local y 
descentralización de actividades mercantiles del mercados de centros de población..." los mercados después de hacer un análisis urbano respecto a las vías y accesos siempre han terminado por instalarse en lugares céntricas, de fácil accesos e intenso tránsito peatonal, al aire libre, en lugares amplios y espaciosos donde fácilmente puedan instalarse el conjunto de puestos que lo conforman. Se debe encontrar de preferencia libre de obstáculos para la comodidad y seguridad de los compradores. Los accesos y circulaciones deben ser cómodos para todos los usuarios y vehículos.

Llevar a cabo de la construcción de un mercado implica varios puntos importantes a considerar, a continuación, a groso modo se mencionarán algunos de los puntos:

- Se debe considerar las costumbres de los compradores y vendedores, su metodología de compra y venta, ya que determinaran en la distribución de los productos.

- El clima influenciara en la elección de materiales pertinentes, propios de la zona en la medida de lo posible. Los vientos y trayectoria del sol determinarán la orientación del proyecto y este la distribución de los productos.

- Es importante el análisis topográfico del terreno.

- Las dimensiones son puntos clave para determinar el número de usuario que lo frecuentaran.

- La organización y funcionamiento de los puestos deberá considerar el número de persona, los equipamientos, el mobiliario, las áreas requeridas por tipo de modulo/venta, así como el flujo del público.

- Analizar la repercusión urbana que provocara el proyecto en el entorno: posible comercio ambulatorio, estacionamientos, trafico, contaminación.

- El estilo arquitectónico, recomienda Plazola, debe influir en la volumetría para integrarse adecuadamente al entorno urbano.

- No se debe dejar de lado el diseño gráfico y el color que dará identidad tanto al mercado como a las diferentes zonas del mismo.

- Las mercancías son los protagonistas del mercado, se debe saber si se venderá productos locales o importados, temporales o permanentes, si necesitara de preparación para su venta o no. Todo eso determinara las 
dimensiones y diseño de los puestos, el frente, el fondo, el alto, los mostradores y la circulación.

- Para terrenos accidentados recomienda una disposición de forma aterrazada, así como se podría utilizar los niveles para construir edificios de varios pisos, siempre teniendo la zona de abasto de mercancías al ingreso y a nivel de la calle.

\subsection{Tipologías complementarias al mercado}

En vista a la incorporación de nuevos usos y tipologías que complementen al mercado y propongan una nueva concepción de mercado como espacio para el ciudadano, se definen las siguientes tipologías que, debido a su carácter cultural y comercial, van de la mano con la función histórica y cívica de plaza de mercado.

Figura 4.5

Scuola di Cucina Lorenzo de' Medici en el Mercado Central de Florencia, Florencia

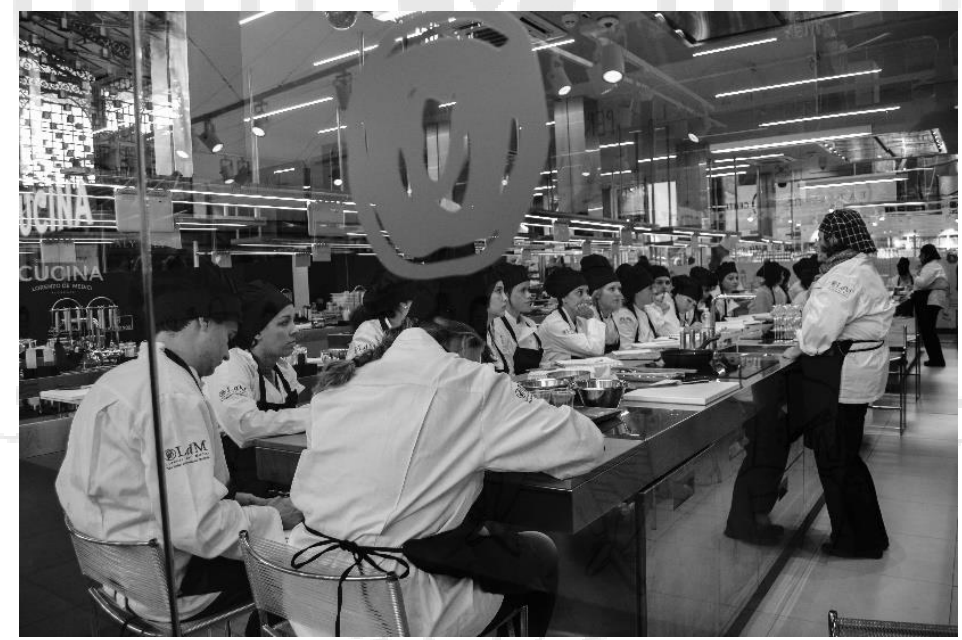

Fuente: fotografía propia

\subsubsection{Teatro}

Plazola menciona que viene del griego theaomal que quiere decir para ver. Edificio abierto o cerrado que cumple con los requisitos de espacio e instalaciones (acústica, 
isóptica, iluminación) para el montaje de escenarios, para representar obras literarias, musicales y espectáculos, a las que asiste el público en general.

Recomienda situar los teatros en zonas céntricas de una ciudad con fácil acceso, deberá contar con estacionamientos propio y debe tener alta resistencia.

Figura 4.6

Anfiteatro en graderías de Piazza di Michelangelo, Florencia

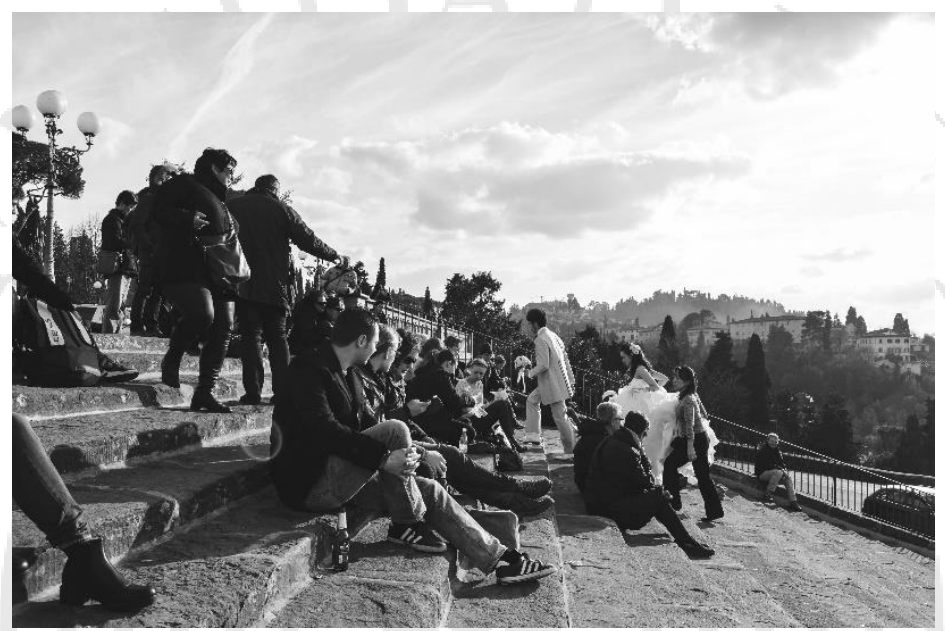

Fuente: fotografía propia

\subsubsection{Galería de arte}

Espacio independiente o dentro de un museo donde se exhiben o presentan colección de objetos que se pueden comprar y vender. Por ser un espacio especializado para la presentación del arte pictórico y escultórico, principalmente requiere dimensiones amplias para que la exhibición de las obras sea grandilocuente. Se establece una estrecha relación entre la arquitectura y el propietario o coleccionista, quien data las indicaciones sobre el desarrollo de los espacios y los objetos de arte (planta libre que permita flexibilidad en cada muestra, según cada artista, cada idea y cada propuesta).

A diferencia de los museos, donde los objetos se exhiben de manera permanente, en las galerías no hay colecciones permanentes, son centros de promoción y formación artística en donde las exposiciones son temporales y se sitúan de manera provisional en espacios concretos con instalaciones definidas según sus necesidades. 
Cada intervención de objetos transformara la percepción de los espacios. Los soportes tecnológicos, sistemas de iluminación, texturas de muros, colocación de mamparas, etc. Se diseñarán concretamente para la obra que se desea exponer.

Arquitectónicamente, las galerías se caracterizan por ser espacios flexibles con grandes alturas y volúmenes, amplia visibilidad y facilidad para instalaciones de iluminación, con núcleos de acceso y circulación vertical claramente establecidos, y facilidad para carga y descarga.

\subsubsection{Restaurantes}

Plazola define restaurante como establecimiento público de comidas y bebidas, que se consumen en un lugar a cambio de pago. Hace hincapié en que la preparación y venta de comidas y bebidas al público requiere de lugares especializados y personal, mobiliario y equipo específico. Los restaurantes siempre tienen cocina el espacio donde se preparan los alimentos y pueden o no tener bar.

\section{Figura 4.7}

Restaurantes dentro del Mercado de San Antón, Madrid

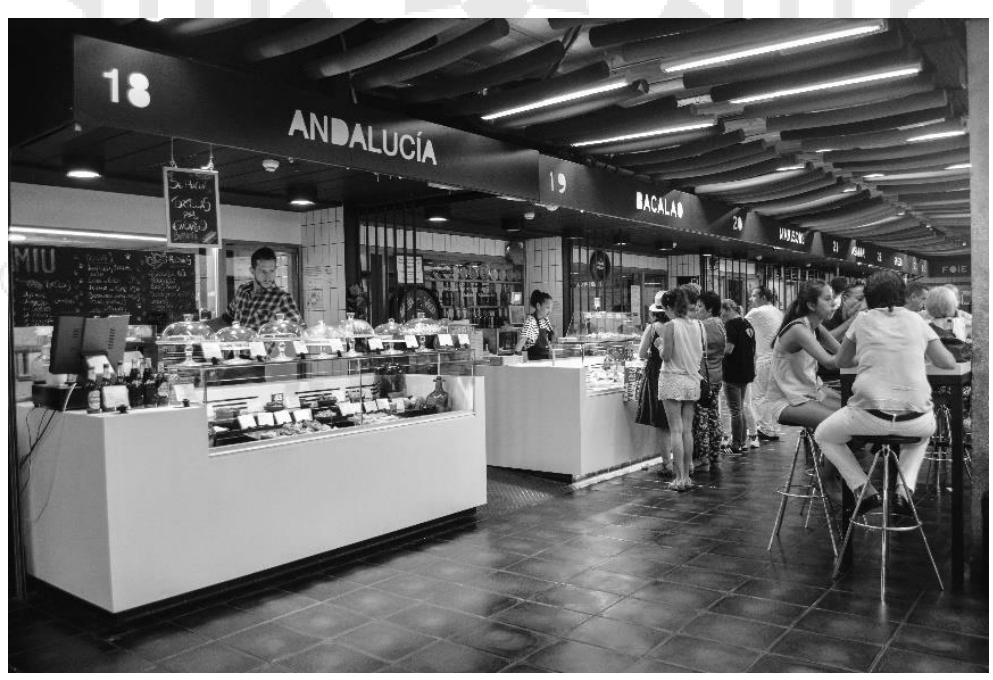

Fuente: fotografía propia 


\subsection{Concepto y categorización del mercado}

\subsubsection{Definiciones de mercado}

Existen diversas definiciones de mercado según diferentes entidades y organizaciones, las cuales se detallarán a continuación:

La Real Academia de la Lengua Española (RAE) define al mercado en base a su función general como el "sitio público destinado permanentemente, o en días señalados, para vender, comprar o permutar bienes o servicios." ("Diccionario de la Lengua Española," s.f.-a)

Dentro del ámbito legislativo del Perú, en función a la última Ley Marco de Promoción y Desarrollo para los Mercados de Abastos (2011), se entiende por mercado de abasto, a un local destinado al abastecimiento de alimentos perecibles y no perecibles, al igual que a ofrecer otros productos tradicionales (no alimenticios) y servicios complementarios. (Congreso de la República, 2011) En su definición, no detalla las funciones específicas ni los tipos de servicios que ofrece, sin embargo, define dentro de su actividad comercial el papel que los mercados de abastos deben desempeñar:

“...son centros comerciales especializados a una oferta biodiversa y de calidad de los productos alimenticios y la gastronomía peruana; fomentan la difusión de hábitos alimenticios saludables y la educación nutricional de la población. Son además espacios de generación de identidad y socialización de la población constituyéndose en atractivos turísticos." (Congreso de la República, 2011)

Por otro lado, instituciones como el Ministerio de Salud y la Municipalidad Metropolitana de Lima, que mantienen una relación indirecta, de supervisión y control con los mercados de abasto, coinciden en definir al equipamiento de igual manera que las políticas y leyes vigentes en el Perú. Describiéndolo como: "Local cerrado en cuyo interior se encuentran distribuidos puestos individuales de venta o de prestación de servicios en secciones o giros definidos, dedicados al acopio y expendio de productos alimenticios y otros tradicionales no alimenticios mayoristas.” (Lima, 1994, p. 2) 
Sin embargo, la Municipalidad Metropolitana de Lima, incluye una cierta catalogación de los mercados, diferenciando su magnitud, tamaño y tipo de gestión: "Mercados Municipales, Micromercados, Mercados Particulares, Cooperativas, Mercadillos, y Ferias Populares en recintos cerrados y Terminales Pesqueros." (Lima, 1994, p. 2)

De esta manera, queda evidenciado que cada entidad u organismo visto, define el concepto de mercado de abasto refiriéndose a su finalidad comercial y de abastecimiento. Asimismo, más que se distinguir y tener diversas regulaciones según tipologías específicas, estas entidades agrupan distintas categorías de mercados minoristas con el término de mercado de abasto.

A pesar de que la reciente política de promoción (2011), tenga como objetivo involucrar dentro de las actividades de los mercados otras actividades complementarias de nutrición, cultura y tradición, es evidente que no existe una compatibilización con las regulaciones de otros organismos que se limitan a controlar y supervisar únicamente la finalidad comercial.

\subsubsection{Categorización y tipologías avaladas a nivel nacional}

Dentro las regulaciones a nivel nacional y Lima Metropolitana, no se especifica una estructura alimentaria en base a categorías y/o tipologías de mercado, dificultando el manejo regulador y administrativo, para determinar normas específicas según el tipo de mercado.

El ente regulador que de alguna manera categoriza los mercados de abastos es la Municipalidad Metropolitana de Lima, la cual los diferencia en la Ordenanza Nº72 del Reglamento de Mercados de 1994 de la siguiente manera:

Mercados Municipales

Micromercados

Mercados Particulares

Cooperativas

Mercadillos 
Ferias Populares en recintos cerrados

Terminales Pesqueros

Si bien es cierto, existe una serie de términos que definen en cierto modo la función y magnitud de algunos mercados, es evidente que hace falta una categorización más extensa, detallada y menos genérica, que permita un mejor orden en la regulación y gestión, para facilitar el control de los distintos mercados por parte de las instituciones.

Por ejemplo, hoy en día el Ministerio de Salud (MINSA) tiene normas que regulan todos los mercados en general, pero, por el contrario, si existiese una distinción más detalla de los diferentes mercados, MINSA podría delegar distintas áreas para un mejor control y regulación de los mismos.

\subsection{Requisitos de la institución}

\subsubsection{El mercado como institución: caso Madrid, España}

\section{- Sistema de administración de mercados en Madrid}

En el ámbito de la administración de la cadena alimentaria, España constituye un ejemplo de organización en cuanto a la gestión, logística y conservación de sus distintos centros de abastecimiento.

El instrumento principal en su política alimentaria es Mercasa, "herramienta fundamental para vertebrar la cadena comercial de los alimentos frescos...". (Mercasa, 2016, p. 7) Esta entidad agrupa a 23 Unidades Alimentarias (Red de Mercas) ubicadas en zonas estratégicas según la distancia a núcleos urbanos, mercados municipales, plataformas de logística, distribución y conectividad con infraestructuras afines. (Mercasa, 2016, p. 7)

Cada Merca de España funciona como un mercado de mercados, que presta servicios a locales de abastecimiento de distintas escalas en el Ayuntamiento correspondiente, pudiendo ser estos: mercados mayoristas, supermercados, mercados municipales, mercados centrales de frutas, carnes y pescados, entre otras. 
En cuanto a la administración de los mercados municipales, estos son controlados y supervisados directamente por el ayuntamiento de su locación. Adicionalmente para esta gestión participan Mercasa y los concesionarios.

En cuanto a la administración directa de los mercados municipales, está dada por un concesionario, cedido y seleccionado por el mismo Ayuntamiento. Este último, encargado en el control, aprobación y supervisión del mismo, plantea una serie de regulaciones y lineamientos que los mercados deben desempeñar, así como también exige la realización por parte del concesionario de un Reglamento Interno especifico, que una vez aprobado por el ayuntamiento debe ser cumplido y supervisado por el concesionario y sus usuarios.

Figura 4.8

Diagrama de la estructura administrativa de los mercados municipales de Madrid

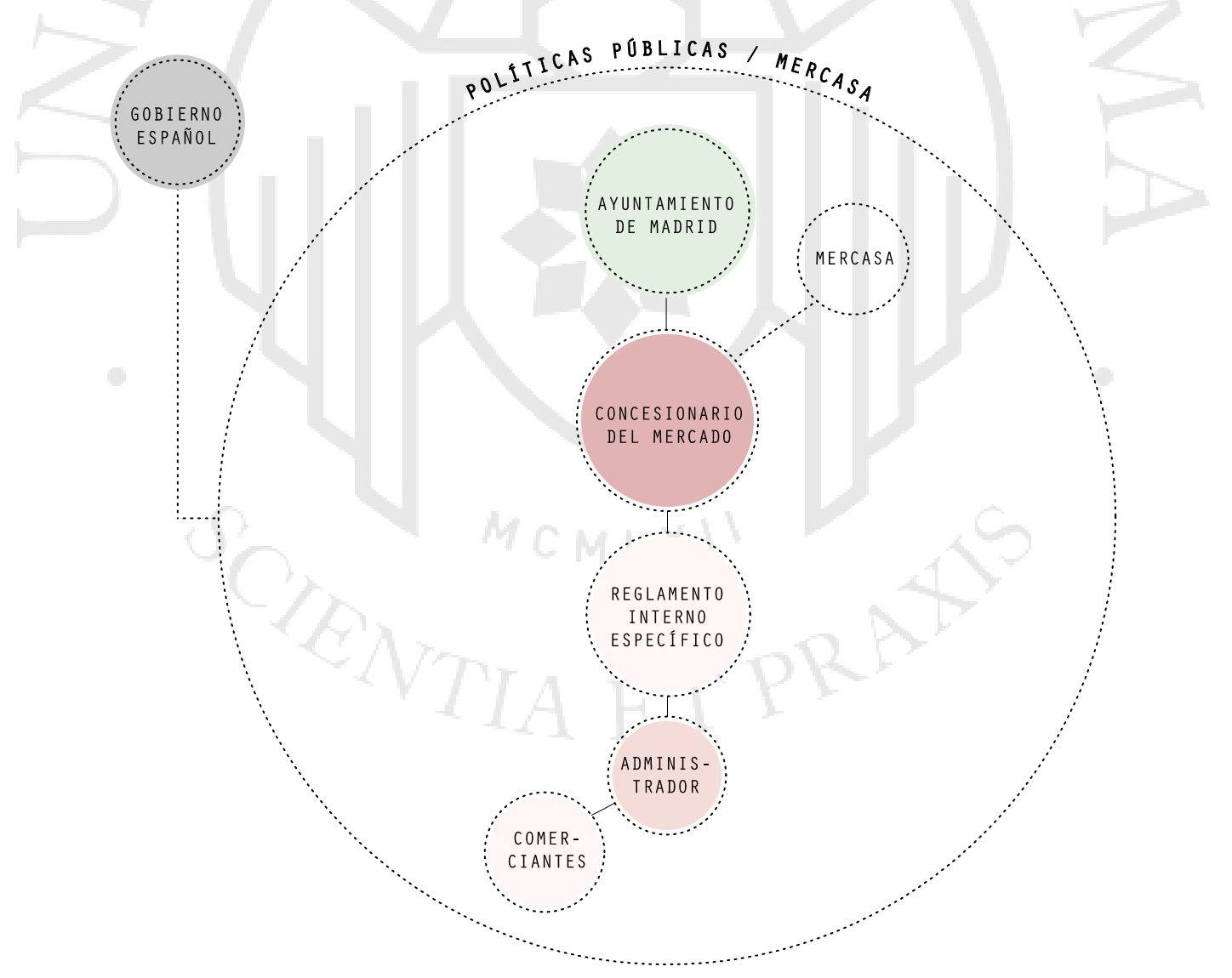

Fuente: (Mercasa, 2016). Elaboración propia 


\section{- MERCASA y su papel respecto a los mercados municipales}

En el contexto de España, los mercados municipales, corresponden a "un conjunto de establecimientos minoristas, en los que predomina la alimentación fresca, agrupados en un edificio (en ocasiones de gran interés histórico-artístico) y que presentan una gestión unitaria (controlada por un ayuntamiento...).” (Mercasa, 2016, p. 166)

Como reacción ante el período de declinación que se vieron involucrados esta tipología de mercados, principalmente por la competencia que significaban otros formatos y el cambio en los consumidores, se tuvo que tomar una serie de medidas que no sólo involucró a los ayuntamientos, sino que consideraron necesario acudir a otros organismos estatales afines.

Mercasa es la empresa pública encargada en la gestión, logística y administración del conjunto de la cadena alimentaria de España. Es administrada por el Estado y tiene como accionistas a la Sociedad Estatal de Participaciones Industriales (SEPI) y el Ministerio de Agricultura, Alimentación y Medio Ambiente, mediante el Fondo Española de Garantía Agraria (FEGA).

Por su parte en el sector mayorista, unifica los procedimientos de gestión y proporciona las pautas comunes a las 23 Unidades Alimentarias de la Red de Mercas. Asimismo, presta servicio "a la producción agraria y pesquera, facilitando la comercialización mayorista procedente de origen; al comercio minorista en todos sus formatos, a la hostelería independiente u organizada, y a las empresas de restauración social". (Mercasa, s.f.)

Como parte de su servicio público en el sector minorista, Mercasa contribuye directamente con los mercados municipales mediante su Programa de Remodelación de Mercados Municipales Minoristas. Es decir, brinda apoyo para el fomento, modernización y cumplimiento de las políticas públicas.

Dentro de sus acciones para la mejora del formato, Mercasa en primer lugar, estudia y analiza la situación de los mercados, con el objetivo de llevar a cabo acciones relevantes de acuerdo a cada caso. A continuación, algunas acciones ya implementadas en mercados:

- $\quad$ Aumento de la variedad de la oferta. 
- Uso de "locomotoras" para la activación comercial de abastecimiento (supermercados, franquicias, establecimientos de descuentos).

- Mejora de los servicios prestados tanto en instalaciones como en el entorno.

- Mejora en los niveles de salubridad e higiene.

- Modernización en la gestión y administración de los locales minoristas (capacitaciones y formación en técnicas de venta, contabilidad).

- Rehabilitación y conservación de mercados instalados en edificios antiguos.

\section{- Políticas públicas}

El Ayuntamiento de Madrid comprende la dirección política y administrativa de la ciudad de Madrid y "sirve con objetividad a los intereses generales de la ciudad...". (Carmena Castrillo, s.f.) Esta institución desde el 2003 ha venido desarrollando políticas públicas y planes para la mejora de los mercados municipales que comprenden su gestión, estas son:

El Plan de Innovación y Transformación de los Mercados de Madrid (20032011)

El Plan Estratégico de Modernización de los Mercados de Madrid (2012-2015)

La nueva ordenanza de Mercados Municipales ANM 2010/62

Los dos primeros planes mencionados, incluyen objetivos como el fomento, la modernización y la implantación de nuevos servicios complementarios. Asimismo, comprenden la creación de la marca "Mercados de Madrid", como parte de su estrategia de promoción. Su diferencia radica en que uno corresponde a la continuación del otro, sin embargo, las líneas de actuación y objetivos son los mismos. (Rodríguez Sebastián, 2014, pp. 6-8)

Por su parte, la Ordenanza de Mercados Municipales, es “el instrumento jurídico encargado de regular todas las actuaciones llevadas a cabo desde el Ayuntamiento para rehabilitar y transformar los mercados de Madrid.” (Rodríguez Sebastián, 2014, p. 9) 


\subsubsection{El mercado como institución: Lima, Perú}

- Estructura administrativa

Según el Ministerio de Salud (MINSA), la Municipalidad Metropolitana de Lima y tomando como ejemplo la Municipalidad de San Isidro, el mercado municipal se encuentra regulado, administrado y organizado de la siguiente manera:

El mercado municipal de San Isidro se haya bajo vigilancia y control de la Municipalidad Distrital, la misma que a su vez está supervisada por la Dirección Municipal de Comercialización y Defensa al Consumidor de la Municipalidad de Lima Metropolitana.

"La Municipalidad supervisará permanentemente el adecuado funcionamiento de los centros de abastos, así como que estos cumplan con las exigencias propias del abastecimiento y comercialización, seguridad, mantenimiento, salubridad, calidad e higiene." (Lima, 1994, p. 3)

Asimismo, cada mercado se encuentra bajo gestión de un administrador específico. Este, deberá ser un servidor público y propuesto por la Gerencia de Servicios a la Ciudad.

De manera paralela, las distintas áreas propias de la Gerencia Municipal (en este caso de la Municipalidad de San Isidro) como "La Gerencia de Autorizaciones y Control Urbano; Bienestar, Salud y Proyección Social; Seguridad Ciudadana; Finanzas y Logística y Servicios Generales, en concordancia con sus funciones establecidas en el Reglamento de Organización y Funciones de la Municipalidad, brindarán el apoyo que requiera la administración en coordinación directa para el cumplimiento..." (Concejo Distrital de San Isidro, 2006, p. 2) de la Ordenanza Nº164-MSI.

Por otro lado, MINSA, como lo establece en su Norma Sanitaria del Funcionamiento de Mercados de Abasto y Ferias, será la encargada de la vigilancia sanitaria, así como de velar por el cumplimiento de lo dispuesto en la misma. 
Figura 4.9

Diagrama de la estructura administrativa del Mercado Municipal de San Isidro

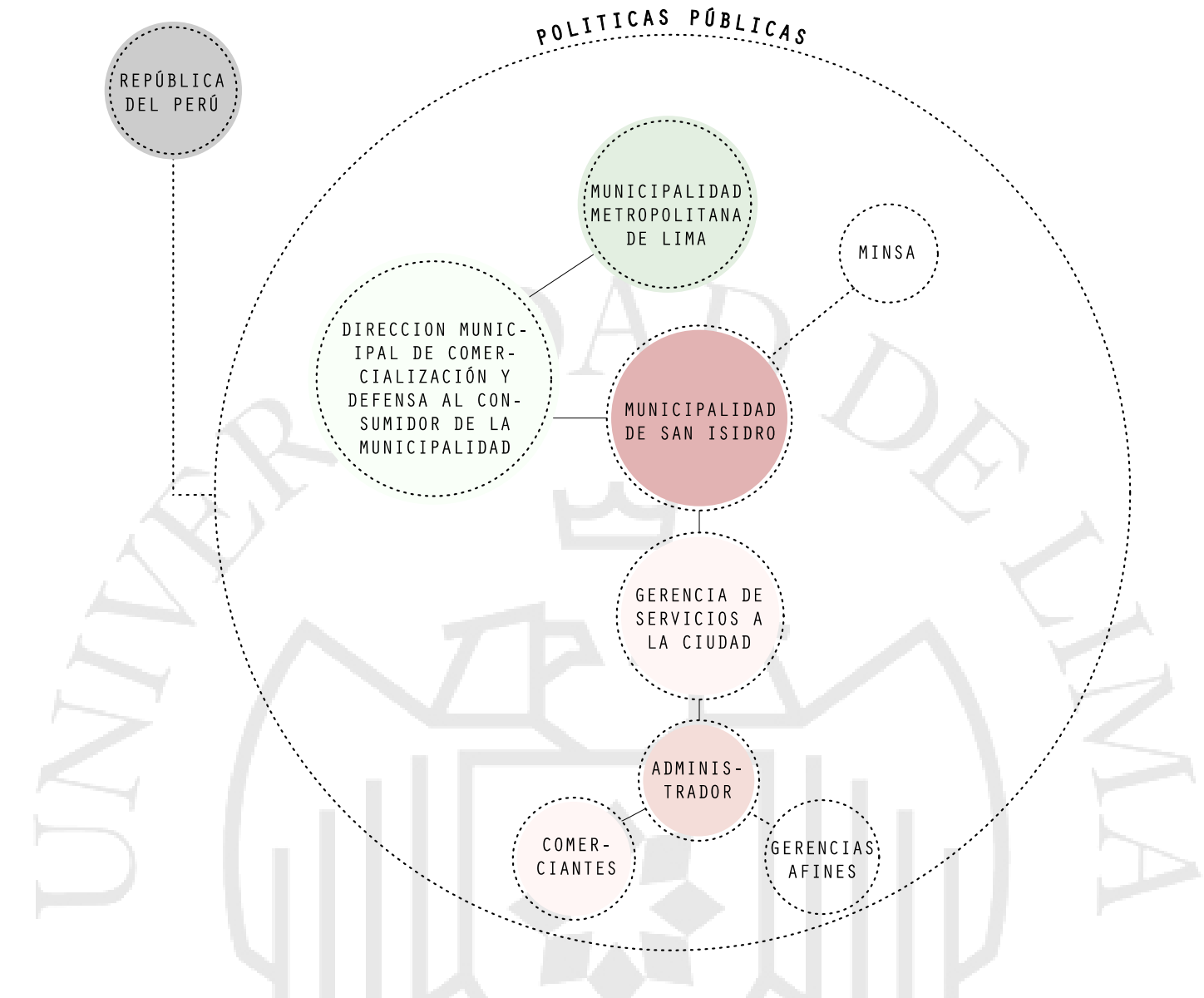

Fuente: (“Ordenanza de Mercados Municipales,” n.d.). Elaboración propia

Estructura administrativa de los Mercados Municipales: Ejemplo San Isidro

- Gobierno

- Municipalidad Metropolitana de Lima

- Dirección Municipal de Comercialización y Defensa al Consumidor de la Municipalidad Metropolitana de Lima.

- Municipalidad de San Isidro

- La Gerencia de Servicios a la Ciudad responsable de administración.

- Administrador del Mercado Municipal. 
- Gerencias de apoyo de acuerdo a la necesidad: Las Gerencias de Autorizaciones y Control Urbano; Bienestar, Salud y Proyección Social; Seguridad Ciudadana; Finanzas y Logística y Servicios Generales.

- Comerciantes

Vemos entonces, que el principal ente regulador es el Gobierno, el cual no solo plantea los lineamientos generales, sino también las políticas públicas. A este organismo, le sigue la Municipalidad Metropolitana de Lima, la cual rige a las diferentes Municipalidades Distritales.

Bajo la normativa de estas municipalidades y como se vio en el caso de San Isidro, en cada mercado se encuentra un administrador encargado del control, aprobación y gestión del mismo. El cual rige y supervisa las regulaciones y lineamientos que los mercados deben desempeñar, determinados por la misma Municipalidad.

\section{- Políticas públicas}

"Desde hace varios años, los mercados y los comerciantes que en ellos trabajan se encuentran atravesando una situación de verdadera emergencia que se viene agravando en un entorno de gran incertidumbre y competencia desigual del gran comercio moderno, lo cual amerita una norma específica que, en el marco de la políticas generales de apoyo a la microempresa adopte un conjunto de medidas orientadas a crear condiciones favorables para que los pequeños comerciantes puedan competir en un espacio globalizado.” (Congreso de la República, 2011, p. 3)

Como parte del nuevo enfoque que ven necesario para el desarrollo e impulso de los mercados de abastos en nuestro país, plantean y reformulan la actividad principal de estos en la Ley Marco de Promoción y Desarrollo para los Mercados de Abasto, involucrando lo siguiente:

“...los mercados de abastos son centros comerciales especializados en una oferta biodiversa de calidad de los productos alimenticios y la gastronomía peruana; fomentan la difusión de hábitos alimenticios saludables y la educación 
nutricional de la población. Son, además, espacios de generación de identidad y socialización de la población constituyéndose en atractivos turísticos." (Congreso de la República, 2011, pp. 11-12)

En otras palabras, esta ley propone crear incentivos con el fin de promover la formalización y mejora de la calidad del empleo y de los servicios prestados por los comerciantes de mercados. Además, pretende facilitar la promoción, desarrollo, formalización y consolidación a fin de mejorar los servicios ofrecidos. (Congreso de la República, 2011, p. 3)

Esta política tiene como lineamientos los siguientes:

- Promover a los mercados como servicios especializados en la comercialización de productos alimenticios.

- Formalizar la propiedad de los mercados.

- Facilitar mecanismos idóneos al crédito para financiar la construcción.

- Impulsar la mejora de infraestructura y desarrollo comercial para mercados de abastos.

- Promover el aporte de la cooperación técnica internacional orientada al desarrollo, crecimiento, así como la construcción y/o remodelación de los mercados de abastos.

- Integrar el programa especial de COFOPRI que planificará, normará, dirigirá y ejecutará el programa especial de privatización para mercados minoristas a nivel nacional conducente a la titulación y formalización de la propiedad.

- Privatizar los mercados municipales y los ubicados en inmuebles del estado.

- Formalizar la conducción de puestos de mercados

- Asimismo, plantea incluir servicios especializados como:

- Financiamiento hipotecario con intereses promocionales para la construcción y/o remodelación de locales.

- Formación de centrales de compra, redes y consorcios entre mercados. 
- Articulación con los agricultores locales e integración a cadenas productivas, proyectos de construcción, remodelación o puesta en valor de la unidad arquitectónica.

- Facilitación de la formalización y certificación de la calidad de los mercados.

- Creación del sello de calidad “MI MERCADO” como imagen institucional y como mecanismo de reconocimiento, estímulo y publicidad para los mercados que cumplan con estándares de calidad en los productos y servicios que ofrecen, así como en la modalidad de gestión y presentación que implementen.

- Establecer un régimen tributario de los mercados de abastos.

Crear CODEMER (Consejo Nacional para el Desarrollo de los Mercados de Abasto), como órgano de coordinación y concertación intersectorial y de participación social en materia de promoción y desarrollo de los mercados de abastos a nivel nacional.

Crear los Consejos Regionales de los Mercados de Abastos, para promover el acercamiento entre diferentes asociaciones de mercados, entidades privadas y asesorías a los mercados y autoridades.

- Entidades reguladoras y afines

- MINSA

"El Ministerio de Salud es un organismo del Poder Ejecutivo que ejerce la rectoría del Sector Salud. Es la Autoridad de Salud a nivel nacional, tiene a su cargo la formulación, dirección y gestión de la política nacional de salud y actúa como la máxima autoridad en materia de salud.” (MINSA, s.f.)

Para el caso de los mercados de abasto, fija lineamientos orientados a un desempeño en el ámbito de la salubridad, así como en el debido manejo y condición higiénica que estos se encuentran, para garantizar al usuario un ambiente limpio y productos saludables. 


\section{- Ministerio de Cultura}

"Es un organismo del Poder Ejecutivo responsable de todos los aspectos culturales del país y ejerce competencia exclusiva y excluyente, respecto a otros niveles de gestión en todo el territorio nacional.” (Cultura, s.f.)

En el caso de los mercados municipales que se rijan a la nueva política pública, caracterizada por la inclusión de actividades de índole cultural, deberá corresponder al Ministerio de Cultura, velar por las buenas prácticas de dichas actividades.

\section{- Municipalidad Metropolitana de Lima}

Este organismo público "Coordina y norma la prestación de los servicios y planifica la infraestructura pública, la organización del transporte y del sistema vial, las actividades comerciales, productivas y, en general, la planificación urbana integral." (Comisión de Descentralización del Congreso de la República, s.f.)

En relación a los mercados municipales, la Municipalidad Metropolitana de Lima, ha desarrollado la Ordenanza Nº72, para la aprobación del nuevo Reglamento de Mercados (1994). Ver a detalle en el Anexo 1. Reglamentos y normas de mercados de abasto de Lima.

\section{- Municipalidad de San Isidro}

Según el artículo 4 de la Ley Orgánica de Municipalidades, "Las municipalidades representan al vecindario, promueven la adecuada prestación de los servicios públicos locales, fomentan el bienestar de los vecinos y el desarrollo integral y armónico de su localidad.” (Comisión de Descentralización del Congreso de la República, s.f.)

Asimismo, "proveen y controlan la prestación de los servicios públicos básicos requeridos para el bienestar de los vecinos y el desarrollo local." (Comisión de Descentralización del Congreso de la República, s.f.) Para nuestro caso de estudio, nos compete las regulaciones y normas expuestas por la Municipalidad de San Isidro, ver detalle en el Anexo 1. Reglamentos y normas de mercados de abasto de Lima. 


\section{- APEGA}

"Institución sin fines de lucro que convoca cocineros, gastrónomos, nutricionistas, restaurantes, investigadores, cronistas gastronómicos, centros de formación en cocina y universidades. Trabaja en alianza con diversas asociaciones de productores, así como con gremios empresariales y entidades públicas.” (APEGA, s.f.)

Mediante su promoción y acciones para con los mercados, APEGA representa un organismo relevante para el desarrollo de nuestra gastronomía peruana, realizando eventos de promoción y difusión, un claro ejemplo es su papel en el desarrollo de la feria anual gastronómica Mistura, así como en las diversas investigaciones afines realizadas.

\section{- MercaRed}

Es el primer programa de desarrollo empresarial de los mercados de abastos y centros comerciales del Perú, creada con la finalidad de preparar a los comerciantes de los mercados de abastos para así evitar que las grandes cadenas de supermercados remplacen por completo los mercados de abastos. Esta organización, tiene como base social a la Confederación Nacional en Mercados y Comercio del Perú "CONFENATM" y además de ofrecer servicios de asesoría en gestión, capacitaciones, consultoría en temas de marketing, atención al cliente, ventas, cuenta con alianzas estratégicas con diversas instituciones nacionales e internacionales. (MERCARED, s.f.) 
Tabla 4.1

Comparación de los reglamentos de las distintas organizaciones reguladoras de los mercados de abasto de Lima

\begin{tabular}{|c|c|c|c|}
\hline TEMAS & $\begin{array}{l}\text { ORDENANZA N }{ }^{\circ} 072 \text { - } \\
\text { MUNICIPALIDAD } \\
\text { METROPOLITANA DE } \\
\text { LIMA }\end{array}$ & $\begin{array}{l}\text { NORMA SANITARIA DEL } \\
\text { FUNCIONAMIENTO DE MERCADOS } \\
\text { DE ABASTO Y FERIAS } \\
\text { MINISTERIO DE SALUD }\end{array}$ & NORMA A.070_ RNE \\
\hline $\begin{array}{l}\text { DEFINICIÓN DE } \\
\text { MERCADO }\end{array}$ & $\begin{array}{l}\text { Local cerrado en cuyo interior } \\
\text { se encuentran establecimientos } \\
\text { de venta en secciones, } \\
\text { dedicados al acopio y } \\
\text { expendio de productos. }\end{array}$ & $\begin{array}{l}\text { Entiéndase a un local cerrado en cuyo } \\
\text { interior se encuentran constituidos o } \\
\text { distribuidos puestos individuales, en } \\
\text { secciones definidas, dedicados a la } \\
\text { comercialización de alimentos, productos } \\
\text { alimenticios y otros tradicionales no } \\
\text { alimenticios. }\end{array}$ & $\begin{array}{l}\text { Se denomina edificación comercial a } \\
\text { aquella destinada a desarrollar } \\
\text { comercialización de bienes o } \\
\text { servicios y actividades cuya finalidad } \\
\text { es la comercialización de bienes o } \\
\text { servicios. }\end{array}$ \\
\hline $\begin{array}{l}\text { CATEGORIZACIÓN DE } \\
\text { MERCADOS }\end{array}$ & $\begin{array}{l}\text { Mercados municipales, } \\
\text { micromercados, mercados } \\
\text { particulares, cooperativas, } \\
\text { mercadillos }\end{array}$ & $\mathbf{X}$ & $\mathbf{X}$ \\
\hline $\begin{array}{l}\text { GESTIÓN DEL } \\
\text { MERCADO }\end{array}$ & $\begin{array}{l}\text { El Administrador supervisado } \\
\text { por La Municipalidad }\end{array}$ & $\begin{array}{l}\text { Las Municipalidades encargados de la } \\
\text { vigilancia sanitaria de mercados }\end{array}$ & $\mathbf{X}$ \\
\hline DIMENSIONAMIENTO & $\mathbf{X}$ & $\mathbf{X}$ & $v$ \\
\hline $\begin{array}{l}\text { ÁREA MÍNIMA DE } \\
\text { MERCADO }\end{array}$ & $\mathbf{X}$ & $\mathbf{X}$ & $\checkmark$ \\
\hline ÁREA DE PUESTOS & $\mathbf{X}$ & $\mathbf{X}$ & $v$ \\
\hline $\begin{array}{l}\text { ÁREA DE SERVICIO } \\
\text { PARA EL PERSONAL }\end{array}$ & $\mathbf{X}$ & $\checkmark$ & $v$ \\
\hline $\begin{array}{l}\text { DIMENSIONES DE } \\
\text { ALMACENAMIENTO }\end{array}$ & $\mathbf{X}$ & $\mathbf{X}$ & $\checkmark$ \\
\hline ALTURA MÍNIMA & $\mathbf{X}$ & $\boldsymbol{v}$ & $3.00 \mathrm{~m}$ \\
\hline MATERIALIDAD & $\mathbf{X}$ & $\begin{array}{l}\text { Impermeable, lavable, antideslizante y sin } \\
\text { grietas }\end{array}$ & $\begin{array}{l}\text { Impermeable, antideslizante y liso, } \\
\text { fáciles de limpiar }\end{array}$ \\
\hline $\begin{array}{l}\text { VENTILACIÓN E } \\
\text { ILUMINACIÓN } \\
\text { NATURAL }\end{array}$ & $\mathbf{X}$ & $\boldsymbol{v}$ & $\checkmark$ \\
\hline DOTACIÓN DE SSHH & $\mathbf{X}$ & $\mathbf{X}$ & $v$ \\
\hline $\begin{array}{l}\text { TRATAMIENTO DE } \\
\text { AGUA Y DESAGÜE }\end{array}$ & $\checkmark$ & $\boldsymbol{V}$ & $\mathbf{X}$ \\
\hline $\begin{array}{l}\text { TRATAMIENTO DE } \\
\text { RESIDUOS }\end{array}$ & $\mathbf{X}$ & $\checkmark$ & $\checkmark$ \\
\hline $\begin{array}{l}\text { ACCESIBILIDAD PARA } \\
\text { PERSONAS CON } \\
\text { DISCAPACIDAD }\end{array}$ & $\mathbf{X}$ & $\mathbf{x}$ & $\checkmark$ \\
\hline $\begin{array}{l}\text { EVACUACIÓN Y } \\
\text { SEGURIDAD }\end{array}$ & $v$ & $\boldsymbol{v}$ & $\checkmark$ \\
\hline ESTACIONAMIENTOS & $\mathbf{X}$ & $\mathbf{X}$ & $\checkmark$ \\
\hline
\end{tabular}

Nota: $\mathrm{x}$ - No Especifica / $\checkmark$ - Especifica

Fuente: elaboración propia 
En la tabla presentada, a manera de resumen se muestran temas relevantes, para el tema de estudio, de las diferentes ordenanzas o normativas que recaen en los mercados de abasto de Lima.

En parte existe una falta de coordinación entre las entidades para seguir un orden al momento de imponer las normas, pues si bien no todos los puntos deberían tocarse de la misma manera en las diferentes entidades, sí es importante que los puntos que toquen coincidan en términos, unidades y especificaciones para evitar dudas y no tener que optar por los valores más críticos cuando se quiere cumplir la normas.

El principal tema que llama la atención es el vacío existente en la categorización de los mercados de abasto. No solo porque la Municipalidad Metropolitana de Lima sea la única que categoriza, sino también por la limitada categorización que propone.

Tanto en el cuadro comparativo de las normas, como en la tabla del Anexo 1, queda evidenciado que, si bien existen normas e intenciones de regulación de los mercados de abasto, estas no resultan del todo claras al momento de compararlas.

\subsubsection{Comparativo Lima_Madrid}

Como hemos mencionado en el presente capítulo tanto el Ayuntamiento de Madrid, como las autoridades que rigen y velan en el contexto de Lima Metropolitana, existe un sistema estructurado en la administración de la cadena alimentaria de ambas locaciones.

A continuación, se presenta un cuadro resumen de los principales organismos que componen la administración de los mercados municipales de estas dos localidades. 
Tabla 4.2

Comparación del sistema de administración de Madrid y Lima

\begin{tabular}{|c|c|c|}
\hline TEMAS & MADRID & LIMA \\
\hline $\begin{array}{l}\text { ORGANISMO PÚBLICO REGULADOR } \\
\text { A NIVEL NACIONAL }\end{array}$ & MERCASA & República del Perú \\
\hline $\begin{array}{l}\text { ORGANISMO PÚBLICO A NIVEL } \\
\text { REGIONAL }\end{array}$ & MERCAMADRID / Ayuntamiento de Madrid & $\begin{array}{l}\text { EMMSA / Municipalidad Metropolitana de } \\
\text { Lima }\end{array}$ \\
\hline ORGANISMO A NIVEL DISTRITAL & Ayuntamiento de Madrid & Municipalidad de San Isidro \\
\hline $\begin{array}{l}\text { ADMINISTRADOR DIRECTO DEL } \\
\text { MERCADO MUNICIPAL }\end{array}$ & Concesionario & Administrador (servidor público) \\
\hline RED DE MERCADOS & 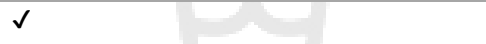 & $\mathbf{X}$ \\
\hline POLÍTICAS PÚBLICAS & $\begin{array}{l}\text { - El Plan de Innovación y Transformación de los } \\
\text { Mercados de Madrid (2003-2011) } \\
\text { · El Plan Estratégico de Modernización de los } \\
\text { Mercados de Madrid (2012-2015) } \\
\text { - La nueva ordenanza de Mercados Municipales } \\
\text { ANM 2010/62 }\end{array}$ & $\begin{array}{l}\text { - Ley Marco de Promoción y Desarrollo para } \\
\text { los Mercados de Abastos (2011) } \\
\end{array}$ \\
\hline
\end{tabular}

Fuente: elaboración propia

\subsection{Conclusiones parciales}

Según los distintos organismos consultados, todos definen al mercado como un lugar donde se comercializan productos para el abastecimiento primario de las personas (alimenticios y no alimenticios). Actualmente, no se ve una correcta categorización y diferencia de magnitudes, funciones y escalas de los distintos mercados existentes. Este factor no facilita la correcta distribución de entes reguladores de los mercados, ya que existe un vacío sobre el cual se apoyan para no tener que cumplir normas y estarse rigiendo a regulaciones. En otros casos, se ven perjudicados por no estar incluidos en las políticas de mejora y visión a futuro de los mercados de abasto, pues hay tipos mercados que no están catalogados, lo cual los deja sin saber a ciencia cierta de qué norma deben regirse.

Finalmente, al estar contemplados de manera genérica en la cadena alimentaria, no logran mejorar ni estar regidos de manera ordenada.

Se ha visto que Madrid está muy organizada y hay un interés muy fuerte para revalorar y hacer resurgir los mercados municipales. Asimismo, plantea una estructura 
administrativa eficiente, con órganos reguladores de índole público, que velan por el cumplimiento y toman medidas para la conservación y mejorar de los mercados. Es de suma importancia el papel realizado por Mercasa, que además de financiar proyectos para los mercados municipales, estudia y analiza cada caso de manera particular.

En el Perú, hace falta un organismo que abarque, así como se ha visto en el caso de España, toda una red organizada de mercados, debidamente diferenciada por su dimensión y radio de influencia, ya que en la práctica, si bien se tienen lineamientos planteados por el Gobierno en función a la mejora y reforma del mercado de tipo municipal, tanto la Municipalidad Metropolitana de Lima como los municipios distritales, no concuerdan en su definición con los alcances que los mercados, según la vigente política pública, deben desempeñar. 


\section{CAPÍTULO V: MARCO OPERATIVO}

\subsection{Introducción}

En la actualidad, puede resultar controversial pensar que los mercados no cumplen una función vigente para el contexto globalizado y complejo en el que vivimos. Se ve que los actuales modelos comerciales están desplazando la necesidad que significaban los mercados para la sociedad.

Sin embargo, a continuación, se analizarán ejemplos de mercados de abasto, específicamente de una escala minorista, sean privados o municipales, que tienen relevancia y significado para su contexto nacional y en casos internacional. Estos ejemplos comparten características similares que serán vistas a lo largo de este capítulo.

Se identificarán mercados de abasto icónicos a nivel mundial. Luego, se detallarán siete mercados que representen las diferentes metodologías de su funcionamiento y sirvan como referentes para una propuesta de mercado para Lima. Para cada uno de los casos a analizar, se tomarán en cuenta ocho variables: ubicación, historia, entorno, tipología, programa, espacio, tecnología e impacto social.

En cuanto a la ubicación, se empezará por realizar un análisis global de la zona que interviene el mercado en cuestión. Asimismo, se identificará los accesos de transporte público, peatonal y ciclo vías dependiendo sea el caso.

La historia será reflejada en una línea de tiempo, la cual detallará fechas y acontecimientos importantes a lo largo de la vida del mercado.

Con relación al análisis del entorno inmediato, se evidenciará la relación entre el mercado y sus alrededores, identificando los accesos principales, secundarios, tratamiento y existencia de espacios púbicos próximos, momentos de encuentro, aparcamiento, entre otros elementos.

En cuanto a la tipología se reflejará el proyecto a nivel esquemático tanto para mostrar la toma de partida del proyecto arquitectónico (morfología), como su clasificación debido a la disposición de los puestos de mercado (tipología). 
Viendo el proyecto a una escala mayor, se cuantificará las áreas de todo el mercado, para evidenciar su respectivo porcentaje que significa en el programa. No se tomarán en cuenta el área de circulación, estructura, ni estacionamientos.

Respecto a la relación espacial y funcionalidad se detallarán distintas intensidades de flujos, tanto de clientes como el personal, el abastecimiento y los residuos. Asimismo, se cuantificará la cantidad de espacio público, semipúblico y privado.

Por otro lado, se mostrará, la innovación de los mercados en cuanto a tecnología, sostenibilidad, sistemas constructivos y aportes en general.

Por último, se medirá su impacto para con la sociedad respecto a las distintas intensidades de influencia (radios de acción), así como también detallar las medidas que se están llevando a cabo para el constante aporte para la ciudad.

Vistos los distintos mercados emblemáticos que existen en el mundo, se han elegido cuatro mercados de España y uno de Italia: El Mercado Santa Caterina, El Mercado de la Barceloneta (Barcelona); El Mercado de San Miguel, El Mercado de San Antón (Madrid); y El Mercado Central de Florencia.

Se eligieron cuatro mercados de España, debido a que existe una reciente política de renovación y promoción de los mercados municipales (2003). Para así, poder ver cómo logra recuperar el tema de la memoria, identidad, turismo y repotenciar estos espacios para el bien de la ciudad.

Para este caso, se eligieron mercados minoristas municipales, a excepción del caso de Madrid, en el cual se optó por uno municipal y uno privado, debido a que este último ha sido pionero en la iniciativa de recuperación de estos establecimientos.

Respecto a la elección del Mercado Central de Florencia, es importante incluirlo porque es un referente que integra cultura, educación, entretenimiento, turismo, entre otros. 


\subsection{Mercado de Santa Caterina}

\subsubsection{Ubicación}

Arquitectos: Enric Miralles / Benedetta Tagliabie EMBT

\section{Equipo:}

Director: Igor Peraza

Ingeniero estructural: Robert Brufau

Ingeniero de cubierta: José María Velasco

Ingeniero: Miquel Llorens

Instalaciones: PGI

Fabricante de cerámica cubierta: Toni Cumbella

Año: $1997-2005$

Cliente: privado (Foment de Ciutat Vella S.A.)

Ubicación: Francesc Cambó, 16. Ciutat Vella, Barcelona, España.

Categoría: mercado privado

Terreno: $5200.0 \mathrm{~m} 2$

\section{Premios:}

2001 ASCER Prize

2005 Premi Nacional de Catalunya

2007 IX Spanish Biennial of Architecture and Urbanism 
Figura 5.1

Collage aérea del Mercado de Santa Caterina

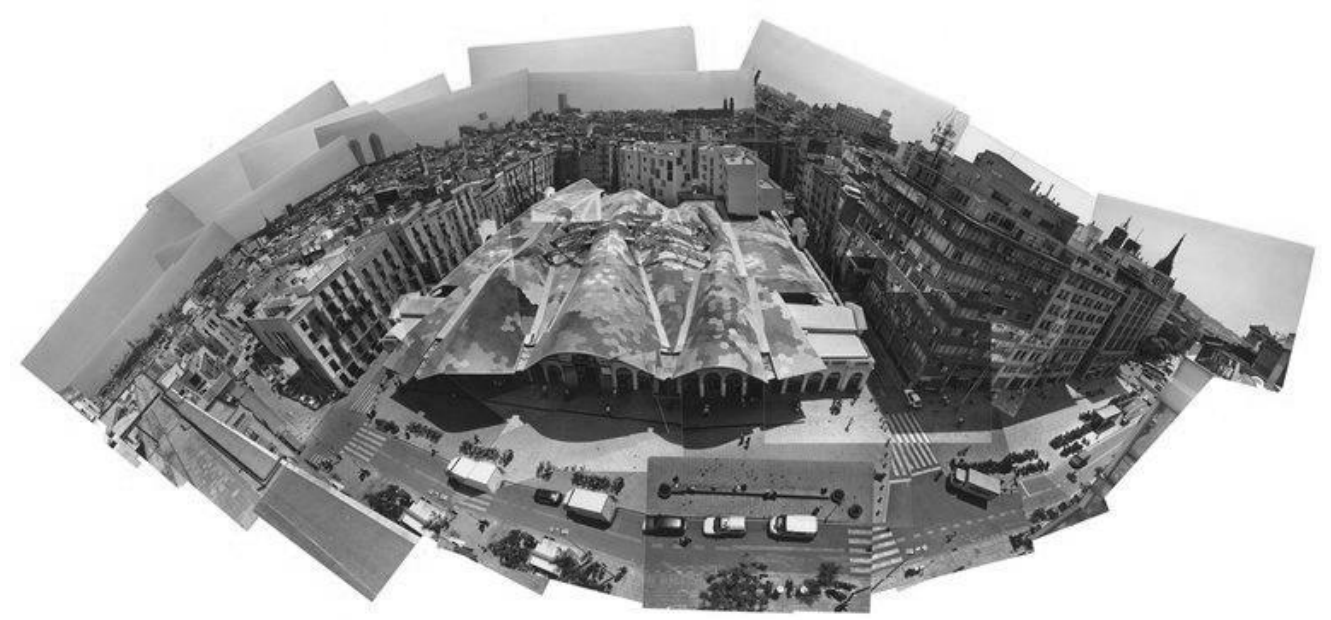

Nota: Imagen editada en blanco y negro

Fuente: Mercar de Santa Caterina (s.f) Enric Miralles Benedetta Tagliabue En: http://www.e-architect.co.uk

\section{Descripción del proyecto:}

El proyecto de remodelación del mercado nace como propuesta a la necesidad de rehabilitación tanto del antiguo Mercado de Santa Caterina, como de la zona en general. Es entonces como, después de ganar el concurso, se inicia la construcción inmediata del mercado, el cual no sólo desarrolla ámbitos arquitectónicos sino también de espacio público, rehabilitación, instalaciones temporales, propuestas de talleres artesanales, implementación de ambientes destinados a la cultura, entre otros.

Así se define el proyecto integrando un bloque de viviendas, un sitio arqueológico y un mercado que funciona como abastecimiento para todo Barcelona. 
Figura 5.2

Vista superior del Mercado de Santa Caterina

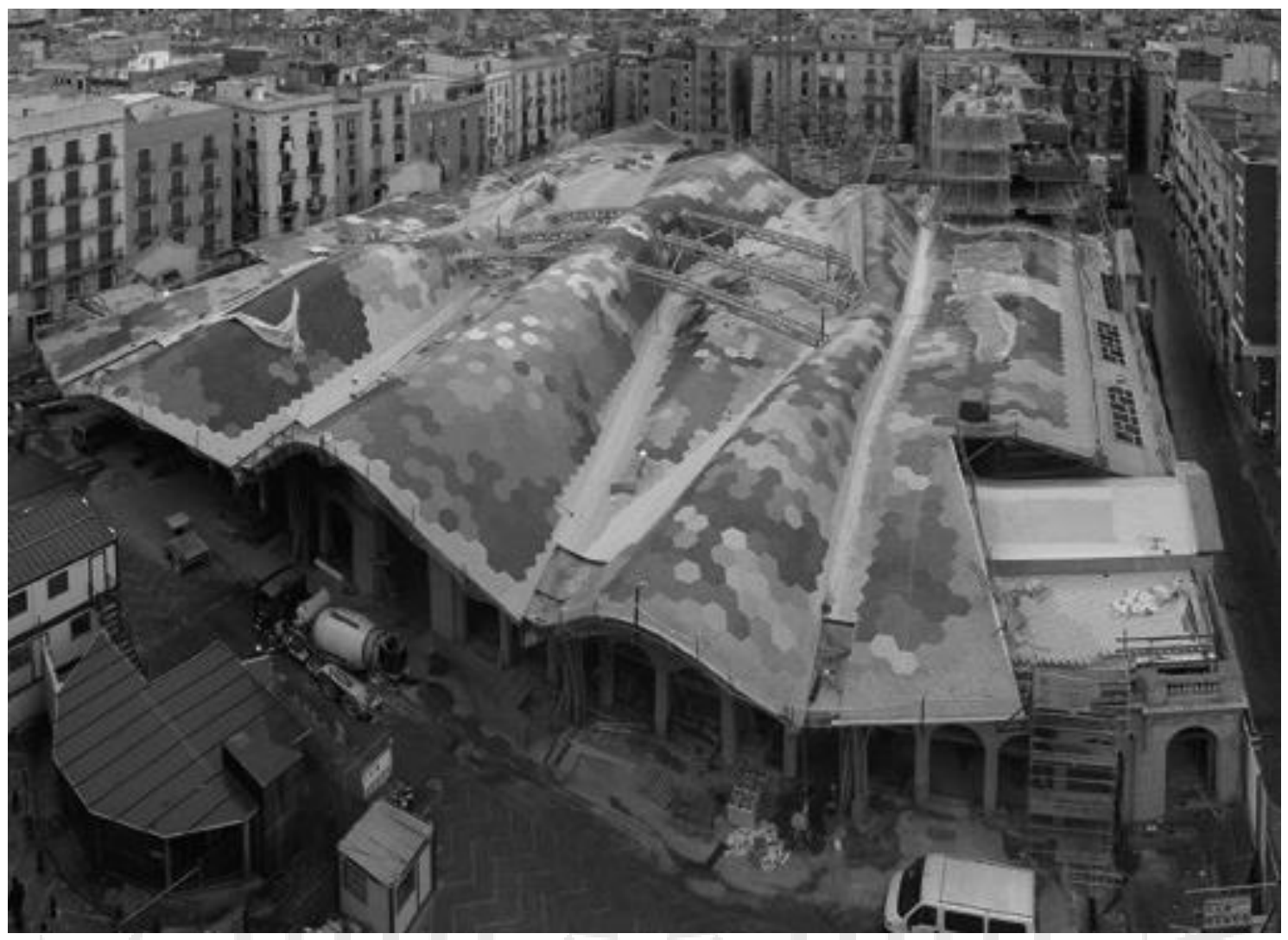

Nota: Imagen editada en blanco y negro

Fuente: Vista general del Mercado de Santa Caterina (enero de 2004) Toni Cumella En: Documento Nuevo Mercado de la Barceloneta 


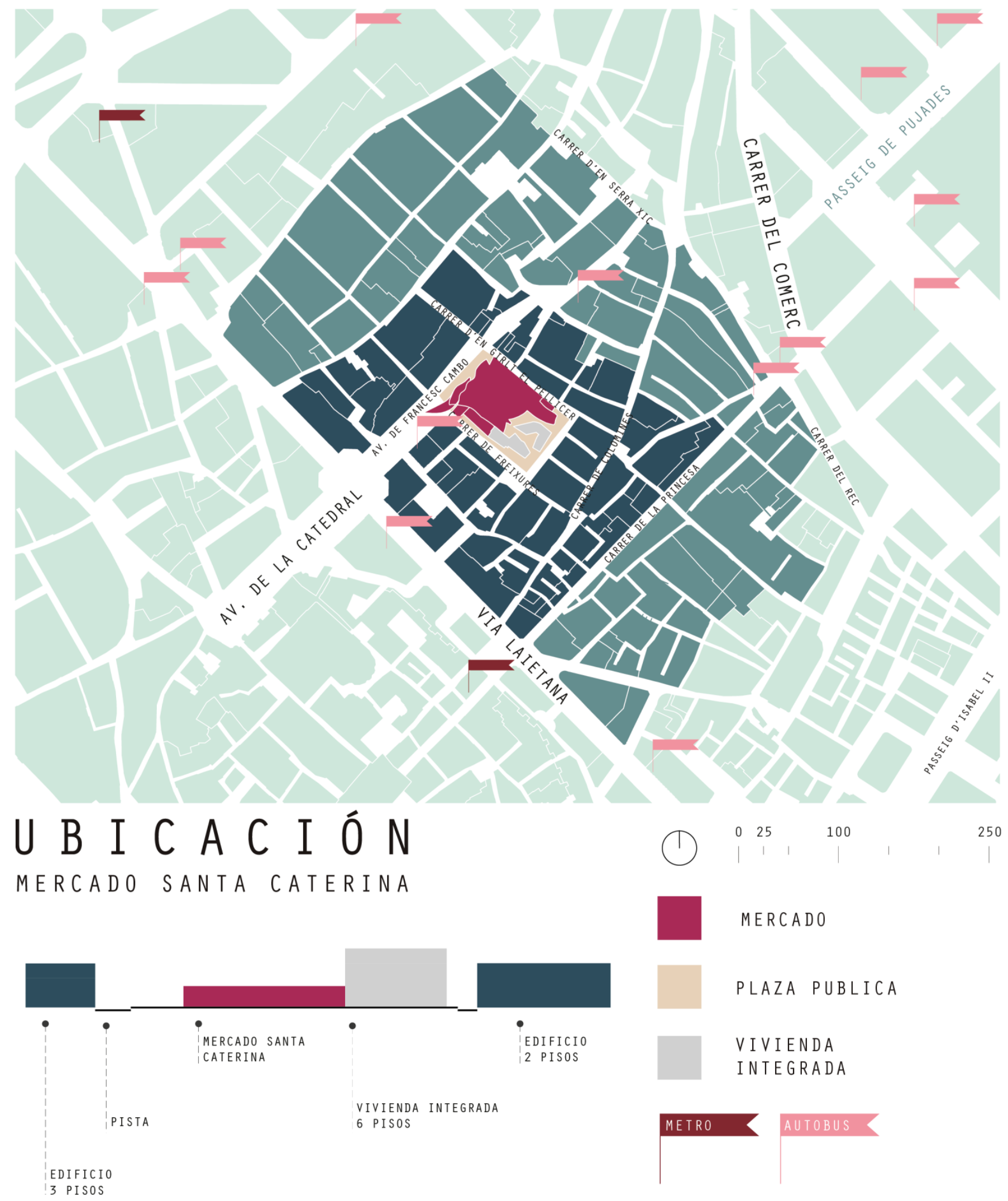


El mercado se encuentra en la región de Cataluña (Barcelona), en el distrito de Ribiera en la Ciutat Vella, sobre la avenida Francesc Combó. Ciutat Vella alrededor de 1980, se encontraba en pésimas condiciones de sanidad e inseguridad, pero renace en la nueva etapa del urbanismo neoliberal cuando se incorporan espacios estratégicos para la competitividad económica global, se llevan a cabo obras de restauración en plazas, calles y se proponen equipamientos para la regeneración urbana tales como el Mercado de Santa Caterina. Hoy en día se refiere a Ciutat Vella como una zona antigua y moderna al mismo tiempo, popular y burguesa, localista y cosmopolita, es el centro histórico de Barcelona y las calles, como dice Gato Pérez, poseen "sabor a ciudadanía".

La complejidad de la trama urbana en la que se ubica el mercado, irregular y desordenada, como si de un plato roto se tratase, acumula la historia de Barcelona de casi dos mil años atrás. Esto trajo un interés por parte del arquitecto, de diseñar un modelo de mercado que permita la adaptación, la fusión y la relación a dicha particular trama urbana.

Es así como se ve en la composición y diseño del proyecto, la continuidad de la trama; las plazas y los ensanchamientos de las calles pasan a través del mercado y lo convienen en parte de un mismo mecanismo urbano. Hecho que además permite reflejar los estratos históricos acumulados.

En el perfil urbano, se contempla la integración de vivienda y espacio público a la propuesta de mercado del arquitecto Enric Miralles, para dar contraste a la densidad residencial que caracteriza la zona. Así es como se desplaza la zona comercial hacia la Av. Cambó, abriendo la construcción del mercado hacia el interior del barrio de Santa Caterina.

Si bien hoy en día, existen pocos paraderos de autobús para el acceso al mercado, la ciudad está dotada de interesantes calles y vías que hacen amena la visita al mercado a nivel peatonal, pues desde que se llega hasta que se va, el visitante es capaz de percibir el ambiente histórico del lugar. 


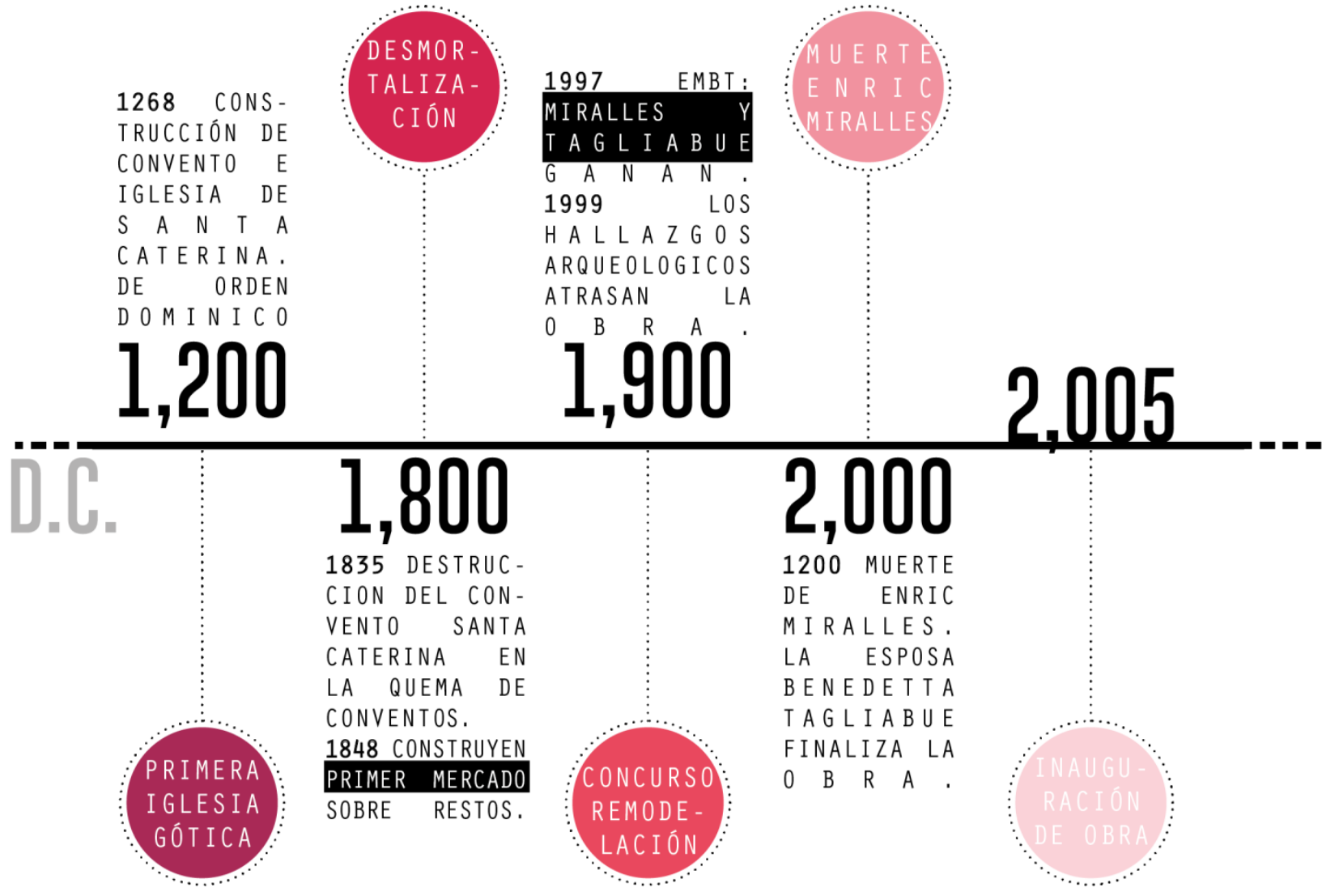

H I S T O R I A

MERCADO SANTA CATERINA

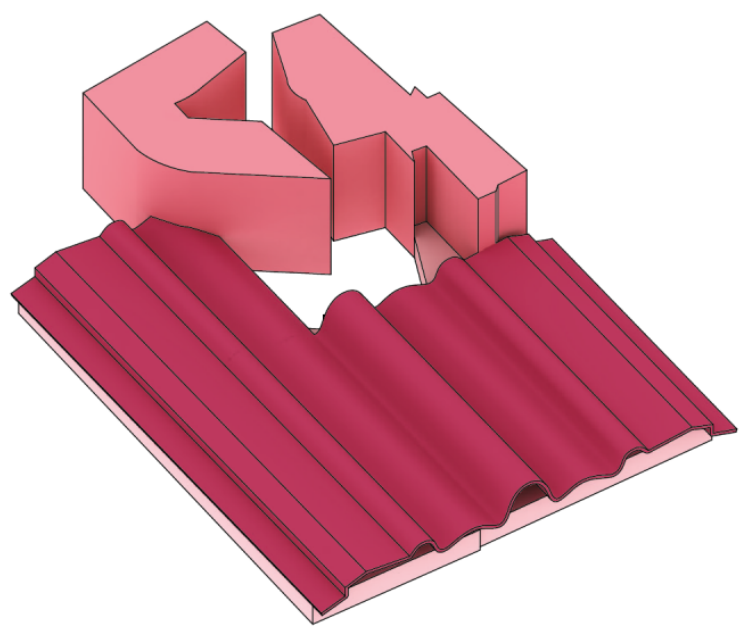




\subsubsection{Historia}

El lugar del Mercado de Santa Caterina lleva en su historia diferentes acontecimientos concentrados en el mismo punto. El mercado remonta su origen al año 1848, llamado en ese entonces el Mercado de Isabel II y construido por el ayuntamiento de Barcelona después de la destrucción de conventos del 25 de julio de 1835.

Figura 5.3

Foto composición de las excavaciones del Mercado de Santa Caterina

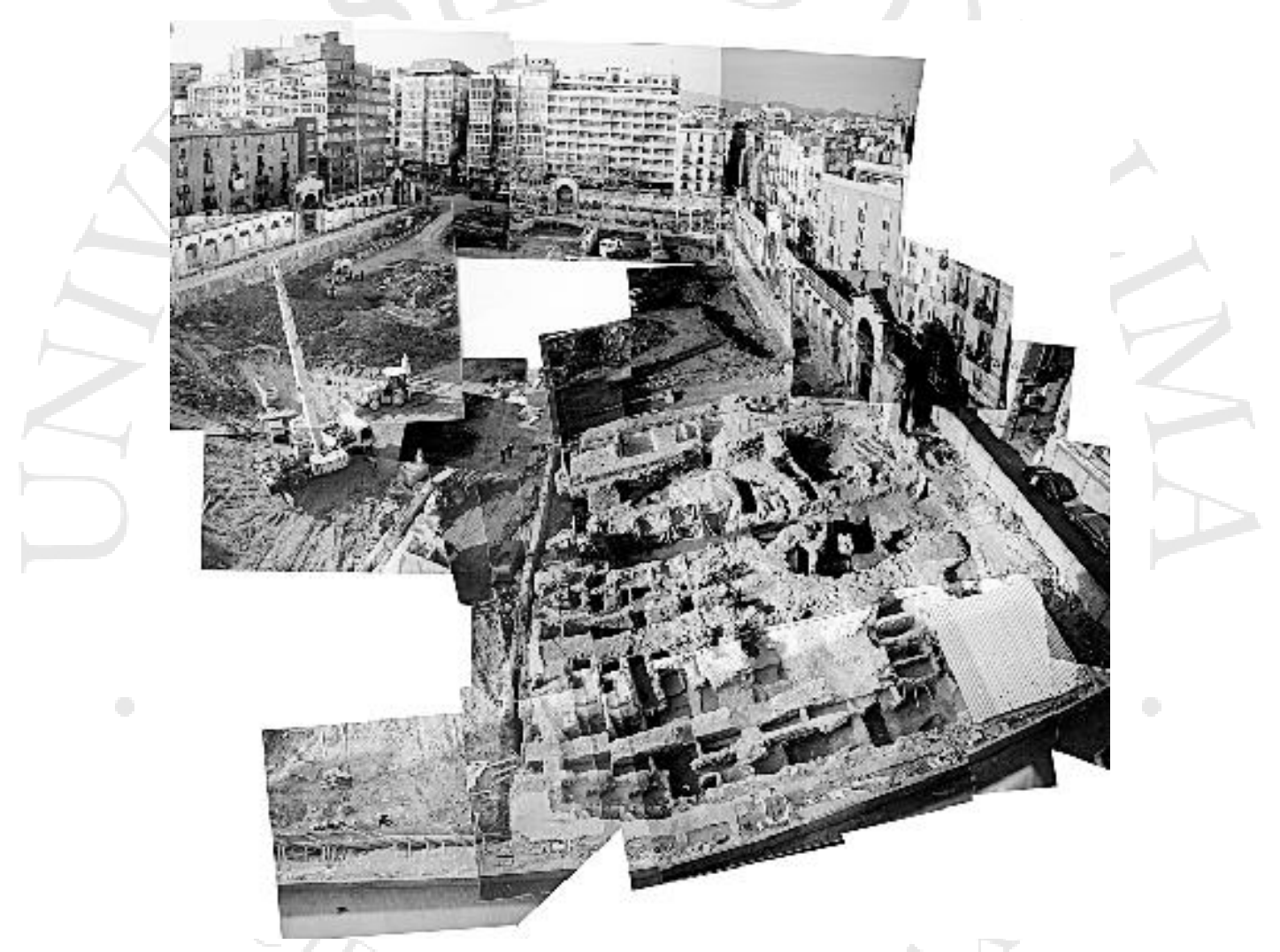

Nota: Imagen editada en blanco y negro

Fuente: Fotocomposición (s.f.) Enric Miralles

En: Documento Mercado Moderno de Santa Caterina

En la década de 1990, los arquitectos Miralles y Tagliabue, ganan el concurso para la remodelación del Mercado de Santa Caterina, que después de un largo periodo de construcción, se atrasó por hallazgos arqueológicos, y finalmente abre sus puertas en mayo del 2005. 
En él, se propone un proyecto de mercado que contribuya a la ciudad, que lleve consigo los diferentes estratos históricos no sólo del lote, sino del barrio en general.

Así, la superposición de diferentes acontecimientos históricos en el lugar es determinante $\mathrm{y}$ ofrece posibilidades para apoyar la identidad del proyecto y de los vecinos.

La idea de tomar la trama urbana como toma de partida del proyecto es una forma de diseñar y proyectar que caracteriza a Miralles. De la misma manera se puede ver en otros proyectos suyos como el Nuevo Parlamento de Escocia, proyecto en el que se refleja la trama de la tierra.

Miralles sostiene "desde el principio hemos trabajado con la intuición de que la identificación del individuo con la tierra conlleva una coincidencia y unos sentimientos colectivos". (Asociación de Investigación de las Industrias de la Madera, s.f., p. 12)

Es así como este proyecto propone instalarse formalmente adaptado a la complejidad del lugar, a través de un esquema que permita expresar la compleja trama de la ciudad y que al mismo tiempo respete los compromisos públicos adquiridos.

\section{Toma de partido:}

El mercado de Santa Caterina nace de una idea vinculada a la continuidad de la irregularidad de la trama urbana que caracteriza la zona. Esta característica se ven reflejada tanto en el plano de techos con las cubiertas curvilíneas, así como en la distribución interior del mercado, al contar con pasillos irregulares que imitan la trama urbana existente. 


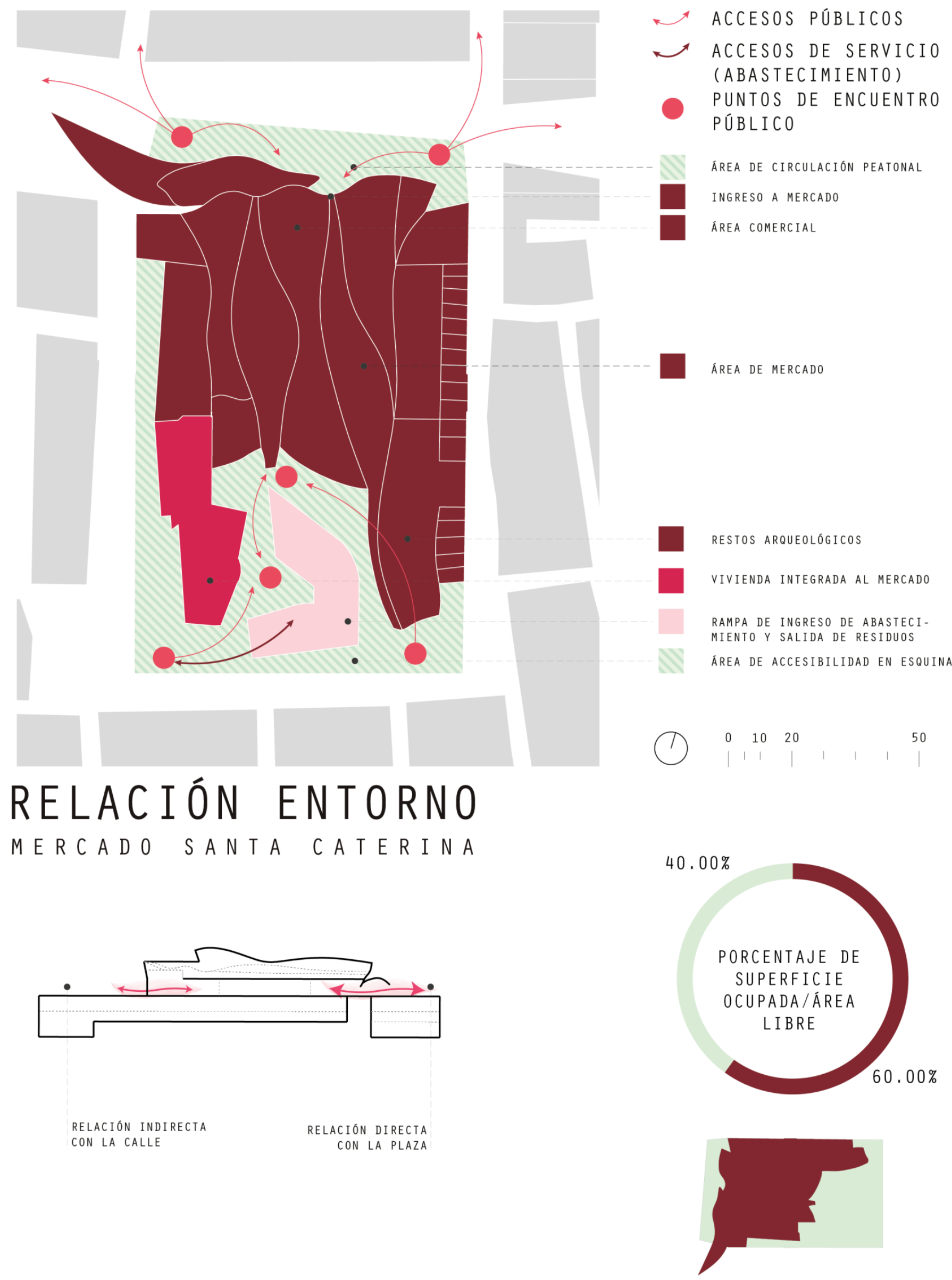




\subsubsection{Entorno}

El remodelado Mercado de Santa Caterina, es hoy en día el motor comercial de la zona, y permite la conexión entre el área comercial de la zona gótica con la de del barrio de Santa Caterina, Sant Pere y Ribiera.

El espacio público proyectado contribuye con puntos de encuentro y articulación de la gente que transitan las calles del borde, logrando que atraviesen el mercado también. Pues los movimientos y la actividad de las personas y los flujos son los elementos que mejor configuran el entorno de un mercado y también los espacios tangentes a este.

El Mercado de Santa Caterina es un proyecto que propone reducir el número de puestos de venta, con el fin de racionalizar los sistemas de accesos y servicios, además de espacios públicos y densidad residencial. El mercado además de vivienda contiene varias áreas de espacio público y circulación peatonal, contribuyendo a la limpieza vehicular de la zona y dotar un ambiente más tranquilo y sostenible.

Figura 5.4

Uso del espacio público del Mercado de Santa Caterina

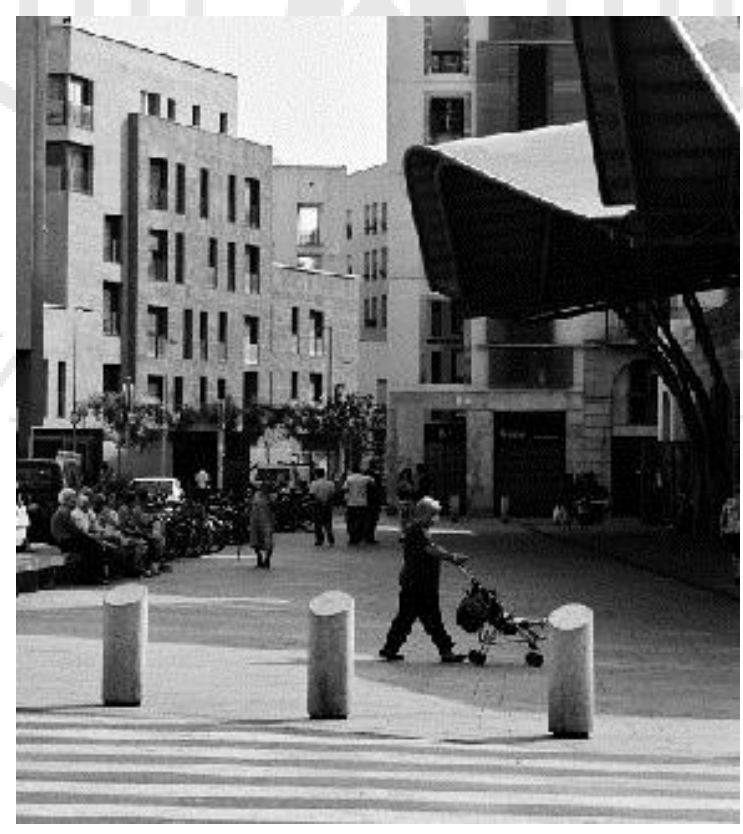

Nota: Imagen editada en blanco y negro

Fuente: Relación con el espacio Público (s.f.) Juan Coll-Barreu

En: Documento Fragmento y Continuidad en el Parlamento de Escocia y el Mercado de Santa Caterina 


\subsubsection{Tipología}

Figura 5.5

Esquema de tipología según distribución de puestos

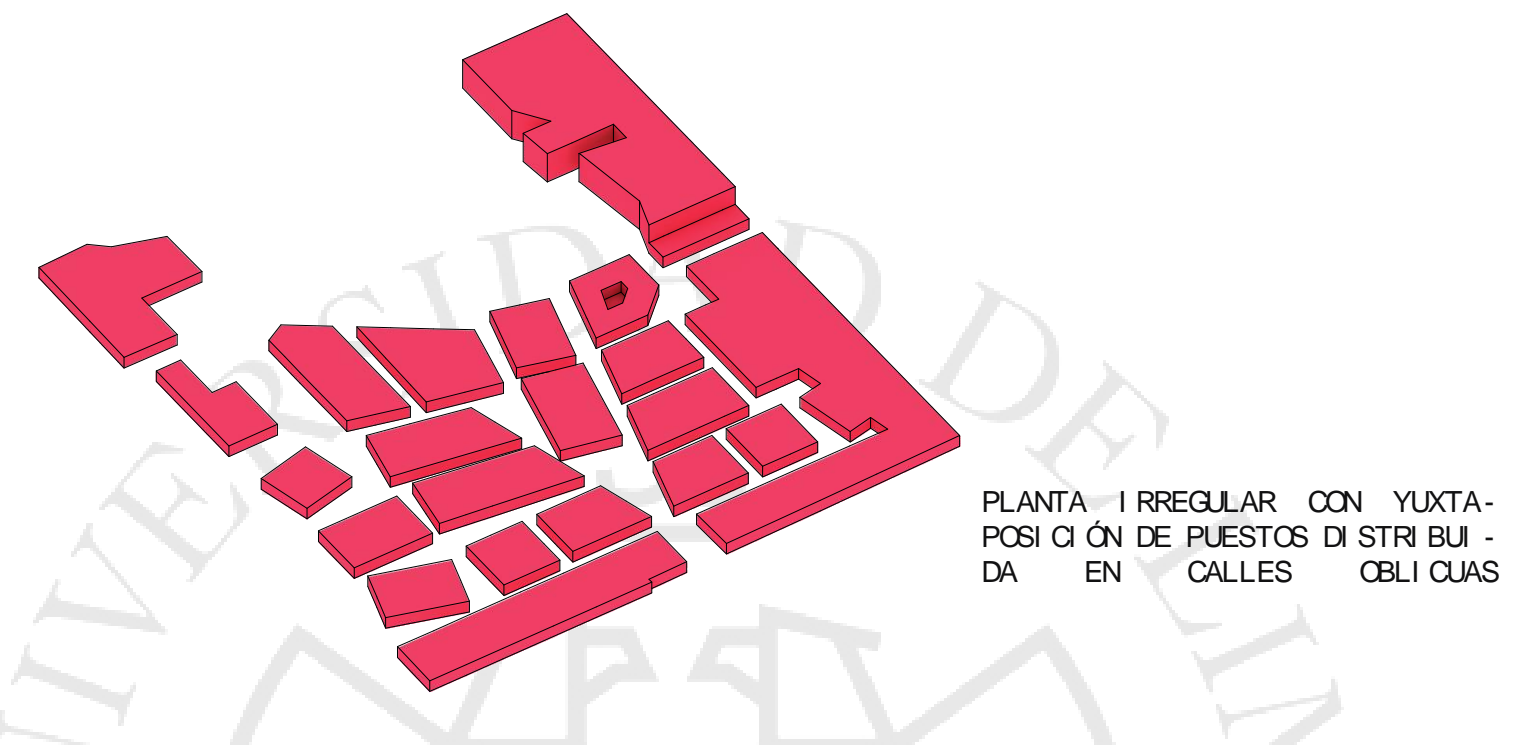

El Mercado de Santa Caterina corresponde a una tipología de planta irregular con yuxtaposición de puestos distribuida en calles oblicuas, libres en su posición angular, ajenas a lo ortogonal.

Es así como vemos que la distribución del mercado es particular, pues los pasadizos conforman un original espacio irregular que facilita y hace dinámica la compra, venta y el flujo peatonal. 


\subsubsection{Programa}

\section{Cuadro de áreas}

Tabla 5.1

Cuadro de áreas del Mercado de Santa Caterina

\begin{tabular}{|c|c|c|c|}
\hline PROGRAMA & AREA (m2) & PORCENTAJE & TOTAL \\
\hline ÁREA DE VENTAS & & & $7732 \mathrm{~m} 2$ \\
\hline Carnes & 561 & $18.04 \%$ & \\
\hline Aves & 146 & $4.70 \%$ & \\
\hline Pescados / Mariscos & 228 & $7.33 \%$ & \\
\hline Embutidos & 119 & $3.83 \%$ & \\
\hline Frutas & 229 & $7.37 \%$ & \\
\hline Verduras & 200 & $6.43 \%$ & \\
\hline Abarrotes & 116 & $3.73 \%$ & \\
\hline Lácteos & 17 & $0.55 \%$ & \\
\hline Licorería & 116 & $3.73 \%$ & \\
\hline SERVICIOS COMPLEMENTARIOS & & & $\mathbf{m} 2$ \\
\hline Juguería / Bares / Café / Restaurantes & 322 & $10.36 \%$ & \\
\hline Otros servicios públicos & 138 & $4.44 \%$ & \\
\hline SERVICIOS GENERALES & & & 179 \\
\hline Almacenes refrigerados & 10 & $0.32 \%$ & \\
\hline Almacenes & 300 & $9.65 \%$ & \\
\hline Descarga & 300 & $9.65 \%$ & \\
\hline Residuos & 10 & $0.32 \%$ & \\
\hline Administración & 12 & $0.39 \%$ & \\
\hline Oficinas & 100 & $3.22 \%$ & \\
\hline SSHH & 32 & $1.03 \%$ & \\
\hline Otros servicios privados & 153 & $4.92 \%$ & \\
\hline TOTAL & & $100 \%$ & 109 \\
\hline
\end{tabular}

Nota: No se considera el área de estacionamiento Fuente: elaboración propia 
CARNES

AVES

PESCADOS/MARISCOS

EMBUTIDOS

FRUTAS

VERDURAS

ABARROTES

LACTEOS

JUGUERÍA / BAR / CAFÉ /

RESTAURANTES

LICORERÍA

ALMACENES REFRIGERADOS

ALMACENES

DESCARGUE

RESIDUOS

A DM I N I STRAC I ÓN

OFIC INAS

SSHH

OTROS SERVICIOS PÚBLICOS

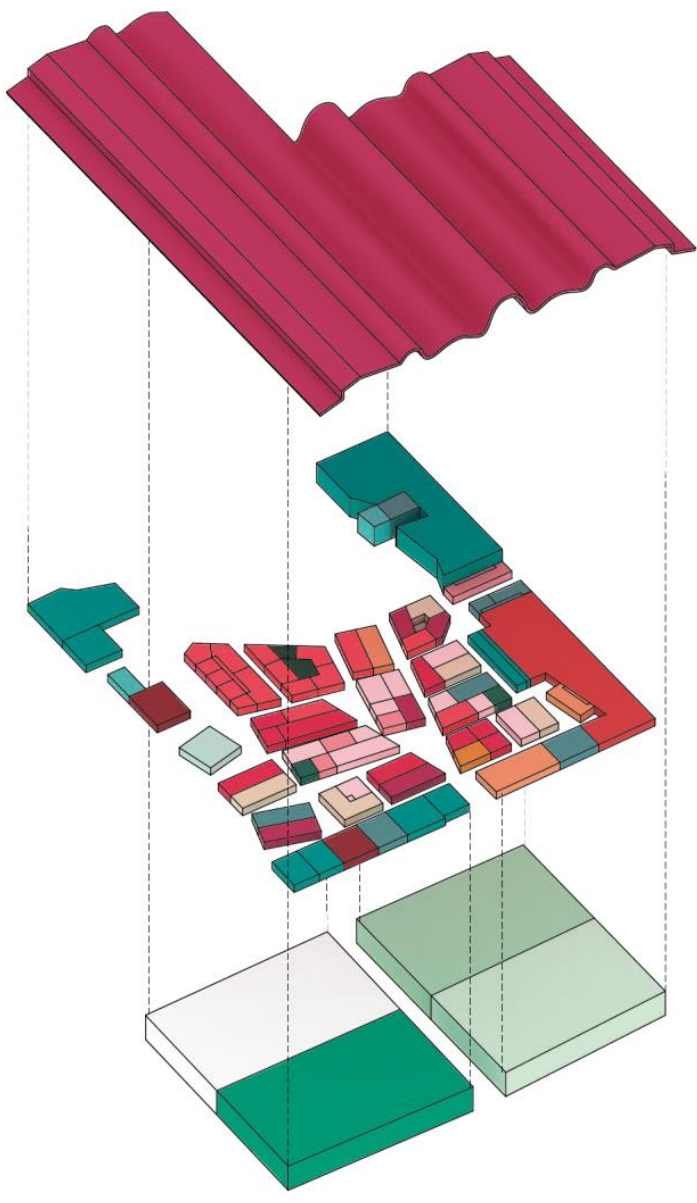

COBERTURA

PRIMER PISO

SOTANO

OTROS SERVICIOS PRIVADOS

\section{$P R O G R A M A$}

MERCADO SANTA CATERINA

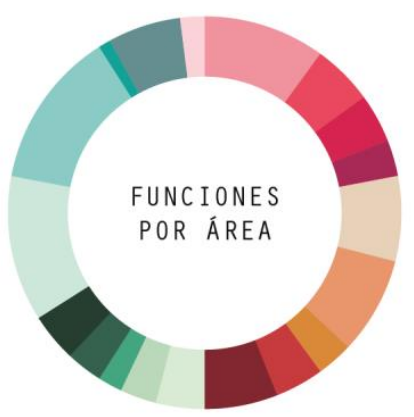




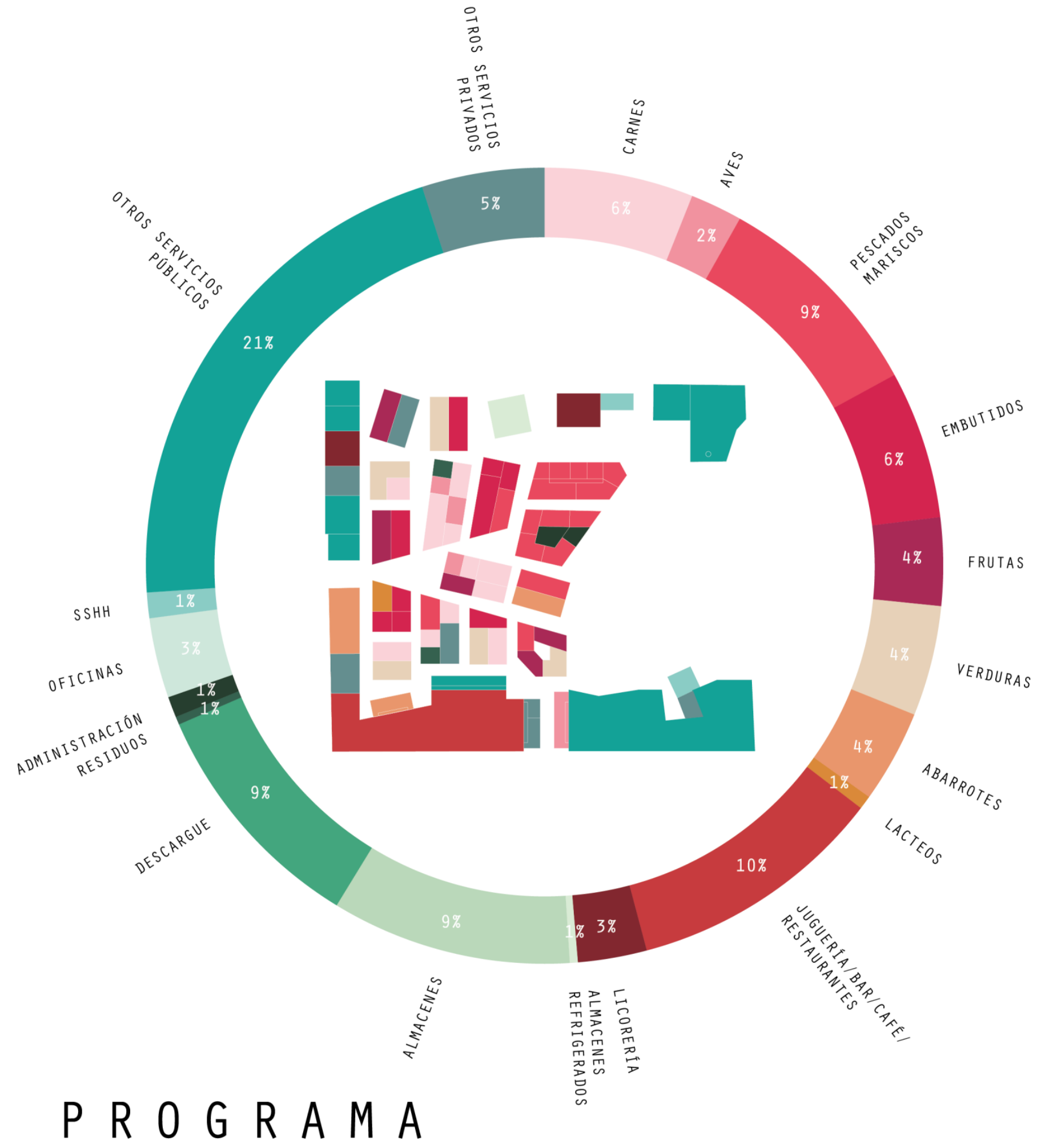

MERCADO SANTA CATERINA

ÁREA TOTAL 3000 M2

"NO SE CONSIDERA ESTACIENAMIENTOS 
INGRESO/SALIDA CLIENTES

SERVICIOS COMPLEMENTARIOS

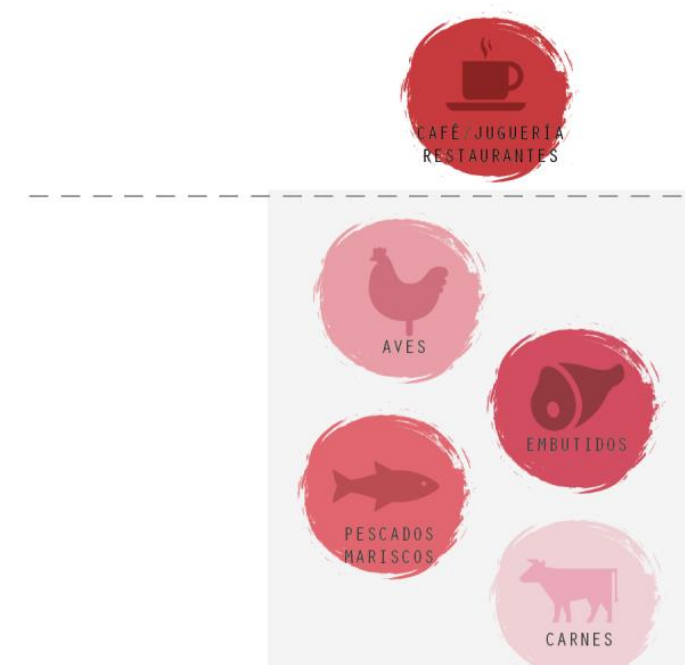

HUMEDOS
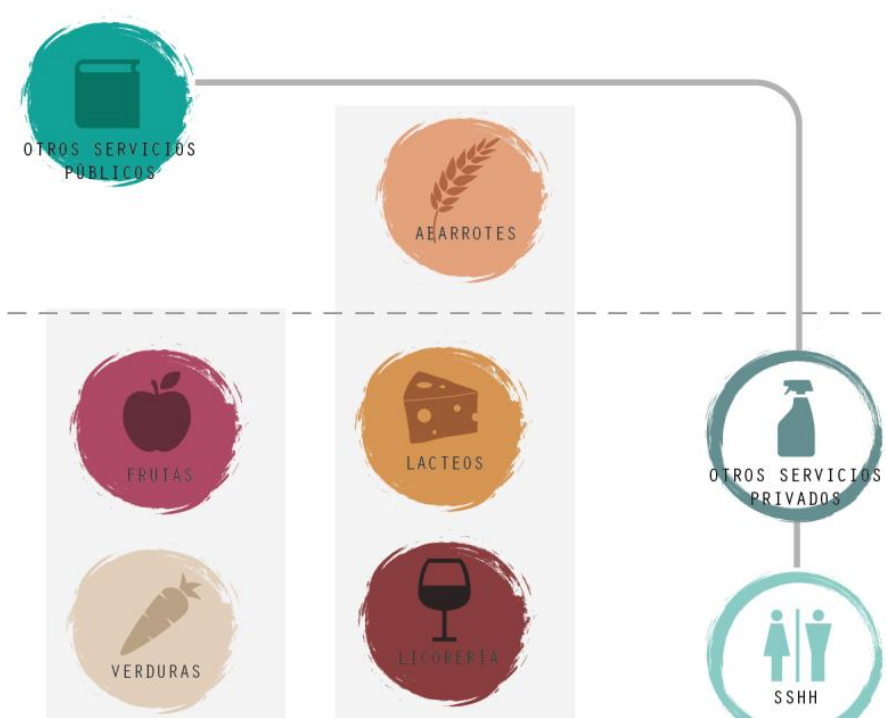

SEMIHUMEDOS

SECOS
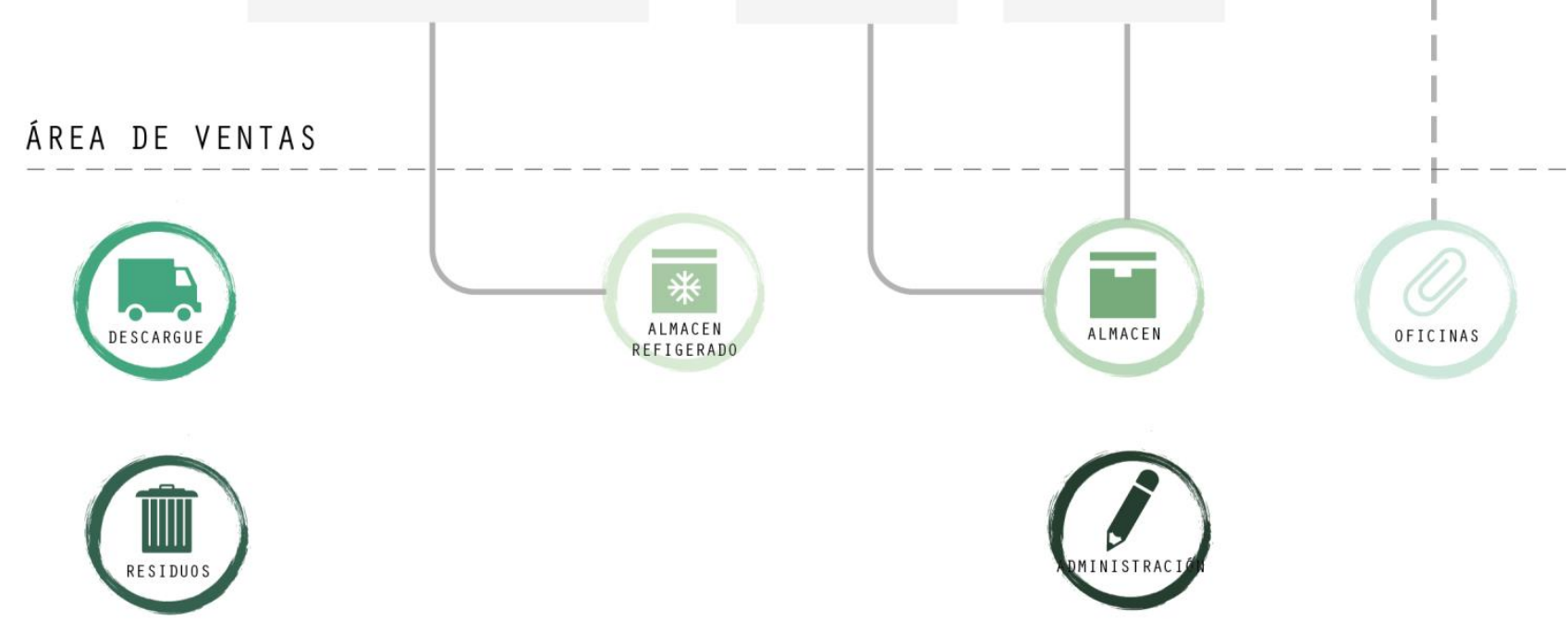

ÁREA DE SERVICIOS GENERALES

\section{R G A N I G R A M A}

MERCADO SANTA CATERINA

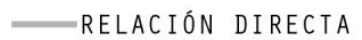

- - - RELACIÓN INDIRECTA

GRUPO DE PRODUCTOS 
El mercado tiene alrededor de $3000 \mathrm{~m} 2$ en cuanto a programa, sin considerar el área de estacionamientos ni los grandes almacenes subterráneos. El equipamiento ofrece diversos servicios tales como: 60 puestos de alimentación fresca, 5 bodegas no alimentarias, tiendas de productos perecibles y no perecibles, lugares de autoservicio, restaurantes, oficinas de información, espacios para el desarrollo de actividades culturales, almacenes, espacios de recolección de residuos, entre otros.

Asimismo, incluye en su programa, venta por internet, servicios de envío a domicilio, actividades sociales y de ocio, participación en fiestas y celebraciones tradicionales, eventos gastronómicos, etc.

Respecto a la relación establecida entre todos estos espacios, queda claro que los servicios complementarios tales como restaurantes, museo arqueológico, puestos de actividad social y cultura, se encuentran siempre al ingreso del mercado, para dar mejor acogida al transeúnte y para llamar el interés del usuario próximo al mercado. En el interior del mercado se desarrolla toda la actividad comercial, mientras que los servicios generales se encuentran en todo el mercado y se distribuyen según su necesidad en los diferentes puestos, por ejemplo, la cámara frigorífica (del primer piso) se encuentra próxima a los productos húmedos tales como la carne, el pollo, el pescado, mientras que los almacenes, se encuentran más cerca de los productos secos como frutos secos, ventas de cereales, productos a granel, etc. 


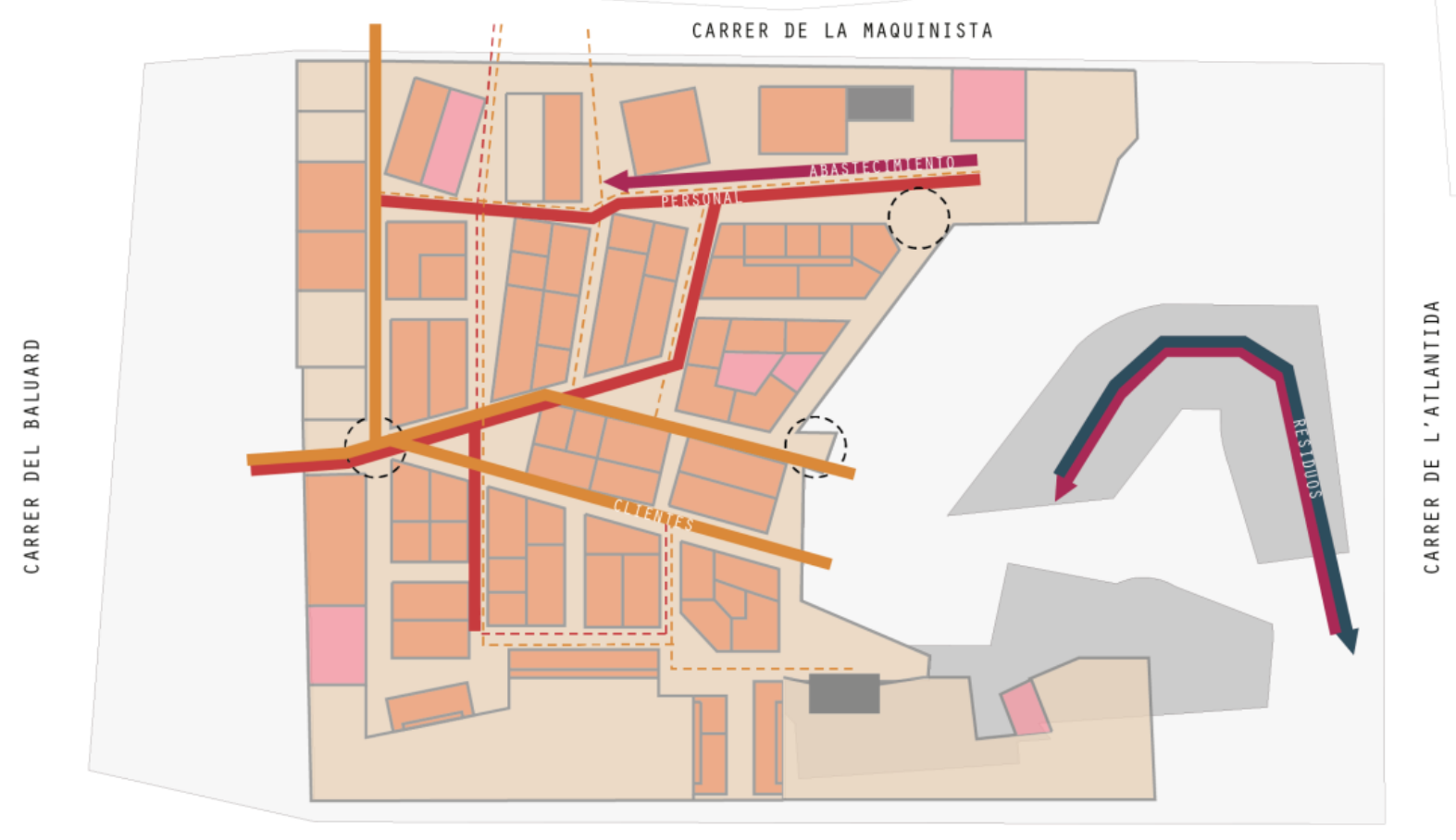

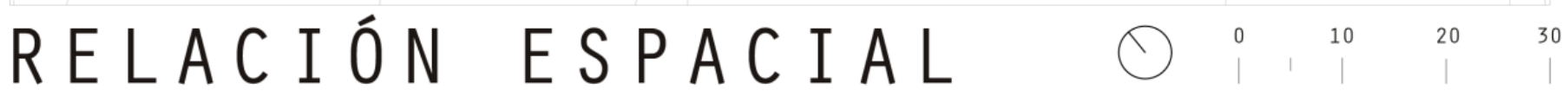
$M E R C A D O S A N T A C A T E R I N A$

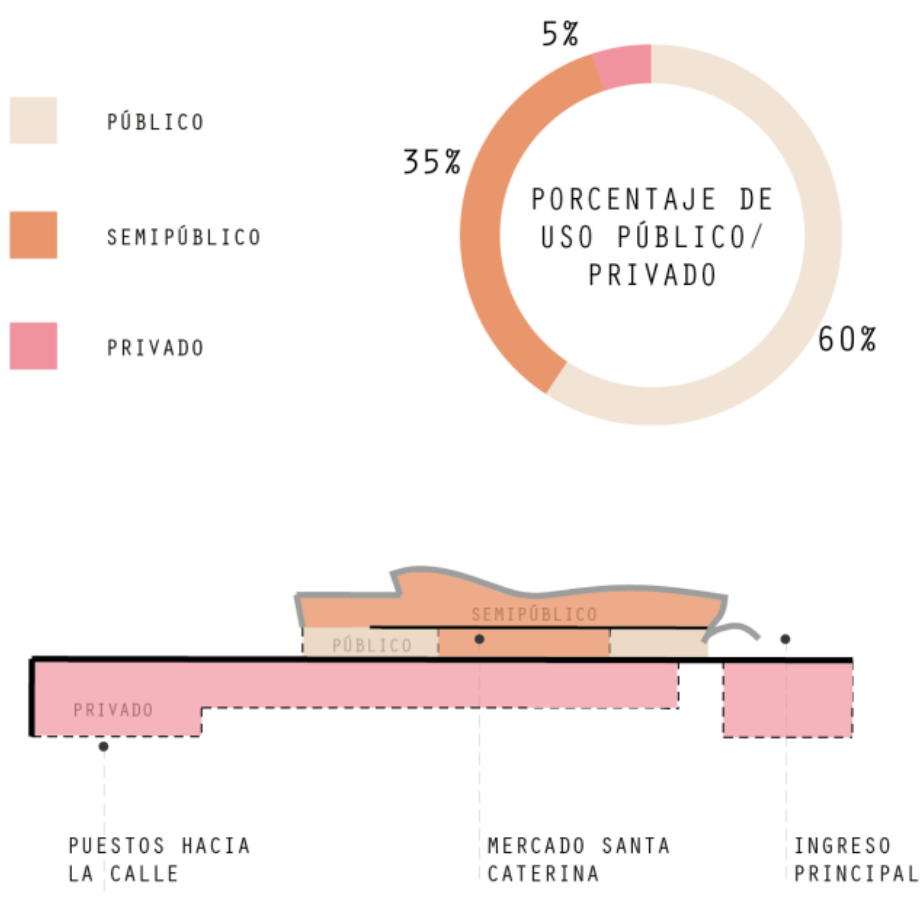
- Flujo intenso de clientes HORARI 0 7:00-19:00
- Flujo moderado de clientes HORARI 0 7:00-19:00
- Flujo intenso de personal HORARIO
- FluJO MODERADO DE PERSONAL HORARI 0 7:00-19:00
- Flujo de abastecimiento HORARIO
- ELIMINACIÓN DE RESIDUOS HORARIO
CIRCULACIÓN VERTICAL

--- PUNTO DE ENCUENTRO 


\subsubsection{Espacio}

Los flujos más intensos de circulación tanto de clientes como del personal se dan por los corredores tanto de manera transversal como longitudinal.

Por otro lado, el abastecimiento y la eliminación de residuos toman una ruta distinta en el mercado, al ser evidente la nula posibilidad de cruce de estos con los clientes.

Los horarios de atención establecidos en el mercado de Santa Caterina son básicamente: Autoservicios de 9am a 9pm, el Espacio Comercial de Mercado de 7:30am a 8:30pm como máximo y los Restaurantes, de 9am a 00am.

El intenso flujo peatonal, lleva a pensar que el mercado es más que un espacio de carácter público, este se convierte en una plaza que contiene distintas actividades y que da pie a la activación de la zona.

Figura 5.6

Flujos de los visitantes al interior del Mercado Santa Caterina

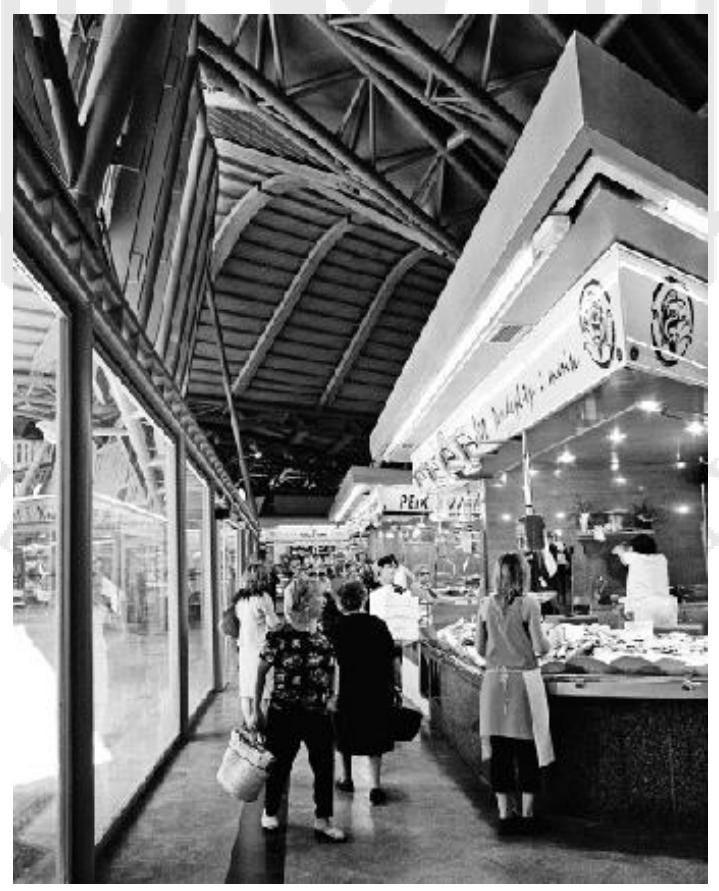

Nota: Imagen editada en blanco y negro

Fuente: Actividad Comercial Interior (s.f.) Juan Coll-Barreu

En: Documento Fragmento y Continuidad en el Parlamento de Escocia y el Mercado de Santa Caterina 
S I STEMA CONSTRUCTIVO

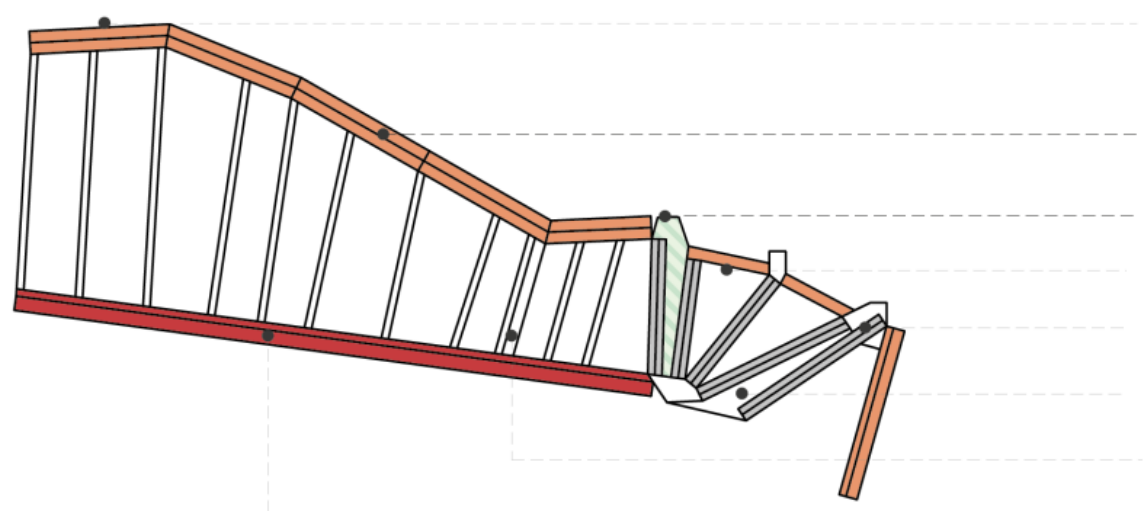

ACABADO FINAL PIEZA CERÁMICA

DOS LAMINAS FINALES DE MADERA

IMPERMEABILIZACION CON SIKABOND

(ARMADO CON FIBRA DE POLIESTER)

LANA DE ROCA

RASTRELES DE $4 \times 4$ MM

CANALONES

VIGAS METALICAS TIPO V

DOS CAPAS DE MADERA DIPUESTAS

CASI A 90 GRADOS

ARCOS DE MADERA

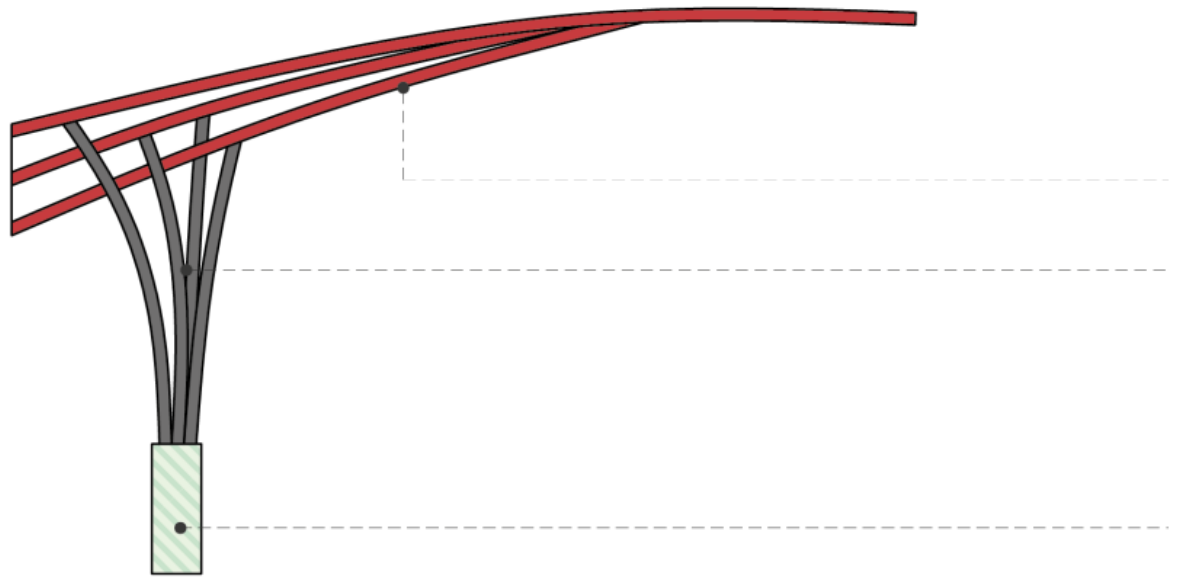

SOBRE LA PARTE CENTRAL DE LAS DOS GRANDES VIGAS ARRANCAN LOS TRES ARCOS METÁLICOS ATIRANTADOS, DE MÁS DE 40 METROS DE LUZ Y 8 METROS DE FLECHA, DE LOS CUALES CUELGA UNA COMPLEJA RED DE VIGAS METÁLI CAS TRIANGULADAS SUSPENDIDAS EN SU PARTE CENTRAL, APOYÁNDOSE EN SUS EXTREMOS POR LAS RAMIFICACIONES DE UNOS SINGULARES ÁRBOLES METÁLICOS.

\section{T E C N O L L O G I I A}

MERCADOSANTA CATERINA

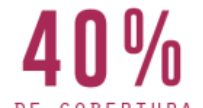

DE COBERTURA ENERGÉTI ICA

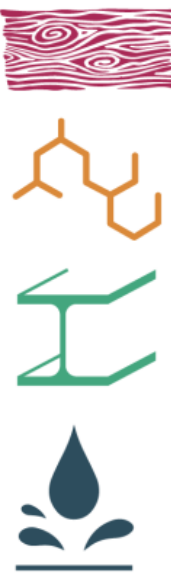

180 PLACAS SOLARES EN LA CUBIERTA

( 18 HILERAS DE DIEZ PLACAS C/U)

GENERAN $30 \mathrm{KW} / \mathrm{H}$

USO DE MADERA PARA EL DISEÑO

ESTRUCTURAL.

CUBierta Ligera DE CERAMicos 200 COLORES.

COMBINACION DE MADERA Y METAL EN LA ESTRUCTURA DEL MERCADO.

SISTEMA DE IMPERMEABILIZACIÓN EN CUBIERTA. 


\subsubsection{Tecnología}

El mercado propone como cubierta una compleja estructura compuesta por un arco metálico y curvaturas estructurales. Esta estructura permite el ingreso de luz y da soporte para poder ubicar la cobertura multicolor de cerámicas, que está configurada por unas escamas que permiten enfatizar la complejidad. Está cubierta cubre un área de $5.500 \mathrm{~m}^{2}$ aproximadamente. Su superficie está decorada con 325.000 hexágonos cerámicos, combinando 67 colores en representación simbólica de las frutas y verduras que se ven en un mercado. Las piezas se pegaron con Sika Bond T8, un adhesivo elástico a base de poliuretano impermeable.

Este mercado está comprometido con el medio ambiente y la sostenibilidad, porque incorpora un sistema de reciclaje selectivo y recogida neumática de residuos lo cual evita la existencia de contenedores de basura expuestos en las calles.

Figura 5.7

Fotocomposición de la maqueta del sistema constructivo de la cobertura

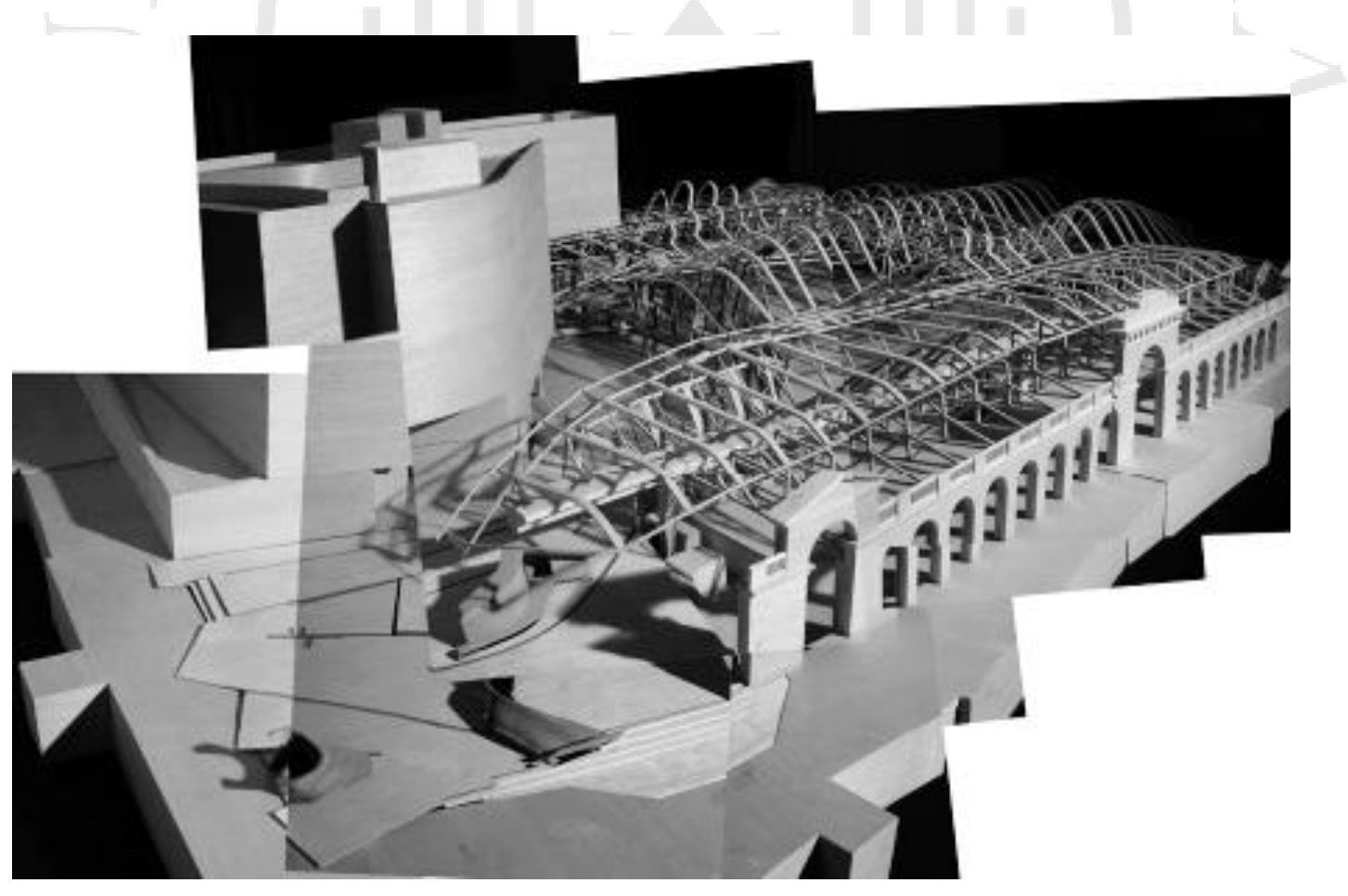

Nota: Imagen editada en blanco y negro

Fuente: Coberturas del Mercado (s.f.) Enric Miralles

En: Documento Fragmento y Continuidad en el Parlamento de Escocia y el Mercado de Santa Caterina 


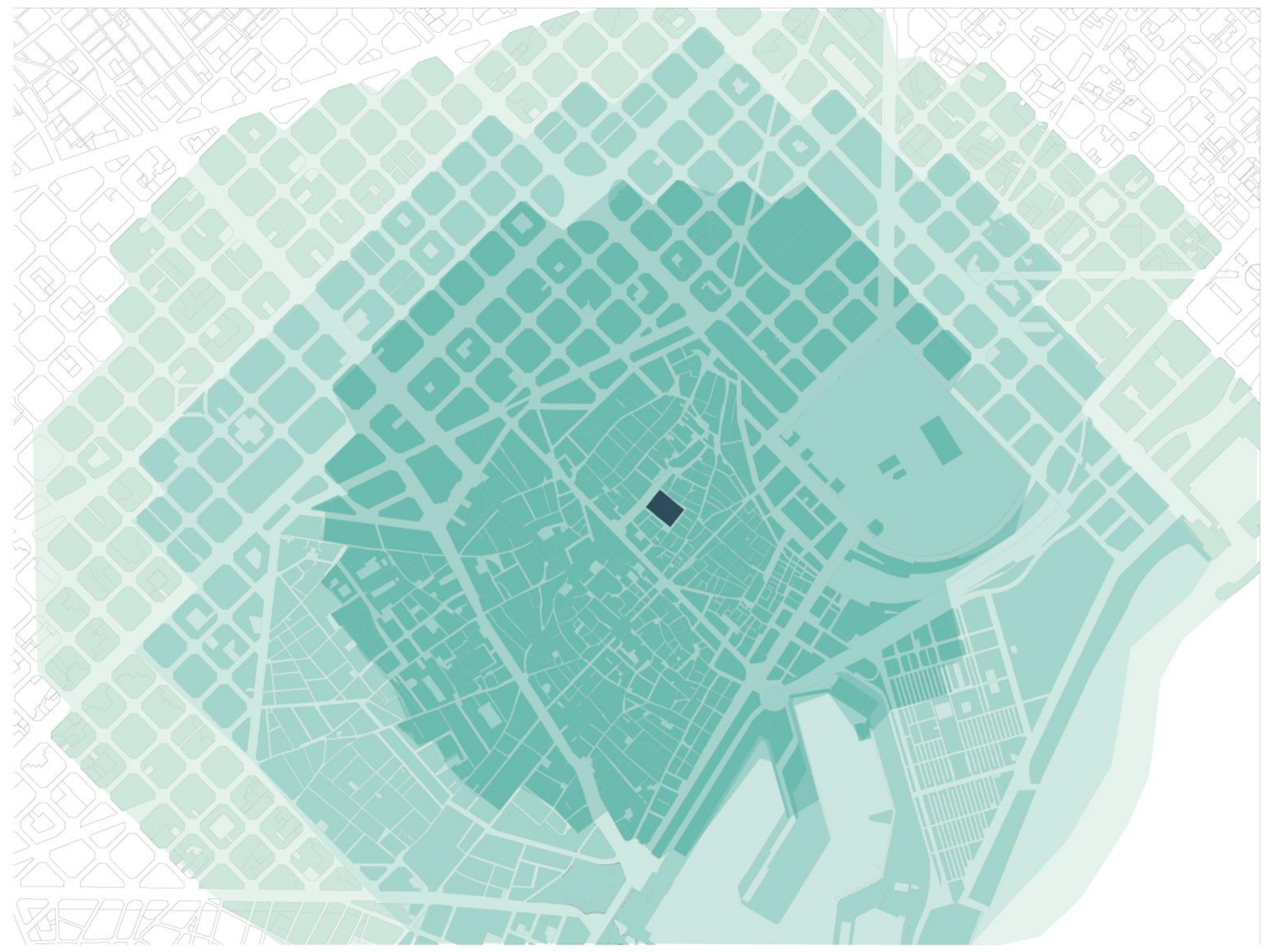

\section{MPACTO SOC I A L}

MERCADO SANTA CATER I N A

MERCADO

ÁREA DE INFLUENCIA DIRECTA

RADIO 1 KM APROX

ÁREA DE INFLUENCIA DIRECTA

ACCESO A TRANSPORTE COLECTIVO

ÁREA DE INFLUENCIA DISPERSA

DILUYE EN EL RESTO DE LA CIUDAD 


\subsubsection{Impacto Social}

El Mercado de Santa Caterina es el resultado de un continuo esfuerzo en conjunto, entre el ayuntamiento y los comerciantes. Este renovado mercado significa un motor de impulso a la transformación del barrio. Desde su inauguración el mercado ha aumentado el flujo de personas en un $15 \%$, lo cual demuestra el éxito y popularidad del mismo. Hoy en día el mercado recibe más de 2 millones y medio de personas entre locales y turistas.

En definitiva, el mercado ha contribuido a la dinamización comercial del barrio, de Sant Pere y Santa Caterina. La asociación de comerciantes del Mercado de Santa Caterina está satisfecha y a gusto con la afluencia de clientes, así como también por el volumen de ventas a diario. Motivo por el cual se celebra todos los 14 y 15 de mayo, el aniversario de mercado.

En Mercado de Santa Caterina además ofrece un aporte de servicio público, con su centro de interpretación arqueológica, dando a conocer importantes vestigios arqueológicos encontrados durante la construcción del mismo, restos de hace más de 4000 años.

Figura 5.8

Actividades en la plaza del Mercado Santa Caterina

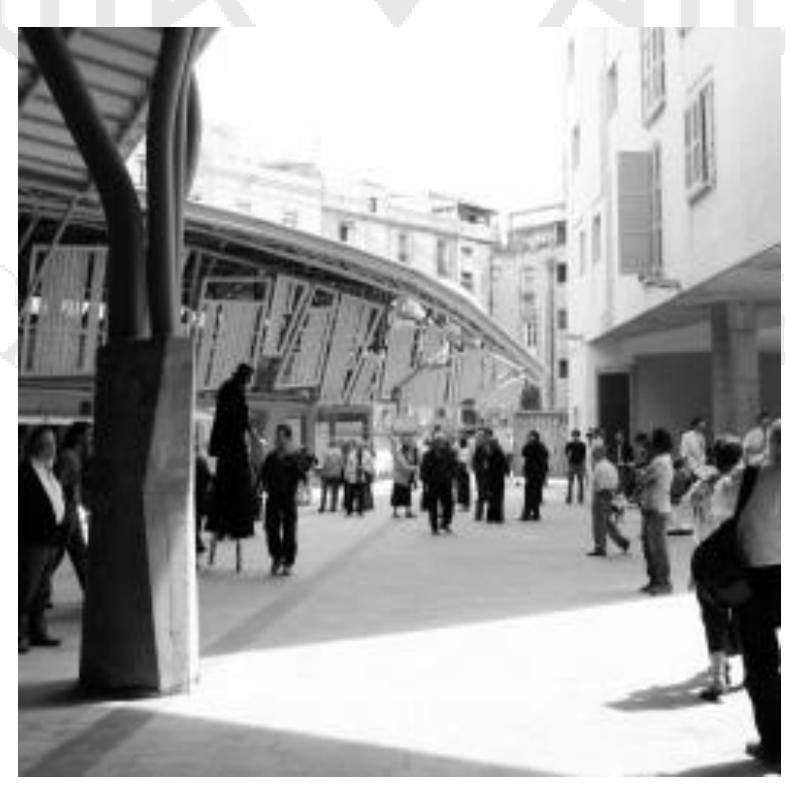

Nota: Imagen editada en blanco y negro

Fuente: Plaza del Mercado (s.f.) Juan Coll-Barreu

En: Documento Fragmento y Continuidad en el Parlamento de Escocia y el Mercado de Santa Caterina 


\subsection{Mercado de la Barceloneta}

\subsubsection{Ubicación}

Arquitecto: MIAS Arquitectes

MIAS Arquitectes / Josep Miàs, Silvia Brandi, Adriana Porta, María Chiara Ziliani, Andreu Canut, Carles Bou

\section{Equipo:}

Ingenieros: JG instalaciones

Socios: Mònica Vila, Ana Moretti and José Miñarro

Año: 2007

Cliente: público

Ubicación: Placa de la Font, 1, 08003 Barcelona, España

Categoría: mercado municipal

Terreno: $5200 \mathrm{~m} 2$

Figura 5.9

Ingreso al Mercado de la Barceloneta

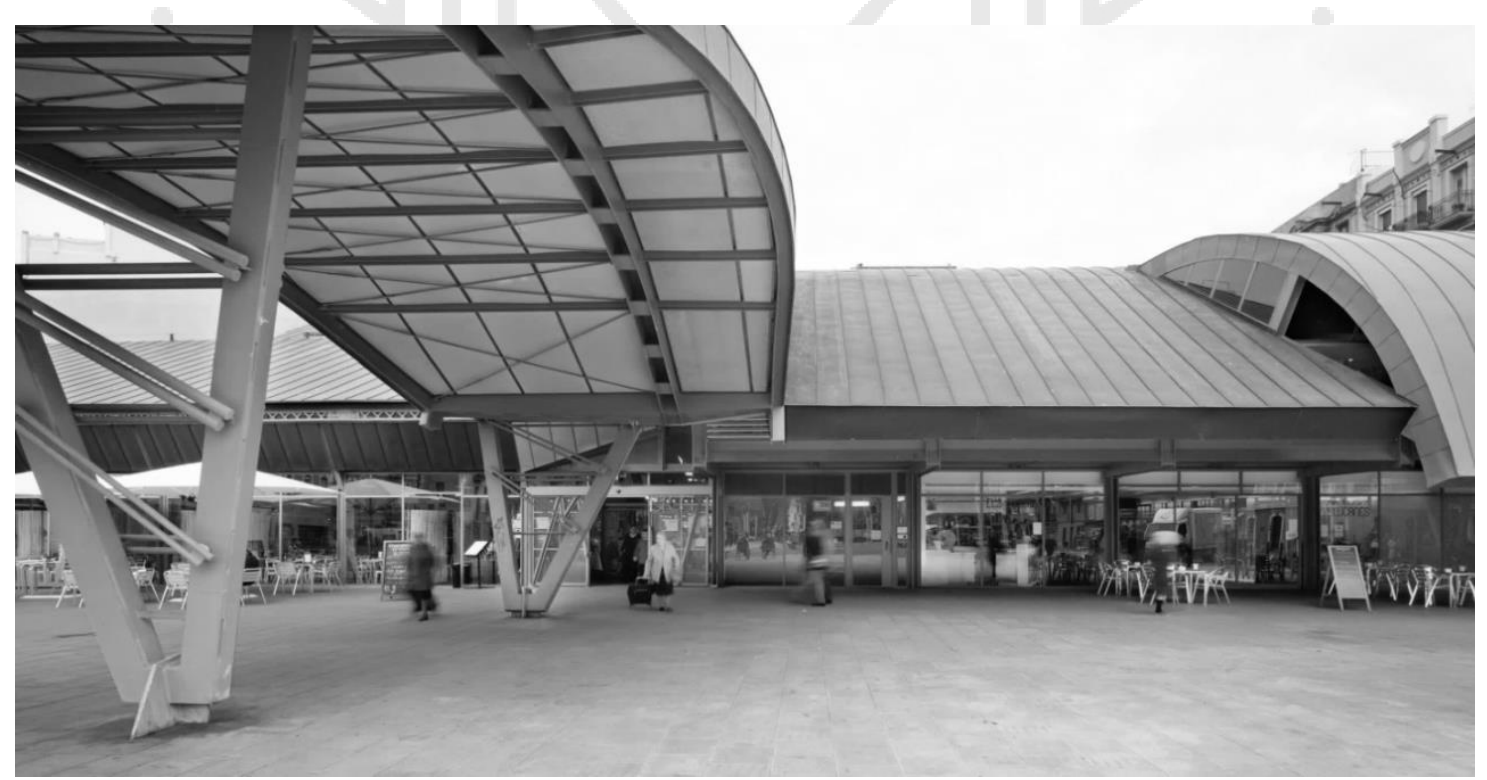

Nota: Imagen editada en blanco y negro

Fuente: Mercado de la Barceloneta y Plaza Pública (s.f.) Adrià Goula En: http://www.archdaily.pe 


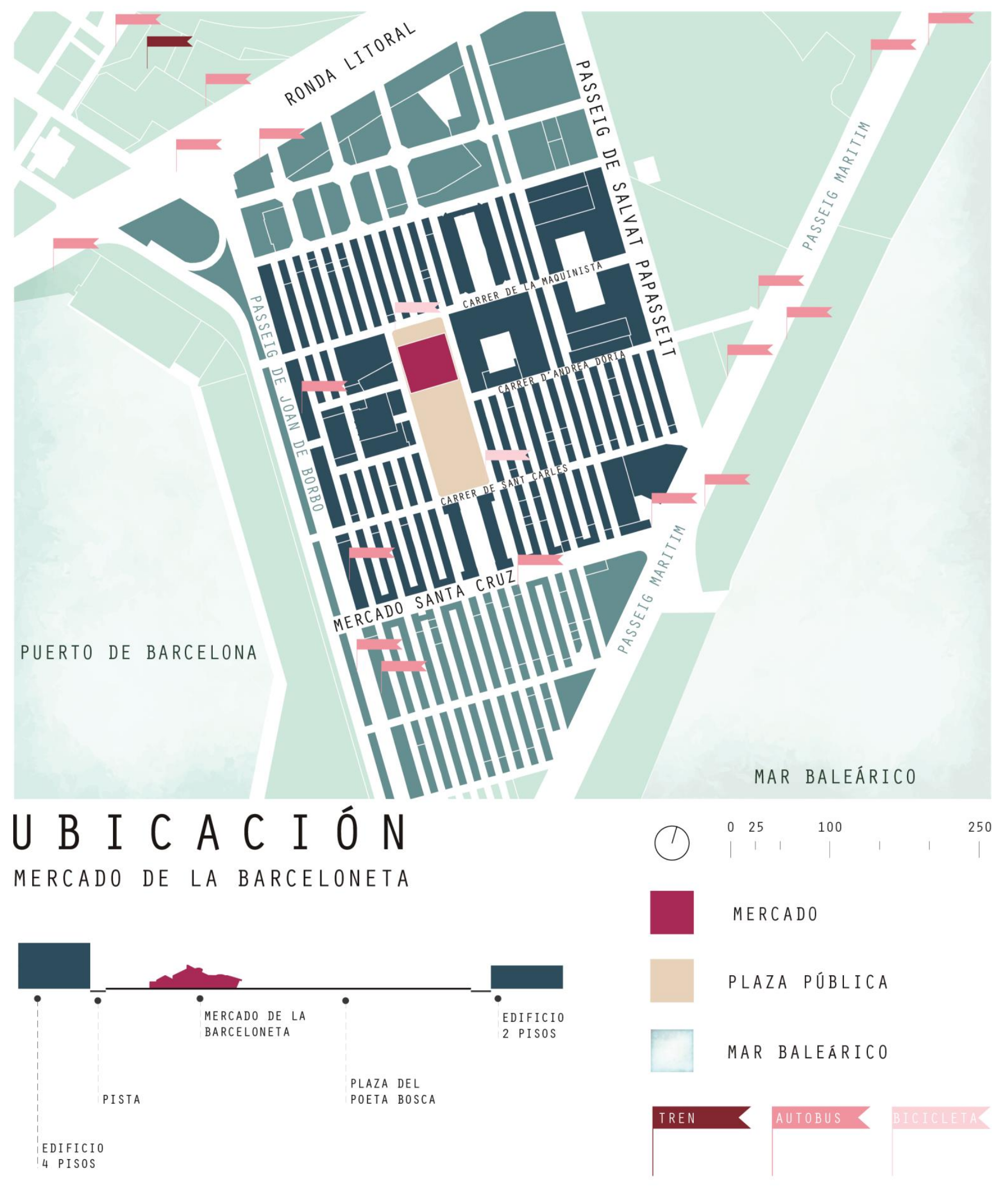


El mercado de la Barceloneta se encuentra ubicado en la Región de Cataluña, en la ciudad de Barcelona, más específicamente en un barrio llamado Barrio de la Barceloneta, ubicado en la plaza de la Fuente. Barrio de carácter marinero y pescador por excelencia, construido y proyectado en 1753 por el ingeniero Próspero de Verboom, para los habitantes de la Ribiera que, al ser construida La Ciudadela por Felipe V, pasaron a perder sus propiedades. Este barrio costero, con lindas playas y atracciones turísticas, de morfología triangular y en cuya estructura urbanística refleja el tipo de urbanismo del periodo de la Ilustración, tiene un trazado rectilíneo uniforme, homogéneo y con manzanas regulares.

Gracias al buen sistema de transporte público, que la ciudad de Barcelona maneja, el mercado se encuentra en un lugar de fácil acceso. Este se encuentra dentro de la Ronda Litoral, y las avenidas principales de Joan Borbo, Mercado Santa Cruz y Passeig de Salvat Papasseit, próximo a la avenida Passeig Maritim que da directamente a la costa del Mar Baleárico. Tanto en estas avenidas principales como en otras secundarias, existen cerca de diez paraderos de autobús, los cuales facilitan la llegada de los usuarios. Asimismo, cuenta con dos estacionamientos de bicicletas los cuales están conectados a la ciudad a través de ciclovías y dotan al proyecto de un carácter más amigable con el medio ambiente.

Como se ve reflejado en la sección del perfil urbano, es evidente que el proyecto, pretende dar un respiro directo al barrio y a la ciudad en general. El hecho de tener una plaza que triplica el área construida significa un aporte de carácter público que permite abrir la trama urbana y dotarla de un espacio abierto. 


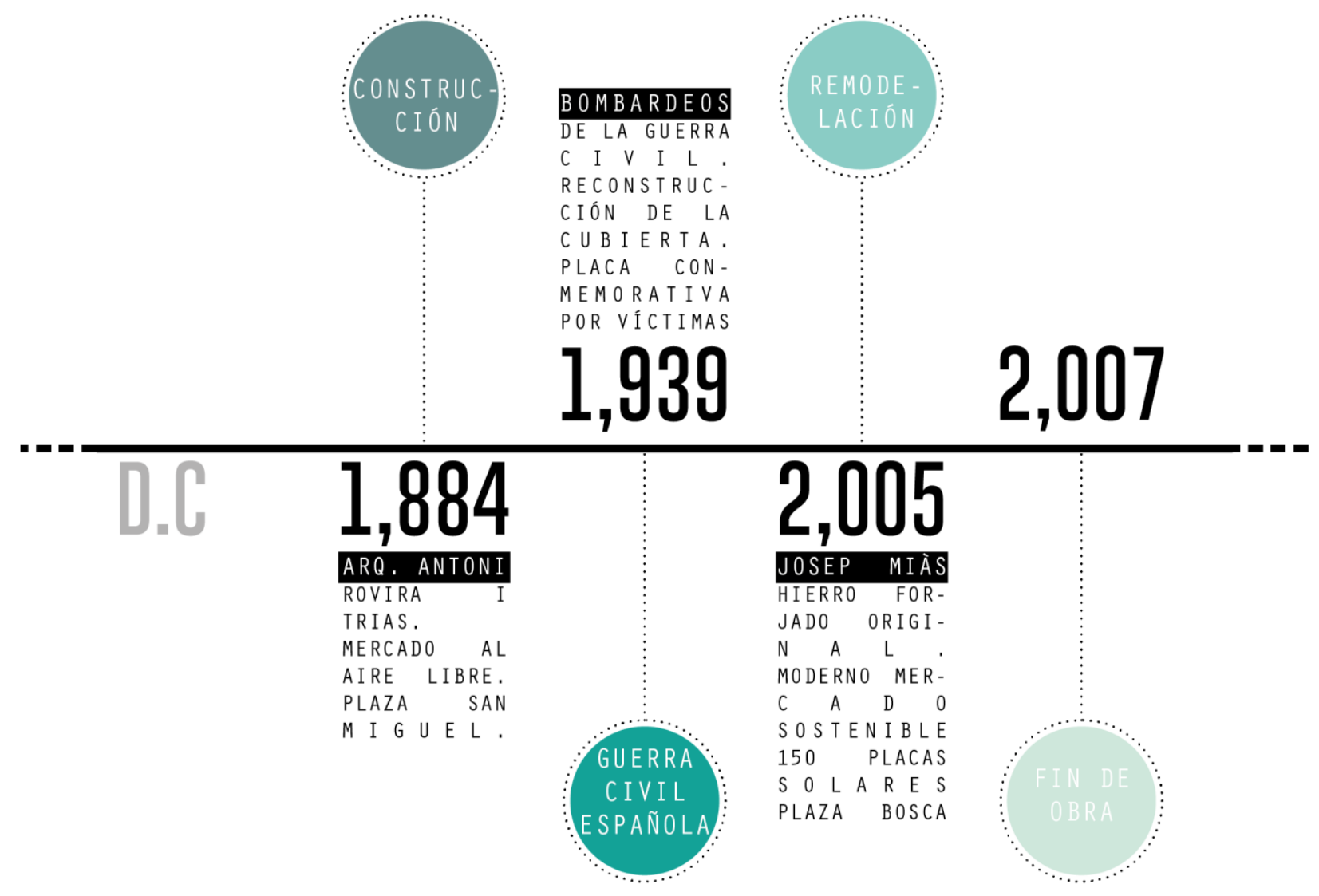

H I S T O R I A

MERCADO DE LA BARCELONETA

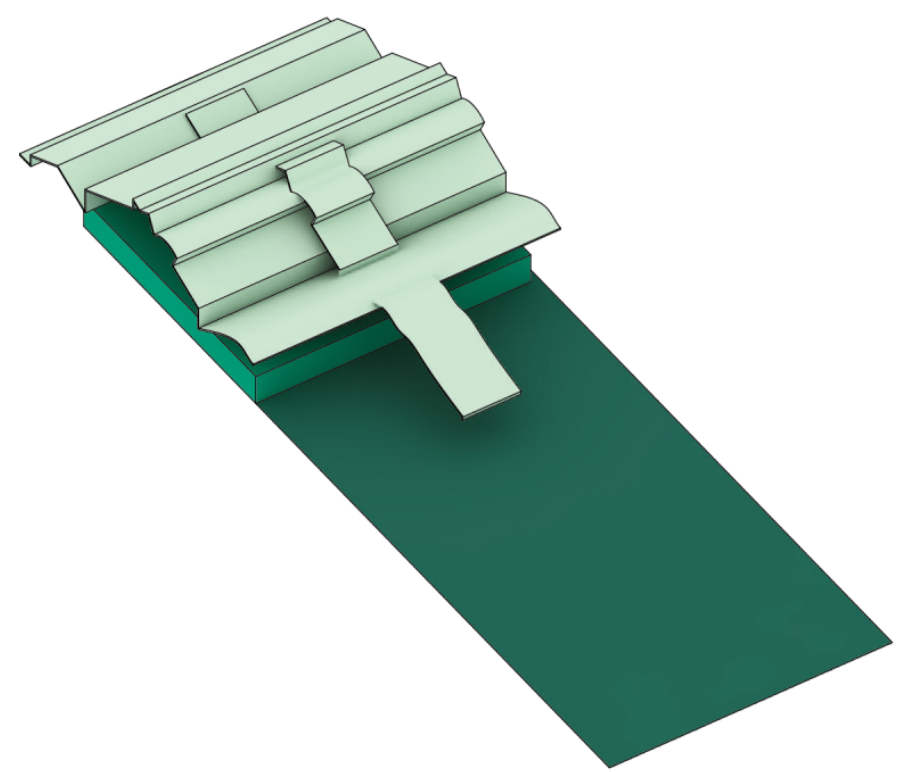




\subsubsection{Historia}

El Mercado de la Barceloneta, se inició como un mercado al aire libre en la plaza, mientras que la infraestructura original data de 1884, cuando Antoni Rovira y Trias diseña un mercado característico de la época con el uso del fierro, distribuidos en una nave central y dos laterales. Desde sus orígenes el mercado ha tenido un carácter eminentemente marinero y pescador, gracias a su privilegiada cercanía al mar.

En 1939 unas revueltas acaban con parte del mercado, por lo que después de los bombardeos de la guerra civil, Antoni reconstruye solo la cubierta. Ya para el 2005, el mercado abre sus puertas con su estructura de hierro forjado original, conservada y expuesta junto con la nueva cobertura.

Figura 5.10

Plaza y Mercado de la Barceloneta

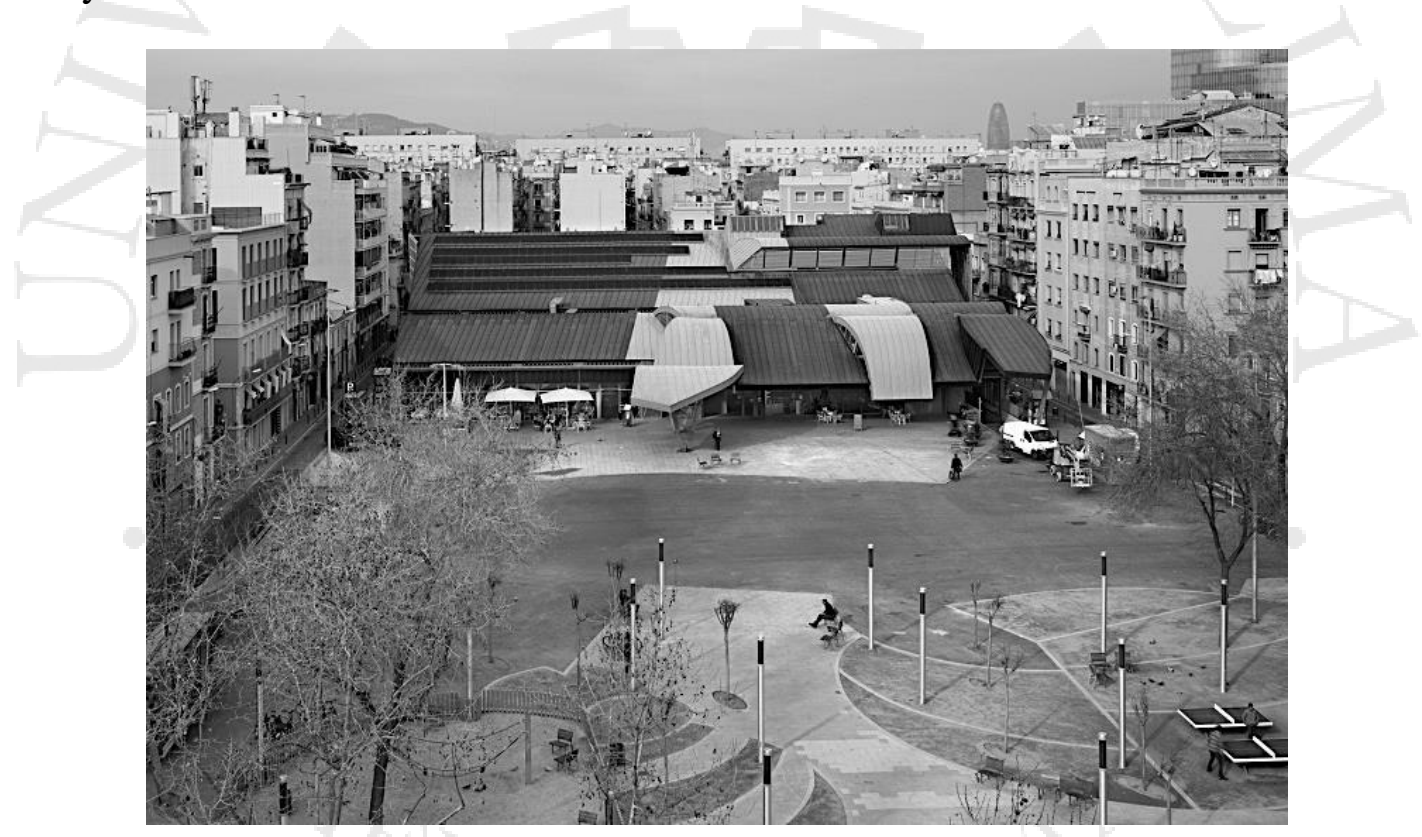

Nota: Imagen editada en blanco y negro

Fuente: Barceloneta Market and Square (s.f.) MIAS Architects

En: miasarquitectes.com

\section{Toma de partido}

El proyecto de la Barceloneta se entiende como una prolongación del barrio, las piezas y los elementos metálicos se pliegan y despliegan para generar espacios y contener al mercado. El mercado junto con la plaza se convierte en un elemento de cohesión social para el barrio. 

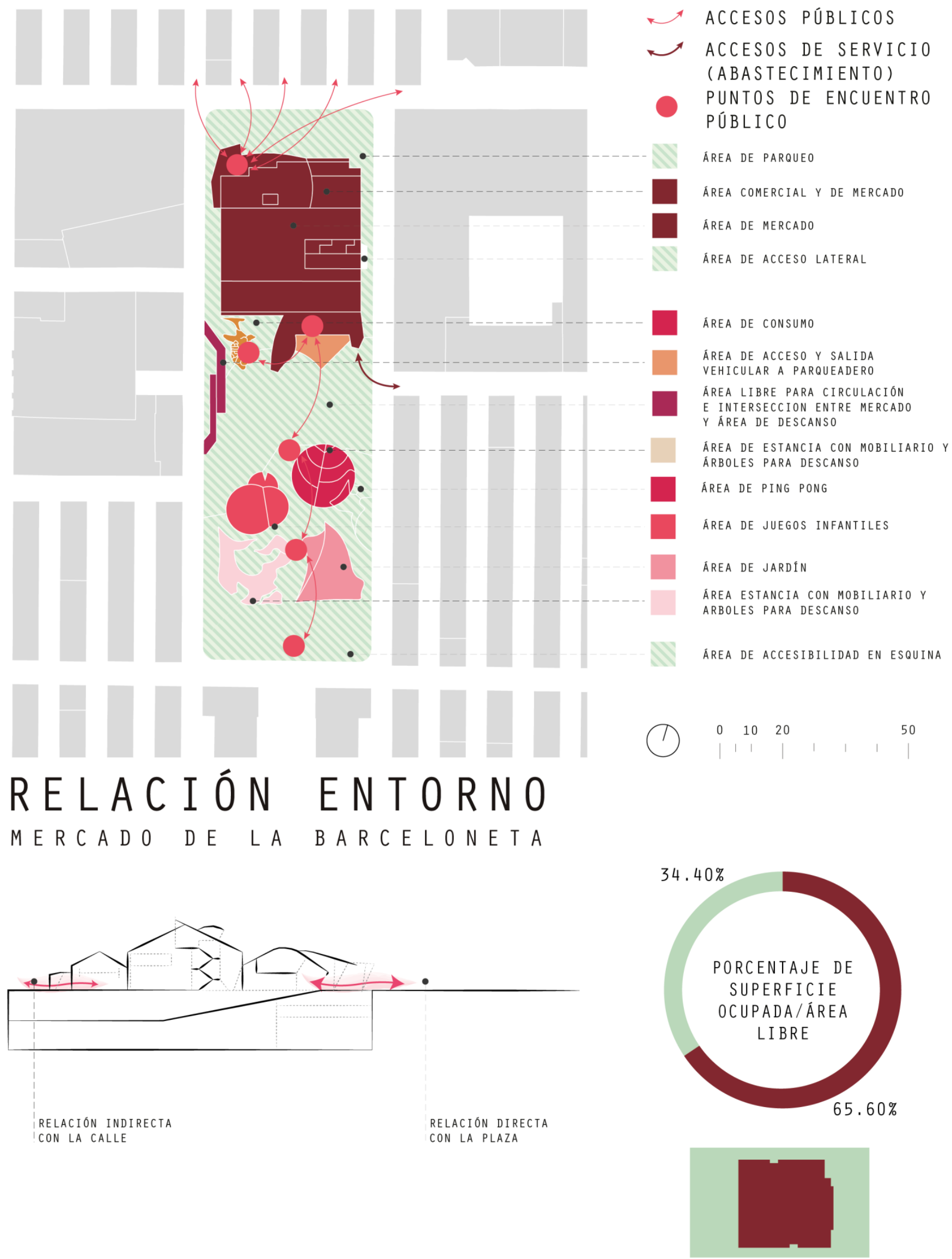


\subsubsection{Entorno}

El proyecto de Josep Mías revaloriza el terreno y la zona en general no solo por la creación de una pérgola al ingreso, como conexión entre mercado y plaza, sino también por todo el tratamiento de espacio público que plantea, la nueva estructura ha generado que los bordes dialoguen con la estructura existente.

El tratamiento de espacio público incluye áreas de parqueo, juegos, jardines, estructuras, áreas verdes, vías y puntos de accesibilidad.

Una de las estrategias del Mercado de la Barceloneta, para el tratamiento y la relación en el espacio público, es orientar la organización del espacio en sentido longitudinal en lugar de seguir la orientación transversal de las tres naves existentes.

\section{Figura 5.11}

Vista peatonal del Mercado de la Barceloneta

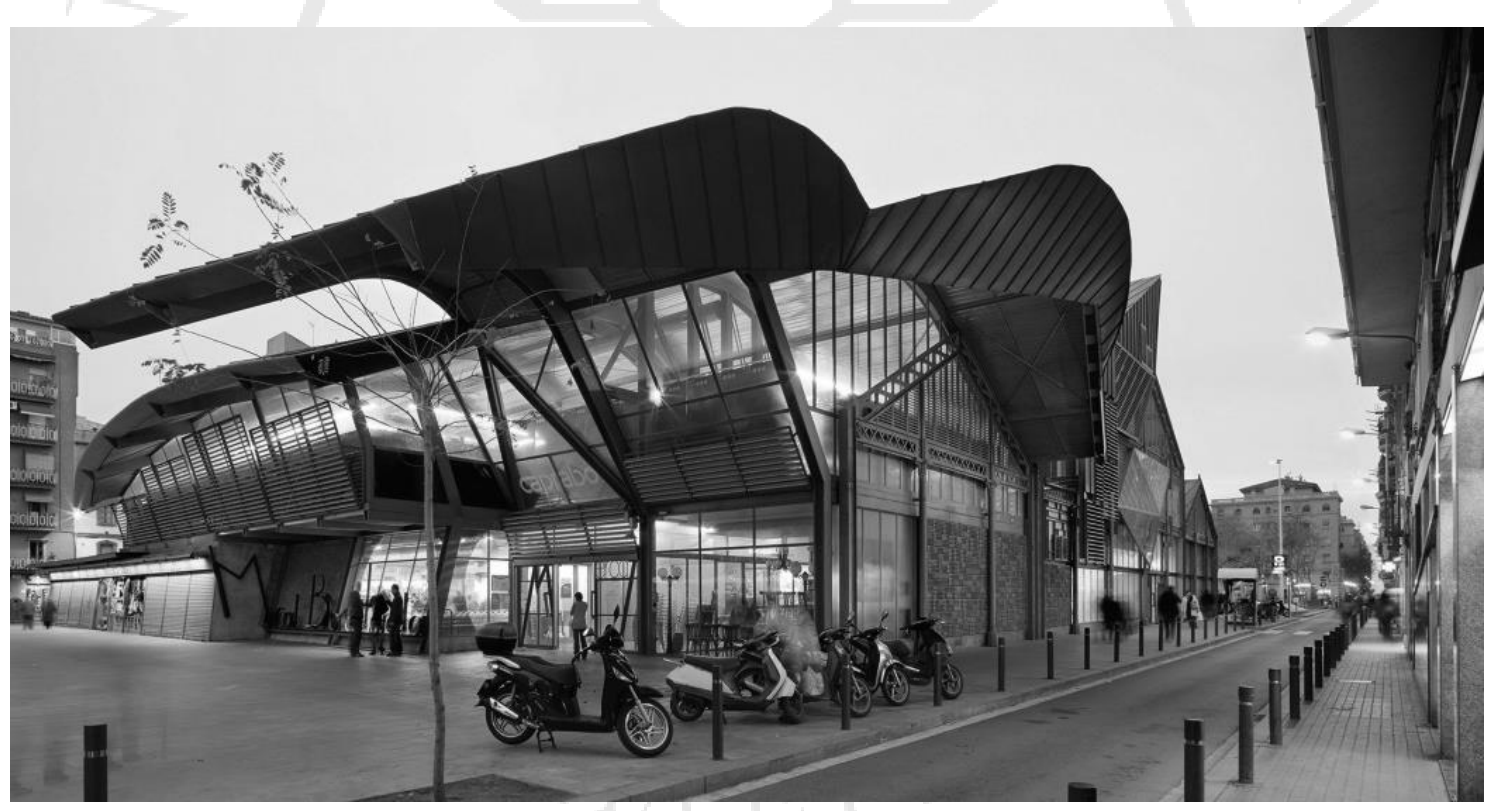

Nota: Imagen editada en blanco y negro

Fuente: Barceloneta Market and Square (s.f.) MIAS Architects

En: miasarquitectes.com 


\subsubsection{Tipología}

Figura 5.12

Esquema de tipología según distribución de puestos

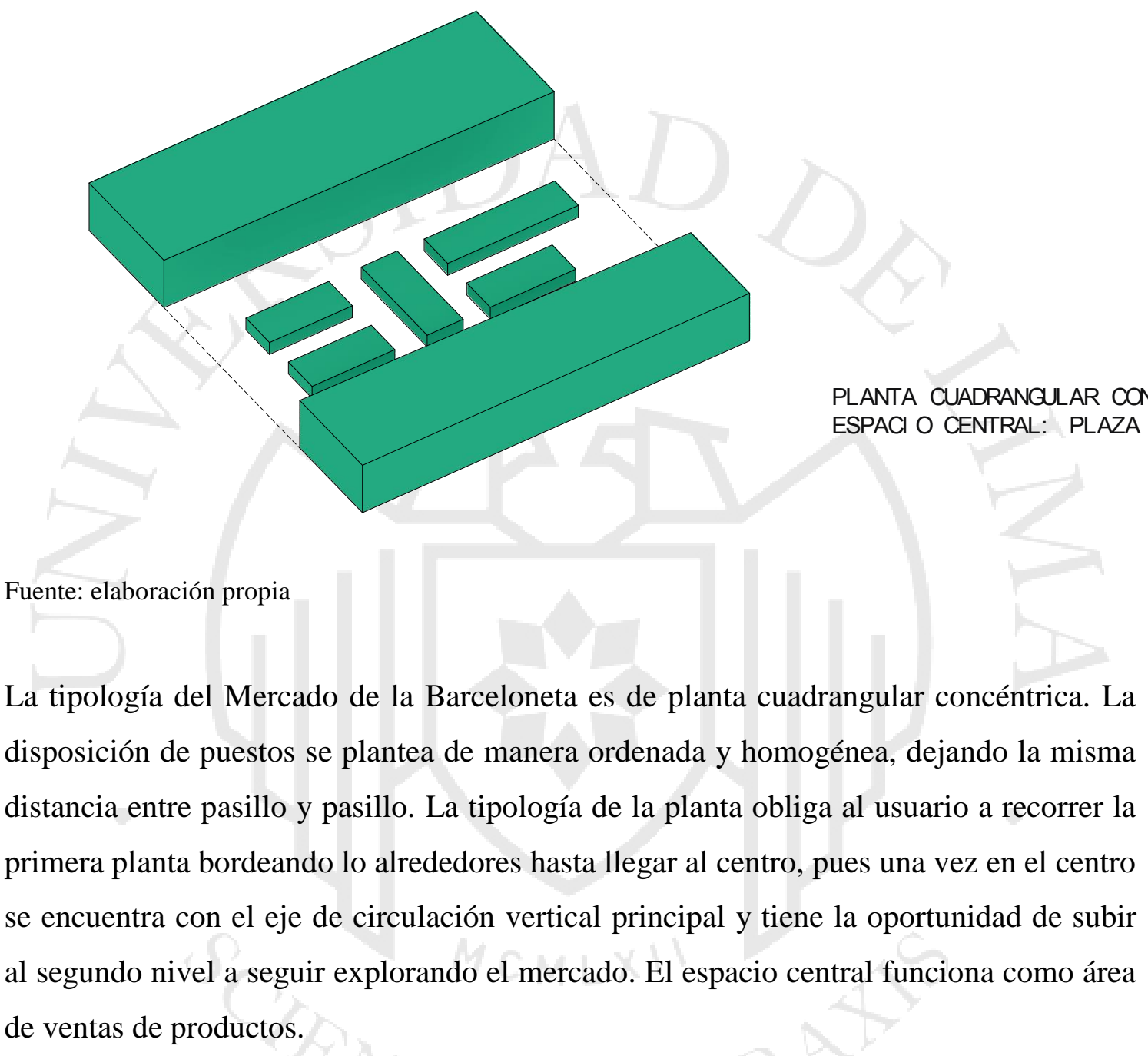




\subsubsection{Programa}

\section{Cuadro de áreas}

Tabla 5.2

Cuadro de áreas del Mercado de Barceloneta

\begin{tabular}{|c|c|c|c|c|}
\hline PROGRAMA & AREA (m2) & PORCENTAJE & \multicolumn{2}{|c|}{ TOTAL } \\
\hline ÁREA DE VENTAS & & & 352 & $\mathbf{m} 2$ \\
\hline Carnes & 48 & $1.95 \%$ & & \\
\hline Aves & 33 & $1.34 \%$ & & \\
\hline Pescados / Mariscos & 108 & $4.38 \%$ & & \\
\hline Embutidos & 36 & $1.46 \%$ & & \\
\hline Frutas & 22 & $0.89 \%$ & & \\
\hline Verduras & 30 & $1.22 \%$ & & \\
\hline Abarrotes & 30 & $1.22 \%$ & & \\
\hline Lácteos & 10 & $0.41 \%$ & & \\
\hline Licorería & 35 & $1.42 \%$ & & \\
\hline SERVICIOS COMPLEMENTARIOS & & & 160 & $\mathbf{m} 2$ \\
\hline Juguería / Bares / Café / Restaurantes & 730 & $29.61 \%$ & & \\
\hline Otros servicios públicos & 430 & $17.44 \%$ & & \\
\hline SERVICIOS GENERALES & & & 53 & $\mathbf{m} 2$ \\
\hline Almacenes refrigerados & 37 & $1.50 \%$ & & \\
\hline Almacenes & 180 & $7.30 \%$ & & \\
\hline Descarga & 72 & $2.92 \%$ & & \\
\hline Residuos & 10 & $0.41 \%$ & & \\
\hline Administración & 30 & $1.22 \%$ & & \\
\hline Oficinas & 180 & $7.30 \%$ & & \\
\hline SSHH & 14 & $0.57 \%$ & & \\
\hline Otros servicios privados & 430 & $17.44 \%$ & & \\
\hline TOTAL & & $100 \%$ & 465 & $\mathbf{m} 2$ \\
\hline
\end{tabular}

Nota: No se considera el área de estacionamiento 
CARNES

AVES

PESCADOS / MARISCOS

EMBUTIDOS

FRUTAS

VERDURAS

ABARROTES

LACTEOS

JUGUERÍA / BAR / CAFÉ /

RESTAURANTES

LICORERÍA

ALMACENES REFRIGERADOS

ALMACENES

DESCARGUE

RESIDUOS

ADM I N I STRACI ÓN

OFICINAS

SSHH

OTROS SERVICIOS PÚBLICOS

OTROS SERVICIOS PRIVADOS
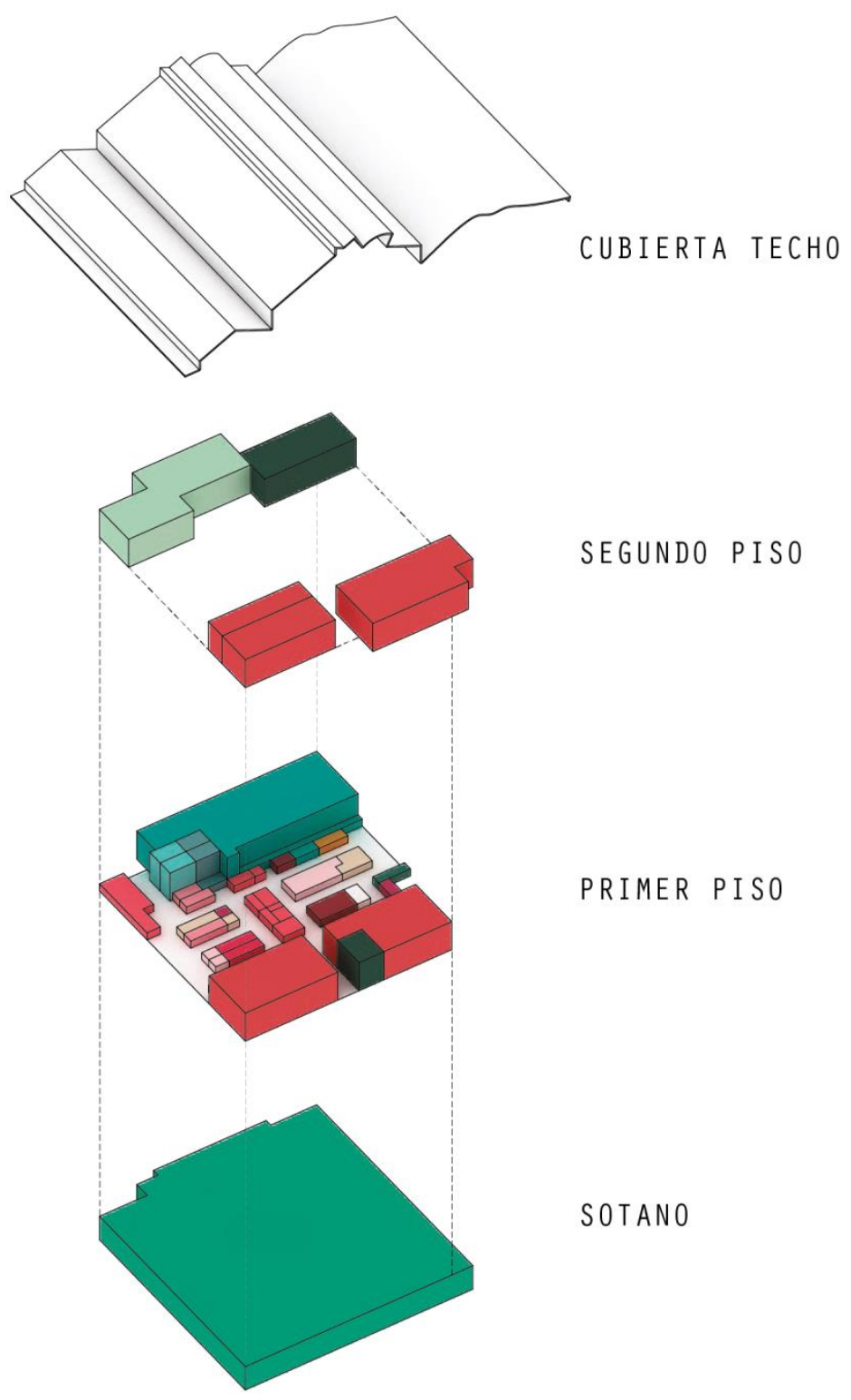

SEGUNDO PISO

PRIMER PISO

SOTANO

\section{$P R O G R A M A$}

MERCADO DE LA BARCELONETA

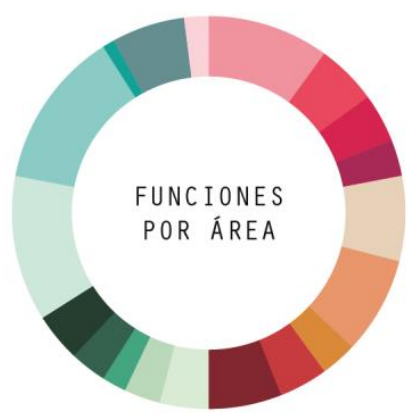




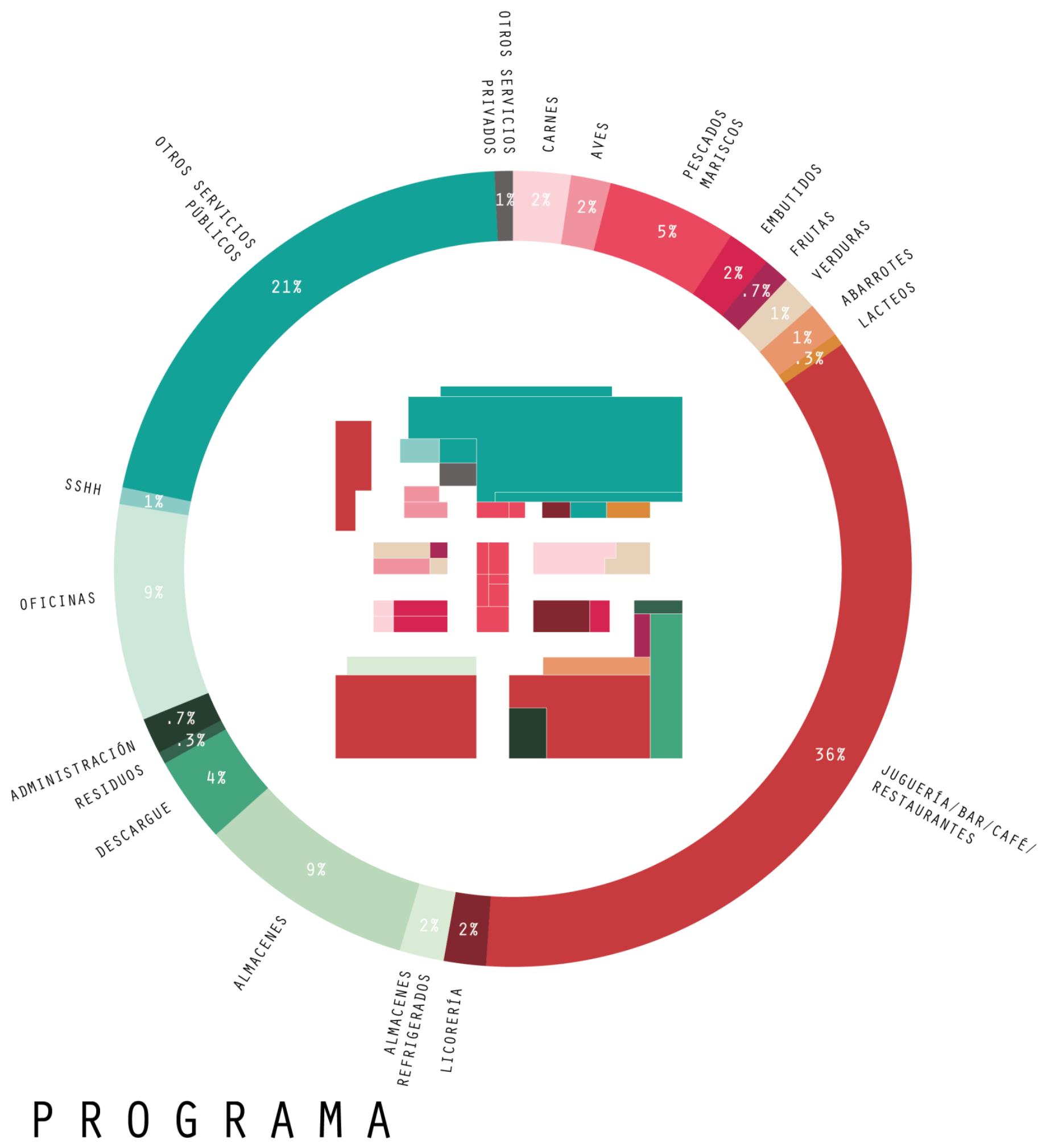

MERCADO DE LA BARCELONETA

ÁREA TOTAL 7100 M2

"NO SE CONSIDERA ESTACIENAMIENTOS 
INGRESO/SALIDA CLIENTES

SERVICIOS COMPLEMENTARIOS

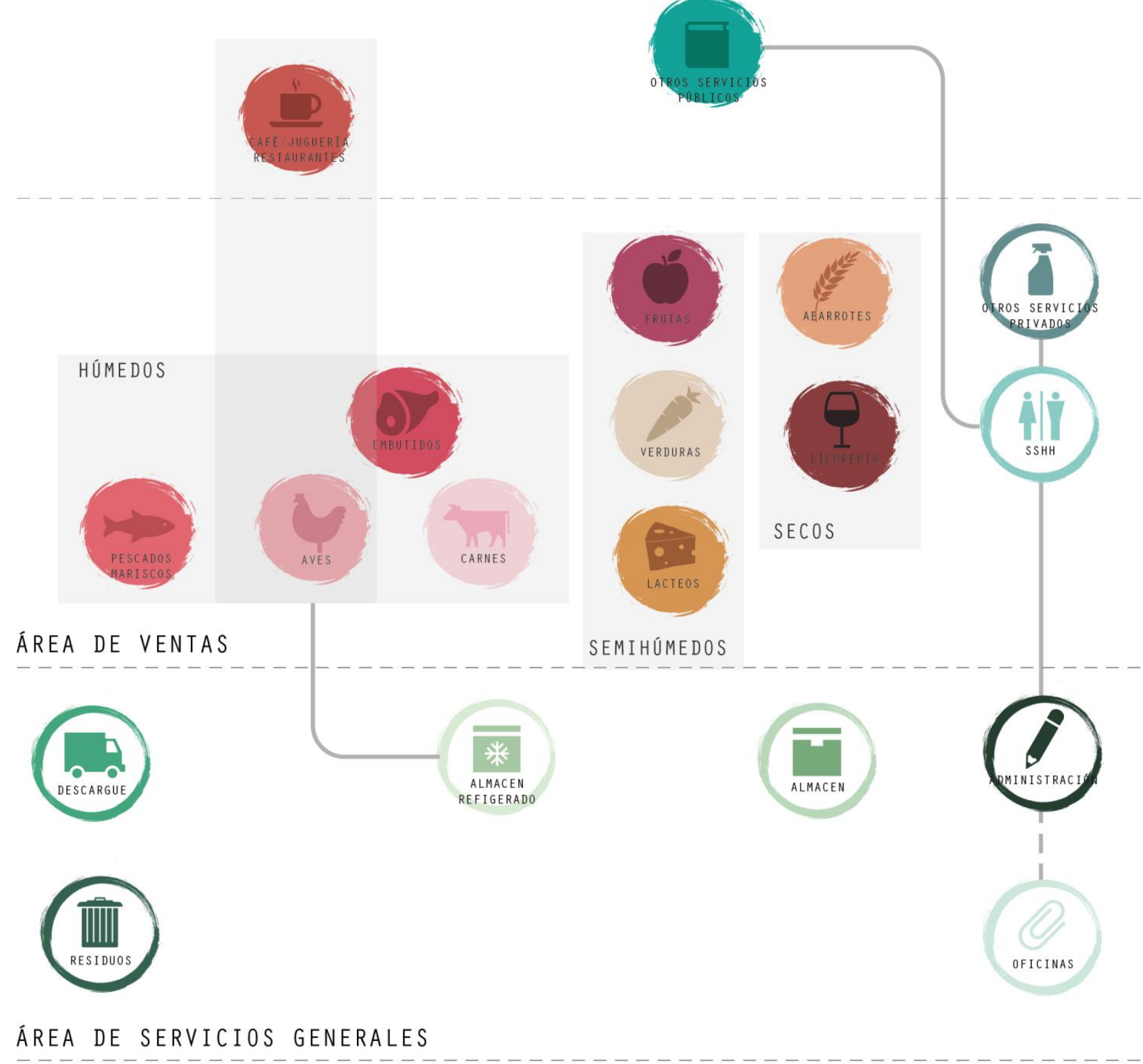

AREA DE SERVICIOS GENERALES

\section{R G A N I G R A M A}

MERCADO DE LA BARCELONETA

- RELACIÓN DIRECTA

- - - RELACIÓN INDIRECTA

GRUPO DE PRODUCTOS 
El proyecto cuenta con nuevos servicios como: un gran estacionamiento, oficinas de información de transporte, autoservicios, entre otros. Además, cuenta con ambientes de servicio general como espacio de montacargas y dos plantas subterráneas para la descarga. Asimismo, añade almacenes para todos los puestos y estacionamientos para todos los clientes.

El Mercado de la Barceloneta es el primero de los 40 mercados de Barcelona en incorporar servicios complementarios como restaurantes al interior y tiendas de autoservicio. 


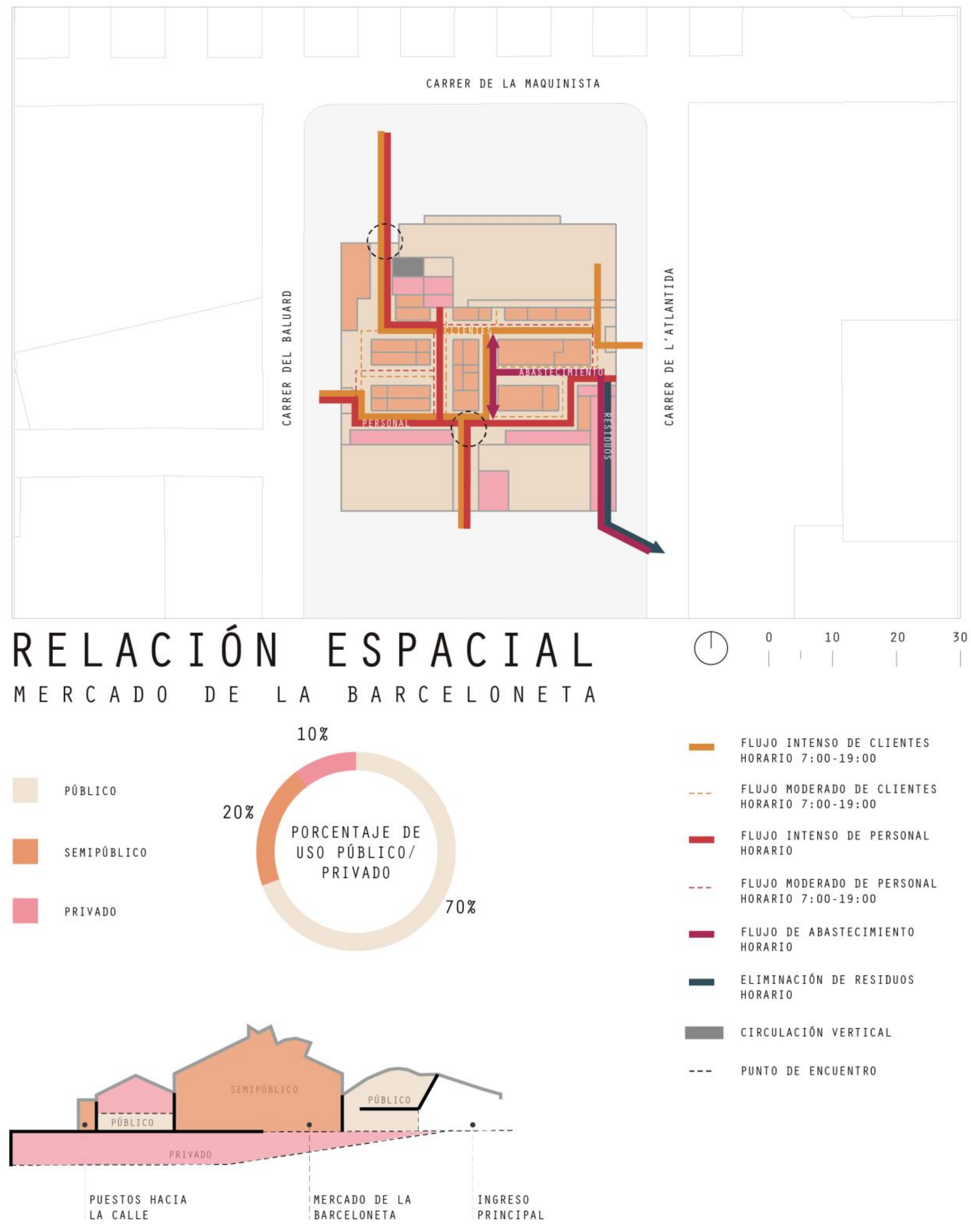




\subsubsection{Espacio}

El Mercado de la Barceloneta cuenta con una planta cuadrangular que permite el ingreso por los cuatro lados, siendo el ingreso más importante aquel que da la plaza de mercado. Tanto el ingreso frontal como posterior concentra un flujo intenso de clientes, mientras que los ingresos laterales son los que concentran el mayor movimiento de personal.

Los horarios de atención que establece el mercado de la Barceloneta son: el área de alimentación de 7:00am a 8:00pm, el restaurante de 8:00am a 12:00pm y el área de autoservicio atiene de 9:00am a 21:00pm.

Figura 5.13

Flujos de los visitantes al interior del Mercado de la Barceloneta

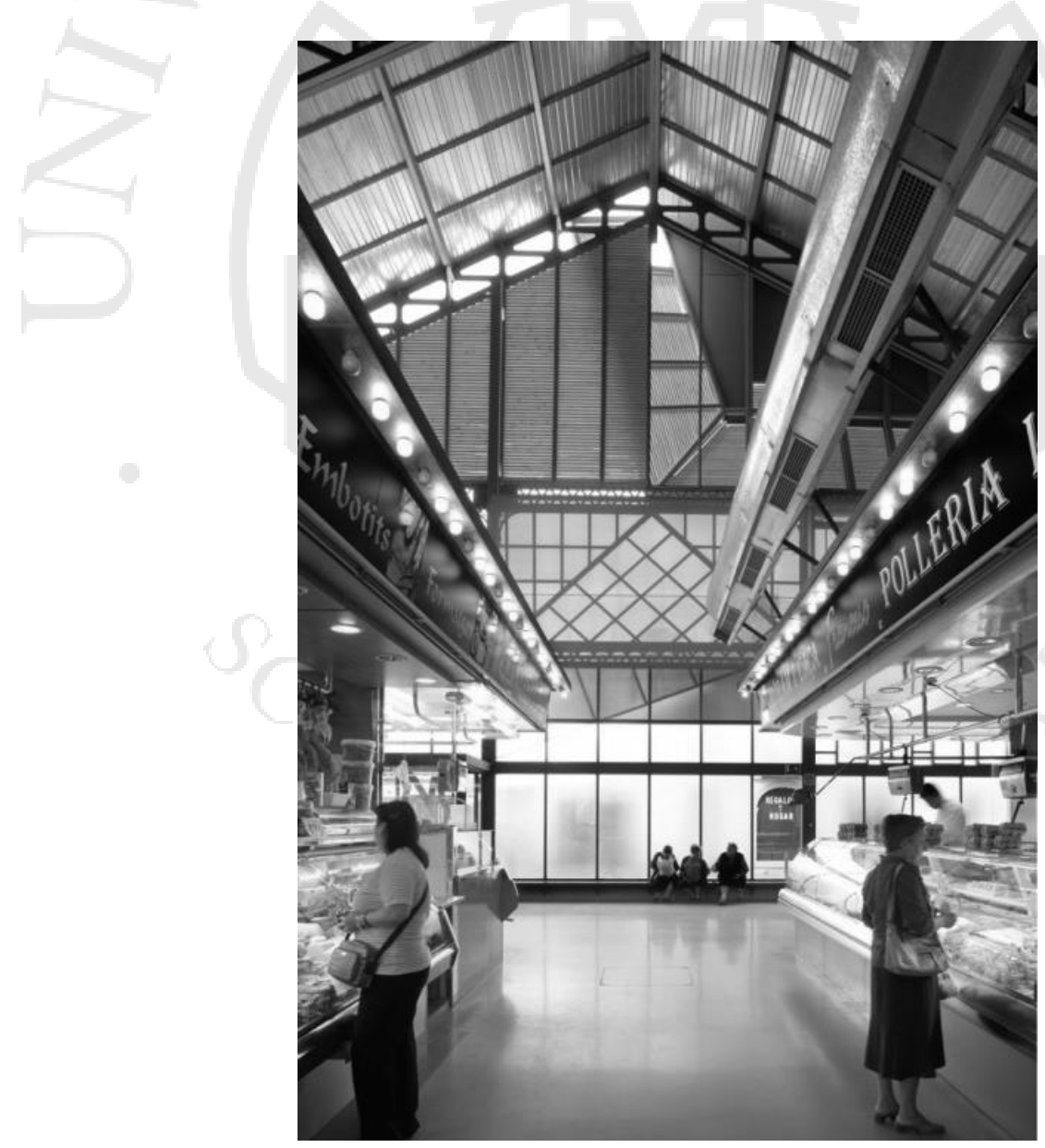

Nota: Imagen editada en blanco y negro

Fuente: Mercado de la Barceloneta (s.f.) Adrà Goula

En: archdaily.pe 


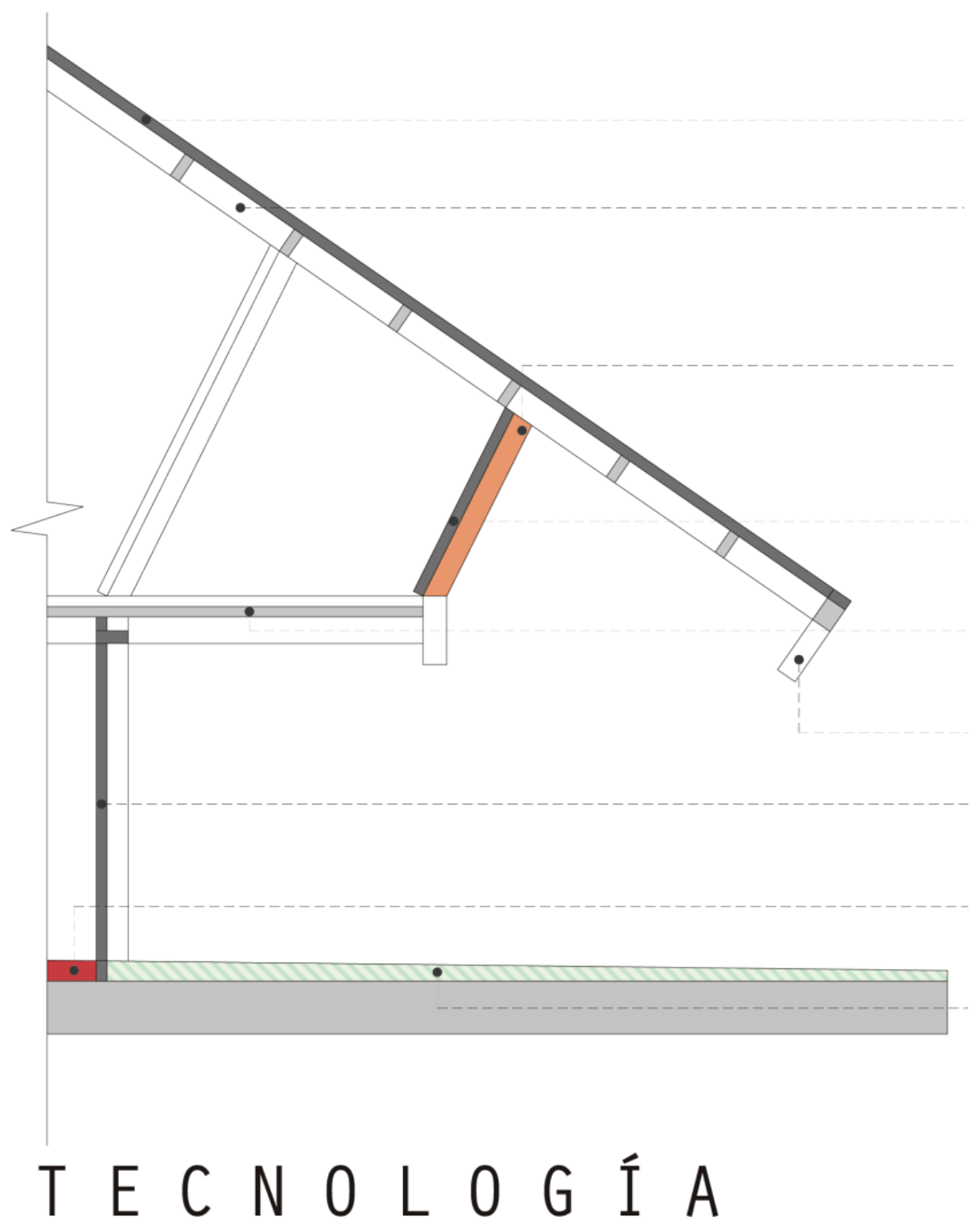

S I STEMA CONSTRUCT IVO

COBERTURA DE MERCADO :

ESTRUCTURA METALICA CON VIGAS ARMADAS EN FORMA DE U.

CUBIERTA DE ZINC DE .82 MM DE GROSOR, LAMINA MODULAR DE POLI ESTER Y LANA DE VIDRIO PARA AISLAMIENTO TERMICO.

ESTRUCTURA PRINCIPAL FORMADA POR PERFILES DE MADERA EN L DE $80 \times 80 \times 80$ MM. LISTONES DE MADERA DE PINO TRATADAS PARA EXTERIOR (BARNIZADAS Y CON UN 40\% DE PINTURA PLÁSTICA) FIJADAS MECÁNICAMENTE SOBRE ESTRUCTURA SECUNDARIA TRANSVERSAL DE PERFILES EN L DE $80 \times 40 \times 5$ MM

CARPINTERIA FIJA. ESTRUCTURA METALICA CON PERFILES DE ACERO Y ACRISTALAMIENTO FIJO DE MÓDULO $60 \times 60$.

PAVIMENTO ARMADO DE 0.75 MM DE ESPESOR SOBRE VIGA SOLERA DE HORMIGON

ACABADO PULIDO CON CAPA DE RESINA INCOLORA

PIEZA DE ZINC SOBRE PIEZA DE ACERO PERFORADO . VOLADIZO

ESTRUCTURA METALICA CON PERFILERIA DE ACERO Y DOBLE VIDRIO LAMINAR DE SEGURIDAD

PAVIMENTO INTERIOR. ACABADO DE TERRAZO LISO DE GRANO PEQUEÑO. COLOCADO CON MORTERO CON HORMIGONERA Y SOBRE CAPA DE ARENA DE 2 CM.

PAVIMENTO EXTERIOR. PAVIMENTO DE PIEDRA NATURAL DE GRANITO DE DIMENSION VARIABLE $\quad Y \quad$ DE 6 CM $\quad$ DE GROSOR COLOCADOS CON MORTERO SOBRE SOLERA DE HORMIGON HA 30 P/ 20 LE A DE CONSISTENCIA PLÁSTICA

MERCADO DE LA BARCELONETA

$14 \%$ DE COBERTURA
ENERGÉTICA
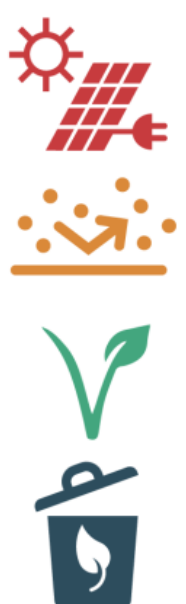

180 PLACAS SOLARES EN LA CUBIERTA

( 18 HILERAS DE DIEZ PLACAS C/U)

GENERAN $30 \mathrm{KW} / \mathrm{H}$

MEJORA DE LA MOVILIDAD Y REDUC -

CIÓN DEL RUIDO AMBIENTAL.

Cubierta Ligera de PANeles metáli -

COS CON AISLAMIENTO TÉRMICO.

RECUPERACIÓN DE ELEMENTOS TRADI -

CIONALES (TIERRAS, MÁRMOLES Y

ESTRUCTURA)

SEPARACIÓN DE RESIDUOS Y RECICLAJE

DE LA QUE SE HACE ABONO. 


\subsubsection{Tecnología}

La característica estructural original de fierro que data de 1884 del Arquitecto Antoni Rovira i Trias, ha sido mejorado y preservada en cuanto a su infraestructura y elementos metálicos.

El Mercado de la Barceloneta está comprometido con el medio ambiente, al incorporar 180 placas solares dispuestas en 18 hileras de 10 cada una. Dichos paneles generan 30 kilowatts por hora de potencia que supone la recolección del $40 \%$ de la cobertura energética del mercado., a esto se suma el plan de separación de residuos y el reciclaje llevado a cabo

Así este mercado es pionera en este sistema de captación de energía, y en el tratamiento y correcta eliminación de residuos orgánicos.

Figura 5.14

Momento de la instalación de la cobertura metálica del Mercado de la Barceloneta

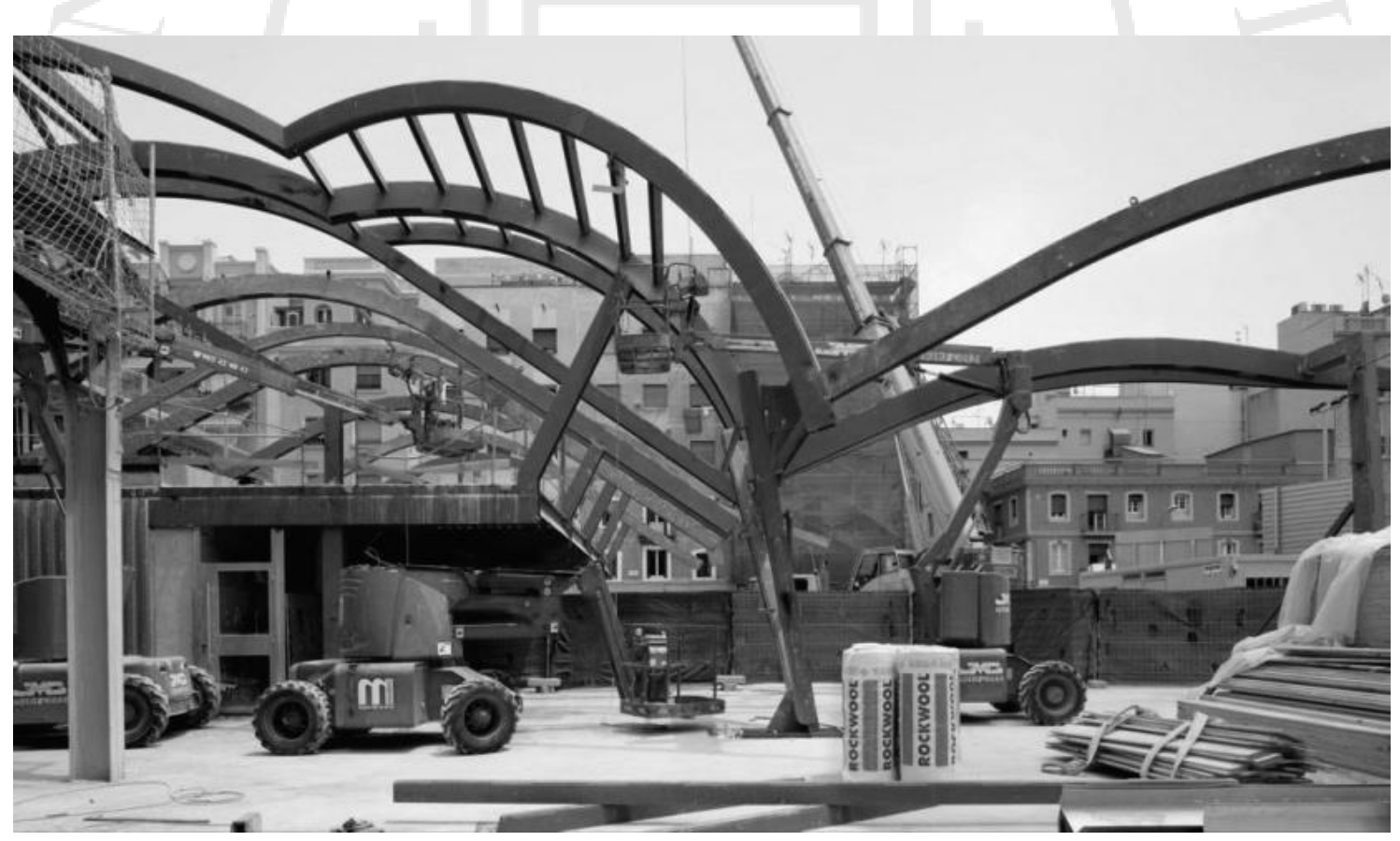

Nota: Imagen editada en blanco y negro

Fuente: Mercado de la Barceloneta (s.f.) MIAS Architects

En: archdaily.pe 


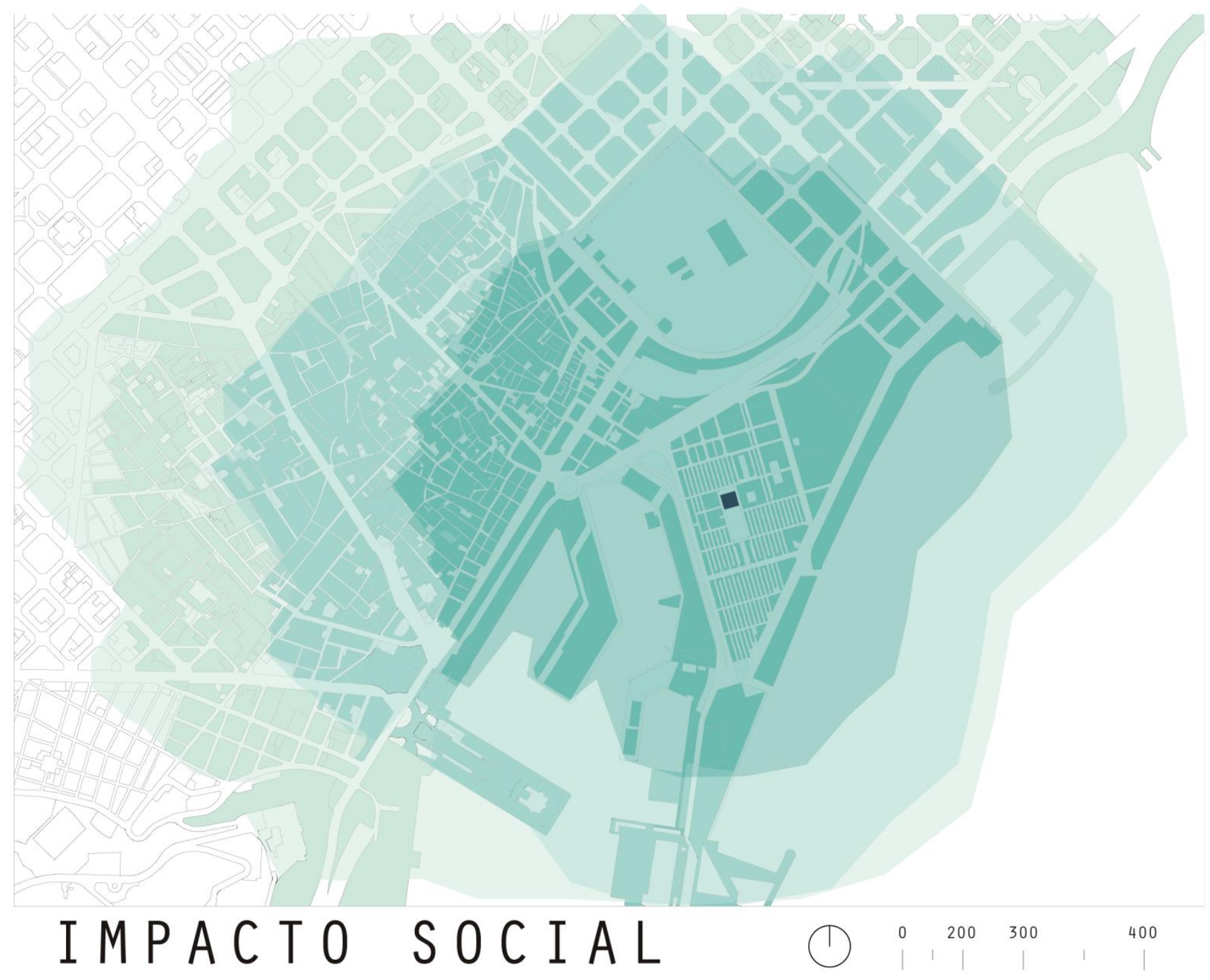

\section{MERCADO DE LA BARCELONETA}

MERCADO

ÁREA DE INFLUENCIA DIRECTA

RADIO 1 KM APROX

ÁREA DE INFLUENCIA DIRECTA

ACCESO A TRANSPORTE COLECTIVO

ÁREA DE INFLUENCIA DISPERSA

DILUYE EN EL RESTO DE LA CIUDAD 


\subsubsection{Impacto social}

En definitiva, la implementación del Mercado de Santa Caterina, trae consigo un impacto positivo para el lugar. El mercado ha contribuido en la dinamización comercial del barrio de Sant Pere y Santa Caterina, así como también, ha permitido que locales de las calles aledañas, que durante mucho tiempo permanecieron cerrados, resurjan y contribuyan a la reactivación del barrio.

La asociación de comerciantes de mercado ha recibido un premio por los constantes esfuerzos de dinamizar la zona y promover el mercado, por su exitosa implementación barrial y su vertiente solidaria para con la ciudad.

Por otro lado, este año, el número de visitantes ha aumentado en un $15 \%$ respecto al año anterior y recibe más de dos millones y medio de personas cada año, entre locales y turistas. Todos están satisfechos con el movimiento activo de la zona que aumenta volumen de ventas día a día.

Sumado a todo esto, el mercado cuenta con espacios donde se exhibe de manera directa la historia de la zona, lo cual ayuda a mantener vivía la identidad del lugar.

Figura 5.15

Relación entre el mercado y la plaza

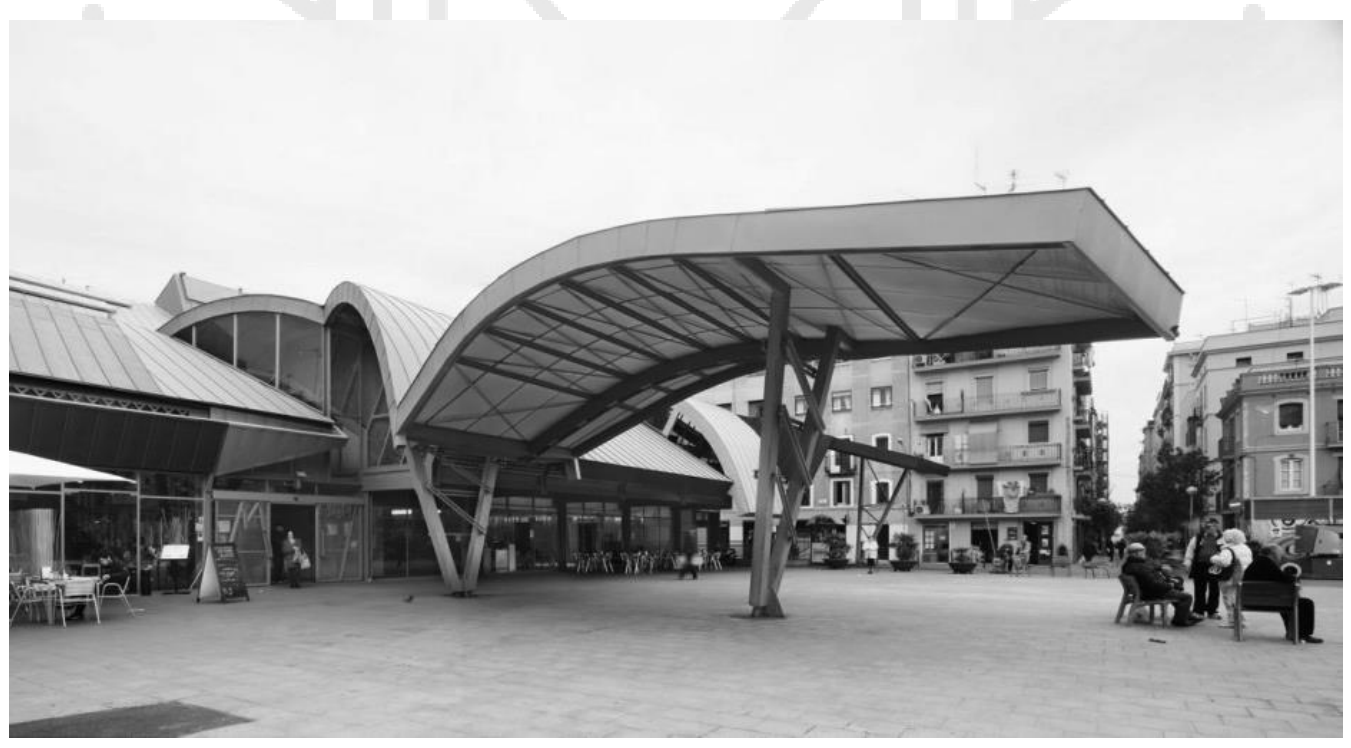

Nota: Imagen editada en blanco y negro

Fuente: Mercado de la Barceloneta (s.f.) Adrà Goula

En: archdaily.pe 


\subsection{Mercado de San Miguel}

\section{Ubicación}

Arquitecto: Alfonso Dubé y Diez

Remodelación: Juan Miguel Alarcón García

Año de construcción: 1916

Año de remodelación: 2009

Cliente: privado (El Gastrónomo de San Miguel)

Ubicación: Plaza de San Miguel, s/n 28005, Madrid

Categoría: mercado privado

Terreno: $1200 \mathrm{~m} 2$

Figura 5.16

Ingreso principal del Mercado de San Miguel

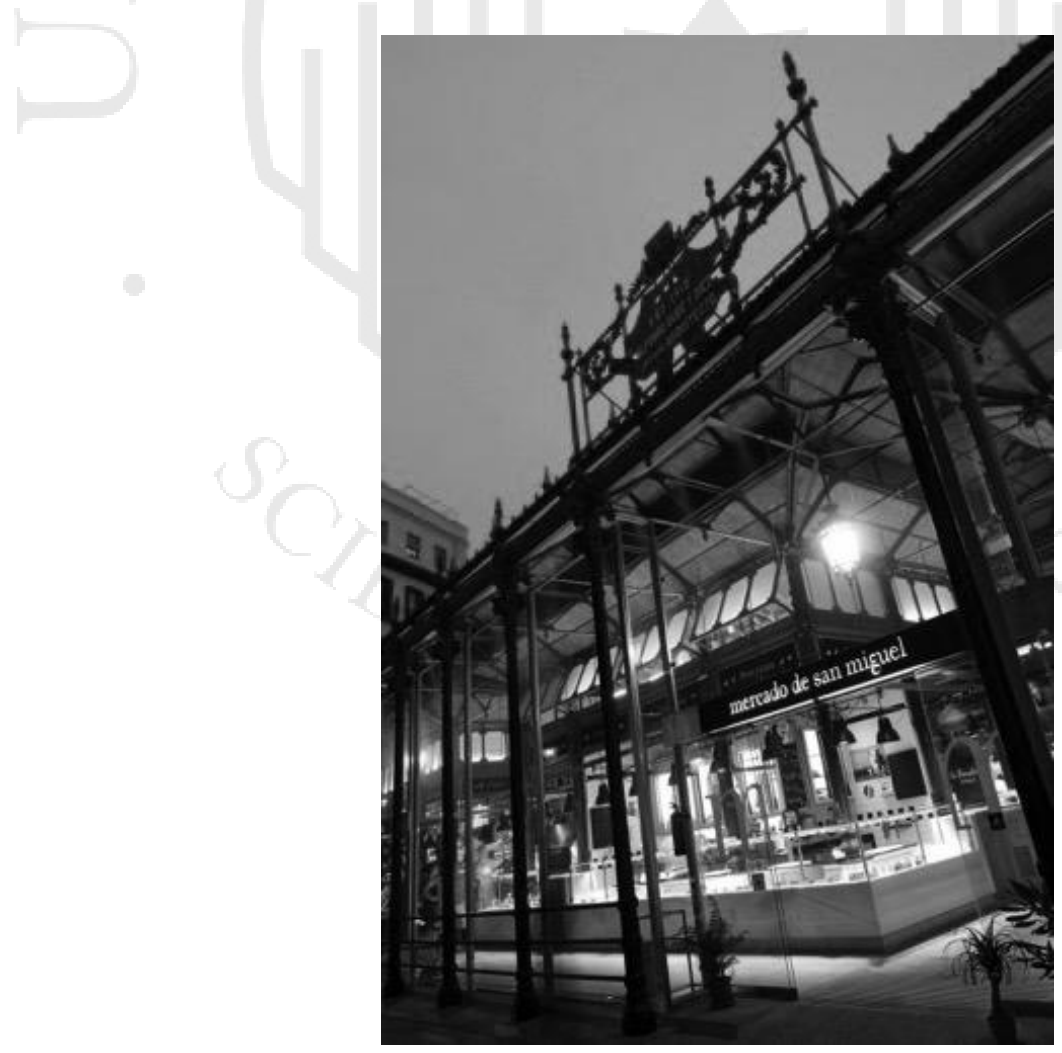

Nota: Imagen editada en blanco y negro

Fuente: Mercado de San Miguel (s.f.)

En: mercadodesanmiguel.es 


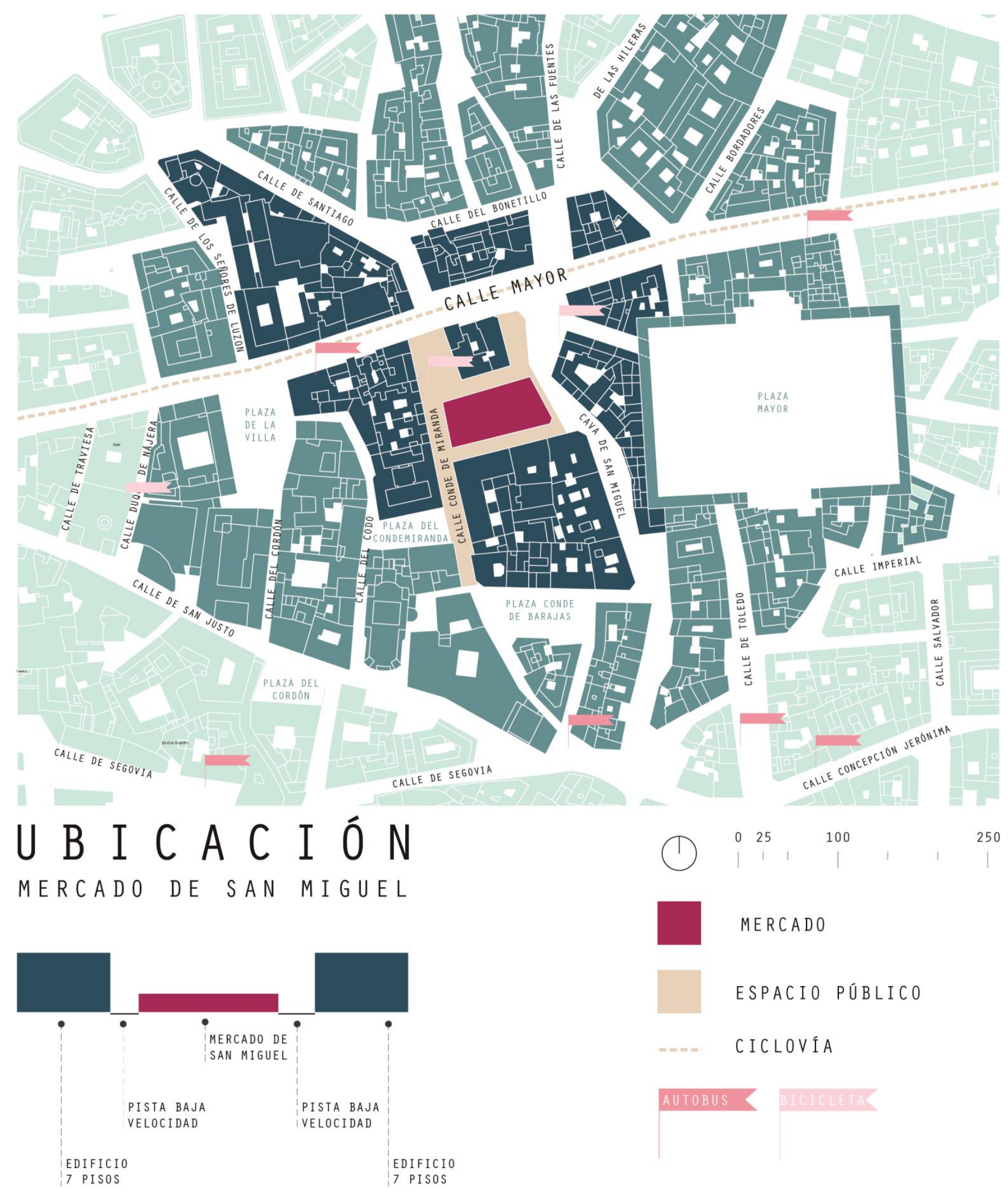


El Mercado de San Miguel se ubica en el centro de la ciudad de Madrid, próximo a la Plaza Mayor, en una de las vías principales de la ciudad: Calle Mayor. Específicamente se ubica en la Plaza San Miguel, la que le da el nombre ya que existió desde el origen del mercado.

La accesibilidad al mercado se puede dar, mediante transporte público, desde paraderos de autobuses próximos al lugar ubicados en vías importantes como la Calle Mayor; desde bicicleta por la proximidad a la ciclovía ubicada en esta última avenida; y a nivel peatonal desde puntos céntricos de la ciudad, como las distintas plazas aledañas.

Al encontrarse en una plaza, está rodeado de calles (Calle Conde Miranda y Cava de San Miguel) con una textura que permite el tránsito vehicular, pero de velocidad lenta, así como estar dotado de espacios de estar propiciados por comercios cercanos con mesas y bancas.

En cuanto a la relación con los vecinos, se puede contemplar que mantiene una escala baja y amigable con respecto a los lotes próximos, manteniendo una escala urbana homogénea. 


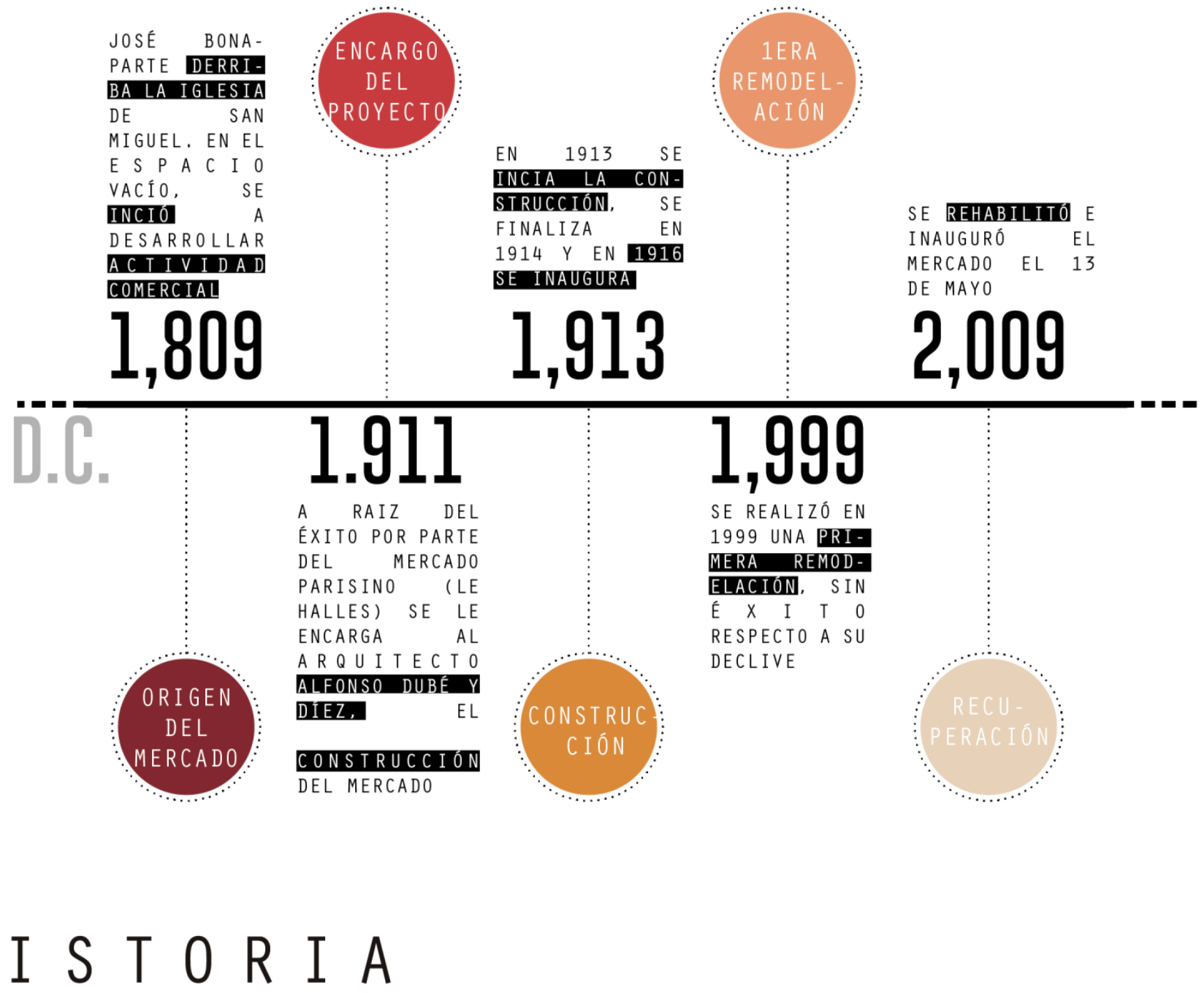

\section{H I S T O R I A}

MERCADO DE SAN MIGUEL

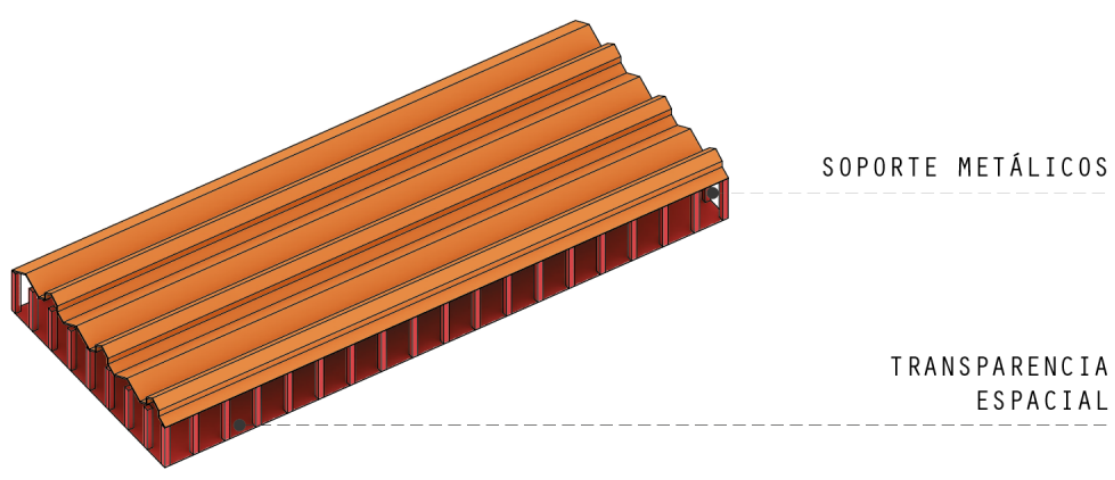




\subsubsection{Historia}

El origen de este mercado de Madrid se remonta a 1809, que con el derribo de la Iglesia de San Miguel, se generó un nuevo vacío en la ciudad. Este espacio fue utilizado como plaza de encuentro y donde poco a poco se empezó a desarrollar de manera espontánea la actividad comercial al aire libre. Debido a los problemas de higiene, por la nula planificación inicial del área comercial y el éxito de la infraestructura de mercado causado por Le Halles en Paris, en 1911 se encarga el proyecto de la construcción del Mercado de San Miguel al arquitecto Alfonso Dubé y Díez. La obra finaliza en 1914, pero su inauguración se realiza dos años después.

Posteriormente, debido al interés de mantener y conservar este tipo de arquitectura de hierro, que lamentablemente en Madrid se sustituyeron o demolieron, en 1999 se remodeló por primera vez. Sin embargo, debido al declive que este tipo de infraestructura sufrió con los nuevos formatos comerciales, no se reactivó la actividad comercial ni motivó a la confluencia de personas. Fue finalmente en el año 2009, que la sociedad El Gastrónomo de San Miguel, inaugura el nuevo mercado restaurado y rehabilitado para además de ofrecer lo tradicional de un mercado, contenga servicios complementarios y vigentes, para la generación de una nueva experiencia que dé pie a la difusión de la gastronomía y cultura española.

\section{Toma de partido:}

El Mercado de San Miguel, tiene una concepción original muy vinculada a los estilos arquitectónicos desarrollados en esa época, con soportes metálicos conformando calles interiores y una fachada recubierta en su mayoría con elementos traslucidos para generar una transparencia espacial. 

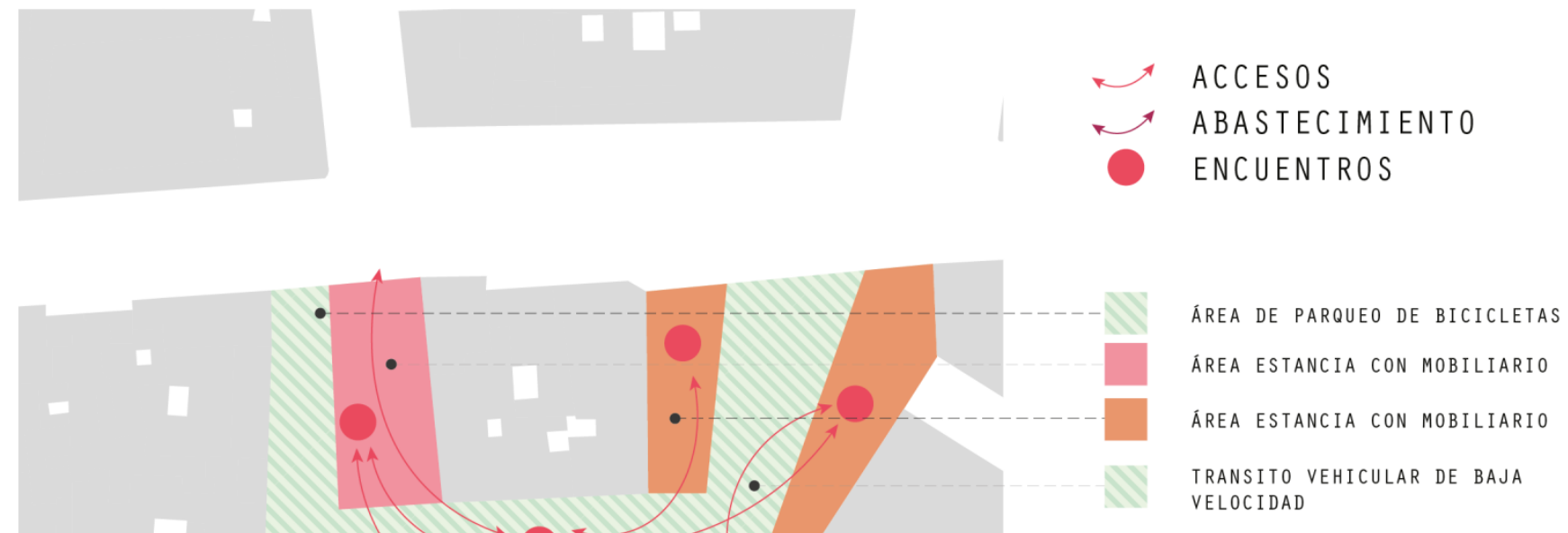
VELOCIDAD

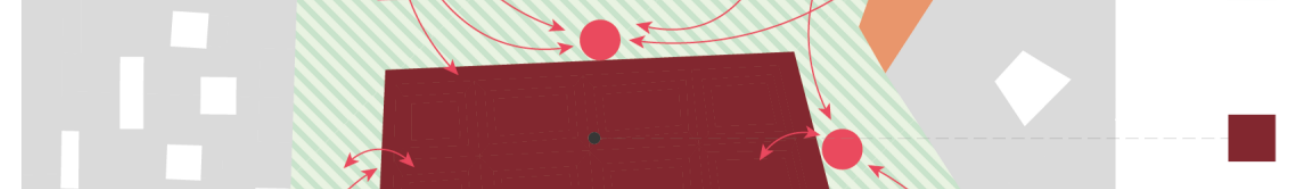

ÁREA DE MERCADO

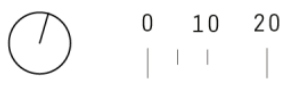

\section{RELACIÓN ENTORNO}

$M E R C A D O D E S A N$ M I G U E L
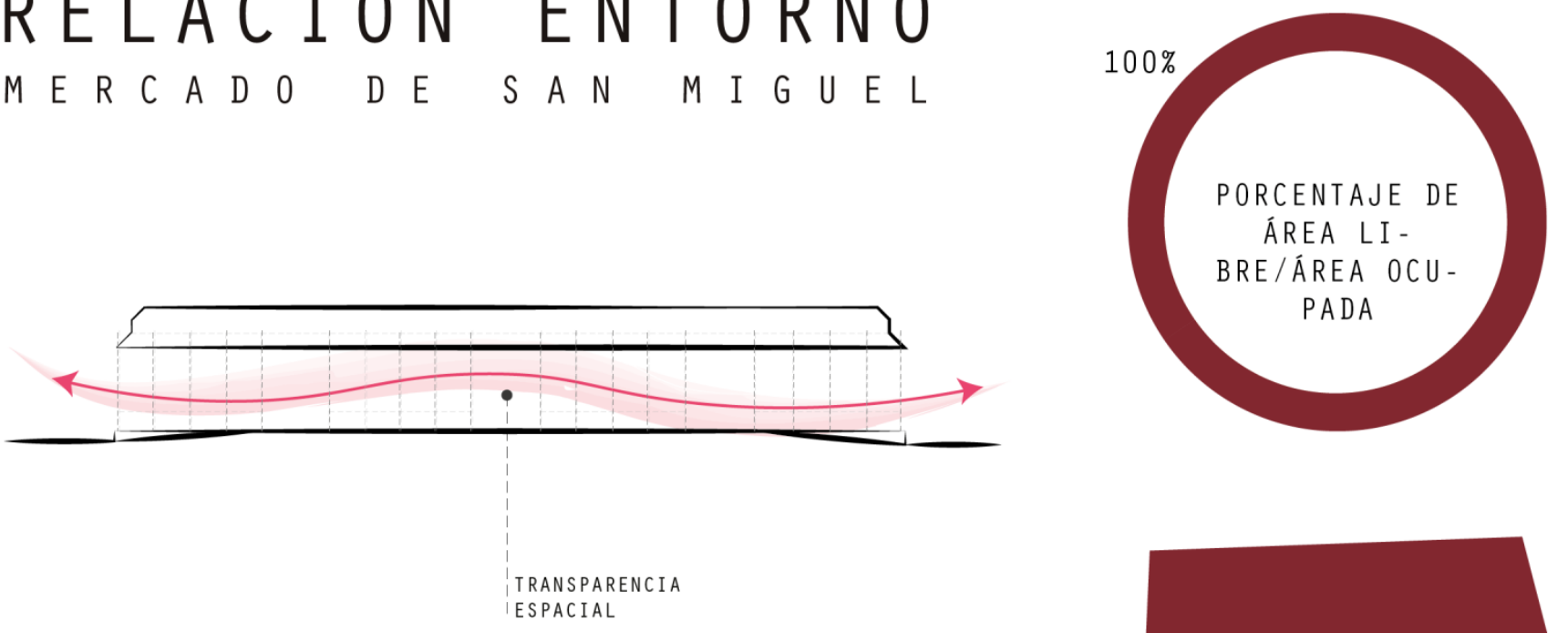

TRANSPARENCI 


\subsubsection{Entorno}

El Mercado de San Miguel se ubica próximo a lugares de encuentro y permanencia de personas, debido a la presencia de mobiliario urbano y la extensión de algunos locales comerciales con lugares de estar al aire libre. Asimismo, se encuentran parqueos de bicicletas contiguos a estos espacios, así como también encuentros de gran cantidad de personas en los ingresos principales al mercado (fachada norte y oeste).

Con respecto a la relación con el exterior, la misma estructura del mercado y su estilo arquitectónico de hierro, ha permitido generar una transparencia espacial al estar conformado de columnas metálicas y vidrio.

En cuanto al aporte de área libre vs. construida, el Mercado de San Miguel utiliza el $100 \%$ de su lote para área vendible. Sin embargo su entorno y ubicación en una plaza permite dotar de espacio público y área libre visualmente al proyecto.

Figura 5.17

Relación del mercado con el entorno próximo

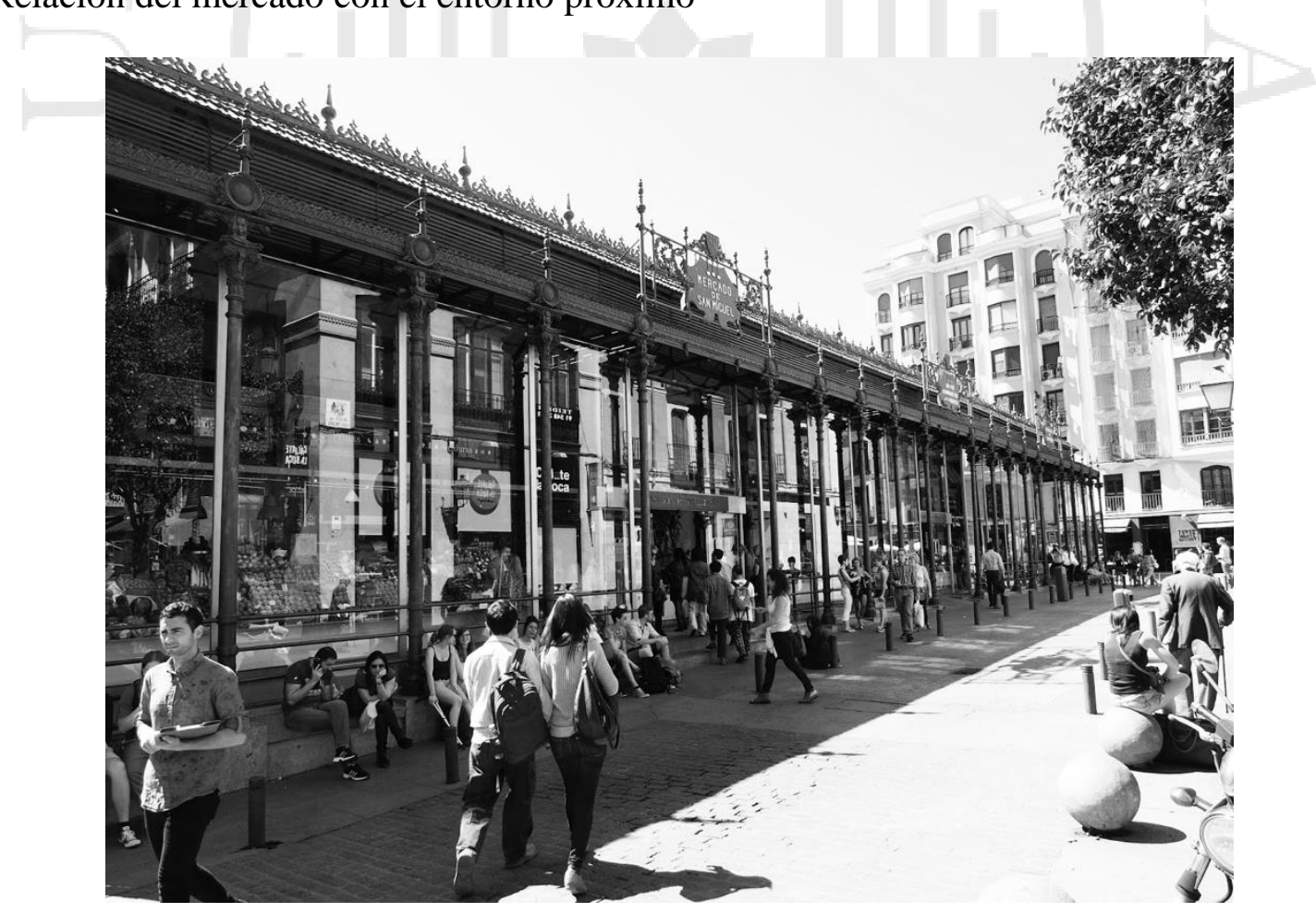

Nota: Imagen editada en blanco y negro

Fuente: Mercado de San Miguel (s.f.) Adrà Goula

En: mercadodesanmiguel.es 


\subsubsection{Tipología}

Figura 5.18

Esquema de tipología según distribución de puestos

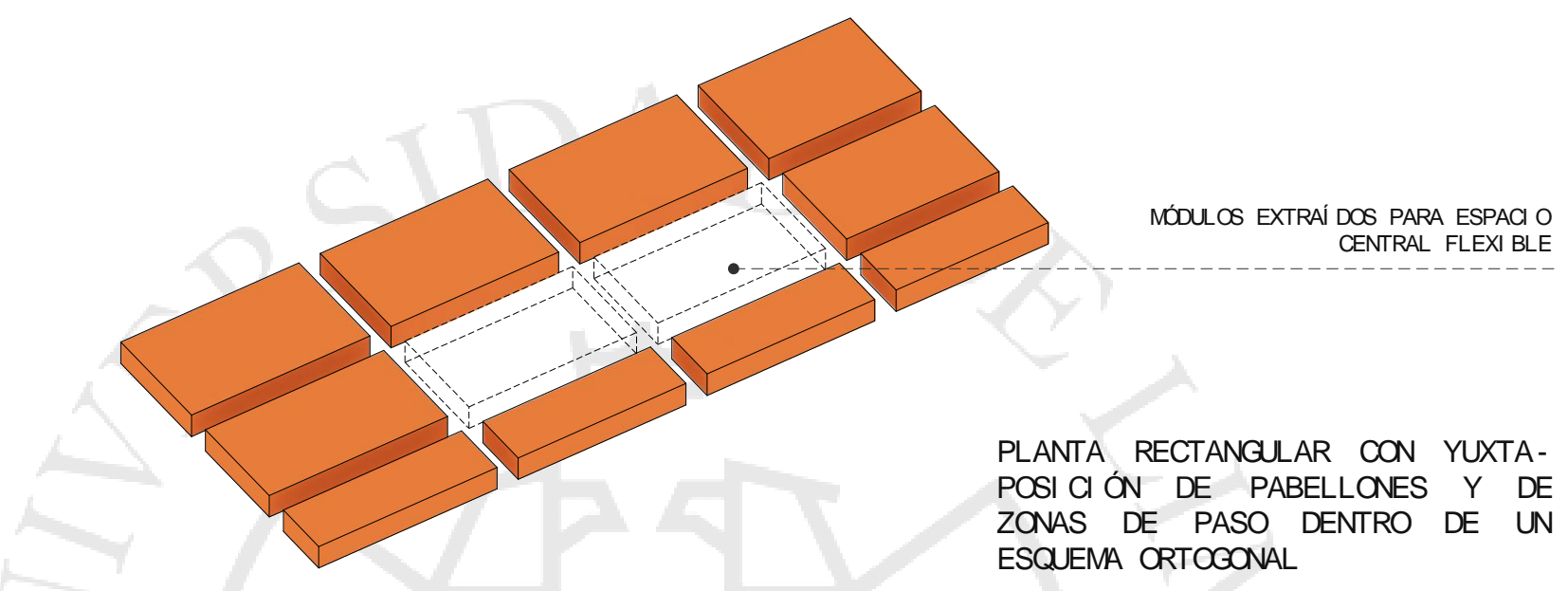

Fuente: elaboración propia

En cuanto al proyecto original, el Mercado de San Miguel fue contemplado con una tipología, según su distribución de puestos de venta, de planta rectangular con yuxtaposición de pabellones y de zonas de paso dentro de un esquema ortogonal. Estuvo organizado mediante "una calle longitudinal y tres transversales dentro de las cuales se distribuyeron los puestos de venta formando una retícula de 8 módulos con cubiertas a dos aguas." (Palomares, s.f.) No obstante, la actual recuperación del mercado liberó dos módulos para la incorporación de un área flexible para la venta de productos en puestos móviles y una zona de barra para la degustación de los clientes. 


\subsubsection{Programa}

\section{Cuadro de áreas}

Tabla 5.3

Cuadro de áreas del Mercado de San Miguel

\begin{tabular}{|c|c|c|c|c|}
\hline PROGRAMA & AREA (m2) & PORCENTAJE & TOTAL & \\
\hline ÁREA DE VENTAS & & & 05.1 & $\mathbf{m} 2$ \\
\hline Carnes & 0 & $0.00 \%$ & & \\
\hline Aves & 0 & $0.00 \%$ & & \\
\hline Pescados / Mariscos & 26.6 & $2.85 \%$ & & \\
\hline Embutidos & 16.8 & $1.80 \%$ & & \\
\hline Frutas & 18.1 & $1.94 \%$ & & \\
\hline Verduras & 18.1 & $1.94 \%$ & & \\
\hline Abarrotes & 43.5 & $4.65 \%$ & & \\
\hline Lácteos & 24.3 & $2.60 \%$ & & \\
\hline Licorería & 57.7 & $6.17 \%$ & & \\
\hline SERVICIOS COMPLEMENTARIOS & & & 394 & $\mathbf{m} 2$ \\
\hline Juguería / Bares / Café / Restaurantes & 173.8 & $18.59 \%$ & & \\
\hline Otros servicios públicos & 220.2 & $23.55 \%$ & & \\
\hline SERVICIOS GENERALES & & & 335.8 & $\mathbf{m} 2$ \\
\hline Almacenes refrigerados & 0 & $0.00 \%$ & & \\
\hline Almacenes & 165.2 & $17.67 \%$ & & \\
\hline Descarga & 0 & $0.00 \%$ & & \\
\hline Residuos & 0 & $0.00 \%$ & & \\
\hline Administración & 82.6 & $8.84 \%$ & & \\
\hline Oficinas & 82.6 & $8.84 \%$ & & \\
\hline SSHH & 5.4 & $0.58 \%$ & & \\
\hline Otros servicios privados & 0 & $0.00 \%$ & & \\
\hline TOTAL & & $100 \%$ & 934.9 & $\mathbf{m} 2$ \\
\hline
\end{tabular}

Fuente: elaboración propia 
LICORERÍA

ALMACENES REFRIGERADOS

ALMACENES

DESCARGUE

RESIDUOS

ADM I N I STRAC I ÓN

OFICINAS

SSHH

OTROS SERVICIOS PÚBLICOS

OTROS SERVICIOS PRIVADOS

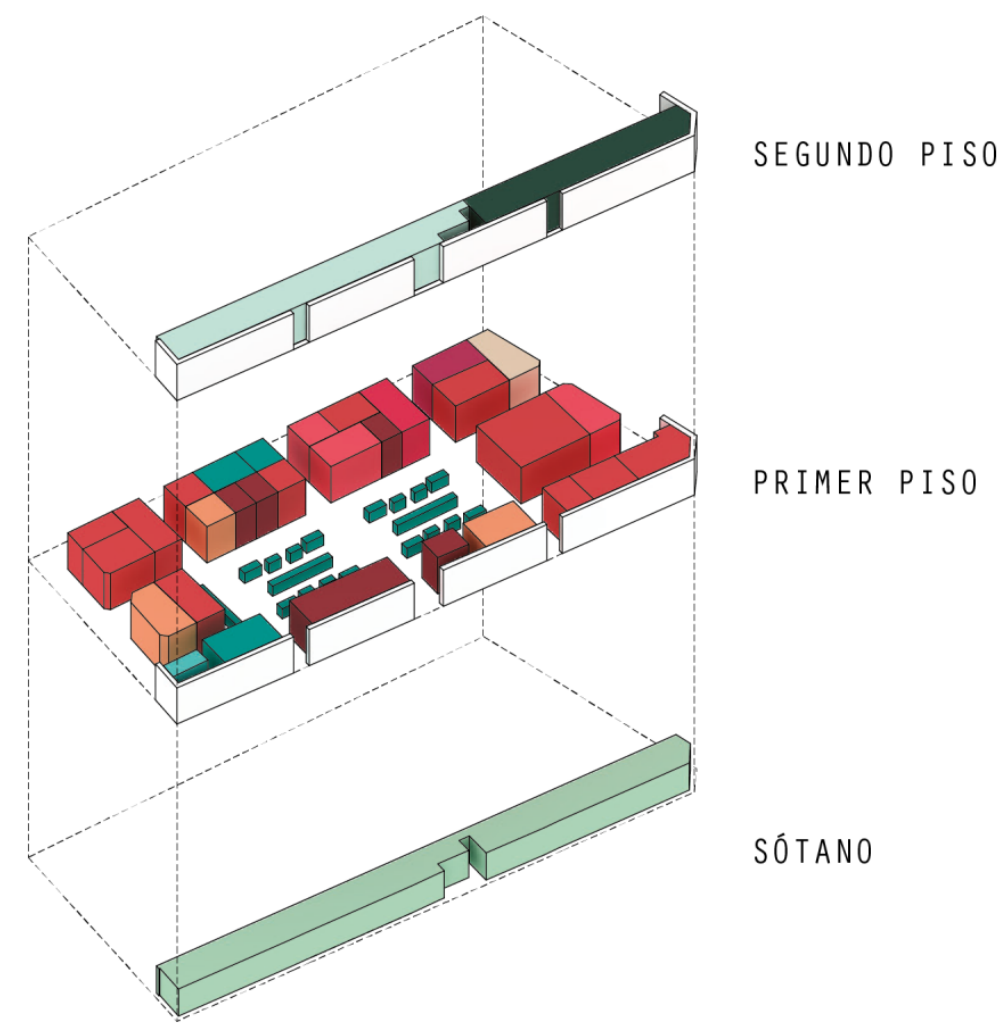

$P R O G R A M A$

MERCADO DE SAN ANTÓN

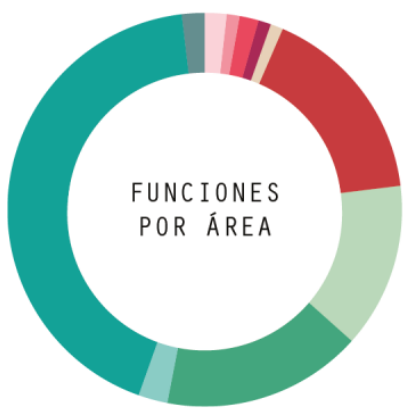




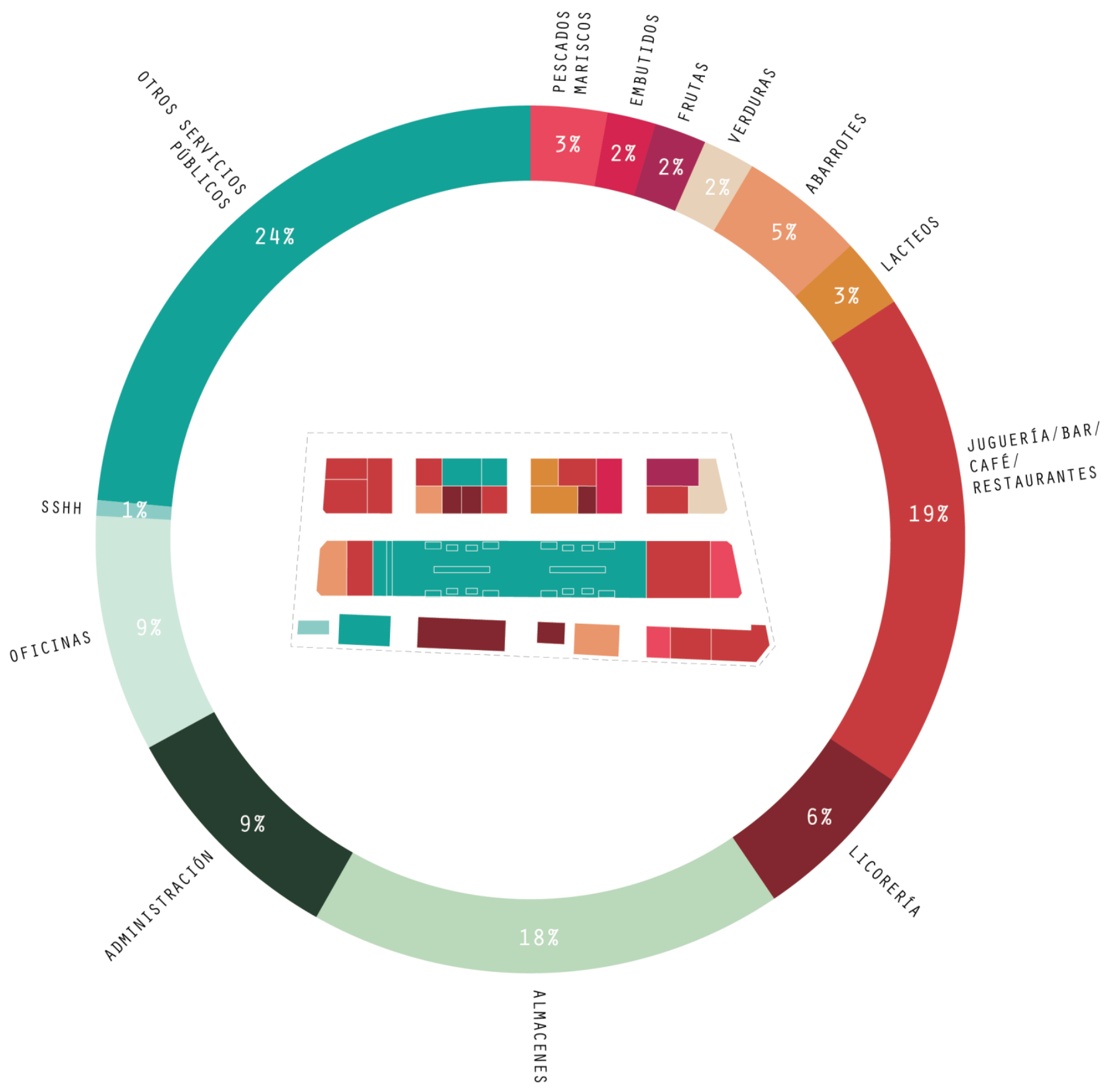

PROGRAMA

MERCADO DE SAN MIGUEL 
INGRESO/SALIDA CLIENTES

SERVICIOS COMPLEMENTARIOS

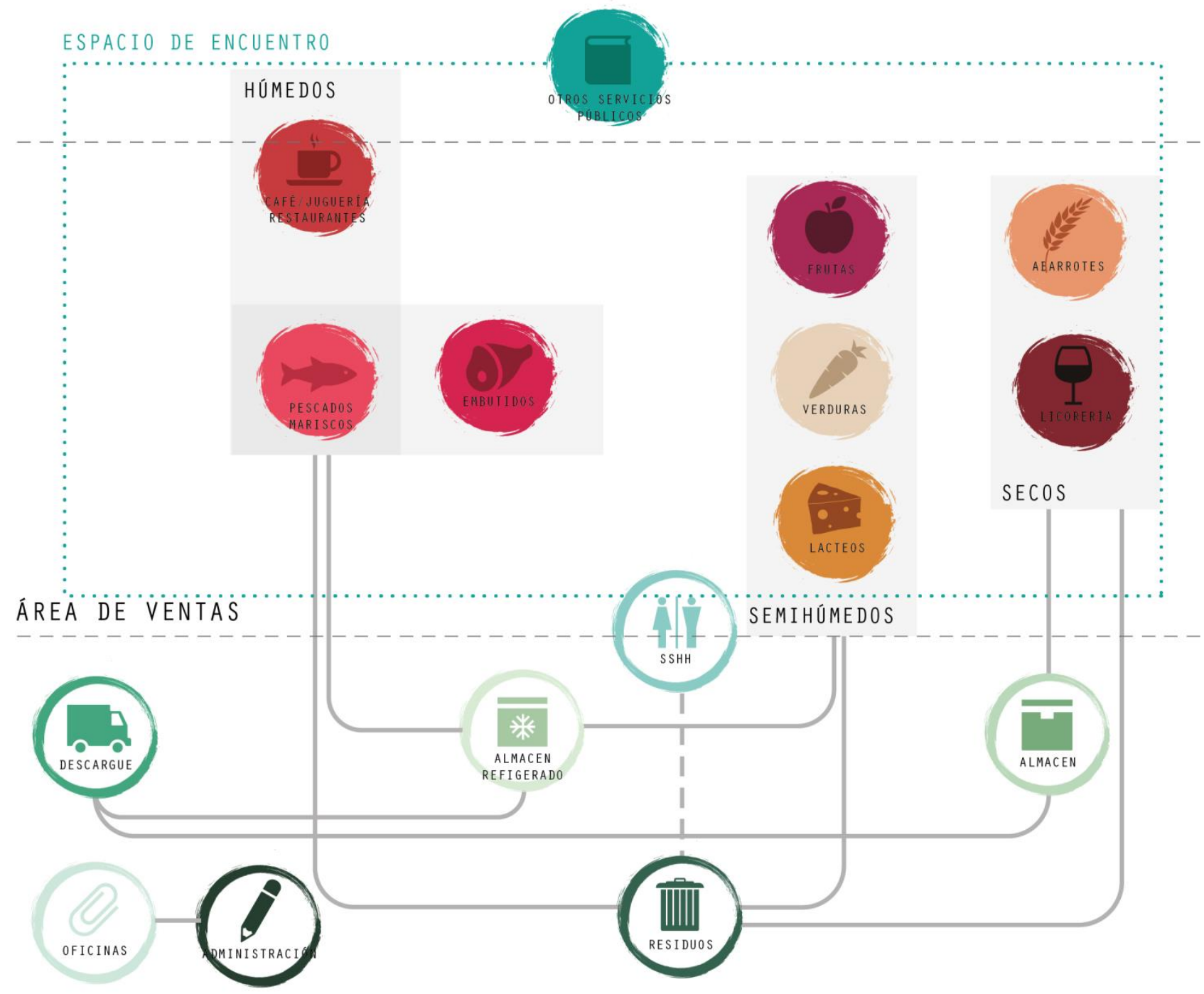

ÁREA DE SERVICIOS GENERALES: SOTANO O PRIMER PISO

0 R G A N I GRAMA

MERCADO DE SAN MIGUEL

RELACIÓN DIRECTA

$=-\quad$ RELACIÓN INDIRECTA

GRUPO DE PRODUCTOS 
El Mercado de San Miguel, ofrece diversos productos y servicios, repartidos en 3 niveles (sótano, primer nivel y segundo nivel). En cuanto al sótano, se ubican las zonas de almacenes y abastecimiento, en el primer piso se ubica toda el área comercial de venta: pescados y mariscos, embutidos, frutas, verduras, abarrotes, lácteos.

Por otro lado, en el mismo nivel comercial se ubican otros servicios complementarios, como lo son los restaurantes, cafés, juguerías, zona de barra, módulos móviles, librerías, y florería. Por último, en el piso superior, no en toda la superficie, se ubican las oficinas y la administración del mercado.

En cuanto a las relaciones de estos espacios, pueden sectorizarse en zonas específicas ya sea próximas al ingreso como encontrarse separados del nivel comercial del mercado. Según su distribución, se encuentran próximos al ingreso principal del mercado, los servicios complementarios: tanto de restaurantes, cafés, juguerías, como de otra índole como la zona de módulos móviles (que cambian según temporada), la librería, y el espacio que engloba el área de encuentro (la zona de la barra).

En cuanto al área de venta, a pesar de encontrarse los distintos puestos de productos húmedos, semihúmedos y secos de manera combinada en todo el mercado, estos guardan en común el canal de abastecimiento; se relacionan con los almacenes según su rubro; y todos generan residuos que posteriormente serán llevados al contenedor próximo del mercado (ubicado en la parte posterior). En cuanto a los demás servicios generales, los SSHH, estos no están directos al espacio de venta. Por último, respecto a las oficinas y la administración, estos se encuentran en el segundo nivel del mercado, hacia el ingreso posterior (ingreso de servicios). 


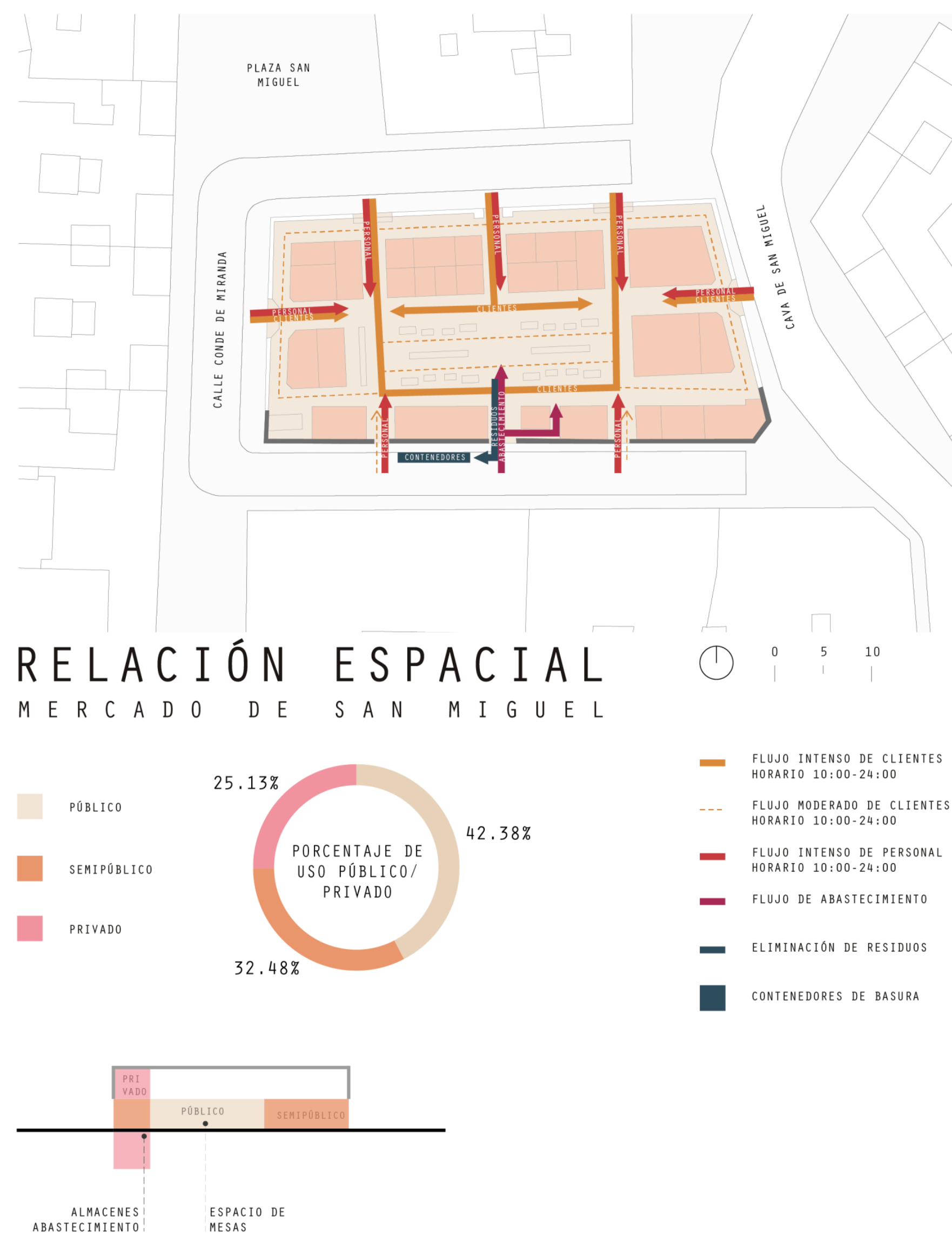




\subsubsection{Espacio}

El mercado tiene ocho ingresos repartidos en sus cuatro lados, de los cuales uno es exclusivo del personal, abastecimiento y salida de residuos.

El ingreso principal se ubica en la fachada norte del mercado, sin embargo, tanto el tránsito de clientes como del personal (10:00-24:00) es visible en todos los puntos de acceso del mercado. Los dos ingresos en la fachada sur del proyecto, a pesar de ser un ingreso público, no reciben muchos visitantes por ser en una fachada alejada a los equipamientos próximos y básicamente utilizadas de servicio.

En cuanto al flujo de abastecimiento y recolección de residuos, este se da en la fachada sur del proyecto, próximo al ingreso del área administrativa y donde también se ubican los contenedores de basura.

\section{Figura 5.19}

Interior del Mercado de San Miguel

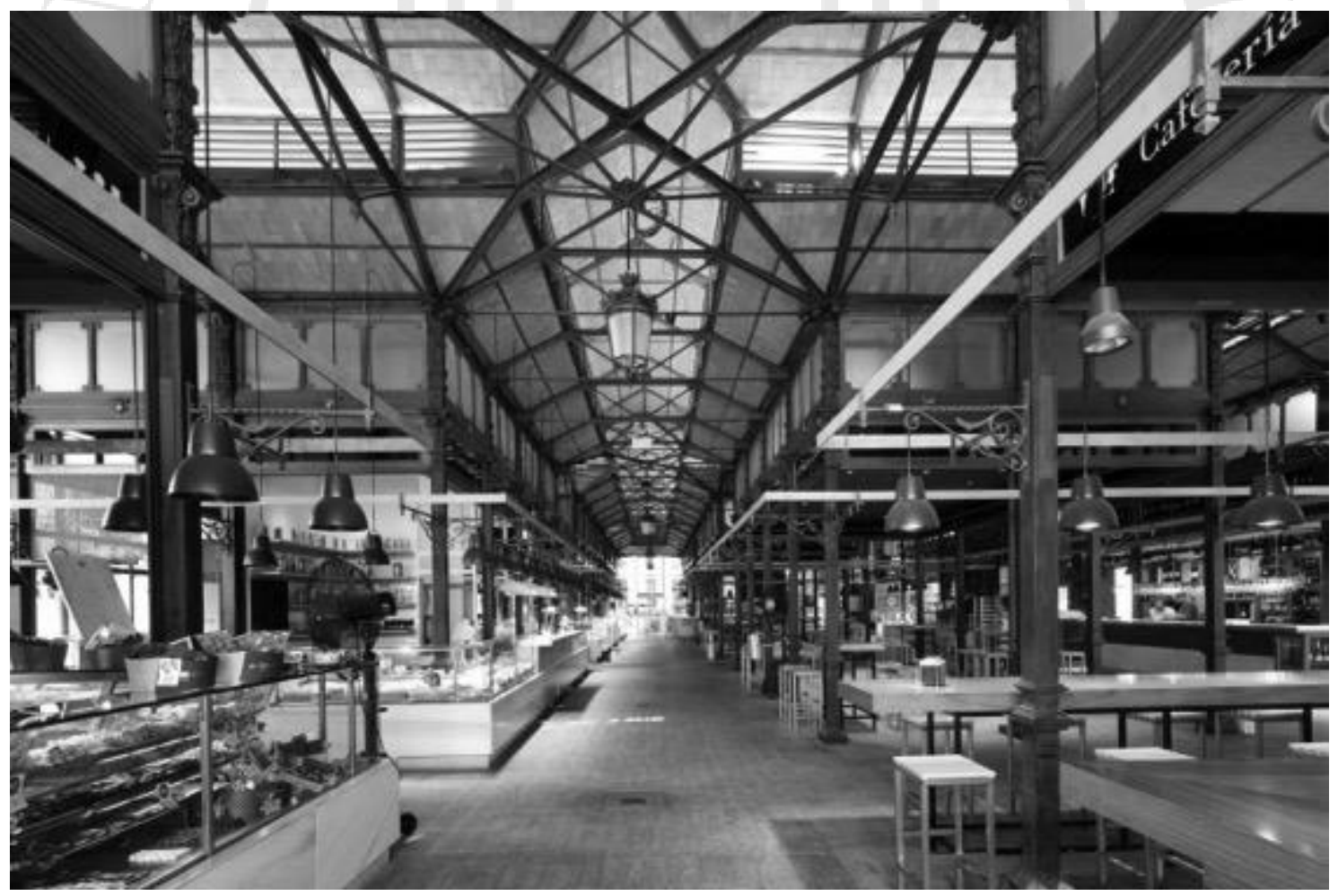

Nota: Imagen editada en blanco y negro

Fuente: Mercado de San Miguel (s.f.)

En: mercadodesanmiguel.es 
DETALLE CONSTRUCTIVO
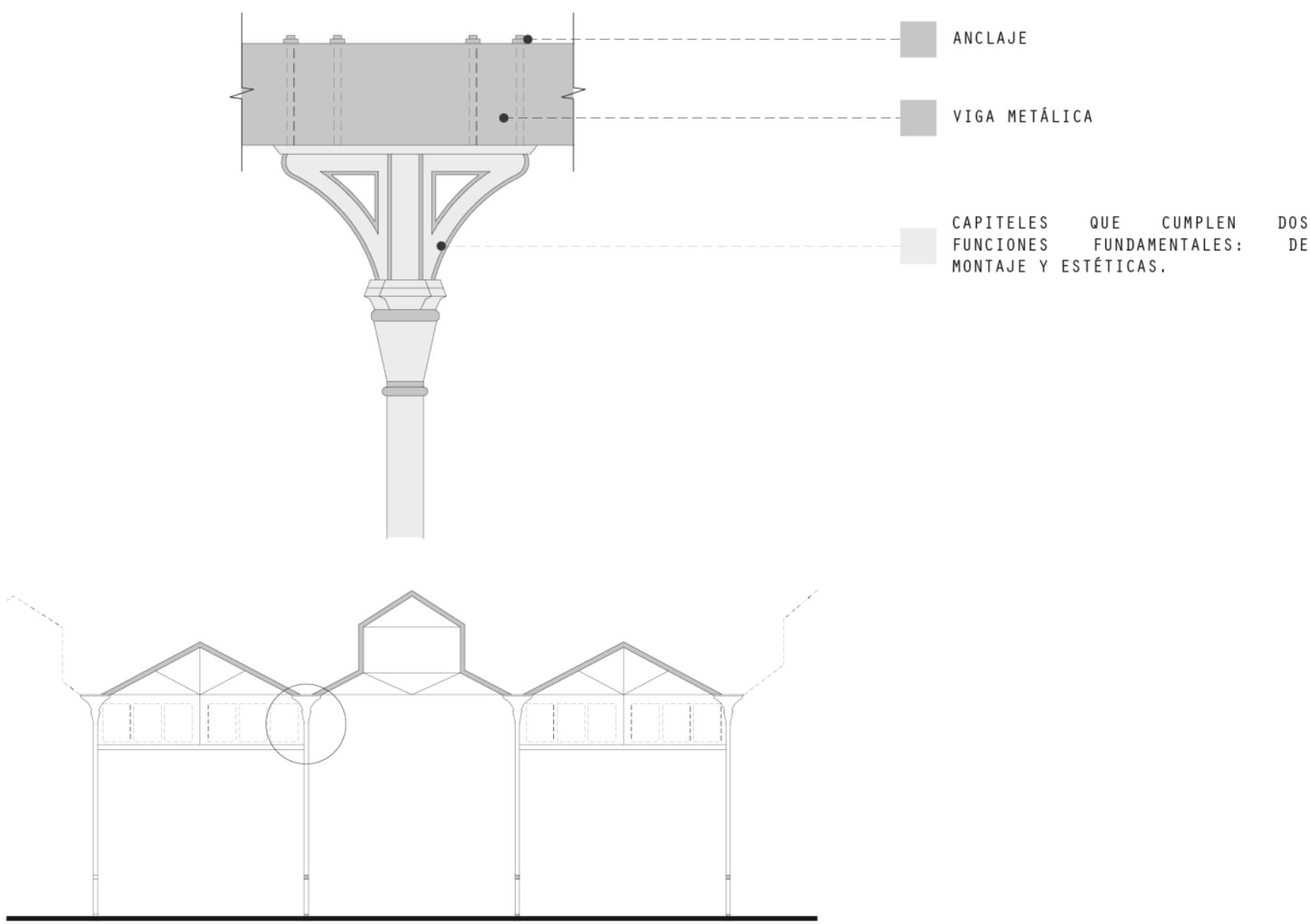

INNOVACIÓN TECNOLÓGICA

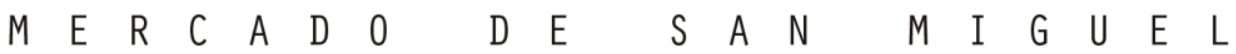

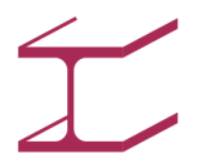

CONSTRUCCIÓN EN HIERRO CON

SOPORTES METÁLICOS DE FUNDICIÓN

SOPORTES METÁLICOS DE FUNDICIÓN REVESTIDOS EN MÁRMOL 


\subsubsection{Tecnología}

Este edificio histórico tiene un sistema constructivo de construcción en hierro, propio de la época de su concepción. La estructura se resolvió con soportes metálicos de fundición que formaban las calles y las manzanas de los puestos interiores. Además de cumplir una función estructural, los capiteles de hierro fueron diseñados para ofrecer un aporte ornamental al diseño de mercado y la fachada.

Figura 5.20

Techo del Mercado de San Miguel

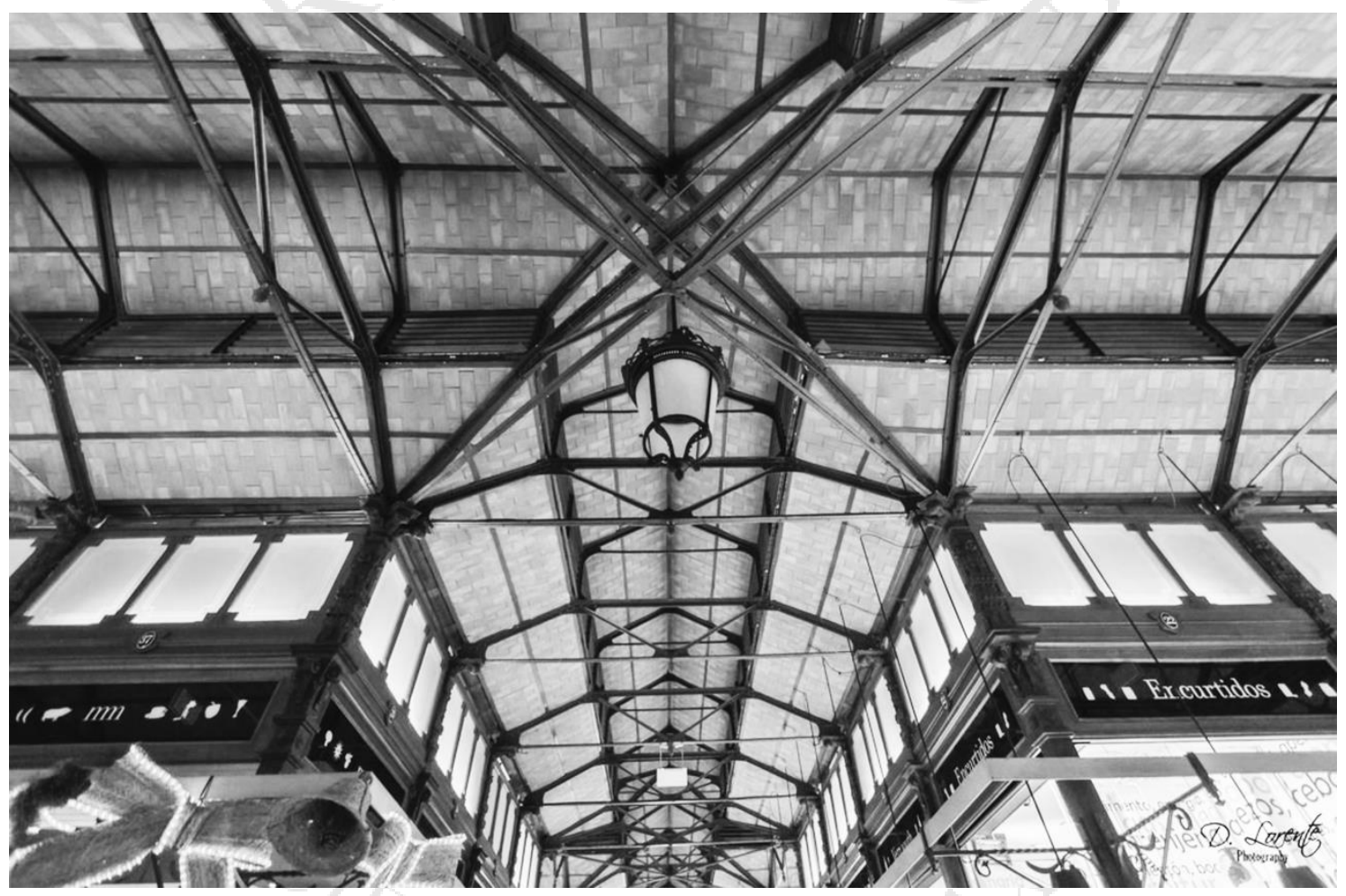

Nota: Imagen editada en blanco y negro

Fuente: Techo del Mercado de San Miguel en Madrid (2014) Domingo Lorente

En: https://www.flickr.com/photos/domingo_lorente/15892547119 


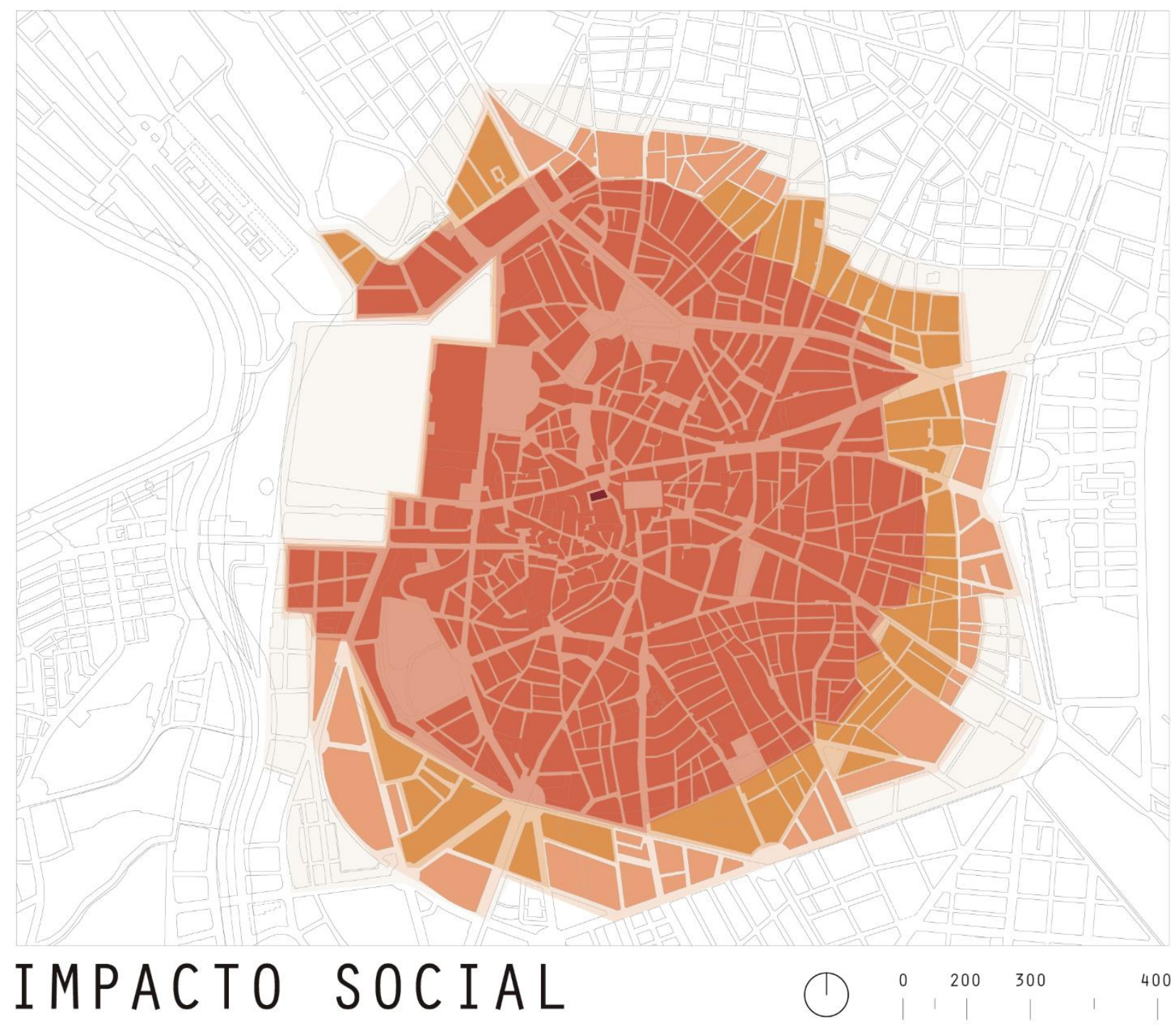

\section{MERCADO DE SAN MI GUEL}

ÁREA DE INFLUENCIA DIRECTA

RADIO 1 KM APROX

ÁREA DE INFLUENCIA DIRECTA

ACCESO A TRANSPORTE COLECTIVO

ÁREA DE INFLUENCIA DISPERSA

DILUYE EN EL RESTO DE LA CIUDAD 


\subsubsection{Impacto social}

La reactivación y remodelación comercial del Mercado de San Miguel contribuyó al proceso de gentrificación de la zona, con la mejora del valor del suelo, la afluencia de personas, la generación de una centralidad al barrio y el permitir un lugar de encuentro entre vecinos y el público en general.

Con el proyecto se vio un impacto no solo a nivel urbano, con el cambio de dinámicas en la zona y la generación de nuevos encuentros, también mejoró la calidad de vida de los habitantes de su alrededor y su satisfacción para con el mercado.

Por otro lado, respecto a su radio de influencia, vemos el impacto directo que los mercados generan $1 \mathrm{~km}$ a la redonda y como se disipa en el resto de la ciudad. El mercado de San Miguel recibe semanalmente 75,000 personas de los cuales $40 \%$ son turistas.

En relación al aporte sostenible, este mercado a pesar de no innovar en sistemas amigables con el medio ambiente tiene una cultura de difusión y aplicación de medidas con impacto sostenible positivo. Por ejemplo, realizan charlas e informan a las personas en temas como la pesca sostenible, además de integrar a sus políticas de venta.

Figura 5.21

Vista interior del Mercado de San Miguel

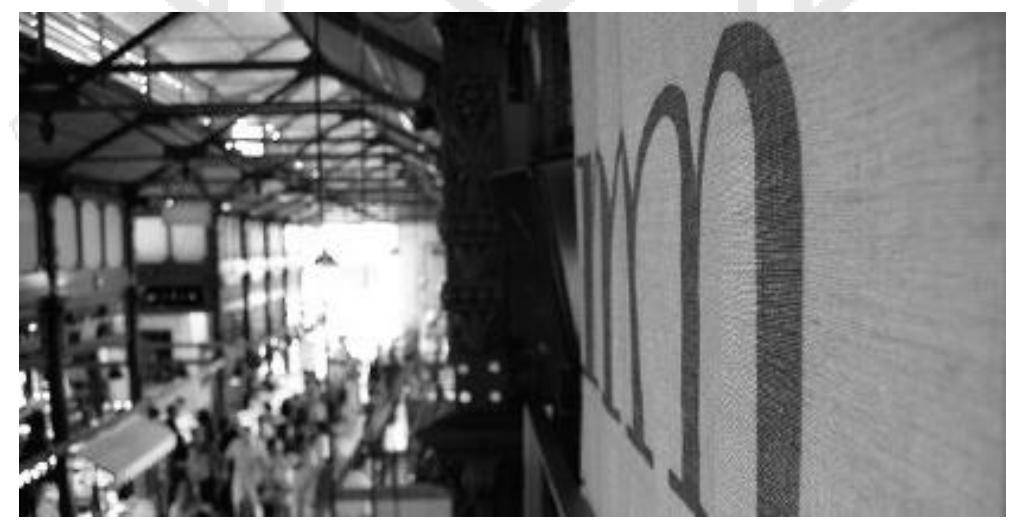

Nota: Imagen editada en blanco y negro

Fuente: Mercado de San Miguel (s.f.)

En: mercadodesanmiguel.es 


\subsection{Mercado de San Antón}

\subsubsection{Ubicación}

Arquitecto: Estudio ATARIA (Antes QVE arquitectos)

Equipo: José María García del Monte, Ana María Montiel Jiménez

Año de construcción: 1945

Año de remodelación: 2004-2011

Cliente: público

Promotor: Asociación de Comerciantes del Mercado de San Antón

Ubicación: Calle de Augusto Figueroa, 24, 28004 Madrid, España

Categoría: mercado municipal

Área construida: $7,354 \mathrm{~m} 2$

Figura 5.22

Interior del Mercado de San Antón

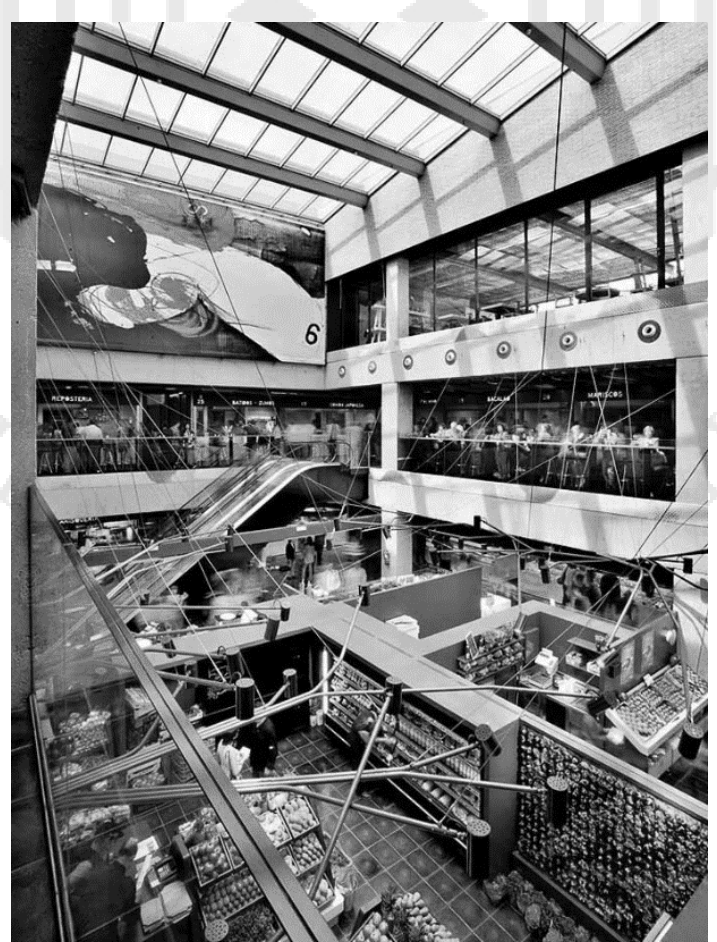

Nota: Imagen editada en blanco y negro

Fuente: Mercado de San Antón (s.f.) BJC Architect Community

En: architect.bjc.es 


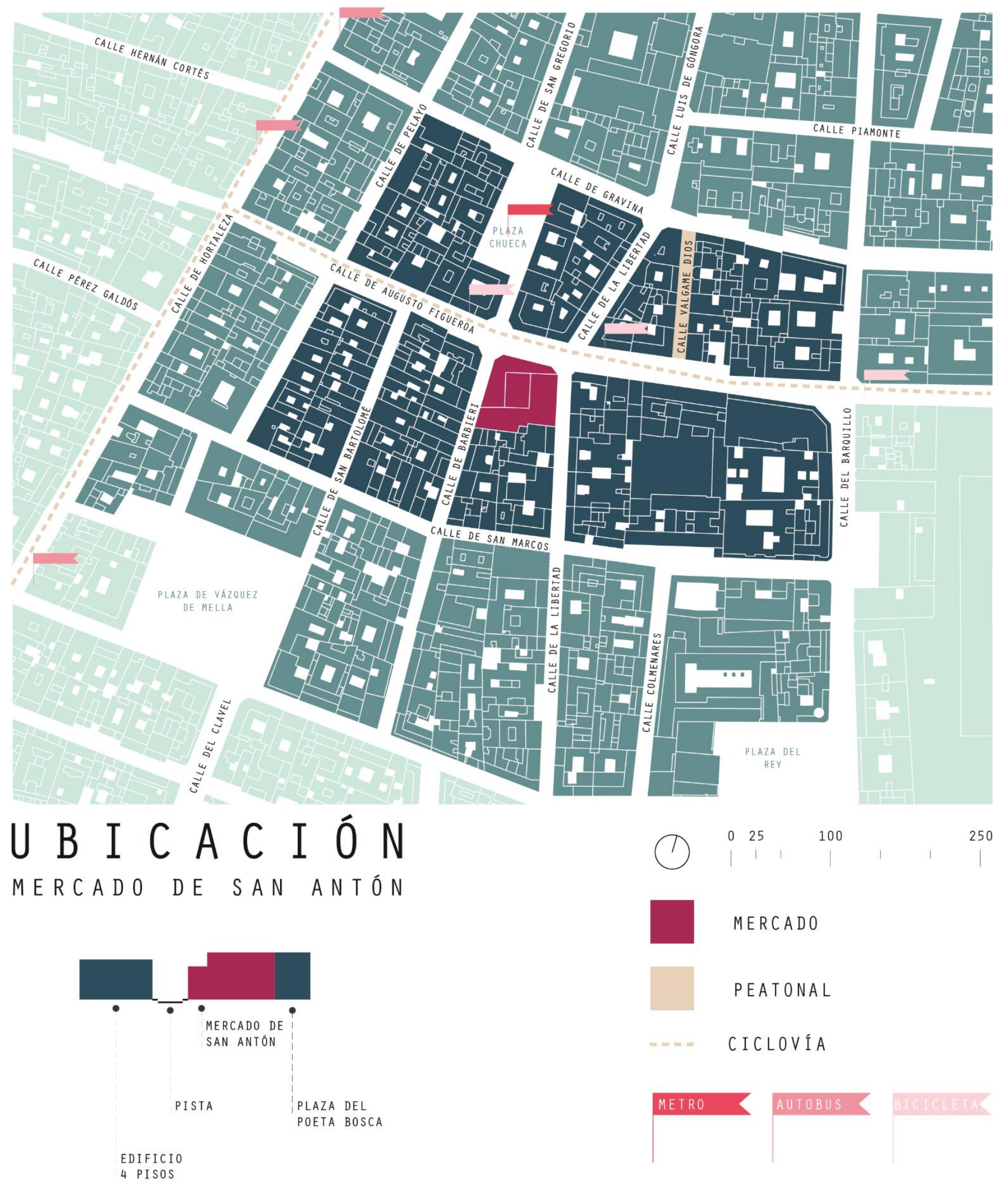


El Mercado de San Antón se ubica la zona de Chueca del Barrio Justicia de la ciudad de Madrid. Se ubica en el mismo centro de la ciudad y cuenta con una accesibilidad muy próxima a las vías y puntos principales de la ciudad. Estas pueden ser mediante el metro, paradas de autobús y una ciclovía que pasa por la Calle de Augusto Figueroa (vía de acceso del mercado).

La sección de las vías que intervienen en el proyecto, son estrechas (como sucede en gran parte de esta zona de Madrid) no permiten amortiguar la llegada de visitantes en un espacio abierto. Asimismo, no se considera amigable el entorno urbano del proyecto ya que, a pesar de estar próximo a una calle peatonal y a paraderos de bicicletas, el transitar por veredas angostas, hace difícil el desplazamiento del peatón.

Figura 5.23

Mercado de San Antón relación con el exterior

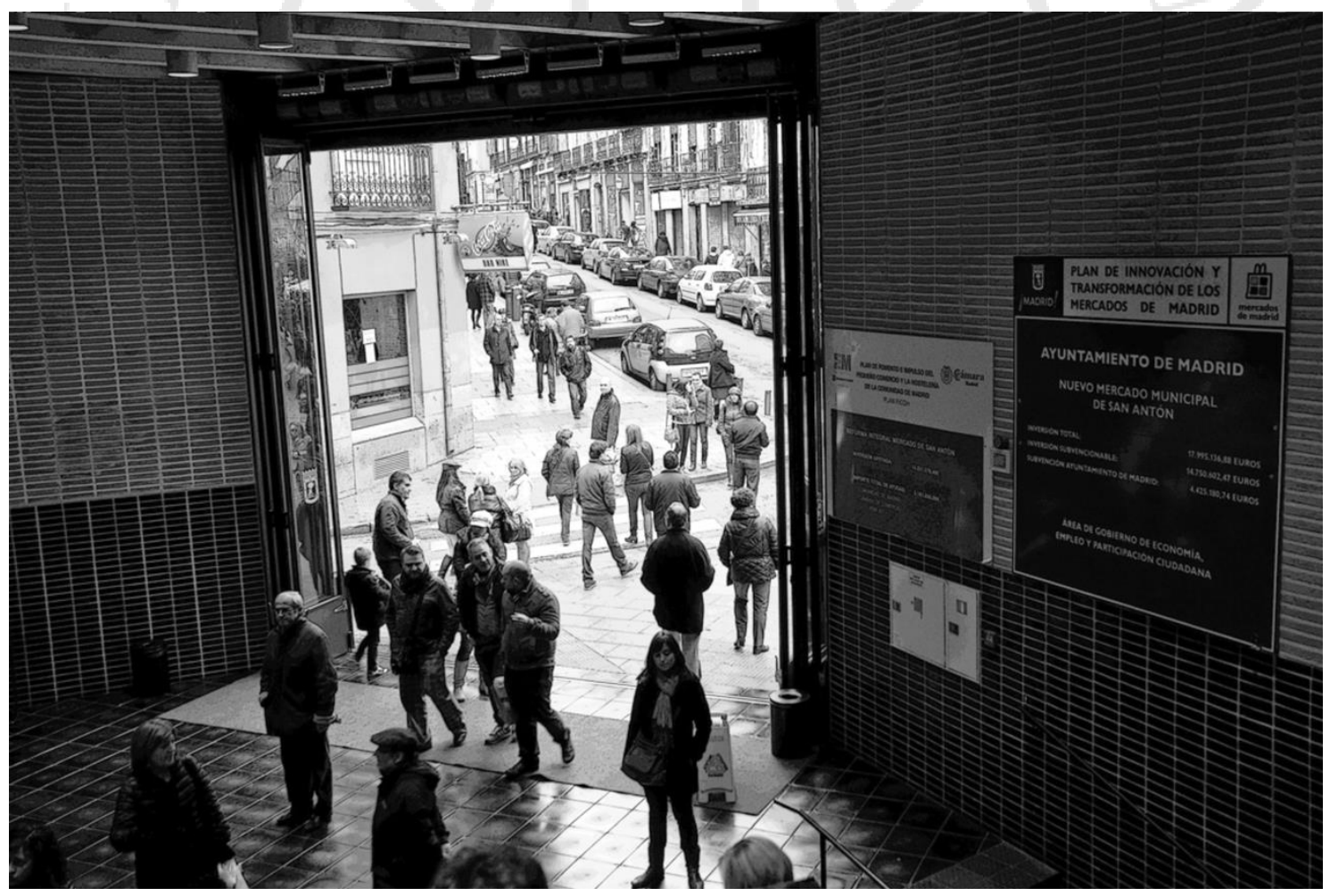

Nota: Imagen editada en blanco y negro

Fuente: Mercado de San Antón - Madrid (2011) Ana Alas

En: https://www.flickr.com/photos/anaalas/6811947859/ 


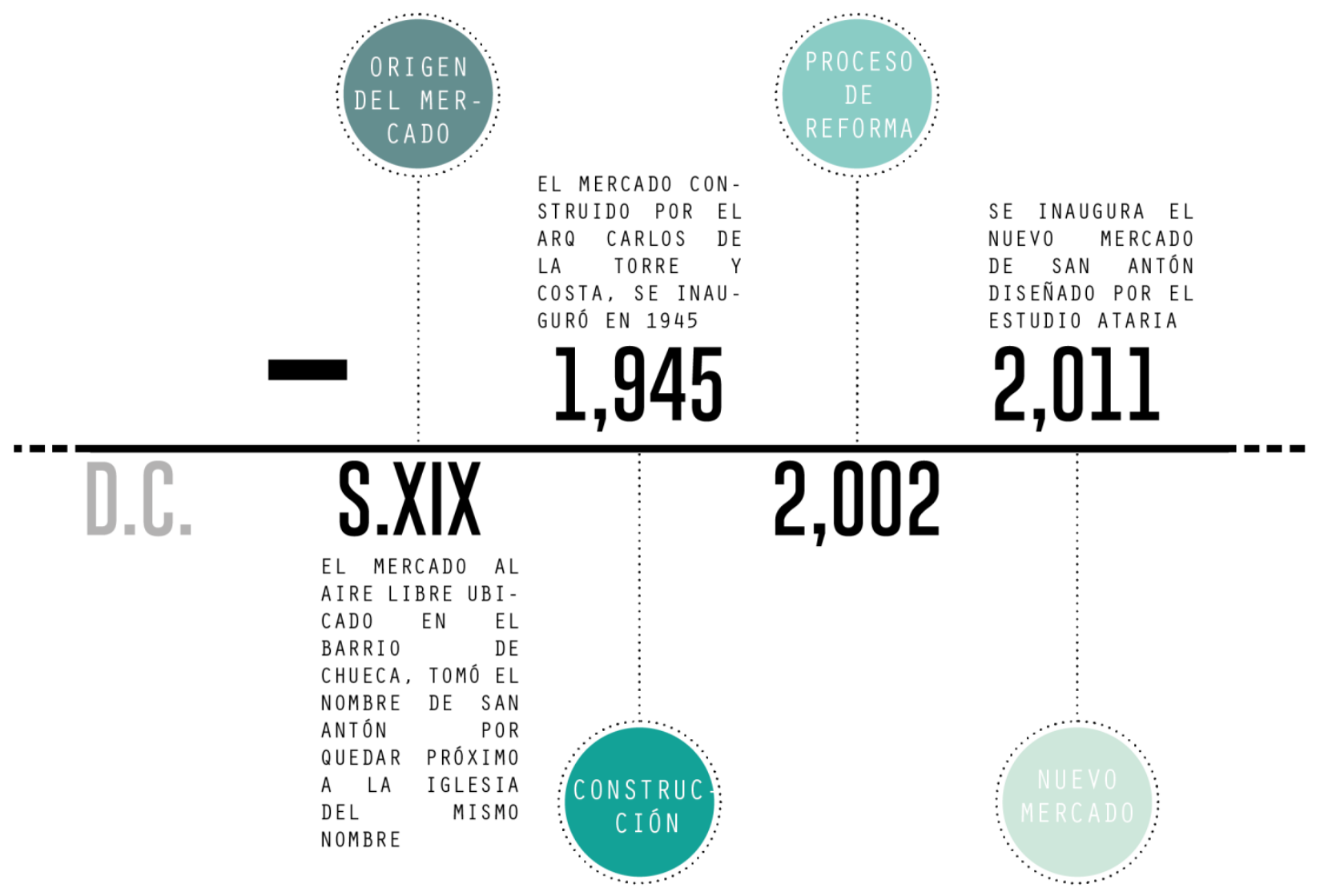

\section{H I S T O R I A}

MERCADO DE SAN ANTÓN

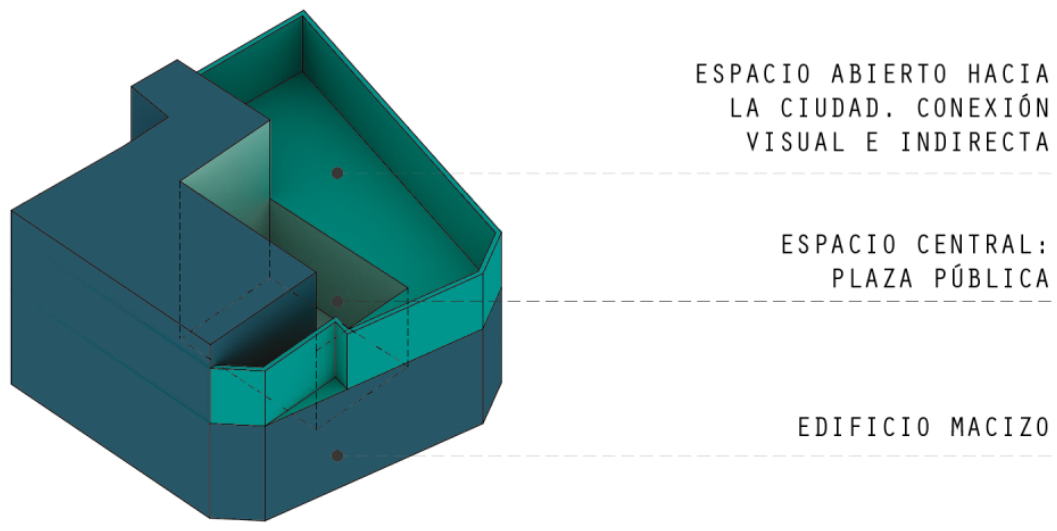




\subsubsection{Historia}

El Mercado de San Antón, al igual que la mayoría de los mercados, tuvo origen como un lugar donde se realizaba la actividad comercial al aire libre (siglo XIX), próximo a la Iglesia San Antón, la cual le dio el nombre. Fue recién en 1945 que el arquitecto Carlos de la Torre y Costa construye el mercado como establecimiento. Después de este momento el desarrollo del mercado radicaba en la compra local de visitantes propios del barrio de Chueca.

Figura 5.24

El Mercado de San Antón en el Barrio de Chueca 1945

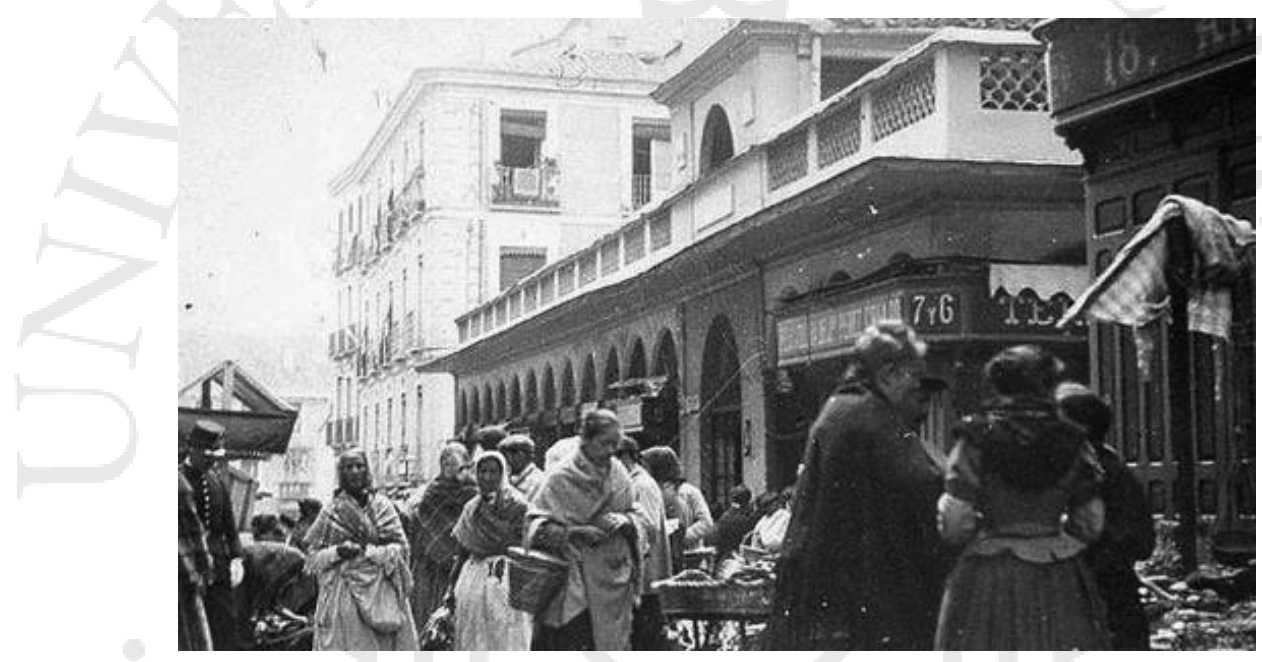

Fuente: Mercado de San Antón 1945 (s.f.) En: blogdelg.es

Posteriormente en el año 2002, la Asociación de Comerciantes decide comenzar un proceso de reforma del mercado, para una mejora y reactivación de la actividad comercial, “apoyándose en el Plan de Modernización y Dinamización de Mercados del Ayuntamiento de Madrid y del Plan FICO de la Comunidad de Madrid." (Robles, 2014)

Sin embargo, debido a la gran inversión que significaba la demolición y nueva construcción del mercado, la Asociación además de apoyarse de estas instituciones públicas (representaban el 35\%), tuvo que incorporar una cadena de supermercado (Supercor) para afrontar los demás gastos. Finalmente, en el año 2011 se inaugura el Nuevo Mercado de San Antón, diseñado por el estudio Ataria. 


\section{Toma de partido:}

La idea del mercado de San Antón era recuperar el concepto de la plaza pública y servir como punto de encuentro para las personas. Asimismo, plantea una conexión hacia el exterior del entorno urbano, pero de manera visual e indirecta en el último piso.

Figura 5.25

Terraza del Mercado de San Antón

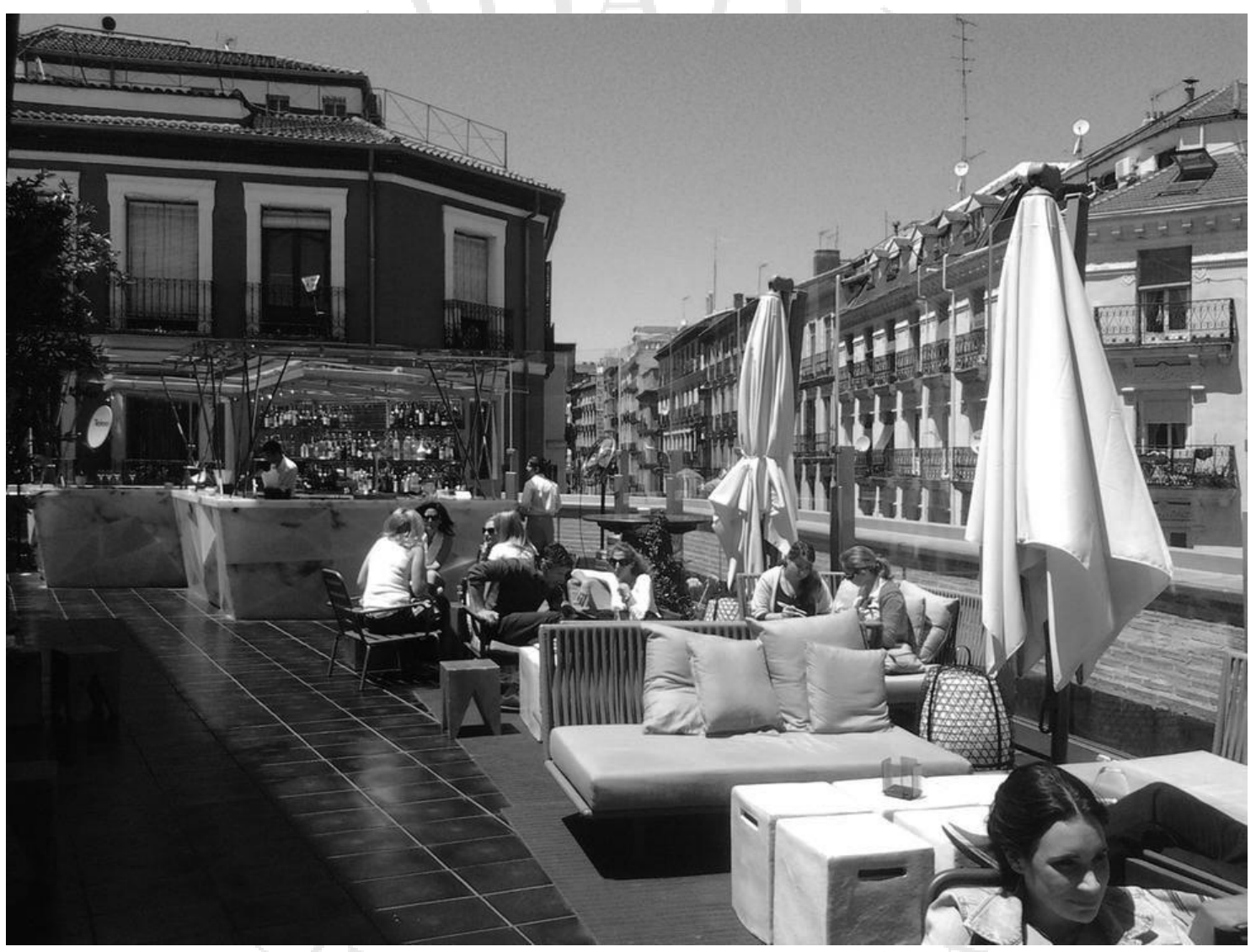

Nota: Imagen editada en blanco y negro

Fuente: Terraza del Mercado de San Antón (s.f.) BeaBurgos

En: minube.com 


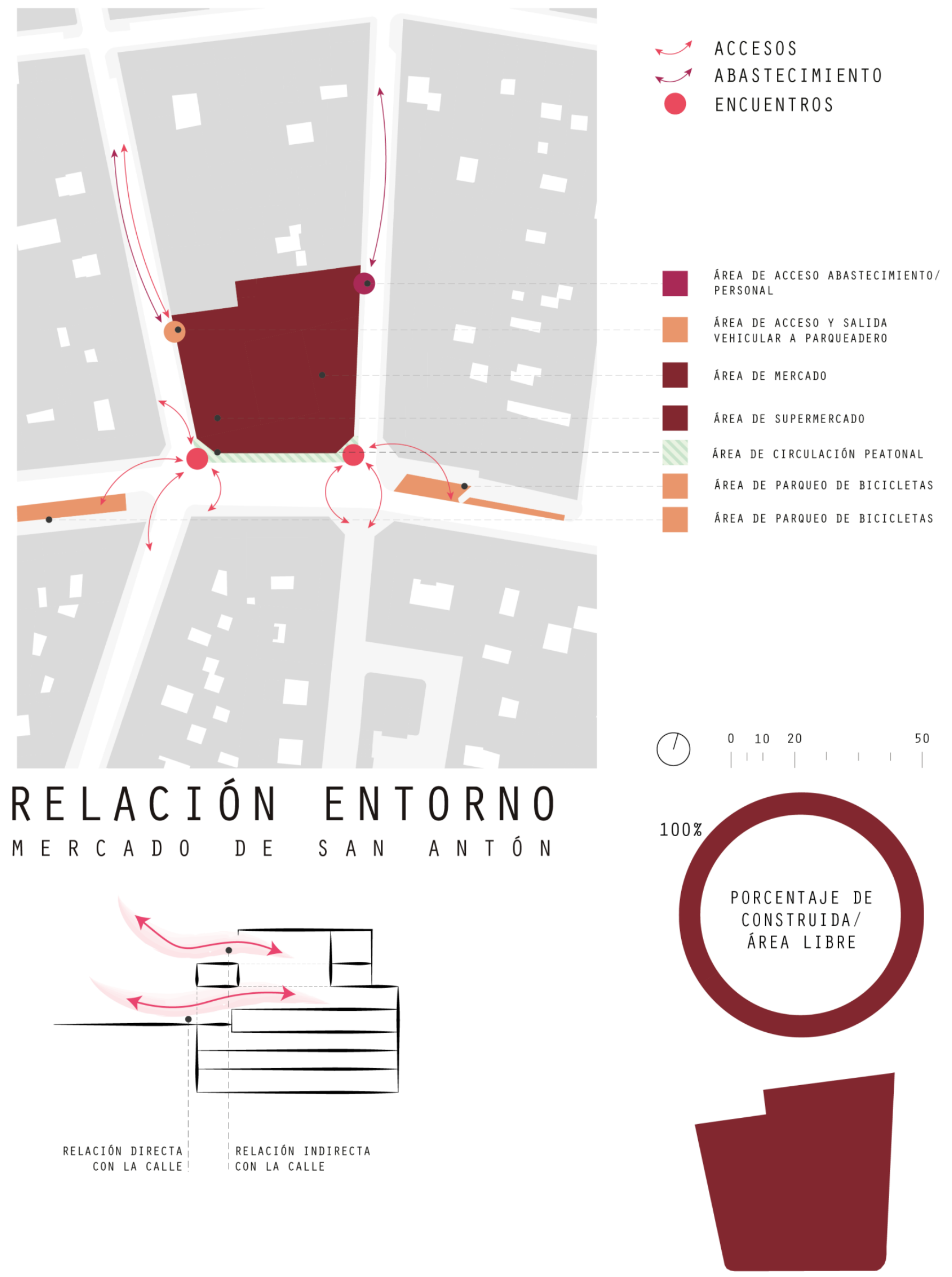




\subsubsection{Entorno}

El Mercado de San Antón ubica sus accesos en las cuatro esquinas de su proyecto. Todas dan a situaciones similares: veredas angostas hacia zona residencial. Sin embargo, las dos entradas principales de clientes del mercado dan a la Calle de Augusto Figueroa, vía con acceso a la ciclovía y a paraderos de bicicletas próximos.

En cuanto a su relación con el exterior, el mercado fue concebido como una masa cerrada, maciza, propia del entorno urbano en donde se encuentra. Sin embargo, existen dos momentos en el que se abre y logra integrarse con el exterior: mediante su ingreso jerárquico de doble altura que conecta con la "plaza" interior (dotándola de un espacio de encuentro que no puede ocurrir en el exterior) y mediante la terraza que logra la única conexión visual hacia el exterior.

Figura 5.26

Fachada principal del Mercado de San Antón

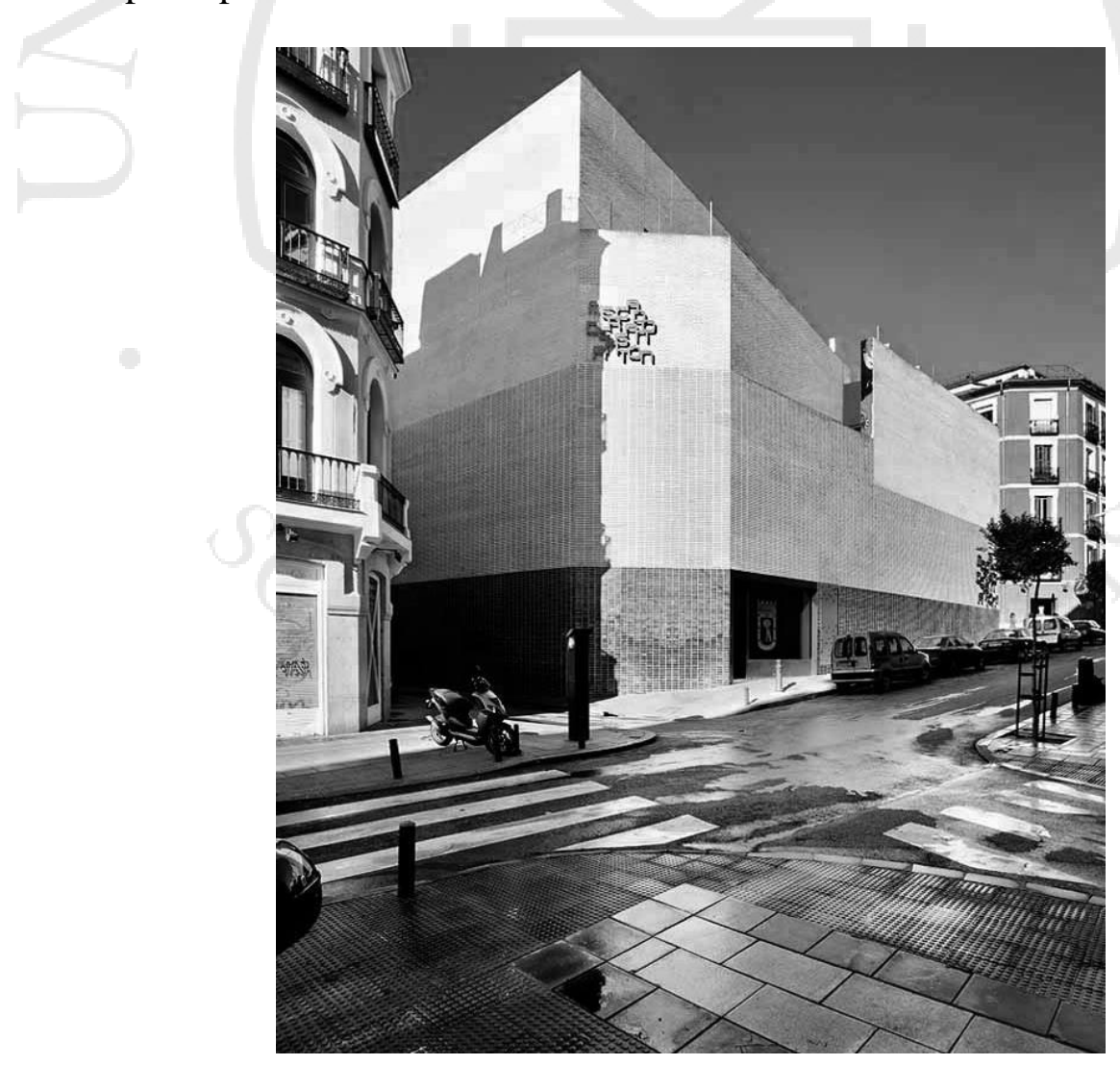

Nota: Imagen editada en blanco y negro

Fuente: Mercado de San Antón (s.f.) BJC Architect Community

En: architect.bjc.es 


\subsubsection{Tipología}

Figura 5.27

Esquema de tipología según distribución de puestos

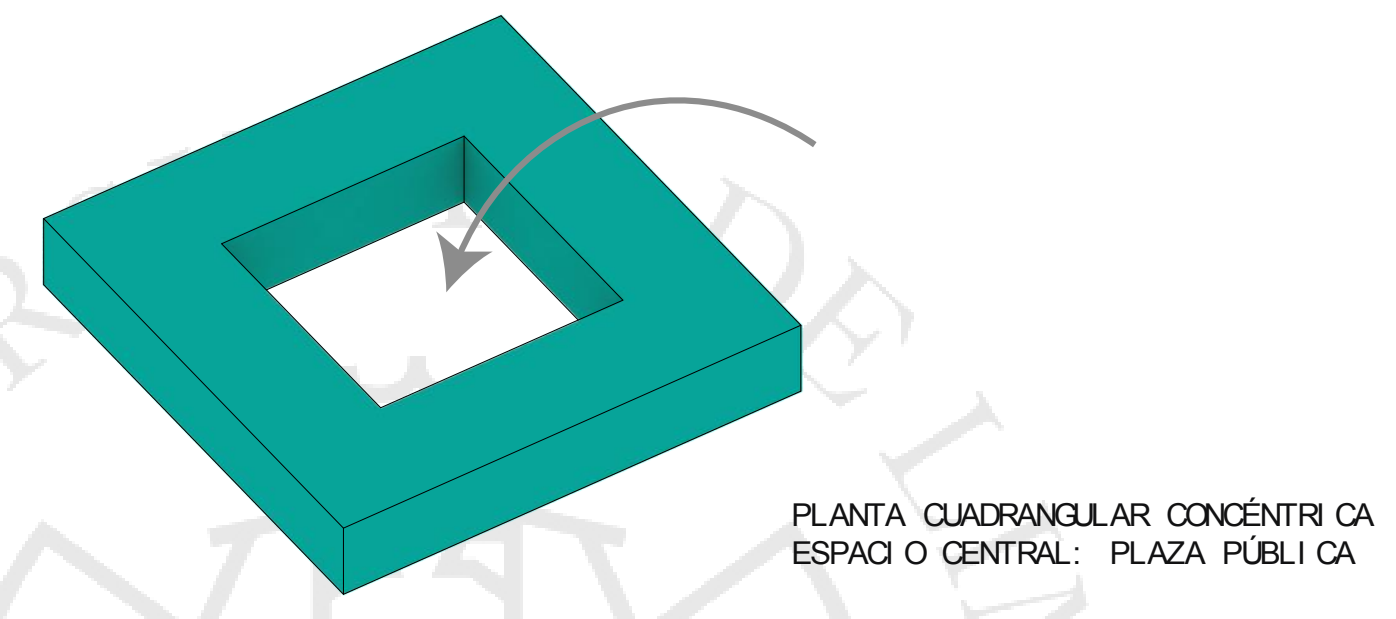

Fuente: elaboración propia

Según la distribución y disposición de los puestos de venta e infraestructura del Mercado de San Antón, se puede considerar que guarda una tipología de planta cuadrangular concéntrica, que según María Dolores Zavala consta de una organización perimetral alrededor de un espacio central que cumple la solución de plaza de mercado. (Zavala Sánchez, 2013, p. 67) 


\subsubsection{Programa}

\section{Cuadro de áreas}

Tabla 5.4

Cuadro de áreas del Mercado de San Antón

\begin{tabular}{|c|c|c|c|c|}
\hline PROGRAMA & AREA (m2) & PORCENTAJE & TOTAL & \\
\hline ÁREA DE VENTAS & & & 231.42 & $\mathbf{m} 2$ \\
\hline Carnes & 63.8 & $1.78 \%$ & & \\
\hline Aves & 37.9 & $1.06 \%$ & & \\
\hline Pescados / Mariscos & 56.02 & $1.56 \%$ & & \\
\hline Embutidos & 0 & $0.00 \%$ & & \\
\hline Frutas & 36.85 & $1.03 \%$ & & \\
\hline Verduras & 36.85 & $1.03 \%$ & & \\
\hline Abarrotes & 0 & $0.00 \%$ & & \\
\hline Lácteos & 0 & $0.00 \%$ & & \\
\hline Licorería & 0 & $0.00 \%$ & & \\
\hline SERVICIOS COMPLEMENTARIOS & & & 2122.2 & $\mathbf{m} 2$ \\
\hline Juguería / Bares / Café / Restaurantes & 593.6 & $16.58 \%$ & & \\
\hline Otros servicios públicos & 1528.6 & $42.70 \%$ & & \\
\hline SERVICIOS GENERALES & & & 1226.2 & $\mathbf{m} 2$ \\
\hline Almacenes refrigerados & 0 & $0.00 \%$ & & \\
\hline Almacenes & 486.1 & $13.58 \%$ & & \\
\hline Descarga & 587.7 & $16.42 \%$ & & \\
\hline Residuos & 0 & $0.00 \%$ & & \\
\hline Administración & 0 & $0.00 \%$ & & \\
\hline Oficinas & 0 & $0.00 \%$ & & \\
\hline SSHH & 85.3 & $2.38 \%$ & & \\
\hline Otros servicios privados & 67.1 & $1.87 \%$ & & \\
\hline TOTAL & & $100 \%$ & 3579.82 & $\mathbf{m} 2$ \\
\hline
\end{tabular}

Nota: No se considera el área de estacionamiento Fuente: elaboración propia 
FRUTAS

VERDURAS

ABARROTES

\section{LACTEOS}

JUGUERÍA/BAR / CAFÉ / RESTAURANTES

LICORERIA

ALMACENES REFRIGERADOS

ALMACENES

DESCARGUE

RESIDUOS

ADM I N I STRAC I ÓN

OFICINAS

SSHH

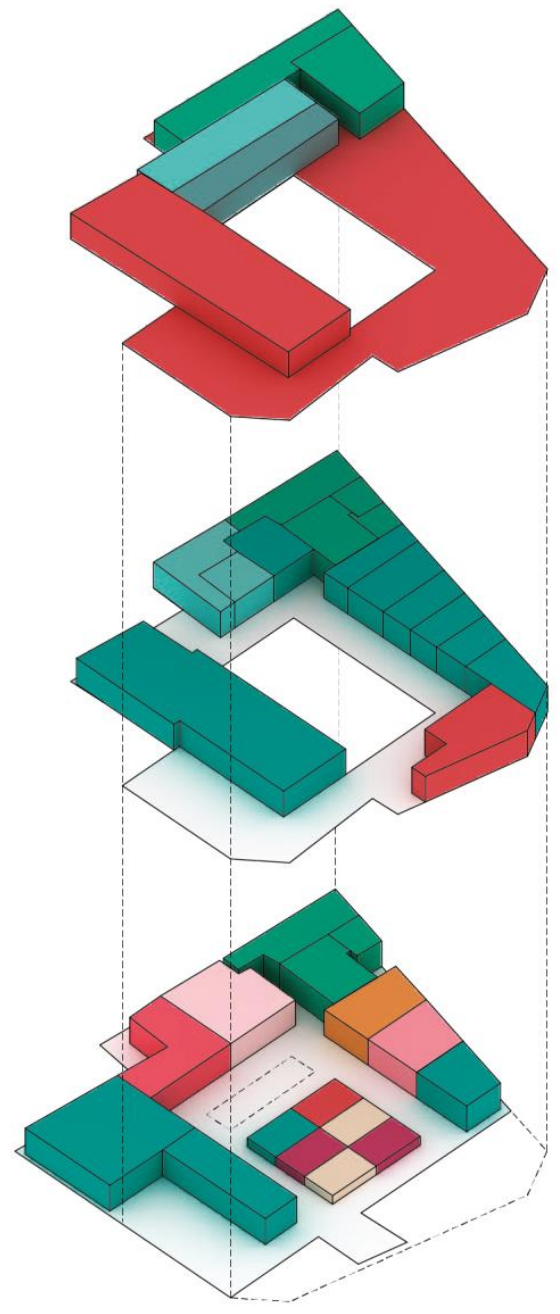

TERCER PISO

SEGUNDO PISO

PRIMER PISO

OTROS SERVICIOS PÚBLICOS

OTROS SERVICIOS PRIVADOS

\section{$P R O G R A M A$}

MERCADO DE SAN ANTÓN

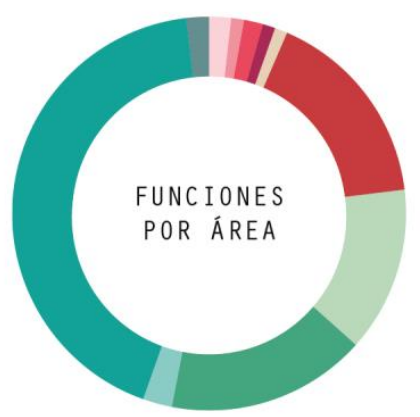




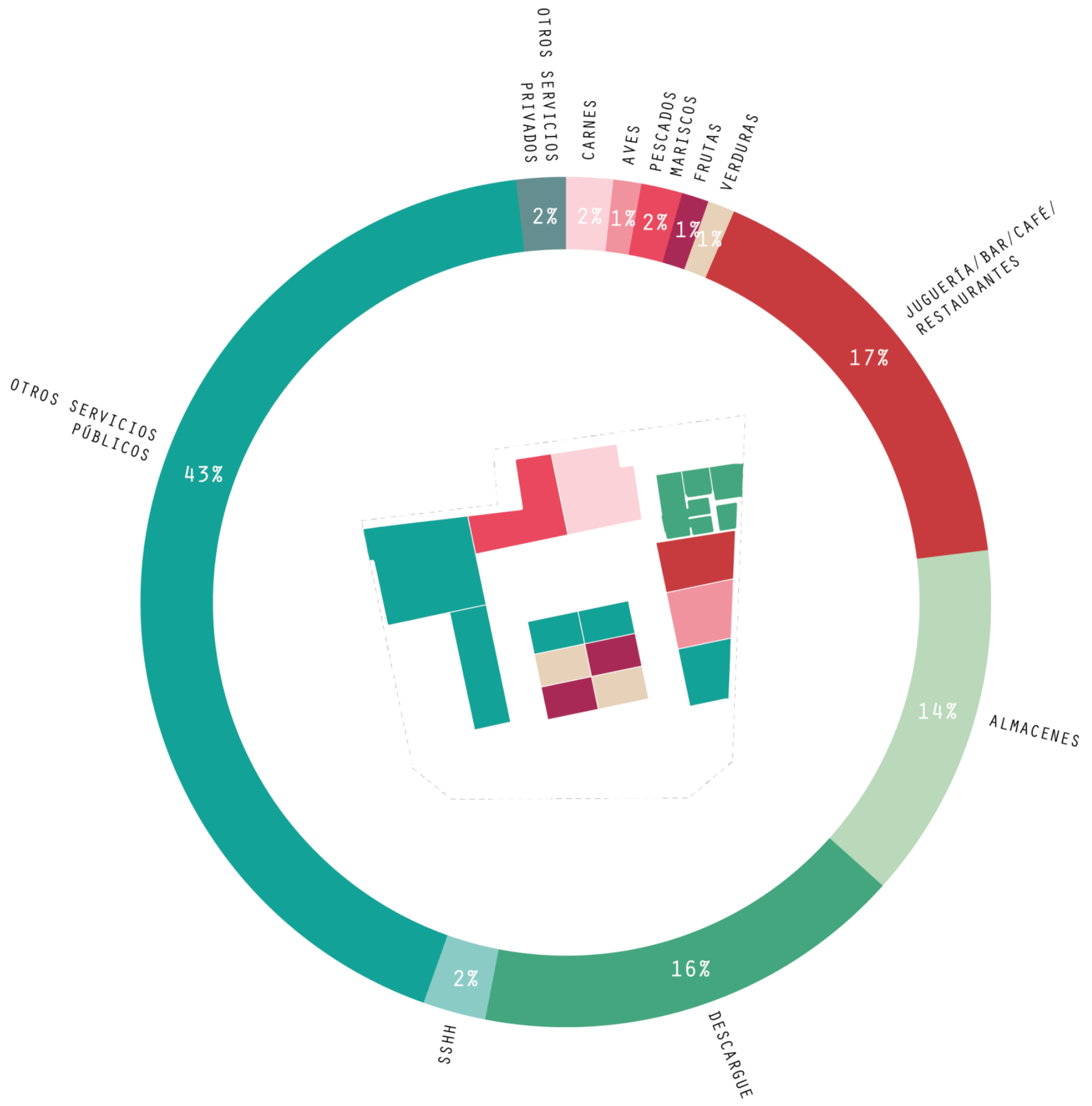

PROGRAMA

MERCADO DE SAN ANTÓN 


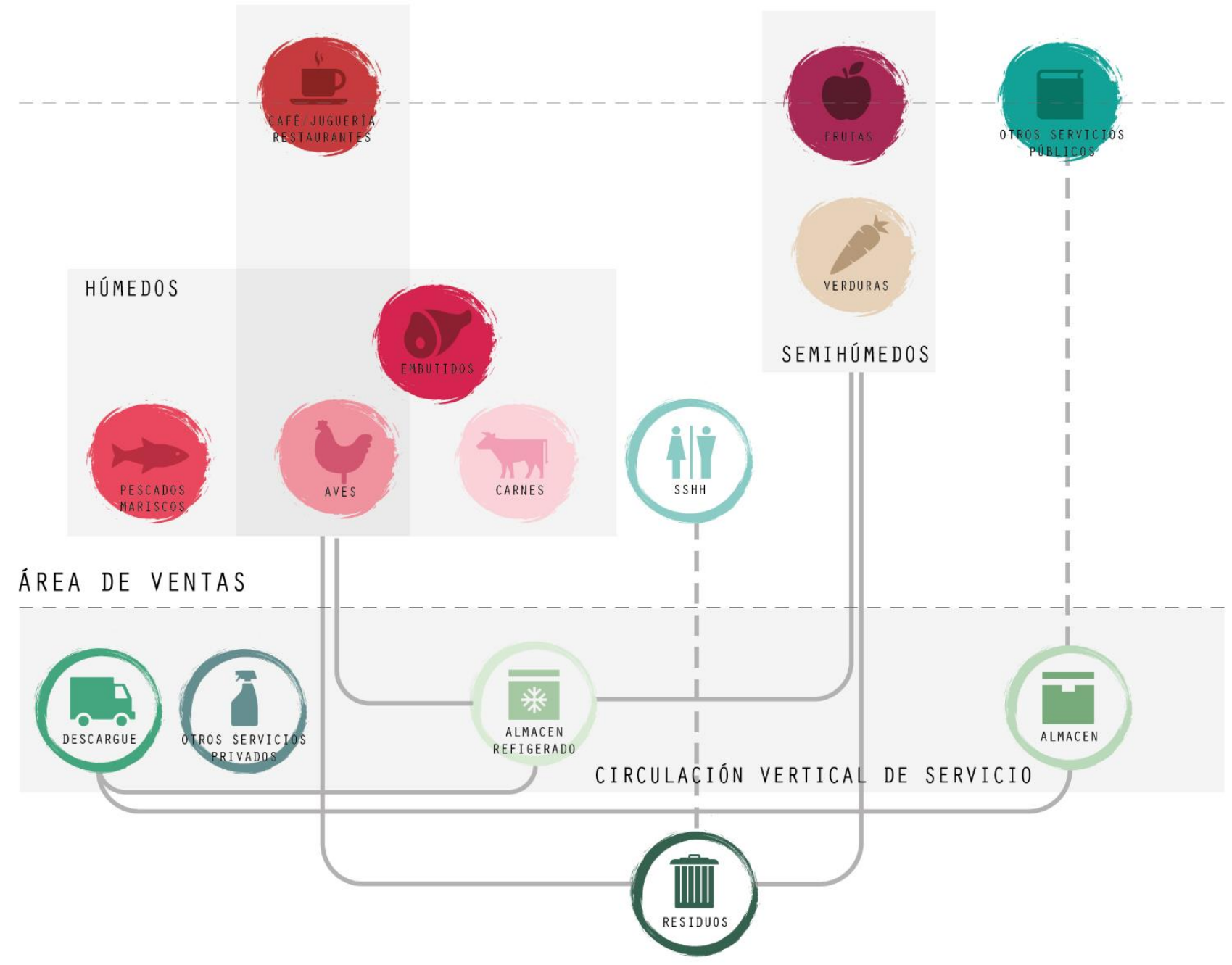

ÁREA DE SERVICIOS GENERALES

O R G A N I GRAMA MERCADO DE SAN ANTÓN

RELACIÓN DIRECTA

$=--\quad$ RELACIÓN INDIRECTA GRUPO DE PRODUCTOS 
El Mercado de San Antón distribuye su programa en siete niveles. En los sótanos se encuentran los estacionamientos y el área de servicios generales como los almacenes, el abastecimiento, y el descargue. Asimismo, se ubica en el primer sótano un primer servicio complementario, el supermercado.

En el primer piso, con conexión directa hacia la calle, se ubican los puestos de venta de alimentación fresca (húmedos, semihúmedos y secos) En cambio en el segundo piso se ubican más servicios complementarios como espacios culturales (galería de arte) y restaurantes. En el caso del tercer nivel, se ubica la terraza cafetería y otros servicios públicos.

En cuanto a las relaciones del proyecto, se puede observar que los tipos de espacio con una relación directa con el ingreso del cliente son los servicios complementarios (supermercado y restaurantes). Una vez ingresado al mercado, el primer contacto es con la "plaza" central, que involucra puestos abiertos de productos alimenticios frescos como verduras y frutas. Los demás servicios están dispuestos en todo el edificio alrededor del área concéntrica. En cuanto a la conexión con los niveles de abastecimiento, descargue y almacenes, el mercado está dotado de dos circulaciones verticales, de los cuales uno está conectado directamente con el área de servicios generales. 

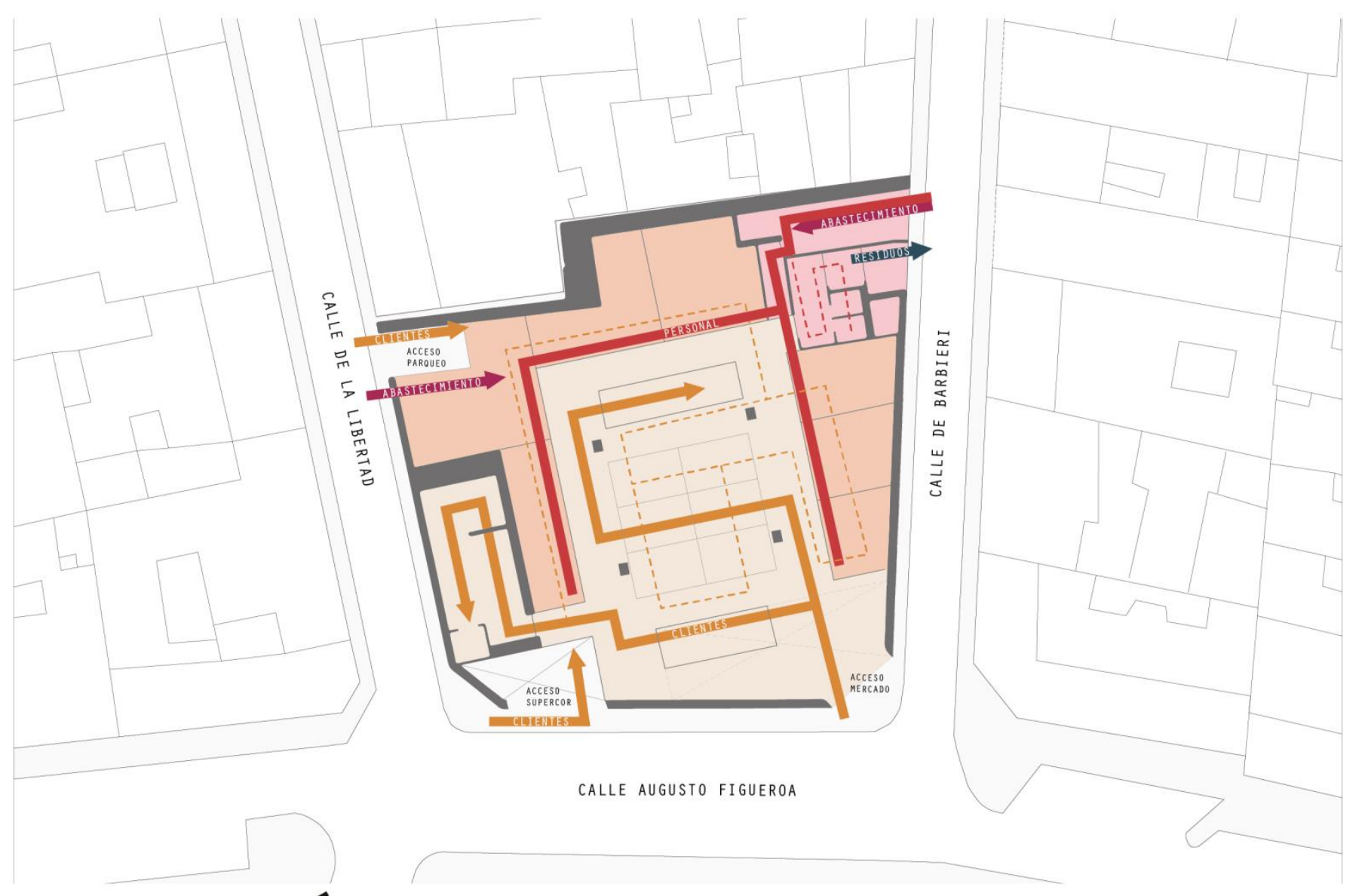

\section{RELACIÓN ESPACIAL}

(1) $\begin{array}{llc}0 & 5 & 10 \\ 1 & 1 & 1\end{array}$

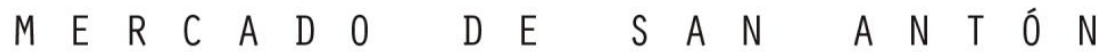

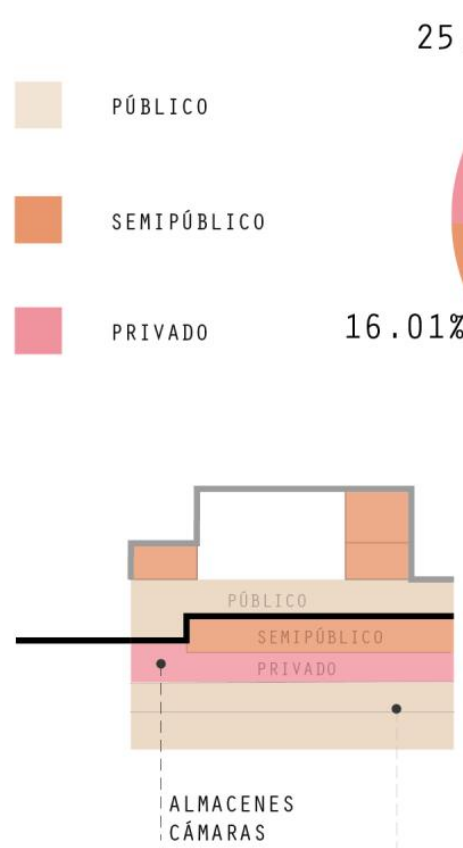

PORCENTAJE DE

USO PÚBLICO/

PRIVADO
$58.51 \%$
FLUJO INTENSO DE CLIENTES HORARI 0 10:00-22:00

FLUJO MODERADO DE CLIENTES HORARIO $10: 00-24: 00$

- Flujo intenso de personal HORARI 0 9:00-24:00

-. FlujO MODERAdO dE PERSONAL HORARIO 9:00-24:00

- FlujO de abastecimiento

ELIMINACIÓN DE RESIDUOS 


\subsubsection{Espacio}

El Mercado de San Antón tiene cuatro accesos diferenciados en uso: dos accesos peatonales para el público, un acceso vehicular tanto para el público como para el abastecimiento y, por último, un acceso para el personal y el abastecimiento menor.

En cuanto a los flujos, los clientes principalmente circulan en el espacio central, al ser utilizado como punto de encuentro. Por otro lado, existen circulaciones verticales exclusivas para este usuario. En cuanto al movimiento del personal, este sucede por medio de la circulación vertical exclusiva que tienen. Asimismo, es utilizada para la eliminación de residuos por la entrada/salida de servicio y personal.

Figura 5.28

Interior del Mercado de San Antón

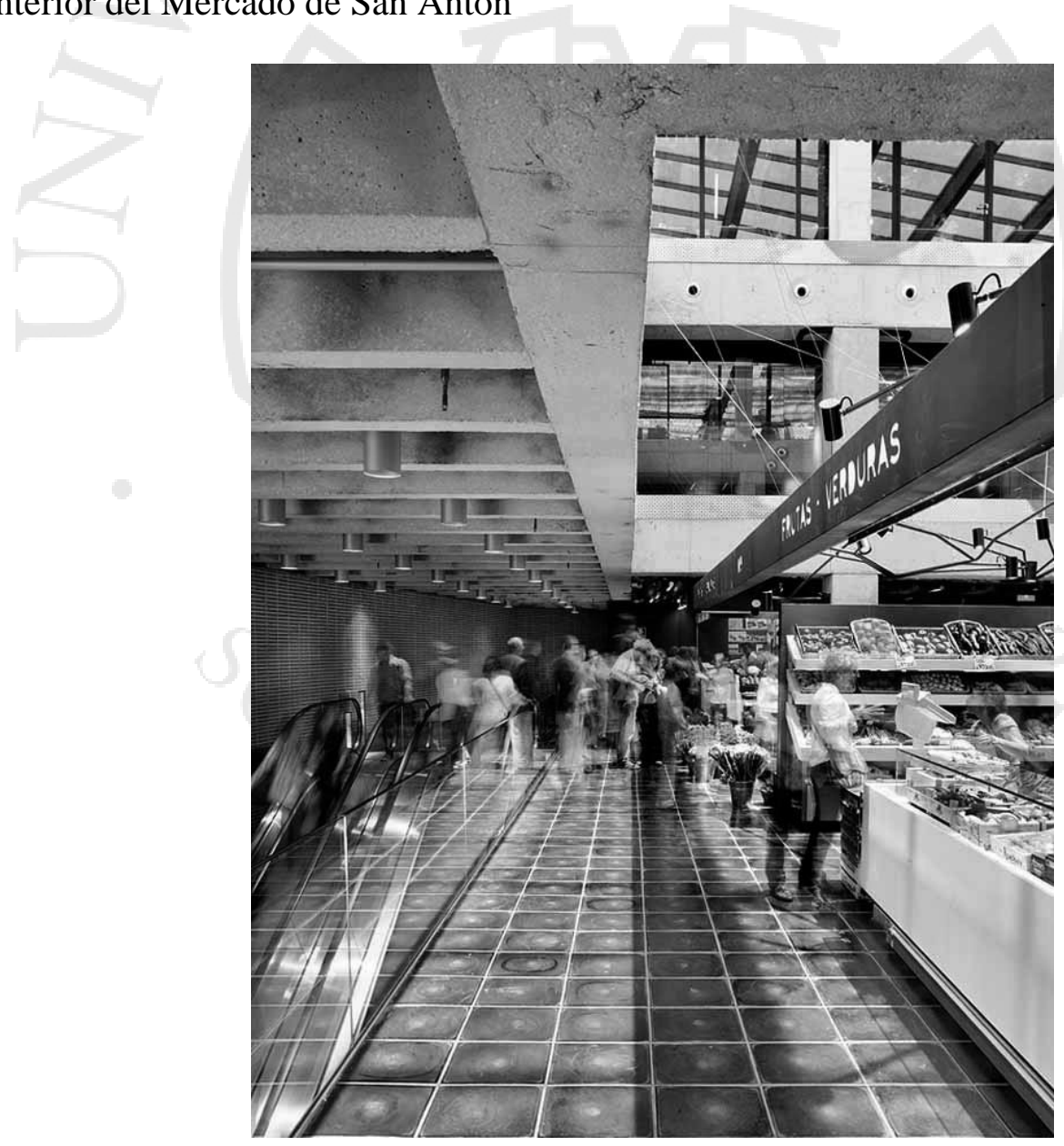

Nota: Imagen editada en blanco y negro

Fuente: Mercado de San Antón (s.f.)

En: estudioataria.com 


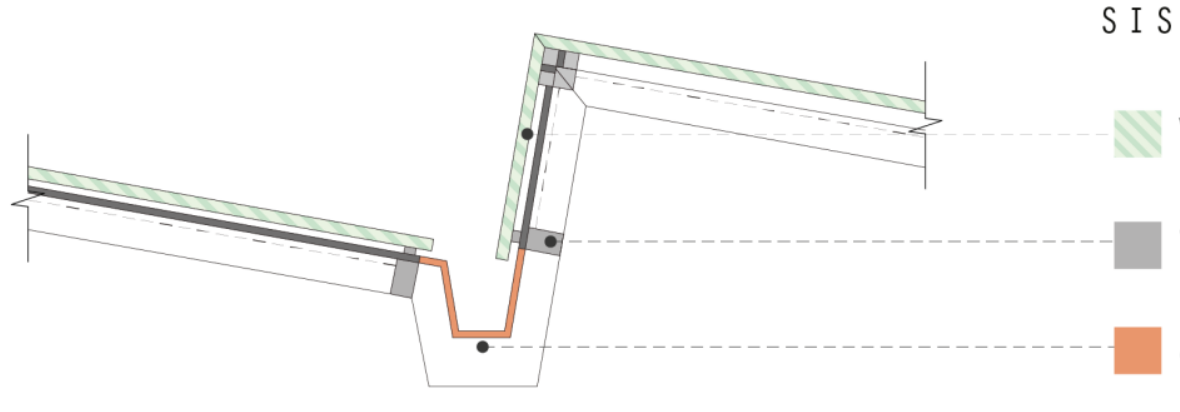

S I STEMA CONSTRUCT IVO

VIDRIO DE PLACAS SOLARES

JUNTA DE ACERO PARA SUJECIÓN DE PLACAS SOLARES

CARTELAS DE SUJECIÓN DE CANALÓN

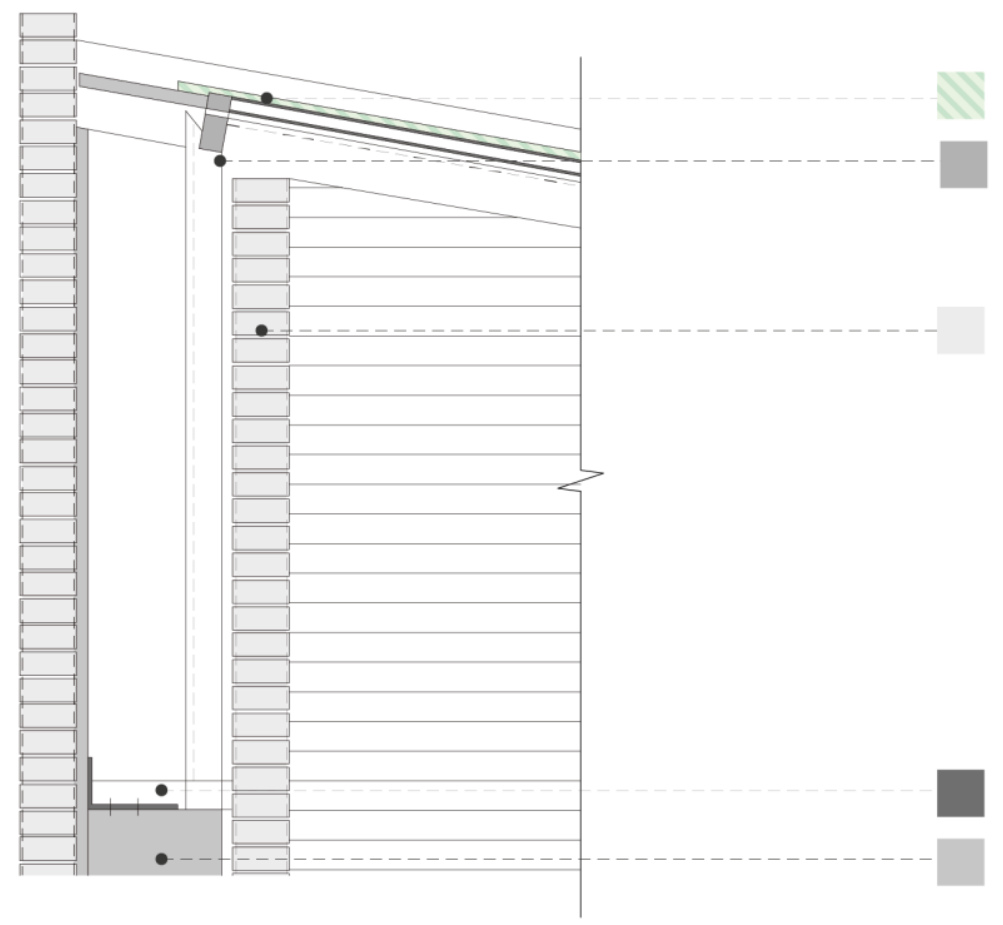

VIDRIO DE PLACAS SOLARES

JUNTA DE ACERO PARA SUJECIÓN DE PLACAS SOLARES

$1 / 2$ PIE DE LADRILLO CV

CHAPÓN DE ACERO GALVANIZADO $E=6 M M$

CONCRETO ARMADO

\section{INNOVACIÓN TECNOLÓGICA}

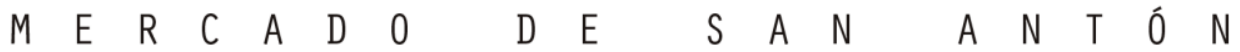
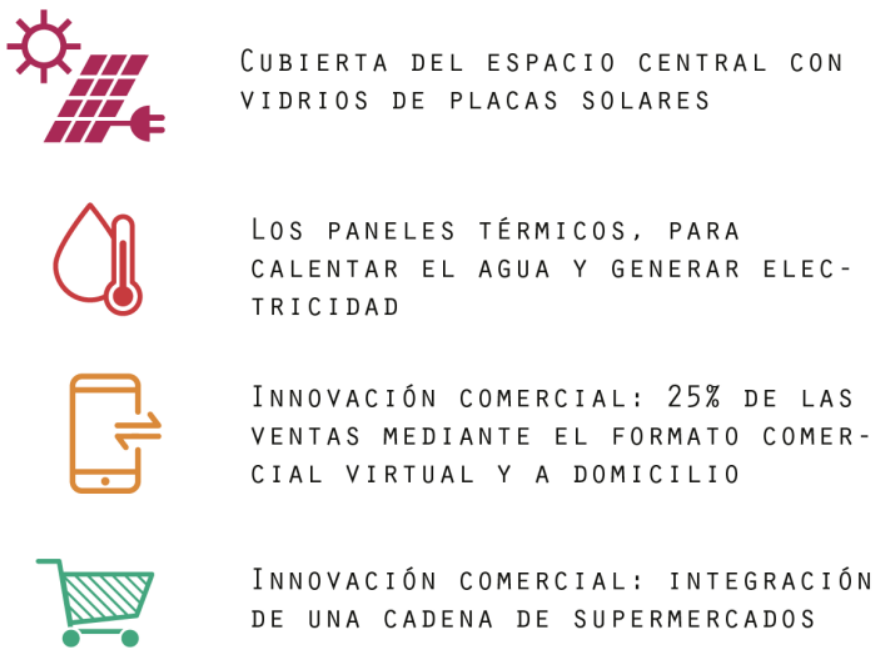

INNOVACIÓN COMERCIAL: INTEGRACIÓN

DE UNA CADENA DE SUPERMERCADOS 


\subsubsection{Tecnología}

El Mercado de San Antón, utiliza dos materiales en la fachada: la base del edificio con basalto y el resto con ladrillo macizo de tejar. Estos materiales no cumplen una función constructiva, por el contrario, cubren la intención de integrarse al paisaje urbano el proyecto.

En cuanto al aporte ecológico del mercado, este utiliza en el techo de la parte central del mercado para iluminar, una claraboya de vidrio con un sistema de paneles solares para captar y utilizar energía renovable.

Por otro lado, en cuanto a innovación comercial incluyen dos propuestas distintas: la utilización de un formato comercial virtual y a domicilio (mediante aplicaciones) e integrar una cadena comercial de autoservicio.

Figura 5.29

Claraboya de vidrio con paneles solares

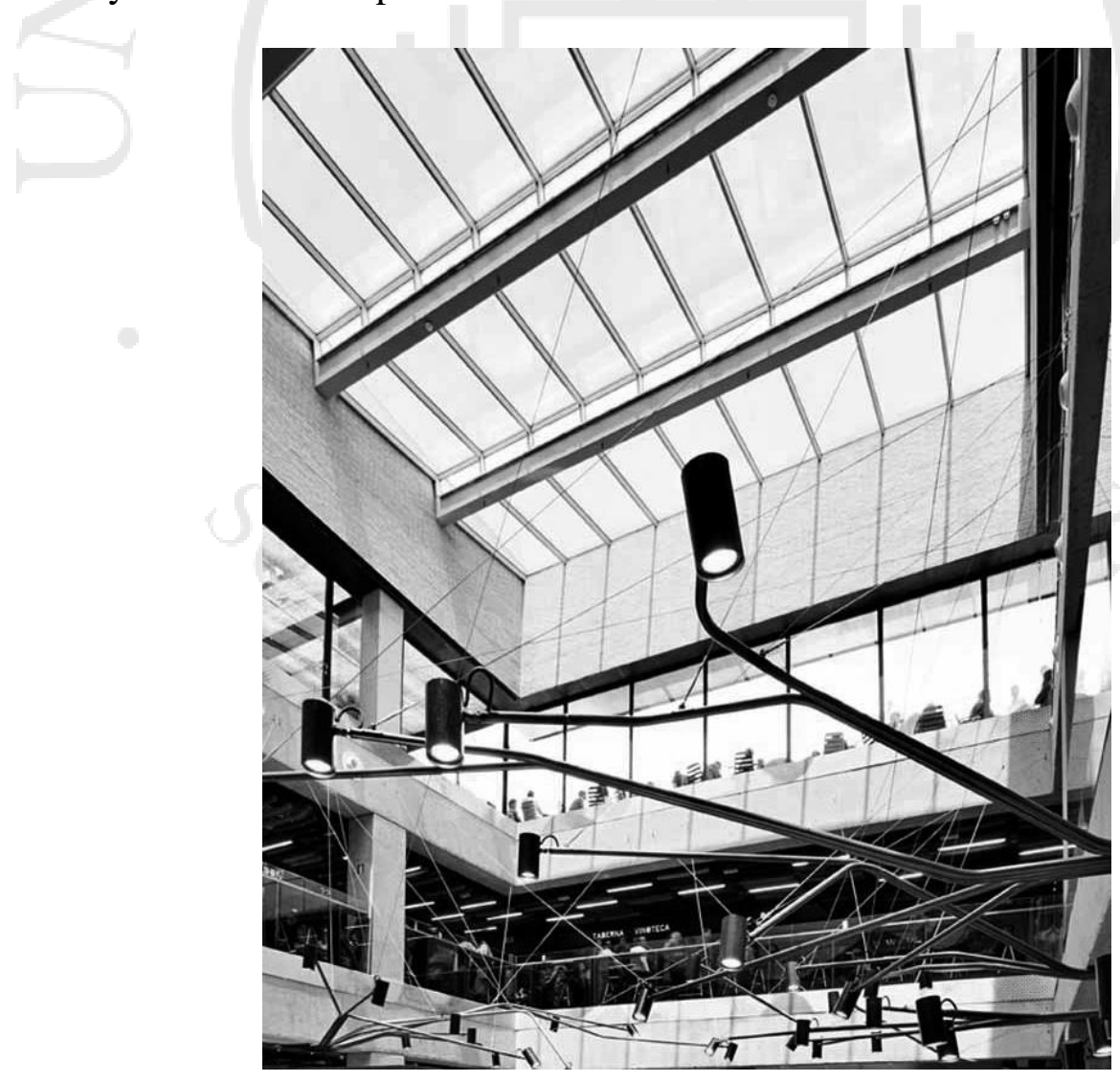

Nota: Imagen editada en blanco y negro

Fuente: Mercado de San Antón (s.f.)

En: estudioataria.com 


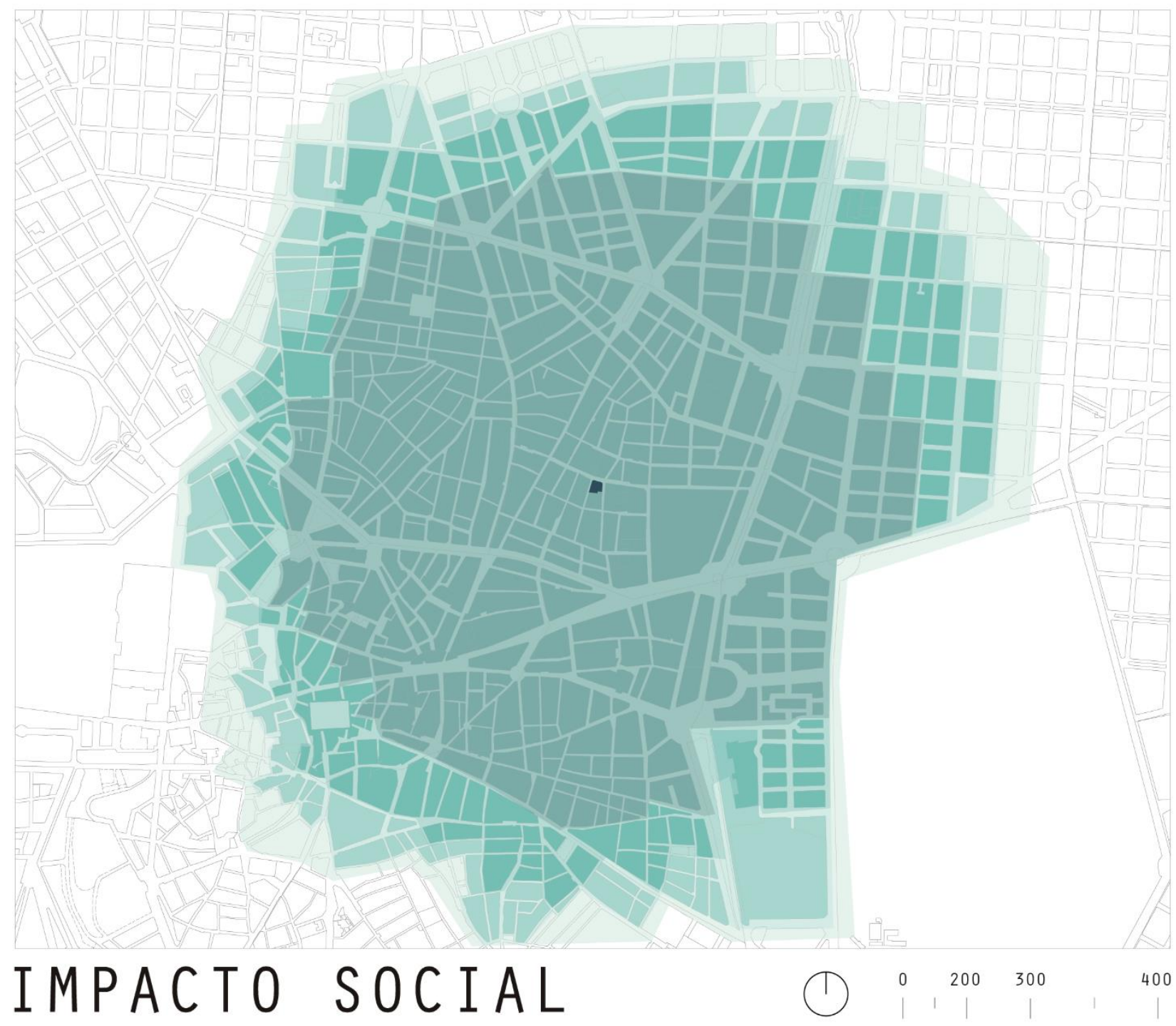

\section{MERCADO DE SAN ANTÓN}

ÁREA DE INFLUENCIA DIRECTA

RADIO 1 KM APROX

ÁREA DE INFLUENCIA DIRECTA

ACCESO A TRANSPORTE COLECTIVO

ÁREA DE INFLUENCIA DISPERSA

DILUYE EN EL RESTO DE LA CIUDAD 


\subsubsection{Impacto social}

En cuanto al impacto social de este mercado, el principal impacto ha sucedido con respecto a la identidad del lugar y a la recuperación de la memoria del mercado de abastos del barrio.

A pesar a haber significado un cambio y reactivación de la zona de Chueca, la falta de identificación por parte de los vecinos, para con el mercado, ha generado una desvinculación de los habitantes próximos con el mismo.

Esto responde a la nula presencia de comerciantes anteriores, que el día de hoy se limita a alquilar sus locales a franquicias que no involucran productos locales. "Un mercado de abastos no es una sociedad artificial y anónima que se reproduce homogéneamente como una franquicia o un supermercado de barrio. El mercado, y los once comerciantes adjudicatarios del mercado ya han tomado conciencia de ello; un mercado tiene que tener raíces en el espacio social para ser reconocido como tal por sus clientes, si no, no funciona.” (Robles, 2014)

Figura 5.30

Movimiento del Mercado de San Antón

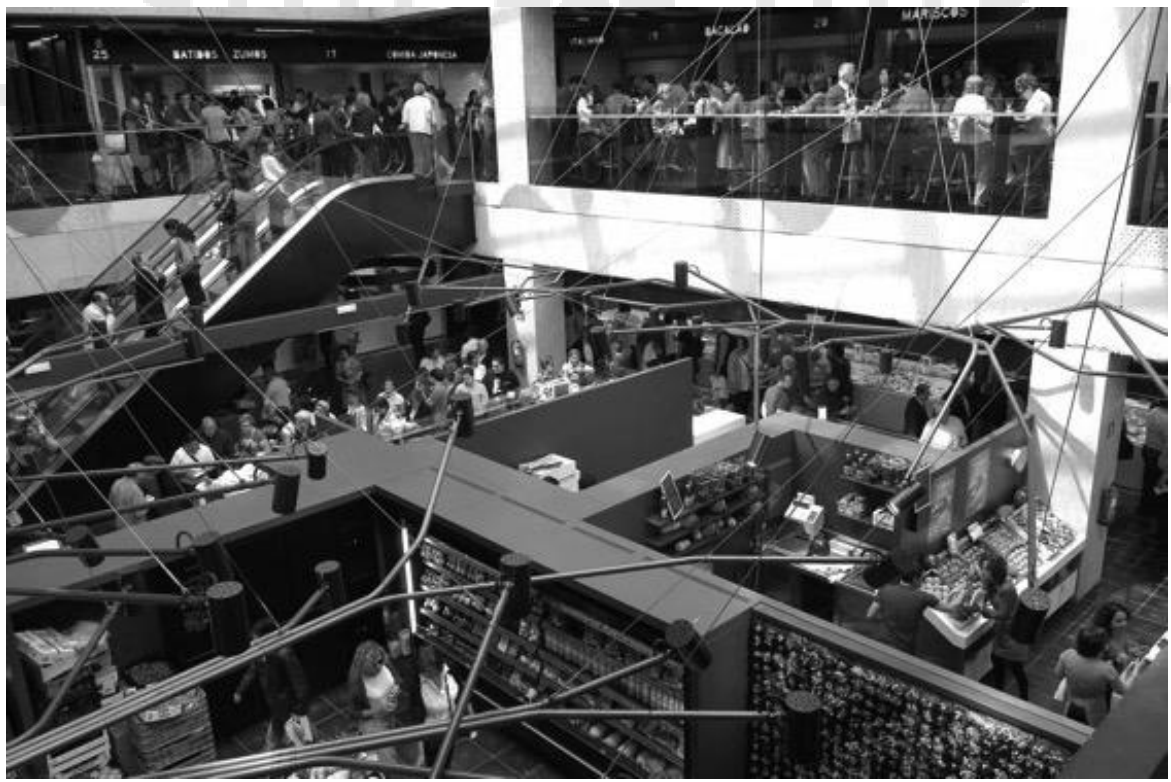

Nota: Imagen editada en blanco y negro Fuente: Mercado de San Antón (s.f.)

En: madrid.es 


\subsection{Mercado Central de Florencia}

\subsubsection{Ubicación}

Arquitecto: Arcea Asóciate

\section{Equipo:}

Gargallo Ingegneria

Eléctrico: Clanis Progetti

Sistema mecánico: Studio Lotti

Estructurales: Ragello Ingegneria, Ingeniero Roberto Nocentini e ingeniero Andrea Cimarri

Año: 1974

Cliente: privado (Edilvannucchi SRL)

Ubicación: Piazza del Mercato Centrale dell'Ariento, Via dell'Ariento, 50123 Firenze, Italia

Categoría: mercado privado

Terreno: $2600 \mathrm{~m} 2$

Figura 5.31

Mercado Central de Florencia

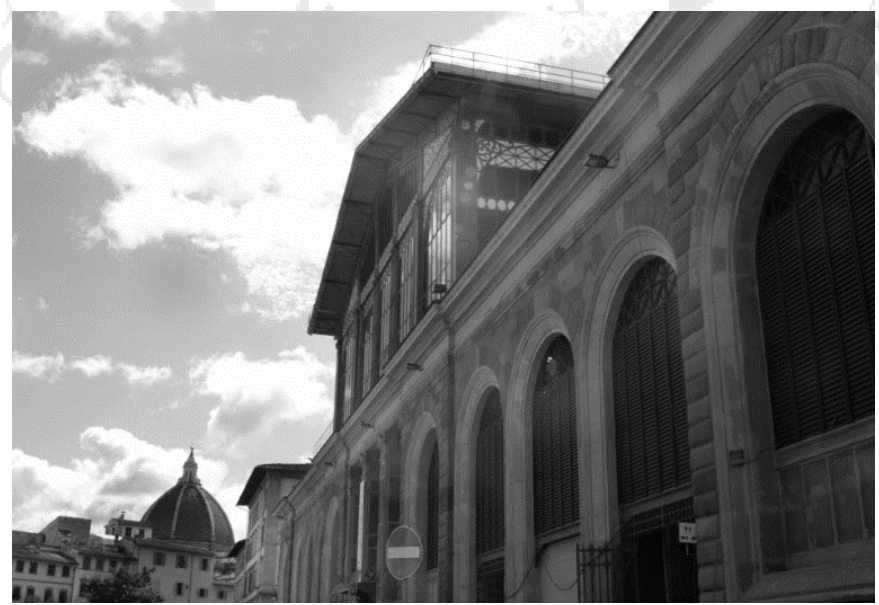

Nota: Imagen editada en blanco y negro

Fuente: Mercado Central de Florencia (s.f.)

En: mercatocentralefirenze.wordpress.com 


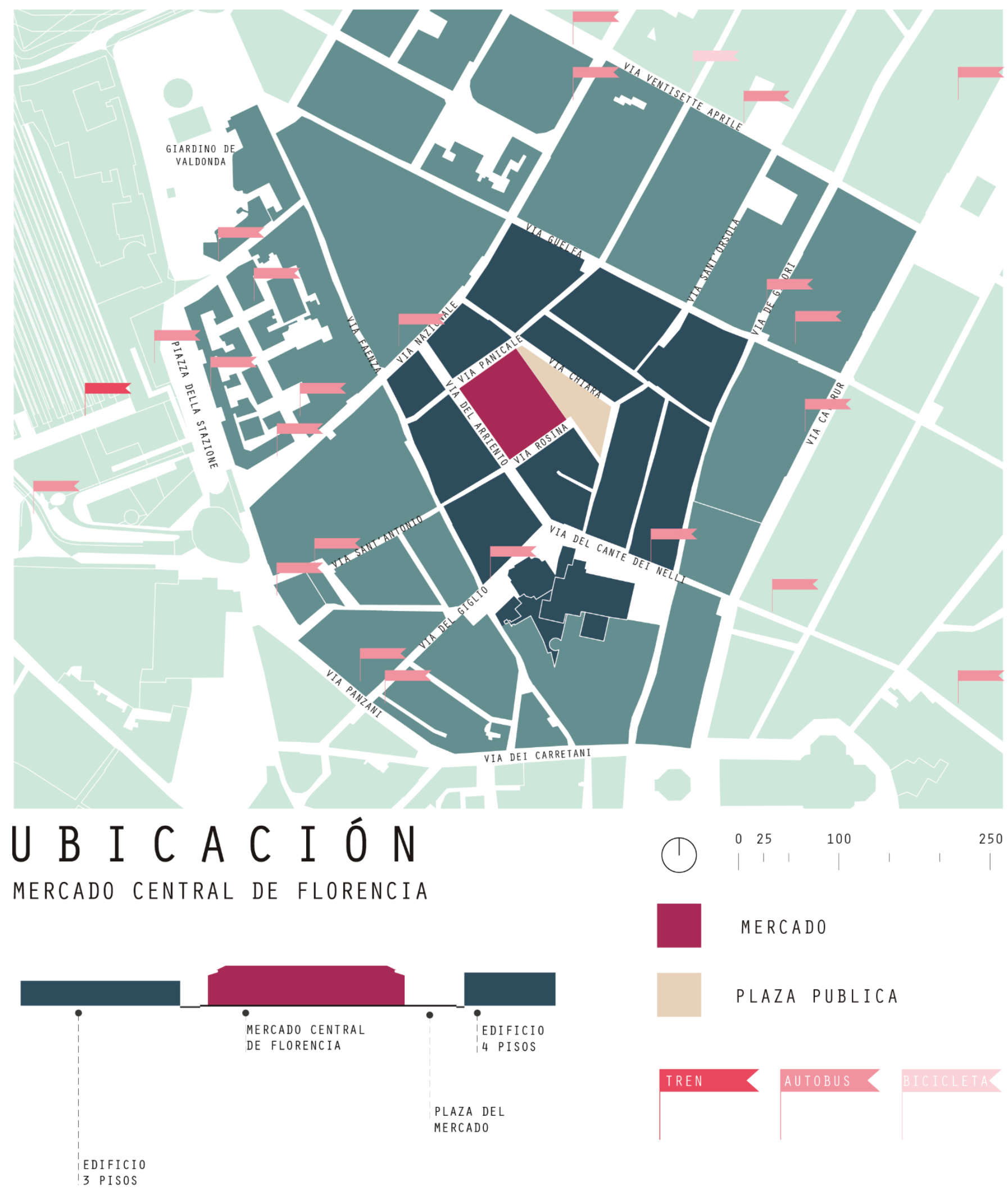


El Mercado Central de Florencia, se encuentra frente a la Plaza del Mercado Central dell'Arriento, entre la vía dell'Arriento, la Via Rosina y Via Panicale, cerca de la Iglesia de San Lorenzo de los Medici, a la cual se conecta a través de una calle en la que funciona una extensión del tradicional mercado, donde se venden productor realizados en cuero.

Está ubicado en un lugar propio del renacimiento, periodo en el que Italia tenia a Florencia como la capital de la ciudad, por ello se considera que cumple una función muy importante y es que permite retroceder en el tiempo a aquel vibrante centro de la antigua Florencia.

Para llegar al mercado existen diversas paradas de bus, en Piazza Unità, en Via Nazionale, Via del Cante dei Nelli y otras paradas aledañas. Para llegar por tren, está relativamente cerca la estación Santa María Novella, a 900 metros. Y en realidad está relativamente cerca a todo, pues se ubica en el centro, a 5 minutos caminando de la Catedral, de la Plaza San Marco de la Fortaleza da Basso, 1'Academia, entre otros.

La sección de la ciudad refleja que el Mercado y la Plaza Central del Mercado, pretenden dar un respiro a la zona, asimismo se entiende que el arquitecto que lo remodeló respeta la altura permitida para el lugar y trabaja respecto a las dimensiones establecidas por el antiguo Mercado de Florencia. 


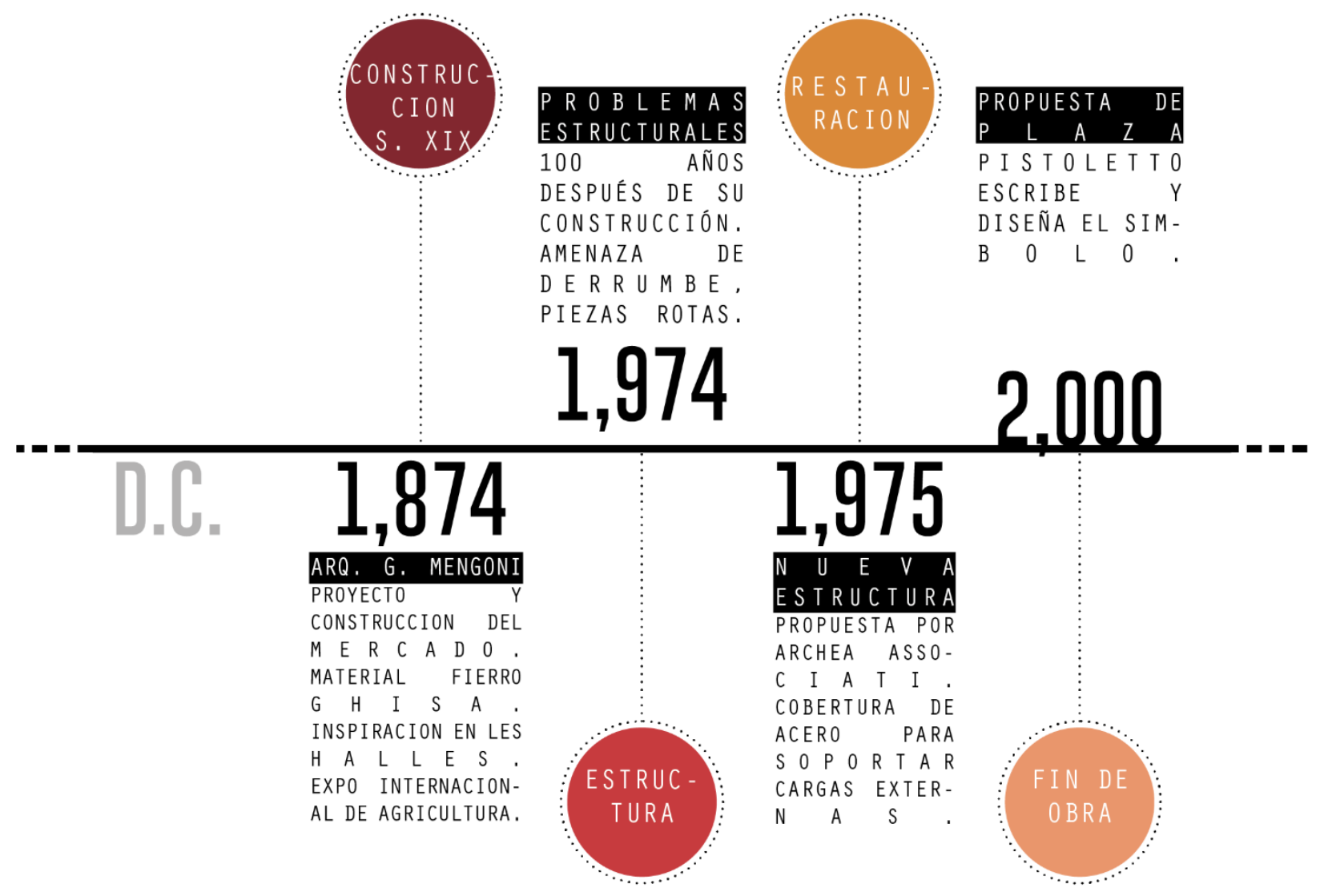

\section{H I S T 0 R I A}

MERCADO CENTRAL DE FLORENCIA

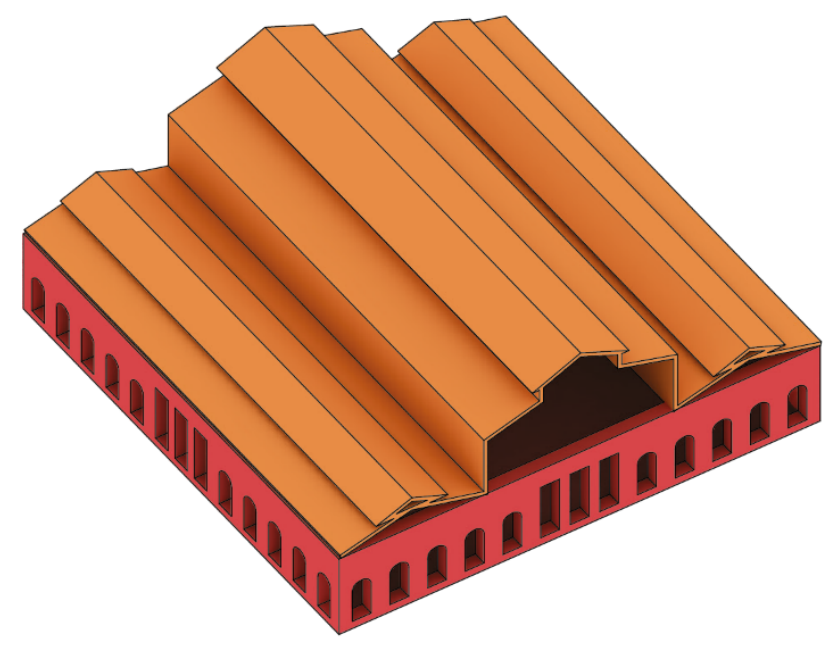




\subsubsection{Historia}

Es a raíz del crecimiento de la población que se destruye el viejo mercado de Florencia y por falta de abastecimiento se planificó la construcción de tres mercados, dentro de ellos el Mercado Central de San Lorenzo, del cual se encargó, el arquitecto Giuseppe Mengoni.

Alrededor de 1874, cuando Florencia era la capital de Italia, el arquitecto Giuseppe Mengoni, proyectó y construyó el Mercado Central de Florencia, con material de hierro característico de la época, con grandes ventanales en el piso superior y arcos en los lados laterales.

Fue construido para la inauguración de la exposición internacional de agricultura. Cien años más tarde, el marcado comienza a mostrar signos de problemas estructurales, algunos elementos rotos ponían en peligro tanto a los visitantes como a los vendedores del mercado, por ello se comienza la construcción de la nueva cubierta como elemento estructural, propuesta por Archea Associati. Una cobertura de acero para soportar grandes cargas externas, sin deteriorar las estructuras inferiores originales.

Figura 5.32

Mercado Central de Florencia

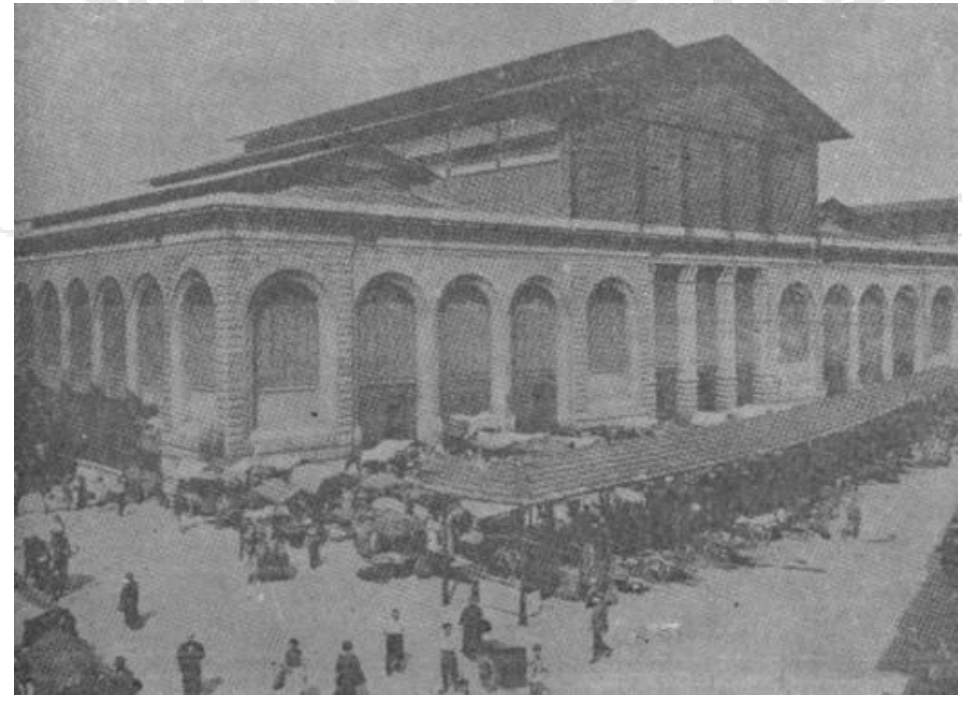

Fuente: Mercato di Firenze (s.f.)

En: Documento Storia e restauro della copertura di acciaio del Mercato Centrale di S. Lorenzo a Firenze 


\section{Toma de partido:}

El Mercado Central de Florencia nace bajo la restauración del Mercado de Florencia el cual en un inicio se construyó con estructuras metálicas, acorde al estilo de la época. La morfología corresponde a la continuación de estilo original del siglo XIX, y respetando las piezas originales se diseña una cobertura de tres naves, con estructuras metálicas. 


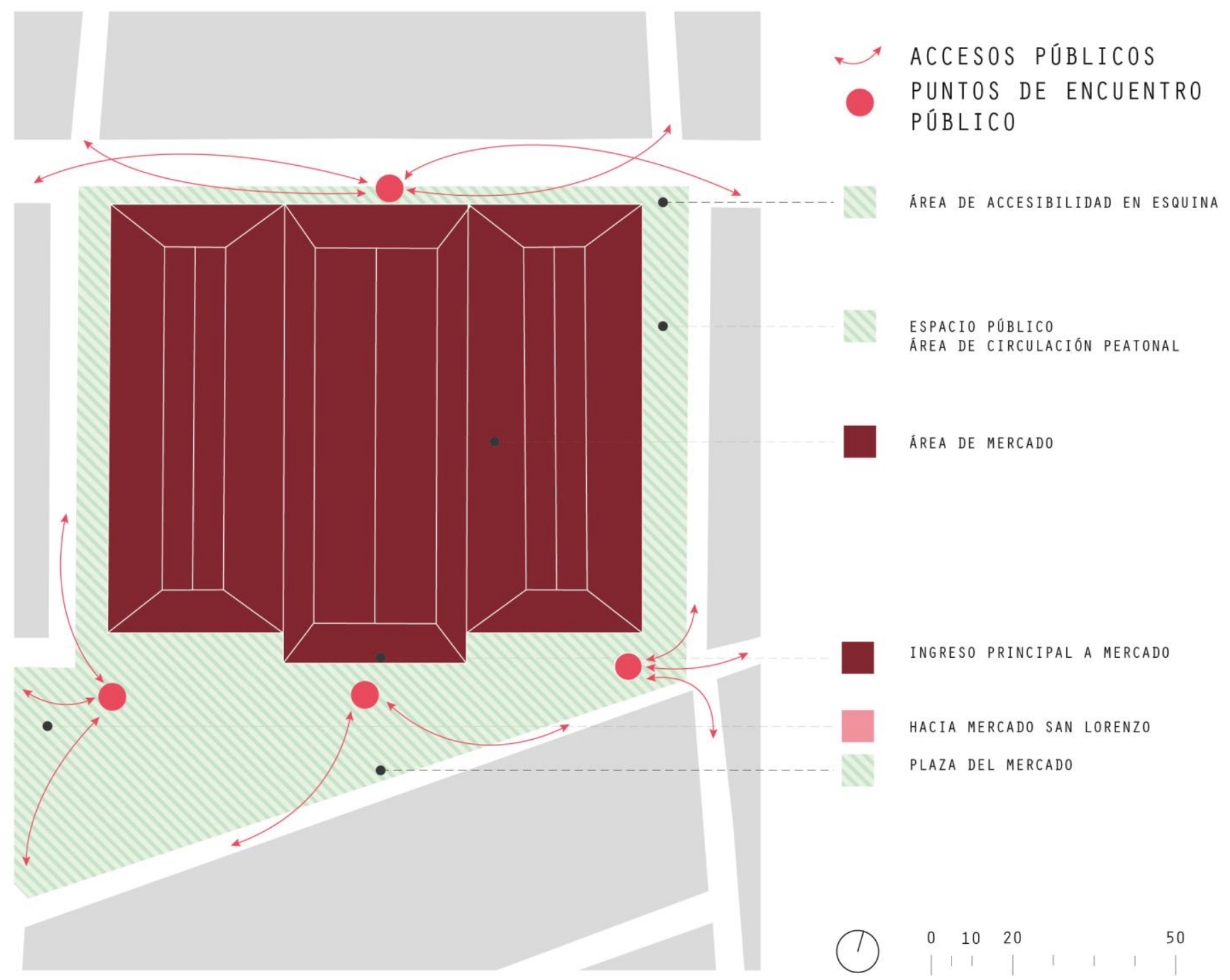

\section{RELACIÓN ENTORNO}

\section{MERCADO CENTRAL DE FLORENCIA}
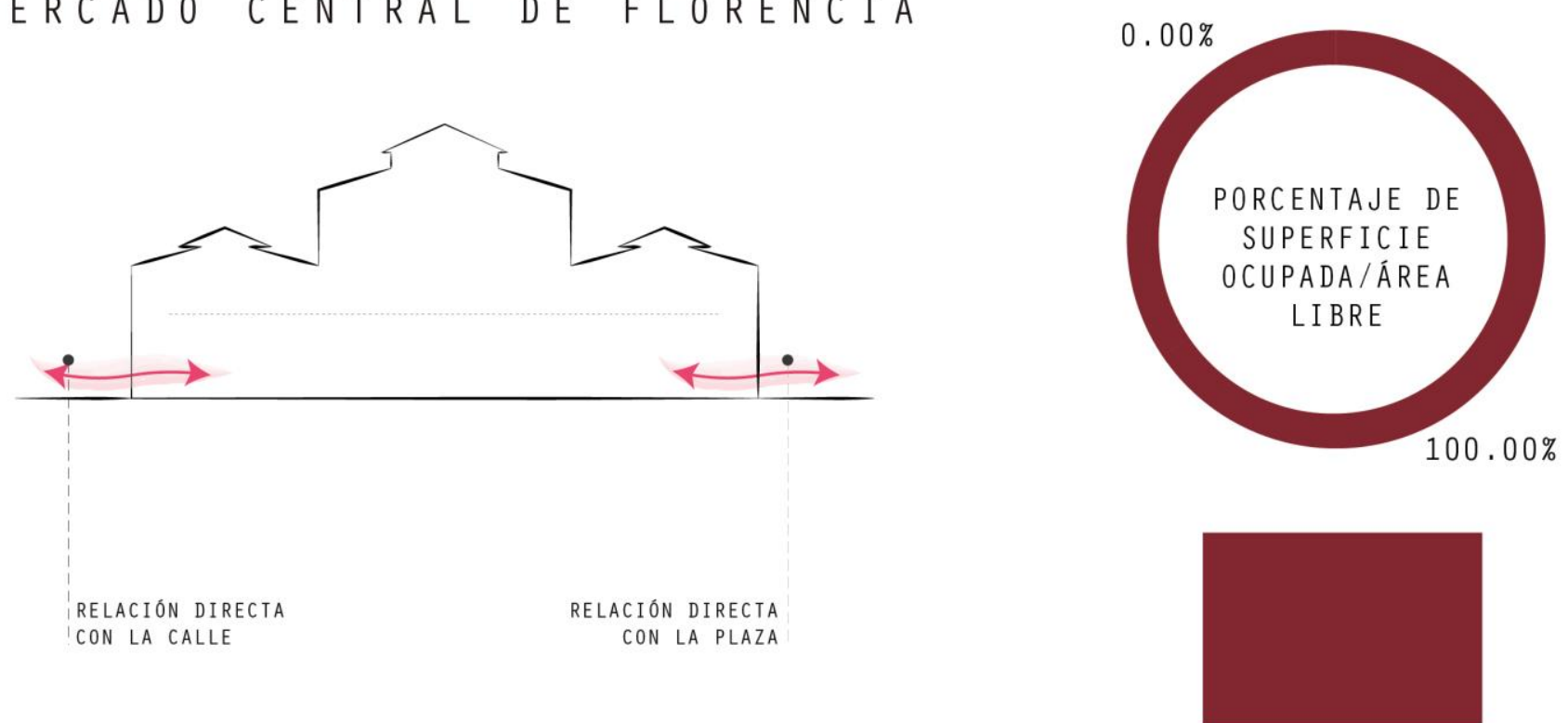


\subsubsection{Entorno}

El Mercado Central de Florencia se encuentra en el corazón del barrio de San Lorenzo, próximo a la catedral de la misma. Las calles del barrio se encuentran en constante movimiento y animación gracias a las paradas de los vendedores que ofrecen artículos diversos. La plaza del mercado, la cual se encuentra en frente al mercado, sirve de punto de convergencia de varias calles y convocar a usuarios a transitar por mercado.

La relación que tienen los ingresos con las calles contiguas son casi directas, su relación con la plaza del mercado es más marcada, pues al tener mayor área, congrega más gente y conecta con el mercado de ambulantes de San Lorenzo.

Figura 5.33

Ingresos al Mercado Central de Florencia

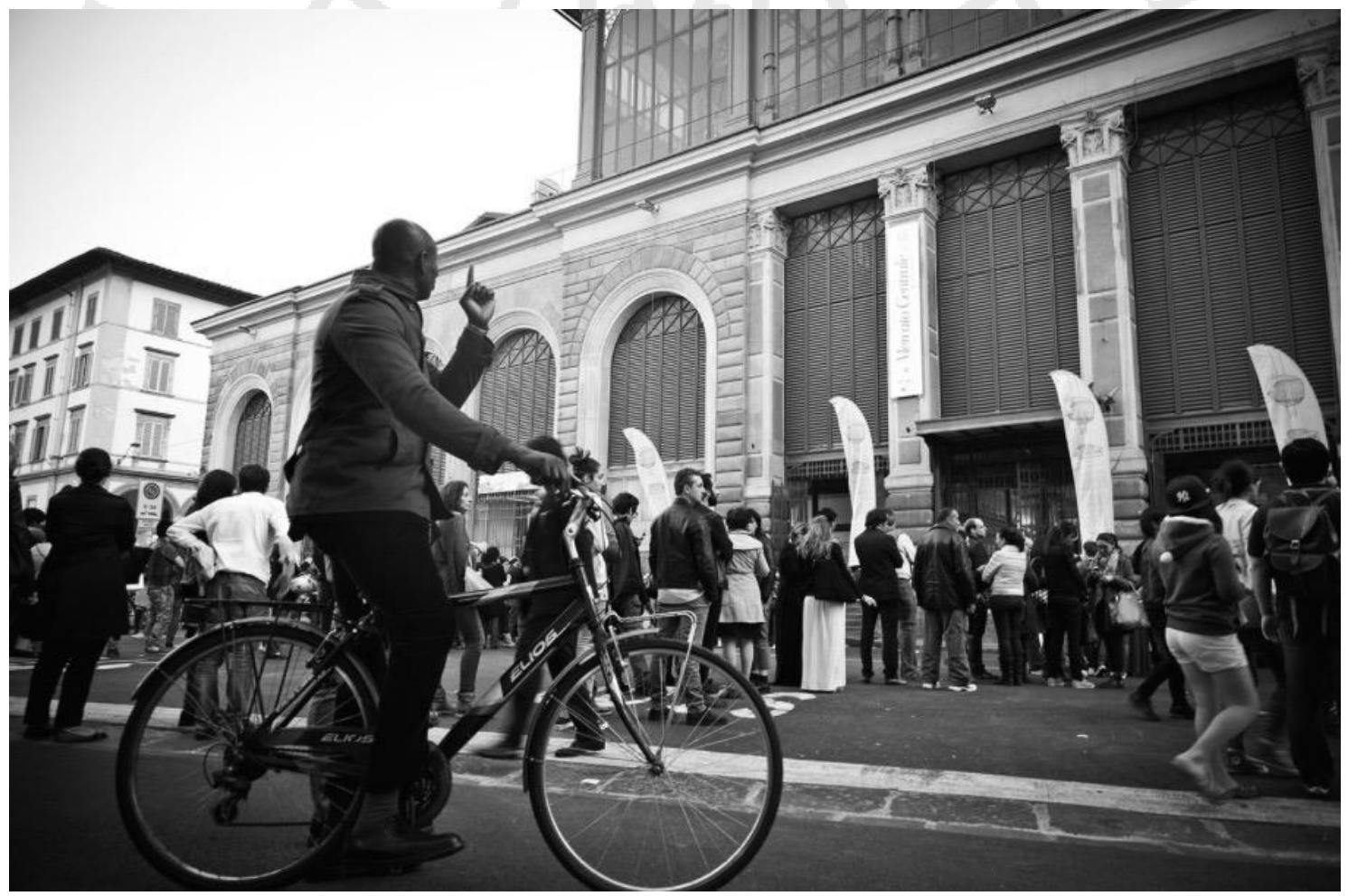

Nota: Imagen editada en blanco y negro

Fuente: Mercado Central de Florencia (s.f.)

En: mercatocentrale.it 


\subsubsection{Tipología}

Figura 5.34

Esquema de tipología según distribución de puestos

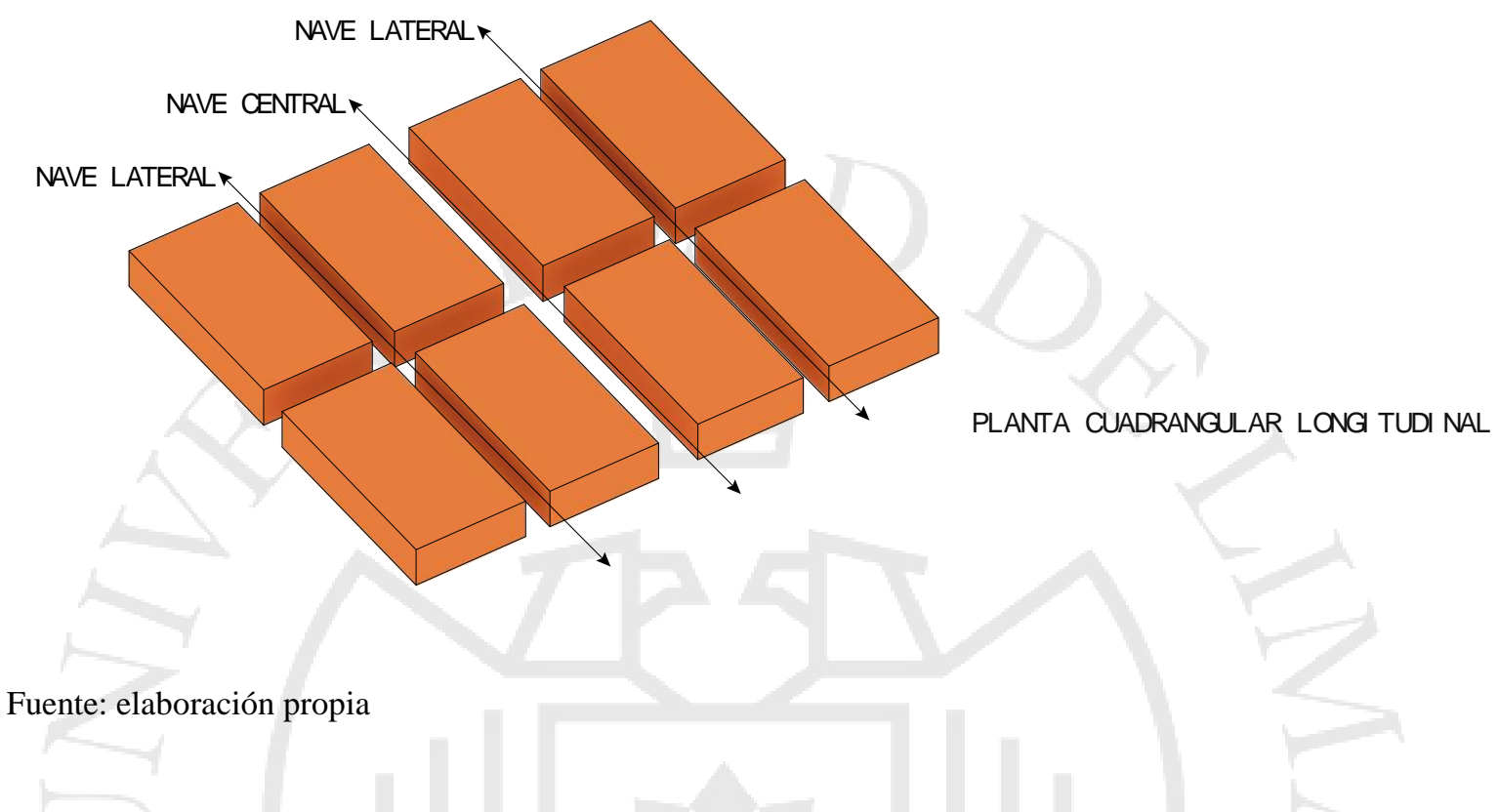

La tipología del Mercado Central de Florencia es considerada una planta cuadrangular longitudinal de una nave central principal y dos naves laterales de menor jerarquía. La disposición de puestos de venta se encuentra en un formato ortogonal, mediante la disposición de calles rectas. 


\subsubsection{Programa}

\section{Cuadro de áreas}

Tabla 5.5

Cuadro de áreas del Mercado Central de Florencia

\begin{tabular}{|c|c|c|c|c|}
\hline PROGRAMA & AREA (m2) & PORCENTAJE & TOTAL & \\
\hline ÁREA DE VENTAS & & & 1824 & $\mathbf{m} 2$ \\
\hline Carnes & 561 & $18.88 \%$ & & \\
\hline Aves & 146 & $4.91 \%$ & & \\
\hline Pescados / Mariscos & 230 & $7.74 \%$ & & \\
\hline Embutidos & 120 & $4.04 \%$ & & \\
\hline Frutas & 230 & $7.74 \%$ & & \\
\hline Verduras & 200 & $6.73 \%$ & & \\
\hline Abarrotes & 195 & $6.56 \%$ & & \\
\hline Lácteos & 27 & $0.91 \%$ & & \\
\hline Licorería & 115 & $3.87 \%$ & & \\
\hline SERVICIOS COMPLEMENTARIOS & & & 808 & $\mathbf{m} 2$ \\
\hline Juguería / Bares / Café / Restaurantes & 670 & $22.55 \%$ & & \\
\hline Otros servicios públicos & 138 & $4.64 \%$ & & \\
\hline SERVICIOS GENERALES & & & 339 & $\mathbf{m} 2$ \\
\hline Almacenes refrigerados & 47 & $1.58 \%$ & & \\
\hline Almacenes & 52 & $1.75 \%$ & & \\
\hline Descarga & 0 & $0.00 \%$ & & \\
\hline Residuos & 12 & $0.40 \%$ & & \\
\hline Administración & 12 & $0.40 \%$ & & \\
\hline Oficinas & 41 & $1.38 \%$ & & \\
\hline SSHH & 38 & $1.28 \%$ & & \\
\hline Otros servicios privados & 137 & $4.61 \%$ & & \\
\hline TOTAL & & $100 \%$ & 2971 & $\mathbf{m} 2$ \\
\hline
\end{tabular}

Nota: No se considera el área de estacionamiento Fuente: elaboración propia 
PESCADOS/MARISCOS

EMBUTIDOS

FRUTAS

VERDURAS

ABARROTES

\section{LACTEOS}

JUGUERIA / BAR / CAFÉ / RESTAURANTES

LICORERÍA

ALMACENES REFRIGERADOS

ALMACENES

DESCARGUE

RESIDUOS

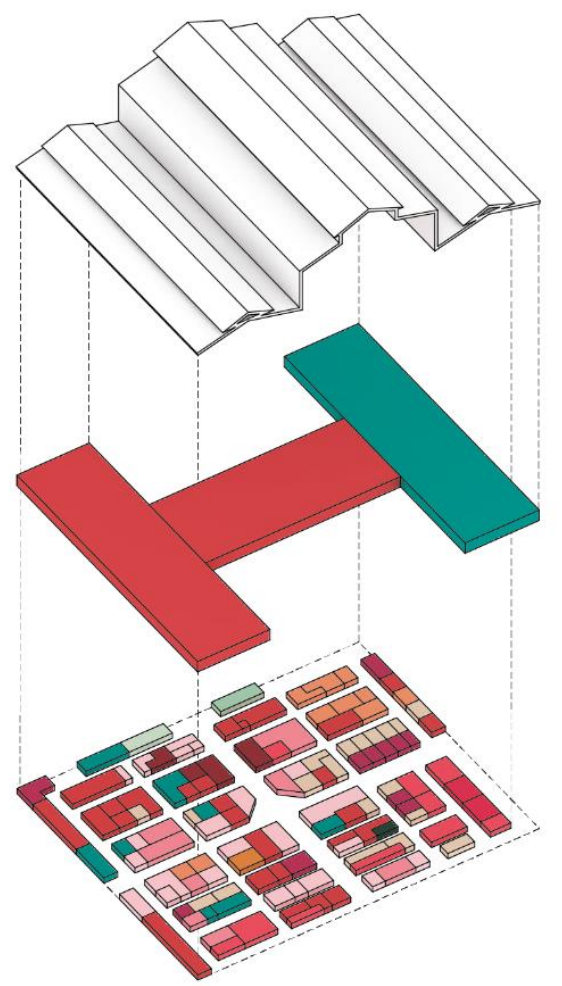

TERCER PISO

SEGUNDO PISO

PRIMER PISO

ADMINISTRACIÓN

OFICINAS

SSHH

OTROS SERVICIOS PÚBLICOS

OTROS SERVICIOS PRIVADOS

\section{$P \quad R O G R A M A$ MERCADO CENTRAL DE FLORENCIA}

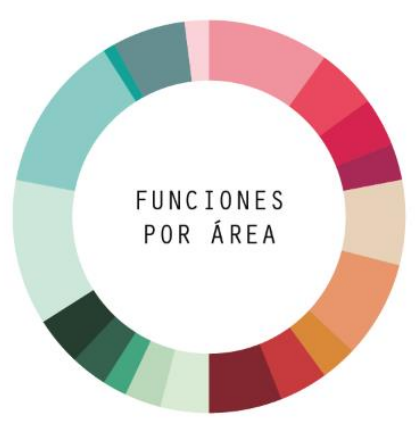




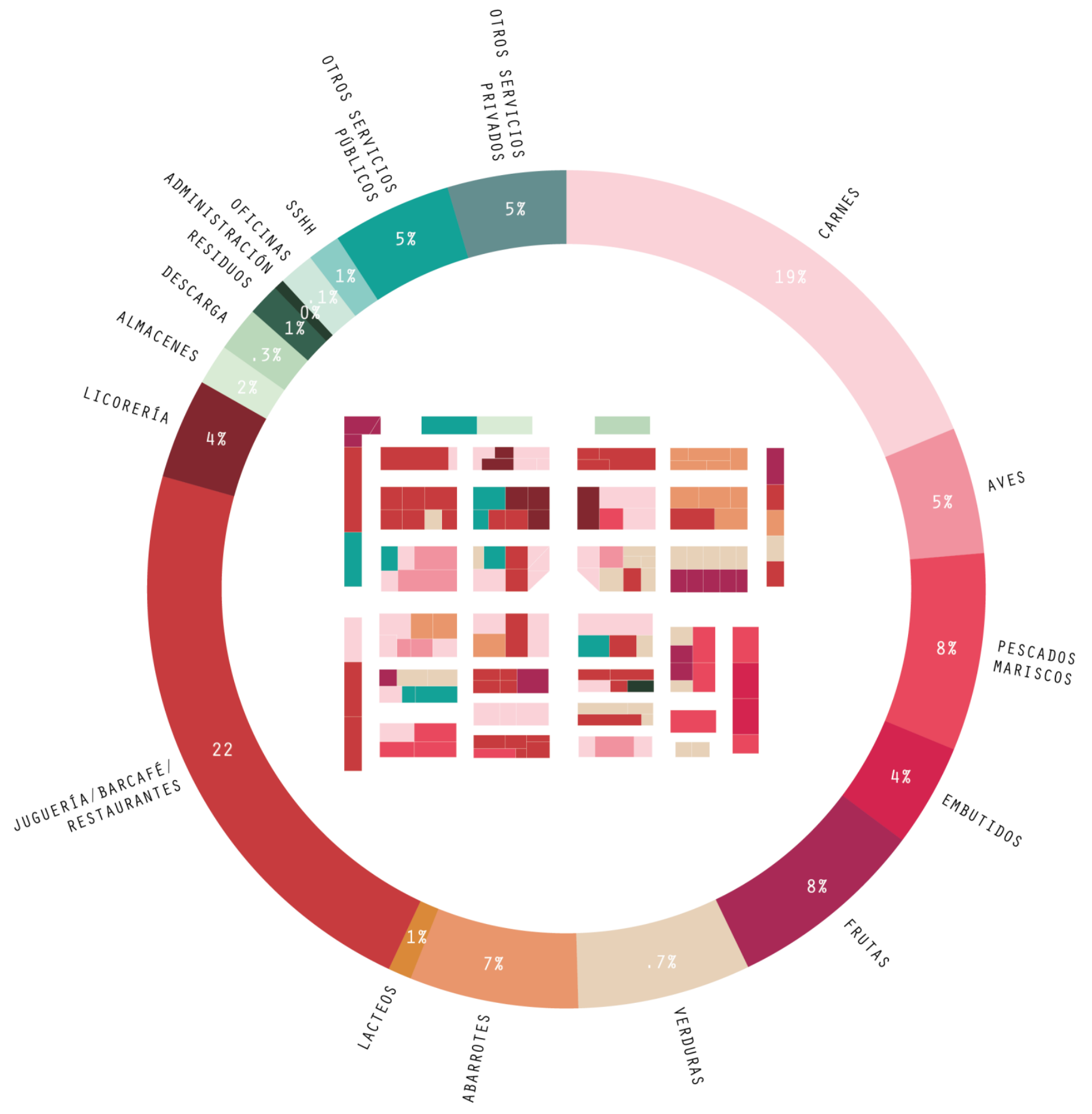

$P R O G R A M A$

MERCADO CENTRAL DE FLORENCia

ÁREA TOTAL 3000 M2

*NO SE CONSIDERA ESTACIENAMIENTOS 
INGRESO/SALIDA CLIENTES

SERVICIOS COMPLEMENTARIOS

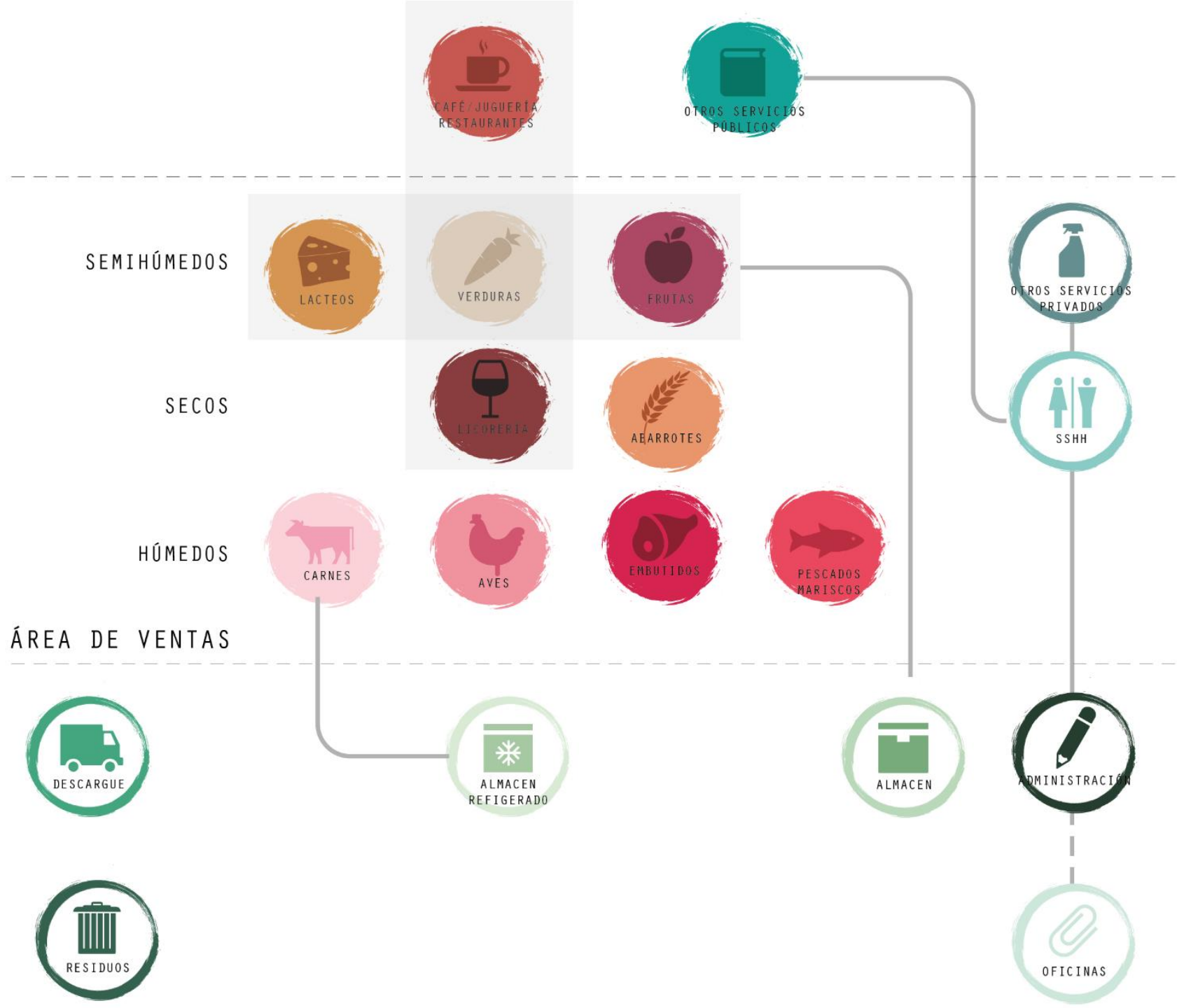

ÁREA DE SERVICIOS GENERALES

0 R G A N I G R A M A

MERCADO CENTRAL DE FLORENCIA

- RELACIÓN DIRECTA

$=-$ RELACIÓN INDIRECTA

GRUPO DE PRODUCTOS 
El Mercado Central de Florencia, cuenta con puestos de productos húmedos tales como pescados, carnes y pollos; productos semihúmedos como frutas y verduras; y productos secos como abarrotes, lácteos, vinos, etc. Todos ellos se encuentran en la primera planta, pues en la segunda, es posible encontrar puestos de servicios públicos complementarios que, a diferencia de otros mercados del mundo, ofrece lugares para comer, restaurantes, bares, librerías, centro gastronómico, tienda de suvenires, entre otros.

Figura 5.35

Interior del Mercado Central de Florencia

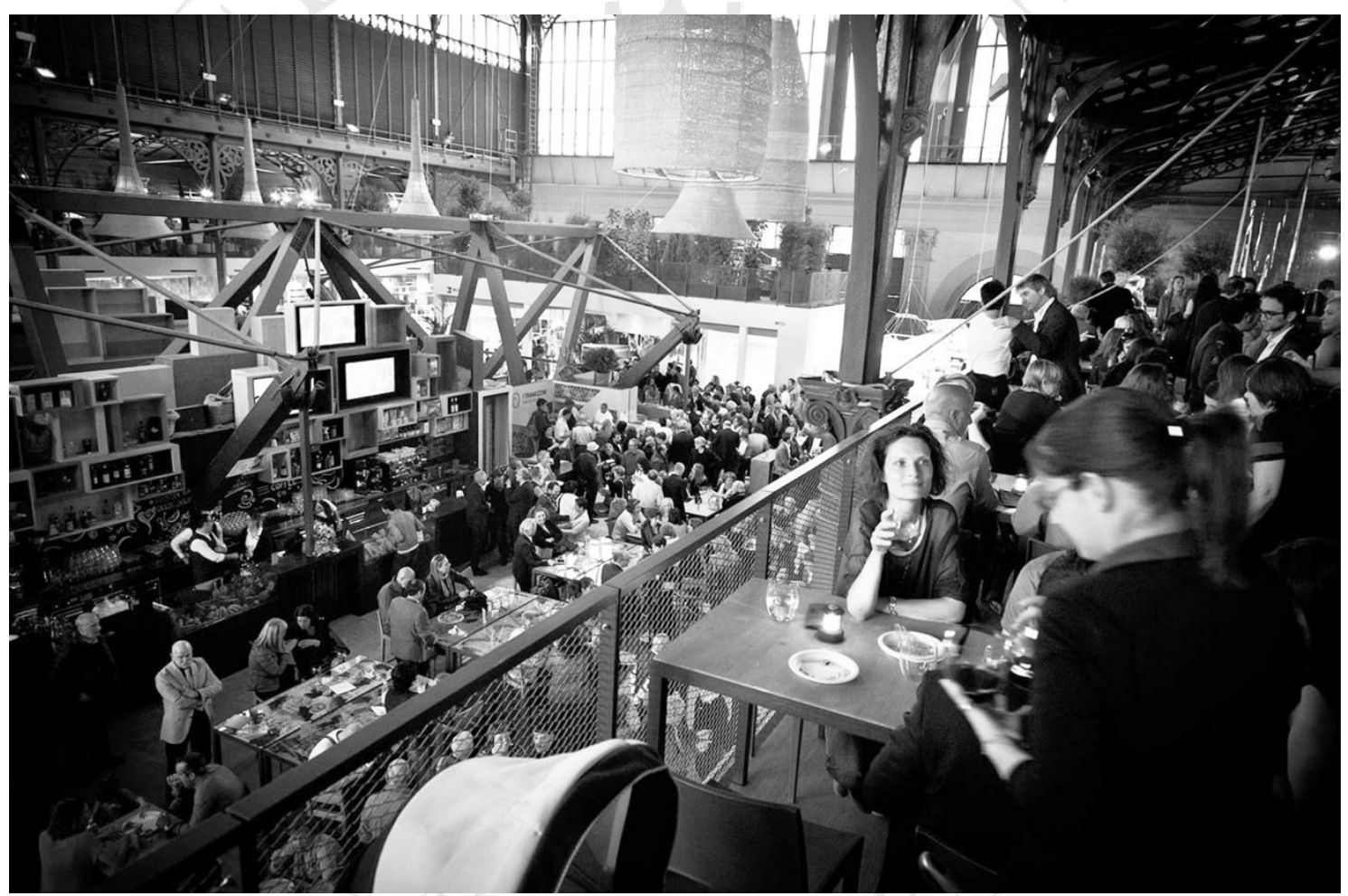

Nota: Imagen editada en blanco y negro Fuente: Mercado Central de Florencia (s.f.) En: mercatocentrale.it 


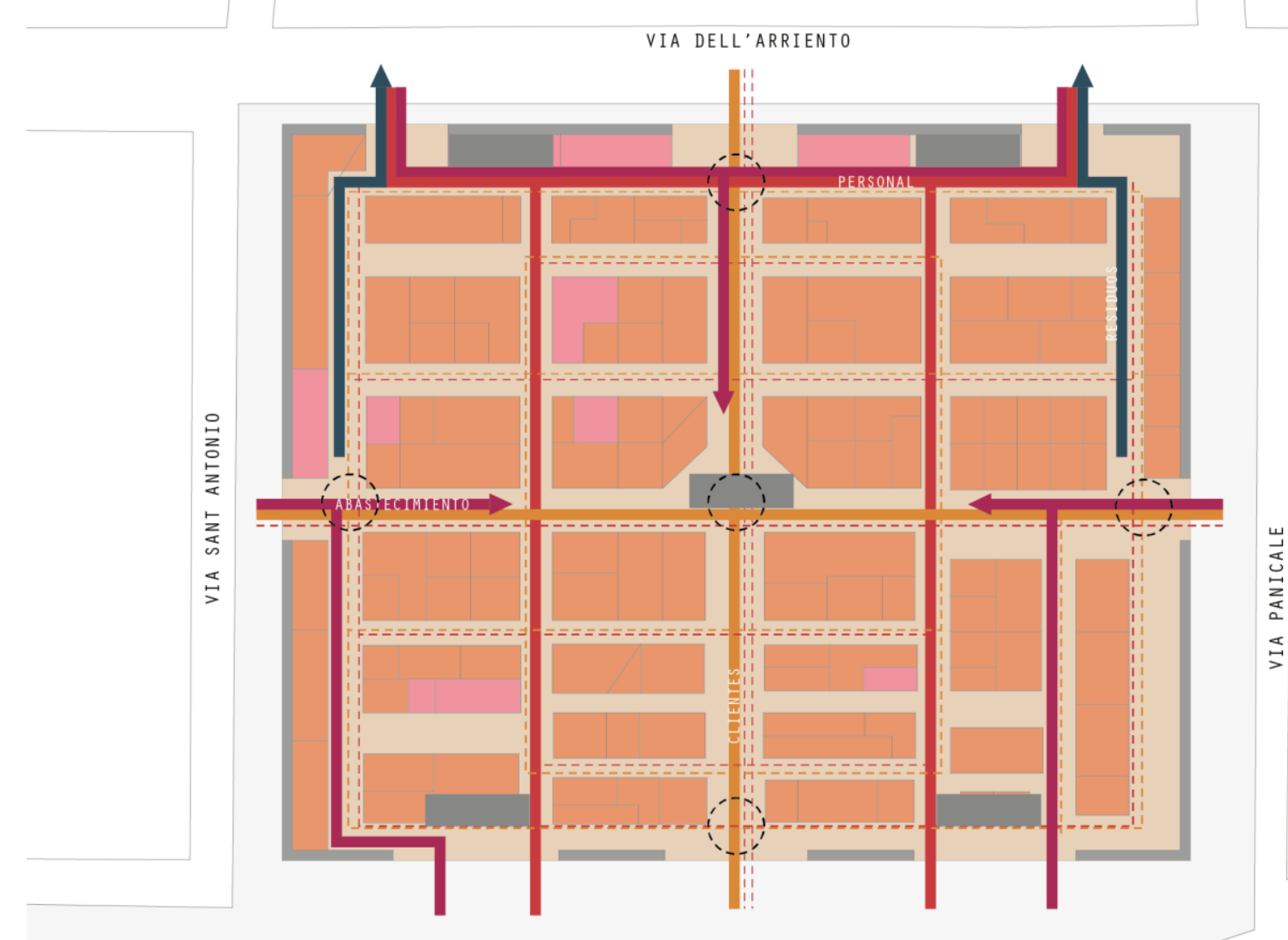

\section{RELACIÓN ESPACIAL}

(1) $\begin{array}{ccccc}0 & 10 & 20 & 30 \\ 1 & 1 & 1 & 1 & 1\end{array}$

MERCADO CENTRAL DE FLORENCIA

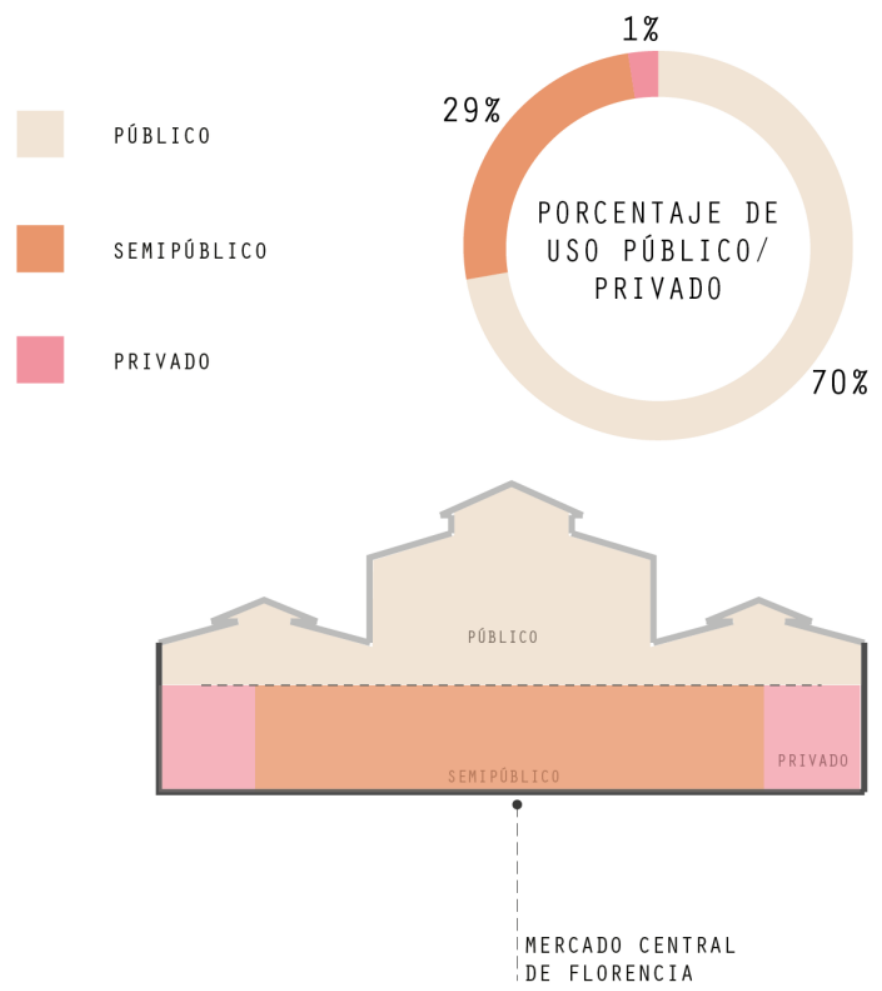

- flujo intenso de clientes HORARI 0 7:00-19:00

- Flujo moderado de clientes HORARI 0 7:00-19:00

- Flujo intenso de personal HORARI 0

- FLUJO MODERADO DE PERSONAL HORARI 0 7:00-19:00

- Flujo de abastecimiento HORARIO

- ELIMINACIÓN DE RESIDUOS HORARIO

DE FLORENCIA 


\subsubsection{Espacio}

El flujo de personas en el Mercado Central de Florencia es bastante ordenado, pues existen dos ejes de fuerte circulación para clientes y para el personal, ejes centrales en sentido vertical y horizontal. El abastecimiento y la salida de residuos se dan únicamente por la parte trasera del mercado, con el fin de no interferir con la circulación delantera tanto de los clientes como de los comerciantes.

Para ingresar existen 12 puerta de ingreso y para acceder al segundo nivel el mercado cuenta con escaleras mecánicas ubicadas por los ingresos de la Plaza Central del Mercado y Via dell'Arriento. Cuenta con unas escaleras centrales en el interior del primer nivel, además de un ascensor para personas con discapacidad al lado de la Plaza del Mercado Central.

El horario de apertura del mercado es de lunes a viernes de 7:00 a 14:00 horas y los sábados de 7:00 a 17:00 horas. Los domingos y días festivos no hay intención al público.

El mercado callejero, por lo contrario, está abierto hasta media tarde, y los restaurantes de la planta superior hasta las 24:00 horas. 
DETALLE CONSTRUCTIVO

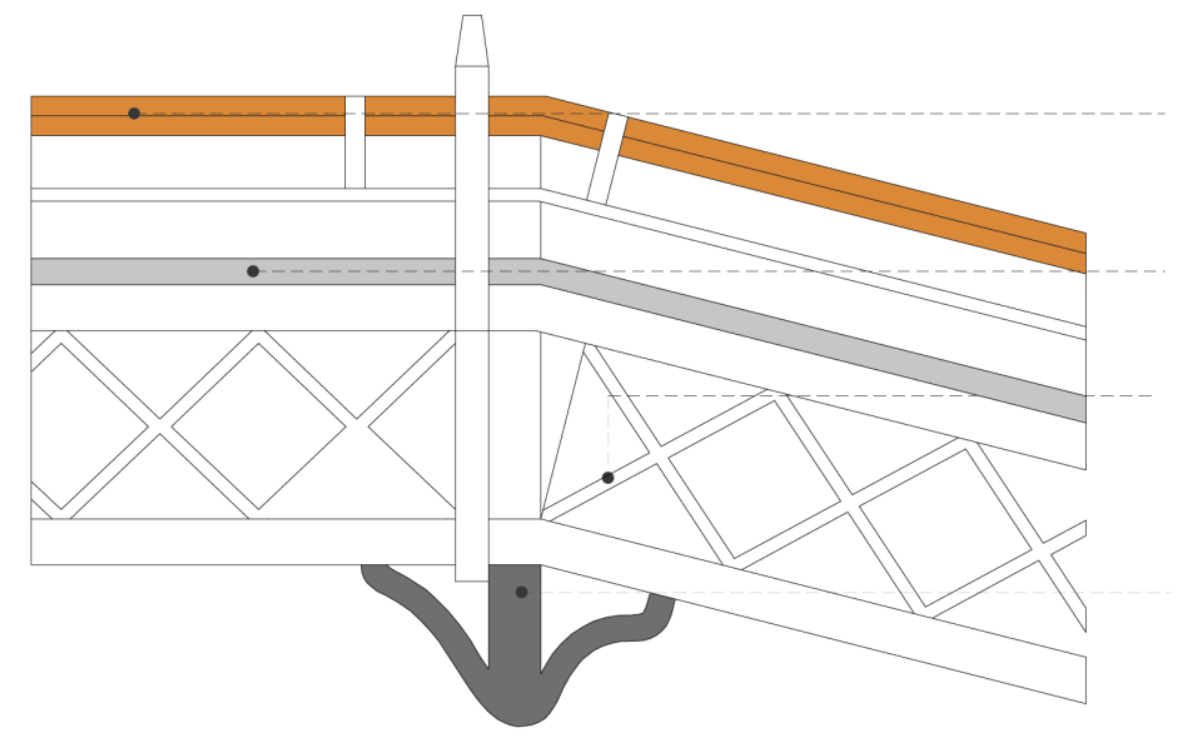

COBERTURA DE MERCADO:

ESTRUCTURA METALICA CON VIGAS

ARMADAS EN FORMA DE I.

CUBIERTA PERFILES DE ACERO DELGADO

NAVE INDUSTRIAL CON TIJERALES.

ORNAMENTO

UNA NAVE CON LUCES DE $30 \mathrm{M}$. X 66,5 M. CON TRES CAPAS DE CELOSIA DE 230 MM DE ESPESOR

DOS NAVES CON LUCES DE 24 M. X 30 M. CON UNA TELA ASFALTICA Y HOJAS DE COBRE DE ESPESOR DE 0.2 MM.

\title{
INNOVACIÓN TECNOLÓGICA
}

\author{
MER C A D O C E N T R A L D E F L O RE N C I A
}

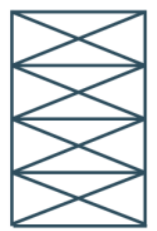

NUEVA ESTRUCTURA DE ACERO DISEÑA-

DA PARA SOPORTAR CARGAS Y PER -

MITIR EL APOYO DE LA ESTRUCTURA

OR I G INAL.

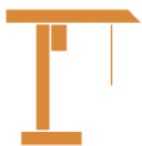

UN AÑO DE RESTAURACIÓN PARA LA

INCORPORACIÓN DE LA NUEVA COBER -

TURA METALICA.

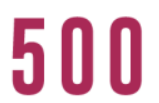

M2

DE SUPERFICIE A SER CUBIERTA CON

LA NUEVA COBERTURA.

LUMINOSIDAD Y EL BRILLO DE LA

CARPINTERÍA EN HIERRO 


\subsubsection{Tecnología}

La estructura del Mercado Central de Florencia está constituida por tres naves longitudinales, las dos del extremo más delgadas que la del centro. La nave industrial compuesta por tijerales tiene una estructura metálica con vigas armadas en forma de "I", así como una cubierta con perfiles de acero delgado.

Figura 5.36

Interior del Mercado Central de Florencia

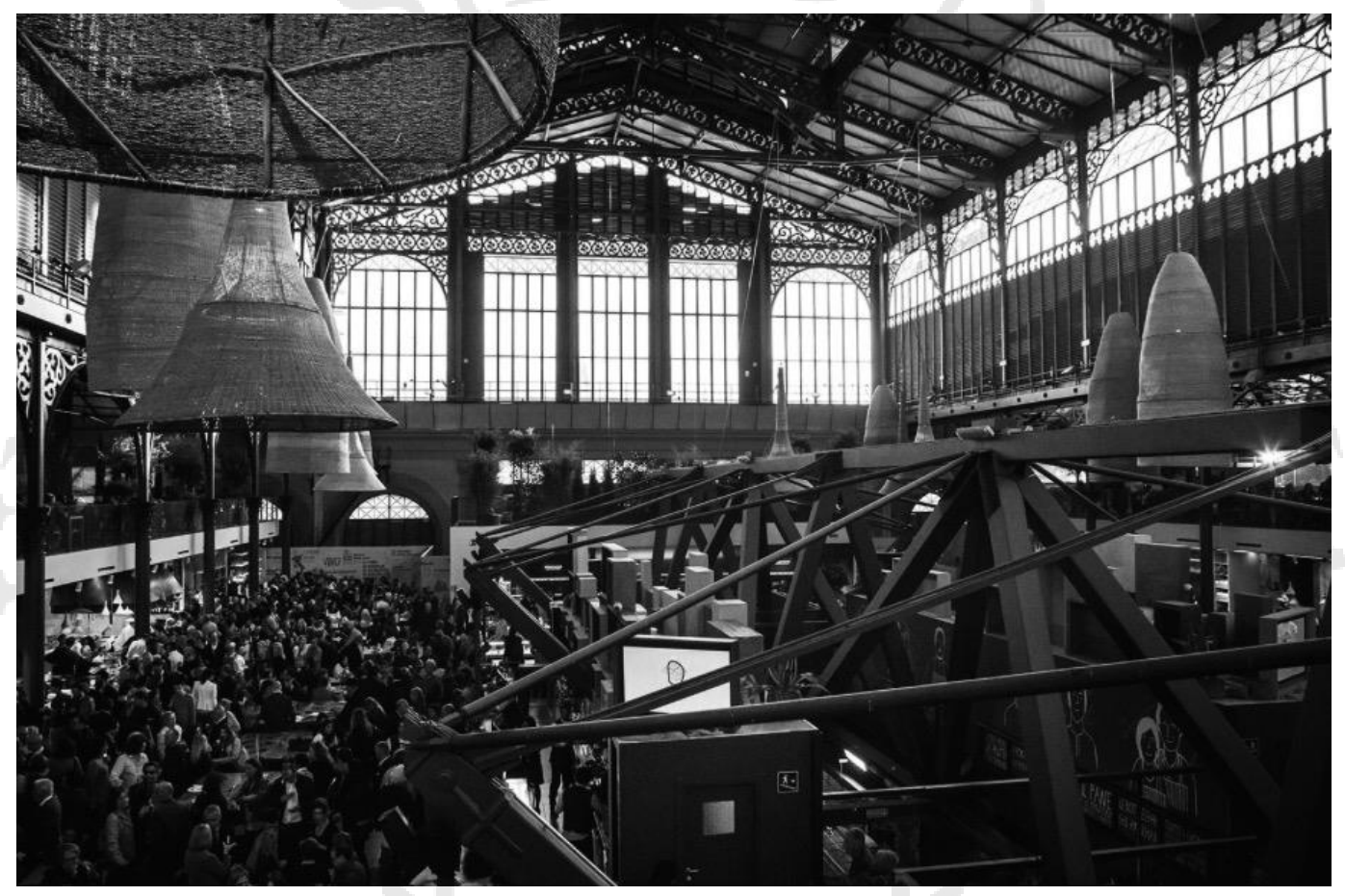

Nota: Imagen editada en blanco y negro Fuente: Mercado Central de Florencia (s.f.) En: mercatocentrale.it 


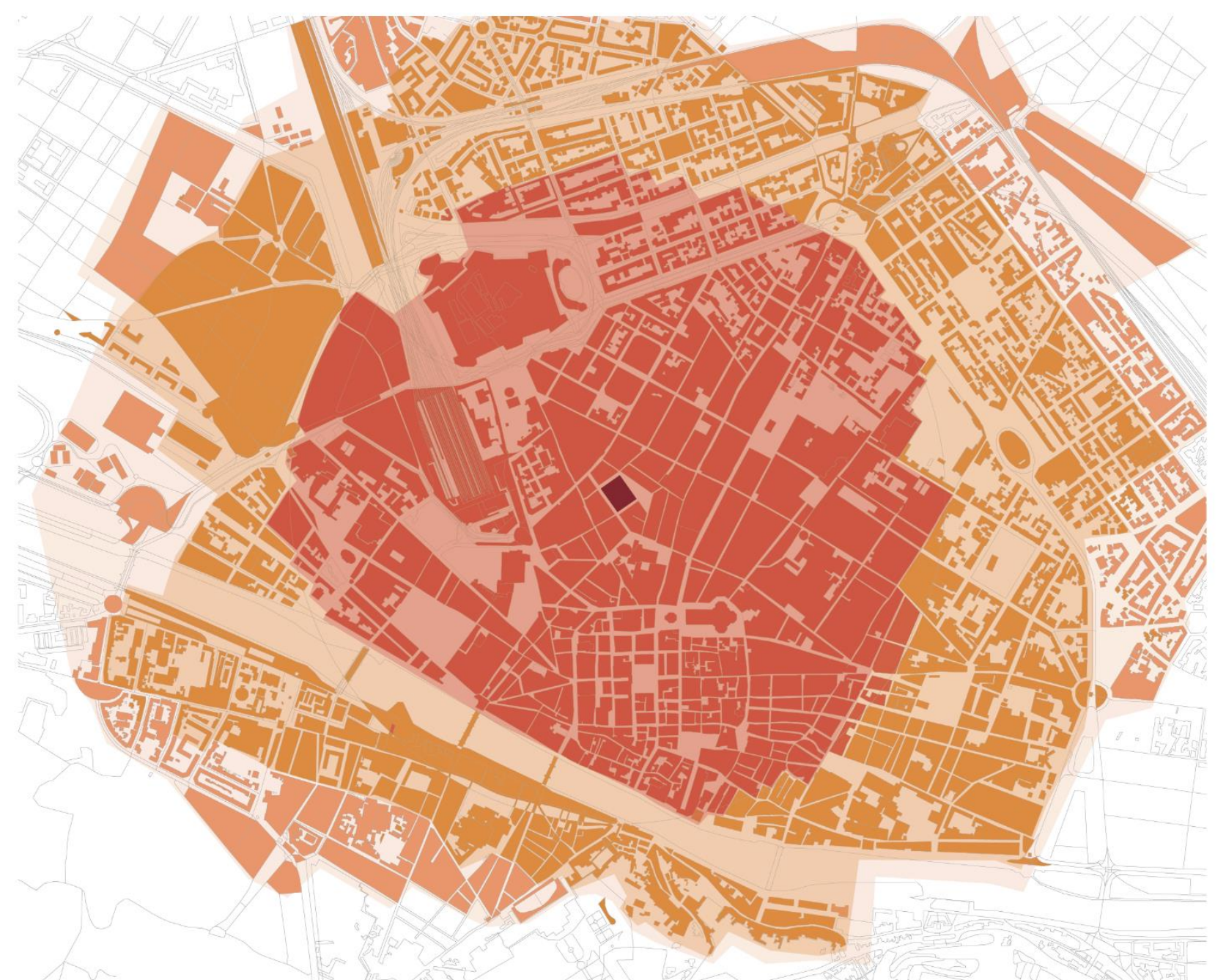

\section{IMPACTO SOCIAL}

MERCADO CENTRAL DE FLORENCIA 


\subsubsection{Impacto social}

El mercado desde sus orígenes ha significado un aporte para el barrio, pues ha sido activador y modelador del entorno. Hoy en día el mercado apunta mucho más al ámbito cultural, ofreciendo platos típicos en sus restaurantes y menús de mercado, incluyendo librerías especializadas en gastronomía y apostando por institutos de aprendizaje culinario.

Figura 5.37

Espacio público del Mercado Central de Florencia

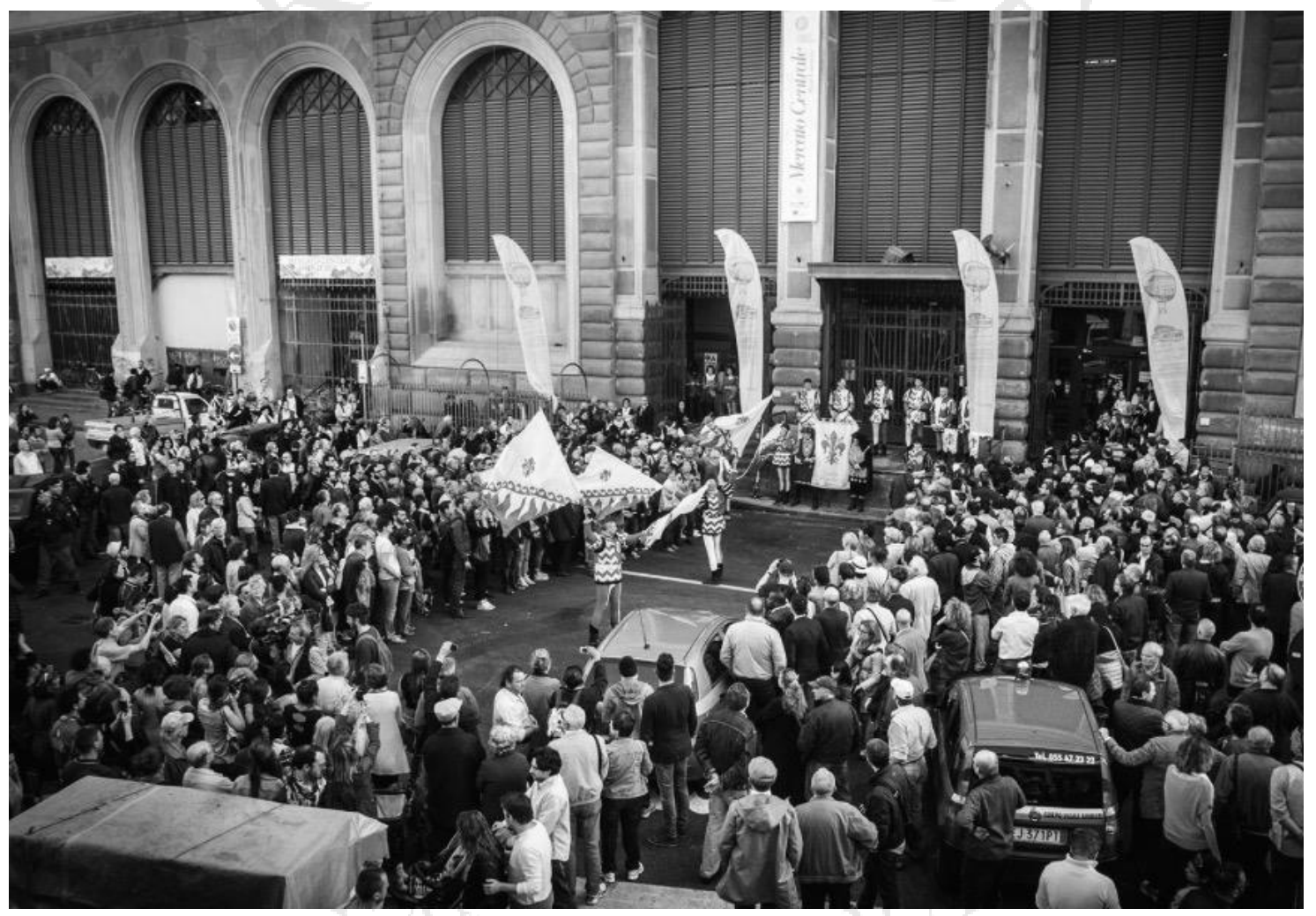

Nota: Imagen editada en blanco y negro Fuente: Mercado Central de Florencia (s.f.) En: mercatocentrale.it 


\subsection{Mercado $\mathrm{N}^{\circ} 1$ de Surquillo}

\subsubsection{Ubicación}

Arquitecto: Alfredo Dammert

Reconstrucción: Ing. Jorge Álvarez Calderón

Año: 1939

Cliente: público

Ubicación: Av. Paseo de la Republica (Ca. Narciso de la Colina), Lima, Perú

Categoría: mercado municipal

Terreno: $4,300 \mathrm{~m} 2$

Figura 5.38

Mercado $N^{\circ} 1$ de Surquillo

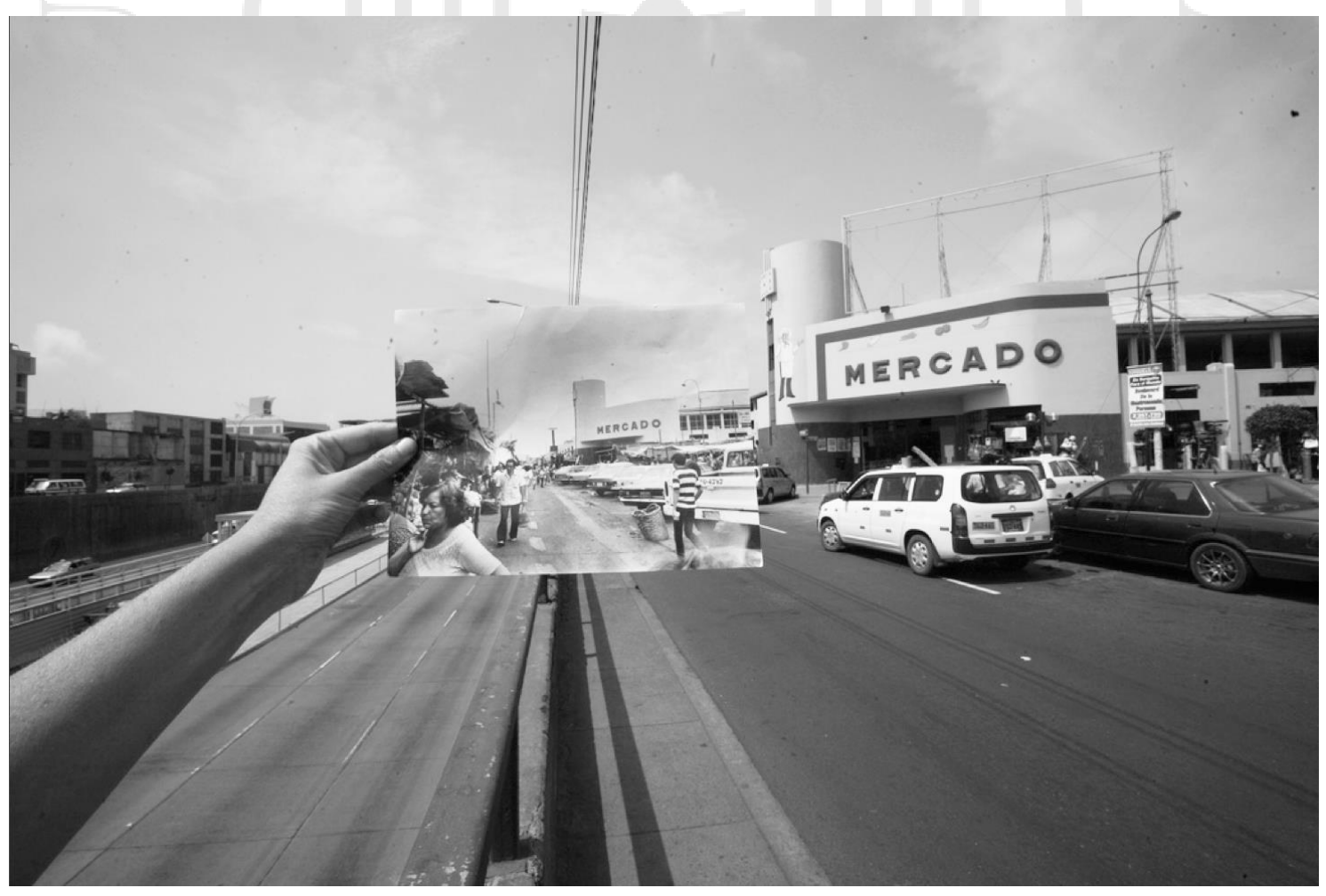

Nota: Imagen editada en blanco y negro

Fuente: Mercado de Surquillo (2010) El Comercio Perú

En: https://www.flickr.com/photos/elcomercioperu/4281803772/ 


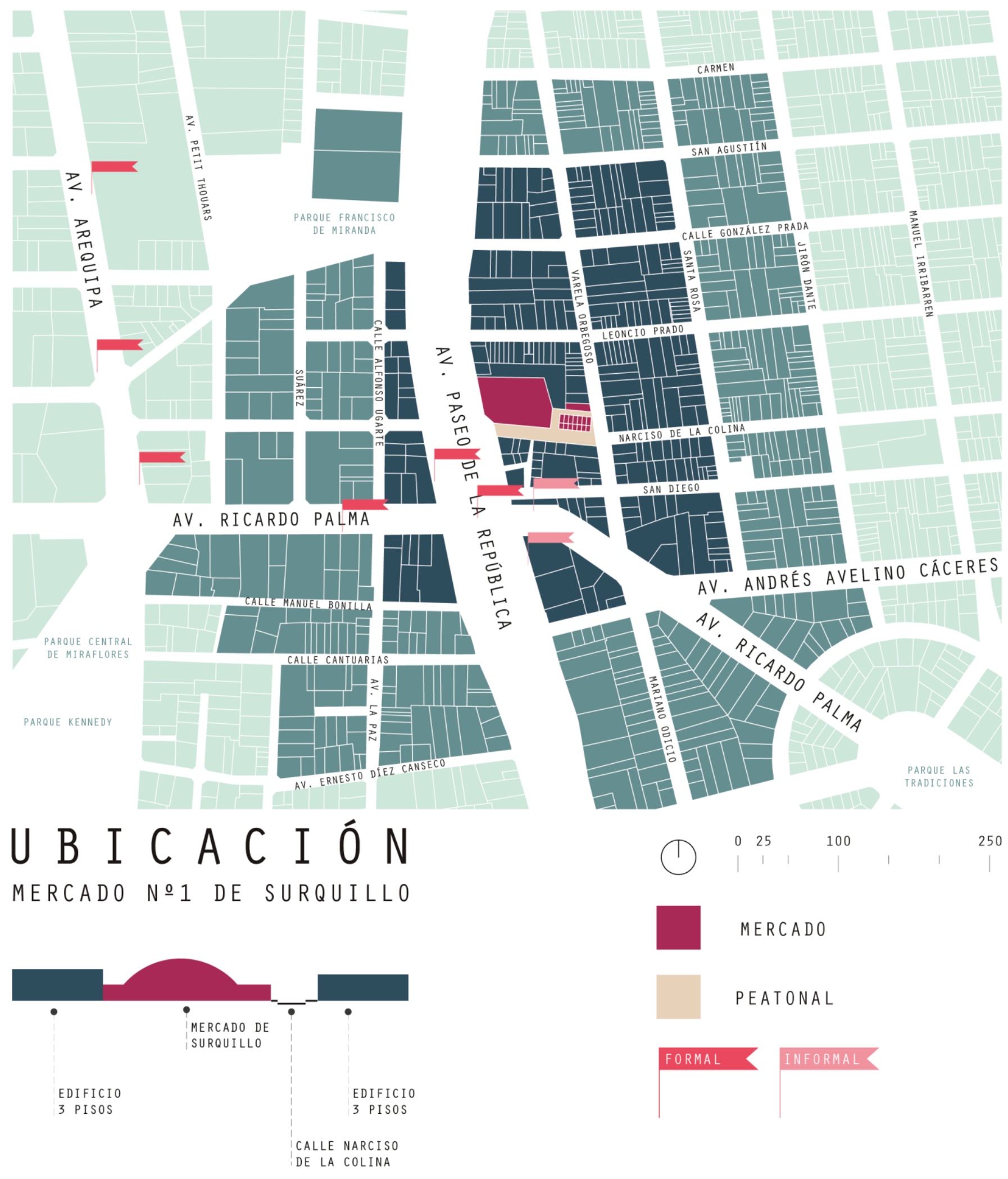


El Mercado de Surquillo, se ubica en el límite de Miraflores con Surquillo, en la misma Av. Paseo de la República. Se encuentra emplazado al lado de la calle Narciso de la Colina, actualmente de carácter peatonal.

En cuanto a la accesibilidad, este mercado está ubicado próximo a paraderos de autobuses formales (indicados con carteles o de la línea del Metropolitano) e informales.

Figura 5.39

Contexto del Mercado $N^{\circ} 1$ de Surquillo

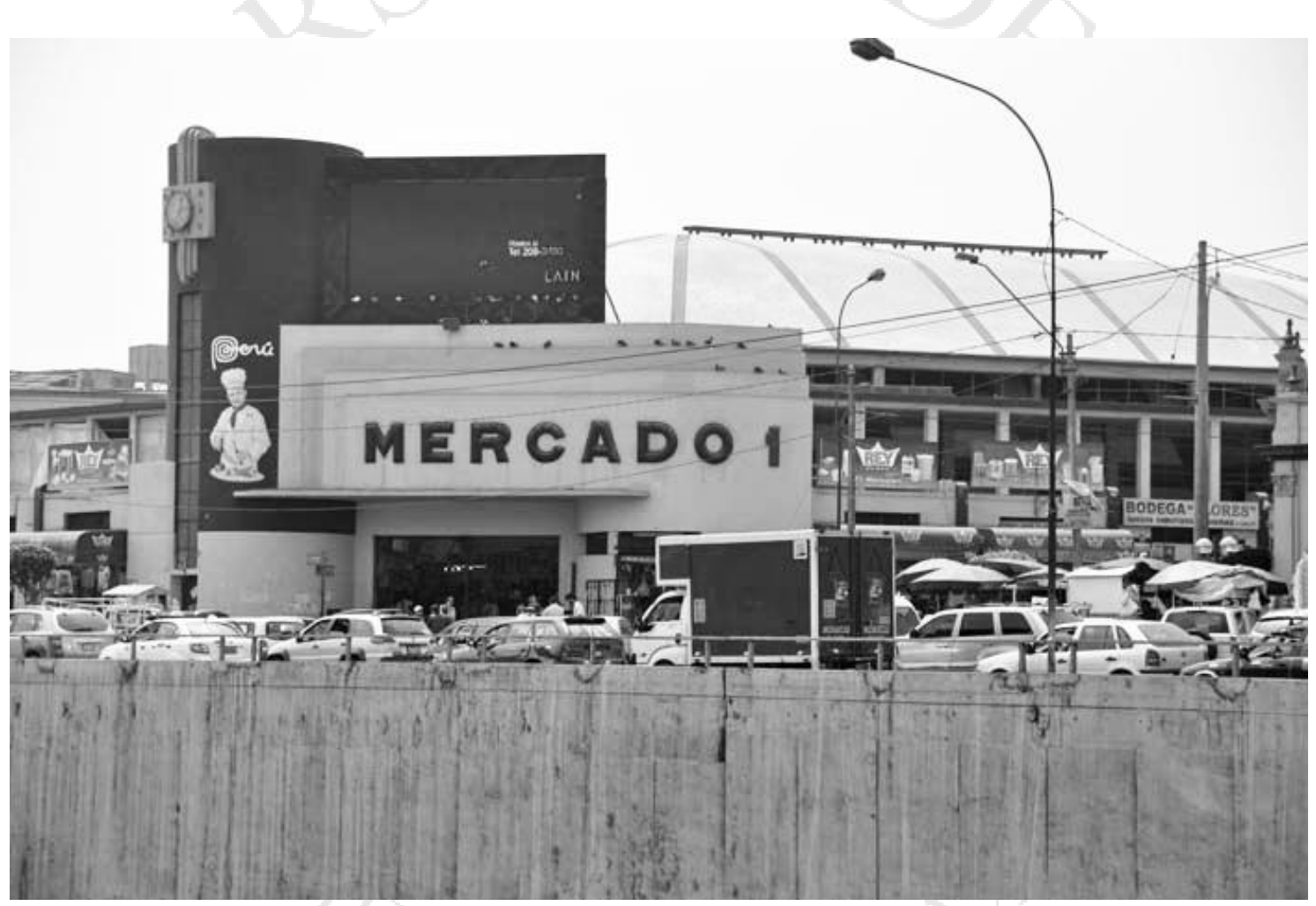

Nota: Imagen editada en blanco y negro

Fuente: Lima Mercado de Surquillo and Historical District (2015) WIRED2THEWORLD

En: http://www.wired2theworld.com/2015/04/06/lima-mercado-de-surquillo-and-historical-district/ 

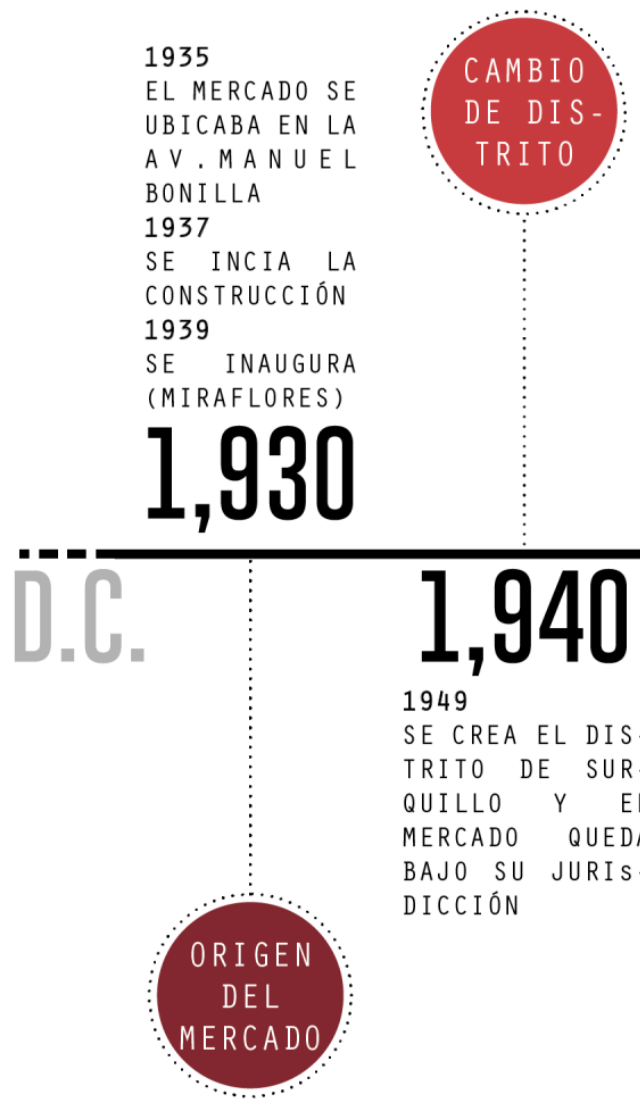
1980
EL MERCADO ES DESTRUIDO POR UN INCENDIO
$1980-1983$
RECONSTRUCCIÓN
Y REHABIL -
I TAC I ÓN

\section{1,980}

SE PEATONALIZA

EL JR.COLINA

PRIORIZANDO EL

TRANSITO DE LOS

CLIENTES

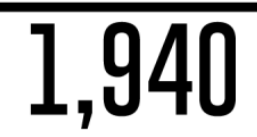

1949

SE CREA EL DIS -

TRITO DE SUR-

QUILLO Y EL

MERCADO QUEDA

BAJO SU JURIS -

DICCIÓN

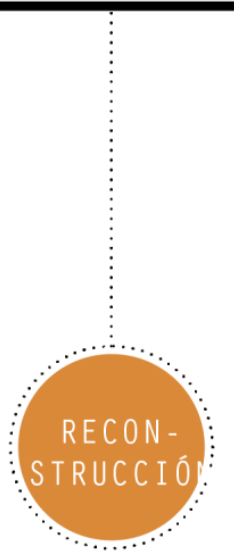

\section{2,005}

2005

M I R A F L O RES

PIDE AL TRI -

BUNAL $\quad$ CON-

ST I T UC I ONAL

LA PERTENEN -

C I A

2007

SE LE OTORGA

LA PROPIEDAD

A MIRAFLORES

PERO QUEDA

BAJO LA

A D M I N I S -

TRACIÓN DE

SURQUILLO

\section{2,010}

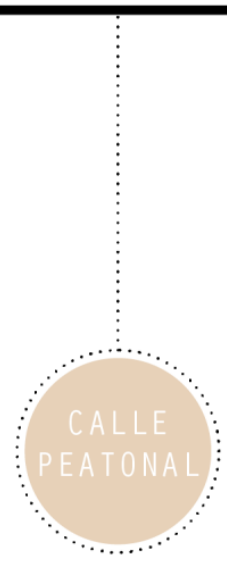

H I S T O R I A

MERCADO No1 DE SURQUILLO

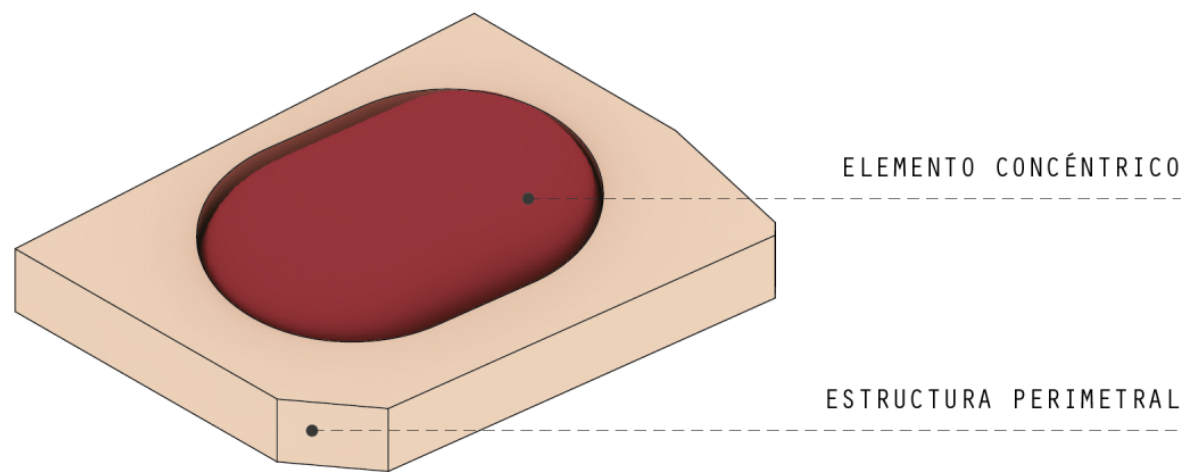




\subsubsection{Historia}

El origen del Mercado de Surquillo inició en la Av. Manuel Bonilla, donde se desarrollaba la actividad ambulatoria comercial. En el año 1937 se inició la construcción del mercado como establecimiento y en el 1939 lo inauguran en el distrito de Miraflores. No es hasta 1949 que el mercado, con la creación del distrito de Surquillo, pasa a ser de esa jurisdicción. En 1980 la infraestructura sufre un incendio y queda destruida, a raíz de esto durante el periodo de 1980 a 1983 se procede a la reconstrucción y rehabilitación del nuevo mercado.

Posterior a este acontecimiento se inicia un proceso legal para determinar la responsabilidad y administración del distrito. En el 2007 el tribunal constitucional otorga la propiedad a Miraflores, pero deja como administración al distrito de Surquillo.

\section{Toma de partido:}

La toma de partida parte del estilo buque y plantea una infraestructura dividida en geometrías: la base en forma de un polígono irregular y en la parte central se ubica un espacio cubierto por una cúpula.

Figura 5.40

Mercado $\mathrm{N}^{\circ} 1$ Surquillo durante su construcción

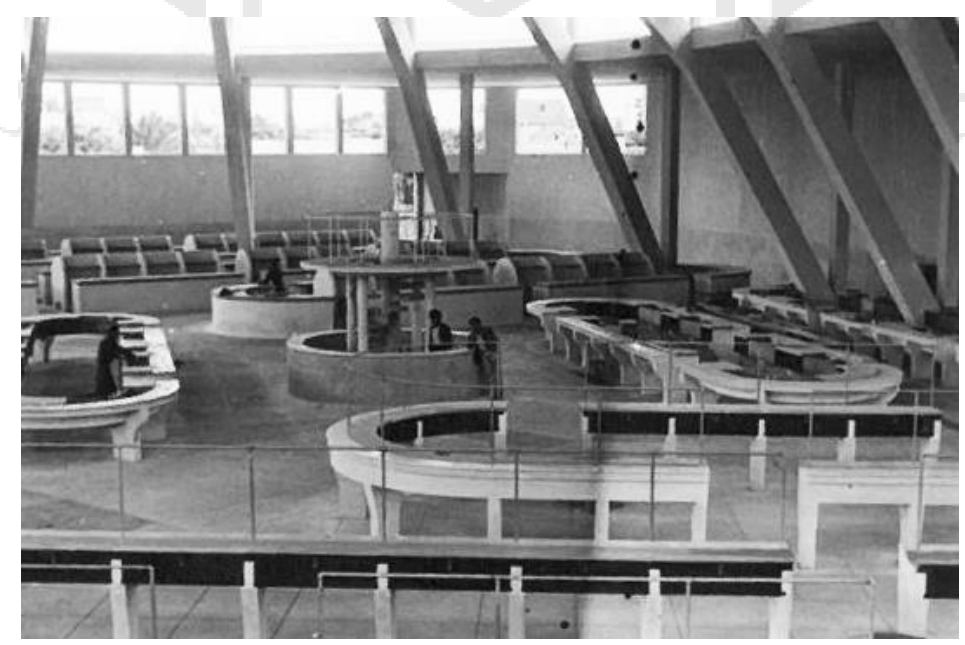

Fuente: Investigación de mercados de Lima, Universidad de Lima 


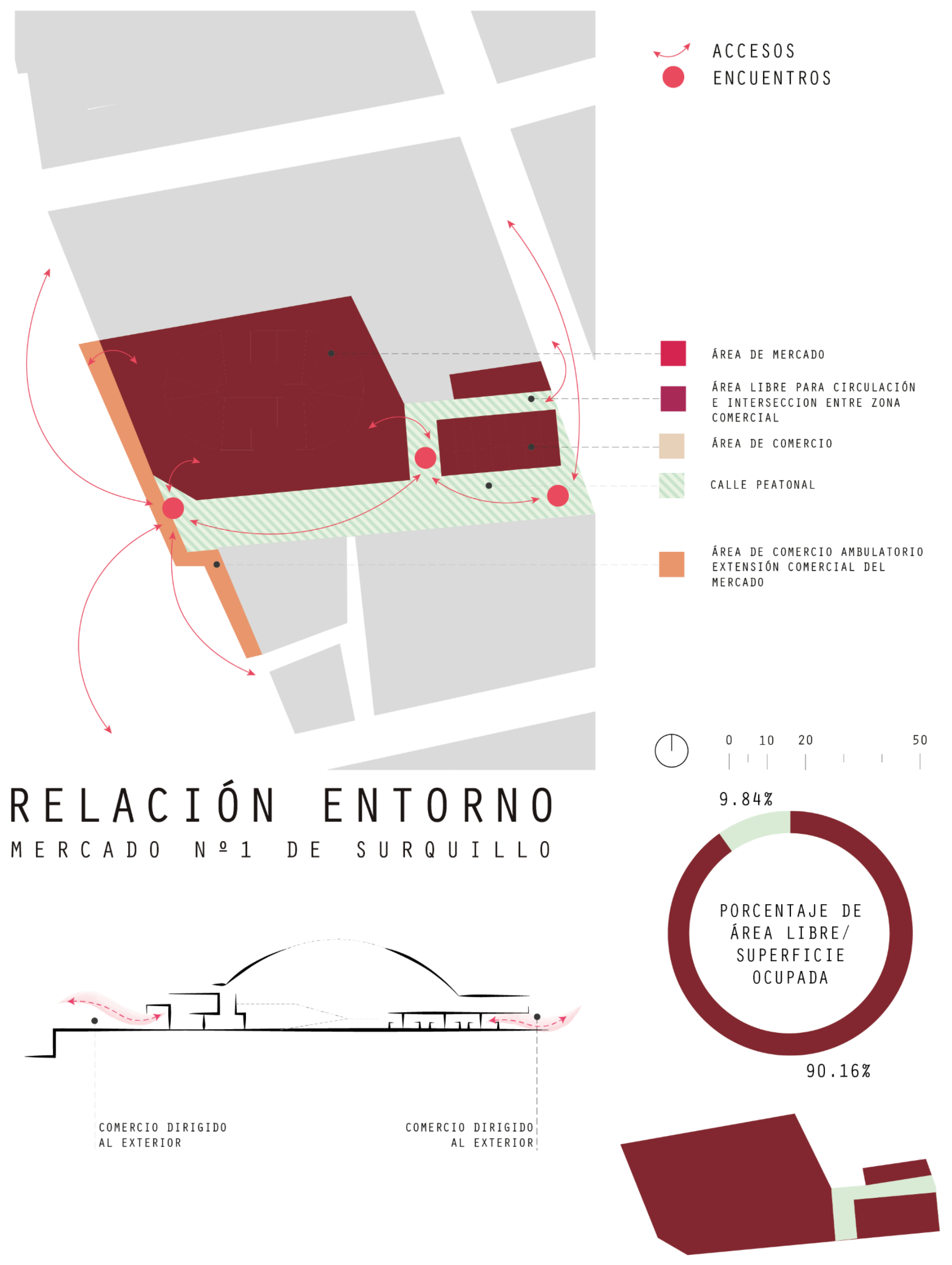




\subsubsection{Entorno}

El Mercado de Surquillo tiene un emplazamiento que se ha visto repotenciado por la vía peatonal, Calle Narciso de la Colina, que permite la generación de encuentros próximos a los accesos que dan a la calle. Asimismo, integra el pasaje que sirve de espacio previo para ir al mercado.

En la sección que colinda con la Av. Paseo de la Republica, se posicionan a lo largo del día, comerciantes ambulantes y hasta en casos carretillas que son extensiones del mismo local comercial.

\subsubsection{Tipología}

Figura 5.41

Esquema de tipología según distribución de puestos
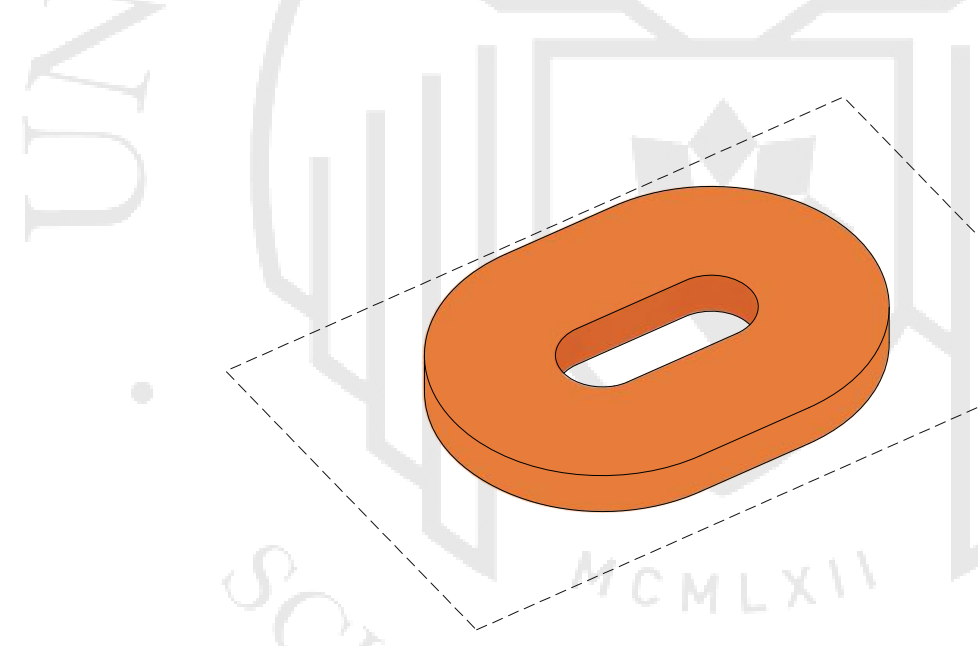

PERI METRO EXTERI OR RECTANGULAR CON I NTERI OR RADI OCÉNTRI CO

Fuente: elaboración propia

La tipología del Mercado de Surquillo está conformada por un perímetro exterior rectangular (aproximado) con interior radiocéntrico, donde se encuentran distribuidos los puestos de venta. Los puestos ubicados en el perímetro están dirigidos y orientados hacia la venta al exterior del mercado, mientras que los puestos ubicados en dirección radial están orientados al comercio dentro del mercado. 


\subsubsection{Programa}

\section{Cuadro de áreas}

Tabla 5.6

Cuadro de áreas del Mercado $\mathrm{N}^{\circ} 1$ de Surquillo

\begin{tabular}{|c|c|c|c|c|}
\hline PROGRAMA & AREA (m2) & PORCENTAJE & TOTAL & \\
\hline ÁREA DE VENTAS & & & 1424.3 & $\mathbf{m} 2$ \\
\hline Carnes & 220.9 & $10.18 \%$ & & \\
\hline Aves & 247.4 & $11.40 \%$ & & \\
\hline Pescados / Mariscos & 38.8 & $1.79 \%$ & & \\
\hline Embutidos & 0 & $0.00 \%$ & & \\
\hline Frutas $>$ & 262.1 & $12.08 \%$ & & \\
\hline Verduras & 263.1 & $12.13 \%$ & & \\
\hline Abarrotes & 392 & $18.07 \%$ & & \\
\hline Lácteos & 0 & $0.00 \%$ & & \\
\hline Licorería & 0 & $0.00 \%$ & & \\
\hline SERVICIOS COMPLEMENTARIOS & & & 290.6 & $\mathbf{m} 2$ \\
\hline Juguería / Bares / Café / Restaurantes & 290.6 & $13.39 \%$ & & \\
\hline Otros servicios públicos & 0 & $0.00 \%$ & & \\
\hline SERVICIOS GENERALES & & & 454.8 & $\mathbf{m} 2$ \\
\hline Almacenes refrigerados & 188.1 & $8.67 \%$ & & \\
\hline Almacenes & 43.1 & $1.99 \%$ & & \\
\hline Descarga & 0 & $0.00 \%$ & & \\
\hline Residuos & 0 & $0.00 \%$ & & \\
\hline Administración & 25.1 & $1.16 \%$ & & \\
\hline Oficinas & 22.7 & $1.05 \%$ & & \\
\hline SSHH & 92.3 & $4.25 \%$ & & \\
\hline Otros servicios privados & 83.5 & $3.85 \%$ & & \\
\hline TOTAL & & $100 \%$ & 2169.7 & $\mathbf{m} 2$ \\
\hline
\end{tabular}

Nota: No se considera el área de estacionamiento

No se están considerando los puestos de mercado en desuso o abandono

Fuente: elaboración propia 
CARNES

AVES

PESCADOS/MARISCOS

EMBUTIDOS

FRUTAS

VERDURAS

ABARROTES

LACTEOS

JUGUERÍA / BAR / CAFÉ /

RESTAURANTES

LI CORERÍA

ALMACENES REFRIGERADOS

ALMACENES

DESCARGUE

RESIDUOS

ADMINISTRAC I ÓN

OFICINAS

SSHH

OTROS SERVICIOS PÚBLICOS

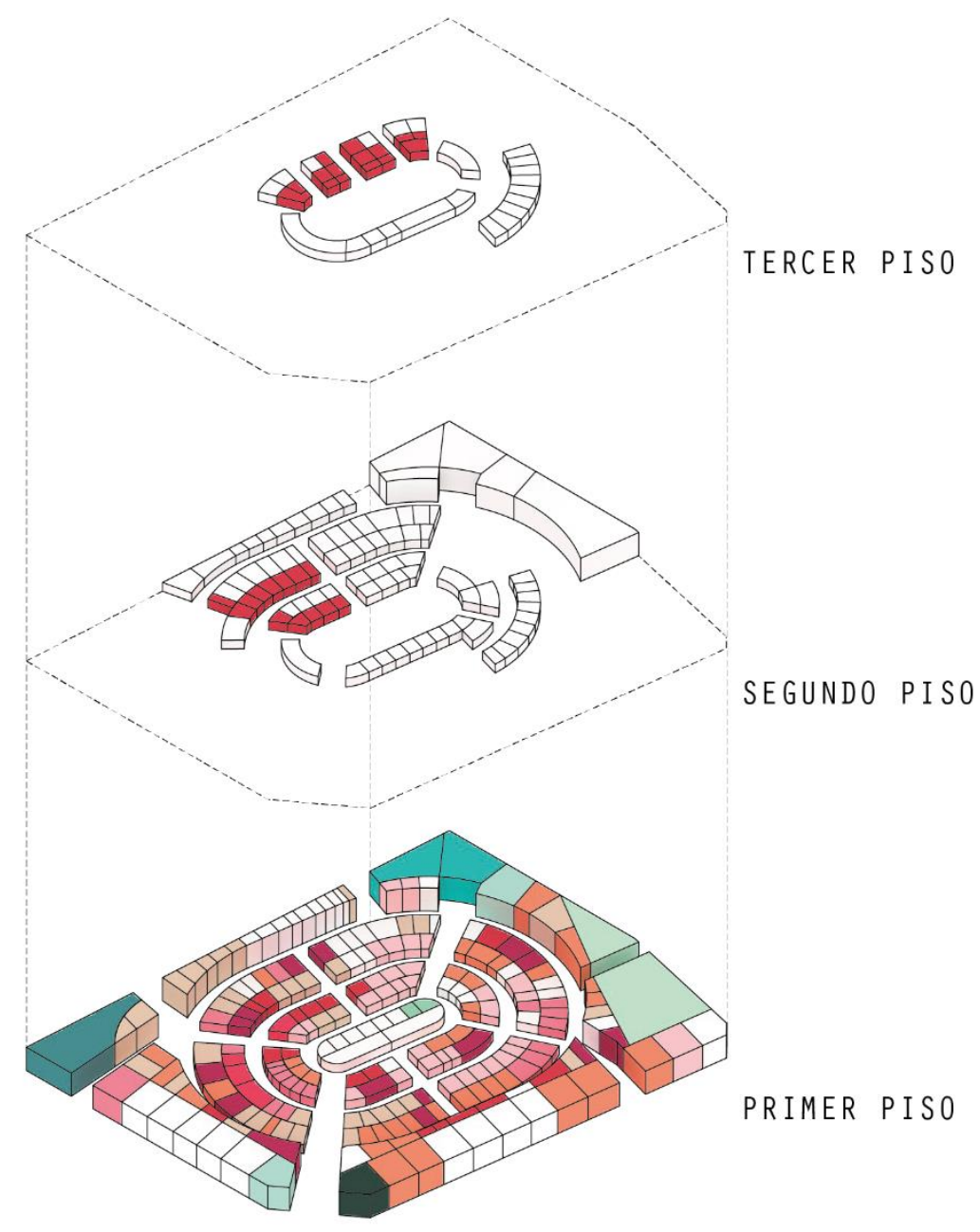

OTROS SERVICIOS PRIVADOS

\section{$\begin{array}{lllllllllllllllllll}P & R & 0 & G & R & A & M & A\end{array}$}

MERCAD0 No1 DE SURQUILLO

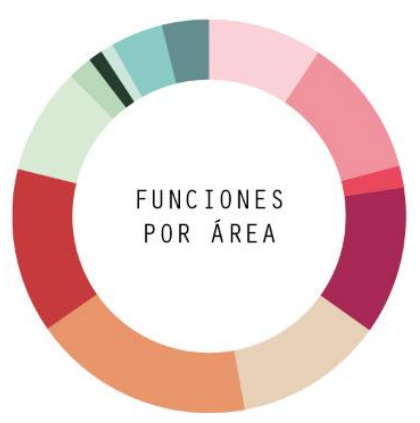




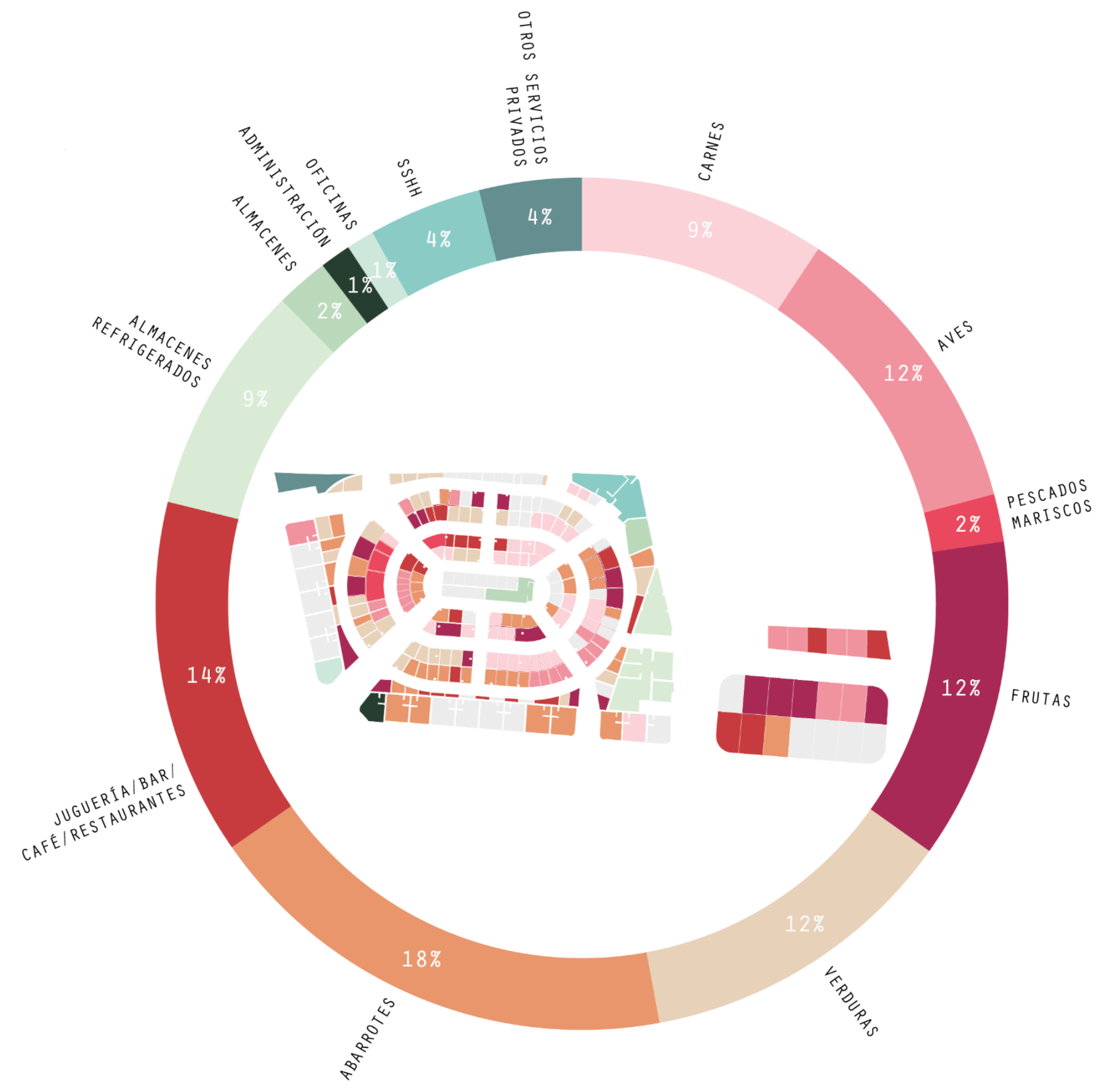

PROGRAMA

MERCADO DE SURQUILLO 


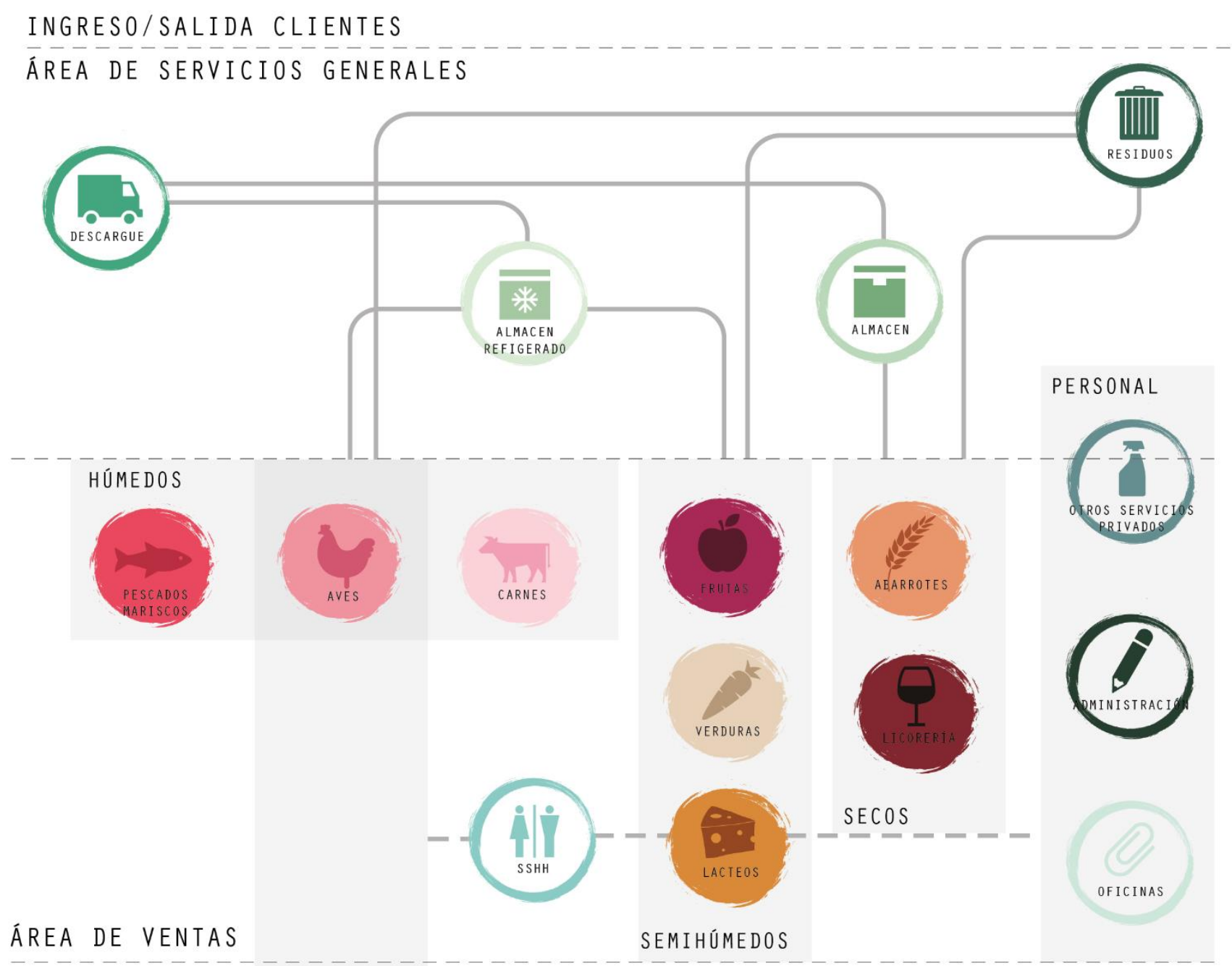

\section{R G A N I G R A M A}


El Mercado de Surquillo, en la primera planta ubica todos los servicios ofrecidos, tanto para el consumidor, así como también para los puntos de venta. En esta planta se ubican los almacenes, las oficinas, la administración, y los distintos puestos de productos (húmedos, semihúmedos, secos) y servicios. En cuanto a la segunda y tercera planta, estos destinados para albergar más puestos de venta y otros servicios de uso privado, no obstante, en la actualidad, los espacios permanecen en su gran mayoría en desuso o utilizados como almacenes de las mismas tiendas del primer piso.

En el Mercado de Surquillo, lo más próximo al ingreso son los servicios de abastecimiento. A pesar de que existen cuatro ingresos los clientes, utilizan en gran medida el acceso próximo al área de servicios donde se ubican los almacenes refrigerados. Después de evaluar esa relación de ingreso-abastecimiento, una vez adentro del establecimiento, se reparten de manera aleatoria la ubicación del tipo de puesto en el mercado. Estos incluyen: pescados, aves, carnes, frutas, verduras, lácteos, abarrotes, vinos, y juguería, restaurantes, etc. Tanto el segundo como en el tercer piso fueron concebido como áreas de ventas, sin embargo, actualmente no están siendo utilizadas por lo que no está siendo contemplado dentro del análisis.

Figura 5.42

Interior del Mercado $\mathrm{N}^{\circ} 1$ de Surquillo

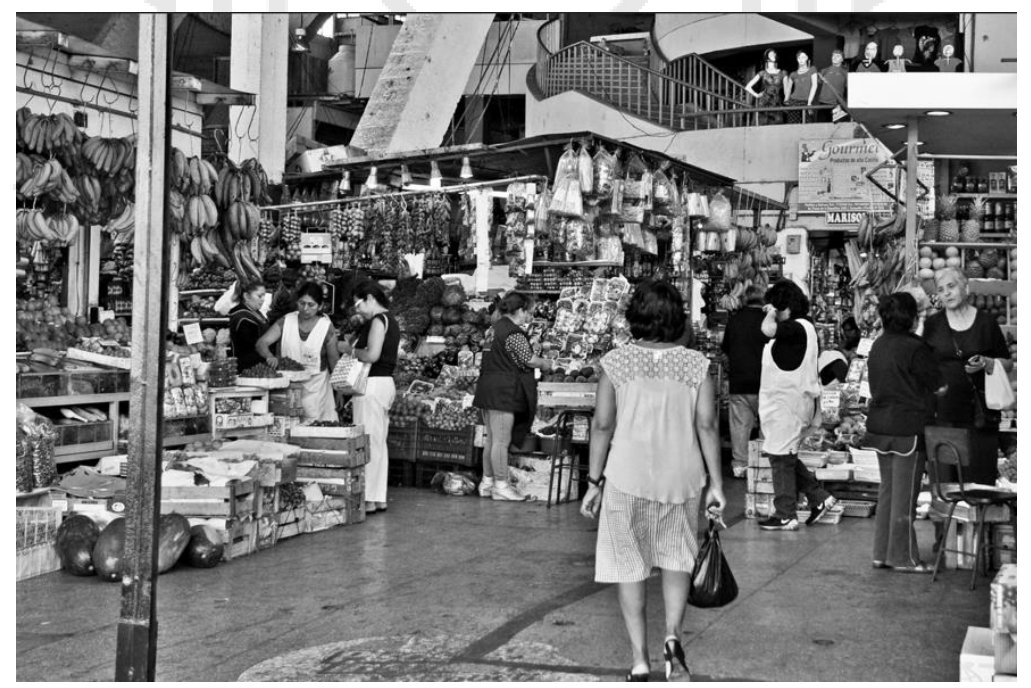

Nota: Imagen editada en blanco y negro

Fuente: Mercado de Surquillo, Lima, Perú (2015) Imattis

En: https://www.flickr.com/photos/lossbylinda/18699830911/ 


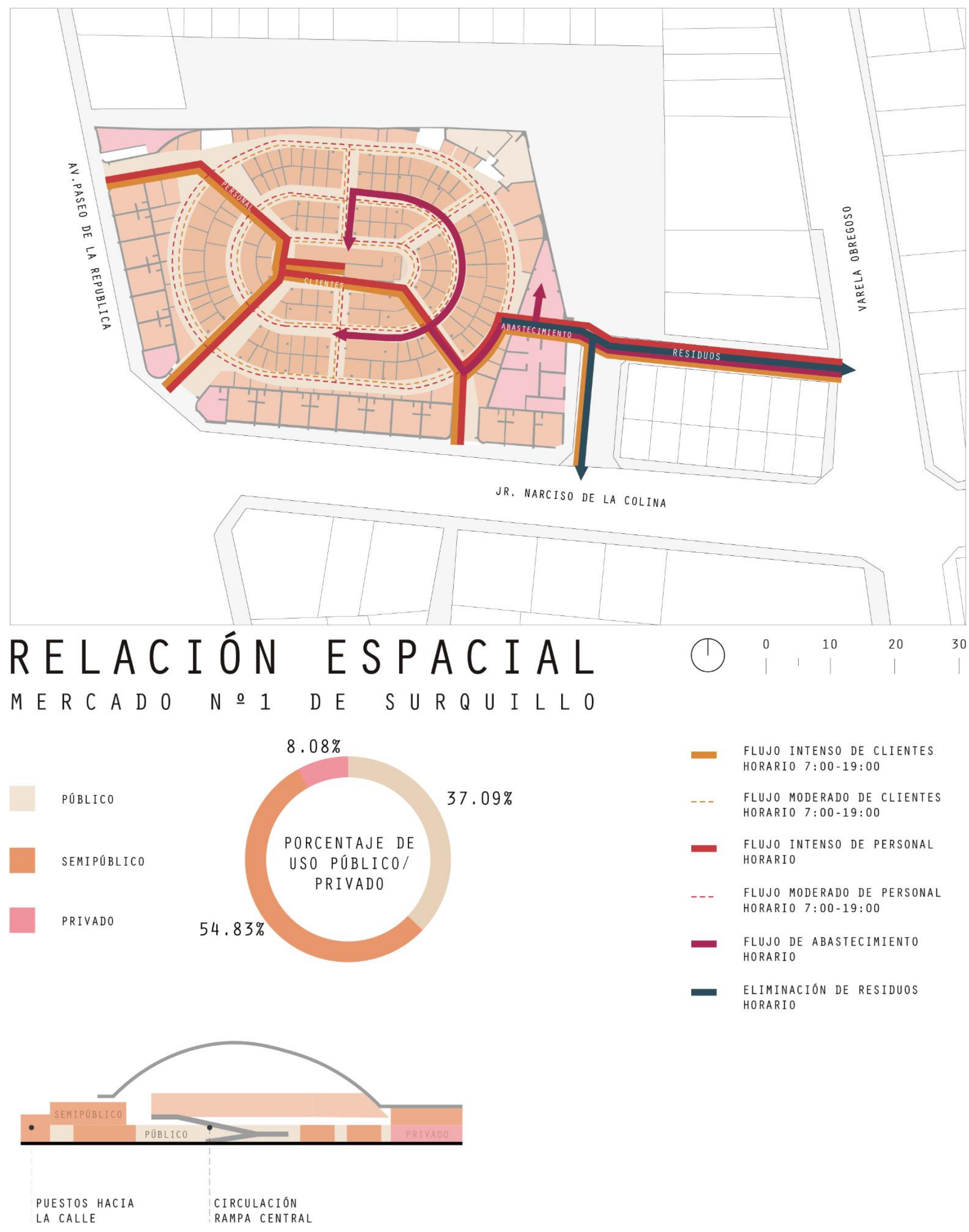




\subsubsection{Espacio}

El Mercado de Surquillo consta de cuatro ingresos peatonales, y su programa viene distribuido en tres plantas concéntricas. En el primer piso se concentra toda la actividad comercial y por ende los flujos de personas. Mientras que uno sube a los siguientes pisos, la actividad comercial disminuye debido a su desocupación.

Los flujos intensos de clientes y personal se dan principalmente, en los accesos (por la llegada de clientes y abastecimiento). Asimismo, ocurre en calles que conectan con los puestos exteriores y en la rampa de circulación vertical.

En cuanto al abastecimiento, este llega de la zona del pasaje Santa Rosa y con menor frecuencia de manera independiente desde las zonas del estacionamiento que dan para Av. Paseo de la República.

En cuanto al manejo de los residuos estos son retirados por la puerta de acceso que da al pasaje, poniendo en evidencia la inexistencia de un flujo eficiente y que garantice una logística certera en la circulación.

\section{Figura 5.43}

Circulación vertical del Mercado $\mathrm{N}^{\mathrm{o}} 1$ de Surquillo

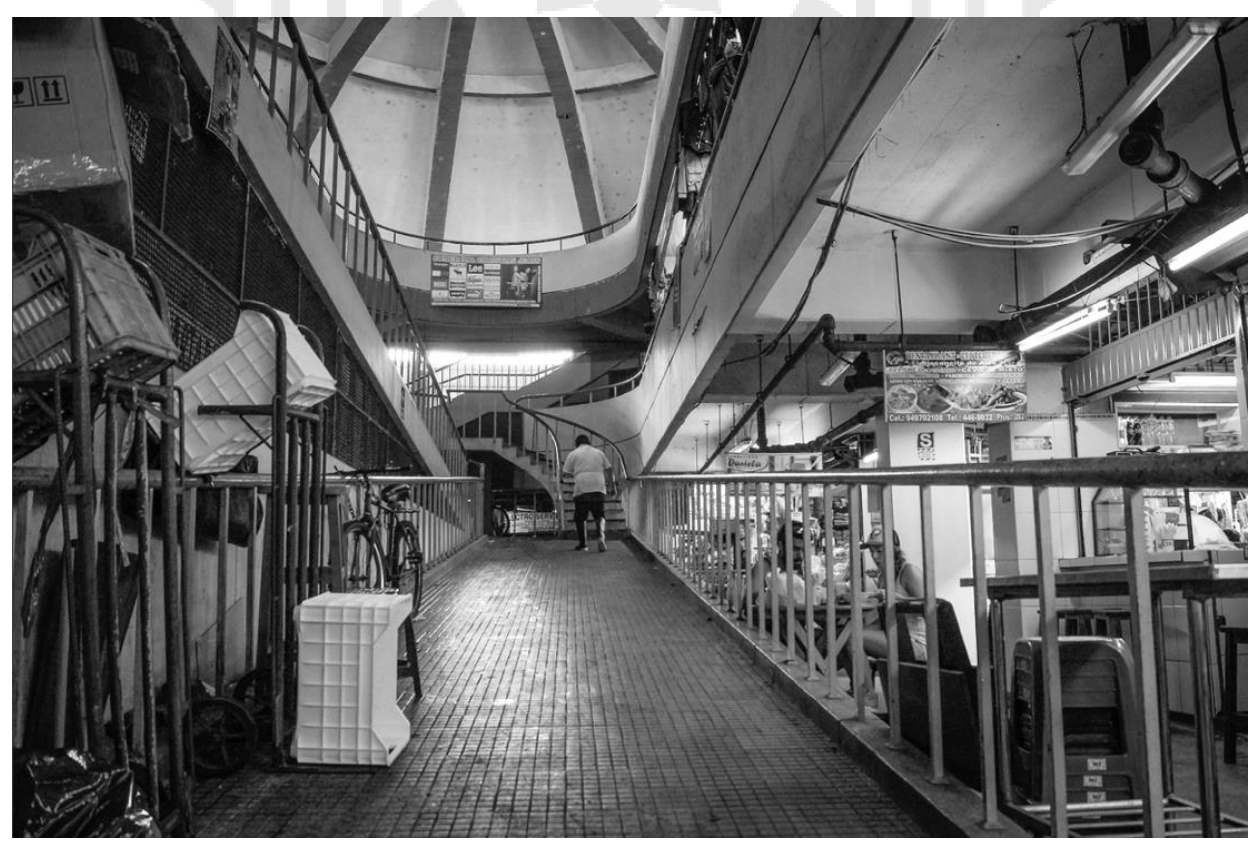

Fuente: Market | Surquillo, Perú (2014) Carlo Paredes

En: https://www.flickr.com/photos/carloparedes/15562583467/ 


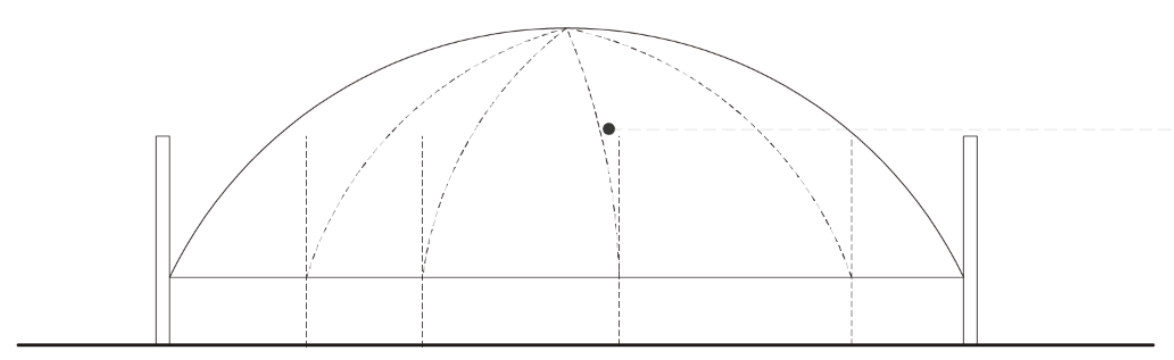

S I STEMA CONSTRUCT IVO

COBERTURA DEL MERCADO :

ESTRUCTURA METALICA EN FORMA DE CÚPULA

ELEMENTOS: COLUMNAS DE CONCRETO Y ARCOS DE ACERO

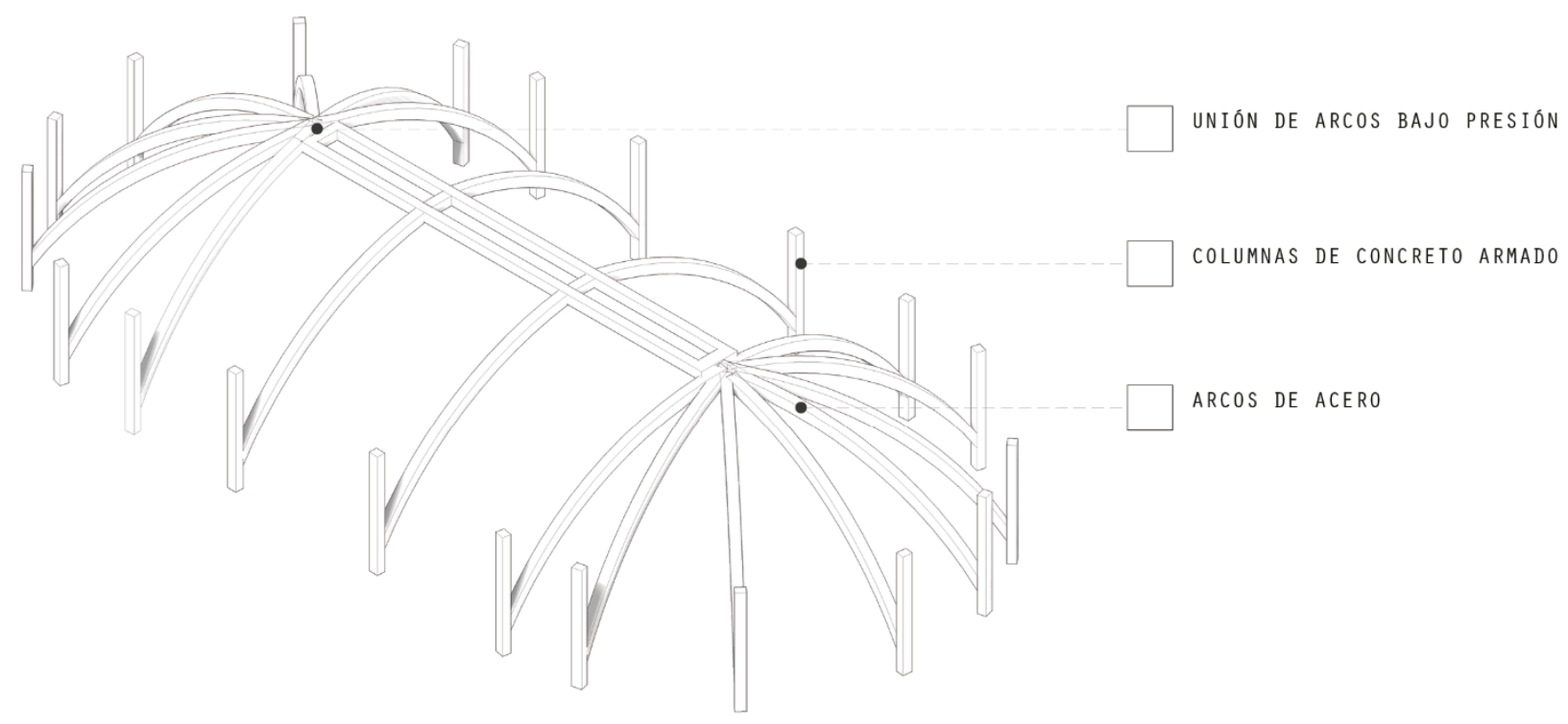

TECNOLOG ÍA

MERCADO N $\cong 1$ DE SURQUILLO

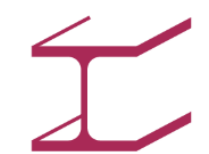

CONSTRUCCIÓN CONCRETO ARMADO Y

ARCOS DE ACERO

M

ESPACIO CENTRAL CUBIERTO UNA

CÚPULA, SISTEMA INNOVADOR PARA LA

ÉPOCA

La Estructura PERMite UnA REPAR -

TICIÓN DE CARGAS DE COMPRESIÓN

DESDE LOS ARCOS HASTA LLEGAR A

LOS ELEMENTOS VERTICALES 


\subsubsection{Tecnología}

En cuanto al sistema constructivo del Mercado de Surquillo, este se diferencia según las distintas zonas existentes. La zona perimétrica, está conformada por muros portantes, la zona central de planta ovalada donde se ubican los puestos de venta, se encuentra una estructura en concreto armado, que conforma la cúpula.

\section{Figura 5.44}

Construcción de la estructura de la cúpula del Mercado N¹ de Surquillo

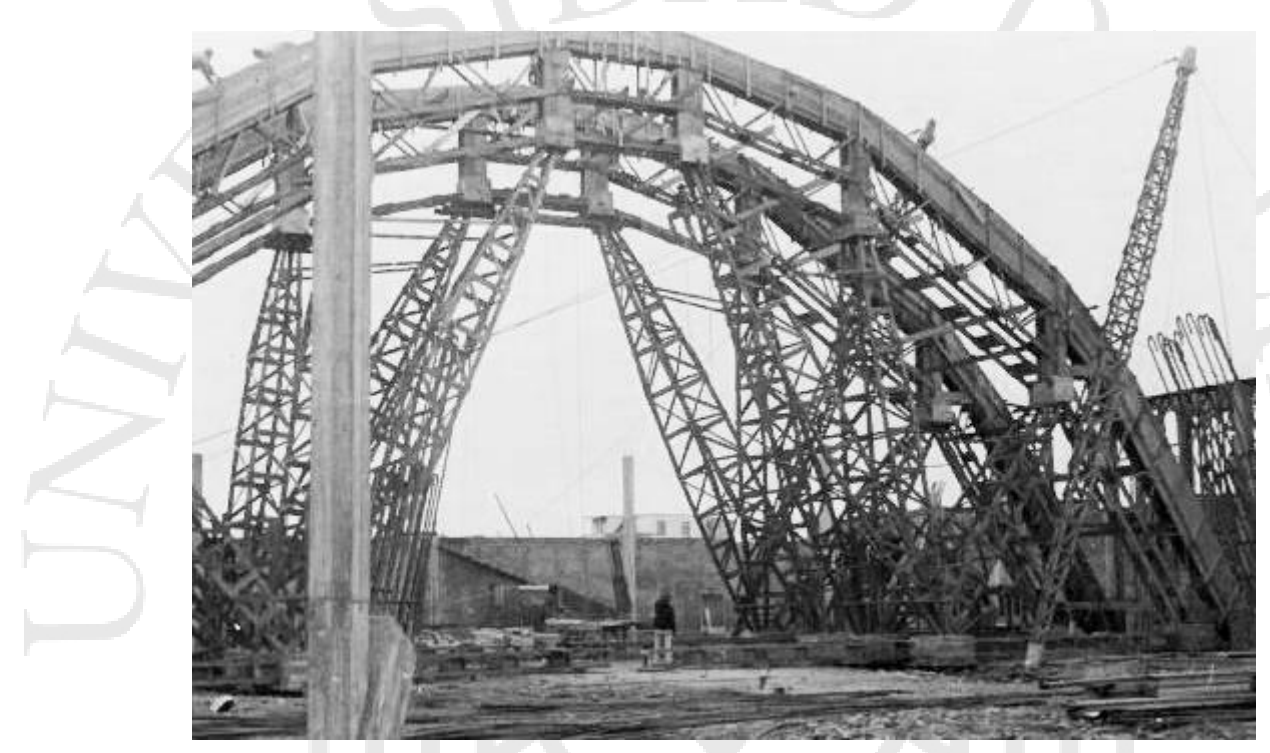

Fuente: Investigación de mercados de Lima, Universidad de Lima 


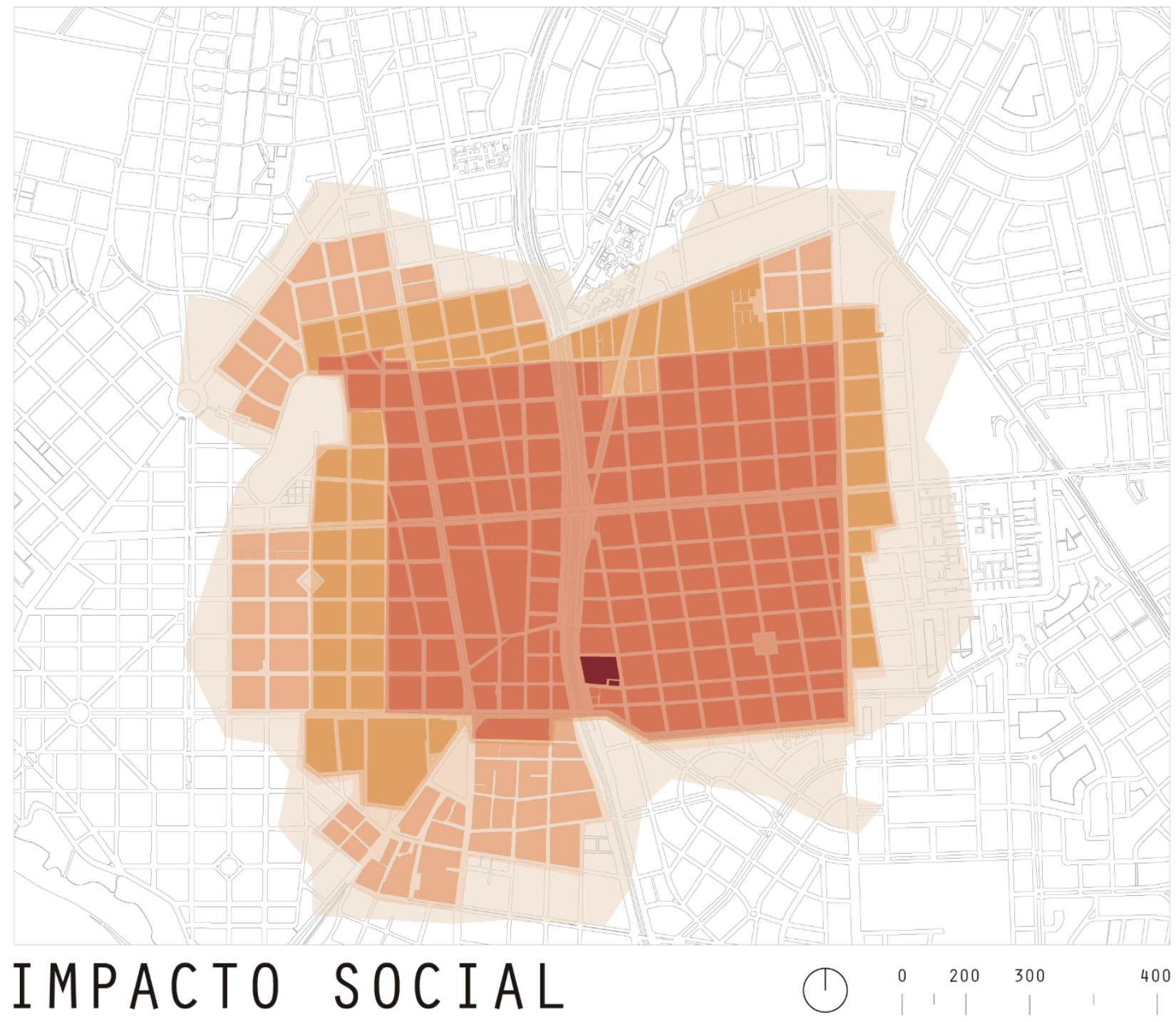

\section{MERCADO DE SURQUIL L 0}

ÁREA DE INFLUENCIA DIRECTA

RADIO 1 KM APROX

ÁREA DE INFLUENCIA DIRECTA

ACCESO A TRANSPORTE COLECTIVO

ÁREA DE INFLUENCIA DISPERSA

DILUYE EN EL RESTO DE LA CIUDAD 


\subsubsection{Impacto social}

En el caso del Mercado de Surquillo, el impacto que ha generado en el contexto limeño radica en la imagen gastronómica que se ha podido llevar a cabo debido a estrategias de publicidad y alianzas con instituciones vinculadas al tema gastronómico. Asimismo, es reconocido en la ciudad en este ámbito, por la diversidad, precio y calidad de productos, más no el mercado como institución.

Figura 5.45

Andrew Zimmern y Gastón Acurio filmando en el Mercado $N^{\circ} 1$ de Surquillo

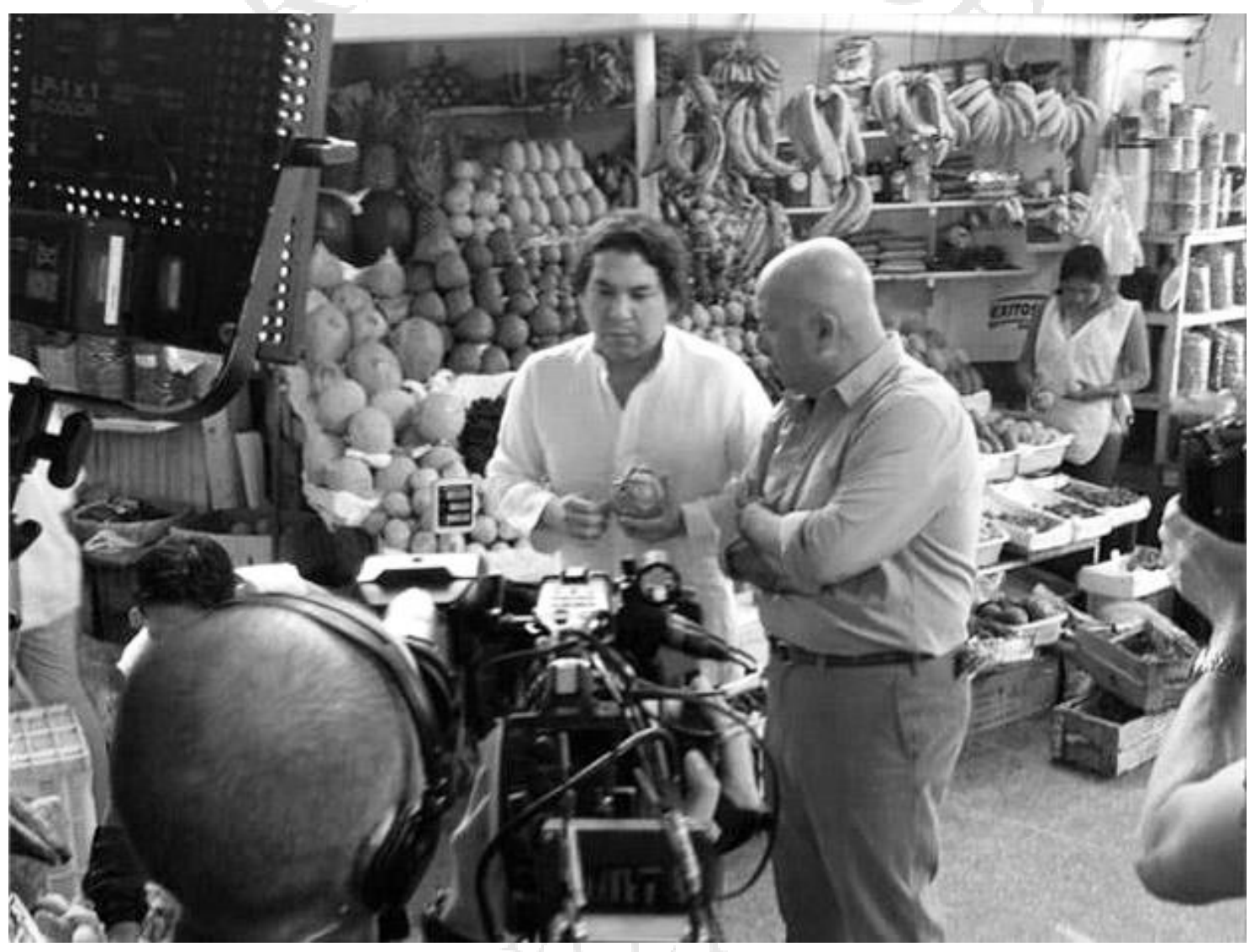

Nota: Imagen editada en blanco y negro

Fuente: Andrew Zimmern of "Bizarre Foods" filming in Lima, Peru (2014) Andrew Zimmern

En: http://www.peruthisweek.com/news-andrew-zimmern-of-bizarre-foods-filming-in-lima-peru-102035 


\subsection{Mercado Central de Lima}

\subsubsection{Ubicación}

Arquitecto: Guillermo Payet

Año: 1967

Cliente: público

Ubicación: Jirón Ucayali 615, Lima

Categoría: mercado municipal

Terreno: $16,400 \mathrm{~m} 2$

Figura 5.46

Vista aérea del Mercado Central de Lima

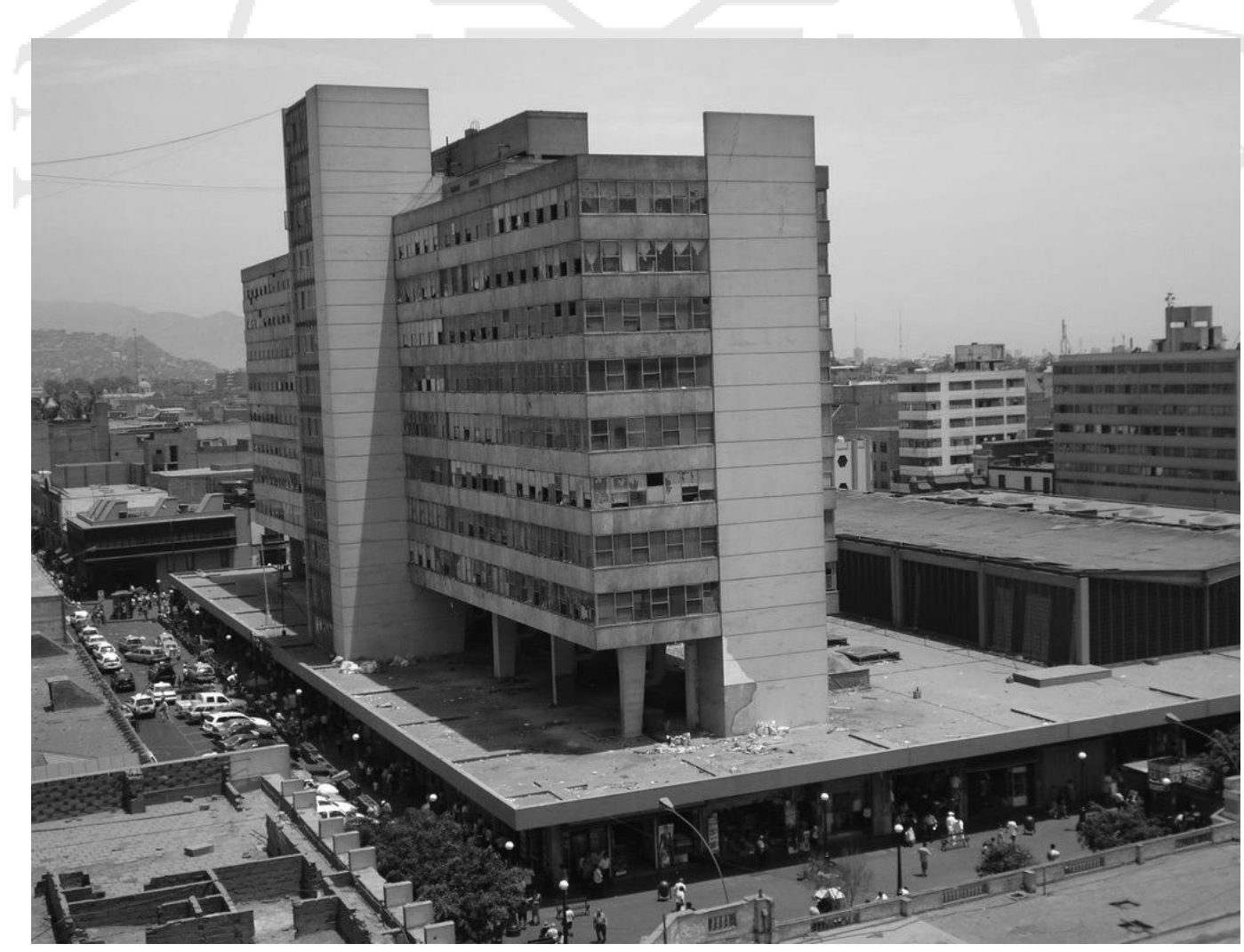

Nota: Imagen editada en blanco y negro

Fuente: Mercado Central de Lima (s.f.)

En: www.panoramio.com 


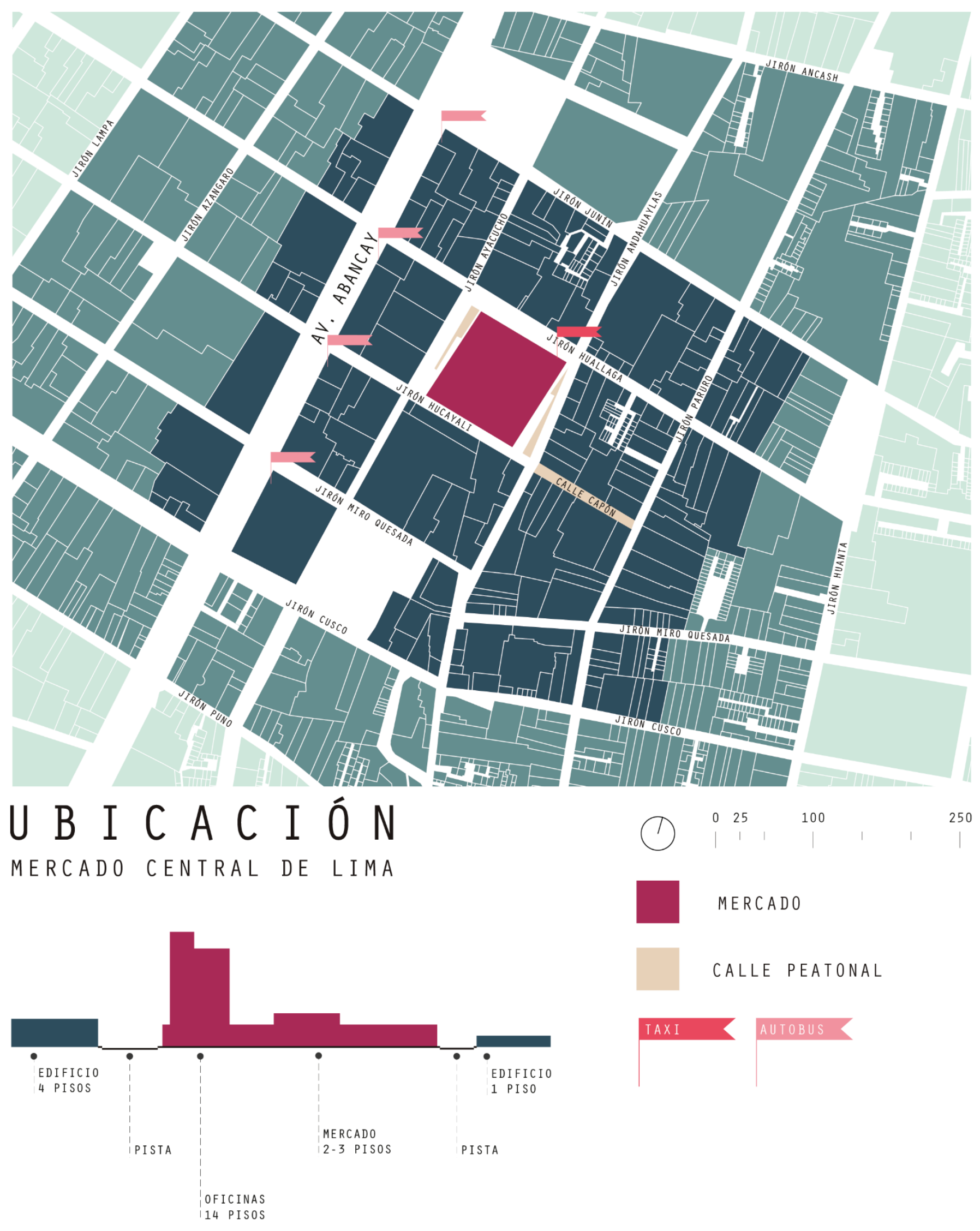


El Mercado Central de Lima se ubica en toda una manzana rodeada por las vías: Jirón Ayacucho, Jirón Huallaga, Jirón Andahuaylas y Jirón Ucayali. Asimismo, tiene cercanía a la Calle Capón, vía peatonal y a lugares comerciales de la zona. La accesibilidad hacia el proyecto es principalmente desde la Av. Abancay, donde a lo largo de esta se ubican paraderos de transporte público.

En cuanto a su impacto en el perfil urbano, el mercado tiene dos situaciones: la sección en el Jirón Ucayali mantiene un perfil homogéneo con el entorno, mientras que, en el Jirón Huallaga, existe un contraste de alturas debido a la proximidad de la torre de oficinas y las alturas de las construcciones aledañas que no superan los 5 pisos.

Figura 5.47

Exterior del Mercado Central de Lima

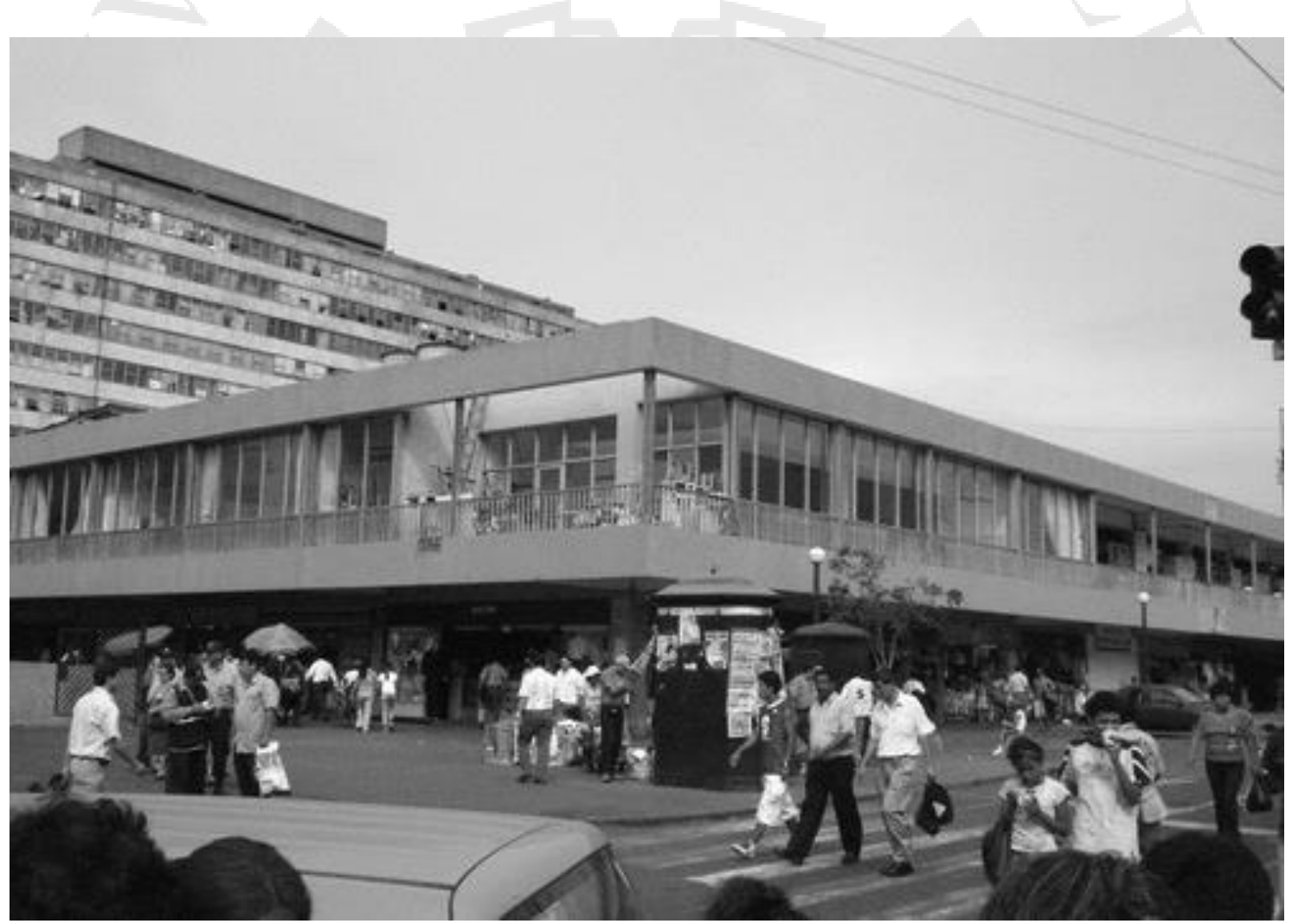

Fuente: Mercado Central de Lima (s.f.)

En: www.panoramio.com 


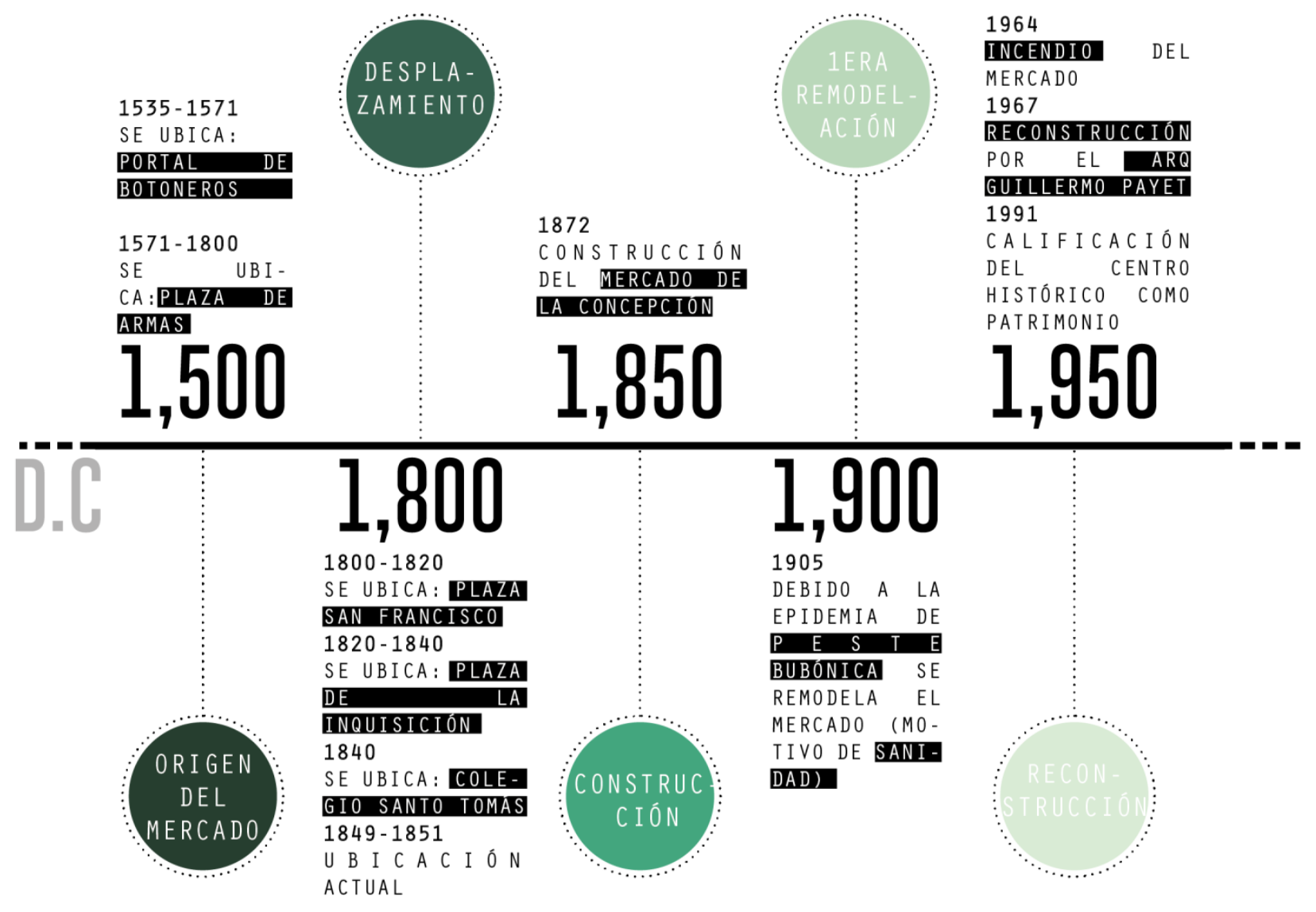

\section{H I S T O R I A}

MERCADO CENTRAL DE LIMA

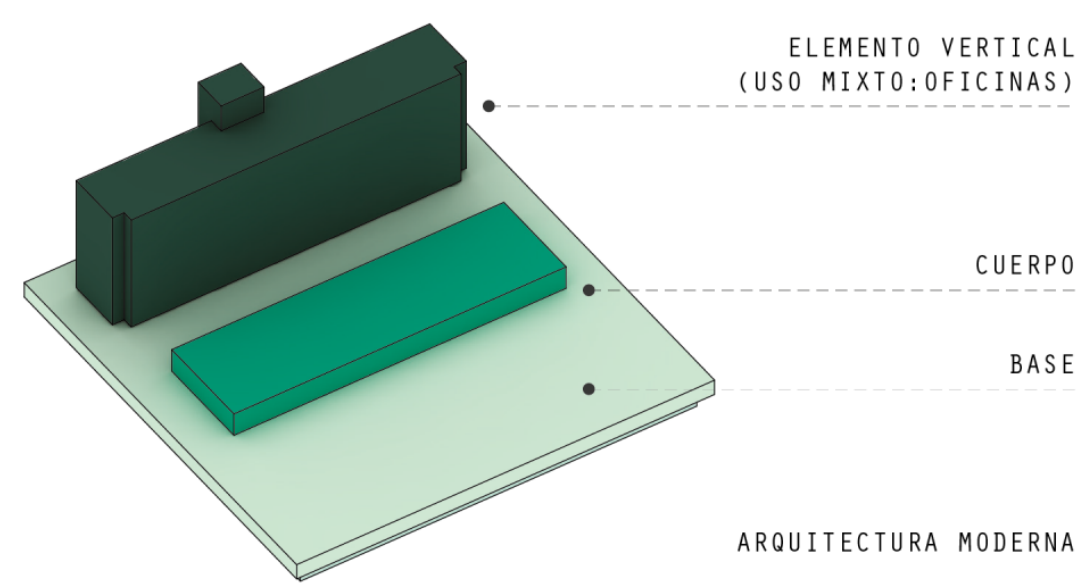




\subsubsection{Historia}

El Mercado Central de Lima tiene origen en la época colonial, con la existencia de actividad comercial a la entrada de la Catedral de Lima (portal de botoneros). Para el año 1571 el mercado se desplaza a la Plaza de Armas, quedándose hasta inicios del siglo XIX, cuando se traslada hacia la Plaza San Francisco. En 1820 este se traslada nuevamente hacia la plaza de la inquisición hasta 1840 que pasa a ubicarse en las inmediaciones del Colegio Santo Tomás.

En 1849, debido al crecimiento de la población y a la demanda de necesidades, durante el régimen de Ramón Castilla se aprueba la construcción de un mercado de abastos. Por este motivo, se expropia el terreno del Convento de la Concepción y en 1872 se construye el Mercado de la Concepción. En 1905, debido a una epidemia de peste bubónica, el mercado es desocupado completamente y remodelado por medidas de sanidad.

Fue en el año de 1964 que, debido a un incendio, el mercado queda destruido por completo, motivo por el cual se llevó a cabo su reconstrucción, diseñada por el arquitecto Guillermo Payet. En 1967 se inaugura el Mercado Central, tal como se conoce hoy en día.

Figura 5.48

Mercado Central de Lima

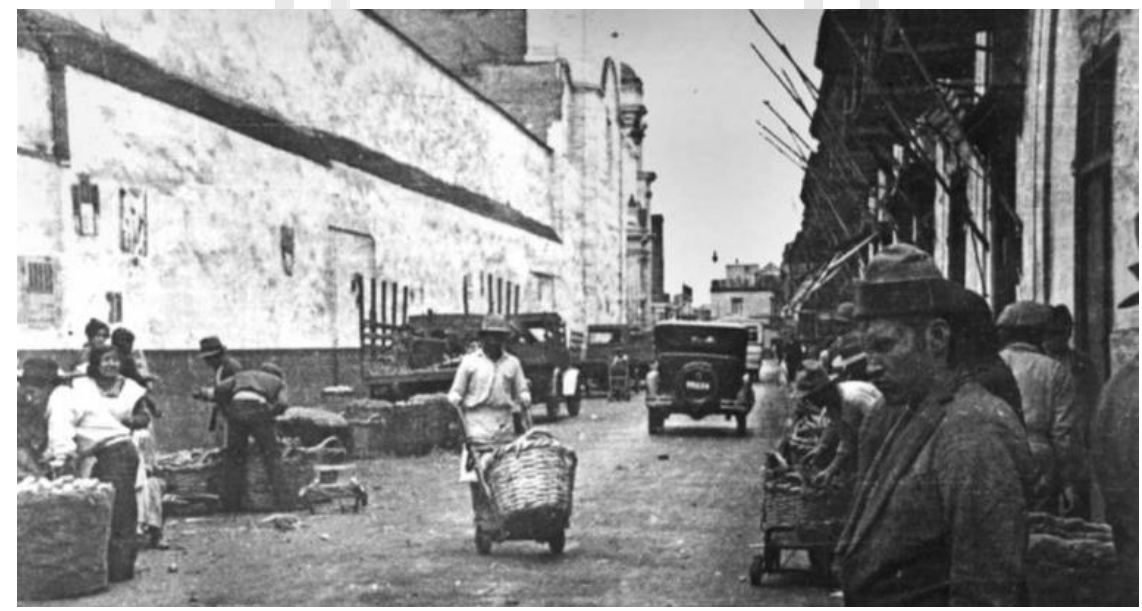

Fuente: Mercado Central de Lima (s.f.)

En: www.panoramio.com 


\section{Toma de partido:}

El Mercado Central está configurado en base al estilo moderno, muy utilizado en la época de su concepción (1967). Está conformado por un basamento comercial y un elemento vertical conformado por la torre de oficinas. 


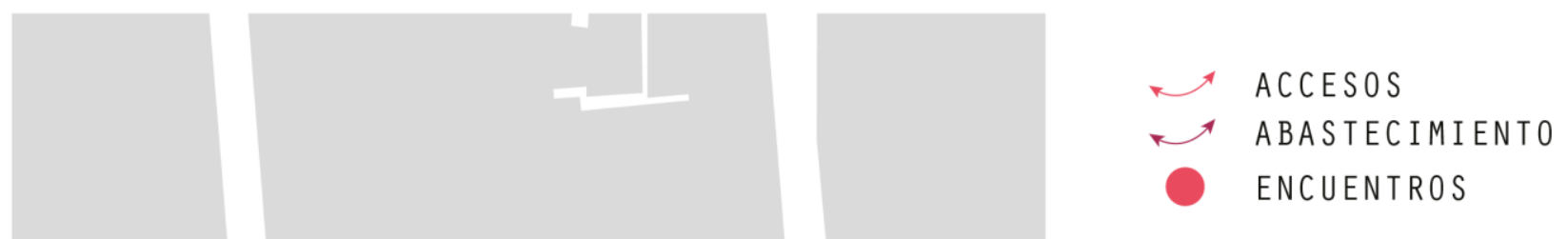

AREA DE PARQUEO

OFICINAS

ÁREA DE COMERCIO

MUNICIPAL

ÁREA DE MERCADO

ÁREA DE ACCESO Y SALIDA DE ABASTECIMIENTO

ÁREA DE CIRCULACIÓN PEATONAL

ÁREA DE SERVICIOS MENORES

ÁREA DE PARQUEO

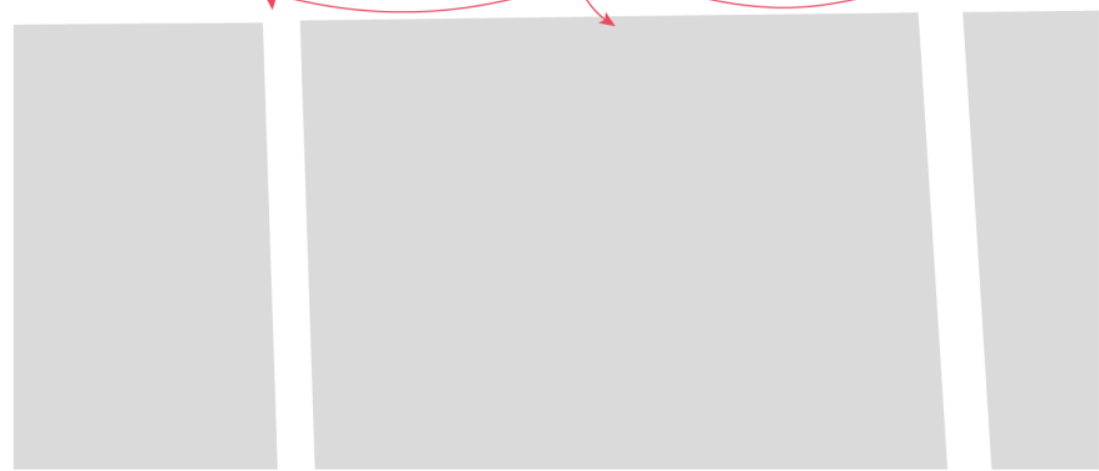

(1)

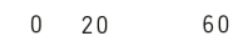

RELACIÓN ENTORNO MERCA D O CENTRAL DE L I M A
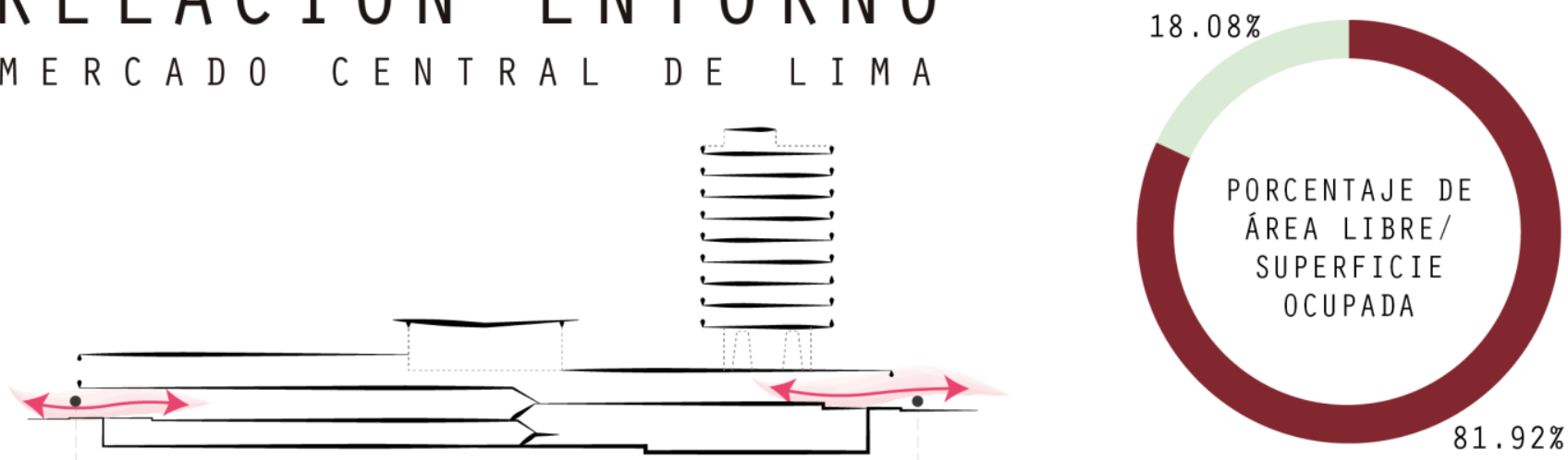


\subsubsection{Entorno}

El Mercado Central tiene cuatro accesos peatonales y dos vehiculares. Estos se ubican en a la mitad de cada lado del mercado donde se desarrollan encuentros de personas y comercio ambulatorio. En cuanto al ingreso vehicular, este es exclusivamente para el abastecimiento e ingreso de camiones al sótano.

El parqueo público se encuentra alrededor de todo el mercado, al igual que las tiendas de comercio municipal (en el primer nivel) que atienden hacia las calles. Para el lado de los Jirones Ayacucho y Andahuaylas, se encuentran veredas más anchas que permiten una mayor circulación peatonal y el desarrollo de comercio de servicios menores.

En cuanto a su relación espacial con el exterior, este se da por los accesos con una conexión directa hacia la zona de ventas y mediante las tiendas del primer nivel que atienden hacia el exterior.

\subsubsection{Tipología}

Figura 5.49

Esquema de tipología según distribución de puestos

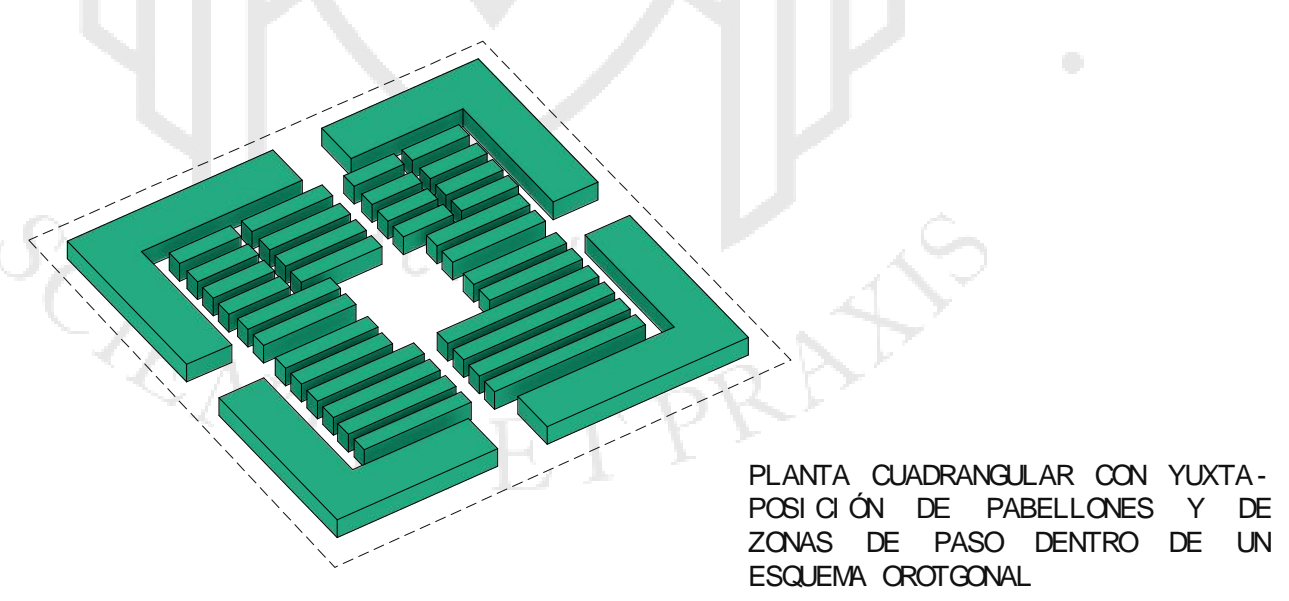

Fuente: elaboración propia

Según su distribución de puestos de venta y distribución del mercado, este tiene una tipología de planta cuadrangular con yuxtaposición de pabellones y de zonas de paso dentro de un esquema ortogonal. 


\subsubsection{Programa}

\section{Cuadro de áreas}

Tabla 5.7

Cuadro de áreas del Mercado Central de Lima

\begin{tabular}{|c|c|c|c|c|}
\hline PROGRAMA & AREA (m2) & PORCENTAJE & TOTAL & \\
\hline ÁREA DE VENTAS & & & 1424.3 & $\mathbf{m} 2$ \\
\hline-47 & 220.9 & $10.18 \%$ & & \\
\hline Aves & 247.4 & $11.40 \%$ & & \\
\hline Pescados / Mariscos & 38.8 & $1.79 \%$ & & \\
\hline Embutidos & 0 & $0.00 \%$ & & \\
\hline Frutas & 262.1 & $12.08 \%$ & & \\
\hline Verduras & 263.1 & $12.13 \%$ & & \\
\hline Abarrotes & 392 & $18.07 \%$ & & \\
\hline Lácteos & 0 & $0.00 \%$ & & \\
\hline Licorería & 0 & $0.00 \%$ & & \\
\hline SERVICIOS COMPLEMENTARIOS & & & 290.6 & $\mathbf{m} 2$ \\
\hline Juguería / Bares / Café / Restaurantes & 290.6 & $13.39 \%$ & & \\
\hline Otros servicios públicos & 0 & $0.00 \%$ & & \\
\hline SERVICIOS GENERALES & & & 454.8 & $\mathbf{m} 2$ \\
\hline Almacenes refrigerados & 188.1 & $8.67 \%$ & & \\
\hline Almacenes & 43.1 & $1.99 \%$ & & \\
\hline Descarga & 0 & $0.00 \%$ & & \\
\hline Residuos & 0 & $0.00 \%$ & & \\
\hline Administración & 25.1 & $1.16 \%$ & & \\
\hline Oficinas & 22.7 & $1.05 \%$ & & \\
\hline SSHH & 92.3 & $4.25 \%$ & & \\
\hline Otros servicios privados & 83.5 & $3.85 \%$ & & \\
\hline TOTAL & & $100 \%$ & 2169.7 & $\mathbf{m} 2$ \\
\hline
\end{tabular}


CARNES

AVES

PESCADOS/MARISCOS

EMBUTIDOS

FRUTAS

VERDURAS

ABARROTES

LACTEOS

JUGUERIA / BAR/CAFÉ/

RESTAURANTES

LICORERÍA

ALMACENES REFRIGERADOS

ALMACENES

DESCARGUE

RESIDUOS

ADMINISTRACIÓN

OFICINAS

SSHH

OTROS SERVICIOS PÚBLICOS

OTROS SERVICIOS PRIVADOS
ED I F I C I 0

OFICINAS

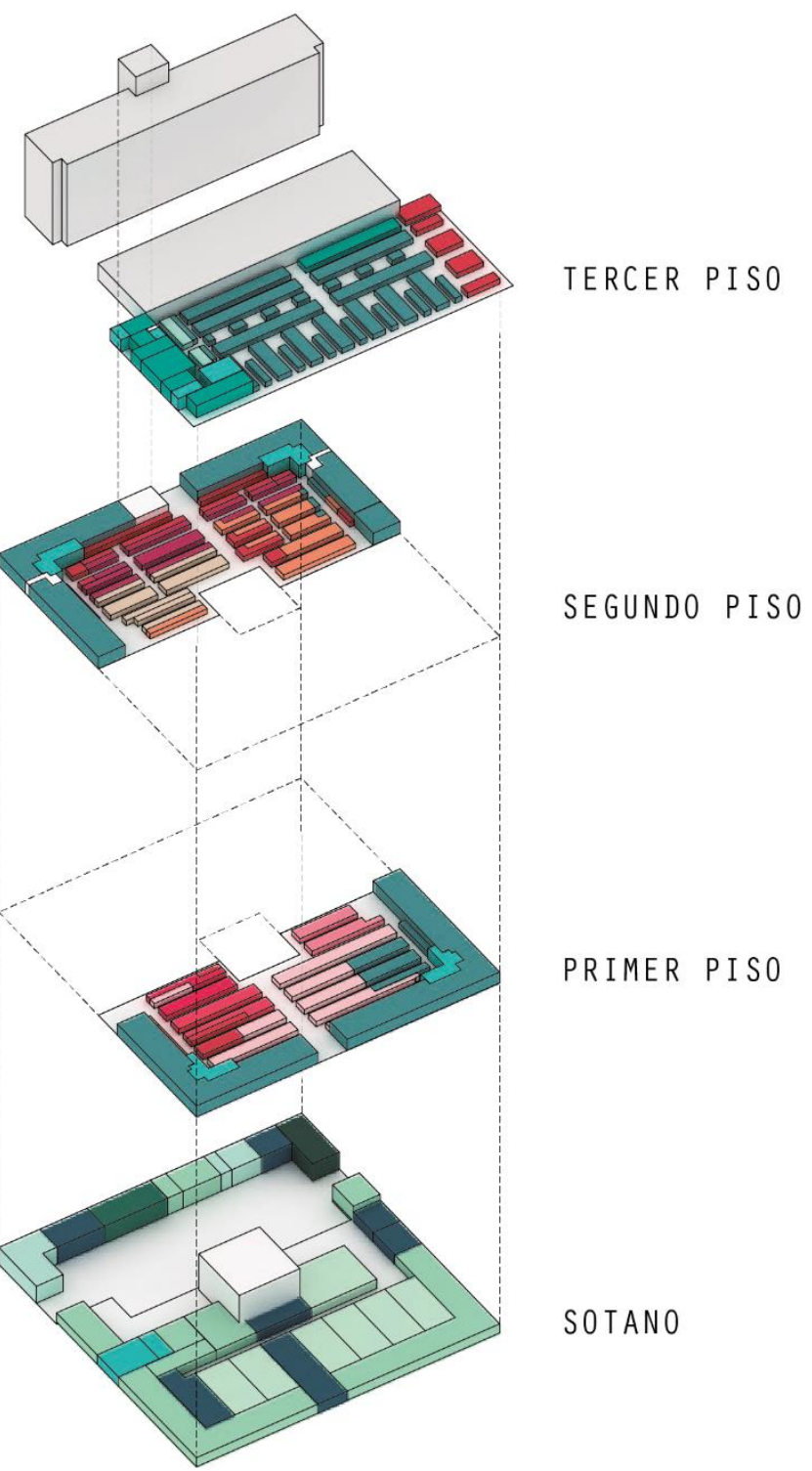

\section{$P R O G R A M A$}

MERCADO CENTRAL DE LIMA

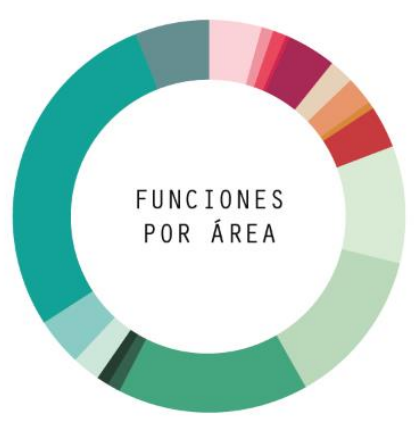




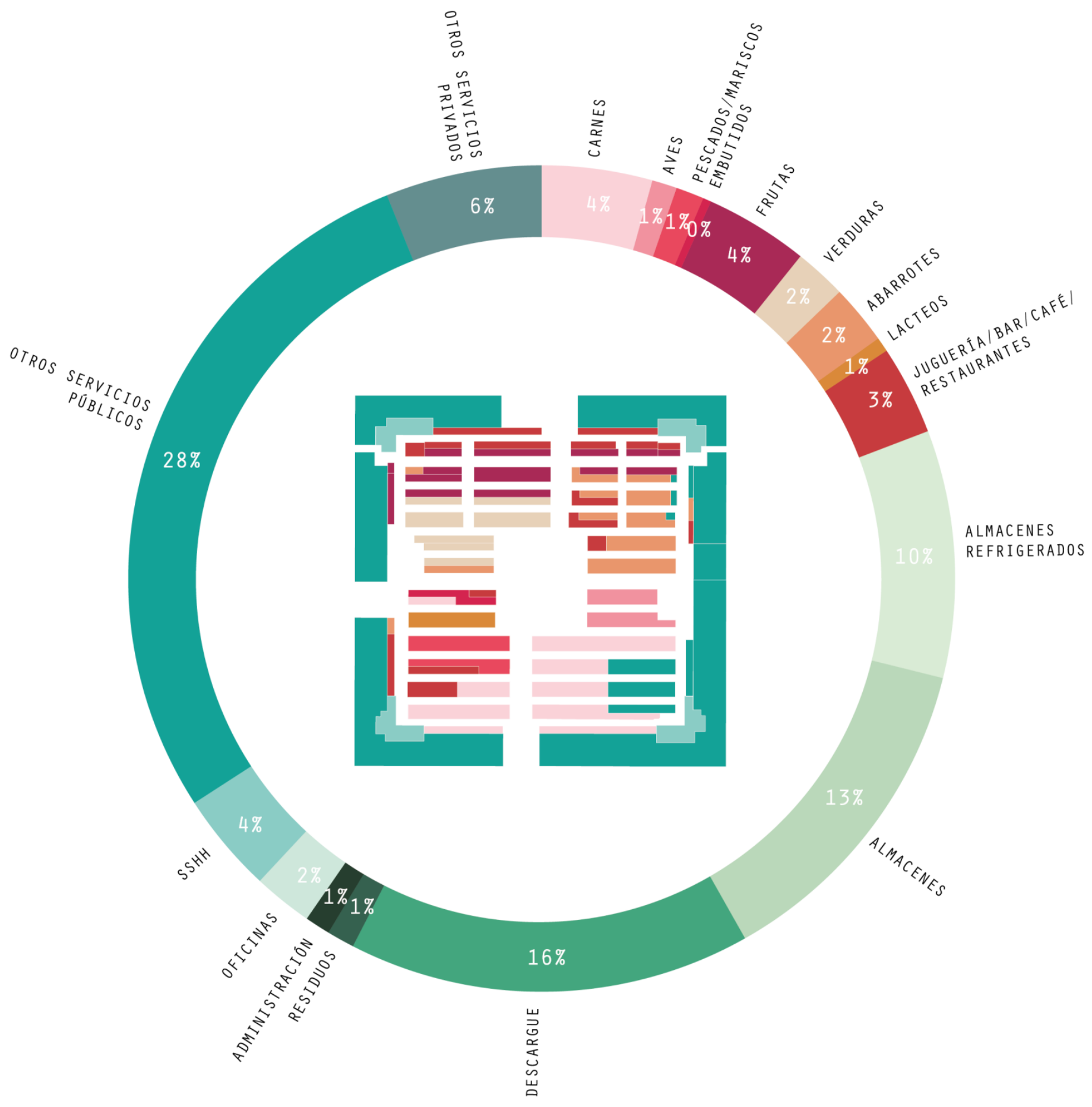

PROGRAMA

MERCADO CENTRAL DE LIMA 


\section{INGRESO/SALIDA CLIENTES}

SERVICIOS COMPLEMENTARIOS

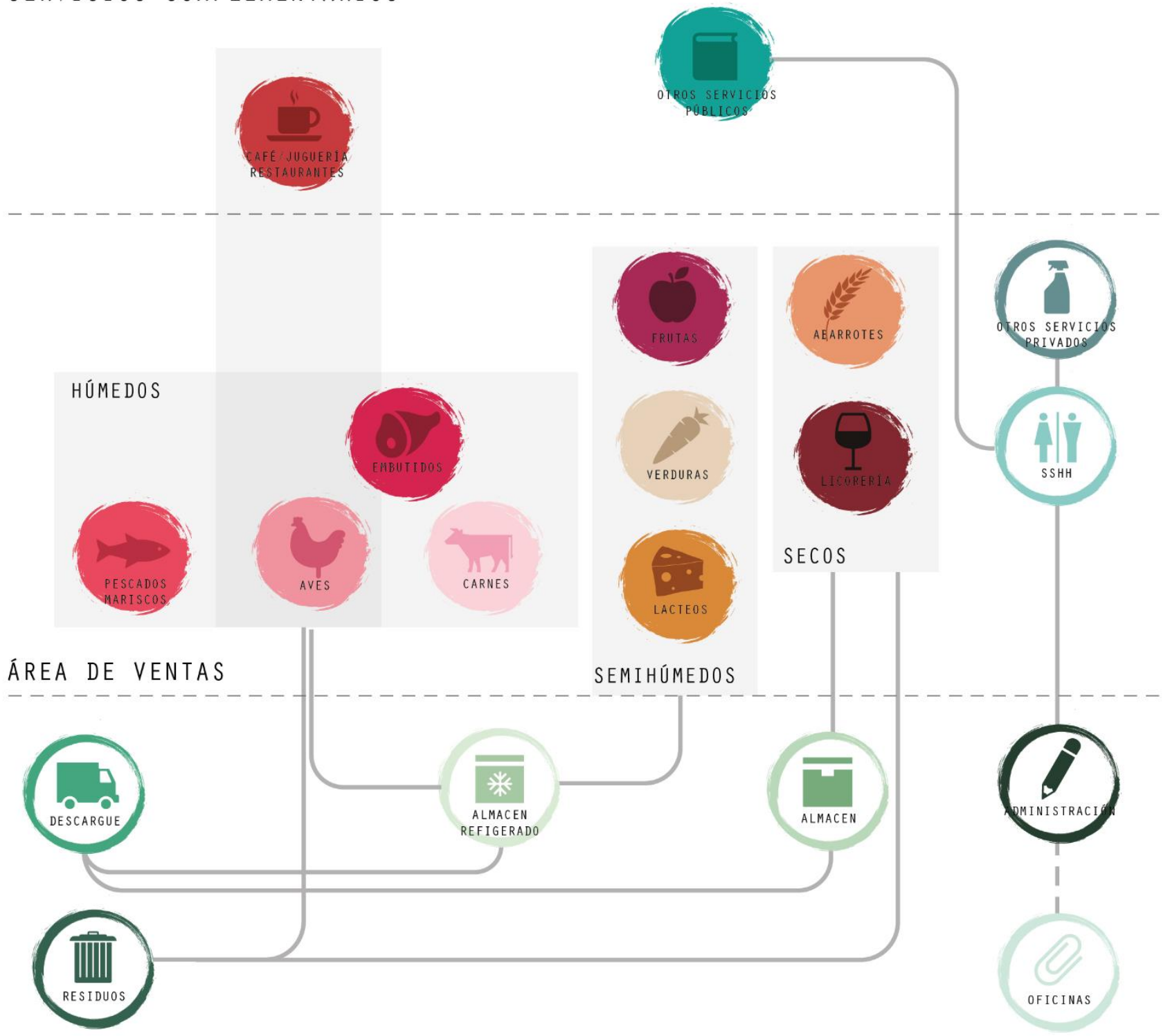

ÁREA DE SERVICIOS GENERALES

\section{O R G A N I G RAMA}

MERCADO CENTAL DE LIMA 


\subsubsection{Programa}

El Mercado Central de Lima tiene un programa de mercado dividido en cuatro niveles. El nivel del sótano está dedicado a la logística del mercado, donde se encuentran los almacenes, las cámaras de refrigeración, la zona de descarga de productos, la parte administrativa y otros servicios de usos privados como los vestidores y servicios del personal.

En la primera y segunda planta, donde se encuentran los accesos hacia el mercado, se ubica el área de ventas. Asimismo, ocurre en la tercera planta, que además de contener este programa comercial, se encuentran otros servicios de uso público. En relación al edificio vertical que contiene la infraestructura, este tiene un ingreso ubicado en el Jirón Huallaga y su programa está conformado por oficinas, el cual no ha sido contemplado para el aporte del programa del mercado.

En cuanto a la relación entre los espacios del Mercado Central, vemos que en el ingreso se da una conexión directa con los puestos de venta de productos de distinta índole (a la encontrada en un mercado) y con las juguerías y restaurantes, que se encuentran dirigidos hacia el exterior. Una vez dentro del mercado se encuentran puestos de productos alimenticios de tipo húmedo, semihúmedo y seco, organizados por grupos de productos en los distintos niveles del mercado. Estos puestos se encuentran verticalmente conectados por una rampa para permitir la conexión con los almacenes, cámaras frigoríficas y la zona de descargue ubicados en el sótano. Por otro lado, la zona de eliminación residuos está ubicado al exterior del mercado, en un contenedor subterráneo.

En todos los niveles se pueden encontrar servicios higiénicos. Y finalmente, respecto a la administración y oficinas, se encuentran en el área de servicios generales ubicados en el sótano junto a la parte de logística. 


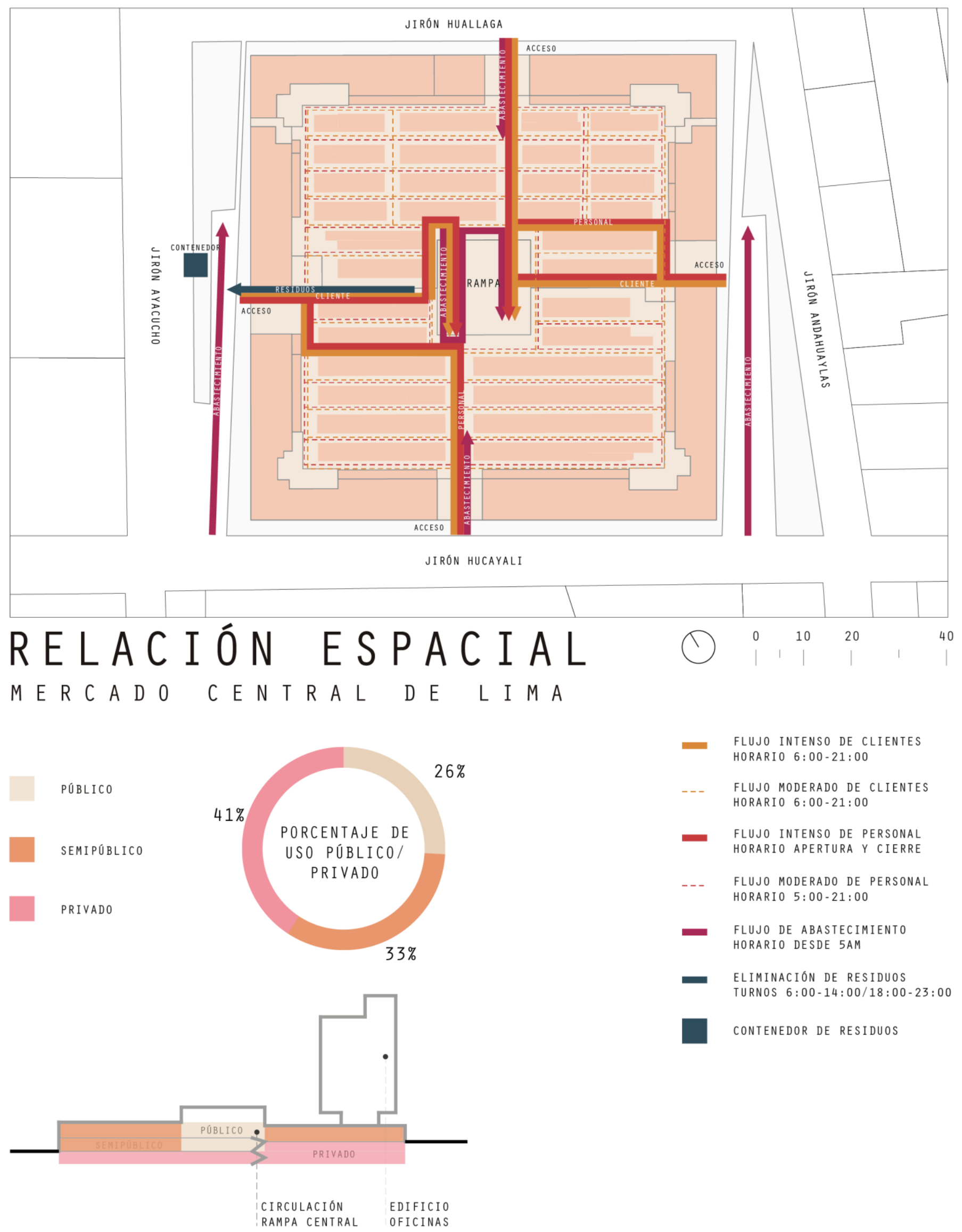




\subsubsection{Espacio}

Los flujos encontrados en el Mercado Central se separan según la circulación del abastecimiento, los clientes, el personal trabajador y la eliminación de residuos. En cuanto al abastecimiento este se da principalmente a tempranas horas de la mañana (5:00 am) sin embargo, en el caso de las frutas, abarrotes, juguerías y restaurantes puede continuar su abastecimiento hasta las $6 \mathrm{pm}$.

La distribución de productos ocurre de dos maneras: la primera mediante la llegada de productos a la zona de descarga (sótano) para hacer uso de las cámaras frigoríficas y almacenes para luego ser distribuidos mediante la rampa hacia los puestos de ventas. Y la segunda mediante la llegada de productos a menor escala, desde los ingresos peatonales principales.

En cuanto al flujo de clientes, de lunes a sábado es intenso durante el horario de apertura (6am) hasta las 10am que baja su intensidad, su atención al público estos días es hasta las 9pm. En el caso de los domingos la concurrencia de personas aumenta antes del cierre (6pm). En ambos casos, el horario de almuerzo se caracteriza por un aumento en la intensidad de flujos dentro del mercado, debido a los puestos de comida.

En cuanto al desplazamiento del personal este inicia desde las 5am, ya que a esa hora es el abastecimiento de la mayoría de los puestos. Sus flujos se dan principalmente al momento de desplazar productos en carretillas por la rampa principal y al momento de la eliminación de residuos hacia el exterior del mercado. Los horarios de eliminación de residuos se realizan en 2 turnos $(6 \mathrm{am}-2 \mathrm{pm} / 6 \mathrm{pm}-11 \mathrm{pm})$ y están organizados por zonas. 
DETALLE CONSTRUCT IVO

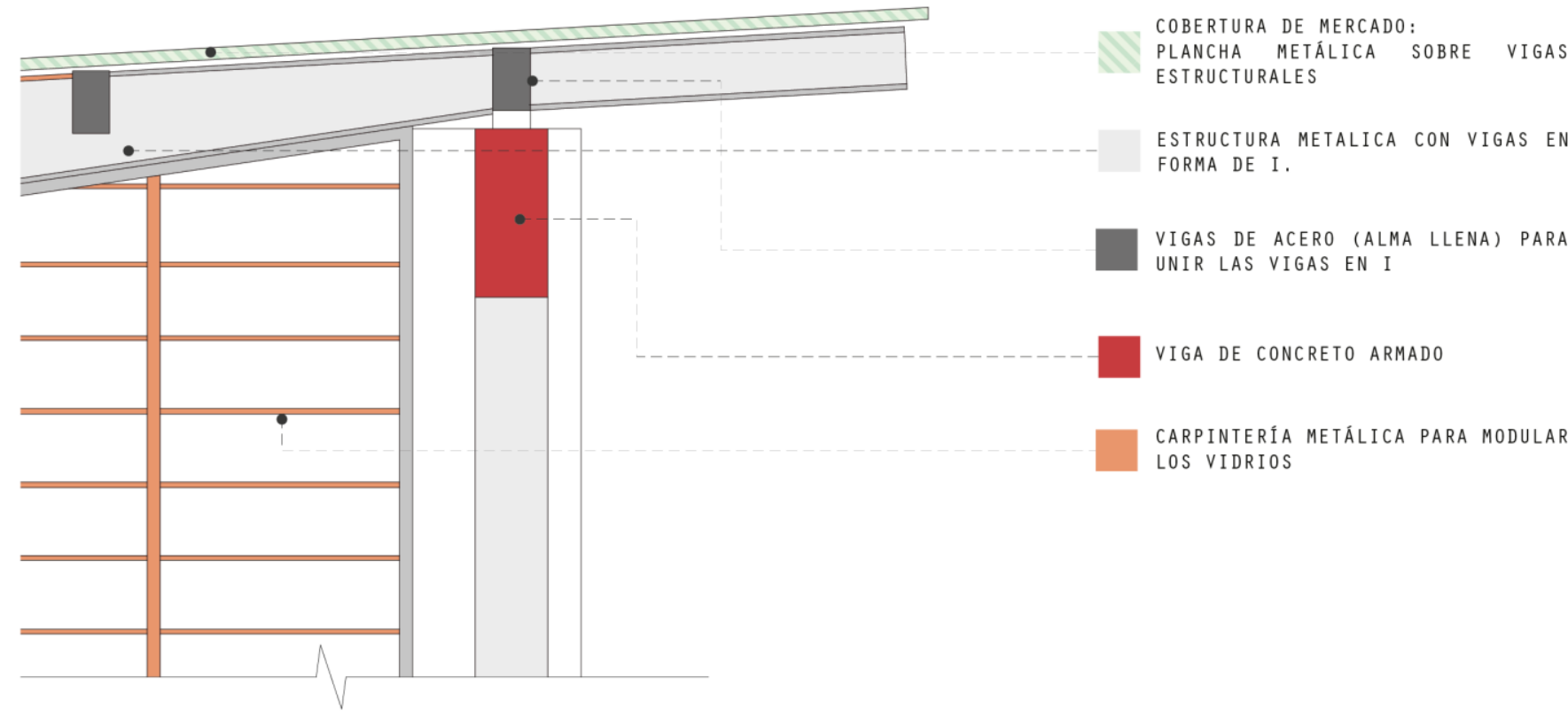

Sistema CONSTRUCTIVO DEL TECHO NAVE INDUSTRIAL

\section{INNOVACIÓN TECNOLÓGICA}

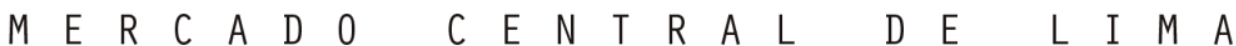

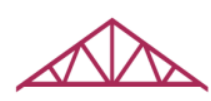

USO DEL SISTEMA CONSTRUCTIVO DE

NAVE INDUTRIAL PARA TECHAR

GRANDES LUCES $82 \times 18$

JUNTAS DE DILATACIÓN EN MÓDULOS

DE $10 \mathrm{M}$

SEPARACIÓN DE RESIDUOS Y RECICLAJE

DE LA QUE SE HACE HARINA DE PESCA -

D 0 . 


\subsubsection{Tecnología}

El Mercado Central de Lima está construido bajo un sistema aporticado de concreto armado. Debido a su extensión, está configurado en nueve bloques separados por juntas de dilatación y modulado ortogonalmente con una separación de columnas de $10 \mathrm{~m}$. Asimismo, contiene losas macizas excepto en la parte central donde se ubica una cobertura de tipo nave industrial, conformado por tijerales de alma llena (acero) de sección variable y un techo metálico.

En cuanto al manejo de residuos, este mercado separa por zonas la recolección y por ejemplo en el caso de la zona de pescados, se reutilizan los sobrantes y residuos para la producción de harina de pescado.

Figura 5.50

Interior del Mercado Central de Lima

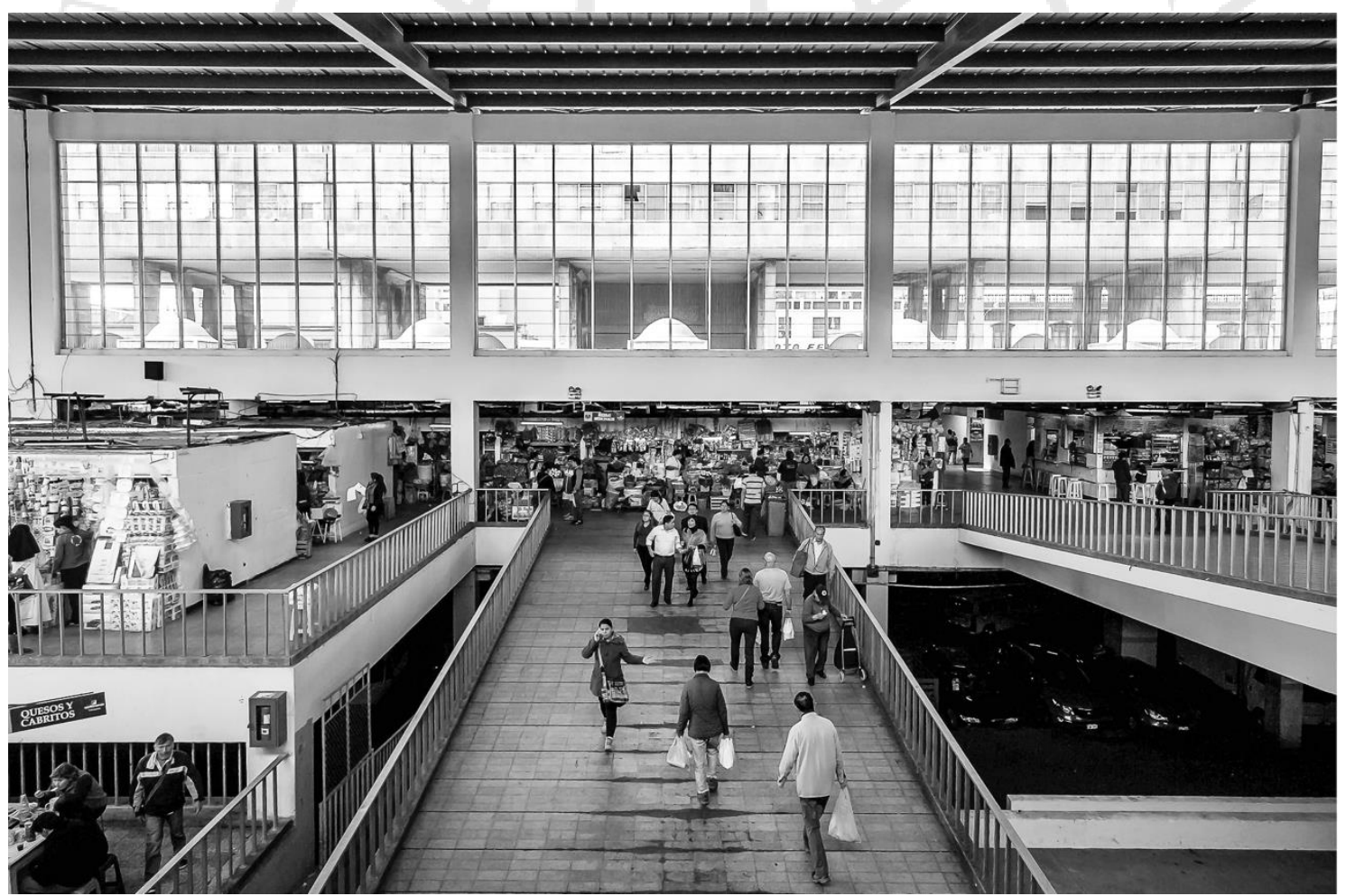

Fuente: Mercado Central de Lima (2014) Marco Silva Navarrete

En: https://www.flickr.com/photos/moonshot_viaje2009/14919769086/ 


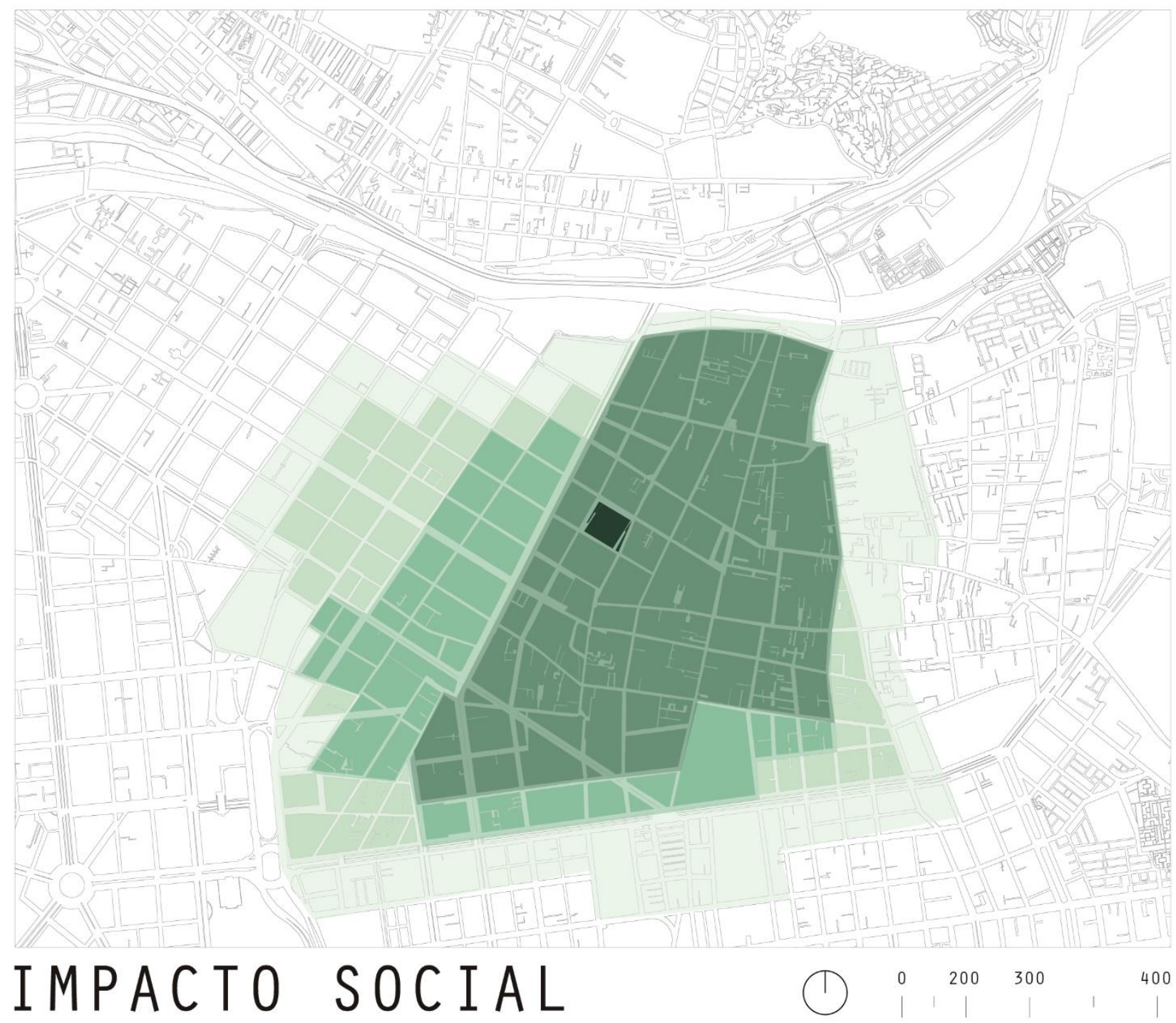

\section{MERCADO CENTRAL DE LIMA}

ÁREA DE INFLUENCIA DIRECTA

RADIO 1 KM APROX

ÁREA DE INFLUENCIA DIRECTA

ACCESO A TRANSPORTE COLECTIVO

ÁREA DE INFLUENCIA DISPERSA

DILUYE EN EL RESTO DE LA CIUDAD 


\subsubsection{Impacto social}

En cuanto a su influencia en la zona, el mercado tiene una repercusión mayor al radio de acción de mercados $(1 \mathrm{~km})$, ya que es concurrido por visitantes no solo del distrito del Cercado de Lima.

El Mercado Central de Lima, representa para nuestra ciudad un ejemplo de infraestructura con un diseño arquitectónico preocupado para un buen funcionamiento, logística para la venta y distribución de productos, al igual que por la circulación e iluminación natural que corresponden aportes resaltantes del mercado.

Figura 5.51

Apunte del Mercado Central de Lima

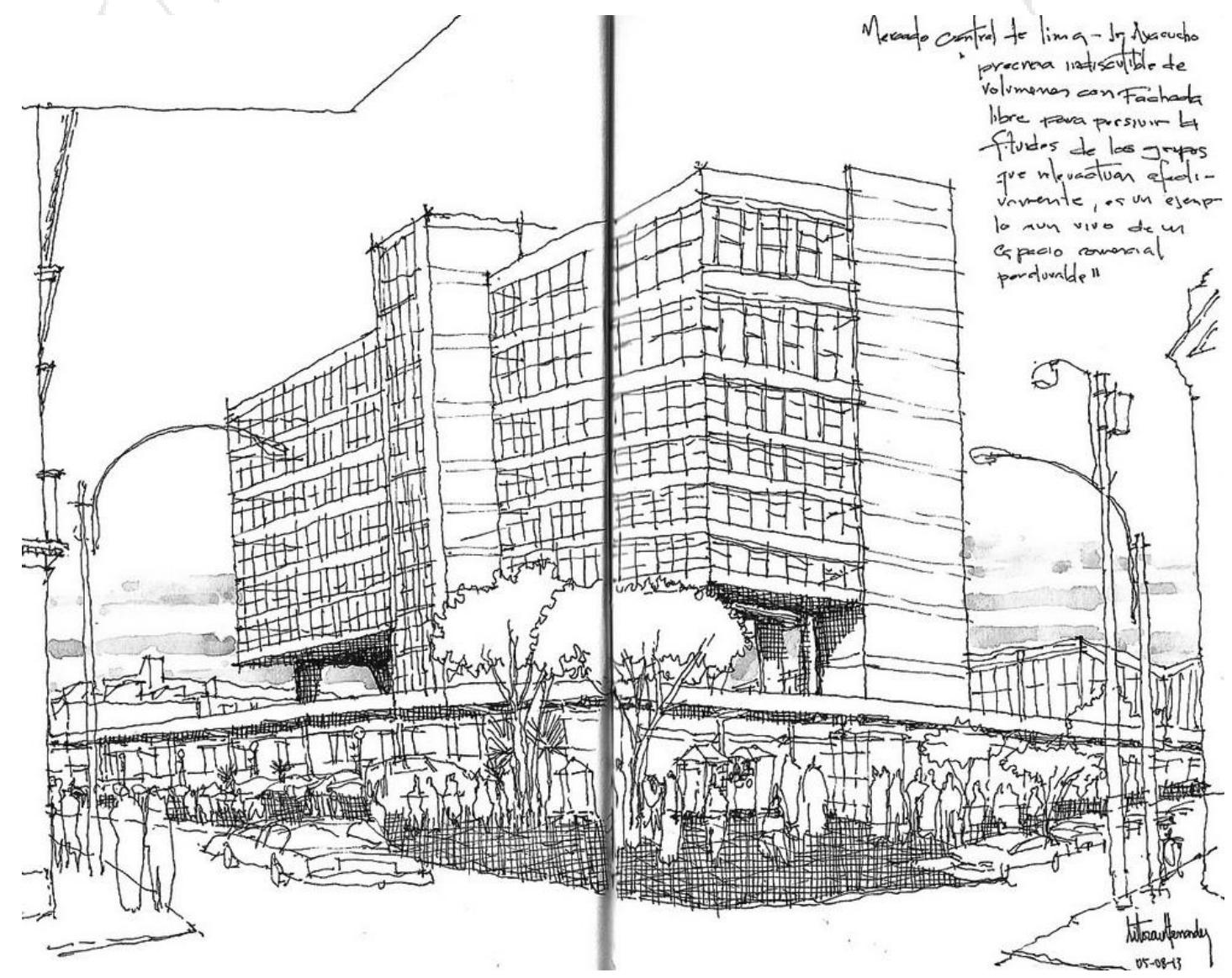

Fuente: Mercado Central de Lima (s.f.) Metàpolis Arquitectura En: flickr.com 


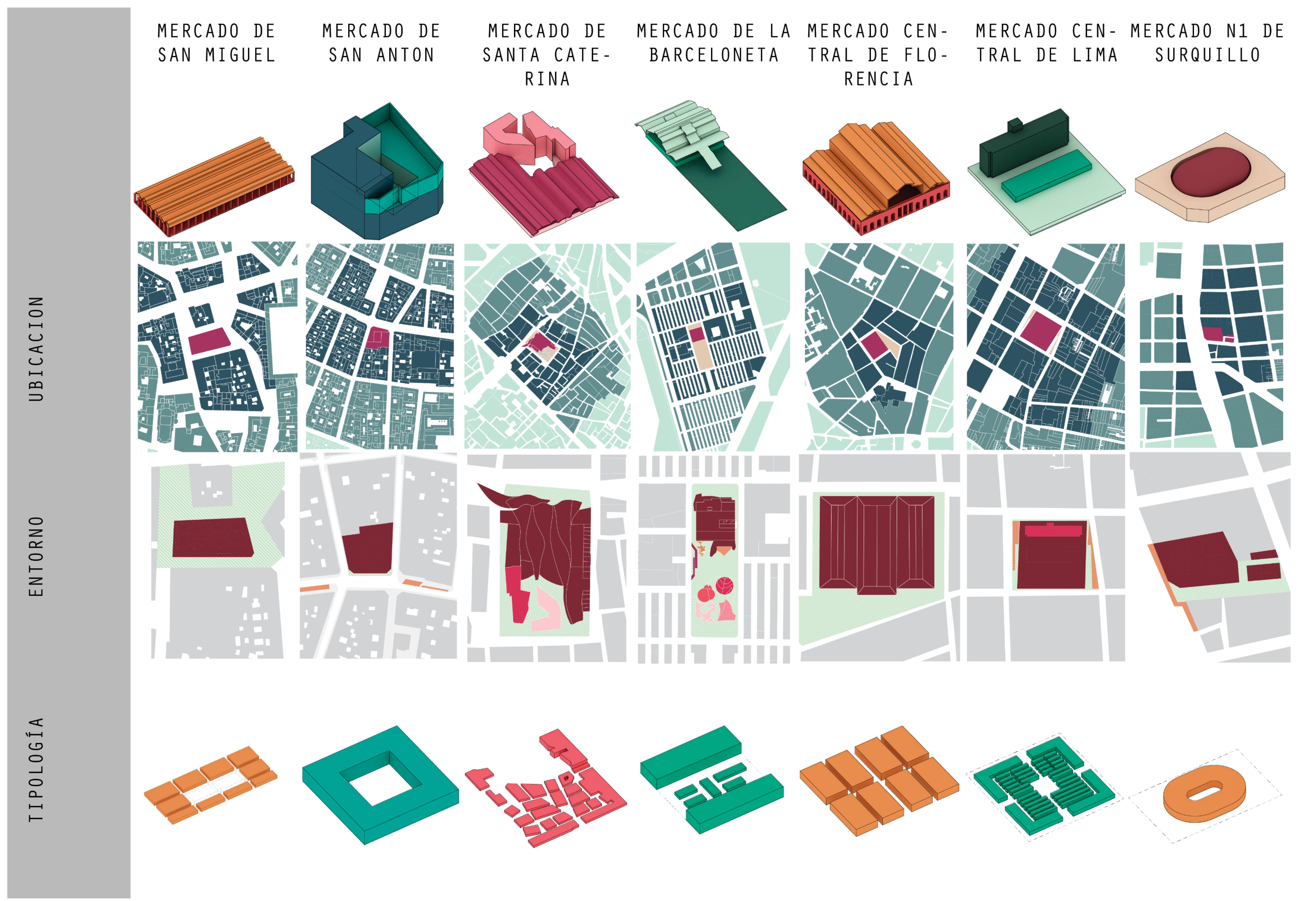




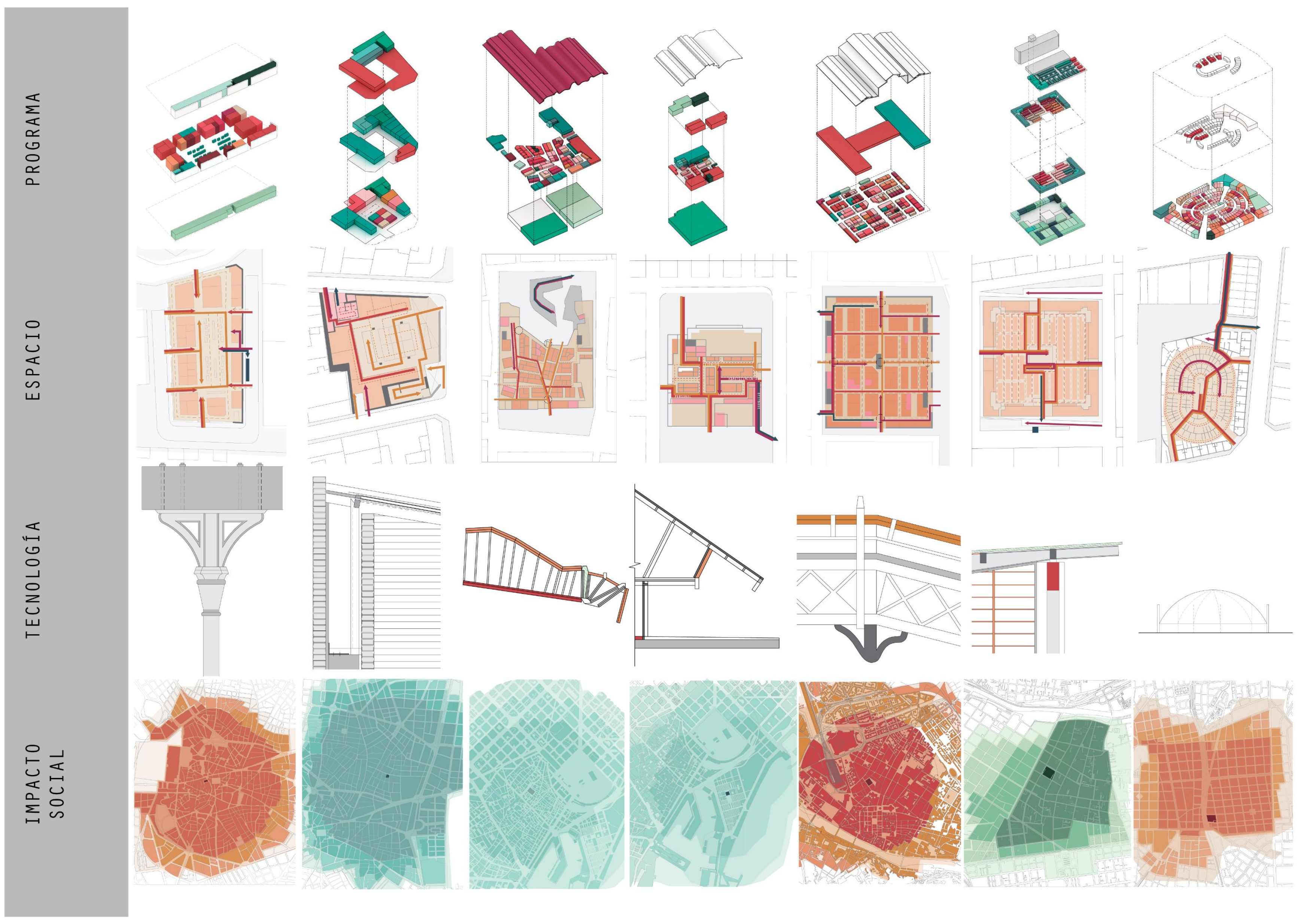




\subsection{Conclusiones parciales}

En cuanto a la ubicación, es relevante y da valor agregado la presencia de plazas o espacios públicos anexos a los mercados. No sólo por lo que la plaza significa a nivel histórico, sino además porque congrega, da pie al encuentro y permite soportar la gran afluencia de gente. Un claro ejemplo es el caso del Mercado de la Barceloneta, que actúa como elemento dinamizador y que fusiona la vida comercial y social en un solo lugar.

En el caso de mercados como el de San Antón, la presencia del espacio público, sólo se ve reflejado en el interior, mas no se proyecta como un aporte urbano para la ciudad.

Se puede comprobar que todos los mercados guardan en esencia la importancia histórica y presencia desde su origen. Lo que convierte en un privilegio al proyectista que busca recuperar ese valor para repotenciar el uso del mercado. En el mercado de Santa Caterina, por ejemplo, el hallazgo de restos arqueológicos significo un valor agregado a la difusión cultural del lugar, que hoy en día se ve reflejado en un museo de sitio.

El mercado como equipamiento urbano es un aporte al entorno próximo de la localidad ya que invita a la interacción, al encuentro y por lo general da un respiro a la trama urbana. Un claro ejemplo de esto es el Mercado de Santa Caterina que, ubicado en plena estructura urbana de plato roto, con calles estrechas, su presencia ha significado una contribución y configuración al barrio.

Por otra parte, que las calles tengan cierta materialidad, diferenciada, ayuda a la reducción de velocidades y tránsito vehicular, dando pie a flujos más amigables con el peatón, como lo son el uso de bicicletas. Aspecto evidenciado en el Mercado de San Miguel, cuyo entorno consta de calles de transito pasivo y hasta se encuentra instaurado mobiliario urbano.

Luego de uniformizar una lista programática común en los mercados tratados, se ha llegado a la conclusión que en la mayoría de los mercados que han sido restaurados o repotenciados, el porcentaje de "Otros Servicios de Uso Público" que incluyen: supermercados, galerías, escuelas culinarias, librerías y espacios de aporte cultural en general, ha sido relevante ya que se han visto que el dotar a los mercados de actividades 
complementarias a la actividad comercial, ayuda a la dinamización de este establecimiento, pues se amplía el radio de interés e influencia del público objetivo.

Considerando un aspecto más funcional y derivado al tratamiento de calidad de los productos, parece necesario mencionar la importancia que debe significar el ratio de almacenes, cámaras frigoríficas y descarga en los establecimientos para un eficiente y eficaz manejo de los productos. Esta consideración se ha visto desde años atrás, evidenciado en la distribución del Mercado Central de Lima, que en su concepción se proyectó y construyó el sótano dedicado principalmente a este fin.

Otros ejemplos contemporáneos que aplican esta observación son los mercados de San Antón, Santa Caterina y el Mercado de la Barceloneta, los cuales seden al proyecto todo un nivel de sótano para esta actividad.

En cuanto a las circulaciones es importante la diferenciación de accesos para las cuatro distinciones de flujos que se han visto, suceden en un mercado. Por ejemplo, en los casos del Mercado de Santa Caterina y el Mercado de la Barceloneta los ingresos y salidas de abastecimiento y residuos nunca interfieren con la circulación ni de los clientes ni de los comerciantes, debido a que dichas actividades se llevan a cabo a través de rampas que conectan la calle con el sótano de abastecimiento. Otro caso emblemático por mencionar es el del Mercado de San Antón que se ha pensado en tener una doble circulación vertical, diferenciada entre servicio y clientes, ambos conectados a accesos exclusivos para cada tipo de actividad.

Se ha visto que la principal innovación tecnología que los mercados desde siempre han aportado, radica en el tipo de cobertura y materialidad propia de la estructura, influenciados por distintas corrientes y el uso de nuevos materiales. Por ejemplo, en el Mercado Central de Florencia se ve el tradicional sistema estructural de tijerales de acero que a la fecha de su construcción significaron un aporte en el ámbito constructivo. Asimismo, hoy en día, el uso de nuevos materiales y equipos de alta tecnología han permito el desarrollo de estructuras y techos con grandes luces y formas que dan importancia particular a los mercados contemporáneos, como lo son el Mercado de Santa Caterina y el Mercado de la Barceloneta.

Por otro lado, el aporte de la tecnología también involucra temas relacionados a la sostenibilidad. Con la aplicación de nuevos sistemas para la captación de luz solar 
que permite el ahorro energético, se ha visto que en los techos del mercado de San Antón y el mercado de la Barceloneta, se logra reservar y captar energía renovable, a través de paneles fotovoltaicos.

El actual interés en la renovación y dinamización de los mercados municipales ha permitido traer a la ciudad la memoria que significaron los mercados antecesores y sus respectivos barrios. En contraste, no en todos los casos se ha podido ver esta total recuperación de la identidad ya que, por ejemplo, en el caso del Mercado de San Antón, el principal factor que derivó a la poca afinidad para con los vecinos del barrio de Chueca fue el retiro del $100 \%$ de los comerciantes locales para la inclusión de productos totalmente ajenos a este. A pesar de que este mercado sea un aporte en la calidad de servicios públicos ofrecidos en la zona, este aspecto de vínculo con el barrio se considera perdido.

No obstante, en otros ejemplos se ha visto que desde la toma de partido se ha involucrado el valor de la identidad y la intención de reflejar la memoria del mismo. Lo cual ha significado tanto en Santa Caterina como Barceloneta un valor agregado parte del éxito y aceptación tanto de extranjeros, pero principalmente de locales. 


\section{CAPÍTULO VI: MARCO CONTEXTUAL}

\subsection{Criterios para la selección del terreno}

Después de entender la problemática de los mercados, la historia, la teoría, las entidades que los regulan y el funcionamiento mediante algunos ejemplos nacionales e internacionales, se decide plantear una propuesta de mercado municipal para la ciudad de Lima, Perú.

Figura 6.1

Conjunto de aerofotografías de Lima, hecho para el Ministerio de Agricultura, 1975

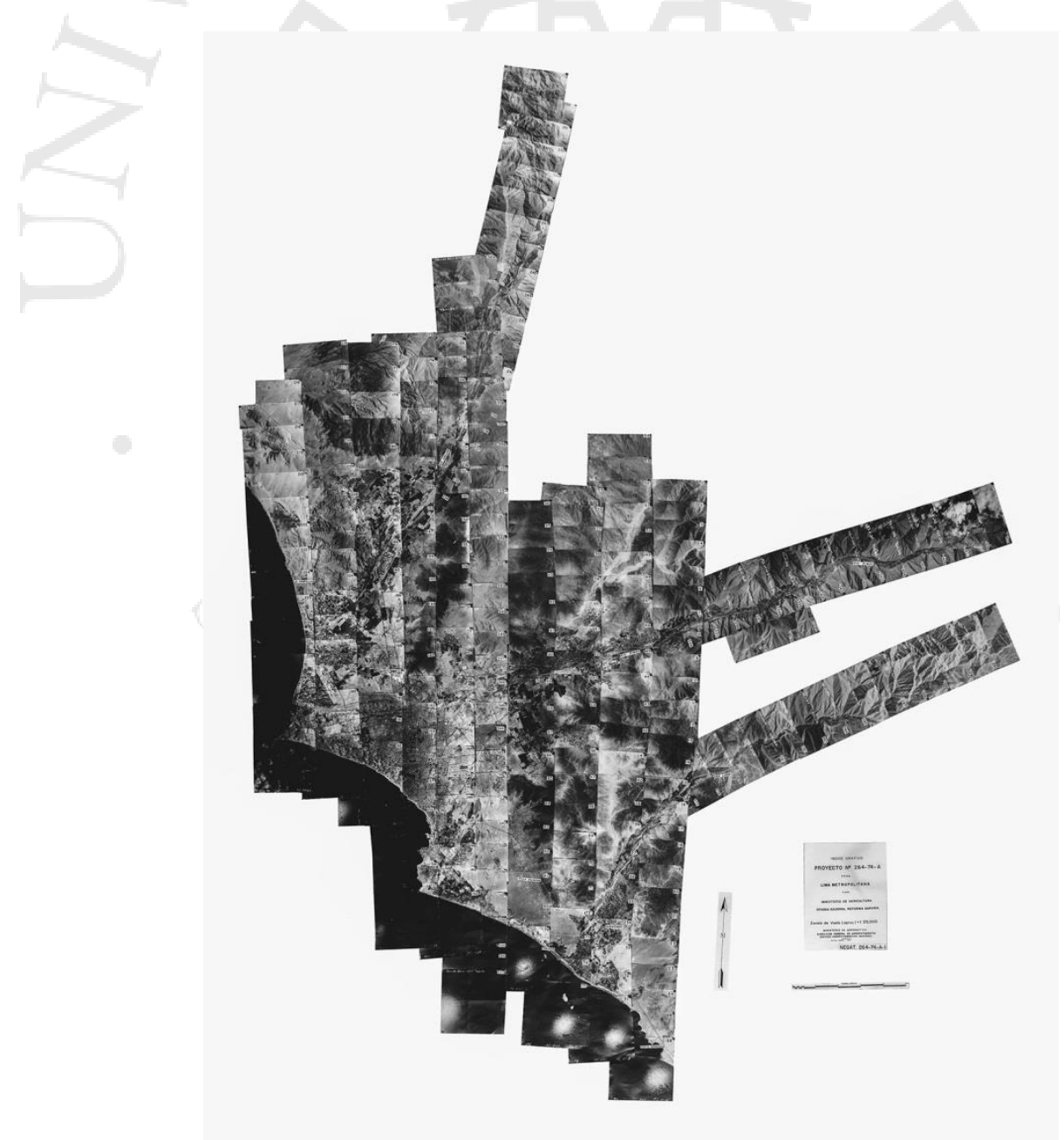

Fuente: Departamento de Aerofotografía de la Fuerza Aérea del Perú 
A continuación, se detallarán los motivos para la ubicación del mismo, explicando el porqué de la intervención en la Costa Verde; el distrito de San Isidro; y la ubicación del terreno en específico.

\subsubsection{Motivos de selección de la Costa Verde}

A lo largo del tiempo diferentes entidades se han visto interesadas en proponer proyectos para la Costa Verde, por ejemplo: Augusto Ortiz de Zevallos y Ruiz de Somocurcio quienes proponían renovar y unificar los malecones limeños; del mismo modo la Corporación Andina de Urbanistas Urvia que propuso en el 2006 ocupar solo el $16 \%$ del terreno de la costa verde para levantar restaurantes, ciclovías y lugares de esparcimiento al pie del acantilado frente al mar. (Gavidia, 2018a, pp. 30-31)

Si la gestión de la ex alcaldesa Susana Villarán gasto 200 millones de soles en restaurar la vía vehicular de la Costa Verde (Gavidia, 2018a, p. 30), ¿por qué no se podría invertir en un proyecto que recupere el uso e imagen del acantilado para la ciudad?

El acantilado la Costa Verde es una de las imágenes más icónicas de la ciudad de Lima y la más desaprovechada. La Costa Verde merece un proyecto que la repotencie e incluya usos que activen la zona, como restaurantes, ciclo vías, zonas de espaciamiento, mercados, talleres; y recupere su imagen y conexión con la naturaleza. Comenzar por un sector de la costa verde podría significar un incentivo para las entidades públicas y privadas para recuperar esta zona tan representativa de la capital. 
Figura 6.2

Aerofotografía de la Costa Verde. Vista San Isidro y Miraflores, Lima 1964

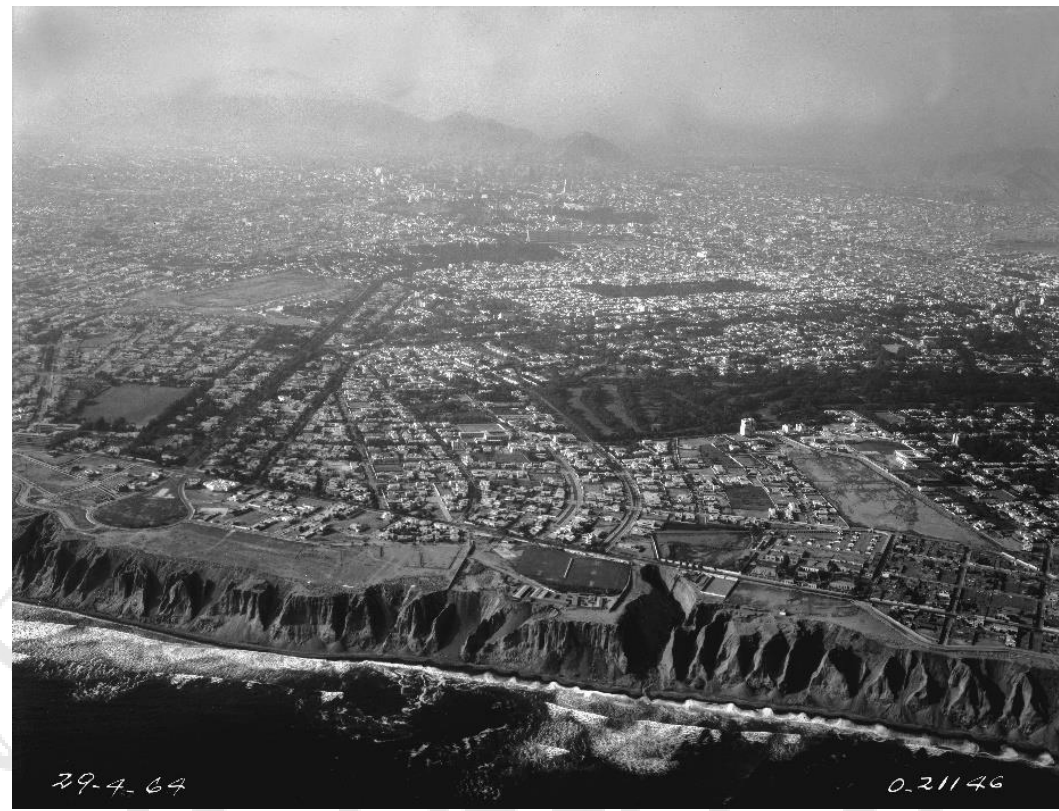

Fuente: Departamento de Aerofotografía de la Fuerza Aérea del Perú

\subsubsection{Motivos de la selección del distrito de San Isidro}

San Isidro corresponde un distrito que funciona de remate de una de las vías metropolitanas más transcurridas de Lima Metropolitana, la Av. Javier Prado, que gracias a su continuidad por la Av. Salaverry termina por llegar al litoral limeño.

El distrito de San Isidro hoy en día cuenta con un gran interés por regenerar sus calles, arborizar sus parques y dar una mejor ciudad a sus vecinos; existe un reciente artículo en la revista Urbania, el cual menciona que la municipalidad de San Isidro está enfocada en "la peatonalización de sus calles, la construcción y mantenimiento de más de $20 \mathrm{kms}$ de ciclo vías, y la recuperación de espacios públicos para actividades culturales han hecho de este tradicional distrito un modelo de ciudad sostenible." (Gavidia, 2018b, p. 38)

"San Isidro es también una comuna donde se entrelaza el pasado con el presente". (Gavidia, 2018b, p. 40) Si bien se encuentra en el distrito parques, bosques y huacas que reflejan una memoria histórica en el distrito, no cuenta con la presencia de espacios cívicos, plazas, que permitan la interacción, activación y permanencia de personas, a favor del encuentro y expresión ciudadana. 
Figura 6.3

Aerofotografía de San Isidro, Lima 1964

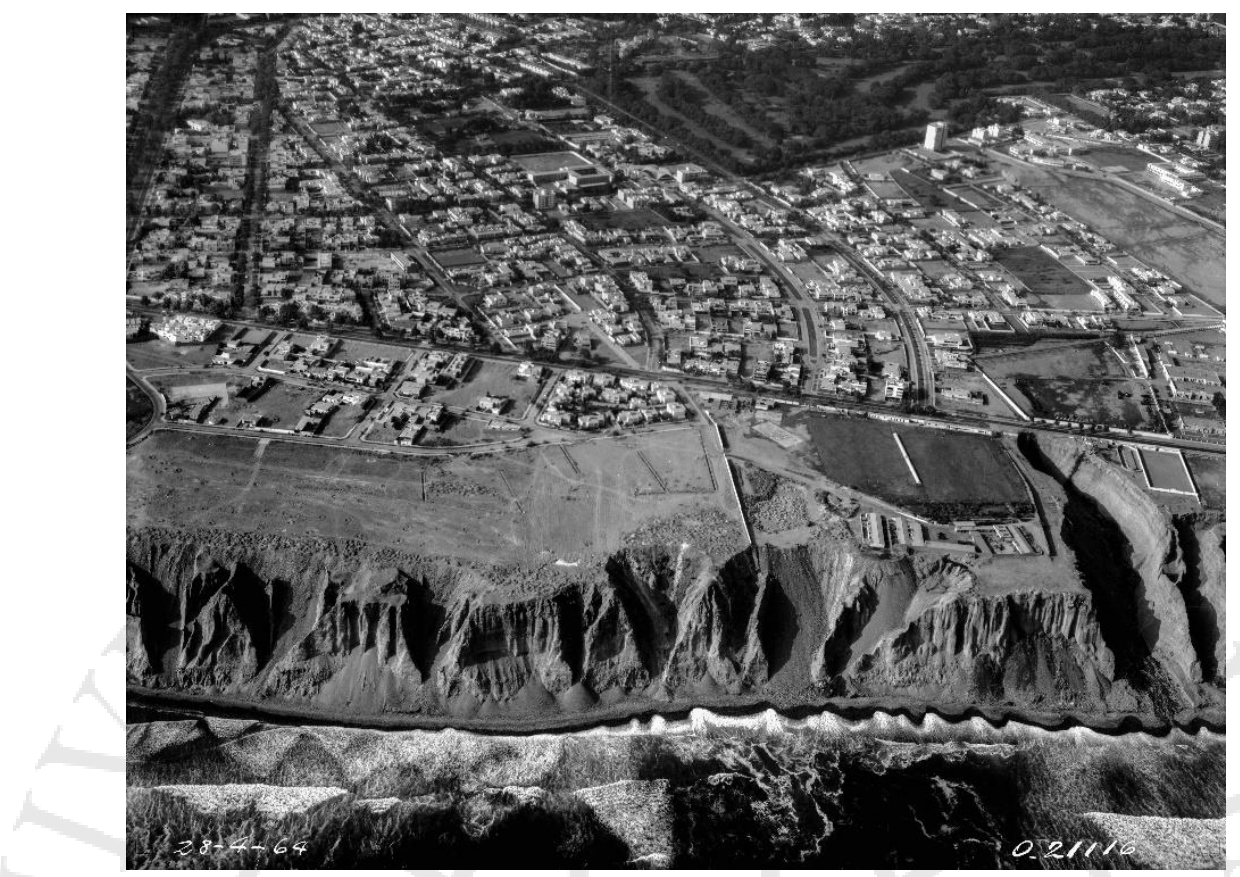

Fuente: Departamento de Aerofotografía de la Fuerza Aérea del Perú

Las áreas libres que se encuentran corresponden a parques, algunas veces de carácter residencial; el Lima Golf Club, de propiedad privada; y el malecón de San Isidro que se encuentra desconectado al de Miraflores, que cuenta con una extensión es de $5 \mathrm{~km}$. Estás áreas libres, pueden ser categorizados como espacios públicos, sin embargo, no en todos los casos son de verdadero uso y apropiación pública.

\subsubsection{Motivos de la selección del terreno}

La Municipalidad de San Isidro cuenta con un vasto terreno ubicado adyacente a la bajada San Martín, que tiene como frente mayor, una parte del acantilado de la Costa Verde limeña. El terreno actualmente niega la presencia del mar, convirtiéndose en una barrera más para la visual hacia el acantilado de la Costa Verde y punto de desconexión con el resto del malecón de San Isidro. Este es utilizado no solo para el uso de oficinas municipales, sino que además contiene un depósito municipal de chatarra y almacenes de maquinarias, motivo suficiente para pensar en la propuesta de un proyecto para ese 
terreno, que aproveche los dotes del terreno, explote la ubicación, la visual y la naturaleza próxima.

Figura 6.4

Aerofotografía del terreno a intervenir, Lima 1956

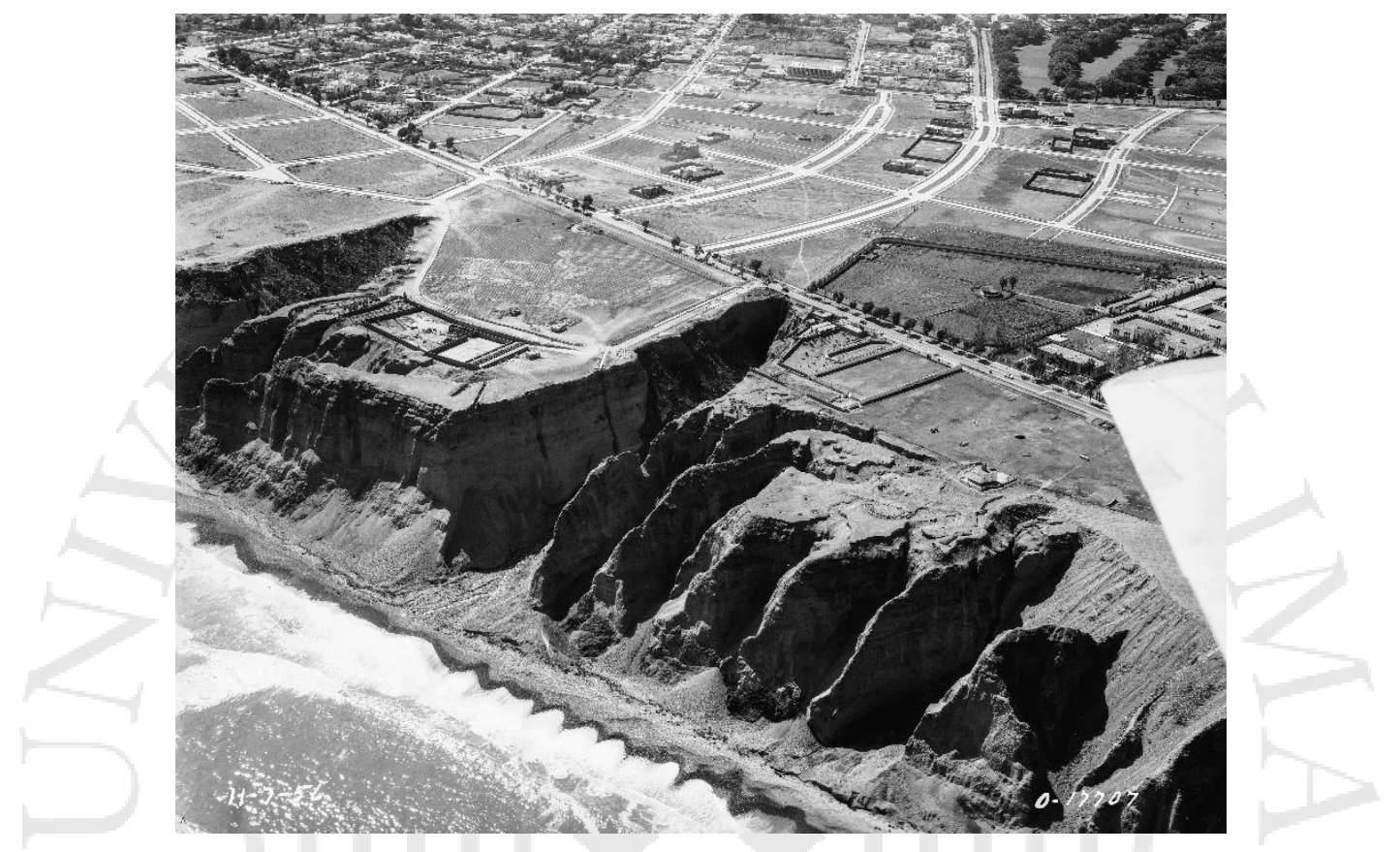

Fuente: Departamento de Aerofotografía de la Fuerza Aérea del Perú

"Todo lo que entorpece la relación saludable de la habitante de la metrópoli con su mar no debe ser permitido. Mientras toda acción que contribuya a preservar las áreas para el uso público y facilitar el acceso en forma responsable debe ser respaldada." (Díaz-Albertini, 2017)

Los planes urbanos de la Costa Verde ponen manifiesto que esta sección del terreno ubicada en la bajada San Martin deberían inclinarse por tener usos mixtos de comercio, cultura, hospedaje y ocio. Si bien la Municipalidad de San Isidro cuenta con una estrecha sección del acantilado, no quita que este mismo terreno se le pueda dar el respectivo tratamiento a fin de no solo repotenciar las áreas verdes y recuperar el mercado que existe actualmente, sino además otorgarle equipamientos culturales y de esparcimiento, así como reubicar las oficinas administrativas municipales y el Centro de Atención primaria que actualmente se encuentran en el terreno. 


\subsection{Análisis del lugar}

A continuación, se detallarán ciertos criterios analizados para un mejor entendimiento del terreno a intervenir y lograr una óptima propuesta. Dentro de este análisis los criterios a utilizar son las condiciones medio ambientales; el sistema de áreas libres; el sistema de cuerpos edificados; el sistema de llenos y vacíos; bordes, barrios; hitos, nodos, sendas; flujos; lugares de interés; zonificación; parámetros del lote; percepción; levantamiento fotográfico del entorno; y potencialidades y limitaciones. 


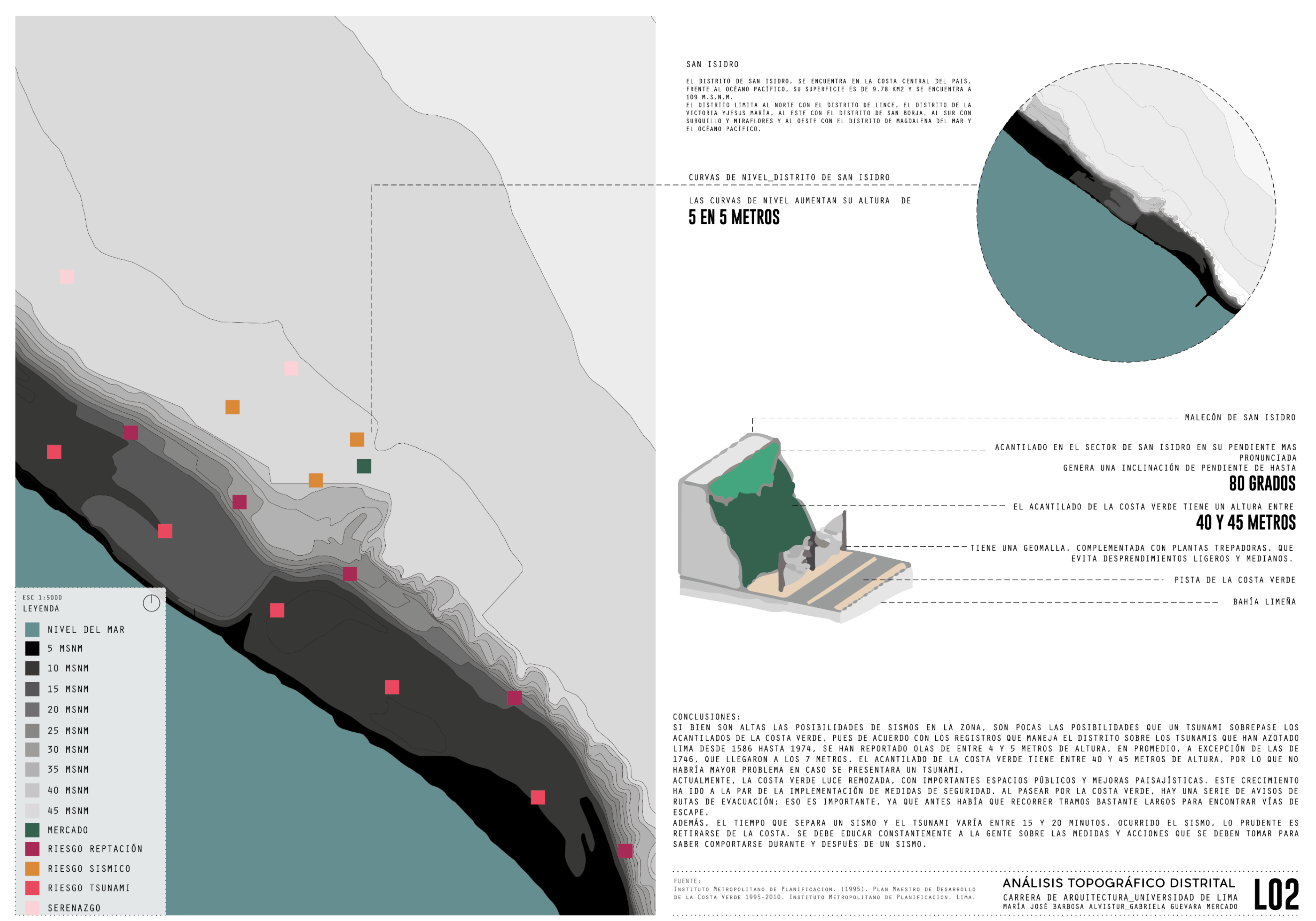




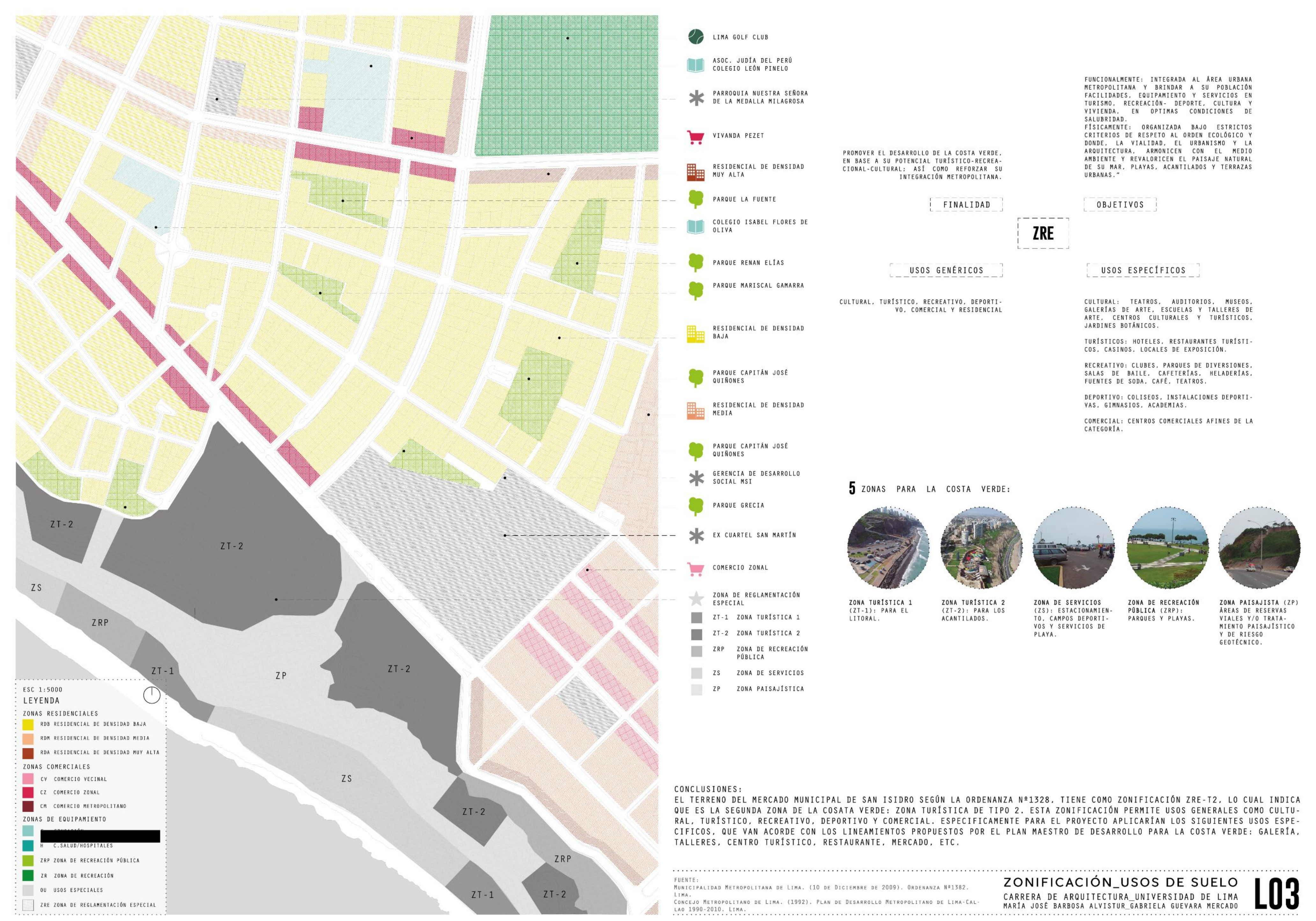




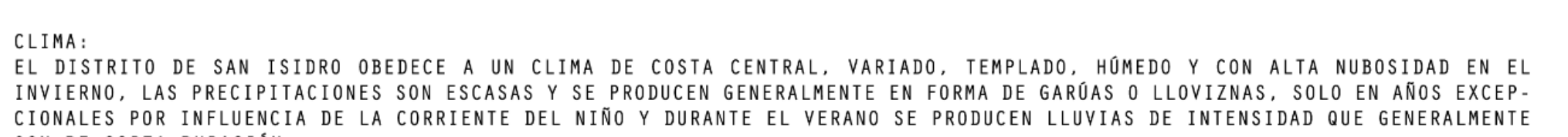
SON DE CORTA DURACIÓN. EN EL VERANO LA TEMPERATURA VARIA ENTRE 18 A 28 GRADOS Y LA HUMEDAD RELATIVA SE
INVIERNO LA TEMPERATURA ES DE 12 A 20 GRADOS Y LA HUMEDAD RELATIVA ENTRE $92 \%$ A $99 \%$.
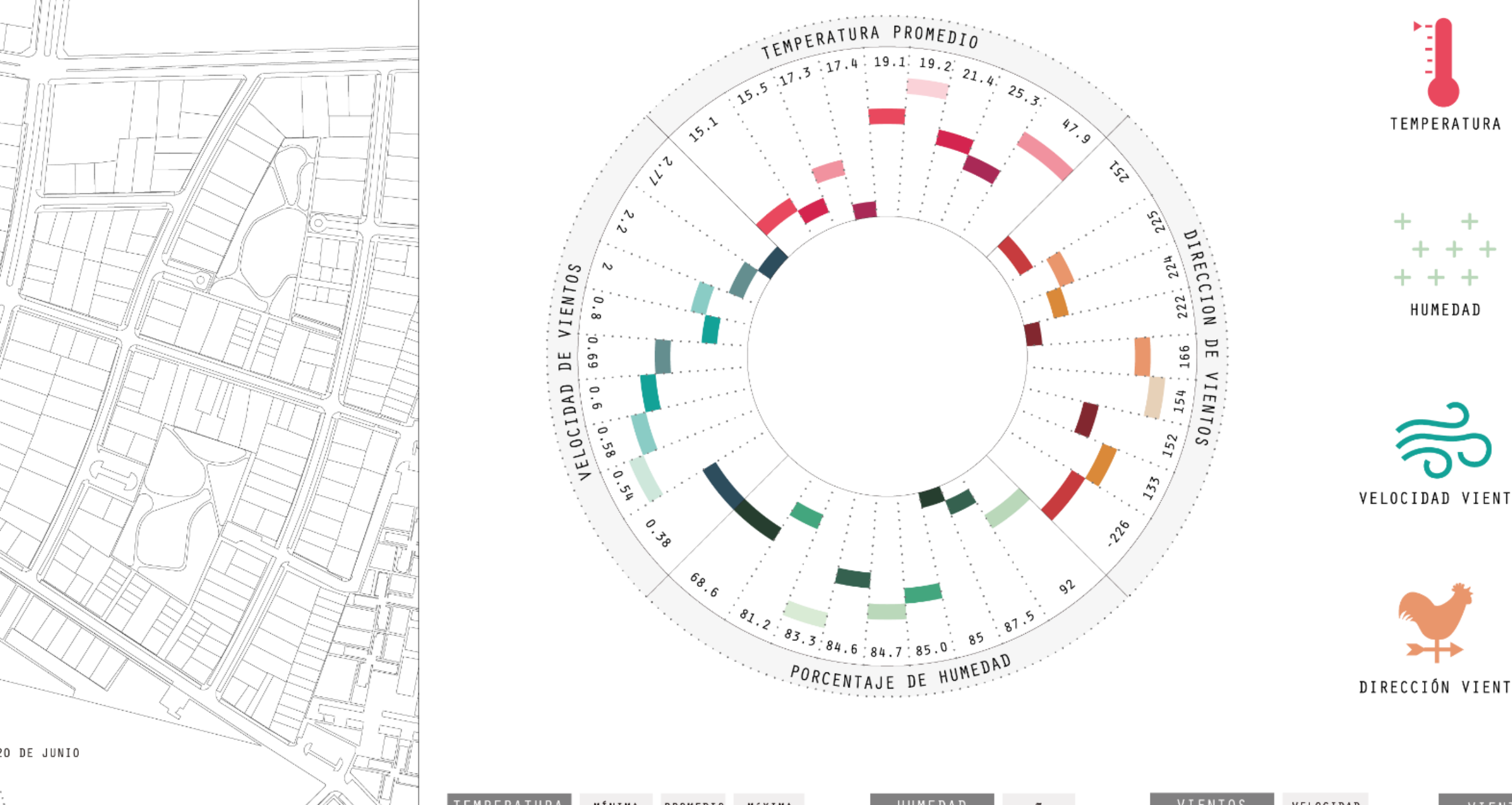

\begin{tabular}{|c|c|c|c|c|c|c|c|c|c|}
\hline TEMPERATURA & MFNIMA & Pronedio & Maxima & HUMEDAD & $z$ & VIENTOS & VELOCIDAD & VIENTOS & dirección \\
\hline 2012 JUL & 17.7 & 19.2 & 22.5 & 2012 JUL & 83.37 & $2012 \mathrm{JUL}$ & 0.54 & 2012 JUL & 154 \\
\hline 2012 JUN & 16.2 & 47.9 & 24.1 & 2012 JUW & 84.72 & 2012 JUW & 0.58 & 2012 Jun & 166 \\
\hline 2012 MAY & 17.2 & 19.16 & 24.9 & $2012 \operatorname{MAY}$ & 85.06 & 2012 MAY & 0.6 & $2012 \operatorname{MAY}$ & 133 \\
\hline 2012 ABR & 17.6 & 21.44 & 29.7 & 2012 ABR & 84.65 & 2012 ABR & 0.69 & 2012 ABR & -226 \\
\hline 2012 MAR & 24.9 & 25.31 & 25.7 & 2012 MAR & 68.63 & 2012 MAR & 0.38 & 2012 MAR & 152 \\
\hline 2012 SEP & 17.2 & 17.3 & 17.4 & 2012 SEP & 92 & 2012 SEP & ${ }^{2}$ & 2012 SEP & 225 \\
\hline 2012 A60 & 14.8 & 15.13 & 15.5 & 2012 AGo & 81.25 & 2012 A60 & 0.8 & 2012 AG0 & 224 \\
\hline $2010 \mathrm{JUL}$ & 15.5 & 15.5 & 15.5 & $2010 \mathrm{JUL}$ & 87.5 & $2010 \mathrm{JUL}$ & 2.2 & $2010 \mathrm{JUL}$ & 251 \\
\hline 2010 JUN & 15.5 & 17.38 & 20.6 & 2010 JUN & 85 & 2010 JUN & 2.77 & 2010 JUN & 222 \\
\hline
\end{tabular}

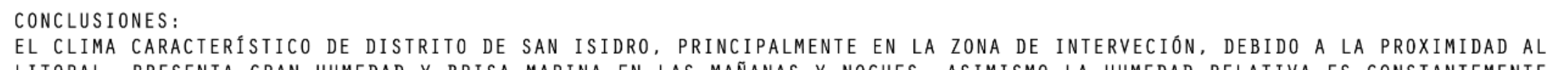

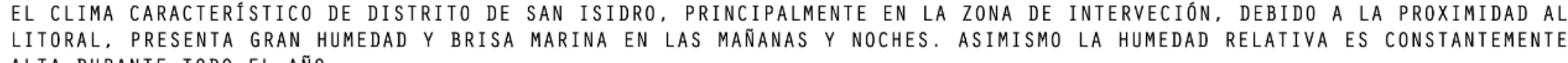

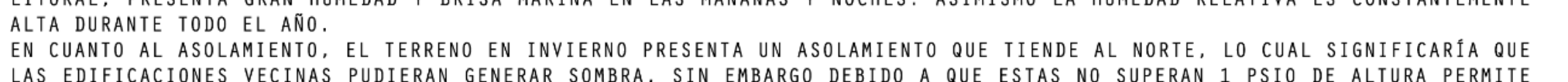

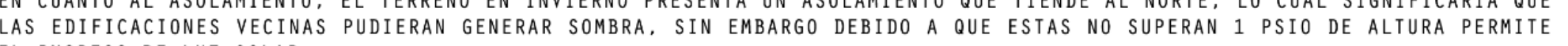

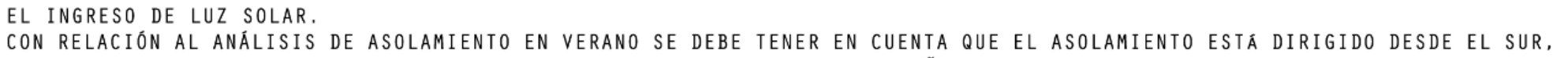
generando luz solar en toda la fachada que da al Litoral. para el diseño Este factor se debe tomar en cuenta. 


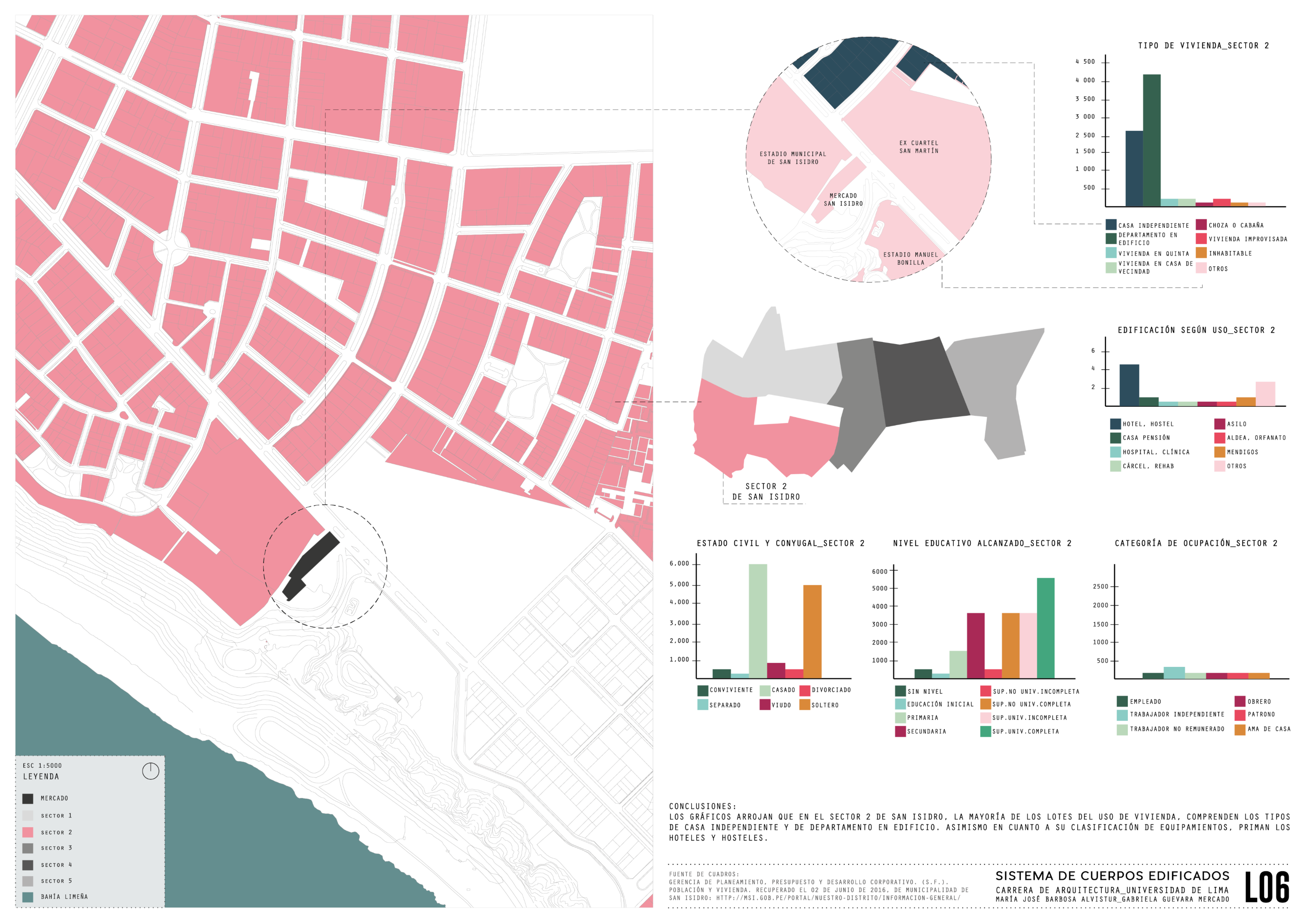




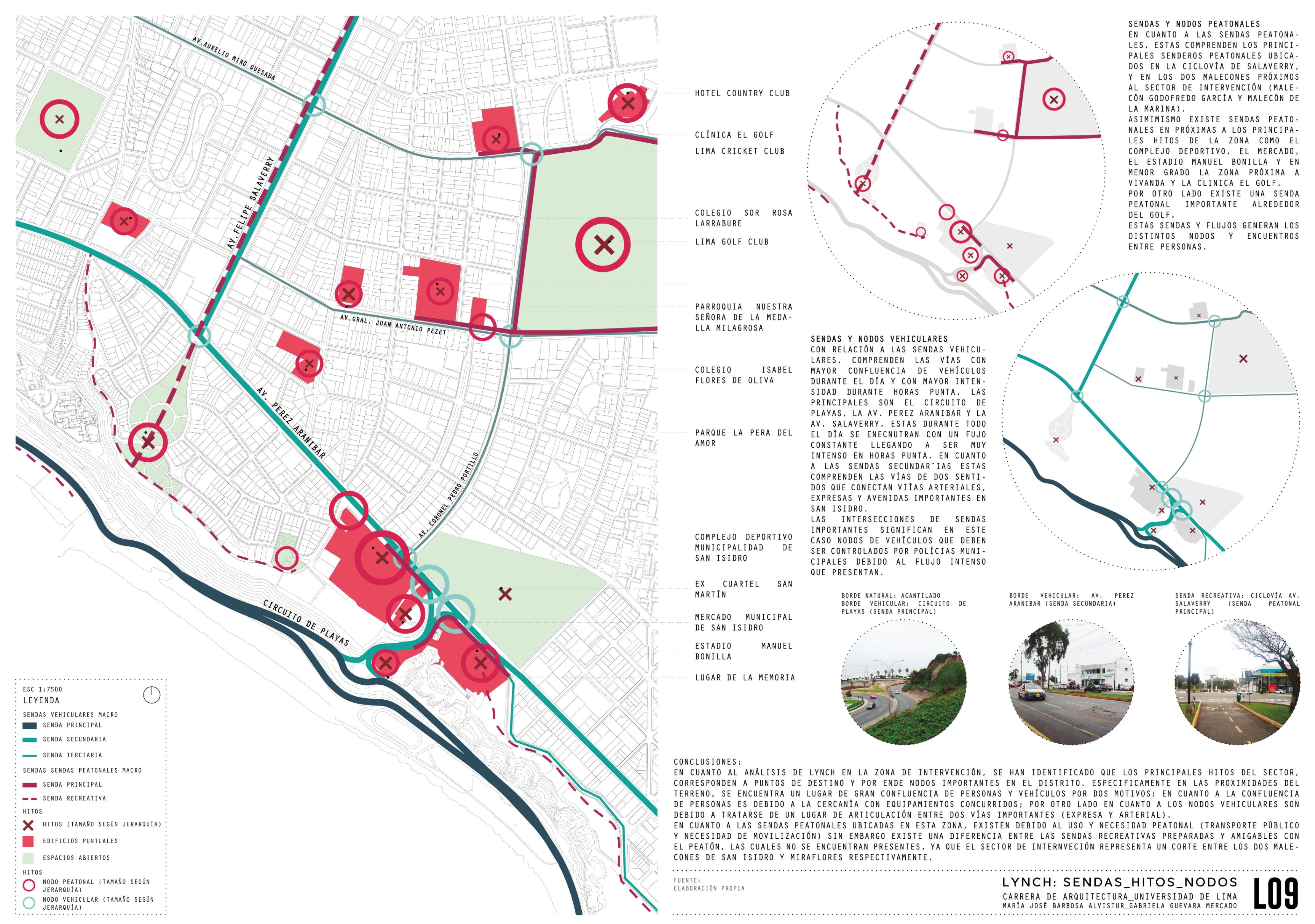




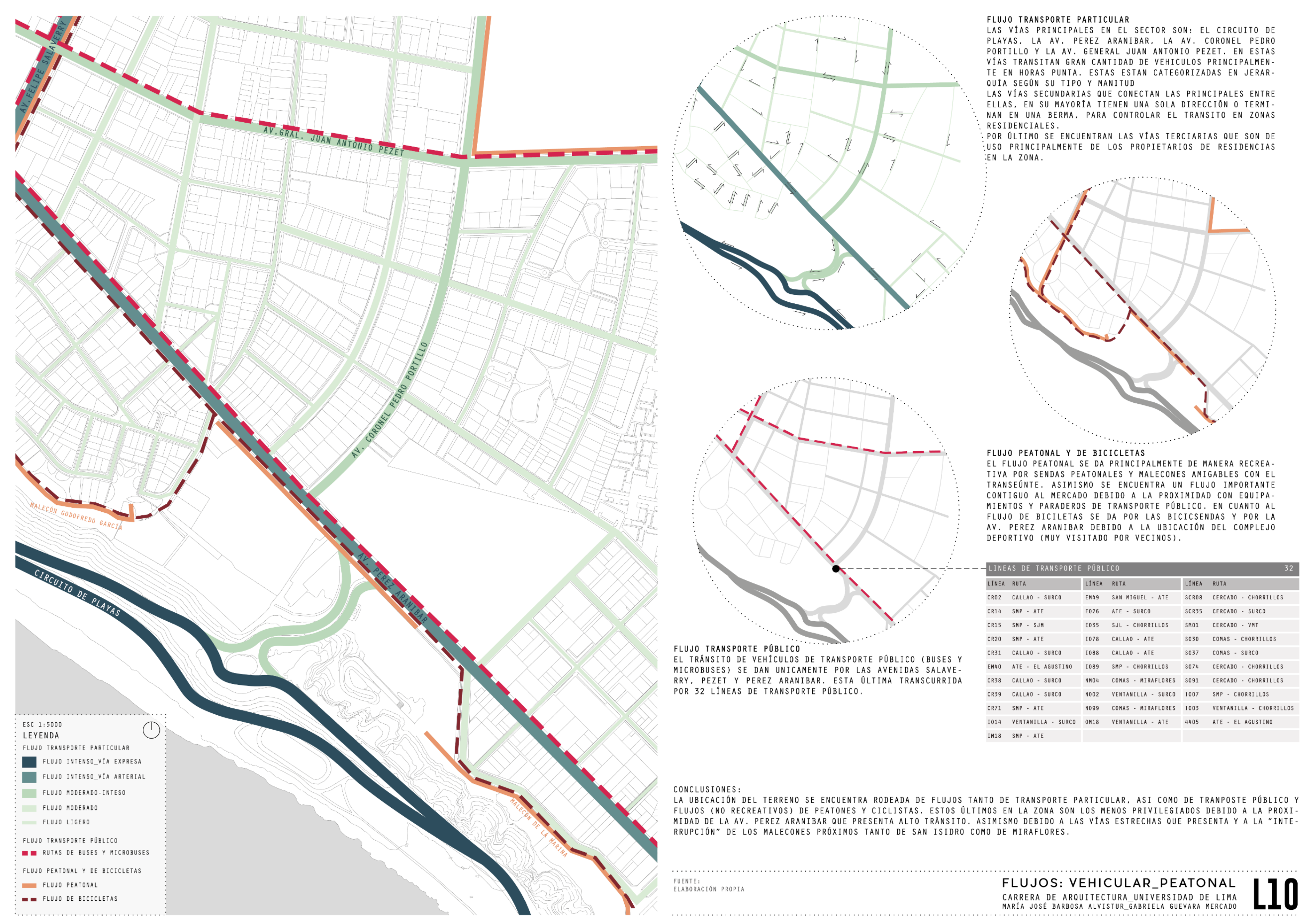




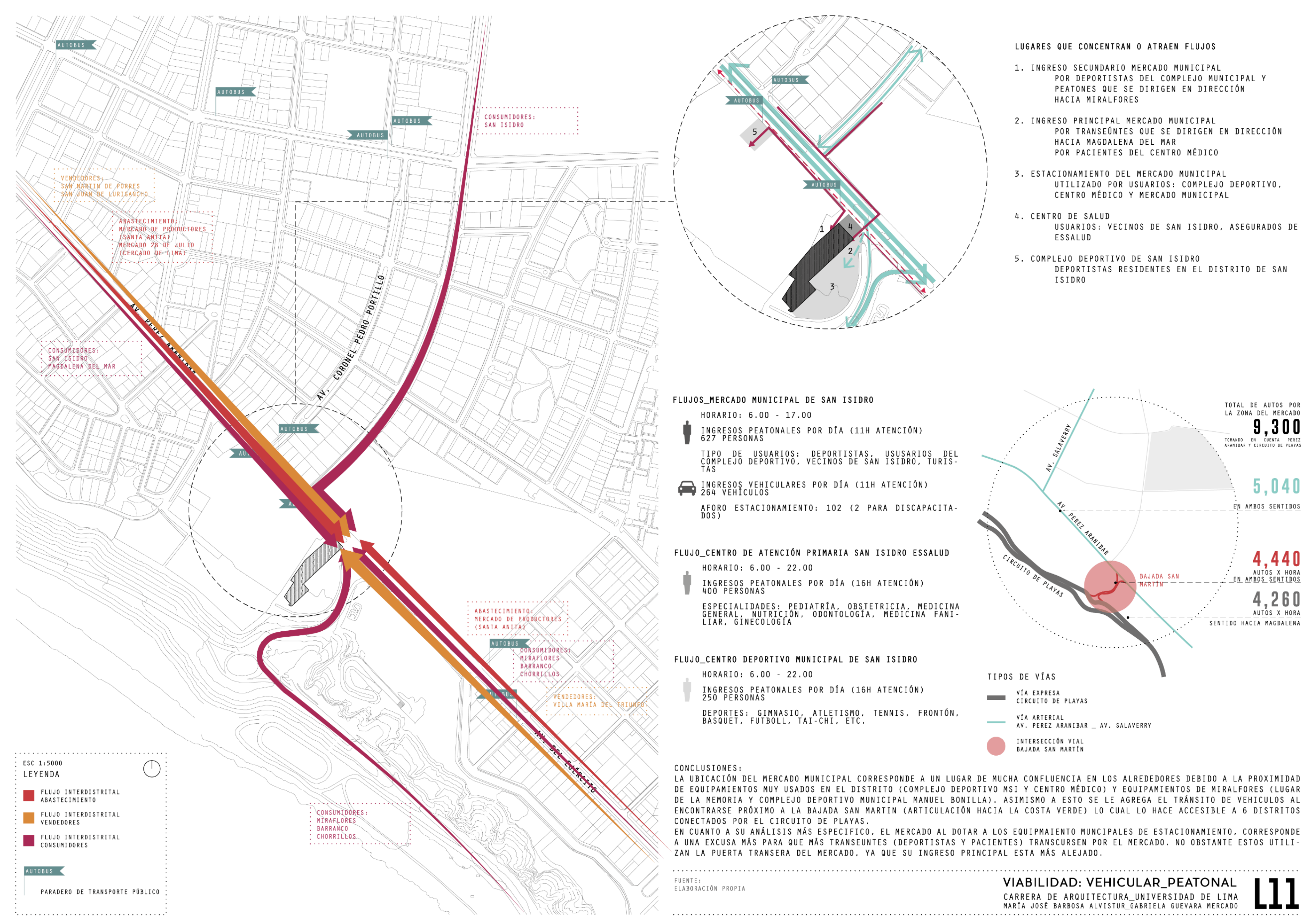


PORCENTAJE de Área paISAJISTICA:

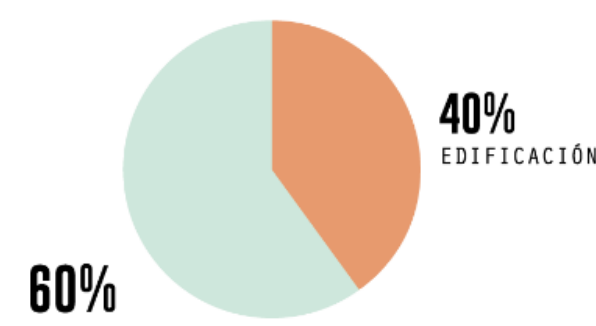

porcentaje en planta

PORCENTAJE ELEVACIÓN
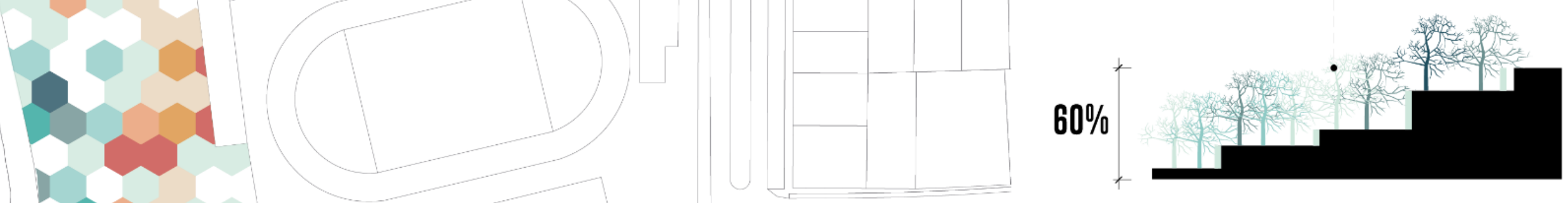

el tratamiento paisajista, no Será menor al $60 \%$

EL TRATAH AREA DEBERÁ CUMPLIRSE TANTO EN PLANTA ASI COMO EN

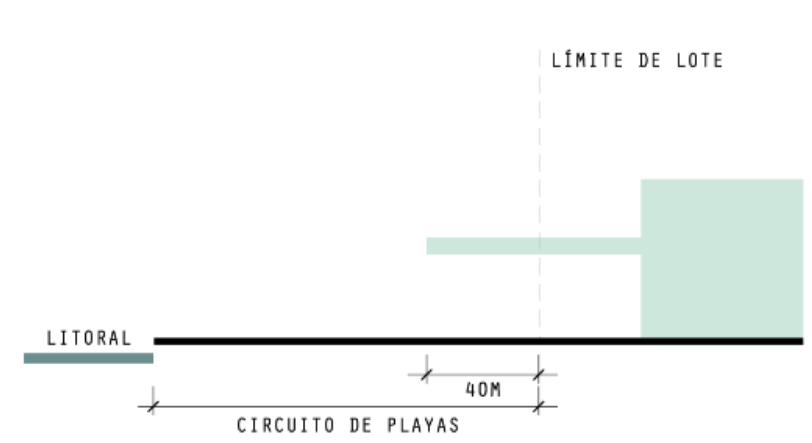

EL PROYECTO PODRÁ utilizar los aires de La vía PRINCIPAL DEL CIRCUITO DE PLAYAS, EN TRAMOS NO CIAS NO MENORES A 400 MTS,

CONCLUSIONES:

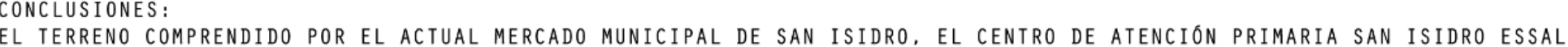

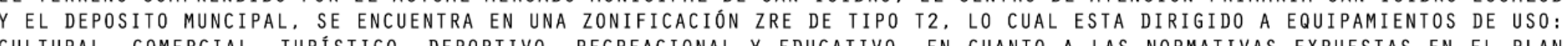

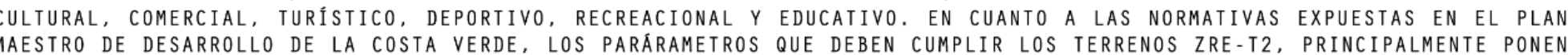

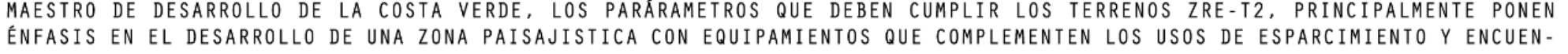

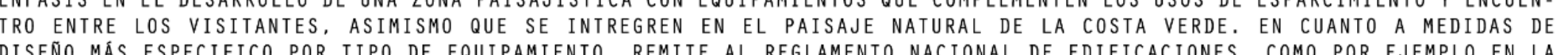
diseño más especifico por tipo de equipamiento, remite al reglamento nacional de edificaciones, como por ejemplo en LA estacionamientos

fuente: Plan maestro de desarrollo de La costa yerde $1995-2010$ 


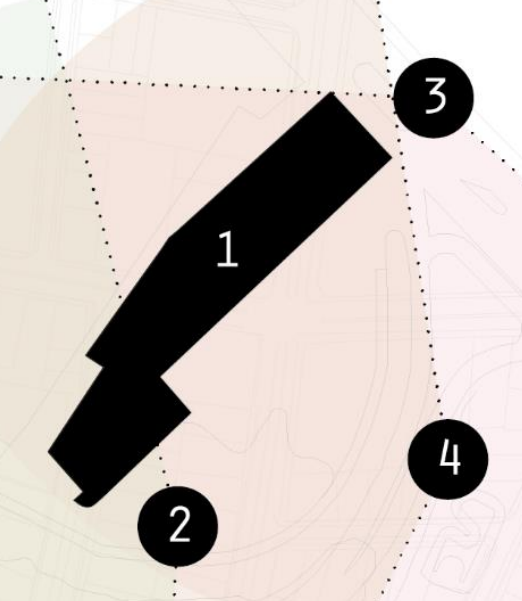

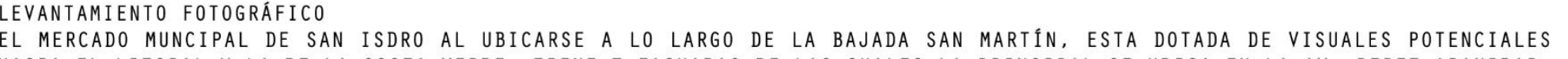
HACIA EL LITORAL Y DA LA COSTA VERDE. TIENE 3 FACHADAS DE LAS CUALES LA PRINCIPAL SE UBICA EN LA AV. PEREL ARANIBAR.

\section{1.}

VISTAS MERCADO MUNIC P PAL
INIERDOR: DESDE LOS PUESTOS DE VEHT

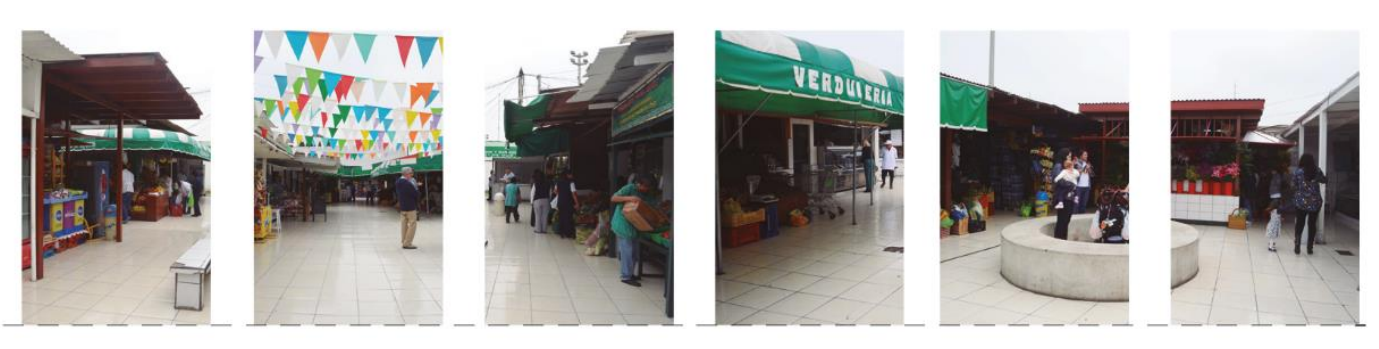

2.

VISTAS MALECÓN EXTERIOR: HACLA EL LLTORAL Y PUERTA 4 :

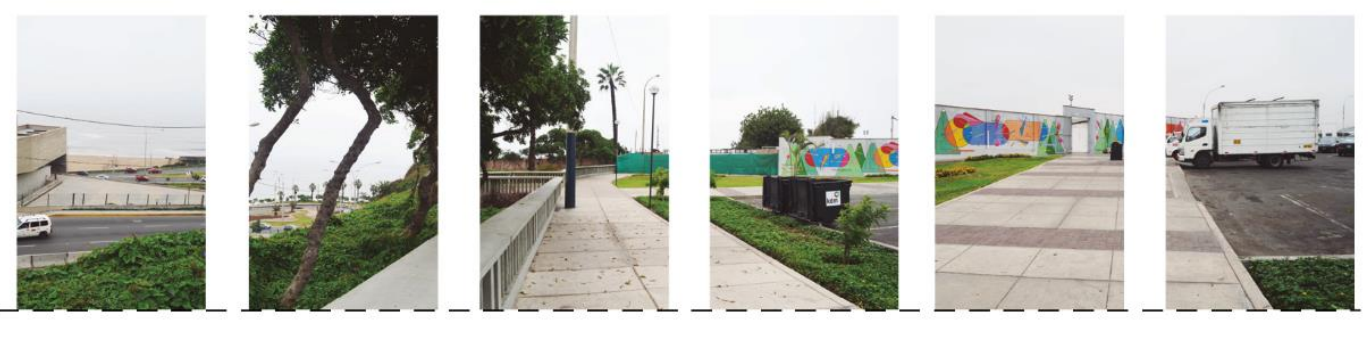

3.

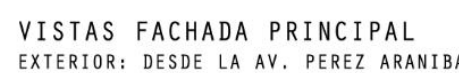
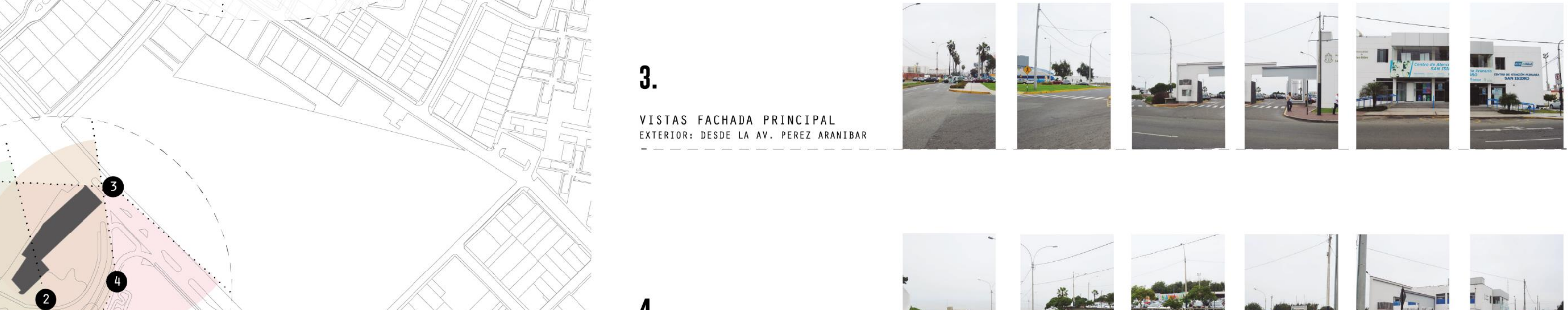

4.

VISTAS FACHADA LATERAL
EXTERIOR: DESDE LA BAADAA SAN MARTI

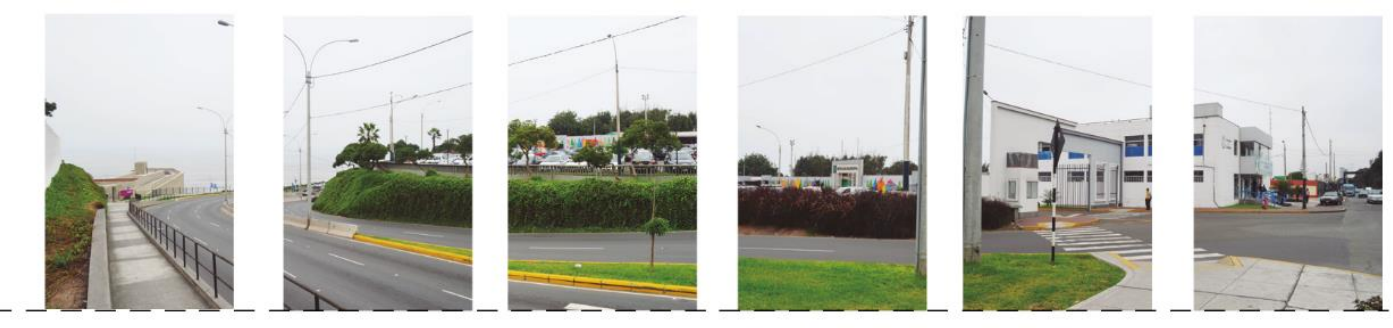




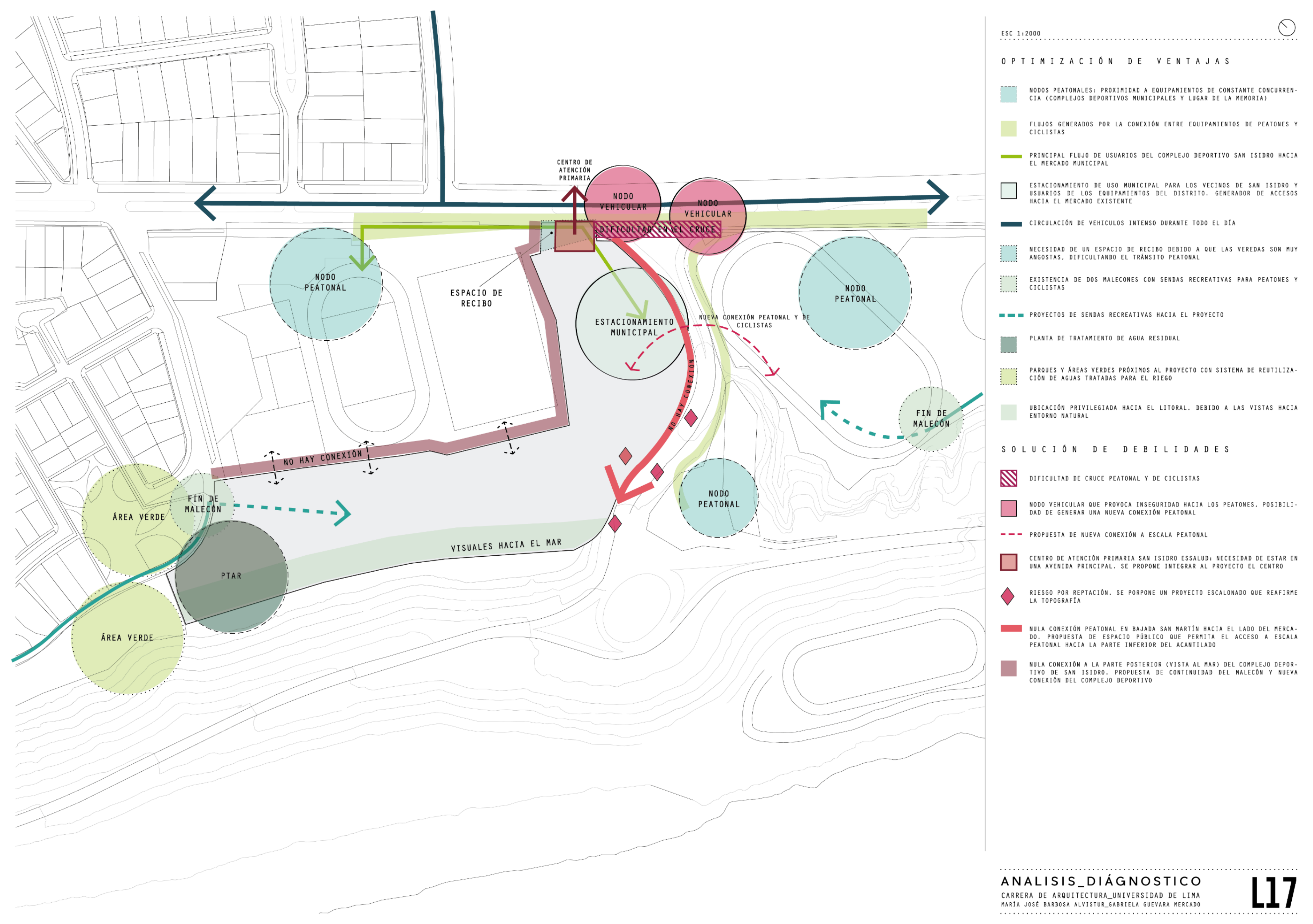




\section{CAPÍTULO VII: CONCLUSIONES}

\subsection{Conclusiones}

Se llega a la conclusión de que la esencia de las ciudades, el origen de ellas está vinculado a la agricultura, a la interacción entre personas y al comercio, ello ha derivado a la instauración de establecimientos esenciales que abarquen estos aspectos para la ciudad, como lo es la plaza, el mercado. Siendo este, el resultante de la espontánea necesidad de intercambiar; y su ubicación, expansión y desarrollo, está determinado por la actividad del ser humano. El intercambio ha significado un recurso para el desarrollo no solo económico sino de relaciones sociales entre localidades y comunidades.

A lo largo del tiempo el mercado ha desempeñado un papel primordial a través de sus distintas funciones como espacio de intercambio, cívico, comercial y de ocio. Es por ello que en la actualidad el vínculo entre las personas y este espacio aún permanece y cumple una función importante en contextos como el nuestro.

Por otro lado, se concluye que, para una respectiva renovación e inclusión de mercados tradicionales en el interés actual, es necesario la incorporación de un porcentaje significativo de otros servicios de uso público que contenga un aporte cultural, educacional, cívico y recreativo, al igual que complementar la actividad comercial del mercado con el espacio de encuentro y se convierta en un equipamiento no solo de interés local sino también turístico. Sin embargo, se debe tener en cuenta no caer en un formato de mercado $100 \%$ turístico pues como ya se mencionó hacer pierda su identidad y esencia local, concentrándose únicamente en satisfacer la demanda de los extranjeros. Por ello se concluye que el formato adecuado para un proyecto de esta naturaleza, definido en el Capítulo III corresponde al modelo de "mercado sostenible".

La gastronomía cumple un papel importante para la búsqueda de una identidad nacional, como en el caso de Perú que, a raíz de los distintos acontecimientos de su historia, ha forjado una gastronomía en base a ese aspecto. 
Como hemos entendido, el espacio público cumple la función de vincula al ciudadano con la ciudad en la que vive, significa para las personas una plataforma de representación y expresión cívica. Por eso para hacer espacio público es indispensable entender el comportamiento del usuario que hará uso de él, entender el lugar que se interviene y base a eso se establecen determinadas dimensiones.

Según especificado respecto al espacio público, estas dimensiones catalogan algunos de estos espacios según su uso y concepción por parte del usuario. Este es el caso del mercado que gracias a su valor social y función para la ciudadanía puede ser considerado como espacio cívico, siendo este último una dimensión del espacio público. El espacio cívico mantiene ciertas características descritas por autores como Jordi Borja, las cuales incluyen su multifuncionalidad, el impacto sobre su entorno y la imagen que proyecta a la ciudad.

Se llega a la conclusión de que todos los mercados guardan consigo un pasado histórico el cual enriquece la esencia y memoria del mismo. Además, en el proceso de revalorización, es necesario incluir este aspecto para no perder la identidad y memoria del lugar donde se encuentra.

En cuanto a la identidad, la arquitectura puede tomar una postura relacionada a rescatar e incluir la identidad del contexto donde se encuentra. Esta teoría respaldada por el regionalismo crítico y teorías sobre identidad latinoamericanas invita a generar una arquitectura propia del entorno, acorde a sus factores externos como el clima, la topografía, la luz, los vientos, entre otros. Estos elementos que corresponden a la identidad del lugar pueden verse relacionados a la memoria sensorial del mismo al generar en los usuarios distinta estímulos a través de sus sentidos.

En relación a la importancia de la memoria lugar, una parte del constituye a la valorización de la memoria del paisaje, que corresponde a la huella generada por la humanidad sobre su entorno. Esta imagen forma parte de la memoria colectiva del grupo que la habita, por lo cual su intervención debe mantener un equilibrio.

A raíz del análisis de casos análogos en los cuales predomina un programa de mercado con usos complementarios, se llega a la conclusión de que es esencial cambiar el mercado tradicional hacia un modelo de mercado sostenible, el cual incorpore otros usos de índole cultural, educacional y de aceptación local, con el fin de ampliar la 
oferta de servicios y el radio de influencia de este en la ciudad, así poder convertir al mercado en un catalizador socio-cultural, en lugar de limitar su función únicamente a abastecer.

Es necesario que un mercado guarde un enfoque global, incorporando elementos de la localidad en la que se encuentra y además sea capaz de representar a toda una cultura, para ser símbolo y tema de interés de la ciudad no solo a nivel nacional sino también internacional. Así, el hecho que el mercado esté atado a su identidad a través de sus insumos y gastronomía local permite articular en distintas escalas la cultura del lugar con el turista, al productor con el consumidor final y al local con la memoria de su lugar.

Debido a que el origen de un mercado deriva de un espacio público donde el encuentro, la interacción entre las personas y la difusión de conocimientos se ha hecho presente, el repotenciar estos espacios, ayuda a revertir el vínculo perdido y dotar a la ciudad de un espacio de encuentro a favor de la cultura.

Una vez analizados los criterios de selección del terreno, llegamos a la conclusión de que la sección de la Costa Verde, perteneciente al distrito de San Isidro, es un lugar con potencial a recuperar ya que un tercio de su extensión frente al litoral niega su relación con el mar y las visuales. Este terreno además cuenta con una accesibilidad desde vías metropolitanas y conectoras próximas a su ubicación, vinculándolo con sus 7 distritos limítrofes y a distritos ubicados a lo largo la costa limeña.

Asimismo, si bien en San Isidro, se ha venido desarrollado la gestión de la movilidad urbana, que conecta espacios públicos, bosques y huacas en este distrito, los que a su vez complementan la oferta de actividades, existe una escasez de espacios cívicos en el distrito, como plazas y lugares de expresión ciudadana. 


\section{CAPÍTULO VIII: PROYECTO}

\subsection{Toma de partido}

El proyecto nace de la idea de regenerar los farallones perdidos del acantilado de San Isidro mediante la incorporación de espacios públicos, los cuales corresponden al espacio intermedio entre los volúmenes arquitectónicos emplazados. La huella resultante de estos espacios de encuentro, trazan el emplazamiento de los farallones arquitectónicos. Como se ve en la imagen a continuación se trabajan los dos bordes (naturales y artificiales) del entorno. El primero que acompaña la parte inferior del terreno acentuando las entradas de los farallones (espacios públicos) y el otro que permite la continuación del malecón de San Isidro y la extensión del Estadio Municipal, con el fin de conectarlo al malecón de Miraflores. 
Figura 8.1

Esquema de toma de partido

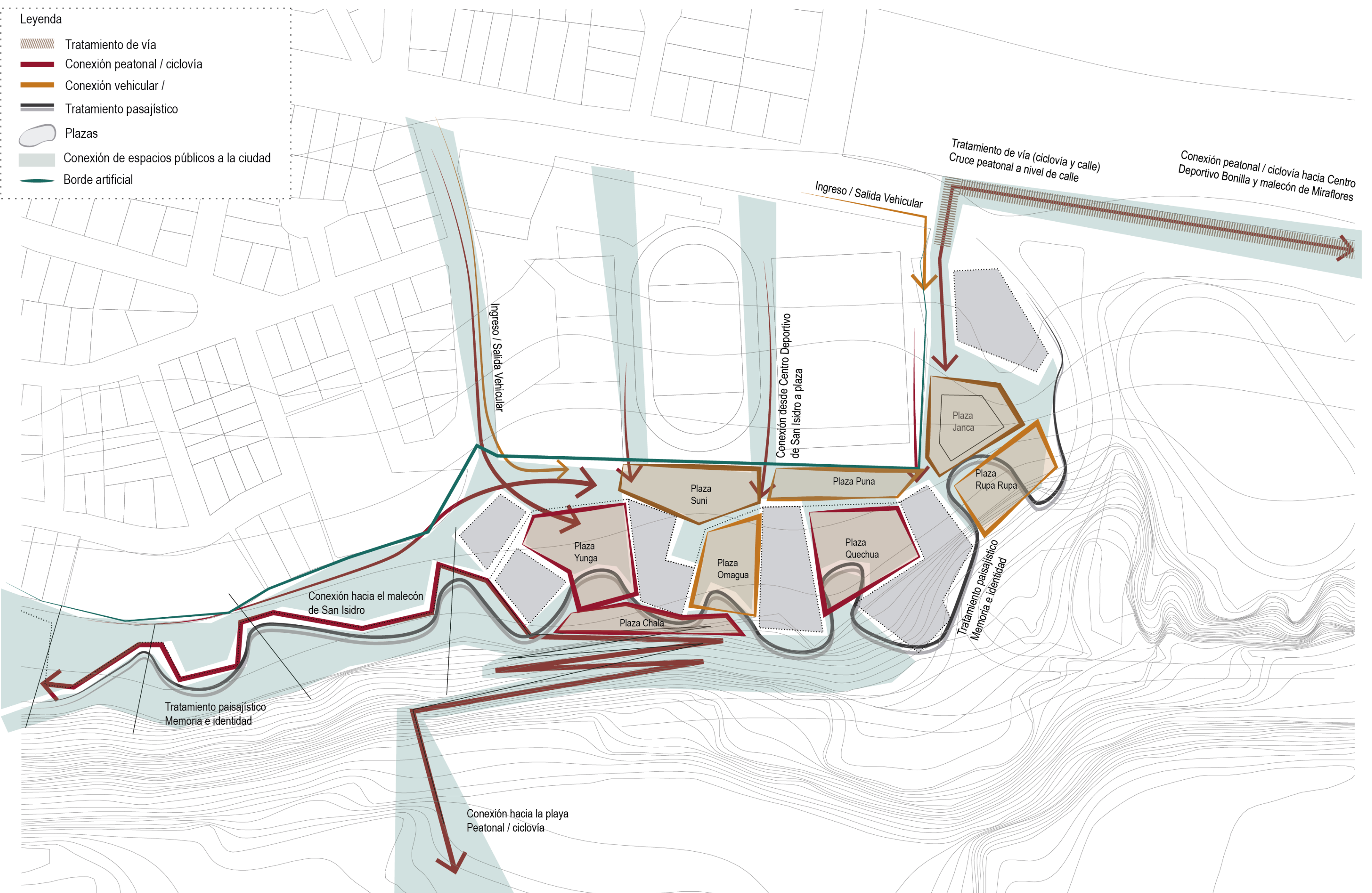




\subsection{Estrategias proyectuales}

El presente proyecto toma en consideración determinadas estrategias para hacer de él una obra adecuada para el medio en el que se encuentra ubicada y hacer del este un lugar grato para frecuentar, generar una repercusión positiva en la urbe en la que se ubica y finalmente proporcionar calidad espacial y calidad de vida a todo usuario que vaya a hacer uso de la misma, ya sea visitantes o personal de trabajo.

A continuación, se detallarán las estrategias en tres bloques diferenciados: estrategias urbanas, estrategias de espacio público y estrategias arquitectónicas, cada una de la cual estará apoyada de un texto de explicación y un gráfico para su mayor entendimiento.

\subsection{Estrategias urbanas}

\subsubsection{Memoria geológica}

Figura 8.2

Estrategia - Memoria del paisaje

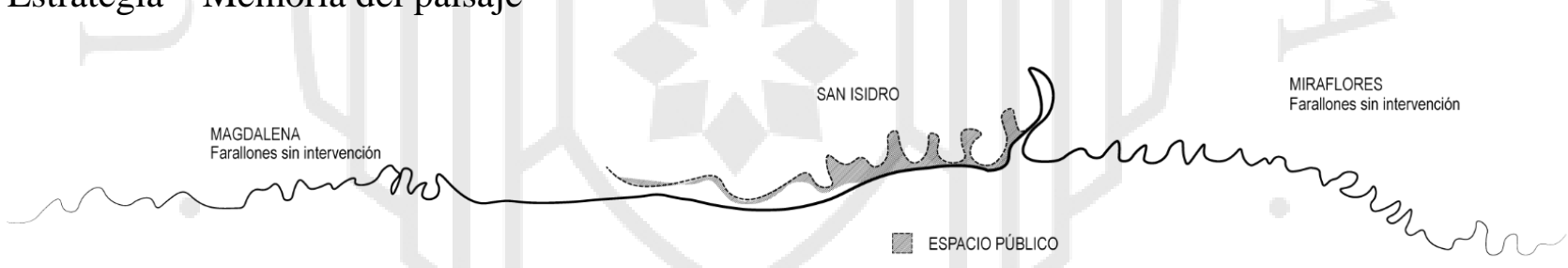

Fuente: Elaboración propia

El acantilado de San Isidro ha sufrido modificaciones topográficas, alterando su morfología original caracterizada por los farallones. Con el proyecto se propone intervenir nuevamente en el suelo del acantilado de San Isidro, pero esta vez con el fin de rescatar esas aberturas de los farallones como memoria del lugar, y lograr aludir a la imagen histórica de los farallones que bien la tiene Chorrillos, Barranco y Miraflores. Estas aberturas históricas propuestas corresponderán a espacios de uso público, para la expresión y recorrido de todos los ciudadanos. 


\subsubsection{Borde}

Figura 8.3

Estrategia - Tratamientos de borde

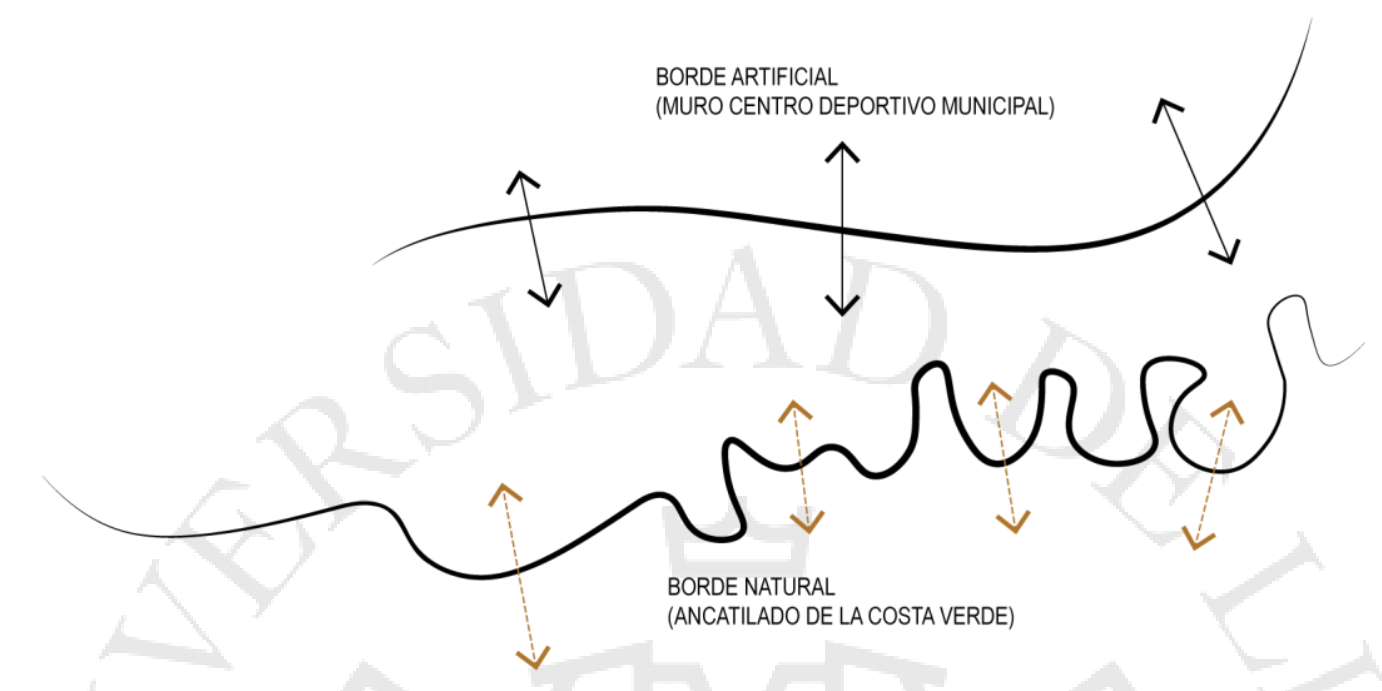

Fuente: Elaboración propia

El acantilado es un borde natural que separa la parte inferior de la costa verde y el mar, de la parte superior urbana. En vista que existen dos bordes (natural y artificial), se considera que el proyecto apuesta por vincular estos mismos un con tratamiento hacia el mar y la costa verde; y otro con tratamiento hacia la urbe, el polideportivo. Ambos proponen espacios públicos anexos al borde y controlan la seguridad y la visual mediante filtros. El primero utiliza filtros con el tratamiento del suelo como el control del ingreso o el control visual con la vegetación, mientras que el segundo utiliza filtros construidos como ductos o parapetos. 


\subsubsection{Circulación y memoria}

Figura 8.4

Estrategia - Recorrido histórico

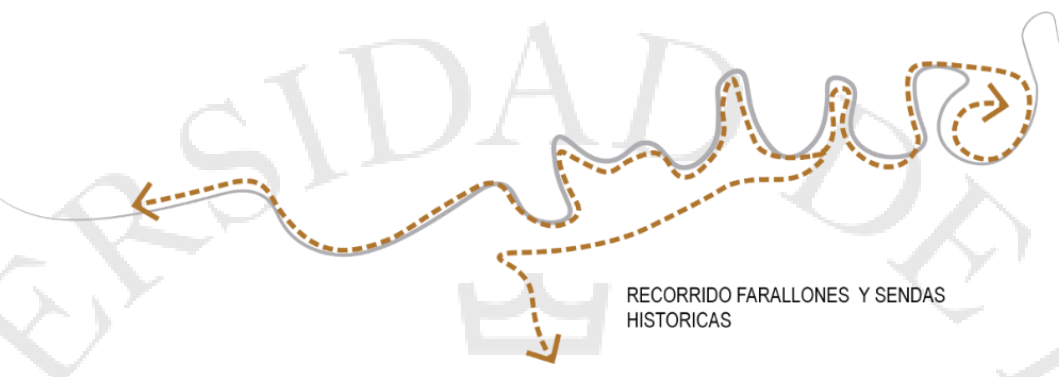

Fuente: Elaboración propia

En cuanto a la idea de recorrer la forma histórica del proyecto se propone una especie de malecón que rodea gran parte de los farallones / plazas y logra conectar la bajado hacia el mar recuperando el actual puente peatonal existente.

\subsection{Estrategias de espacio público}

\subsubsection{Materialidad y paisaje}

Figura 8.5

Estrategia - Materialidad y paisaje

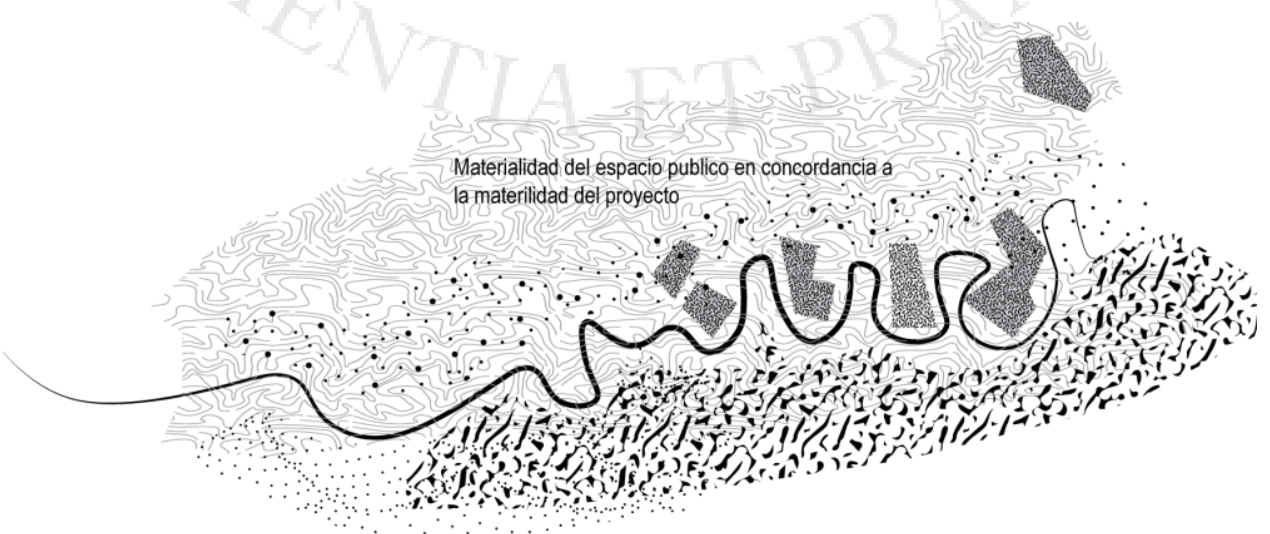

Fuente: Elaboración propia 
El entorno en el que el proyecto se encuentra ubicado es bastante particular y su tratamiento debe ser trabajado metódicamente. El uso de árboles para generar sombra es elemental, el uso de geomalla para cubrir zonas no intervenidas con plantaciones que requieren poca agua. Asimismo, para remitir la condición original de este entorno el uso de un tratamiento árido hace referencia a la huella histórica.

\subsubsection{Espacio público a escala peatonal}

Figura 8.6

Estrategia - Escala en plazas
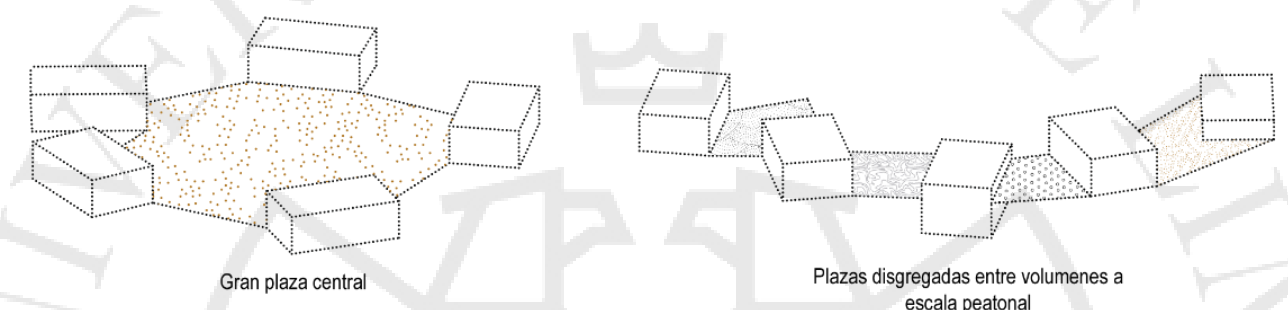

Fuente: Elaboración propia

Se pretende disgregar las plazas hasta llegar a una escala peatonal, de tal manera que se pueda generar una mayor variedad de espacios íntimos, según la ubicación en la que se encuentra y su proximidad con equipamientos; el nivel sobre el nivel del mar en el que se encuentre el usuario; y las visuales a las cuales apunte.

\subsubsection{La plataforma como espacio público}

\section{Figura 8.7}

Estrategia - Espacio público como plataforma

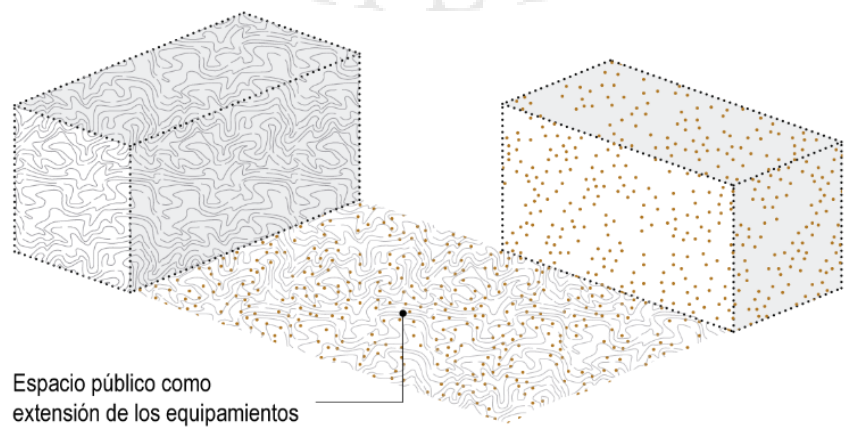

Fuente: Elaboración propia 
Se propone diferenciadas plataformas de espacio público para un uso y función determinado por cada tipo de usuario según el equipamiento próximo al que se encuentre la plaza.

\subsubsection{Plaza cívica}

Figura 8.8

Estrategia - Plaza cívica

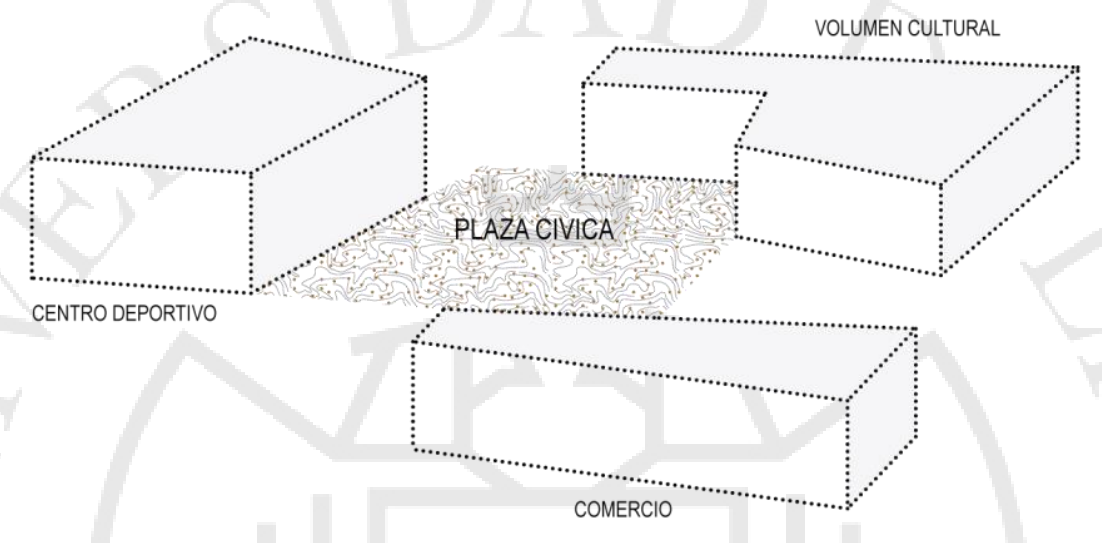

Fuente: Elaboración propia

Según lo estudiado se entiende por plaza cívica como una dimensión del espacio público, un espacio público que invita a todos los ciudadanos a participar de él por los diversos servicios ofrecidos. Además, respecto a San Isidro, el distrito hoy en día no cuenta con espacios de uso cívico al cual pueda acercarse a realizar actividades ciudadanas. Es por ello que el proyecto propone plazas de uso cívico con equipamientos comerciales, culturales y de ocio. Estos espacios son los que conforman la huella arquitectónica en el proyecto, y pueden identificarse como espacios de transición entre equipamientos, los cuales por su diseño y emplazamiento permiten al ciudadano transitar, permanecer, descansar y expresarse. 


\subsubsection{Intensidades / velocidades de recorrido}

Figura 8.9

Estrategia - Intensidades de recorrido

FRECUENCIAS DE USO / VELOCIDADES DE RECORRIDO
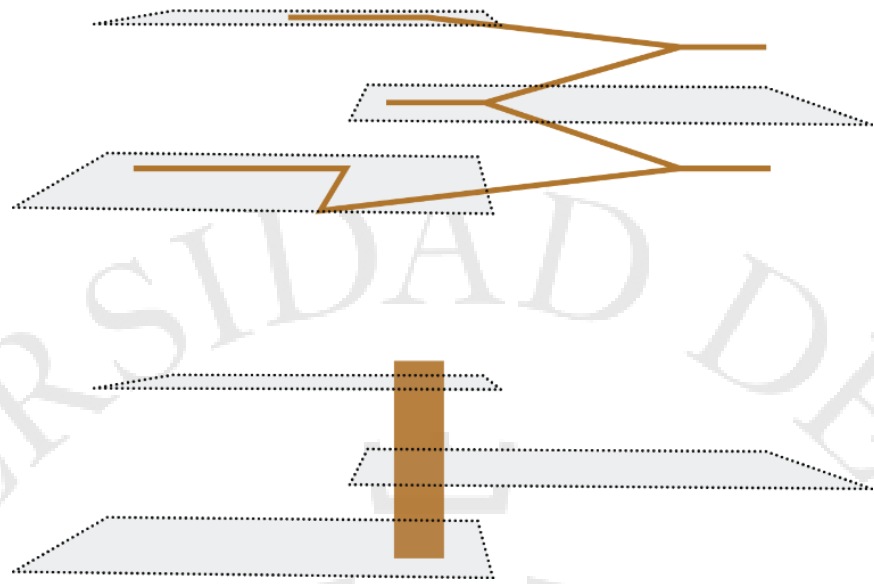

Fuente: Elaboración propia

Al ser un proyecto ubicado en el acantilado de la costa verde limeña con variedad de estímulos para el usuario se propone dos diferentes condiciones de recorrido, un recorrido procesional el cual provoca encuentros, dinamismo entre las plazas y permite la continuidad del malecón y otro recorrido inmediato dentro de las instalaciones, el cual se rige a la función, a la evacuación y el abastecimiento.

\subsubsection{Tratamiento topográfico en espacios públicos}

Figura 8.10

Estrategia - Intensidades de recorrido
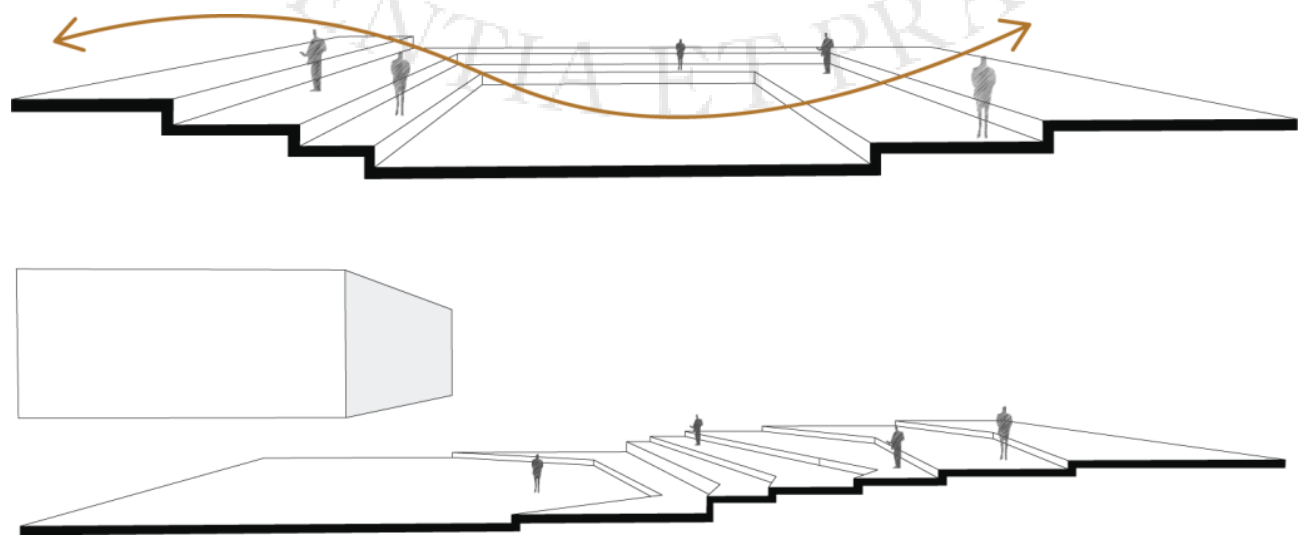

Fuente: Elaboración propia 
Con el fin de lograr una diferenciada especialidad también en el exterior, en las plazas, se propone generar las plataformas de espacio público en desniveles, de tal manera que se logre trabajar como un filtro de luz, de vientos y de condiciones espaciales, para generar cierta dinámica entre la función, el uso y el usuario.

\subsubsection{Plazas interiores}

Figura 8.11

Estrategia - Plazas interiores

Fuente: Elaboración propia

Las intenciones de generar espacios de encuentro dentro de las instalaciones se desprenden de la idea de invadir la arquitectura de espacio público, de tal manera que el usuario que lo frecuente sienta la constante conexión con el entorno próximo, con el espacio público, con la plaza cívica. Es así como se propone la idea de generar encuentros de personas, encuentros de culturas y fusionar los espacios de permanencia con los espacios de espera y circulación. 


\subsection{Estrategias arquitectónicas}

\subsubsection{Arquitectura como huella resultante}

Figura 8.12

Estrategia - Arquitectura como huella resultante

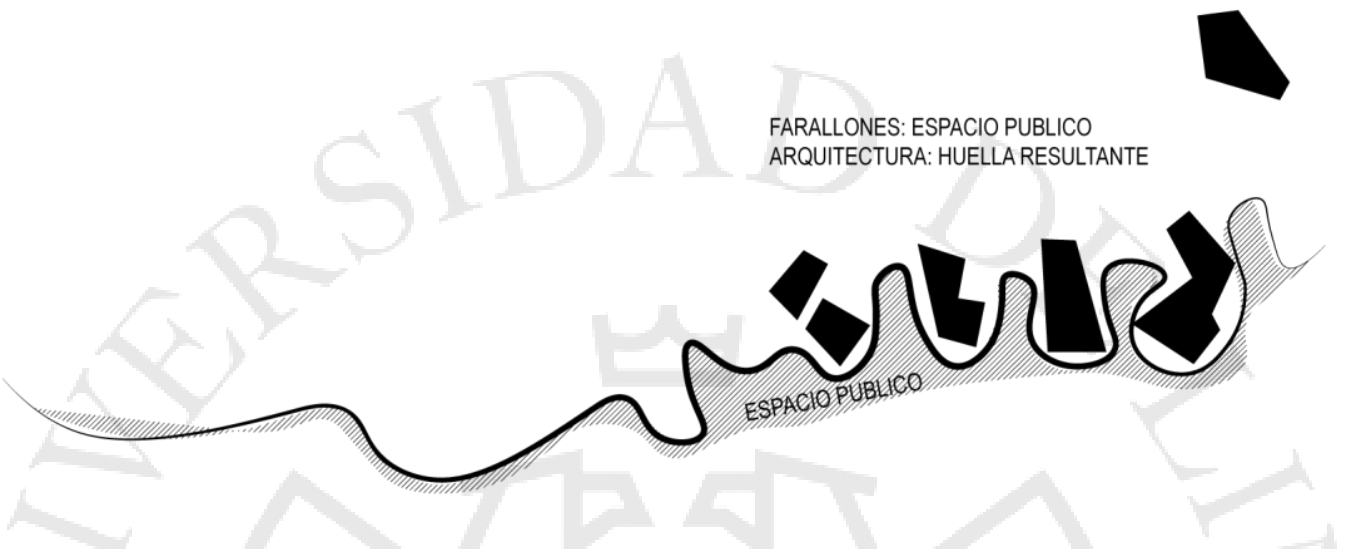

Fuente: Elaboración propia

El proyecto parte de la circulación y de la generación de espacios público a lo largo de este recorrido por los farallones. Así es como la arquitectura toma forma ubicándose en la huella resultante de este recorrido y por ende de los espacios públicos.

\subsubsection{Arquitectura como filtro}

Figura 8.13

Estrategia - Arquitectura como filtro

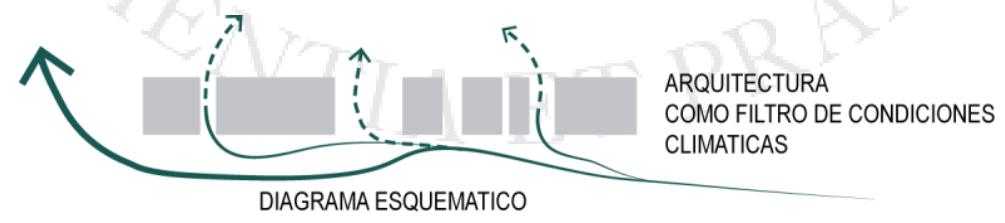

Fuente: Elaboración propia

La disposición de los volúmenes y el tratamiento del espacio público propone a utilizar a la arquitectura como filtro para la captura de sensaciones. De esta manera que lograr ser un filtro de la luz, de vientos, del clima en general, esto con el control de las 
aberturas hacia el Mar, con el tratamiento adecuado de la topografía y con la identificación de la dirección del viento y el recorrido solar.

Figura 8.14

Estrategia - Arquitectura como filtro

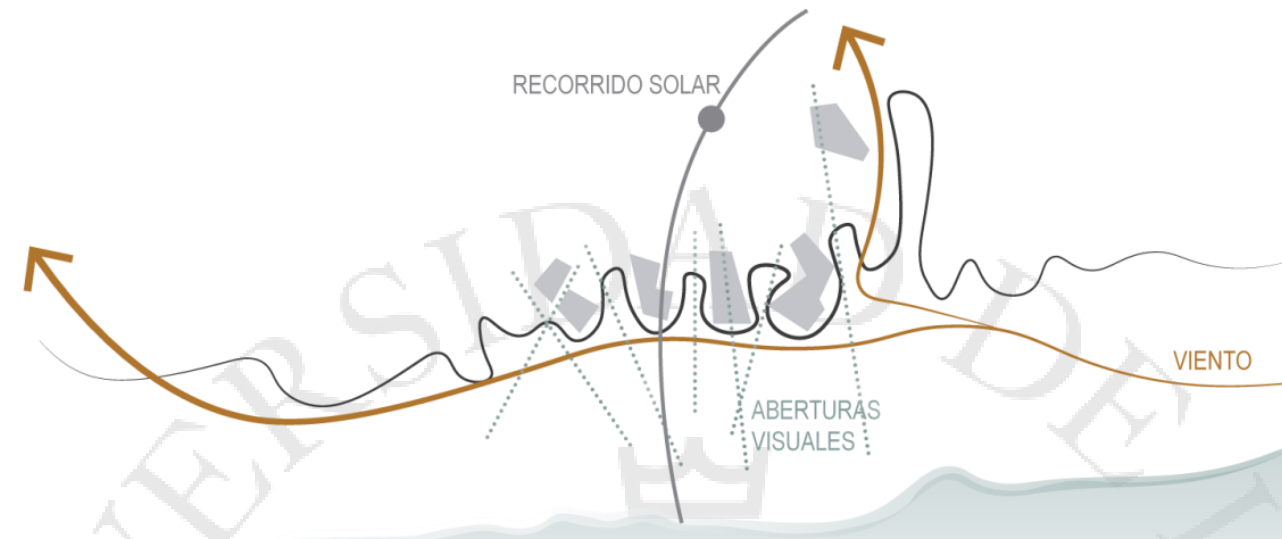

OCEANO PACIFICO

Fuente: Elaboración propia

\subsubsection{Filtro de sentidos}

Figura 8.15

Estrategia - Filtro de sentidos

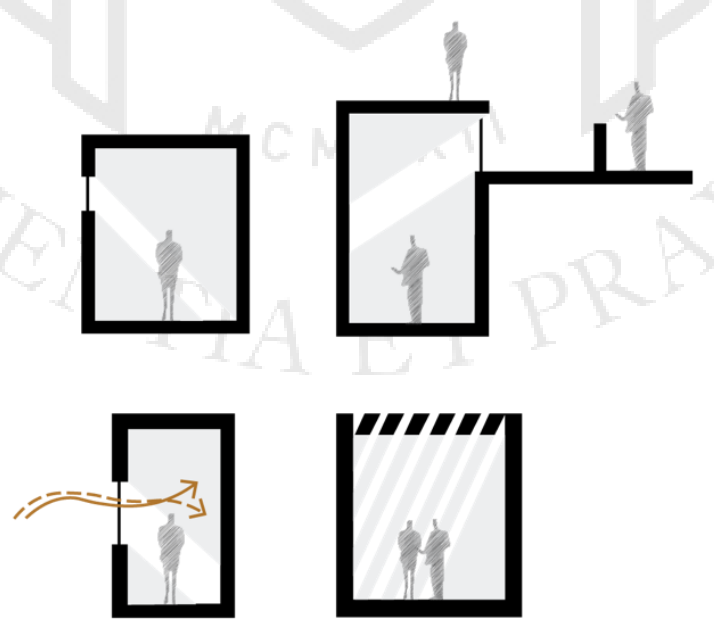

Fuente: Elaboración propia 
Se pretende estimular todos los sentidos de los usuarios, capturarlos e intensificarlos con la propuesta. La vista con las diferentes visuales y filtros de luz a lo largo del proyecto; el tacto: con la materialidad árida presente tanto en la arquitectura como en el entorno; el olfato: con la constante conexión al entorno, al mar, el olor de la brisa marina y las diferentes especies de árboles regados por el espacio público; finalmente el oído: con el sonido de las olas del mar, las aves y la naturaleza inserta en el proyecto.

\subsection{Proyecto}

El lugar: El proyecto se encuentra en Av. Augusto Pérez Araníbar, San Isidro. El lugar elegido se sustenta en el marco previo. El terreno en el que se encuentra el proyecto tiene un área total de $44021.86 \mathrm{~m} 2$. El clima la franja costera de San isidro, distrito en el que se encuentra el proyecto es de tipo árido con deficiencia de lluvias durante todo el año y un ambiente atmosférico húmedo. Tiene una temperatura media anual de $18^{\circ} \mathrm{C}$. La temperatura máxima en los meses veraniegos puede llegar a $\operatorname{los} 30^{\circ} \mathrm{C}$ y la mínima a $\operatorname{los} 12^{\circ} \mathrm{C}$ en época invernal. Las sensaciones de calor o frio que se dan de acuerdo a las estaciones correspondientes, están en función de la alta humedad atmosférica que domina el ambiente de la capital.

La zona y el medio ambiente: el terreno intervenido se encuentra en el acantilado de la costa verde, que cuenta con una altura aproximada de $50 \mathrm{~m}$. La propuesta se asienta al terreno respetando la topografía existente y los volúmenes se disponen respetando de acuerdo a la memoria geológica del lugar.

Criterios de diseño:

- Emplazamiento: como bien se ha mencionado se pretende regenerar lo farallones del acantilado en el sector de san isidro, con ellos proponer espacios públicos al aire libre y es en la huella resultante en donde se emplazan los volúmenes que contendrán todo el programa arquitectónico.

- Espacio público / plaza cívica: según lo estudiado en san isidro hay una evidente carencia de espacios cívicos que congreguen a la ciudadanía, es por ello que el proyecto propone además es un tratamiento de espacio público a lo largo de todo el proyecto, espacios cívicos para el uso de todo usuario. 
- Respetando el entorno: el proyecto presenta una postura respetuosa con el medio que lo rodea. Al encontrarse en el acantilado de la costa verde de lima, se ve con la necesidad de acentuarse a él y hacer de las pendientes un potencial; es así como los volúmenes dispuestos generando plazas intermedias, permiten que los usuarios se encuentren en constante conexión con el mar, con la topografía, con el cielo. A su vez, los volúmenes tratan de ser lo menos invasivos posibles para no opacar la vista de ningún transeúnte de la ciudad.

- Recorridos y transiciones: los recorridos por lo que se apuesta en el proyecto son dos recorridos diferenciados entre sí: aquel recorrido rápido - el que utilizan el personal y los clientes en su día a día - y el recorrido pausado - aquel por el que optan el usuario que sale a pasear, hacer uso de las plazas públicas, etc.

- Materialidad: se propone en la arquitectura tanto interior como exterior con materiales áridos que vayan acorde al acantilado en el que se encuentran.

- Sostenibilidad: el proyecto al tomar estrategias de emplazamiento contribuye con la sostenibilidad al evitar el uso de aire acondicionado y calefacción.

- Identidad: la propuesta de este proyecto considera la identidad del lugar en el que se trabaja como uno de los pilares fundamentales.

\section{Memoria descriptiva}

Ubicación: el proyecto se encuentra ubicado en Av. Augusto Pérez Araníbar, San Isidro.

Características del terreno existente: la propuesta pretende abarcar la mayor cantidad de área en tratamiento paisajista y el resto implementar con equipamiento cultural, comercial y de entretenimiento.

La propuesta: El presente proyecto opta por intervenir casi en la totalidad del área del terreno, con el fin de generar una conexión urbana con el contexto (hacia la av. el Ejército y el Malecón de San Isidro) y otorgar, a la ciudad de Lima, un tratamiento de espacio público digno de ser frecuentado y equipamientos de uso y activación 
ciudadana. Cabe mencionar que el volumen del hotel -ubicado próximo a la Av. El Ejército- y el volumen de oficinas y el Centro de Atención Primaria -ubicado próximo a la Ca. Godofredo García- quedarán propuestos como cabida para considerar los estacionamientos requeridos y el correcto cálculo de usuarios. El proyecto se concentra en los tres volúmenes centrales y en el tratamiento de espacio público de todo el terreno.

\section{Volumen del centro de convenciones:}

El volumen del centro de convenciones cuenta con tres niveles, el primer nivel, es decir el nivel inferior, cuenta con el cuarto de bombas y las cisternas para los dos pisos superiores. El segundo nivel cuenta con módulos de venta, una zona de lectura que se fusiona con el entorno próximo, un pequeño centro financiero con bancos y cajeros y un auditorio con su respectivo foyer y cafetería. En el tercer nivel se propone más módulos de venta delicatesen y un área de comedor.

\section{Volumen de comercio:}

El volumen central es prácticamente de comercio completo, cuenta con tres niveles. En el primer nivel se propone un restaurante de un área total de $1,301.76 \mathrm{~m} 2$, además del cuarto de bombas y las cisternas para abastecerlo (494.47m2) y tanto el segundo como el tercer nivel cuentan, en casi toda el área construida, con módulos de venta de mercado $(3,373.58 \mathrm{~m} 2)$.

\section{Volumen cultural-educacional:}

El volumen cultural-educacional cuenta con cuatro niveles. El nivel inferior propone dos restaurantes con vista al océano pacífico con un área de 1,297.77m2. El segundo nivel del volumen cuenta con varios módulos de venta de mercado $(1,466.62 \mathrm{~m} 2)$ y algunas áreas de comedor además del cuarto de bombas y las cisternas correspondientes para abastecer el volumen $(501.48 \mathrm{~m} 2)$. El tercer nivel tiene también módulos de venta, pero además cuenta con una cafetería, con una galería de arte y con talleres educativos, tanto los talleres educativos como el mercado cuentan con salidas a las plazas próximas. Finalmente, el cuarto nivel cuenta con algunos módulos de venta más una guardería y cuarto de lactancia, con un huerto al aire libre de horticultura y juegos para los niños y su respectivo depósito. 


\section{Abastecimiento:}

La manera de abastecer el proyecto es estratégica. Se propone un primer sótano en el segundo nivel del proyecto con depósitos, almacenes, cámaras de almacenamiento, estacionamientos, entre otros ambientes necesarios para lograr un óptimo abastecimiento a todo el mercado, a los módulos de venta y a los restaurantes. El segundo sótano se encuentra en el tercer nivel del proyecto; cuenta con toda un área de estacionamientos que sirven tanto para el hotel, la municipalidad, el centro médico, el mercado, el centro de convenciones, el centro financiero, el centro cultural, entre otros.

Cabe indicar que todos los volúmenes y cada uno de los niveles cuentan con sus respectivos servicios higiénicos, con sus respectivos ductos de circulación vertical y con sus respectivas salidas de emergencia.

\subsection{Programa arquitectónico}

En base al análisis de proyectos referenciales especificados en el marco operativo, se propone para el presente proyecto, nuevos usos que potencien y le den un valor agregado al mercado, que inviten a los usuarios a frecuentarlo. Por este motivo se incluye programa cultural (centro de convenciones, anfiteatro, galería de arte), programa educativo, (talleres educativos, zona de lectura) programa comercial (módulos de mercado, restaurantes), programa de entretenimiento (espacios públicos dinámicos, juego para niños), plazas cívicas, etc. 
Tabla 8.1

Resumen de áreas del programa arquitectónico

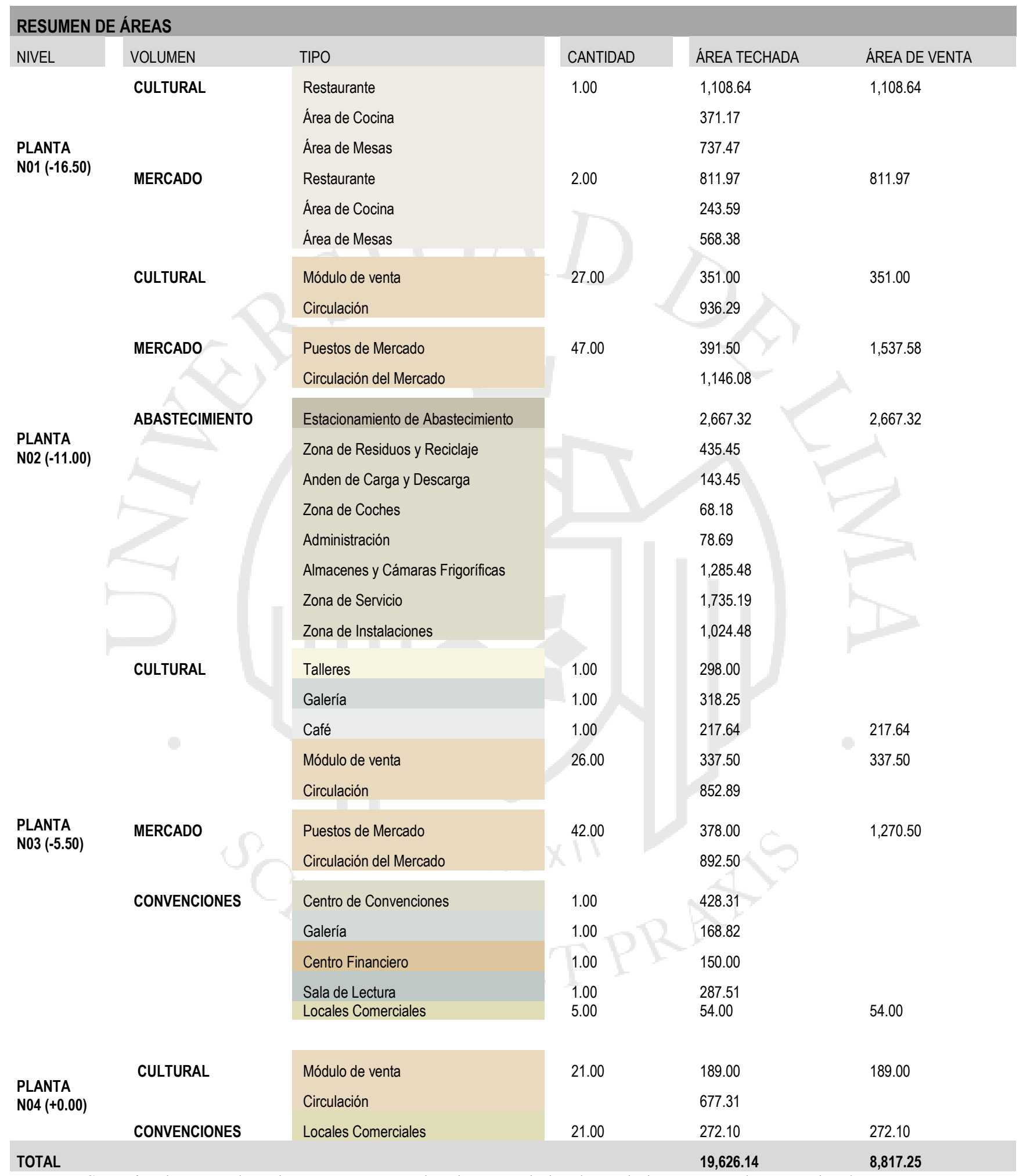

Se entiende como área de venta en mercados, la suma de las áreas de los puestos de venta, las áreas para la exposición de los productos y las áreas que ocupan las circulaciones abiertas al público. 


\subsection{Cuadros y cálculos de usuario}

Para el cálculo de usuarios del proyecto se han evaluado los referentes analizados en el marco operativo respecto al número de puestos, visitantes y turistas por día. En la evaluación se relacionó el número de visitantes turistas con el número de turistas que pernoctan en la ciudad con el fin de sacar el porcentaje promedio de los turistas que pernoctan en la ciudad y visitan el mercado. Con este análisis se determina que el número de visitantes de la propuesta es de 3,795.52 representando el 354\% respecto a los visitantes del mercado actual.

Tabla 8.2

Análisis y cálculo de usuario del proyecto

\begin{tabular}{|c|c|c|c|c|c|c|c|c|c|c|c|}
\hline NOMBRE DEL MERCADO & $\begin{array}{c}\text { ÁREA } \\
\text { OCUPADA }\end{array}$ & CIUDAD & $\begin{array}{l}\text { NÚMERO DE } \\
\text { PUESTOS }\end{array}$ & $\begin{array}{c}\text { VISITANTES } \\
\text { X DIA }\end{array}$ & $\begin{array}{c}\text { NUM. DE } \\
\text { TURISTAS X DIA } \\
\text { (internacionales) }\end{array}$ & $\begin{array}{l}\text { RATIO } \\
\text { VISITANTE / } \\
\text { PUESTO }\end{array}$ & INCREMENTO & $\begin{array}{c}\text { AÑO } \\
\text { EVALUACIÓN } \\
\text { (TURISMO) }\end{array}$ & $\begin{array}{l}\text { TURISTAS QUE } \\
\text { PERNOCTAN AL } \\
\text { AÑO }\end{array}$ & $\begin{array}{l}\text { TURISTAS } \\
\text { QUE } \\
\text { PERNOCTAN } \\
\text { X DÍA }\end{array}$ & $\begin{array}{l}\text { \% TURISTAS } \\
\text { QUE VAN AL } \\
\text { MERCADO X DIA }\end{array}$ \\
\hline PROMEDIO & $2,810.00$ & & 88.60 & $9,318.18$ & $3,727.27$ & 182.78 & & & $5,478,319.80$ & $15,009.10$ & $26 \%$ \\
\hline Mercado de San Miguel & $1,500.00$ & Madrid & 34.00 & $12,142.90$ & $4,857.16$ & 357.14 & & 2011 & $4,027,892.00$ & $11,035.32$ & $44.01 \%$ \\
\hline Mercado de San Antón & $1,260.00$ & Madrid & 21.00 & $3,500.00$ & $1,400.00$ & 166.67 & $300 \%$ de visitantes $/ 32 \%$ ventas & 2011 & $4,027,892.00$ & $11,035.32$ & $12.69 \%$ \\
\hline Mercado de Santa Caterina & $3,000.00$ & Barcelona & 65.00 & $6,225.80$ & $2,490.32$ & 95.78 & $30 \%$ en ventas & 2014 & $6,256,934.00$ & $17,142.28$ & $14.53 \%$ \\
\hline Mercado de Florencia & $5,790.00$ & Florencia & 23.00 & $5,277.80$ & $2,111.12$ & 229.47 & & 2014 & $6,821,947.00$ & $18,690.27$ & $11.30 \%$ \\
\hline Mercado de la Boquería & $2,500.00$ & Barcelona & 300.00 & $19,444.40$ & $7,777.76$ & 64.81 & & 2014 & $6,256,934.00$ & $17,142.28$ & $45.37 \%$ \\
\hline & & & & & & & & & 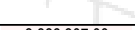 & & \\
\hline Mercado de San Isidro & $9,775.00$ & Lima & & & & & & 2014 & $3,886,307.00$ & $10,647.42$ & $2,723.52$ \\
\hline Actual & & & 58.00 & $1,072.00$ & 428.80 & 18.48 & & & & & \\
\hline Propuesta & & & 212.00 & $3,795.52$ & $1,518.21$ & 17.90 & $354 \%$ de visitantes & & & & \\
\hline CALCULODE DEMANDA & $3,795.52$ & & & & & & & & & & \\
\hline
\end{tabular}

Para el proyecto se realizaron los siguientes cálculos de estacionamientos, servicios higiénicos para el personal y público tomando en cuenta la normativa del RNE y en algunos casos lo planteado por el Plan Maestro de Desarrollo de la Costa Verde, como el cálculo de estacionamientos para hoteles y oficinas en el predio. 
Tabla 8.3

Cálculo de estacionamientos

\begin{tabular}{|c|c|c|c|c|}
\hline \multicolumn{5}{|c|}{ CÁLCULO DE ESTACIONAMIENTOS } \\
\hline Usos & AREAS & AFORO & REQUERIMIENTO & ESTACIONAMIENTOS \\
\hline \multicolumn{5}{|l|}{ ÁREAS DESARROLLADAS } \\
\hline \multicolumn{5}{|l|}{ RESTAURANTES } \\
\hline PERSONAL (ÁREA DE COCINA) & 614.76 & 220 & $\begin{array}{l}1 \text { ESTACIONAMIENTO } \\
\text { CADA } 20 \text { PERS. }\end{array}$ & 11 \\
\hline PÚBLICO (ÁREA DE MESAS) & $1,305.85$ & 261 & $\begin{array}{l}1 \text { ESTACIONAMIENTO } \\
\text { CADA } 20 \text { PERS. }\end{array}$ & 13 \\
\hline \multicolumn{5}{|l|}{ PUESTOS DE MERCADO } \\
\hline PERSONAL & & 178 & $\begin{array}{l}1 \text { ESTACIONAMIENTO } \\
\text { CADA } 10 \text { PERS. }\end{array}$ & 18 \\
\hline PÚBLICO & $2,808.08$ & 1404 & $\begin{array}{l}1 \text { ESTACIONAMIENTO } \\
\text { CADA } 50 \mathrm{~m} 2\end{array}$ & 56 \\
\hline \multicolumn{5}{|l|}{ MODULO DE VENTA } \\
\hline PERSONAL & & 148 & $\begin{array}{l}1 \text { ESTACIONAMIENTO } \\
\text { CADA } 15 \text { PERS. }\end{array}$ & 10 \\
\hline PÚBLICO & 877.50 & 157 & $\begin{array}{l}1 \text { ESTACIONAMIENTO } \\
\text { CADA } 15 \text { PERS. }\end{array}$ & 10 \\
\hline ADMINISTRACION & 78.69 & 8 & $\begin{array}{l}1 \text { ESTACIONAMIENTO } \\
\text { CADA } 10 \text { PERS. }\end{array}$ & 1 \\
\hline TALLERES & 298.00 & 60 & $\begin{array}{l}1 \text { ESTACIONAMIENTO } \\
\text { CADA } 20 \text { PERS. }\end{array}$ & 3 \\
\hline GALERÍA & 487.07 & & & \\
\hline PERSONAL & & & $\begin{array}{l}1 \text { ESTACIONAMIENTO } \\
\text { CADA } 6 \text { PERS. }\end{array}$ & 1 \\
\hline PÚBLICO & & 162 & $\begin{array}{l}1 \text { ESTACIONAMIENTO } \\
\text { CADA } 10 \text { PERS. }\end{array}$ & 16 \\
\hline CAFETERÍAS & 217.64 & & & \\
\hline PERSONAL (ÁREA DE COCINA) & 65.29 & 7 & $\begin{array}{l}1 \text { ESTACIONAMIENTO } \\
\text { CADA } 20 \text { PERS. }\end{array}$ & 0 \\
\hline PÚBLICO (ÁREA DE MESAS) & 152.35 & 102 & $\begin{array}{l}1 \text { ESTACIONAMIENTO } \\
\text { CADA } 20 \text { PERS. }\end{array}$ & 5 \\
\hline CENTRO DE CONVECIONES & & 187 & $\begin{array}{l}1 \text { ESTACIONAMIENTO } \\
\text { CADA } 15 \text { ASIENTOS }\end{array}$ & 12 \\
\hline SALA DE LECTURA & 287.51 & 63.89 & $\begin{array}{l}1 \text { ESTACIONAMIENTO } \\
\text { CADA } 10 \text { PERS. }\end{array}$ & 6 \\
\hline LOCALES COMERCIALES & 326.10 & & & \\
\hline \multicolumn{5}{|l|}{ PERSONAL } \\
\hline PÚBLICO & & 87.35 & $\begin{array}{l}1 \text { ESTACIONAMIENTO } \\
\text { CADA } 15 \text { PERS. }\end{array}$ & 6 \\
\hline CENTRO FINANCIERO & 150.00 & & & \\
\hline PERSONAL & & 30 & $\begin{array}{l}1 \text { ESTACIONAMIENTO } \\
\text { CADA } 15 \text { PERS. }\end{array}$ & 2 \\
\hline PÚBLICO & & 15 & $\begin{array}{l}1 \text { ESTACIONAMIENTO } \\
\text { CADA } 10 \text { PERS. }\end{array}$ & 2 \\
\hline \multicolumn{5}{|l|}{ ÁREAS CALCULADAS } \\
\hline LOCALES COMERCIALES & $2,984.26$ & & & \\
\hline PERSONAL & & & & 0 \\
\hline PÚBLICO & & 799 & $\begin{array}{l}1 \text { ESTACIONAMIENTO } \\
\text { CADA } 100 \mathrm{~m} 2 \text { DEL ÁREA } \\
\text { TECHADA TOTAL } \\
1\end{array}$ & 30 \\
\hline HOTEL & $7,460.65$ & 785 & $\begin{array}{l}\text { CADA } 100 \mathrm{~m} 2 \text { DEL ÁREA } \\
\text { TECHADA TOTAL } \\
\text { SUPERFICIE DESTINADA }\end{array}$ & 75 \\
\hline CENTRO DE ATENCIÓN PRIMARIA & $1,300.60$ & & $\begin{array}{l}\text { PARA } \\
\text { ESTACIONAMIENTO: } 6 \% \\
\text { DEL ÁREA TECHADA } \\
1 \quad \text { ESTACIONAMIENTO }\end{array}$ & 3 \\
\hline SERVICIOS MUNICIPALES & $1,478.14$ & 156 & $\begin{array}{l}\text { CADA } 100 \mathrm{~m} 2 \text { DEL ÁREA } \\
\text { TECHADA TOTAL }\end{array}$ & 15 \\
\hline
\end{tabular}


TOTAL DE ESTACIONAMIENTOS PROYECTADOS

SOT 01

TOTAL ESTACIONAMIENTOS EXCEDENTES
318

318.00
25

\section{CÁLCULO DE ESTACIONAMIENTOS PARA DISCAPACITADOS}

Art. 16, Capítulo II de la Norma A.120 del R.N.E. donde se indica que: de 51 a 400 estacionamiento se destinan 2 por cada 50 estacionamientos

\section{TOTAL ESTACIONAMIENTOS REQUERIDOS}

293.40

TOTAL

DISCAPACITADOS*

ESTACIONAMIENTOS

${ }^{* *}$ Estacionamientos para discapacitados está dentro del total de estacionamientos requeridos

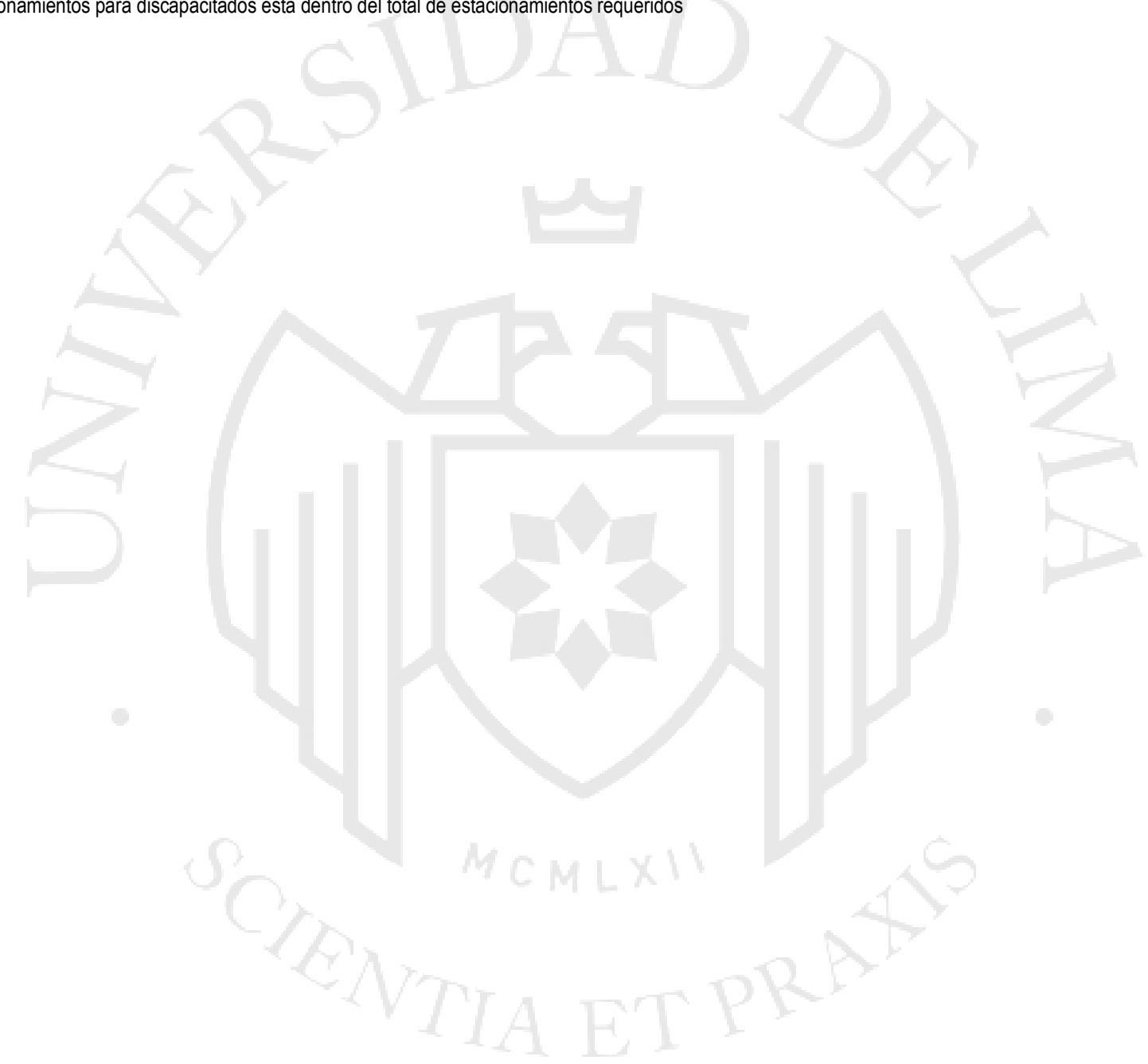


Tabla 8.4

Cálculo de dotación de servicios planta N01 y N02
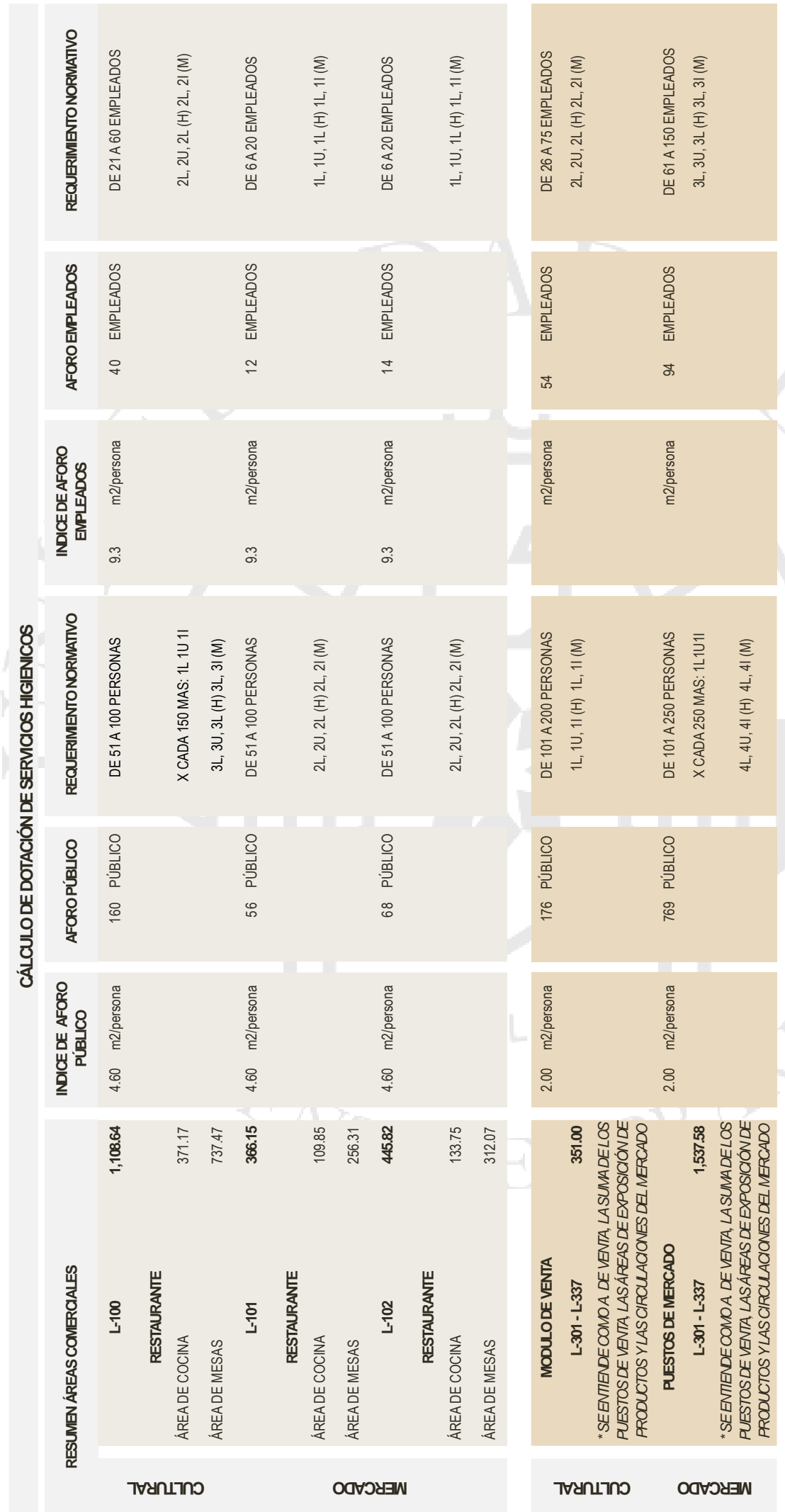

(OS'9L-) LON
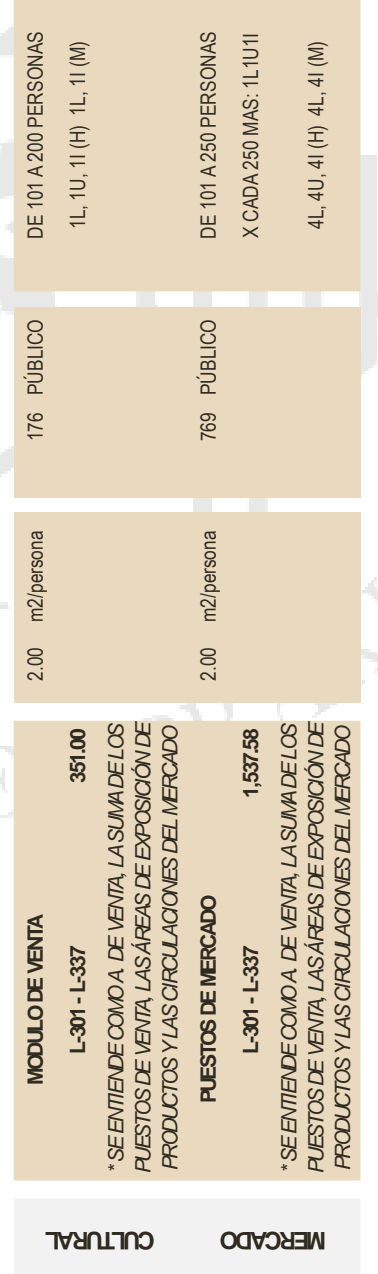
究 잉 
Tabla 8.5

Cálculo de dotación de servicios planta N03 y N04
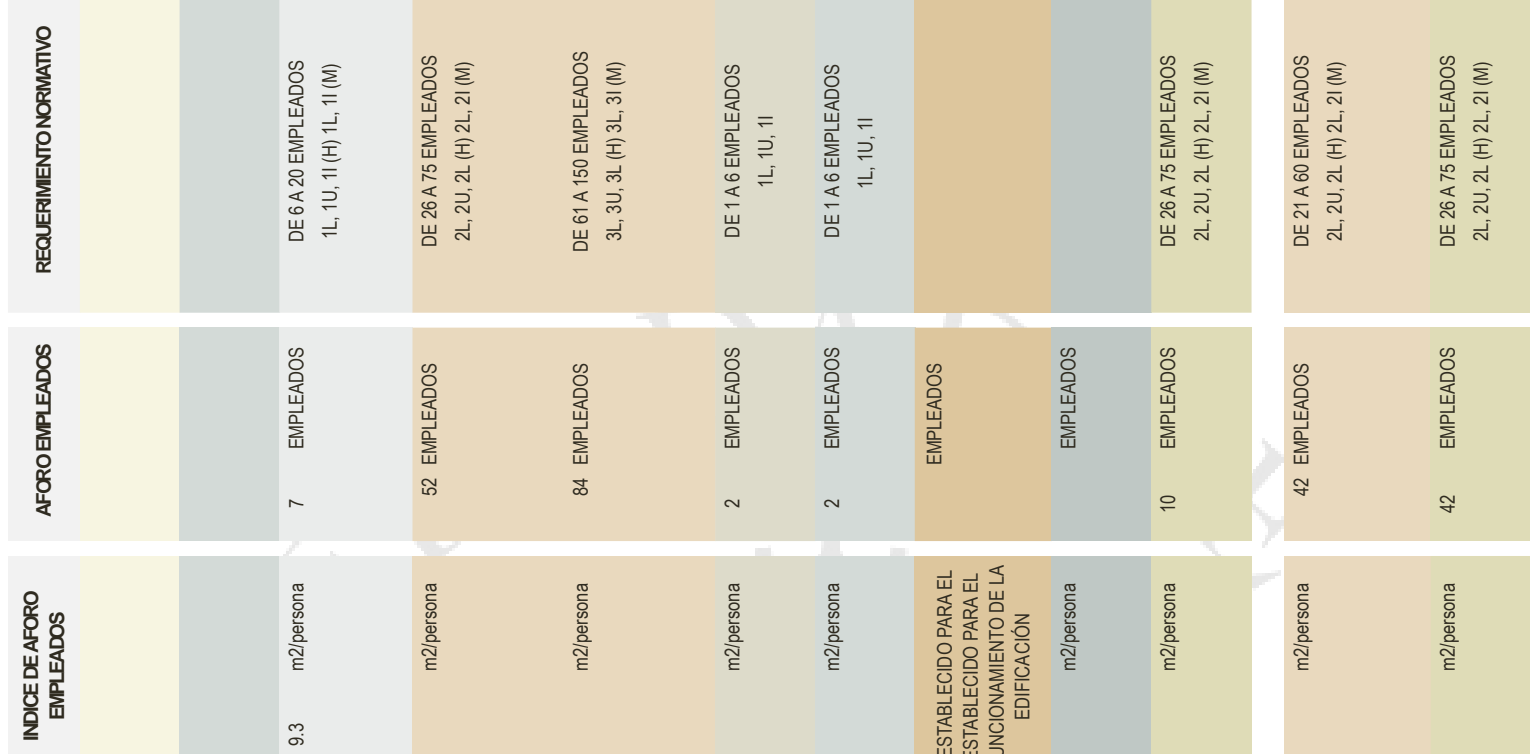

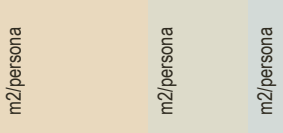
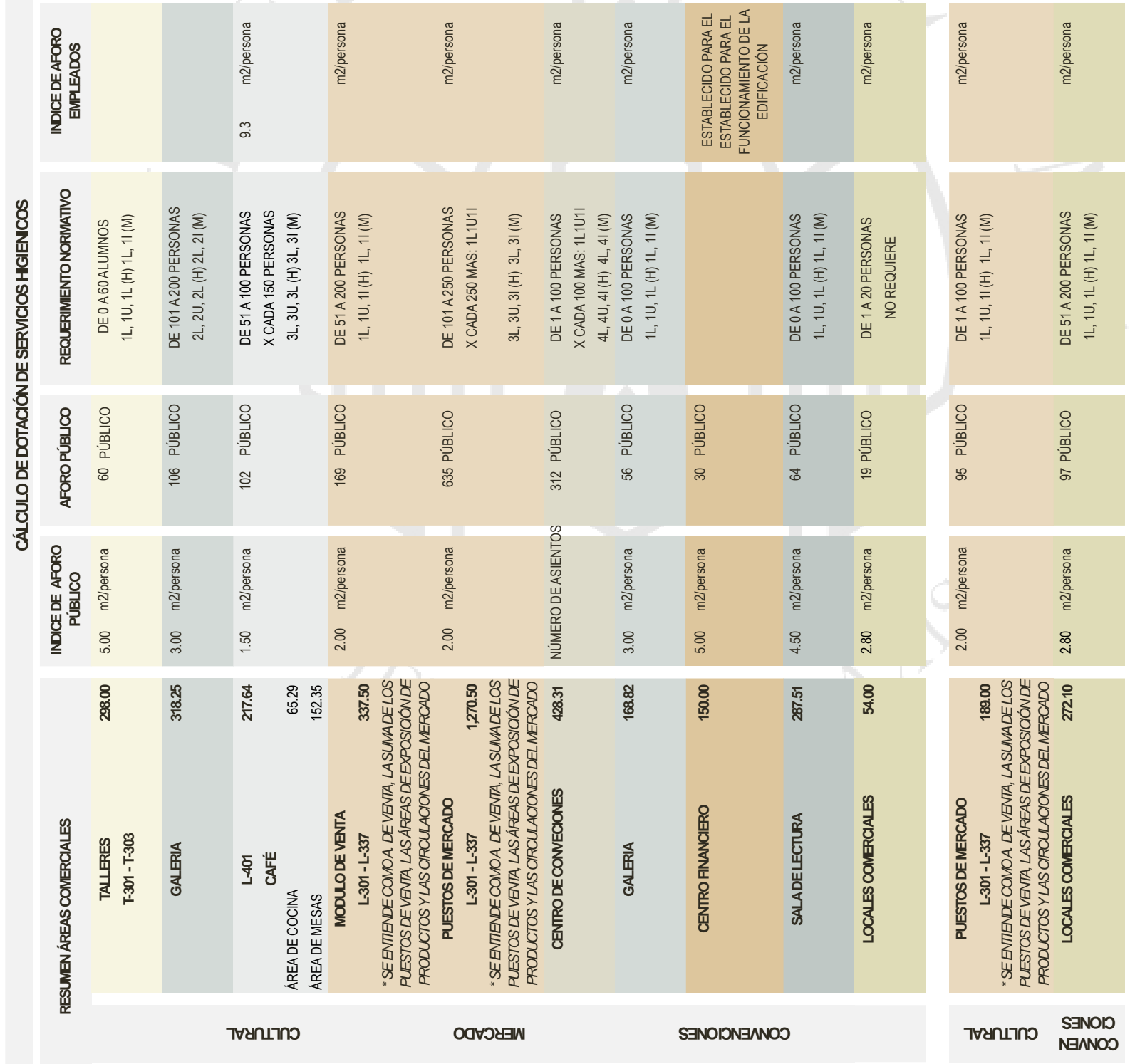

(OS'S-) EON $\forall I N \forall / 7$

$\left(00^{\circ} 0^{+}\right)$tON $\forall I N \forall 7 d$ 


\subsection{Cabida}

Tabla 8.6

Cabida y áreas del proyecto

MERCADO MUNICIPAL DE SAN ISIDRO

\begin{tabular}{|c|c|c|c|c|c|c|}
\hline AREAS EXISTENTES DESARROLLADAS & $\begin{array}{l}\text { CANTIDAD } \\
\text { EXISTENTE } \\
\text { (und) }\end{array}$ & $\begin{array}{l}\text { CANTIDAD } \\
\text { PROPUESTA } \\
\text { (und) }\end{array}$ & $\begin{array}{c}\text { ÁREA } \\
\text { PROPUESTA (m2) }\end{array}$ & $\begin{array}{l}\text { AFORO } \\
\text { TOTAL }\end{array}$ & $\begin{array}{l}\text { REQUERIMIENTO } \\
\text { ESTACIONAMIENTOS }\end{array}$ & ESTACIONAMIENTOS \\
\hline RESTAURANTES & 0 & 3 & 1920.61 & 481 & & 24 \\
\hline PERSONAL (ÁREA DE COCINA) & & & 614.76 & 220 & $\begin{array}{l}1 \text { ESTACIONAMIENTO } \\
\text { CADA } 20 \text { PERS. }\end{array}$ & 11 \\
\hline PÚBLICO (ÁREA DE MESAS) & & & 1305.85 & 261 & $\begin{array}{l}1 \text { ESTACIONAMIENTO } \\
\text { CADA } 20 \text { PERS. }\end{array}$ & 13 \\
\hline PUESTOS DE MERCADO & 43 & 112 & & 1582 & & 74 \\
\hline PERSONAL & & & & 178 & $\begin{array}{l}1 \text { ESTACIONAMIENTO } \\
\text { CADA } 10 \text { PERS. }\end{array}$ & 18 \\
\hline PÚBLICO & & & 2808.08 & 1404 & $\begin{array}{c}1 \text { ESTACIONAMIENTO } \\
\text { CADA } 50 \mathrm{~m} 2\end{array}$ & 56 \\
\hline MODULO DE VENTA & 15 & 100 & & 305 & & 20 \\
\hline PERSONAL & & & & 148 & $\begin{array}{c}1 \text { ESTACIONAMIENTO } \\
\text { CADA } 15 \text { PERS. }\end{array}$ & 10 \\
\hline PÚBLICO & & & 877.5 & 157 & $\begin{array}{l}1 \text { ESTACIONAMIENTO } \\
\text { CADA } 15 \text { PERS. }\end{array}$ & 3 \\
\hline ADMINISTRACION & 1 & 1 & 78.69 & 8 & $\begin{array}{l}1 \text { ESTACIONAMIENTO } \\
\text { CADA } 10 \text { PERS. }\end{array}$ & 1 \\
\hline TALLERES & 0 & 4 & 298 & 60 & $\begin{array}{l}1 \text { ESTACIONAMIENTO } \\
\text { CADA } 20 \text { PERS. }\end{array}$ & 3 \\
\hline SALA DE EXPOSICIONES & 0 & 2 & 487.07 & 163 & & 17 \\
\hline PERSONAL & & & & 1 & $\begin{array}{l}1 \text { ESTACIONAMIENTO } \\
\text { CADA } 6 \text { PERS. }\end{array}$ & 1 \\
\hline PÚBLICO & & & & 162 & $\begin{array}{l}1 \text { ESTACIONAMIENTO } \\
\text { CADA } 10 \text { PERS. }\end{array}$ & 16 \\
\hline CAFETERÍAS & 0 & 2 & 217.64 & 109 & & 5 \\
\hline PERSONAL (ÁREA DE COCINA) & & & 65.29 & 7 & $\begin{array}{l}1 \text { ESTACIONAMIENTO } \\
\text { CADA } 20 \text { PERS. }\end{array}$ & 0 \\
\hline PÚBLICO (ÁREA DE MESAS) & & & 152.35 & 102 & CADA 20 PERS. & 5 \\
\hline CENTRO DE CONVENCIONES & 0 & 1 & & 187 & $\begin{array}{l}\text { 1 ESTACIONAMIENTO } \\
\text { CADA } 15 \text { ASIENTOS }\end{array}$ & 12 \\
\hline SALA DE LECTURA & 0 & 1 & 287.51 & 63.89 & $\begin{array}{l}1 \text { ESTACIONAMIENTO } \\
\text { CADA } 10 \text { PERS. }\end{array}$ & 6 \\
\hline LOCALES COMERCIALES & 0 & 3 & 326.1 & 87.35 & & 6 \\
\hline PÚBLICO & & & & 87.35 & $\begin{array}{l}1 \text { ESTACIONAMIENTO } \\
\text { CADA } 15 \text { PERS. }\end{array}$ & 6 \\
\hline LOCALES DE ENTIDAD PUBLICA & 0 & 3 & 150 & & & 4 \\
\hline PERSONAL & & & & 30 & $\begin{array}{l}1 \text { ESTACIONAMIENTO } \\
\text { CADA } 15 \text { PERS. }\end{array}$ & 2 \\
\hline PÚBLICO & & & & 15 & $\begin{array}{l}1 \text { ESTACIONAMIENTO } \\
\text { CADA } 10 \text { PERS. }\end{array}$ & 2 \\
\hline
\end{tabular}




\subsection{Viabilidad}

\subsubsection{Estudio de mercado}

\section{Determinación de la zona de impacto}

Determinación de los distritos incluidos en la zona de influencia por su ubicación y proximidad al proyecto.

Tabla 8.7

Tiempo de viaje por distrito

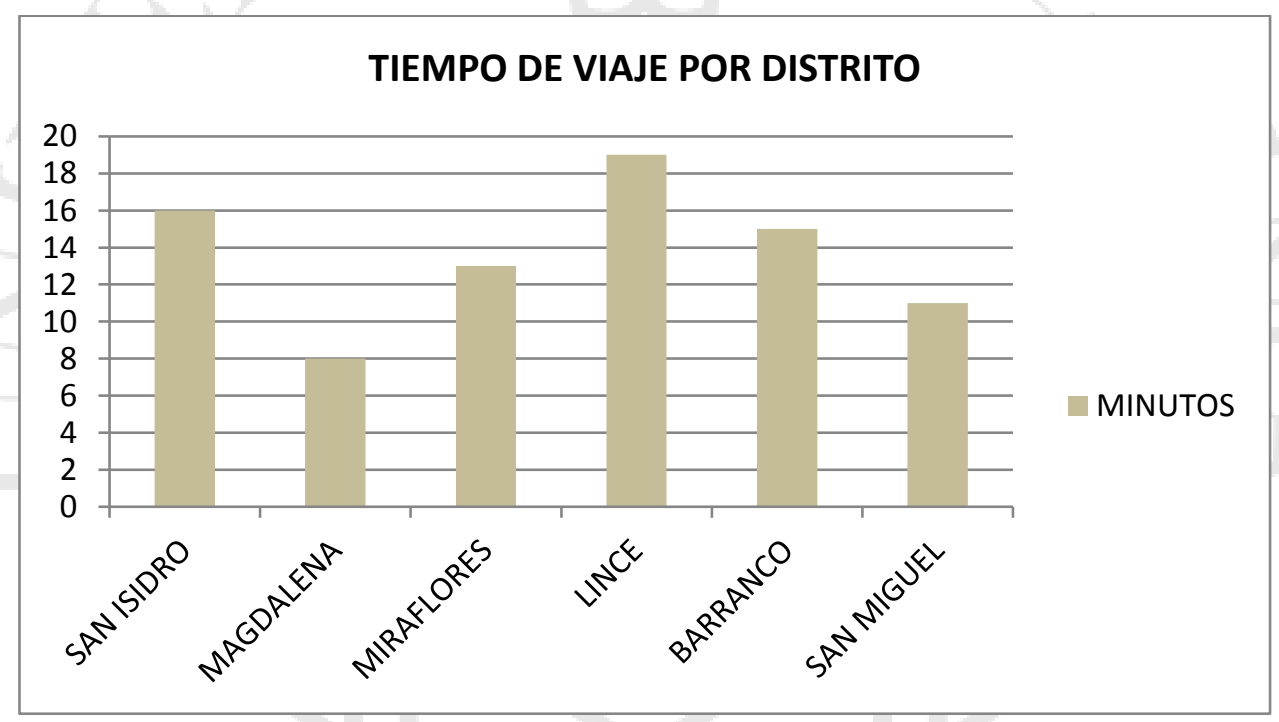

A continuación, se indica gráficamente el tiempo de viaje promedio de visita al Nuevo Mercado de San Isidro con vehículo, desde los diferentes distritos aledaños, se toma como referencia la Municipalidad de cada distrito: 
De San Isidro al mercado de productores de san isidro: 16 minutos

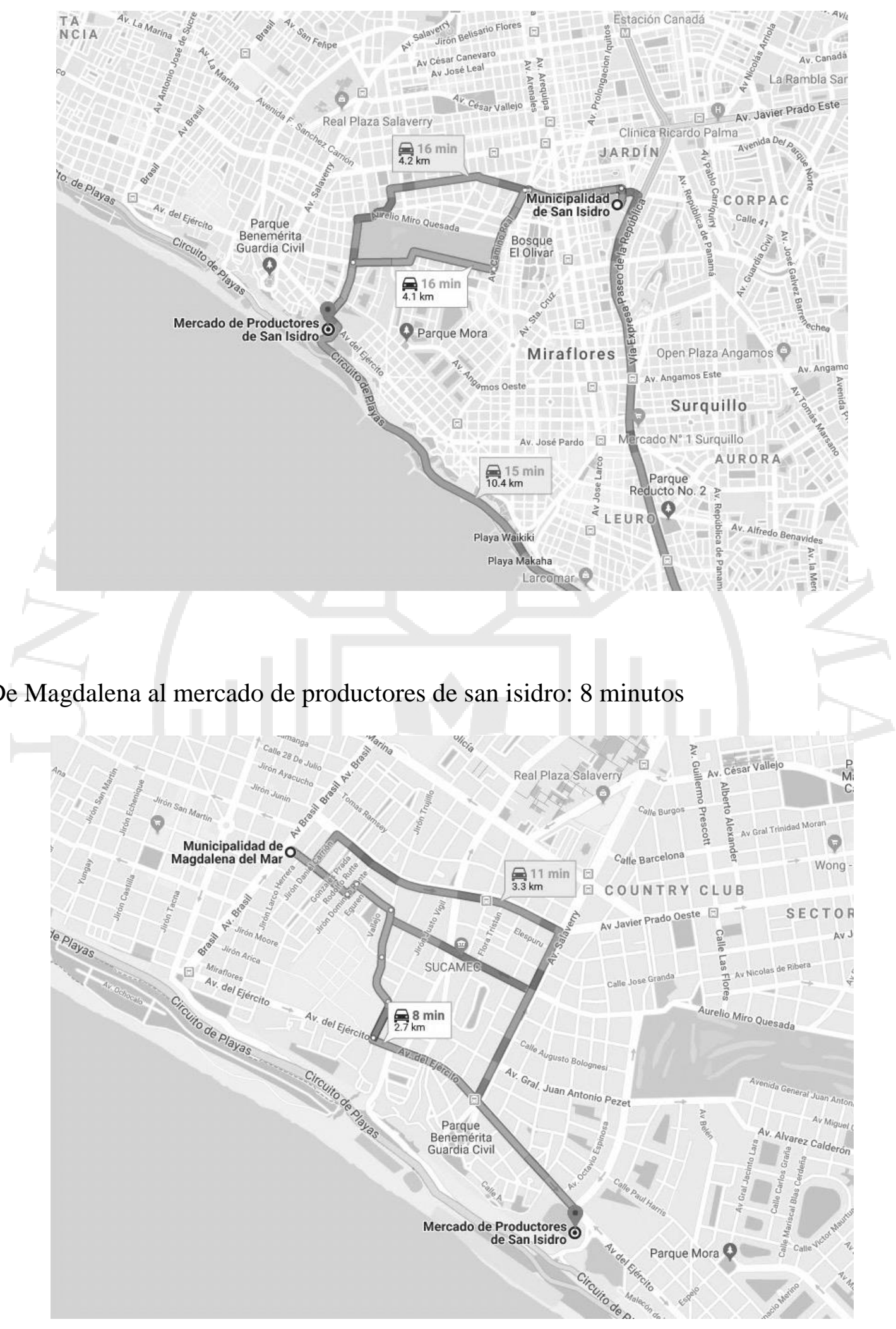


De Miraflores al mercado de productores de san isidro: 12 minutos

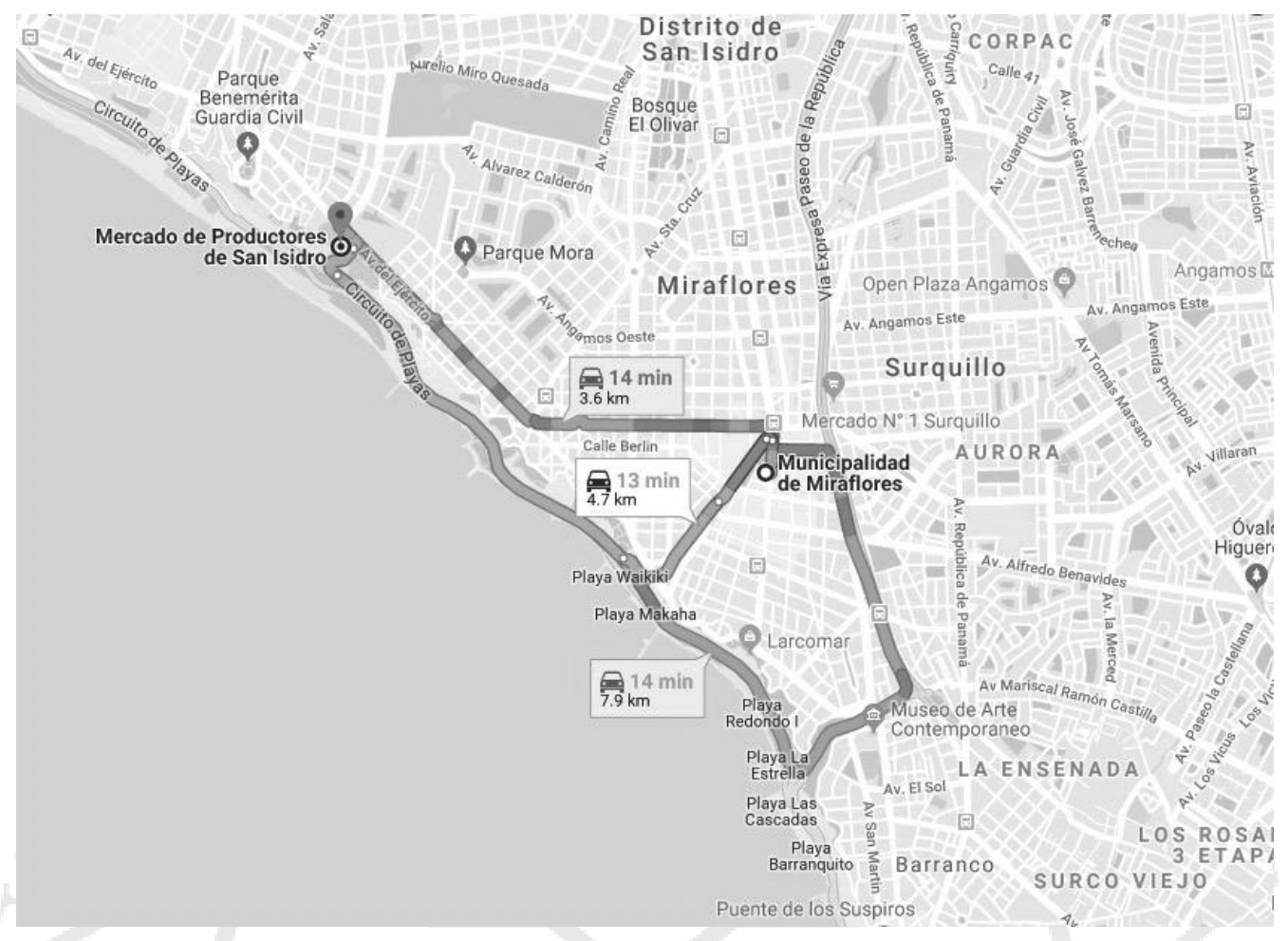

De Lince al mercado de productores de san isidro: 19 minutos

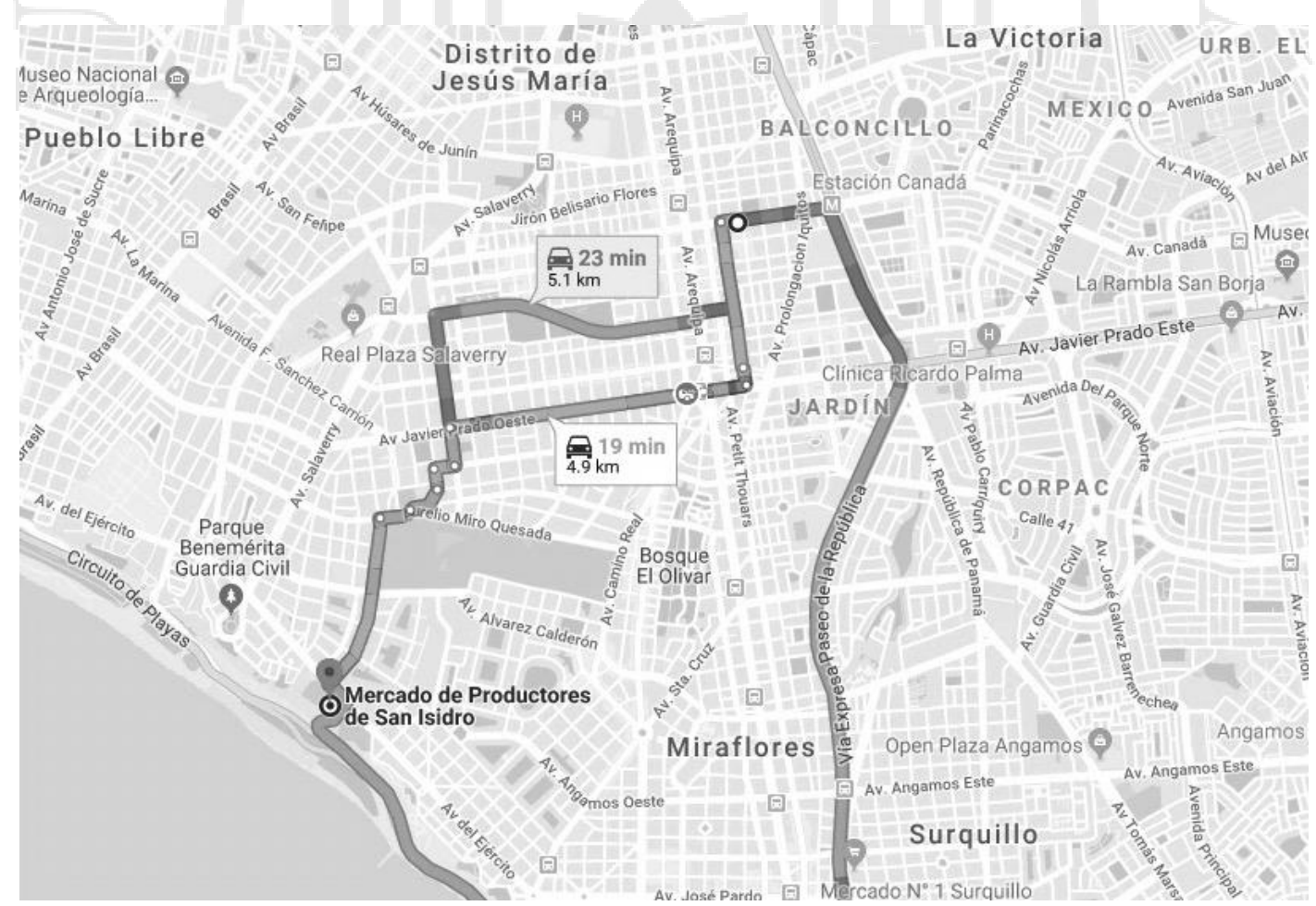


De Barranco al mercado de productores de san isidro: 15 minutos

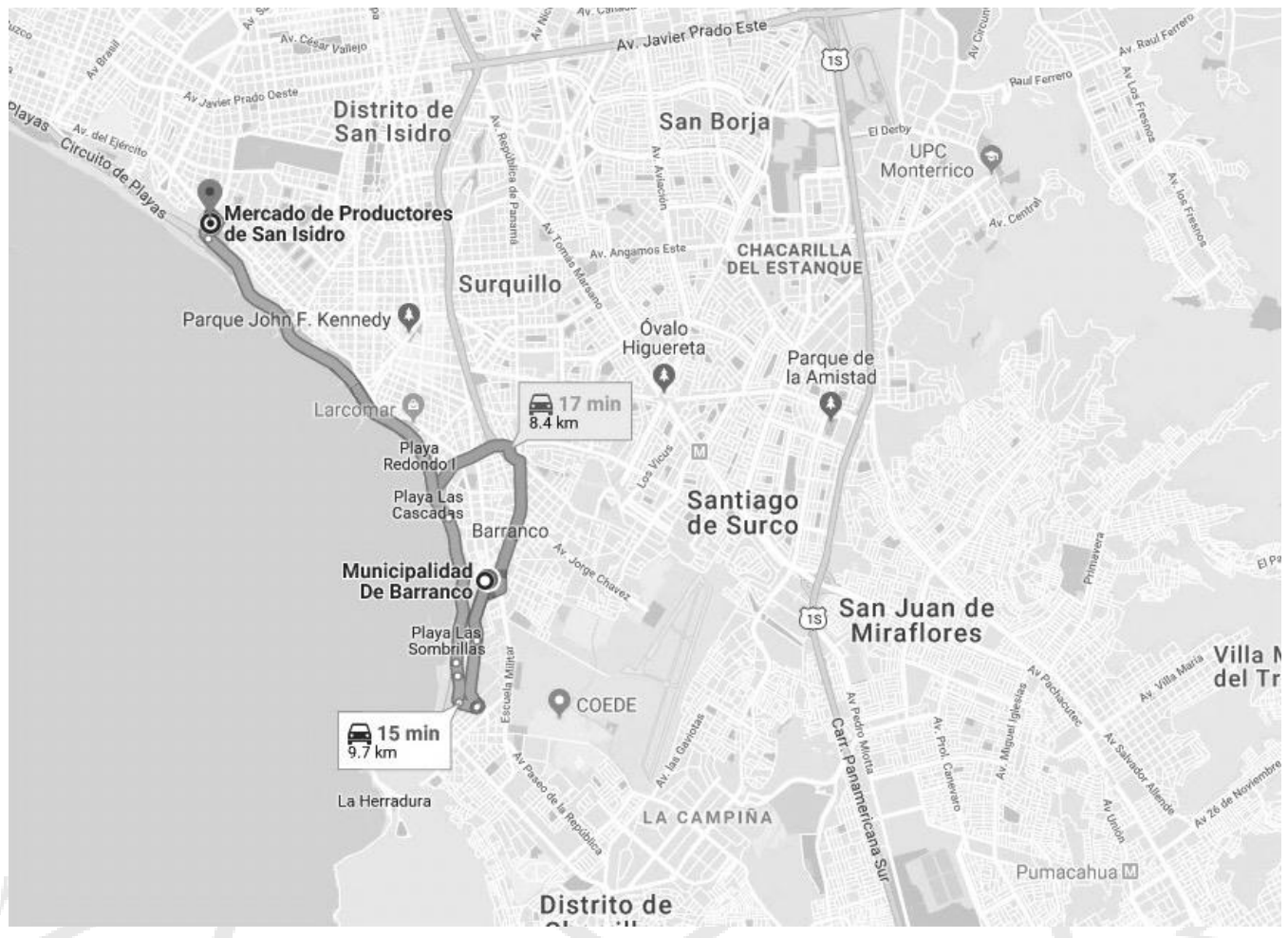

De San Miguel al mercado de productores de san isidro: 13 minutos

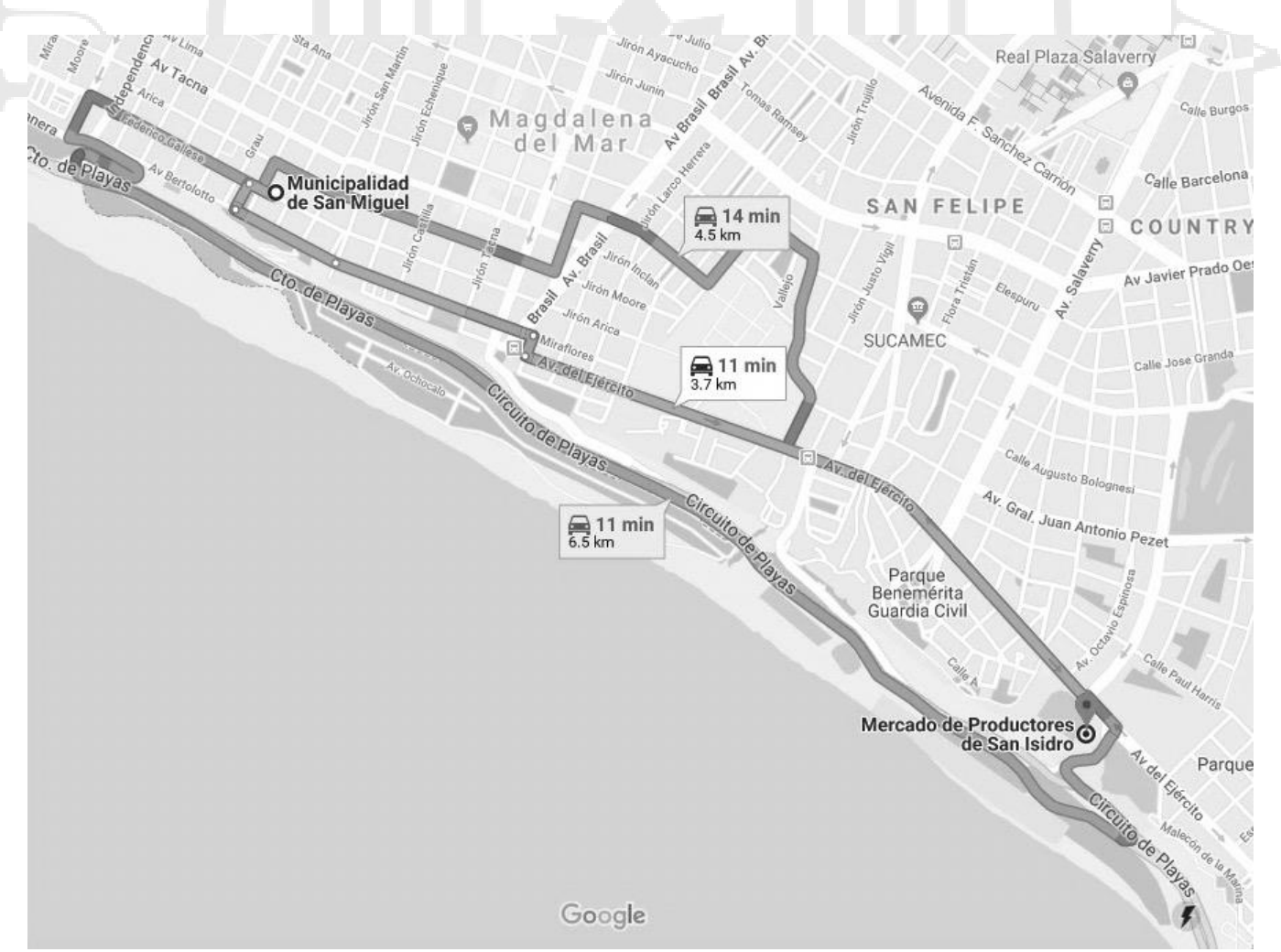




\section{Identificación de las zonas de influencia del Nuevo Mercado de San Isidro desde la perspectiva de la demanda potencial:}

Dado que el proyecto inmobiliario consiste en la implementación de un equipamiento socio-comercial, existen demandantes potenciales (empresas y personas naturales) cercanos y lejanos interesados en tener un espacio en el Nuevo Mercado de Productores de San Isidro. Para determinar las dos zonas de influencia para demanda potencial se plantearon los siguientes factores:

Zona de influencia cercana

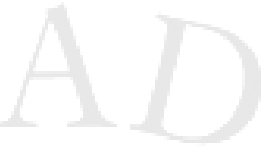

- Tiempo que toma trasladarse al proyecto de manera peatonal y en bicicleta.

- La zona comercial en donde se encuentra el proyecto.

- Tipos de negocio con mayor potencial de demanda en adquirir un espacio comercial.

Figura 8.16

Zona de influencia cercana al Mercado de Productores de San Isidro, Lima

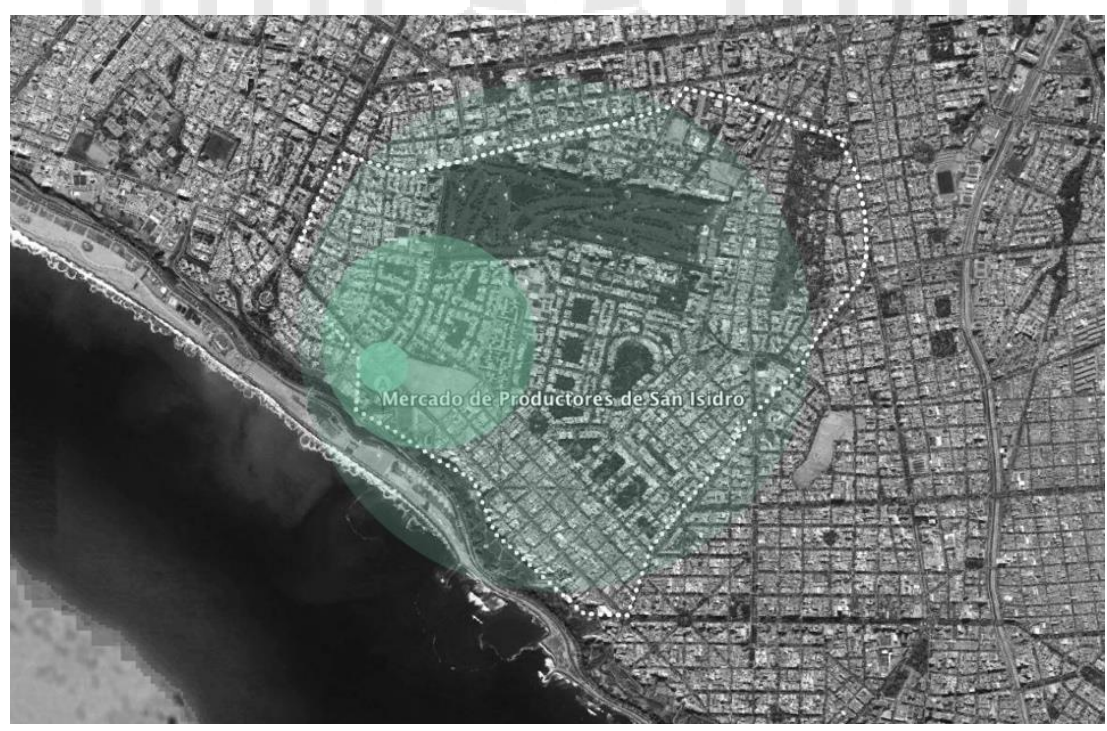

Fuente: Elaboración propia

Zona de influencia lejana

- Tipo de proyecto inmobiliario que será el Nuevo Mercado de San Isidro.

- Búsqueda de un espacio atractivo para que las empresas se sientan a gusto 
- Capacidad adquisitiva de los hogares cercanos y lejanos que visitan la zona donde se encuentra el proyecto.

- Nivel de atractivo de la Costa Verde.

Figura 8.17

Zona de influencia lejana al Mercado de Productores de San Isidro, Lima

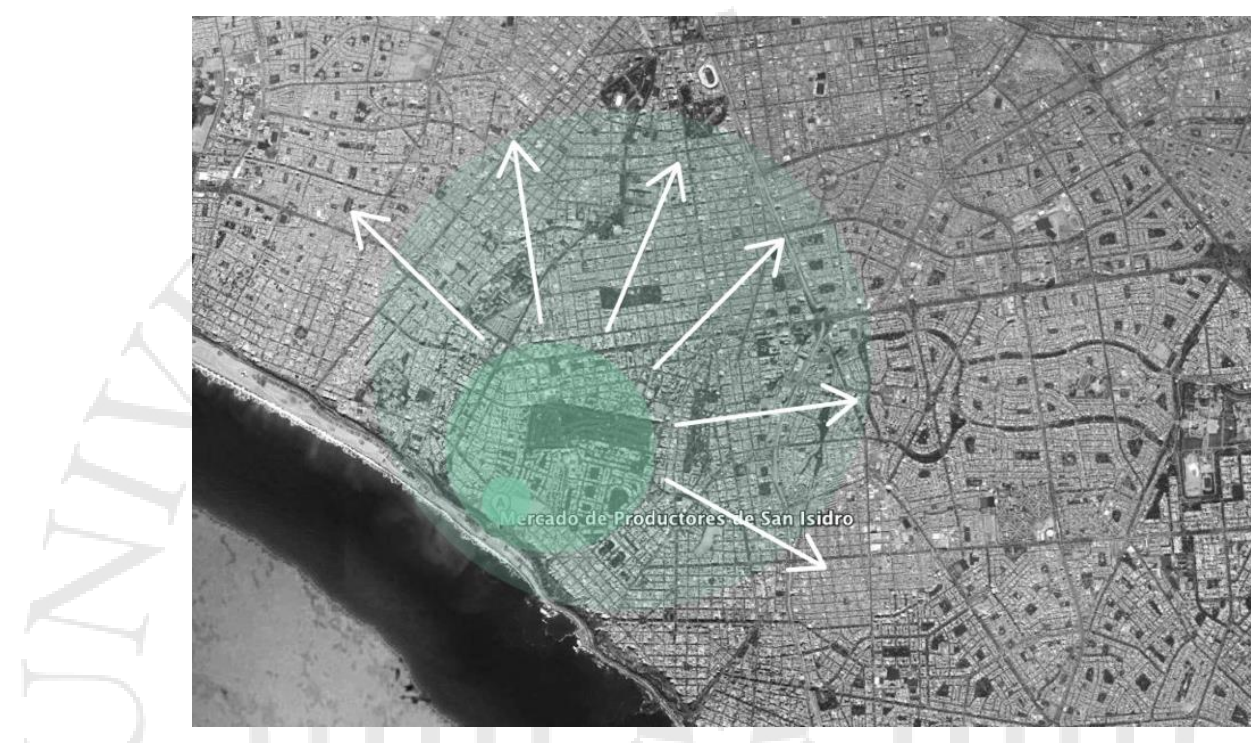

Fuente: Elaboración propia

El tipo de proyecto inmobiliario que plantea el Nuevo Mercado de San Isidro que incluye locales comerciales, módulos de venta, restaurantes, salas de exposición, salas de lectura, zonas de usos múltiples, talleres, hospedaje, entre otros; propone una oferta comercial atractiva para empresas interesadas que no necesariamente se encuentren dentro de la zona de influencia cercana. Por tanto, se puede determinar que la zona de influencia lejana del proyecto, desde la perspectiva de la demanda potencial, son todos los distritos de Lima Metropolitana, debido a que empresas de distintos rubros se encuentran en diversas partes de la capital.

\subsubsection{Panorama general del proyecto}

\section{Grado de atractivo de la ubicación del proyecto inmobiliario}

La ubicación del predio donde se plantea el proyecto Nuevo Mercado de Productores de San Isidro es atractivo debido a múltiples factores entre los que destacan: la alta 
afluencia de público debido a la ubicación cercana al malecón de Miraflores, Centro Deportivo Municipal, el Centro de Atención Primaria y el Golf de San Isidro; el gran desarrollo del sector inmobiliario y su proyección en relación al Cuartel San Martín; y a la fácil accesibilidad a la zona. Otra variable relevante es que el predio se encuentra cerca de distritos con hogares de alta capacidad adquisitiva; se ubica frente al Cuartel San Martín; y finalmente está relativamente cerca al centro financiero y a diversos atractivos turísticos.

\section{Descripción del actual mercado municipal de San Isidro}

El Mercado de San Isidro tiene cerca de 50 años de existencia. Su funcionamiento y tradición lo ha convertido en el principal mercado de abastos del distrito, ya que es visitado diariamente por los vecinos de la zona, clientes de distritos aledaños y turistas.

Las principales características que presenta actualmente el mercado son:

Propietario: Municipalidad Distrital de San Isidro, la misma que a su vez está supervisada por la Dirección Municipal de Comercialización y Defensa al Consumidor de la Municipalidad de Lima Metropolitana.

Número de puestos: 60 puestos de venta de mercado

Área: $8349.01 \mathrm{~m} 2$

Puertas de ingreso: 5 puertas de ingreso

Principales negocios que existen en el mercado:

- Venta de mercado tradicional (carnes, pescados, futas, verduras, abarrotes)

- Venta de otros productos

- Módulo de venta de menú 
Tabla 8.8

Actual mercado de productores de San Isidro

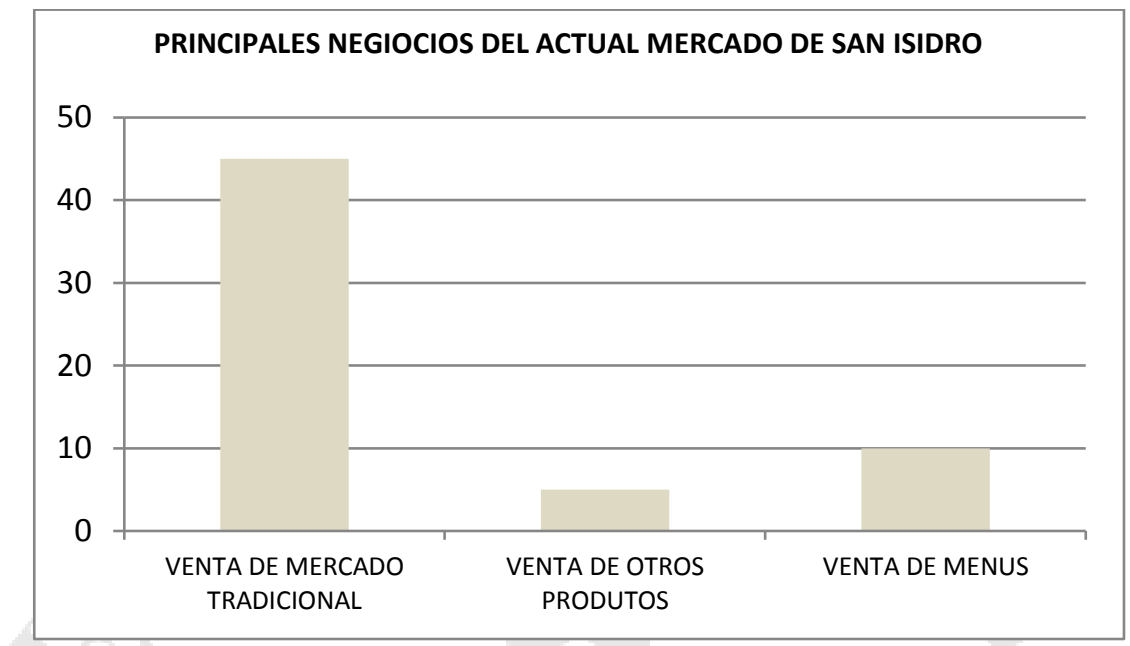

Fuente: Elaboración propia

\subsubsection{Análisis del usuario}

\section{Demandas potenciales}

La cercanía a algunos puntos gastronómicos de algunos distritos próximos a la zona de influencia del proyecto genera un mayor interés por parte de los clientes directos, quienes finalmente arrendaran un espacio comercial en el proyecto. Los puntos gastronómicos que potencialmente pueden pertenecer a la zona de influencia del proyecto del nuevo mercado de productores de San Isidro son:

Zonas gastronómicas cercanas

Av. La Mar

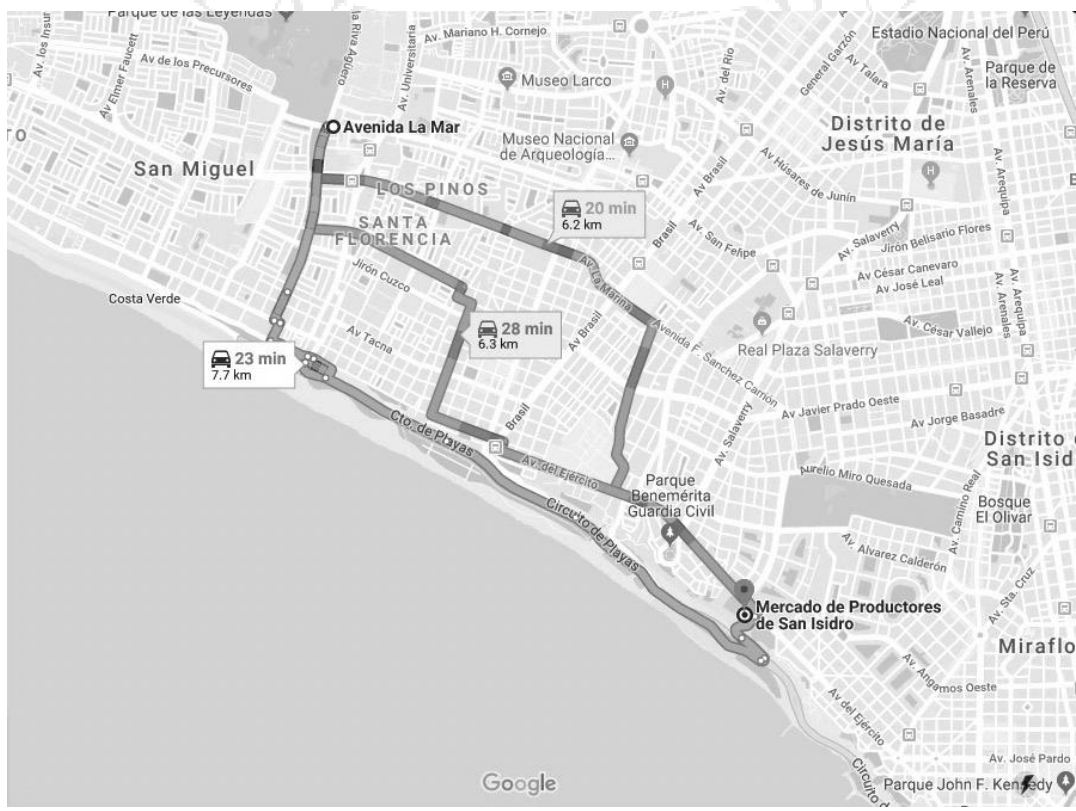




\section{Ovalo Gutiérrez}

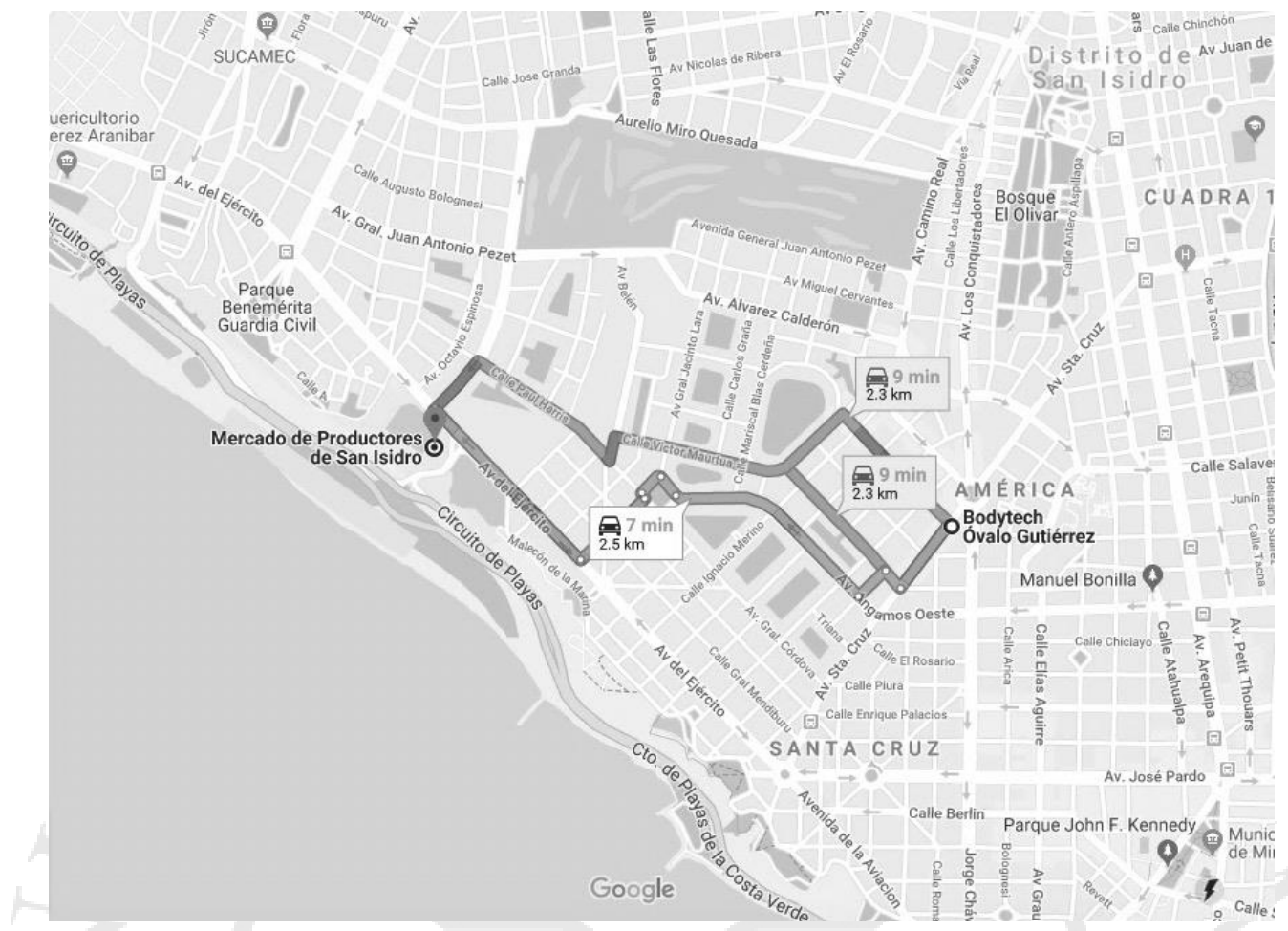

Av. 28 de julio

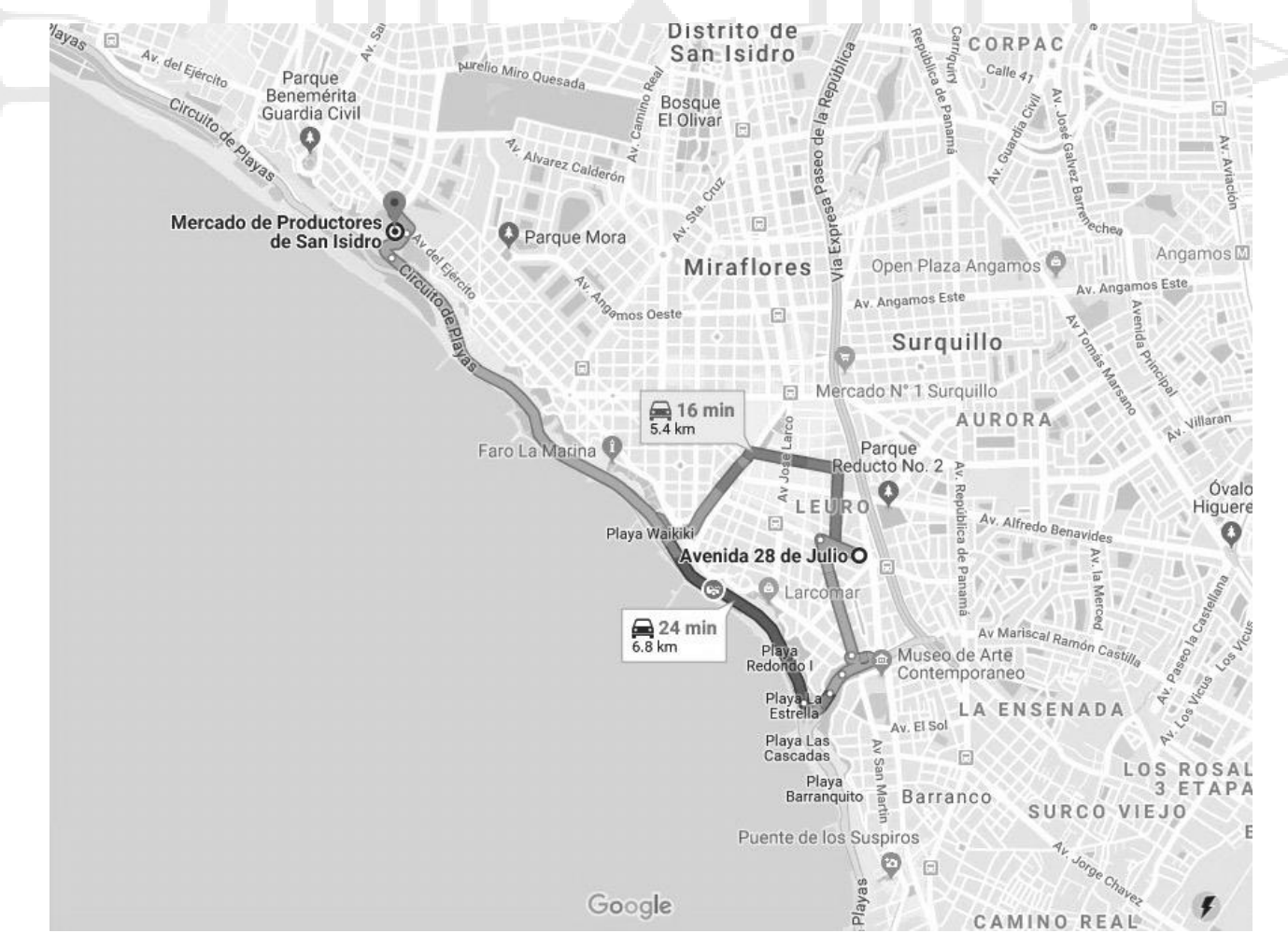


Zonas gastronómicas lejanas:

\section{Larcomar}

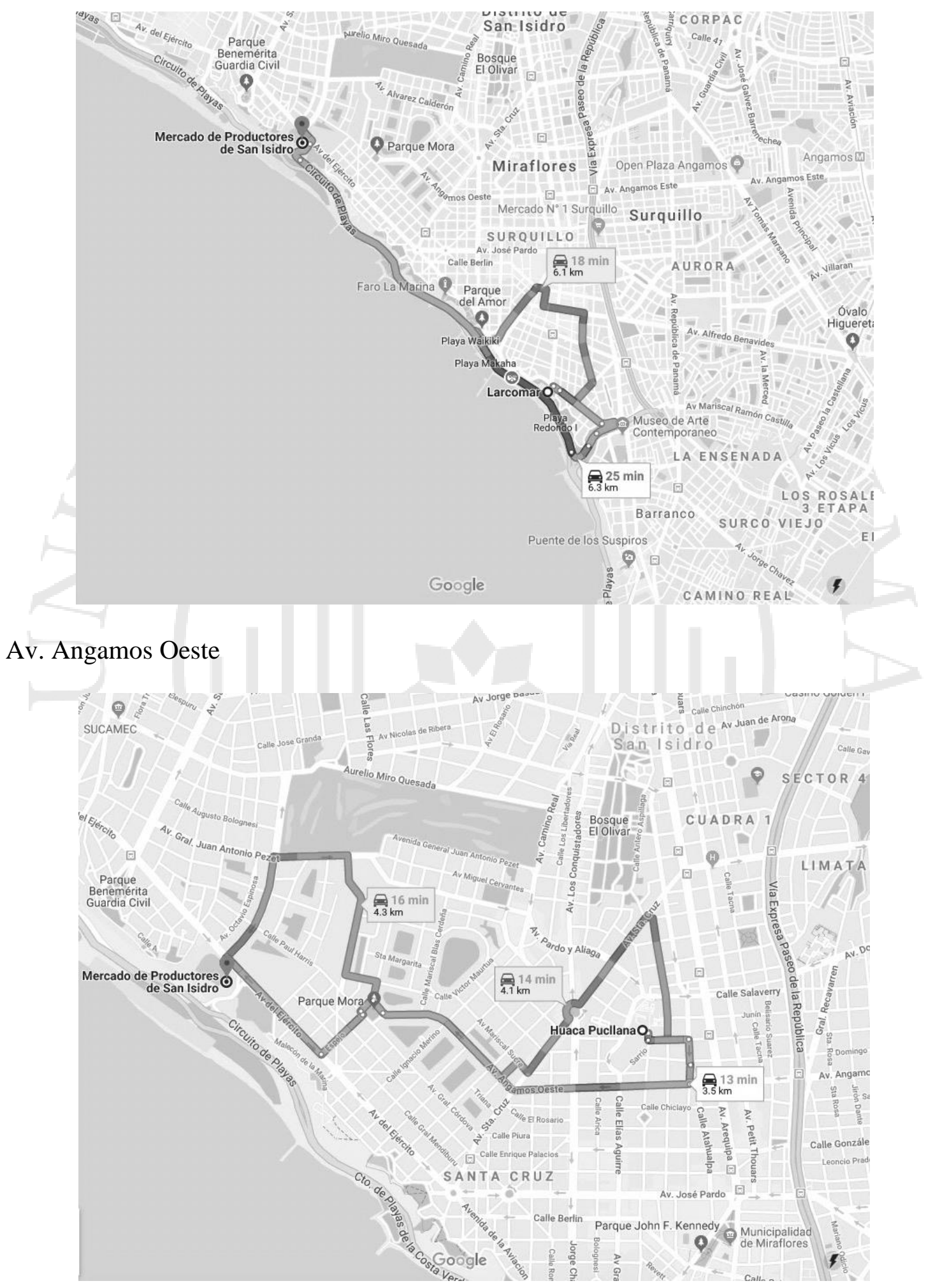




\section{Caracterización del cliente final del Nuevo Mercado}

Estilos de vida: para nuestro caso de estudio es relevante mencionar que la propuesta del nuevo mercado de productores de San Isidro estará orientada no solo a los estilos de vida de las conservadoras y los resignados, sino más bien contará con el interés de las modernas, los progresistas y los sofisticados también, en vista a la postura innovadora del mercado, el aspecto cultural que ofrecerá y las conservadoras y los resignados.

\subsubsection{Oferta y demanda de estacionamiento y almacenes}

La diversidad de usos de la zona que involucra el Centro Cívico de San Isidro y la proximidad de equipamientos municipales (oficinas, centro deportivo, centro de atención primaria) genera una gran demanda de estacionamientos, principalmente por visitantes y vecinos de la zona.

Con relación a las actividades relacionadas en la zona y a la información de los comerciantes se determinó que se analizaría el flujo vehicular y la oferta cercana al proyecto. En relación al flujo vehicular en la zona, se ha medido en campo un total de 9,300 vehículos por hora. Y actualmente encontramos en la zona 2 edificios con oferta de estacionamientos concesionados por la empresa Los Portales, en la Av. Ejército (a $1.1 \mathrm{~km}$ respecto al proyecto) y en la Av. Salaverry (a $1.6 \mathrm{~km}$ respecto al proyecto).

Además de la demanda de estacionamientos de la zona, uno de los requerimientos e interés del cliente directo (empresas y negocios potenciales) son el requerimiento de espacio para almacén o deposito. Los mismos que deben estar conectados al área de abastecimiento y facilitar el desplazamiento de los productos hacia el área de venta.

Los tamaños que se ofertan en el proyecto varían de 6.9 a 30m2, los mismos que se encuentran en el área de abastecimiento ubicada en el nivel -11.00.

El precio propuesto por metro cuadrado del espacio de almacén $\$ 21.2(\mathrm{~S} / .70)$ y el periodo de alquiler varía de 1 a 3 años. 


\subsubsection{Gestión comercial}

El esquema de negocio propuesto para el proyecto se basa en una Asociación PúblicoPrivada (APP), el cual consta en un mecanismo para el desarrollo de infraestructura a favor de la ciudad, mediante la inversión privada e intervención del Estado.

El proyecto consta de áreas comerciales, que generan una renta mensual; estacionamientos y depósitos, para su alquiler: hospedaje y oficinas, que tienen ingresos; además de espacios públicos, plazas cívicas, áreas verdes y centros culturales que requieren de ingresos para su mantenimiento y funcionamiento.

El financiamiento de la construcción está dado por una IIC (fondo de inversión), cuyo retorno radica bajo la condición de una concesión de 40 años después de la construcción del bien. Asimismo, el ente privado, en este periodo, se encarga de la administración, mantenimiento y funcionamiento de las distintas áreas de proyecto.

Durante el tiempo de concesión la municipalidad se beneficia con infraestructura para los servicios cívicos y administrativos municipales, los cuales corresponden al Centro de Atención Primaria y las oficinas municipales.

Una vez culminado el tiempo de concesión, la administración del proyecto pasa a cargo de la Municipalidad de San Isidro. Mediante los ingresos generados por la renta de espacios comerciales, el ente público, podrá encargarse del mantenimiento y funcionamiento de las áreas públicas, culturales y cívicas, que no representan ingreso alguno.

\subsubsection{Estrategias comerciales}

Como se mencionó anteriormente, existen dos tipos de clientes (directo y final) que intervienen en el proyecto y por ende las estrategias comerciales deben ser manejadas de manera distinta. El cliente directo corresponde a las empresas y marcas que arrendarán los espacios comerciales, mientras que el final es el usuario que visitará y consumirá en los distintos locales comerciales.

Para el caso del cliente directo, además de mantener una comunicación directa con los retailers mediante la creación de un organismo dentro de la empresa se 
utilizarán estrategias BTL y ATL. Ambas para difundir el modelo de proyecto que se propone y los beneficios a las empresas que se interesen en participar.

En cuanto a las estrategias de publicidad ATL se implementaría para captar clientes por canales de difusión masiva como revistas del rubro como carteles publicitarios y redes sociales. En cuanto a las estrategias BTL, según la base de datos creada con nuestros clientes potenciales se les enviará una carpeta de presentación creativa para promocionar nuestro producto y marca. Además de comunicar nuestro enfoque de inversión, a futuras empresas, mediante eventos para los potenciales clientes. Estas estrategias BTL permitirían una comunicación más directa con los potenciales clientes.

Asimismo, otra estrategia que motive las empresas participar en el proyecto, son las alianzas estratégicas con organismos vinculados al sector turismo y desarrollo gastronómico del Perú. Estas mismas aportarían parte de la promoción del proyecto y el respaldo para convertir el Mercado de San Isidro en un foco en la atención turística local e internacional, que incentive la demanda de empresas futuras que participen en el proyecto. Organismos como Apega, y Promperú corresponderán a aliados en la gestión comercial y de promoción del proyecto. Asimismo, junto a estos organismos la misma Municipalidad de San de San Isidro cumplirá un papel de promotor para el respaldo y promoción para con las empresas de interés.

En cuanto al cliente final se realizarán estrategias referidas a campañas publicitarias en distintos medios escritos y digitales, mediante la creación de una marca del mercado. Asimismo, con la ayuda de las alianzas estratégicas se participará en campañas publicitarias y eventos vinculados al turismo y gastronomía.

\subsubsection{Gestión económica - financiera}

\section{Etapas del proyecto}

El proyecto, al ser una propuesta emplazada en la topografía del acantilado de la costa verde; contar con varias plazas e ingresos en distintos niveles; y constar de 5 volúmenes conectados por un estacionamiento de vehículos y un área de abastecimiento común, presenta un esquema de construcción de una sola etapa. 
El planteamiento en una sola etapa se justifica, además, por el hecho de que el inversionista aportará para el proyecto los gastos de la construcción, mientras que la municipalidad de San Isidro tendrá como único aporte el terreno en cuestión que actualmente es de su propiedad. Se ha evaluado la inversión e ingresos que genera el proyecto para justificar su respectiva rentabilidad.

El área construida total que contempla el proyecto es de 45,862.04m2, el cual consta de 5 volúmenes. Estos se conforman por el siguiente esquema: el área del Volumen Municipal, que incluye las oficinas municipales (nuevas oficinas y reubicación de las oficinas del predio), la reubicación del Centro de Atención Primaria; el Volumen del Hospedaje 5 estrellas, que incluye locales comerciales; el Volumen del Mercado, que incluye espacios de abastecimiento del mercado, y espacios comerciales; el Volumen Cultural, que incluye locales comerciales, restaurantes y talleres; el Volumen de Convenciones; un sótano con espacios para estacionamientos; zona para el personal, depósitos y almacenes, cisternas, bombas y subestación; y tratamiento de espacio público. El total de tratamiento de espacio público de 15,216.39m2.

Tabla 8.9

Cuadro de áreas del proyecto

\begin{tabular}{lr} 
CUADRO DE ÁREAS & \multicolumn{1}{c}{ m2 } \\
Área Construida & $1,300.60$ \\
Centro de Atención Primaria & $1,478.14$ \\
Oficinas Municipales & $1,954.95$ \\
Volumen de Convenciones & $11,673.99$ \\
Estacionamiento & $2,154.68$ \\
Zona para personal & 724.77 \\
Depósitos y Almacenes & $1,568.71$ \\
Cisternas, bombas y subestación & $2,984.26$ \\
Locales comerciales & $7,460.65$ \\
Hotel 5 estrellas & $3,620.05$ \\
Volumen de Mercado & $5,283.57$ \\
Abastecimiento & $5,657.68$ \\
Volumen Cultural & \\
& $45,862.04$ \\
ÁREA CONSTRUIDA TOTAL & \\
Tratamiento de Espacio Público / Áreas Verde & $4,351.41$ \\
Cubresuelos y árboles & 751.09
\end{tabular}


Grava

Porcelanato de alto transito formato trapezoidal grande

Porcelanato de alto transito formato trapezoidal mediano

Cemento pulido

Piso de concreto estampado

Tratamiento de andenería

ÁREA DE ESPACIO PÚBLICO TOTAL

Fuente: Elaboración propia

\section{Financiamiento del proyecto}

El Plan Maestro de Desarrollo de la Costa Verde propone usos para la activación de las zonas del acantilado mediante la incorporación de equipamientos relacionados al turismo, comercio y cultura.

El proyecto al incluir usos mixtos, comerciales y de hospedaje, podrá obtener un retorno en una cierta cantidad de años, siento una propuesta atractiva no solo para el inversionista sino también para La Municipalidad de San Isidro, ya que con este proyecto aportaría a la ciudad espacios de encuentro y de vínculo con la costa verde y conexión con el entorno próximo.

Para el financiamiento del proyecto se busca que el futuro inversionista encuentre en este una oportunidad de inversión rentable, que además genere un impacto en aspectos urbanos, sociales y medioambientales. Para ello se han planteado equipamientos que cubran el interés tanto de actores como la Municipalidad de San Isidro (dueño del predio) y el inversionista que financiará el proyecto.

El esquema de la Asociación Publica Privada se resume de la siguiente manera: la construcción corresponde a una inversión por parte de un fondo de inversión (IIC), mientras que el aporte de la municipalidad corresponde al terreno de su propiedad.

Se ha calculado un presupuesto estimado para el proyecto, el cual comprende los distintos elementos que intervienen en la inversión a parte del de la construcción. En cuanto al estimado de costo de la construcción se ha calculado respecto a un ratio de $\$ 600$ x m2, según opinión de expertos. Por otro lado, se ha calculado el costo del tratamiento de espacio público. En cuanto al cálculo de ingresos se ha tomado en cuenta un periodo de ingresos por 10 años. El análisis de ingresos, por sectores, será detallado más adelante. 
Tabla 8.10

Presupuesto estimado

NUEVOMERCADO MUNICIPAL DE SANISIDRO PRESUPUESTOESTIMADO

\begin{tabular}{|c|c|c|c|c|c|c|}
\hline & & & \multicolumn{2}{|r|}{ DOLARES } & \multicolumn{2}{|c|}{ DOLARES } \\
\hline ITEM & DESCRIPCION & UNIDAD & METRADO & PU \$ & & PARCIAL \\
\hline \multirow[t]{10}{*}{1} & DEL PROYECTO & & & & & \\
\hline & Area construida total (incluye sotanos) seleccionar según altura & $\$ / \mathrm{m} 2$ & $45,862.04$ & 20.00 & & $917,240.76$ \\
\hline & Levantamiento topográfico & $\$$ & 1 & $1,500.00$ & & $1,500.00$ \\
\hline & Estudio de suelos & $\$$ & 1 & $1,500.00$ & & $1,500.00$ \\
\hline & Arquitectura & $\$ / m 2$ & $45,862.04$ & 10.00 & & $458,620.38$ \\
\hline & Estructuras & $\$ / m 2$ & $45,862.04$ & 3.00 & & $137,586.11$ \\
\hline & Instalaciones sanitarias & $\$ / \mathrm{m} 2$ & $45,862.04$ & 1.50 & & $68,793.06$ \\
\hline & Instalaciones eléctricas & $\$ / m 2$ & $45,862.04$ & 1.50 & & $68,793.06$ \\
\hline & Instalaciones electromecánicas & $\$ / m 2$ & $45,862.04$ & 1.50 & & $68,793.06$ \\
\hline & Indeci (señalización y evacuación) & $\$ / \mathrm{m} 2$ & $45,862.04$ & 0.50 & & $22,931.02$ \\
\hline \multirow[t]{5}{*}{2} & DELAS UCENCIAS & & & & & \\
\hline & $3 \%$ del costo total de obra según Valores Oficiales & $\%$ & $3 \%$ & $17,280,676.87$ & & $518,420.31$ \\
\hline & Anteproyecto & $\%$ & $1 \%$ & $17,280,676.87$ & & $172,806.77$ \\
\hline & Proyecto & $\%$ & $3 \%$ & $17,280,676.87$ & & $518,420.31$ \\
\hline & Conformidad de obra & $\%$ & $19.85 \%$ & $1,258.00$ & & 249.71 \\
\hline \multirow[t]{13}{*}{3} & DELACONSTRUCCION & & & & & \\
\hline & Centro de Atención Primaria & $\$ / \mathrm{m} 2$ & $1,300.60$ & 600.00 & & $780,360.00$ \\
\hline & Oficinas Municipales & $\$ / m 2$ & $1,478.14$ & 600.00 & & $886,884.00$ \\
\hline & Volumen de Convenciones & $\$ / m 2$ & $1,954.95$ & 600.00 & & $1,172,967.06$ \\
\hline & Estacionamiento & $\$ / m 2$ & $11,673.99$ & 600.00 & & $7,004,394.00$ \\
\hline & Zona para personal & $\$ / m 2$ & $2,154.68$ & 600.00 & & $1,292,805.00$ \\
\hline & Depositos y Almacenes & $\$ / m 2$ & 724.77 & 600.00 & & $434,862.00$ \\
\hline & Cisternas, bombas y subestación & $\$ / m 2$ & $1,568.71$ & 600.00 & & $941,228.40$ \\
\hline & Locales comerciales & $\$ / \mathrm{m} 2$ & $2,984.26$ & 600.00 & & $1,790,556.00$ \\
\hline & Hotel 5 estrellas & $\$ / m 2$ & $7,460.65$ & 600.00 & & $4,476,390.00$ \\
\hline & Volumen de Mercado & $\$ / m 2$ & $3,620.05$ & 600.00 & & $2,172,028.14$ \\
\hline & Abastecimiento & $\$ / m 2$ & $5,283.57$ & 600.00 & & $3,170,139.00$ \\
\hline & Volumen Cultural & $\$ / m 2$ & $5,657.68$ & 600.00 & & $3,394,609.08$ \\
\hline \multirow[t]{9}{*}{4} & DEL ESPACIO PÚBUCO Y ÁREAS VERDES & & & & & \\
\hline & Cubresuelos y árboles & $\$ / m 2$ & $4,351.41$ & 10.00 & & $43,514.10$ \\
\hline & Cubresuelo & $\$ / m 2$ & 751.09 & 10.00 & & $7,510.90$ \\
\hline & Grava & $\$ / \mathrm{m} 2$ & 834.10 & 7.55 & & $6,293.66$ \\
\hline & Porcelanato de alto transito formato trapezoidal grande & $\$ / m 2$ & $2,820.79$ & 65.00 & & $183,351.35$ \\
\hline & Porcelanato de alto transito formato trapezoidal mediano & $\$ / \mathrm{m} 2$ & $1,212.73$ & 65.00 & & $78,827.45$ \\
\hline & Cemento pulido & $\$ / m 2$ & $3,384.77$ & 13.48 & & $45,643.11$ \\
\hline & Piso de concreto estampado & $\$ / m 2$ & 467.94 & 18.67 & & $8,737.72$ \\
\hline & Tratamiento de andenería & $\$ / m 2$ & $1,393.56$ & 13.48 & & $18,785.19$ \\
\hline \multirow[t]{4}{*}{5} & SERMCIOS PUBUCOS & N & & & & \\
\hline & Suministro de agua y desagüe & Unid. & 1.00 & $10,000.00$ & & $10,000.00$ \\
\hline & Suministro de energía eléctrica & Unid. & 1.00 & $10,000.00$ & & $10,000.00$ \\
\hline & Instalaciones de gas & Unid. & 1.00 & $10,000.00$ & & $10,000.00$ \\
\hline \multirow[t]{2}{*}{7} & DE LA GERENCIA DE PROYECTO & & & & & \\
\hline & Porcentaje del gasto administrativo & $\%$ & $10.0 \%$ & $28,952,883.74$ & & $2,895,288.37$ \\
\hline 8 & |INVERSIONTOTAL & & & SUMA TOTAL DE GASTOS & & $33,790,829.06$ \\
\hline ITEM & DESCRIPCION & UNIDAD & METRADO & INGRESO POR 10 AÑOS (\$) & & PARCIAL \\
\hline \multirow[t]{6}{*}{9} & INGRESOS & & & & & \\
\hline & SECTOR DE OFICINAS & & & $3,785,660.00$ & $\$$ & $3,785,660.00$ \\
\hline & SECTOR COMERCIAL & & & $16,029,184.00$ & $\$$ & $16,029,184.00$ \\
\hline & SECTOR HOTELERO & & & $25,309,830.00$ & $\$$ & $25,309,830.00$ \\
\hline & SECTOR ESTACIONAMIENTOS & & & $18,393,372.00$ & $\$$ & $18,393,372.00$ \\
\hline & SECTOR DEPOSITOS Y ALMACENES & & & $1,461,136.00$ & $\$$ & $1,461,136.00$ \\
\hline \multirow[t]{5}{*}{10} & |INGRESOTOTAL & & & INGRESO POR VENTAS & $\$$ & $64,979,182.00$ \\
\hline & & & & UTILIDAD BRUTA & $\$$ & $31,188,352.94$ \\
\hline & & & & IMPUESTO & & $30 \%$ \\
\hline & & & & UTILIDAD NETA & $\$$ & $21,831,847.06$ \\
\hline & & & & RENTABILIDAD & & $65 \%$ \\
\hline
\end{tabular}


En cuanto a los ingresos que se generaran una vez concluida la obra se ha tomado en cuenta los sectores que generan una utilidad para el inversionista: sector de oficinas, comercial, hotelero, estacionamientos y depósitos y almacenes. Se está tomando en cuenta un periodo de 10 años para los ingresos y porcentajes de utilidad respecto a cada sector.

En el caso del sector de oficinas se considera el ingreso respecto al supuesto que la municipalidad alquile o ahorre en cuanto a la reubicación de las oficinas municipales existentes en el predio, tomando en cuenta el precio promedio de alquiler de oficinas por la zona.

En cuanto al sector comercial se toma en cuenta un valor por $\mathrm{m} 2$ tomado por referentes lejanos y cercanos a la zona de influencia. Se toma en cuenta una utilidad del $80 \%$ considerando que el espacio rentado se encuentra dentro del complejo donde existirán gastos como seguridad, limpieza, entre otros.

En el caso del sector hotelero se considera el ingreso respecto a los servicios de hospedaje. Se ha tomado en cuenta el precio promedio de hospedaje en hoteles 5 estrellas por la zona.

En cuanto a los estacionamientos se está considerando que estos van a generar un ingreso por precio por hora que la municipalidad considere. A pesar de que actualmente la tarifa es de S/.9.6, se está considerando una tarifa de \$1.5 (S/.4.95) la hora. Por último, en cuanto al ingreso por renta de almacenes de depósitos se está tomando en cuenta un ratio promedio por $\mathrm{m} 2$ de $\$ 21$. 
Tabla 8.11

Análisis de ingresos por sectores

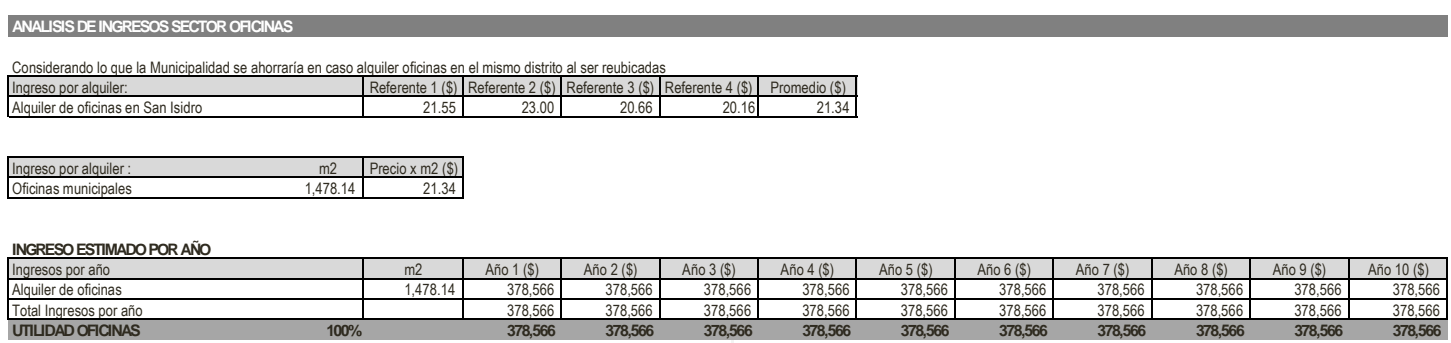

ANALSIS DEINGRESOS SECTOR CONERCIAL

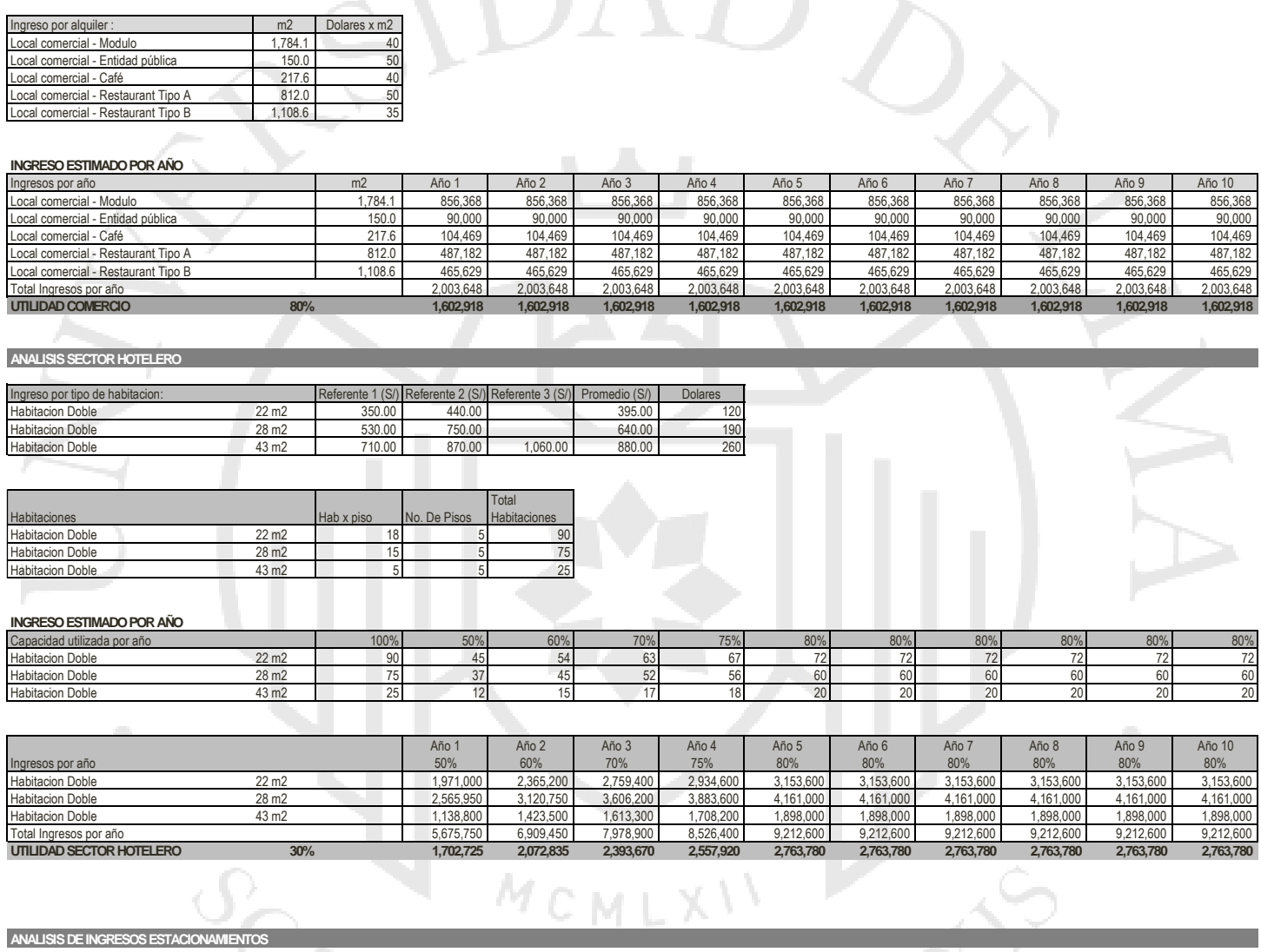

ANALSIS DEINGRESOS ESTACIONAMENTOS

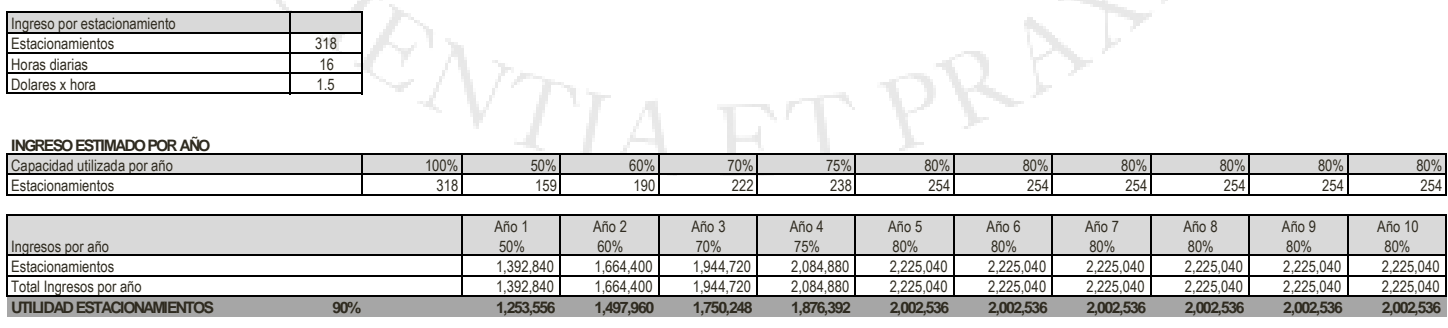

ANALSIS DEINGRESOS DEPOSTTOS Y ALMACENES

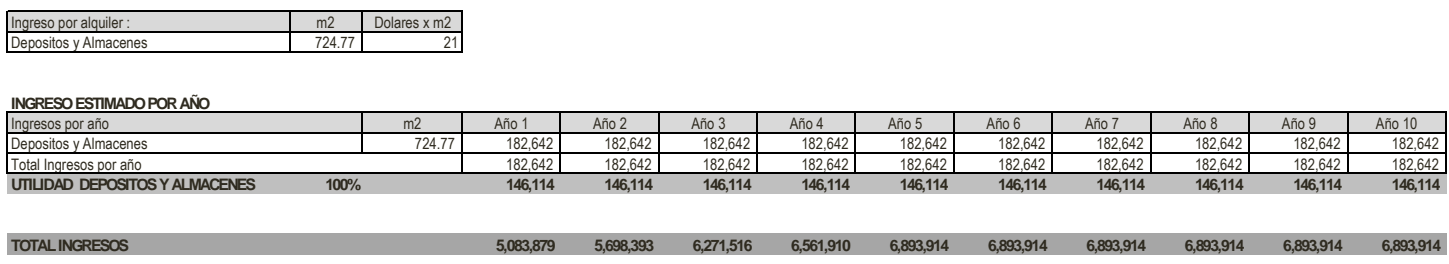


Para el cálculo del punto de equilibrio y la rentabilidad que genera el proyecto, se ha realizado un flujo de caja el cual considera la inversión y los ingresos generados por el mismo proyecto desde el año 3. Cuando se evalúa el flujo de caja económico se puede apreciar que la inversión realizada en los 2 primeros años se recupera en los próximos seis años.

Para la realización de este proyecto se está considerando dos etapas de financiamiento. El primer año un financiamiento de $\$ 20,000,000$, el segundo uno de $\$ 18,000,000$, ambos a una tasa de interés de $6 \%$. En el flujo de caja financiero se aprecia que la amortización de ambos préstamos se efectúa en 10 años, considerando un periodo de gracia de 2 años y 1 año respectivamente. 
Tabla 8.12

Flujo de caja económico y financiero

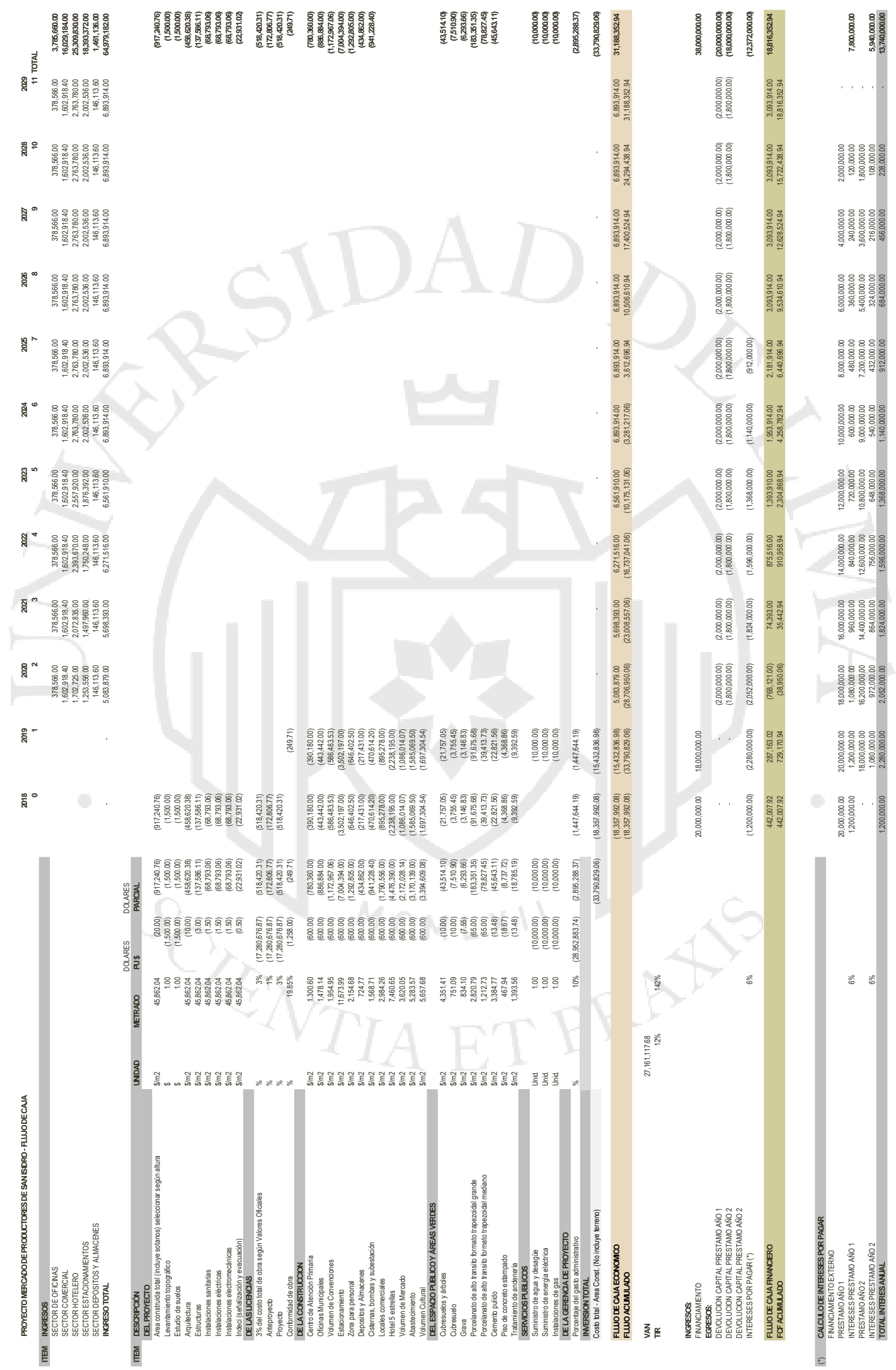




\section{REFERENCIAS}

Aceves Alvarez, O. (2013). Regionalismo, posmodernismo y América Latina. Santiago, Chile.

Alonso, R. (2017). Revista City Manager. Retrieved from http://revistacitymanager.com/revista/2017/jan-gehl-ciudades-para-la-gente/

APEGA. (n.d.). APEGA Sociedad Peruana de Gastronomía. Retrieved May 2, 2016, from http://www.apega.pe/nosotros/que-es-apega

APEGA Sociedad Peruana de Gastronomía. (2012). Gastronomía peruana al 2021. Lima: CEPLAN. Retrieved from http://www.apega.pe/publicaciones/documentosde-trabajo/gastronomia-peruana-al-2021.html

APEGA Sociedad Peruana de Gastronomía. (2013). El Boom Gastronómico Peruano al 2013. Lima: APEGA.

Asociación de Investigación de las Industrias de la Madera. (n.d.). El Parlamento de Escocia. La obra maestra de EMBT. Retrieved May 22, 2016, from http://infomadera.net/uploads/articulos/archivo_5007_23397.pdf

Borja, J. (2000). El espacio público, ciudad y ciudadanía. Barcelona: Electa.

Borja, J. (2003). La Ciudad Conquistada. Madrid: Alianza Editorial.

Cánepa Koch, G. (2011). Cocina e identidadla culinaria peruana como patrimonio cultural inmaterial. Ministerio de Cultura.

Cánepa Koch, G., Hernández Macedo, M., Biffi Isla, V., \& Zuleta García, M. (2011). Cocina e Identidad: La Culinaria Peruana Como Patromonio Cultural Inmaterial. Lima: Cultura, Ministerio de Cultura.

Carmena Castrillo, M. (n.d.). Decreto de 13 de junio de 2015 de la Alcaldesa. Madrid. Retrieved from http://www.madrid.es/UnidadesDescentralizadas/PerfilContratante/Contenidos/Jun io2015/20150613 DECRETO .pdf 
Childe, V. G. (1992). Los orígenes de la Civilización. Fondo De Cultura Economica USA.

Retrieved

from

https://books.google.com.pe/books/about/Los_orígenes_de_la_Civilización.html?i $\mathrm{d}=$ FYURPwAACAAJ\&pgis $=1$

Comisión de Descentralización del Congreso de la República. (n.d.). Ley Orgánica de Municipalidades. Retrieved from http://www4.congreso.gob.pe/comisiones/1998/descentralizacion/leyorga.htm

Concejo Distrital de San Isidro. (2006). Ordenanza N 164-MSI. Lima.

Congreso de la República. (2011). Ley Marco de Promoción y Desarrollo para los $\begin{array}{llll}\text { Mercados de } & \text { Abastos. } & \text { Rima. }\end{array}$ http://www2.congreso.gob.pe/Sicr/TraDocEstProc/TraDoc_condoc_2006.nsf/d995 75da99ebfbe305256f2e006d1cf0/6bd132d8c78a146e0525782c00786c49/\$FILE/0 4652.pdf

Cortés, H. (1770). Carta Tercera de Relación. In Historia de Nueva España. México.

Crespi Vallbona, M., \& Domínguez Perez, M. (2016). Los mercados de abastos y las ciudades turísticas. Pasos.

Cultura, M. de. (n.d.). Ministerio de Cultura. Retrieved May 2, 2016, from http://www.cultura.gob.pe/es/informacioninstitucional/quienessomos

De la Torre, L. M., \& Sandoval Peralta, C. (2004). La Reciprocidad en el Mundo Andino. (E. Abya-Yala, Ed.). Quito.

Delgado, F., San Martín, J., \& Torrico, D. (n.d.). La reciprocidad andina: principio de seguridad vital. Cultivando Ecológicamente y Comercializando Con Equidad.

Di Siena, D. (2009). Espacios Sensibles. Escuela Técnica Superior de Arquitectura de Madrid, Madrid.

Díaz-Albertini, J. (2017, June). Los Yuyos food court, por Javier Díaz-Albertini. El Comercio.

Diccionario de la Lengua Española. (n.d.). Retrieved May 2, 2016, from http://dle.rae.es/?id=OyRtG0r

Dobles Alvarado, R. (n.d.). Regionalismo crítico: En busca de la diversidad cultural. 
Ferraro, E. (2002, August). Reseña de Trueque intercambio y valor. Iconos, Revista de Ciencias Sociales. Retrieved from www.flacso.edu.ec/docs/i14_ferraro.pdf

Frampton, K. (1990). Lugar, forma e identidad: hacia una teoria del regionalismo crítico. In Nueva arquitectura en América Latina: presente y futuro. Mexico: Ediciones G. Gili, S.A.

Gaete, C. M. (2016). Archdaily. Retrieved from https://www.archdaily.pe/pe/792920/5consejos-de-diseno-urbano-elaborados-por-el-arquitecto-jan-gehl

García Calderón, L. (n.d.). El Mercado de barrio hace ciudad.

García Perez, E., Rodríguez, A., \& Maiello, V. (2016). La transformación de los mercados municipales de Madrid: nuevas fronteras de la gentrificación comercial.

Gavidia, D. (2018a, March). Lima imposible. Revista Urbania Premium N²2, 30-31.

Gavidia, D. (2018b, March). San Isidro Ciudad jardín. Revista Urbania Premium $N^{\circ} 22$.

Ginocchio Balcázar, L. (2012). Pequeña agricultura y gastronomía. Oportunidades y desafios. Lima: APEGA.

HABITAT, U. (2013). Streets as Public Spaces and Drivers of Urban Prosperity. UN Habitat.

Halbwachs, M. (1990). Espacio y Memoria Colectiva. Colima, Mexico.

Hernández Aja, A. (1997). La ciudad de los ciudadanos. Madrid.

Institut de Cultura de Barcelona. Consell d'Administració. (2013). El Born CC. Barcelona.

Instituto Metropolitano de Planificación. (1995). Plan maestro de desarrollo de la costa verde. Lima.

Instituto Nacional de Estadistica e Informatica. (2017). Censo Nacional de Mercados de Abastos 2016, resultados a nivel nacional. Lima.

Kuri Pineda, E. (2017). La Construcción Social de la Memoria en el Espacio: una aproximación sociológica. Mexico.

Lima, A. de la M. de. (1994). Ordenanza No 072.

Maderuelo, J. (2010). Paisaje y patrimonio. Madrid: Abada Editores. 
Medina, F. X., \& Álvarez, M. (n.d.). El lugar por donde pasa la vida... Los mercados y demanda urbanas contemporáneas: Barcelona y Buenos Aires.

Medina Luque, F. X. (2014). Mercados y espacio público: transformación y renegociación de nuevas demandas urbanas. Análisis comparativo de casos (Barcelona, Budapest, Buenos Aires). Barcelona.

Mercados de Lima: una mirada a su pasado y presente. (2015). Retrieved April 25, 2016, from http://elcomercio.pe/gastronomia/peruana/mercados-lima-mirada-supasado-y-presente-noticia-1863331

MERCARED. (n.d.). Mercados en Red. Retrieved May 2, 2016, from http://www.mercadosenred.com/que-es-Mercared.htm

Mercasa. (n.d.). Mercasa. Retrieved April 28, 2016, from http://www.mercasa.es/nosotros

Mercasa. (2016). 50 años de Mercasa. Mirando al futuro, un paso por delante. Madrid: Mercasa.

MINSA. (n.d.). MINSA - Ministerio de Salud del Perú. Retrieved May 2, 2016, from http://www.minsa.gob.pe/portalminsa/directorioinstitucional/nododis.asp?nodo=01

Mistura 2014 recibió a 420,000 visitantes peruanos y extranjeros. (2014). Gestión.

Molano, O. L. (2007, May). Identidad culutral un concepto que evoluciona. Revista Opera.

Ordenanza de Mercados Municipales. (n.d.). Retrieved April 27, 2016, from https://sede.madrid.es/sites/v/index.jsp?vgnextoid=2435133de763d210VgnVCM2 000000c205a0aRCRD\&vgnextchannel=6b3d814231ede410VgnVCM1000000b20 $5 \mathrm{a} 0 \mathrm{aRCRD}$

Palomares, S. (n.d.). Mercado de San Miguel. Madrid. Todo un referente. Retrieved May 22, 2016, from http://www.plazasdelmercado.com/2015/01/mercado-de-sanmiguel-madrid-todo-un.html\#.V0FCRIc7HIN

Pérez Morales, E. (2008). Naturaleza, Paisaje y Memoria. Alturas y ciudades del Reino de Quito en la experiencia viajera del siglo XVIII, 27.

Pérgolis, J. C. (2002). La Plaza. El Centro de la Ciudad. Bogotá: Editorial Stia Libris 
Ediciones.

PLAM Lima y Callao 2035: plan metropolitano de desarrollo urbano. (2035). Municipalidad Metropolitana de Lima. Retrieved from https://books.google.com/books?id=z6_OjgEACAAJ\&pgis=1

Plazola Cisneros, A., Plazola Anguiano, A., \& Plazola Anguiano, G. (1999). Enciclopedia de Arquitectura Plazola (Vol. 1-10). Mexico: Plazola Editores.

Robles, J. I. (2014). La evolución de los mercados municipales. El caso del Mercado de San Antón, Madrid. Retrieved May 22, 2016, from http://ecosistemaurbano.org/urbanismo/la-evolucion-de-los-mercadosmunicipales-el-caso-del-mercado-de-san-anton-madrid/

Rodríguez Sebastián, A. (2014). Los Nuevos Mercados Municipales de Madrid. Universidad Politécnica de Madrid.

Soler, M. (2004a). Del ágora griega al foro romano. In Alimentos ¿qué hay detrás de la etiqueta? Barcelona: Viena.

Soler, M. (2004b). Del suq musulmán al mercado feudal. In Alimentos ¿qué hay detrás de la etiqueta? Viena.

Villegas, P. (2010). Del tianguis prehispánico al tiaguis colonial: Lugar de intercambio y predicación (siglo XVI). Estudios Mesoamericanos. Revista Del Programa de Posgrado En Estudios Mesoamericanos.

Zavala Sánchez, M. D. (2013). Intervenciones contemporáneas en los mercados municipales representativos de Cataluña y Valencia, construidos a finales del siglo XIX y principios del XX. Universitat Politècnica de Catalunya (UPC). 


\section{BIBLIOGRAFÍA}

AA.VV. (2013). El Libro de la Economia. Madrid: Akal.

Rioja, E. (1931). El libro de la vida. Madrid: Akal.

Aceves Alvarez, O. (2013). Regionalismo, posmodernismo y América Latina. Santiago, Chile.

Acurio, G. (2008). 500 años de fusión la historia, los ingredientes y las nuevas propuestas de la cocina peruana. Lima: Punto y Coma Editores S.A.C.

Alberti, G., \& Mayer, E. (1974). Reciprocidad e intercambio en los Andes peruanos. Instituto de Estudios Peruanos. IEP ediciones. https://doi.org/10.1017/CBO9781107415324.004

Alguacil, J. (2008). Espacio público y espacio político: La ciudad como el lugar para las estrategias de participación. Polis (Santiago) (Vol. 7). Sevilla. https://doi.org/10.4067/S0718-65682008000100011

Alonso Latorre, R. (2013). La resurrección del mercado: los nuevos mercados municipales atraen clientes a tiendas gourmet y propuestas innovadoras. Emprendedores: las claves de la economía y el éxito profesional. Hachette Filipacchi. Retrieved from https://dialnet.unirioja.es/servlet/articulo?codigo=4118087

Alonso, R. (2017). Revista City Manager. Retrieved from http://revistacitymanager.com/revista/2017/jan-gehl-ciudades-para-la-gente/

APEGA. (n.d.). APEGA Sociedad Peruana de Gastronomía. Retrieved May 2, 2016, from http://www.apega.pe/nosotros/que-es-apega

APEGA Sociedad Peruana de Gastronomía. (2013). El Boom Gastronómico Peruano al 2013. Lima: APEGA.

APEGA Sociedad Peruana de Gastronomía. (2012). Gastronomía peruana al 2021. Lima: CEPLAN. Retrieved from http://www.apega.pe/publicaciones/documentos-de-trabajo/gastronomia-peruana-al2021.html 
Arango, S. (2013). Espacios públicos lineales en las ciudades latinoamericanas. Revista Nodo.

Archivo Histórico El Comercio. (2013). Súper Market, el primer supermercado del Perú. $\quad$ Retrieved May 1, 2016, from http://elcomercio.pe/blog/huellasdigitales/2013/03/super-market-el-primer-superme

Ardila, M. (2010, May 1). Breve aproximación al origen de la forma de las ciudades. EXPEDITIัO. Retrieved from http://revistas.utadeo.edu.co/index.php/EXP/article/view/697

Arellano, R. (2010). Al medio hay sitio. El crecimiento social según los Estilos de Vida. Lima: Editorial Planeta Perú.

Armengol Martín, M. T. (2009). Los mercados de abastos: evlución y relación con la transformación de la oferta comercial en la ciudad de las Palmas de Gran Canaria.

Asociación de Investigación de las Industrias de la Madera. (n.d.). El Parlamento de Escocia. La obra maestra de EMBT. Retrieved May 22, 2016, from http://infomadera.net/uploads/articulos/archivo_5007_23397.pdf

Asociación Peruana de Empresas de Investigación de Mercados. (2005). Niveles socieconómicos en Lima Metropolitana y Callao. Lima.

Batista Barreta, J. M. (2011). Mercados municipales en Portugal: Escenarios para el año 2030. Distribución y consumo. Mercasa. Retrieved from https://dialnet.unirioja.es/servlet/articulo?codigo $=3808945$

Borja, J. (2003). La Ciudad Conquistada. Madrid: Alianza Editorial.

Borja, J. (2000). El espacio público, ciudad y ciudadanía. Barcelona: Electa.

Bromley, J., \& Barbagelata, J. (1945). Evolución urbana de Lima... Talleres gráficos de la editorial Lumen, s. a. Retrieved from https://books.google.com/books?id=XmN9AAAAMAAJ\&pgis=1

Cánepa Koch, G. (2011). Cocina e identidadla culinaria peruana como patrimonio cultural inmaterial. Ministerio de Cultura. 
Cánepa Koch, G., Hernández Macedo, M., Biffi Isla, V., \& Zuleta García, M. (2011). Cocina e Identidad: La Culinaria Peruana Como Patromonio Cultural Inmaterial. Lima: Cultura, Ministerio de Cultura.

Carman, M. (2005). El barrio del Abasto o la invención de un lugar noble. Runa: archivo para las ciencias del hombre. Instituto de Ciencias Antropológicas (ICA). Retrieved from https://dialnet.unirioja.es/servlet/articulo? codigo=5069750\&info=resumen\&idioma=SP A

Carmena Castrillo, M. (n.d.). Decreto de 13 de junio de 2015 de la Alcaldesa. Madrid. Retrieved from http://www.madrid.es/UnidadesDescentralizadas/PerfilContratante/Contenidos/Junio20 15/20150613 DECRETO .pdf

Casares Ripol, J. (2003). Los mercados municipales y el futuro de las ciudades. $\begin{array}{lllll}\text { Distribución } & y & \text { consumo. } & \text { Mercasa. } & \text { Retrieved }\end{array}$ https://dialnet.unirioja.es/servlet/articulo? codigo $=633063$

Casares Ripol, J., \& Rebollo Arévalo, A. (2005). Los mercados minoristas como valor de las ciudades. Distribución y consumo. Mercasa. Retrieved from https://dialnet.unirioja.es/servlet/articulo? codigo $=1367441$

Casares Ripol, J., \& Rebollo Arévalo, A. (2001). Respuesta de los Mercados Municipales a las nuevas formas de comercio. Distribución y consumo. Mercasa. Retrieved from https://dialnet.unirioja.es/servlet/articulo?codigo=207843

Castro Martínez, P. V., Oltra, J., Sanahuja Yll, M. E., \& Escoriza Mateu, T. (2003). ¿Qué es una Ciudad?: aportaciones para su definición desde la Prehistoria. Scripta Nova: Revista electrónica de geografía y ciencias sociales. Facultad de $\begin{array}{llll}\text { Geografía } & \text { Historia. } & \text { Retrieved }\end{array}$ https://dialnet.unirioja.es/servlet/citart?info=link\&codigo=668467\&orden=6954

Castro, D. (2008). Ciudad Centros de Abasto. Bogotá: Escala.

Centro para la sostenibilidad ambiental de la Universidad Peruana Cayetano Heredia. (2014). Identifiación de ecosistemas y servicios ecosistémicos dentro del ámbito de la costa verde. 
Childe, V. G. (1992). Los orígenes de la Civilización. Fondo De Cultura Economica USA. Retrieved from https://books.google.com.pe/books/about/Los_orígenes_de_la_Civilización.html?id=FY URPwAACAAJ\&pgis $=1$

Comisión de Descentralización del Congreso de la República. (n.d.). Ley $\begin{array}{llll}\text { Orgánica } & \text { de } & \text { Municipalidades. } & \text { Retrieved }\end{array}$ http://www4.congreso.gob.pe/comisiones/1998/descentralizacion/leyorga.htm

Concejo Distrital de San Isidro. (2006). Ordenanza Nº 164-MSI. Lima.

Congreso de la República. (2011). Ley Marco de Promoción y Desarrollo para los Mercados de Abastos. Lima. Retrieved from http://www2.congreso.gob.pe/Sicr/TraDocEstProc/TraDoc_condoc_2006.nsf/d99575da 99ebfbe305256f2e006d1cf0/6bd132d8c78a146e0525782c00786c49/\$FILE/04652.pdf

Cortés, H. (1770). Carta Tercera de Relación. In Historia de Nueva España. México.

Crespi Vallbona, M., \& Domínguez Perez, M. (2016). Los mercados de abastos y las ciudades turísticas. Pasos.

Cultura, M. de. (n.d.). Ministerio de Cultura. Retrieved May 2, 2016, from http://www.cultura.gob.pe/es/informacioninstitucional/quienessomos

De la Torre, L. M., \& Sandoval Peralta, C. (2004). La Reciprocidad en el Mundo Andino. (E. Abya-Yala, Ed.). Quito.

de Pádua Carrieri, A., Dutra Murata, I. B., Teixeira, J. C., Gontijo, B. M., \& Tijoux, M. E. (2012). Metamorfoseando los mercados centrales: El turismo gastronómico como estrategia en el Mercado Central de Santiago (Chile) y el Mercado Municipal de São Paulo (Brasil). Estudios Y Perspectivas En Turismo, 21(1), 88-107. Retrieved from http://search.ebscohost.com/login.aspx?direct=true \&db=fua\&AN=70547732\&lang=es $\&$ site $=$ ehost-live

Delgado, F., San Martín, J., \& Torrico, D. (n.d.). La reciprocidad andina: principio de seguridad vital. Cultivando Ecológicamente Y Comercializando Con Equidad. 
Di Siena, D. (2009). Espacios Sensibles. Escuela Técnica Superior de Arquitectura de Madrid, Madrid.

Díaz-Albertini, J. (2017, June). Los Yuyos food court, por Javier Díaz-Albertini. El Comercio.

Dirección General de Desarrollo Urbano. (1972). Defensas del litoral y habilitación de nuevas playas de Lima Metropolitana. Lima.

Dobles Alvarado, R. (n.d.). Regionalismo crítico: En busca de la diversidad cultural.

Domiciliarios, C. (2006). Administración del Mercado Municipal.

Eiroa García, J. J. (2002). Sobre el origen del urbanismo y el modelo de vida urbana en el viejo y nuevo mundo. Evolución urbana y actividad económica en los núcleos históricos. Universidad de Murcia. Retrieved from https://dialnet.unirioja.es/servlet/articulo?codigo=1125626

Espinoza Soriano, W. (1987). Artesanos, transacciones, monedas y formas de pago en el mundo andino siglo XV y XVI. Lima: Banco Central de Reserva.

Fernández Domínguez, J. R., \& Anchela Ocaña, A. I. (2012). Los mercados minoristas como instrumentos de dinamización comercial y de regeneración urbana. Abaco: Revista de cultura y ciencias sociales. CEES, Centro de Cultura y Ciencias Sociales. Retrieved from https://dialnet.unirioja.es/servlet/articulo?codigo=4143975

Fernández, R. (1995). El laboratorio americano. Biblioteca Nueva.

Ferraro, E. (2002, August). Reseña de Trueque intercambio y valor. Iconos, Revista de Ciencias Sociales. Retrieved from www.flacso.edu.ec/docs/i14_ferraro.pdf

Flores H, I. (n.d.). Identidad cultural y el sentimiento de pertenencia a un espacio social: una discusión teórica.

Frampton, K. (1990). Lugar, forma e identidad: hacia una teoria del regionalismo crítico. In Nueva arquitectura en América Latina: presente y futuro. Mexico: Ediciones G. Gili, S.A. 
Gaete, C. M. (2016). Archdaily. Retrieved from https://www.archdaily.pe/pe/792920/5-consejos-de-diseno-urbano-elaborados-por-elarquitecto-jan-gehl

Gallego Dueñas, F. J. (2009). La plaza pública. Uso propandístico del espacio urbano.

García Calderón, L. (n.d.). El Mercado de barrio hace ciudad.

García Perez, E., Rodríguez, A., \& Maiello, V. (2016). La transformación de los mercados municipales de Madrid: nuevas fronteras de la gentrificación comercial.

Gavidia, D. (2018, March). San Isidro Ciudad jardín. Revista Urbania Premium $N^{\circ} 22$.

Gavidia, D. (2018, March). Lima imposible. Revista Urbania Premium $N^{\circ} 22$, $30-31$.

Ge, N., \& Urbano, D. D. (2015). Reglamento Nacional de Edificacion RNE. Lima.

Gehl, J. (2013). Ciudades para la gente, 260.

Gerencia de Desarrollo Empresarial de la MML. (n.d.). Red de mercados de abastos competitivos y la cadena de la gastronomía. Lima.

Giménez, G. (n.d.). La cultura como identidad y la identidad como cultura.

Ginocchio Balcázar, L. (2012). Pequeña agricultura y gastronomía. Oportunidades y desafios. Lima: APEGA.

González Barbosa, C. A. (n.d.). La identidad espacial: constructo entre la reciprocidad del espacio físico y la presencia del individuo. Universidad de Puerto Rico.

González Palacios, C. (2016). El pensamiento social andino: una alternativa al modelo occidental de inclusión social.

Guardia, M. (2006, July 1). LOS MERCADOS EN LAS CIUDADES. LAS POTENCIALIDADES DE UN APARENTE ANACRONISMO. Revista M. Retrieved from http://revistas.ustabuca.edu.co/index.php/REVISTAM/article/view/1059 
HABITAT, U. (2013). Streets as Public Spaces and Drivers of Urban Prosperity. UN Habitat.

Halbwachs, M. (1990). Espacio y Memoria Colectiva. Colima, Mexico.

Hernández Aja, A. (1997). La ciudad de los ciudadanos. Madrid.

Hernandez, J. A. (1999, November 20). Central de Abasto de la Ciudad de Mexico: Es un riesgo latente. El Norte, p. 19. Retrieved from http://fresno.ulima.edu.pe/ss_bd00102.nsf/RecursoReferido?OpenForm\&id=PROQUES T-41716\&url=/docview/316148645?accountid=45277

Hirth, K. (n.d.). Los mercados prehispánicos. La economía y el comercio. $\begin{array}{llll}\text { Arqueología } & \text { Mexicana, } & \text { Retrieved } & \text { from }\end{array}$ http://www.arqueomex.com/S2N3nEconomia122.html

INEI. (2017). Nota de Prensa. Lima.

Institut de Cultura de Barcelona. Consell d'Administració. (2013). El Born CC. Barcelona.

Institut Municipal de Mercats de Barcelona. (n.d.). The Markets of the Mediterranean. Institut Municipal de Mercats de Barcelona.

Instituto Metropolitano de Planificación. (1995). Plan maestro de desarrollo de la costa verde. Lima.

Instituto Nacional de Estadistica e Informatica. (2017). Censo Nacional de Mercados de Abastos 2016, resultados a nivel nacional. Lima.

Jacobs, J. (1975). La Economía de las ciudades. Península. Retrieved from https://books.google.com/books?id=YgIpOwAACAAJ\&pgis=1

Kuri Pineda, E. (2017). La Construcción Social de la Memoria en el Espacio: una aproximación sociológica. Mexico.

Las, N. Y. D. E., Regionales, C., \& Medio, D. E. L. (1999). Titulo i, (166), 130.

Lima, A. de la M. de. (1994). Ordenanza No 072. 
Los seminarios de Arquitectura Latinoamericana (SAL). (1980). Discursos latinoamericanistas en los debates arquitectónicos de la decada de 1980. Cuaderno de Notas 16.

Maderuelo, J. (2010). El paisaje urbano. Estudios Geográficos.

Maderuelo, J. (2010). Paisaje y patrimonio. Madrid: Abada Editores.

Malinowski, B., \& De la Fuente, J. (2005). La economía de un sistema de mercados en México. un ensayo de etnografía contemporánea y cambio social en un valle mexicano.

Margueliche, J. C. (2015). Memoria, Identidad y Representaciones Sociales en el Paisaje (Pos)Industrial. Universidad Nacional de La Plata.

Medina Luque, F. X. (2014). Mercados y espacio público: transformación y renegociación de nuevas demandas urbanas. Análisis comparativo de casos (Barcelona, Budapest, Buenos Aires). Barcelona.

Medina, F. X., \& Álvarez, M. (n.d.). El lugar por donde pasa la vida... Los mercados y demanda urbanas contemporáneas: Barcelona y Buenos Aires.

Mercados.US. (n.d.). Origen del Mercado. Retrieved April 25, 2016, from http://www.mercados.us/financieros/capitales/segmentacion/origen_del_mercado/

MERCARED. (n.d.). Mercados en Red. Retrieved May 2, 2016, from http://www.mercadosenred.com/que-es-Mercared.htm

Mercasa. (2016). 50 años de Mercasa. Mirando al futuro, un paso por delante. Madrid: Mercasa.

Mercasa. (2016). 50 años de Mercasa. Mirando al futuro, un paso por delante. Madrid: Mercasa.

Mercasa. (n.d.). Mercasa. Retrieved April 28, 2016, from http://www.mercasa.es/nosotros

Miás, J. (n.d.). El Mercado de la Barceloneta. Barcelona.

MINSA. (n.d.). MINSA - Ministerio de Salud del Perú. Retrieved May 2, 2016, from http://www.minsa.gob.pe/portalminsa/directorioinstitucional/nododis.asp?nodo=01 
Molano, O. L. (2007, May). Identidad culutral un concepto que evoluciona. Revista Opera.

MrManNoticias. (2015). MrManNoticias BlogspotTitle. Retrieved from https://mrmannoticias.blogspot.com/2017/09/ciudades-para-la-gente-por-jan-gehl.html

Municipalidad de Magdalena del Mar. (2014). Plan de Manejo de Residuos Sólidos Municipaliad de Magdalena del Mar. Lima. Retrieved from http://magdalenaenlinea.pe/ordenanzas/Ordenanza016-MDMM-2014 anexo 1.pdf

Municipalidad de Magdalena del Mar. (2012). Municipalidad de Magdalena del Mar. Estudio de Generación y Caracterización de Residuos Sólidos.

Municipalidad Metropolitana de Lima. (2013). Guía para la Competitividad de Mercados de Abasto. Lima.

Murford, L. (2014). LA CIUDAD EN LA HISTORIA. (Pepitas de Calabaza, Ed.). Retrieved from http:/www.casadellibro.com/libro-la-ciudad-en-lahistoria/9788493943783/1996669

nstituto Metropolitano de Planificacion. (1995). Plan maestro de desarrollo de la costa verde 1995-2010. Programa de inversiones. Lima.

Palomares, S. (n.d.). Mercado de San Miguel. Madrid. Todo un referente. Retrieved May 22, 2016, from http://www.plazasdelmercado.com/2015/01/mercado-desan-miguel-madrid-todo-un.html\#.V0FCRIc7HIN

Pavez, M. I. (1996, August). Espacios públicos integrados y accesibilidad como objetivo cívico.

Penagos, J. L. O. (2009). Rumbo al Bicentenario. Retrieved April 25, 2016, from http://blog.pucp.edu.pe/blog/juanluisorrego/2009/05/24/historia-del-peru-colonialuna-sintesis/

Pérez Morales, E. (2008). Naturaleza, Paisaje y Memoria. Alturas y ciudades del Reino de Quito en la experiencia viajera del siglo XVIII, 27.

Pérgolis, J. C. (2002). La Plaza. El Centro de la Ciudad. Bogotá: Editorial Stia Libris Ediciones. 
Plazola Cisneros, A., Plazola Anguiano, A., \& Plazola Anguiano, G. (1999). Enciclopedia de Arquitectura Plazola (Vol. 1-10). Mexico: Plazola Editores.

Polonio Armada, J. (2003). Mercados de Abastos: Alimentos para el pueblo, alimentos para la hacienda. Ámbitos.

Polonio Armada, J. (2003). Mercados de Abastos: alimentos para el pueblo, alimentos para la hacienda. Ambitos: revista de estudios de ciencias sociales y humanidades. Asociación de Estudios de Ciencias Sociales y Humanidades. Retrieved from https://dialnet.unirioja.es/servlet/articulo?codigo=2603903

Presidente, E. L., \& República, D. E. L. A. (2010). Ley Marco de Licencia de Funcionamiento, (180), 5-7.

Puxeu, J. (n.d.). Remodelacion de mercados tradicionales modernizacion comercial y rehabilitacion urbana. Distribución Y Consumo.

Quicaño, M. I. (2014). Lineamientos técnicos para el desarrollo de polos de estructuración de la costa verde. Lima.

Rajschmir, C. (2000, January). Understanding the city: Abasto in Buenos Aires. Museum International. Retrieved from http://10.0.4.87/1468-0033.00246

Rebollo Arévalo, A. (2003). El papel de los mercados municipales en la vertebración de las tramas urbanas. Distribución Y Consumo.

Reynolds, A. (2013). El regionalismo crítico y la representación lationamericanista en la prosa temprana de Darío. Revista Iberoamericana.

Rioja-Scott, I. (2015, April). El Mercado. Industria Alimenticia, p. 35. Retrieved from

http://search.ebscohost.com/login.aspx?direct=true \&db=bth\&AN=102493238\&lang=es $\&$ site $=$ ehost-live

Robles, J. (2014). Local markets and digital technologies: Among e-commerce and new forms of conviviality. Anthropologica. Pontificia Universidad Católica del Perú. Retrieved from https://dialnet.unirioja.es/servlet/articulo? $\operatorname{codigo}=5039583 \&$ info=resumen\&idioma=SP A 
Robles, J. I. (2014). La evolución de los mercados municipales. El caso del Mercado de San Antón, Madrid. Retrieved May 22, 2016, from http://ecosistemaurbano.org/urbanismo/la-evolucion-de-los-mercados-municipales-elcaso-del-mercado-de-san-anton-madrid/

Rodríguez Sebastián, A. (n.d.). Análisis de la transformación de los mercados de abastos madrileños. Madrid.

Rodríguez Sebastián, A. (2014). Los Nuevos Mercados Municipales de Madrid. Universidad Politécnica de Madrid.

Rodríguez, A. (2014). La transformación de los mercados municipales de Madrid. Análisis legislativo, comercial, y económico de los mercados de abastos madrileños. Territorios en formación (Vol. 0). Escuela Superior de Arquitectura de Madrid (UPM). Retrieved from http://polired.upm.es/index.php/territoriosenformacion/article/view/2990

Saldaña, E. E. Z. (2014, May 15). Arroz con mango: A propósito de la comida peruana y la identidad. Pozo de Letras. Retrieved from http://revistas.upc.edu.pe/index.php/pozo/article/view/221

Salíngaros, N., \& Pagliardini, P. (2010). Geometría y vida del espacio urbano.

Sassano, S. (2001). Transformación de un espacio urbano: el caso del Mercado de Abastos de Buenos Aires. Anales de geografía de la Universidad Complutense. Departamento de Análisis Geográfico Regional y Geografía Física. Retrieved from https://dialnet.unirioja.es/servlet/articulo?codigo $=86562 \&$ info $=$ resumen $\&$ idioma $=$ SPA

Sempat Assadourian, C. (1982). El Sistema De La Economia Colonial. Perú.

Seño Asencio, F. (2013). Acerca del valor patrimonial de los Mercados Municipales y Plazas de Abastos de nuestro entorno. Cuadernos de los Amigos de los Museos de Osuna. Amigos de los Museos de Osuna. Retrieved from https://dialnet.unirioja.es/servlet/articulo? codigo $=4736109$

Soja, E. W. (2009). Postmetrópolis : estudios críticos sobre las ciudades y las regiones. Traficantes de Sueños. Retrieved from https://books.google.com/books?id=4WEpQwAACAAJ\&pgis=1

Solano Ramos, R. (n.d.). La información y el conocimiento en el mundo andino. 
Soler, M. (2004). Del suq musulmán al mercado feudal. In Alimentos ¿qué hay detrás de la etiqueta? Viena.

Soler, M. (2004). Del ágora griega al foro romano. In Alimentos ¿qué hay detrás de la etiqueta? Barcelona: Viena.

Suárez Roja, L. A. (2011). Mercados y mercaderes. Hacia una antropología de las prácticas económicas. Universidad Nacional Mayor de San Marcos.

Takano, G., \& Tokeshi, J. (2007). Espacio público en la ciudad popular: reflexiones y experiencias desde el Sur.

Tangires, H. (2008). Public Markets (First Edit). Mexico: W.W Norton \& Company.

Tangires, H. (2008). Public Markets. W.W. Norton. Retrieved from https://books.google.com/books?id=-agV_7-DQk4C\&pgis=1

Tangires, H. (2005). Public Markts and the City: A Historica Perspective. Retrieved April 25, 2016, from http://www.pps.org/blog/6thmktstangires/

Toca, A. (1990). Nueva arquitectura en América Latina: presente y futuro. Mexico.

Tresserras, J., \& Medina, F. X. (2007). Patrimonio gastronómico y turismo cultural en el Mediterráneo. Barcelona.

Villegas, P. (2010). Del tianguis prehispánico al tiaguis colonial: Lugar de intercambio y predicación (siglo XVI). Estudios Mesoamericanos. Revista Del Programa de Posgrado En Estudios Mesoamericanos.

Waisman, M. (1991). Cuadernos Escala. Bogotá.

Yaranga, Y. (2015). La comunicación para el desarollo desde los mercados populares: estudio de caso del mercado "Santa Rosa" de Chorrillos. Pontificia Universidad Católica del Perú.

Zambrano Torres, M. R. (2015). Corrientes posmodernas vistas desde América Latina. La arquitectura "latinoamericana" en la crítica arquitectónica de Marina Waisman. 
Zavala Sánchez, M. D. (2013). Intervenciones contemporáneas en los mercados municipales representativos de Cataluña y Valencia, construidos a finales del siglo XIX y principios del XX. Universitat Politècnica de Catalunya (UPC). 